
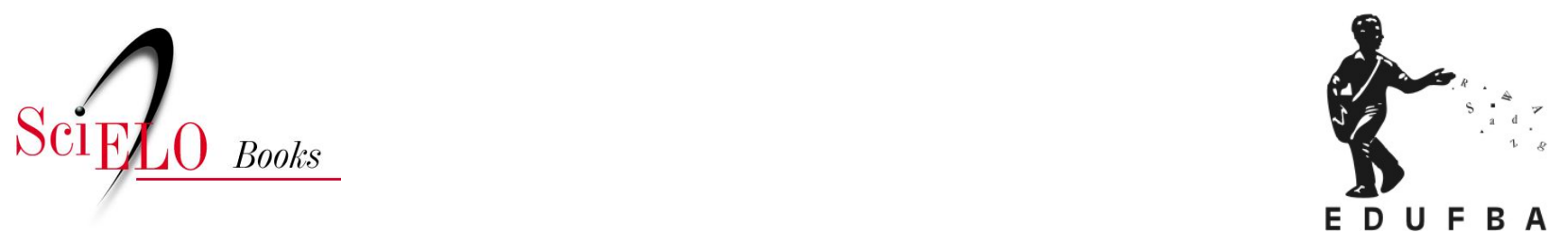

\title{
Dietário (1582-1815) do Mosteiro de São Bento da Bahia edição diplomática
}

\author{
Alicia Duhá Lose \\ Dom Gregório Paixão \\ Anna Paula Sandes de Oliveira \\ Gérsica Alves Sanches \\ Célia Marques Telles (collab.)
}

\section{SciELO Books / SciELO Livros / SciELO Libros}

LOSE, AD., et al. and TELLES, CM., collab. Dietário do Mosteiro de São Bento da Bahia: edição diplomática [online]. Salvador: EDUFBA, 2009. 380 p. ISBN 978-85-2320-936-0. Available from SciELO Books $<\underline{\text { http: } / / \text { books.scielo.org }>\text {. }}$

\section{(2)(1)(2)}

All the contents of this chapter, except where otherwise noted, is licensed under a Creative Commons Attribution-Non Commercial-ShareAlike 3.0 Unported.

Todo o conteúdo deste capítulo, exceto quando houver ressalva, é publicado sob a licença Creative Commons Atribuição - Uso Não Comercial - Partilha nos Mesmos Termos 3.0 Não adaptada.

Todo el contenido de este capítulo, excepto donde se indique lo contrario, está bajo licencia de la licencia Creative Commons Reconocimento-NoComercial-CompartirIgual 3.0 Unported. 


\title{
Dietário (I582-I8I5) do Mosteiro de São Bento da Bahia: edição diplomática
}

\author{
Alicia Duhá Lose \\ Dom Gregório Paixão, OSB \\ Anna Paula Sandes de Oliveira \\ Gérsica Alves Sanches
}

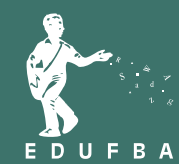




\section{Dietário (1582-1815) do Mosteiro de São Bento da Bahia: edição diplomática}




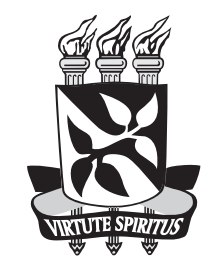

\section{Universidade Federal da Bahia}

\section{Reitor}

Naomar de Almeida Filho

\section{Vice-reitor}

Francisco José Gomes Mesquita

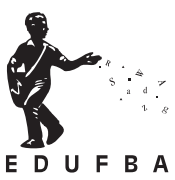

\section{Editora da Universidade Federal da Bahia}

\section{Diretora}

Flávia M. Garcia Rosa

\section{Conselho Editorial}

Ângelo Szaniecki Perret Serpa

Caiuby Alves da Costa

Charbel Ninõ El-Hani

Dante Eustachio Lucchesi Ramacciotti

José Teixeira Cavalcante Filho

Maria do Carmo Soares Freitas

\section{Suplentes}

Alberto Brum Novaes

Antônio Fernando Guerreiro de Freitas

Armindo Jorge de Carvalho Bião

Evelina de Carvalho Sá Hoisel

Cleise Furtado Mendes

Maria Vidal de Negreiros Camargo 


\author{
ALICIA DUHÁ LOSE \\ DOM GREGÓRIO PAIXÃO, OSB \\ ANNA PAULA SANDES DE OLIVEIRA \\ GÉRSICA ALVES SANCHES \\ Colaboração de \\ CÉLIA MARQUES TELLES
}

\title{
Dietário (1582-1815) do Mosteiro de São Bento da Bahia: edição diplomática
}


Direitos para esta edição, cedidos à Editora da Universidade Federal da Bahia. Feito o depósito legal.

Alícia Duhá Lose

Nídia Lubisco

Revisão

\section{fapesb 界}

Fundação de Amparo

à Pesquisa do Estado da Bahia

$$
\text { Apoio }
$$

Sistema de Bibliotecas - UFBA

Dietário do Mosteiro de São Bento da Bahia : edição diplomática / Alicia Duhá Lose ... [et al.] ; colaboração de Célia Marques Telles. - Salvador : Edufba, 2009. 380 p. : il.

ISBN 978-85-232-0574-4 (broch.)

1. Mosteiro de São Bento da Bahia - Arquivos. 2. Ordens monásticas e religiosas Bahia. 3.Linguística histórica. 4. Análise do discurso. I. Lose, Alicia Duhá. II. Telles, Célia Marques.

\section{Editora afiliada à:}

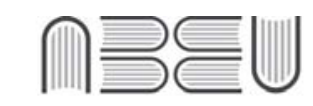

Associação Brasileira das Editoras Universitárias

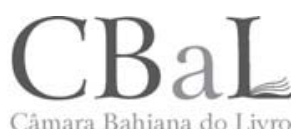

Câmara Bahiana do Livro

\section{EDUFBA}

Rua Barão de Jeremoabo, s/n Campus de Ondina 40.170-115 Salvador-Bahia-Brasil Telefax: (71) 3283-6160/6164/6777 edufba@ufba.br www.edufba.ufba.br 
Aos monges do Mosteiro de São Bento da Bahia, a sua cultura, a sua história... 


\section{AGRADECIMENTOS}

Ao Arquiabade Dom Emanuel D’Able do Amaral, pela confiança em nós depositada; A Dom Clemente, Dom Adriano, Dom Agostinho, Dom Ivan, Dom Filipe, Dom Miguel, Dom Mauro Roberto e tantos outros monges da casa, a quem fizemos tantas e tão insistentes perguntas ao longo da realização deste trabalho;

A Dom Rafael, pela acolhida em tão importante espaço sob sua responsabilidade: a Biblioteca do Mosteiro de São Bento da Bahia e o seu Centro de Documentação e Pesquisa do Livro Raro;

A Dom Bonifácio e seus cães, pelas visitas na janela;

Ao Irmão Pio e a todos os demais "garis de livro", por ajudar a preservar esse tão preciso patrimônio documental;

A Dom Filipe, Arquivista do Mosteiro, pelo empenho e cuidado com as "jóias" do nosso acervo;

A Dom Clemente da Silva Nigra (in memoriam) por ter se ocupado com tanto zelo e paixão dos documentos desse tão rico acervo e por nos ter deixado esse legado;

A Marla, Jaque, Lívia, Marília, Paulo Afonso, Perla, Aline, Ton, Hirão e Adrianas 1 e 2, incansáveis companheiros de trabalho;

A Reinaldo, Anderson, Davi, Dom Martinho, Seu Gerson, Jorge e a toda equipe da Biblioteca pelo companheirismo nesta jornada;

À Prof ${ }^{\mathrm{a}}$. Dr ${ }^{\mathrm{a}}$. Célia Marques Telles, supervisora institucional da coordenadora deste projeto no seu Estágio Pós-doutoral (PPGLL/UFBA), pela confiança e amizade, mais uma vez, e pela sua eterna orientação;

À Universidade Federal da Bahia, por mais esta acolhida;

À Fundação de Amparo à Pesquisa do Estado da Bahia, pelo tão indispensável apoio financeiro a este trabalho;

Ao colega e amigo Américo Venâncio Lopes Machado Filho, pelas partilhas.

A todos aqueles que contribuíram para a feição dessa publicação.

Nosso muito obrigado a todos, de coração! 


\section{SUMÁRIO}

APRESENTAÇÃo 11

1 INTRODUÇÃO 13

2 OS MOSTEIROS BENEDITINOS 17

2.1 OPRIMEIRO MOSTEIRO BENEDITINO DO NOVOMUNDO 18

2.2 SÃO BENTO 20

3 DIETARIO DAS VIDAS E MORTES DOS MONGES, Q' FALECERÁO NESTE MOSTEIRO DE S. SEBASTIÃO DA BAHIA DA ORDEM DO PRINCIPE DOS PATRIARCHAS S. BENTO ....................................................................................................23

3.1 HISTÓRIAS E PECULIARIDADES RELATADAS NO DIETARIO ……………......... 23

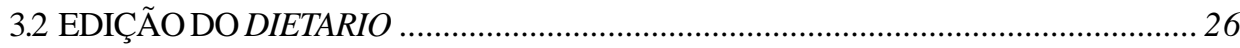

3.2.1 Histórico da edição ........................................................................................................... 26

3.3 DESCRIÇÃOEXTRÍNSECADOMATERIAL:

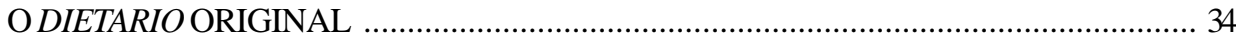

3.4 PROPOSTAPARAOTRABALHO DEEDIÇÃO ..................................................... 38

3.4.1 Critérios de Edição ......................................................................................................... 39

3.4.2 Etapas do trabalho ........................................................................................................ 41

3.5 CARACTERÍSTICAS INTRÍNSECAS DO DOCUMENTO:

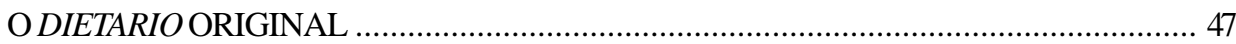

4 ABREVIATURASPRESENTES NOTEXTO .............................................................. 51

5 TRANSCRIÇÃO ...................................................................................................................... 61

6 CONSIDERAÇÕES FINAIS ................................................................................. 367

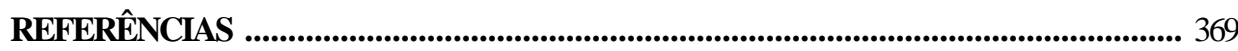

ÍNDICEDENOMES _......................................................................................... 373 


\section{APRESENTAÇÃO}

O oitavo degrau da humildade consiste em que o monge nada faça senão o que lhe recomendam a

Regra comum do mosteiro e os exemplos dos

mais velhos

(Regra de São Bento 7,55)

Um transeunte que cruza a Avenida Sete de Setembro, no centro da Cidade do Salvador, talvez não imagine que os muros seculares da quatrocentenária Arquiabadia de São Sebastião da Bahia, tradicionalmente conhecido como Mosteiro de São Bento, guarde muito mais do que um patrimônio material de valor incalculável.

A grande riqueza do velho Mosteiro está na sua renovação contínua e na vida que transita dentro de seus muros seculares. Seu maior patrimônio, portanto, são seus monges.

Não é fácil, para um leitor que tem à mão a Regra de São Bento, imaginar que aquele texto é vivido, ininterruptamente, ao longo de mais de 1500 anos. Não é fácil compreender como os ensinamentos de um romano do século VI possam influenciar grupos de homens e mulheres do século XXI e fazer com que muitos deles larguem tudo, até mesmo uma parte de suas histórias, para viver uma existência baseada na oração, na humildade, no despojamento, na obediência, em busca de um Tesouro que supera todo tesouro: Jesus Cristo. Aquele a quem se procura é o eterno encontrado. E aquele que $\mathrm{O}$ encontrou, ganhou toda a sua vida.

É nesse espírito de busca e de encontro que devemos entender a vida e as obras daqueles que tudo deixaram por amor a Cristo. É nessa busca da contemplação, do já e do ainda não, que penetraremos num oceano de existência, muito além de um simples viver.

O jovem que ingressa num mosteiro pouco sabe sobre a vida que ali vai encontrar. Mas ele sente que lá está o que busca, mesmo sem o conhecimento pleno do Espírito que o chama para a vida monástica. Vivendo anos de uma experiência que se dá pela recepção da experiência dos mais velhos, ele descobre não apenas o modus vivendi monástico, mas percebe que esse modo de vida pode lhe fazer alcançar mais facilmente o que busca no fundo do seu coração.

É exatamente esse dom de viver que encontramos no Dietário dos Monges do Arquicenóbio da Bahia. Nada ali é por acaso. Tudo nos remete a uma experiência de homens que viveram profundamente o seu tempo, ao tempo que saborearam o Verbo da Vida. Ali estavam homens que não quiseram ver a vida passar, mas participaram intensamente de cada segundo dado pelo Senhor, como tempo propício de preparação para o grande encontro.

O trabalho eficiente de Dom Gregório Paixão, monge de nosso Mosteiro, da Professora Dra. Alícia Duhá Lose, Coordenadora de nossa Faculdade São Bento, e das alunas Anna Paula Sandes e Gérsica Sanches, torna essa obra um documento magistral para a posteridade, porque não apenas leram e escreveram sobre uma história do passado, mas têm a oportunidade de viver, diariamente, a história de outros monges, estes ainda vivos, que desejam construir uma história de vida e de santidade, certos de que 
perseverantes são aqueles que experimentarem o sono reparador dos que partiram, até o momento propício da ressurreição.

Que a luz da história de nossos predecessores, nas terras da Bahia, nos leve ao Amado e, n'Ele, a todos os que constroem conosco uma vida muito além da vida, em busca do Tesouro que não se acabará jamais.

Que o Cristo nos conduza, juntos, para a vida eterna (RB 72,12), como nos ensinou nosso santo Patriarca, a exemplo do que aconteceu com nossos antepassados.

Salvador, 21 de março de 2009

Festa do Trânsito de São Bento

Dom Emanuel d'Able do Amaral, OSB

Arquiabade do Mosteiro de São Bento da Bahia 


\section{INTRODUÇÃO}

Na seqüência desta obra, apresentam-se os resultados finais obtidos pelo projeto intitulado Dietário (1582-1815) do Mosteiro de São Bento da Bahia: edição diplomática. Tal pesquisa, em nível de pós-doutoramento, esteve vinculada ao Programa de Pós-Graduação em Letras e Linguística da UFBA, sob a supervisão institucional da Profa. Dra. Célia Marques Telles, e contou com o apoio financeiro da FAPESB. Este trabalho, no entanto, resulta da continuação de um trabalho há muito iniciado por Dom Gregório Paxião, OSB, monge do Mosteiro de São Bento da Bahia.

Foi realizado em sala contígua ao Setor de Obras Raras do Centro de Documentação e Pesquisa do Livro Raro, na Biblioteca Histórica do Mosteiro de São Bento da Bahia, com infraestrutura disponibilizada pelo próprio Mosteiro.

Contribuiram também, de forma decisiva, para este trabalho, Anna Paula Sandes de Oliveira e Gérsica Alves Sanches, bolsistas PIBIC/FAPESB/UFBA, ambas sob a orientação da Profa. Dra. Alícia Duhá Lose.

O presente trabalho debruçou-se sobre o documento manuscrito em um volume, composto de 154 fólios escritos em recto e verso, Dietario das vidas e mortes dos Monges, q' falecerão neste Mosteiro de S. Sebastião da Bahia da Ordem do Principe dos Patriarchas S. Bento ${ }^{1}$, que relata, brevemente, a vida e a morte de cada um dos monges que viveram e morreram nessa instituição religiosa, sendo organizado conforme a ordem cronológica de falecimento dos monges.

A narrativa inicia em 1582, um ano após a fundação da instituição religiosa, e encerra em 1815. Dessa maneira, acredita-se na importância desse estudo no que diz respeito à ampla contribuição para a Linguística Histórica, ao disponibilizar dados que permitem o acesso a um discurso linguístico do período, e para a História, por possibilitar o contato com um discurso tão abrangente, que nesse texto revela o cotidiano da instituição religiosa e, de certo modo, da cidade do Salvador.

O hábito de registrar as histórias de vida dos antecessores religiosos é compartilhado entre muitos mosteiros seculares, sendo que, para os monges, esse documento desempenha a função primordial de legar à própria comunidade a memória

\footnotetext{
${ }^{1}$ Ao longo do trabalho, referir-se-á ao documento apenas como Dietario, em virtude da extenção do seu título.
} 
daqueles predecessores, entendendo essa prática como reverência aos mais velhos, associando-a ao sufrágio dos mortos, momento em que se ora pelos monges falecidos.

Tendo em vista que o Dietario consiste numa narração histórica, feita em ordem cronológica, pode-se compreendê-lo como uma crônica, de acordo com a definição proposta por Massaud Moisés, no Dicionário de termos literários (1974).

$\mathrm{O}$ registro era (e ainda hoje é) feito por monges que exerciam a função de cronista ou arquivista, normalmente monges mais velhos, considerados sábios e de conduta admirável, cabendo a eles descrever a vida dos monges que falecessem.

No Mosteiro da Bahia, o Dietario é, ainda hoje, diariamente lido durante a refeição da noite, instante em que os religiosos afastam-se, momentaneamente, das suas obrigações e reúnem-se a fim de alimentar o corpo físico.

De posse de um documento tão rico em informações, efetuou-se a transcrição do texto, atentando-se para as normas de edição conservadora exigidas em tal caráter de edição. Esse empreendimento foi feito em atendimento à solicitação do monge Dom Gregório da Paixão, OSB, atual bispo auxiliar da Arquidiocese de Salvador.

$\mathrm{Na}$ tentativa de preservar o documento, iniciou-se, há quase 80 anos, um trabalho de edição por Dom Clemente da Silva Nigra, bibliotecário do Mosteiro por volta da primeira metade do século XIX. Esse monge promoveu uma transcrição manuscrita do documento utilizada para leitura diária no refeitório. Tal transcrição preservou, de maneira geral, todas as características intrínsecas do texto (2007).

Em meados da década de 80, o monge Dom Gregório da Paixão, OSB, datilografou a transcrição manuscrita produzida por Silva Nigra e, depois, digitou a sua versão datilografada. Assim, é preciso sinalizar que os monges que realizaram tais trabalhos visavam conservar todas as características do original, mesmo não tendo o conhecimento dos princípios filológicos.

Ao tratar do documento, torna-se indispensável explicitar que se trabalha com a hipótese de o texto manuscrito original ter cinco scriptores distintos, pelo fato de a função de cronista ter duração variada e pela identificação das peculiaridades Linguísticas e gráficas de cada scriptor, assim como pelas variações no tracejamento das letras e pela disposição da mancha escrita em cada fólio.

O trabalho em questão promoveu a transcrição do Dietario a partir do cotejo entre a versão digitada, elaborada e fornecida por Dom Gregório Paixão, e o original manuscrito, digitalizado para leitura. A partir daí, nascerão dois tipos diversos de edição. A primeira - edição esta que se apresenta agora - é a diplomática, na qual não 
serão desdobradas as abreviaturas, que são apresentadas na sua disposição gráfica original, no de diz respeito ao uso de sinais e a sobrescrita. No entanto, esta edição apresenta uma completa lista de abreviaturas e seus respectivos desdobramentos. A segunda edição apresentará uma versão modernizada do texto, realizada a pedido dos monges, para ser publicada em livro, divulgando, assim, para o público não especializado, a história do Mosteiro. 


\section{OS MOSTEIROS BENEDITINOS}

Por ser o Mosteiro baiano a continuação milenar da história beneditina, iniciada por São Bento no ano 480 d.C., os monges beneditinos da Bahia são autênticos herdeiros da tradição bibliográfica (produção e conservação), possuindo, em seus arquivos, grandes raridades em livros e manuscritos do Brasil.

Sabe-se que, na Idade Média, Vivarium, na Calábria (Itália), é o primeiro mosteiro a ser identificado com o livro. $\mathrm{Na}$ época, o Mosteiro era dirigido pelo romano Cassiodoro, que achava que os mosteiros deveriam abrigar a produção literária da Antiguidade, por isso redigiu para os monges copistas algumas regras de transcrição e ortografia, que perduraram por séculos. O acervo contava com uma centena de códices. No entanto, foi o Mosteiro de Monte Cassino (529 d.C.), fundado pelo próprio São Bento, que marcou o início do movimento sistemático de editoração medieval.

Seguindo essa tradição, o Mosteiro de São Bento da Bahia, o primeiro das Américas, possui uma Biblioteca com 300 mil volumes, inaugurada juntamente com o Mosteiro em 1582, e conserva um Arquivo com centenas de milhares de documentos raros, de suma importância para a história da Bahia e do Brasil. Em função disso, possui o segundo maior acervo de documentos e livros raros do Brasil, cujas obras antigas constituem, depois da Biblioteca Nacional, o mais importante acervo de obras raras do Brasil.

Esta edição se inicia com um pequeno histórico do Mosteiro de São Bento da Bahia, posto que o texto que se está editando, está diretamente envolvido e faz parte desta história. Pelo mesmo motivo, traça-se um rápido perfil de São Bento, fundador da Ordem e que redigiu a Regra pela qual se pautam até hoje todos os mosteiros beneditinos do mundo. 


\subsection{O PRIMEIRO MOSTEIRO BENEDITINO DO NOVO MUNDO}

Desde 1575, monges beneditinos portugueses foram enviados às terras brasileiras para avaliar a possibilidade concreta da fundação de um mosteiro em terras d'além mar. O local indicado seria a Cidade de São Salvador da Bahia, devido aos insistentes pedidos da população local.

Em 1580, o Capítulo Geral da Congregação Lusitana da Ordem de São Bento aprovou a fundação de um Mosteiro de São Bento na Bahia, o qual viria a ser o primeiro de todo o Novo Mundo e um dos primeiros fora da Europa.

Os monges fundadores, em número de nove, chegaram à Bahia na Páscoa de 1582, fixando-se num terreno fora da cidade, onde já havia uma pequena ermida dedicada a São Sebastião.

No ano de 1584, o Mosteiro foi elevado à condição de Abadia com o designação de São Sebastião da Bahia, mas, popularmente, ficou conhecido como Mosteiro de São Bento da Bahia. As características físicas do edifício monástico, assim como suas atividades, começavam a ser estruturadas e definidas, concorrendo para isso o trabalho dos monges e a colaboração de benfeitores como Francisco Barcellon e Gabriel Soares, Catarina Paraguaçu, Garcia D’Ávila, dentre outros.

Pautando-se pela Regra de São Bento (texto escrito no séc. VI), as atividades dos monges se desenvolveram de forma gradativa e contínua. Com a consolidação do Mosteiro da Bahia, em torno de 1586, surgiram solicitações de novas fundações por parte da população de outras cidades da Colônia. Os monges baianos partem para fundar novos mosteiros nas cidades de Olinda (1586), Rio de Janeiro (1590) e São Paulo (1598).

No ano de 1596, o Mosteiro da Bahia recebe o título de Arquicenóbio do Brasil. Cria-se a Província Brasileira da Congregação Lusitana, tendo como Casa Geral a Abadia de São Sebastião da Bahia. Outros mosteiros são elevados à condição de Abadia: Olinda e Rio de Janeiro (1596) e São Paulo (1635).

Em 1624, a Cidade de Salvador foi invadida por tropas holandesas e o Mosteiro foi transformado em quartel militar holandês. O relato deste fato se acha de forma marcante logo no início do Dietário: 
Neste $m^{m o}$ anno, quando o Monstr ${ }^{o}$ já contava quarenta annos de fundação, invadirão os Olandeses esta terra, e como erão uma infernal mistura de Luteranos, e Calvinistas, e prim. ${ }^{\text {ro }}$ objecto de suas dannadas intenções, foi o total estrago dos templos sagrados, aos quaes ao depois de roubados, e saqueados os arrasarão, deixando tudo assolado, e destruido; os Religiosos $p .^{a}$ salvarem as vidas, se retirarão $p^{a}{ }^{a}$ o Certão, aonde padecendo $\mathrm{m}^{\text {tas }}$ necessidades, lamentavão a total destruição de um Mostr ${ }^{\circ} q$ 'tanto lhes custara, assim andarão até q' as armas portuguesas, e castelhanas triunfando destes mortaes inimigos da fé catholica, os poserão em vergonhosa retirada no seguinte anno de 1.625.

Os monges refugiaram-se nos engenhos do Recôncavo até a retirada dos holandeses, quando a vida monástica retoma o seu curso com o regresso dos religiosos e a recuperação das instalações do Mosteiro, como também sua ampliação.

No século XVIII, quando uma grande peste assolou a Cidade, exterminando grande número de pessoas, parte do Mosteiro foi transformado em enfermaria para o atendimento dos doentes.

No século XIX, em 1827, a então Província Brasileira ganha autonomia em relação à Congregação Lusitana, tornando-se a Congregação Brasileira da Ordem de São Bento, tendo como Casa Geral a Abadia da Bahia. A partir de 1855, o Mosteiro de São Bento da Bahia e os demais mosteiros brasileiros viveram dias de trevas, quase sendo extintos por falta de religiosos, devido à perseguição empreendida pelo governo imperial, que fechara os noviciados das Ordens Religiosas no Brasil, aos moldes de Pombal, em Portugal.

Na segunda metade do século XIX, os monges foram arautos da abolição da escravatura no Brasil. Em 1867, o Abade Geral da Bahia determinou a libertação de todos os escravos da Ordem de São Bento no Brasil, assumindo as consequências deste ato: o comprometimento considerável da economia do Mosteiro e ainda a hostilidade e a perseguição política dos grandes senhores da época, que tentavam, a todo custo, sufocar o movimento abolicionista. Também no século XIX, novamente o Mosteiro cedeu parte de suas instalações, transformadas em enfermaria, para abrigar os feridos e mutilados na guerra de Canudos.

Com a queda do Império e a Proclamação da República, o Abade Geral da Bahia, Frei Domingos da Transfiguração Machado, escreve ao Papa Leão XIII, pedindo o envio de monges europeus para assegurar a existência da Ordem Beneditina em terras brasileiras. Acolhido o pedido, os monges alemães da Congregação de Beuron foram 
enviados, chegando ao Mosteiro da Bahia em 1899. Retoma-se a vida conventual com novo fervor.

O Mosteiro de São Bento da Bahia, com sua presença multissecular no cenário cultural baiano e brasileiro, destaca-se como instituição plenamente inserida no desenvolvimento local e regional através da promoção e preservação das artes, da cultura e do saber.

Desde sua chegada à antiga capital da América portuguesa, nos idos de 1581, a ordem beneditina tem sido co-participante da história da Cidade, tanto nos seus avanços mais significativos quanto nas vicissitudes que se impuseram ao longo do tempo.

O Mosteiro de São Bento da Bahia, tendo mais de quatro séculos de tradição e história viva, constitui espaço privilegiado para a produção e difusão do conhecimento. Guardião do tempo e da memória, através de regras determinadas no séc. VI por seu fundador, São Bento, o Mosteiro possui um rico acervo constituído de documentos manuscritos que datam desde o séc. XVI. Entre eles encontram-se: bulas papais, cartas de profissão dos monges, sermões, documentos relativos à vida privada do Mosteiro, documentos de grandes personalidades como Catarina Paraguaçu, Gabriel Soares e Diogo Álvares, Garcia d'Ávila, cartas de alforria de escravos, documentos de compra e venda de escravos, documentação relativa às propriedades de toda a região metropolitana de Salvador, livros de pedidos de oração, e o Dietario das vidas e mortes dos Monges, q' faleceráo neste Mosteiro de S. Sebastião da Bahia da Ordem do Principe dos Patriarchas $S$. Bento - documento encadernado em um volume, que relata a história de cada monge que passou pelo Mosteiro de São Bento da Bahia, desde a sua fundação, em 1581, até 1815 .

O Mosteiro não apenas se constitui em guardião de todo este acervo raro, mas foi palco, cenário e personagem de inúmeros acontecimentos históricos importantes para a história da Bahia e em especial para a cidade de Salvador. Desde a sua fundação, os monges beneditinos são guardiões da história e da tradição de São Bento.

\subsection{SÃO BENTO}

As informações biográficas documentais a respeito de São Bento não são abundantes. O relato mais aceito é a curta biografia escrita por São Gregório Magno, em 
cerca de 593 d.C., dada à luz em um livro conhecido por Diálogos. Esta falta de informações sobre ele, de acordo com Dom Gregório Paixão, OSB (1886, p. 29), provavelmente,

[...] se deve ao fato de que São Bento não tomou parte em nenhum acontecimento importante do seu tempo, quer político, quer eclesiástico, a causa principal foi a sua humildade. Quis permanecer no silêncio. Escreveu a sua regra e a entregou aos discípulos, escondendo-se nas sombras do esquecimento.

Embora São Gregório, em seu livro, preocupe-se mais com fatos exemplares da vida de São Bento e deixe de fora informações biográficas relevantes, sabe-se que São Bento, Patriarca dos monges do Ocidente, nasceu por volta de 480 em Núrsia, pequena cidade da Úmbria, no Império Romano. Ainda jovem, fez-se monge eremita, inspirado pelos grandes vultos do movimento monástico que se formara no Egito e na Palestina, cerca de 200 anos antes. Depois de fundar 12 pequenos mosteiros na cercanias de Subiaco, proximidades de sua gruta de eremita, partiu para Monte Cassino, onde fundou o célebre mosteiro do mesmo nome. Ali escreveu a famosa Regra dos Mosteiros. A partir daí, os beneditinos se expandiram em toda a Europa, fundando centenas de mosteiros que seguiram, e seguem até hoje, a Regra de Bento.

A Regra de São Bento foi a grande norma espiritual da Idade Média e condicionou a transformação da Europa em ponta de lança da civilização do Ocidente e do mundo. Por esta razão São Bento foi proclamado Padroeiro da Europa pelo Papa Paulo VI, em 1964. (SÃO BENTO, 1993, prefácio)

Esta regra, composta há 15 séculos, já foi objeto de incontáveis traduções e estudos, pois

\begin{abstract}
A vida religiosa, as instituições monasticas, desde sua origem, tiveram a estima, o respeito e a veneração dos povos. [...] O monachismo representava o mais alto esforço pela realização do ensino [...], o exemplo mais compacto e integral da pureza e efficacia dessa boa nova que vinha remir o mundo; não era, pois de surprehender, que o mundo o reverenciasse. (CHÉRANCÉ, 1910 , p. v)
\end{abstract}

Os primeiros religiosos, assim como se dá até hoje,

Longe de evitarem a companhia dos outros christãos, [...] personificavam ou creavam em torno de si toda uma sociedade christan. Longe de pensarem só em sua salvação, trabalhavam, sem descanço, primeiro na salvação dos infieis, depois na conservação da fé e dos costumes nas christandades novas 
nascidas de sua palavra. Longe de se limitarem á oração ou ao trabalho manual, cultivavam e propagavam com ardor toda sciencia e literatura que possuia o mundo de seu tempo. Os lugares apartados a que os levara no principio o amor da solidão, transformavam-se rapidamente, e como pela força das coisas, em cathedraes, em cidades, em colonias urbanas ou ruraes, destinadas a servir de centros, de escolas, de bibliotecas, de officinas, de cidadellas para as familias, os bandos, as tribus convertidas aos poucos. Em torno dessas cathedraes monasticas e das principaes communidades, formaram-se logo cidades que duraram até hoje [...] (MONTALEMBERT, [18--?], p. 152 apud CHÉRANCÉ, 1910, p. vii-viii).

Desta forma, tem-se a vida religiosa intricada à vida cultural de toda a sociedade ocidental.

A Regra de São Bento vem sendo seguida há mais de mil e quinhentos anos sem interrupção, nas mais diferentes culturas, com as adaptações necessárias às situações particulares. Embora distante, pelos anos, da sociedade atual, não perdeu sua vitalidade [...] (PAIXÃO, 1996, p. 48). 


\section{DIETARIO DAS VIDAS E MORTES DOS MONGES, Q' FALECERÁO NESTE MOSTEIRO DE S. SEBASTIÃO DA BAHIA DA ORDEM DO PRINCIPE DOS PATRIARCHAS S. BENTO}

O Dietario traz informações sobre a história do Mosteiro, desde a sua fundação, em 1581, até o ano de 1815. Esta história é contada através do resumo da vida de cada um dos monges que passou por ali ao longo desses anos. Esse documento continua sendo escrito até os dias atuais, no entanto, o volume que ora se edita é o mais antigo e, por isso, o mais importante dos existentes, pois a narrativa que segue sendo escrita se apresenta agora em papel moderno (no formato ofício ou A4, alcalino) e tendo seu texto datilografado e depois digitado.

\subsection{HISTÓRIAS E PECULIARIDADES RELATADAS NO DIETARIO}

Ao longo dos 154 fólios que compõem o Dietario das vidas e mortes dos Monges, q' faleceráo neste Mosteiro de S. Sebastião da Bahia da Ordem do Principe dos Patriarchas S. Bento aparecem histórias comuns e histórias surpreendentes. Ao início dos relatos, lê-se a seguinte advertência:

Em cumprim. ${ }^{\text {to }}$ ao decreto do $\left\langle\uparrow>\left[\uparrow S S^{m o}\right] P^{e} .^{e}\right.$ Urbano oitavo, protesto $q$ ' nestas vidas de Monges, $q$ ' escrevo, $q .{ }^{d o}$ referir algum caso milagroso, algum beneficio especial de Deos; e quando disser, q' passarão a Bemaventurança, e da m. ${ }^{\text {ma }}$ sorte quando fallar algumas veses nesta palavra Santo, $q$ ' tudo isto he disendo respeito - aos costumes, $e$ nas acções, e não as pessõas, e q' tambem não paraq' se lhe dẽ outro credito, mais do que aquelle, que mereceo a fé humana.

O tom de todo relato é de bastante comoção religiosa. Os monges são elencados por ordem cronológica de falecimento, relatando-se, de forma breve, a vida e as obras religiosas de cada um; indicando local de nascimento, de profissão, suas funções na vida monástica, motivos de sua morte e os detalhes de seus últimos momentos; assim como a data de sua morte e o nome do Abade da época em questão. 
Acrescentam-se a isso, em alguns momentos, narrativas mais alongadas quando há casos peculiares a apresentar, a exemplo do relato da vida do monge que foi expulso por 3 vezes e por 3 vezes foi readmitido no Mosteiro; o do monge que deixa a casa monástica para juntar-se a uma mulher; o do monge que, adiantado em anos, apresentava sinais de esclerose e protagonizava cenas quixotescas, como a que se destaca a seguir:

O vigesimo terceiro foi o P. Fr. Agostinho da Piedade nascido em Portugal, e professo nesta caza. [...] Da Itapoam foi removido p. ${ }^{a}$ a Capella de N. S. da Graça neste tp. ${ }^{\circ}$ pertencente a este Mosteiro, achava-se ja adeantado em annos, e destituido de forças

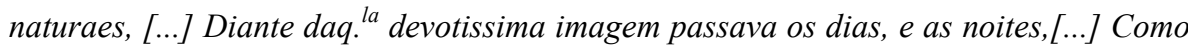
neste $t p^{o}$ corrião os necessitados, e aflictos [...] aquelles $q^{\prime} p^{r}{ }^{r}$ impossibilitados não podião ir implorar o socorro daquela soberanissima Rainha do Anjos mandarão pedir ao P. Fr. Agostinho o menino, q' a S. sustenta em seus braços; o P. tirando-o com toda a reverencia, o entregava com toda a decencia, a $q .{ }^{m}$ lho pedia; porem como algumas vezes se não lembrava, do q' fazia, p. ${ }^{\text {la }}$ continua oração em $q$ ' andava, e $p^{\text {los }} m^{\text {t.os }}$ annos $q$ ' tinha, $q .{ }^{\text {do }}$ voltava $p^{a}$ a Igreja, e via a falta do menino nos braços da Sr. ${ }^{a}$, ficava como louco, e olhando p. $^{a}$ os outros altares, vendo, $q$ ' o menino não estava na Igreja, com as lagrimas nos olhos, sahia pellas visinhanças, formando queixas de que tinha desaparecido o menino dos braços de sua Mãy Santissima, e que elle não se lembrava a $q{ }^{m}$ o tinha dado, perguntando com as palavras da Esposa $S^{\text {ta }}$ a todos os que encontrava se sabião a onde estava o amado da sua alma? Quem o tinha logo o entregava compadecido daquella virtuoza sincerid. ${ }^{e}$ ' so se empregava em couzas Santas. Quando ja o P. ${ }^{e}$ se via na posse daq. ${ }^{\text {e }}$ celestial Tesouro, contente, alegre, saudozo corria a levar a Snr. ${ }^{a}$ a noticia de q' tinha aparecido a joia mais precioza dos seus santissimos braços; punha-o no altar e ao depois de lhe dar repetidos osculos nos pes, e de o adorar com reverentes genuflexoens, $p^{a}{ }^{a}$ explicar a saud. ${ }^{e}$ em $q^{\prime}$ o tinha posto a sua auzencia, lhe tomava uma amoroza satisfação de se ter auzentado da Igreja, exid. ${ }^{\circ}$ a companhia de sua May Santissima, $q^{\prime}$ com t..$^{\circ}$ gosto o tinha em seus braços, e nelles o tinha levado.$^{r}$ terras destantes, e caminhos trabalhozos $p .^{a}$ o livrar da morte $q$ ' lhe queriao dar os seus inimigos, e elle agora lhe fugia todas as vezes, q' queria. Reprehend. ${ }^{\circ}$ o menino com estas, e outra suavissamas palavras, que elle sabia compor, o restituia ao seu deliciozo Trono, q' erão os braços da Snr. ${ }^{a}$, e ajoelhado em terra se despedia satisfeito. [...] 
Outro relato interessante, que apresenta um toque fantasioso, é o da vida do Padre Frei Ambrozio do Espirito Santo:

[...] Deste Monge se contão alguns casos que lhe accontecerão revestidos de umas circunstancias que parece lhe diminuem o credito. [...] O primeiro caso, he, que [...] huma noite estando conversando uns moradores da terra, que era mal assombrado o caminho por onde se subia para uma alta Penha na qual estava uma Ermida de N. S. ${ }^{\text {ra }}$ O P. ${ }^{e}$ ouvindo a conversa para os tirar daquelles prejuisos, disse que elle iria a aquellas horas ate o mais alto da Penha onde estava a Ermida, e para signal tocaria o sino da mesma capela, e sem mais demora se poz a caminho, porem a poucos passos se encontrou com um espantozo vulto, que mudando-se em varias formas o fora accompanhando ate o lugar destinado; chegou a capela e querendo tocar o sino, achou embaraçado na corda outro vulto de mais horrenda figura que o primeiro; sempre lançou mão da corda e tocou o sino, porem ao mesmo tempo aquelle animal immundo o impelio com tanta força, e violencia, que no mesmo instante veio pelos ares cahir a porta da mesma casa aonde o estavão esperando: admirados todos de verem o P. ${ }^{e}$ junto a si logo que ouvirão o sino, elle sem turpação alguma lhes referio o que havia passado. Dizia o dito $P^{e}{ }^{e}$ que N. $S^{\text {ra }}{ }^{\text {com aq. }}$ se apegara quando lançou mão a corda, o livrara de algum grande perigo que lhe podia succeder; e este he o unico e sufficiente motivo que nos pode persuadir a darmos credito ao successo referido.

Seguindo-se este relato, e em diversos outros, percebe-se uma tendência ao milagroso, como são os casos de diversos monges que foram surpreendidos pelos irmãos mortos que voltavam, por vezes, para pedir oração, perdão ou, simplesmente, desculpas. Veja-se o que se escreve sobre isso ainda no relato da vida do P. F. ${ }^{\text {r }}$ Ambrozio do Espírito Santo:

O segundo caso foi: que não podendo este Religiozo em uma noite adormecer se levantara pelas 11 horas, e sahira para um eirado que ficava perto de sua cella aonde costumavão conversar $o^{2}$ Religiozos nas horas permitidas, e vendo que estava la outro Religiozo, se chegara a elle a saber quem era, e conhecendo ser um Monge que havia

\footnotetext{
${ }^{2}$ Realmente, no original, não há concordância de número; o artigo está no singular e o substantivo está no plural.
} 
dias tinha morrido, lhe perguntara que vinha ca buscar, ao q'o defunto respondeo que vinha solicitar o perdão de uma restituição em que estava a hum Religiozo de um pouco de dinheiro que achara dentro em uma bolsa que lhe cahira indo elle para a horta em uma tarde dispensada, e como não restituiu e nem pedio perdão em vida, agora por divina permissão vinha fazer esta diligencia. $O P^{e}{ }^{e}$ tomando por sua conta o seo disencargo foi dar parte ao Prelado e ao Religiozo do que tinha passado, e conseguido o perdão de um e outro voltou com a resposta ao defuncto o q. ${ }^{l}$ ao depois de lhe agradecer o beneficio que lhe fizera desaparecera. O terceiro caso, he, que a este Religiozo veio pedir um Monge falecido, que quizesse o accompanhar no coro a rezar o officio Divino pelas faltas que nelle tinha commettido, por se não inclinar ao Gl. Patri na forma que devia, e que o $P^{e}{ }^{e}\left[\right.$ 个ao $q$ o $P^{e}{ }^{e}$ ] annunindo propoz-se fazer $<$ de um $>$ [ 个no espaço de um] anno desde huma hora da noite ate as duas, [个-e depois disso deixou de assistir o religiozo [ $\downarrow$ fallecido a essas obrigações] [...]

A maioria dos relatos constantes nos 154 fólios do Dietario, no entanto, denota que as vidas ali relatadas eram de pessoas simples, trabalhadoras e que pregavam incondicional obediência à Regra de São Bento e aos ensinamentos de Deus, vivendo uma vida regrada e plena de sacrifícios (cilícios, orações, penitências etc.) e de muito trabalho em função da comunidade monástica e em função do próximo. Através do Dietario, compreende-se um pouco mais desta instituição multissecular, espalhada pelos quatro cantos do Mundo, que é a Ordem de São Bento.

\subsection{EDIÇÃO DO DIETARIO}

\subsubsection{Histórico da edição}

O Dietario é um documento de uso quotidiano nos mosteiros. Ele relata a história do Mosteiro de São Bento da Bahia e da própria Bahia, através do resumo da vida de cada um dos monges que passou por ali ao longo dos séculos. 
Há um costume milenar, na vida dos mosteiros, que ainda perdura em nossos dias que consiste em ler, diariamente, o relato da vida dos monges que faleceram naquele mosteiro.

Atualmente, no Mosteiro de São Bento da Bahia, esta atividade ocorre durante a refeição da noite. O monge que ocupa a função de "leitor" lê para os demais o relato da vida dos monges que faleceram, ao longo dos séculos, naquele dia do mês. Ao final da leitura, são mencionados os monges, cujo aniversário de morte ocorre no dia seguinte. Isso é feito para que constem já das primeiras orações dos irmãos no dia seguinte.

A prática de redação e da leitura deste tipo de documento remonta aos primeiros séculos de existência dos mosteiros beneditinos. No caso do Dietario do Mosteiro de São Bento da Bahia, essa leitura diária foi feita, durante muitos anos, diretamente a partir do documento original. Sendo assim, em função do uso contínuo e com o passar do tempo, o documento, encadernado em um volume, foi ficando bastante desgastado.

Em virtude disto, pode-se dizer que este trabalho de edição, que ora se apresenta, foi iniciado há quase 80 anos, por um monge chamado Dom Clemente da Silva Nigra, OSB, que na época ocupava a função de bibliotecário do Mosteiro. Com o objetivo de poupar o volume origial, Silva Nigra procedeu a uma transcrição, ainda manuscrita, para uso diário no refeitório.

Em função deste objetivo, a edição feita por ele, que consta sob o número 336 do Arquivo Arquiabacial, está organizada por dia e mês, de acordo com o nosso calendário gregoriano, e não por ordem cronológica de morte de cada monge, a exemplo do volume original. Desta forma, na edição de Silva Nigra aparecem na mesma página, por exemplo, o quinto monge a falecer no Mosteiro de São Bento da Bahia e o ducentézimo oitavo quinto, pois faleceram, ambos, nos dias 5 e 6 de janeiro, respectivamente, porém, com a diferença de mais de um século entre uma morte e outra (Fig. 1). 


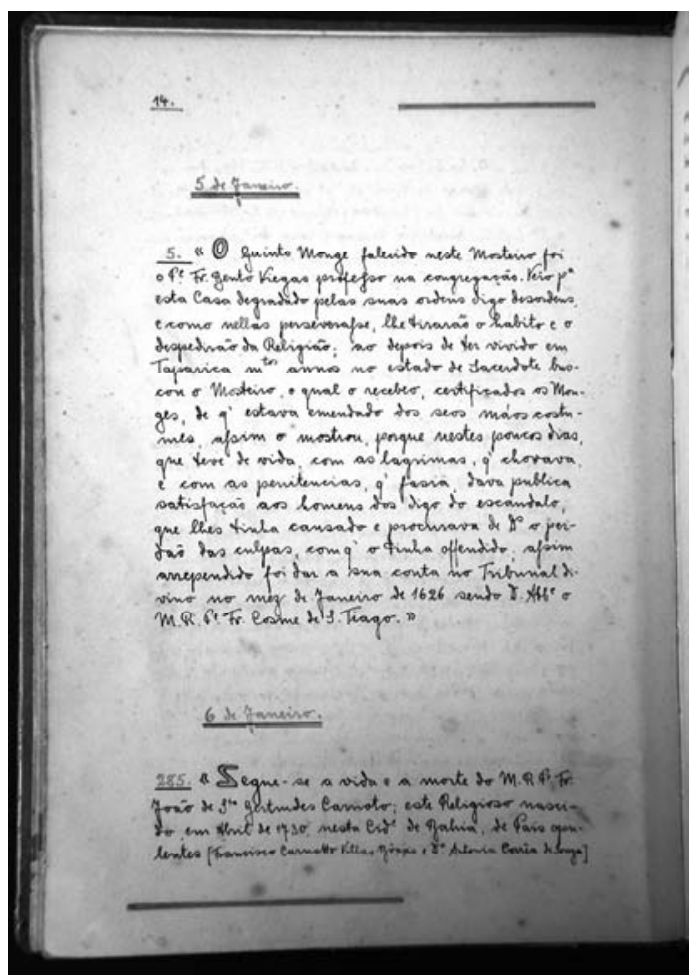

Figura 1: Página dos dias 5 e 6 de janeiro Fonte: Dietário (edição de Silva Nigra)

Nesta edição de Silva Nigra foram mantidas todas as abreviaturas e o texto foi transcrito na íntegra, reproduzindo, inclusive, o traçado das letras $(<\mathrm{s}>$ longo, por exemplo, quando o scriptor o utiliza) (Fig. 2) com exceção de alguns saltos-bordões.

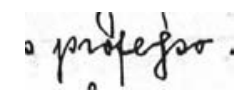

Figura 2: Palavra professo escrita com $<\mathrm{s}>$ longo e $<\mathrm{s}>$ curto Fonte: Dietário (edição de Silva Nigra)

No entanto, dela não constam o termo de abertura e de encerramento constantes do original. O título que lá se encontra também difere do título original: é bastante simplificado e faz referência à categoria que o Mosteiro passou a pertencer (Arquicenóbio), diferente daquela em que o documento original foi escrito (Fig. 3). 


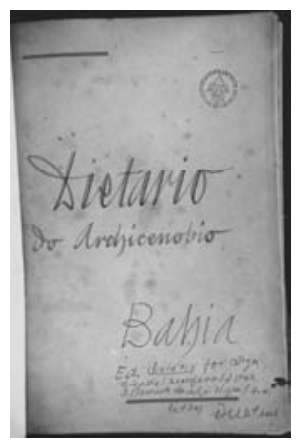

Figura 3: Título; folha de rosto

Fonte: Dietario (edição de Silva Nigra)

Em dissonância com todo esse cuidado e fidelidade ao documento original, ao longo de todo o volume (do Dietario original) encontram-se alterações feitas a lápis e a tinta - algumas com caneta hidrocor verde, igual à utilizada por Silva Nigra na sua edição -, além de vários comentários feitos às margens (Fig. 4 e 5).

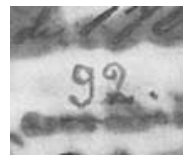

Figura 4: Alteração posterior feita a tinta Fonte: Dietario (original)

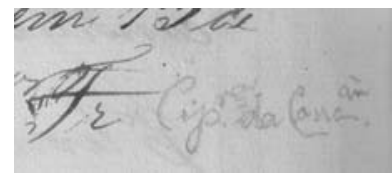

Figura 5: Anotação posterior feita a lápis Fonte: Dietario (original)

Ademais, foi inserida uma numeração de páginas. Todas as alterações, por sua vez, têm caráter de "correção gramatical” e "correção" de datas e dados. (Fig. 6)

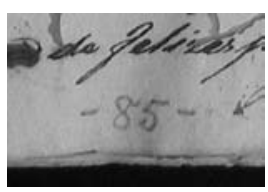

Figura 6: Numeração posterior inserida no documento Fonte: Dietario (original) 
Essas alterações, a princípio, foram atribuídas a Dom Clemente da Silva Nigra, entretanto, após ter-se conhecimento da separata, Igreja do Mosteiro de São Bento da Bahia: história de sua construção, e feitas algumas averiguações, surgiu uma dúvida quanto ao responsável pelas informações acrescidas posteriormente.

Atualmente, cogita-se a possibilidade de que Dom Mateus Ramalho Rocha, OSB, do Mosteiro do Rio de Janeiro, tenha procedido também a alterações, quando da sua estada no Mosteiro baiano, haja vista que ele, na citada separata, que é de sua autoria, repreende Dom Clemente da Silva Nigra por não ter atentado para as incoerências de algumas datas, nomes e de determinadas outras informações contidas no Dietario... Esta repreensão recai justamente sobre os elementos que estão alterados no documento original. Ademais, percebe-se na folha de rosto da edição de Silva Nigra a assinatura de Dom Mateus, cuja letra se assemelha muito à encontrada em interferências posteriores inseridas nos volumes da Coleção dos Livros do Tombo do Mosteiro de São Bento da Bahia, constantes também Arquivo do Mosteiro ${ }^{3}$ (Fig. 7).

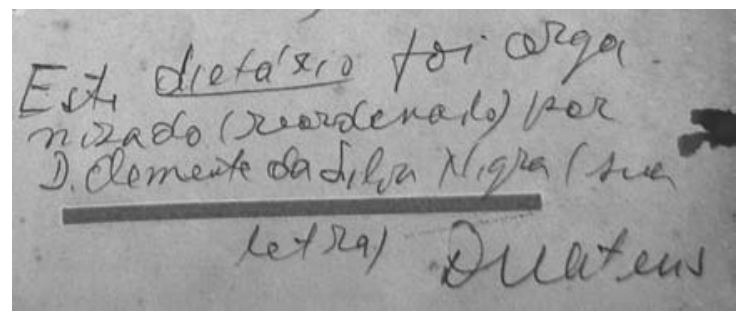

Figura 7: Comentário inserido por Dom Mateus Ramalho da Rocha; folha de rosto 4 Fonte: Dietário (edição de Silva Nigra)

Nos anos 80, um outro monge, Dom Gregório Paixão, OSB, datilografou o texto do Dietario..., também para cumprir a função de leitura diária, com base na transcrição manuscrita feita na década de 1930. Este documento é o Códice 493.1 do Arquivo do Mosteiro (Fig 8).

\footnotetext{
${ }^{3}$ Estes documentos estão sendo editados pelo mesmo grupo de pesquisa e contam com o apoio finacneiro da FAPESB e do Mosteiro, sob a coordenação da Profa. Dra. Alícia Duhá Lose, congregando uma equipe de nove pessoas até o momento.

${ }^{4}$ Transcrição: "Este dietário foi organizado (reordenado) por D. Clemente da Silva Nigra (sua letra) D. Mateus
} 


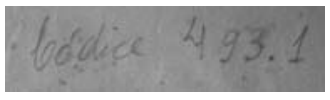

Figura 8: Indicação do número de tombo; folha de rosto

Fonte: Dietário (edição de Dom Gregório Paixão)

Nesta edição, o título do documento é alterado mais uma vez, atualizando a informação relativa à categoria que o Mosteiro passou a pertencer, mas trazendo de volta a informação de que ele trata "dos monges que faleceram no Aquicenóbio da Bahia" (Fig. 9).

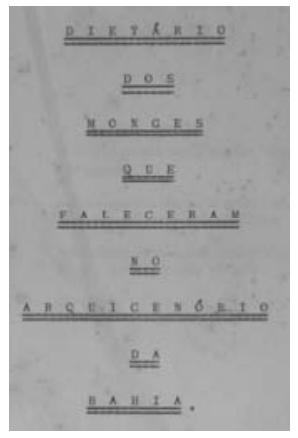

Figura 9: Título; folha de rosto Fonte: Dietário (edição de Dom Gregório Paixão)

Esta edição apresenta a mesma ordem dada por Dom Clemente da Silva Nigra, ou seja, obedece aos dias do mês e não à ordem cronológica de falecimento. No entanto, acrecidas às informações do original encontra-se uma lista das abreviaturas utilizadas tão somente - na edição (Fig. 10) e dois índices: um onomástico e outro de assuntos, o que facilita sobremaneira a busca de informações.

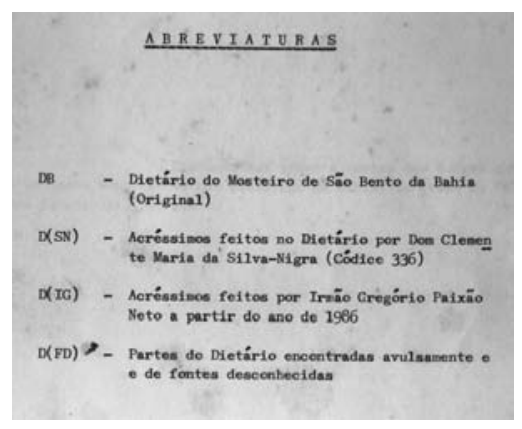

Figura 10: Lista de abreviaturas Fonte: Dietário (edição de Dom Gregório Paixão) 
Como se pode perceber pelas indicações da citada lista, tanto a edição de Dom Gregório Paixão, na época Irmão Gregório, como a de Dom Clemente da Silva Nigra atualizam informações que não são abarcadas pelo documento original (que se encerra em 1815). O Irmão Gregório separa, ainda, um dia do mês em cada página datilografada (Fig. 11), diferentemente do que faz Silva Nigra.

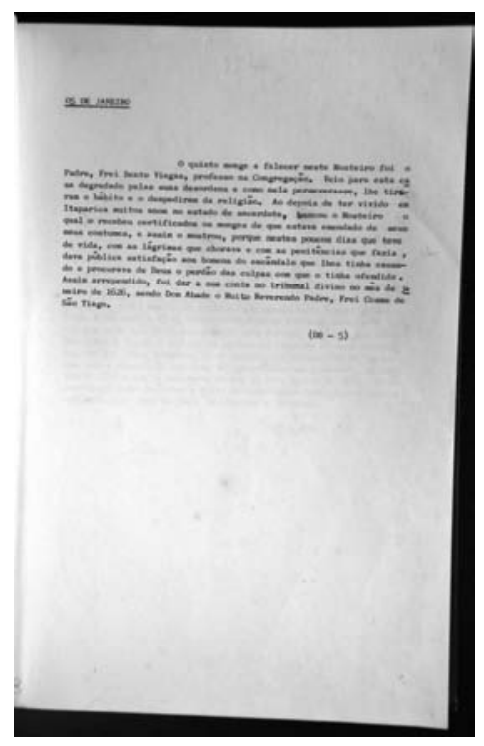

Figura 11: Fólio de 5 de janeiro Fonte: Dietario (edição de Dom Gregório Paixão)

Anos depois, esse mesmo monge, procedeu à digitação de todo o texto com base no material datilografado por ele. Desta vez, restituindo a ordem encontrada no documento original. Ambos os monges, embora sem conhecimentos filológicos, buscaram manter o texto na sua forma original, fazendo o que se poderia denominar de uma transcrição diplomática, não desdobrando, sequer, as abreviaturas. No entanto, em nenhuma das edições anteriores foi obedecida a disposição do texto na página, transcrevendo-se todas, em todas elas, em linha corrida.

Há cerca de um ano e meio, este último monge, atual Bispo Auxiliar de Salvador, solicitou a ajuda especializada para dar continuidade a esse trabalho de edição. Desde então, tem-se trabalhado nesse intuito, realizando as etapas que virão relatadas adiante. Posteriormente, foram incorporadas à equipe mais duas 
pesquisadoras, alunas do Curso de Graduação em Letras, em nível de iniciação científica. 


\subsection{DESCRIÇÃO EXTRÍNSECA ${ }^{5}$ DO MATERIAL: O DIETARIO} ORIGINAL

O Dietario das vidas e mortes dos monges, q' faleceráo neste Mosteiro de $S$. Sebastião da Bahia da Ordem do Principe dos Patriarchas S. Bento é o documento de número 155 do Arquivo Arquiabacial do Mosteiro de São Bento da Bahia (Arquiabadia de São Sebastião da Bahia), cujo responsável ocupa o posto monástico de Arquivista (Fig. 12).

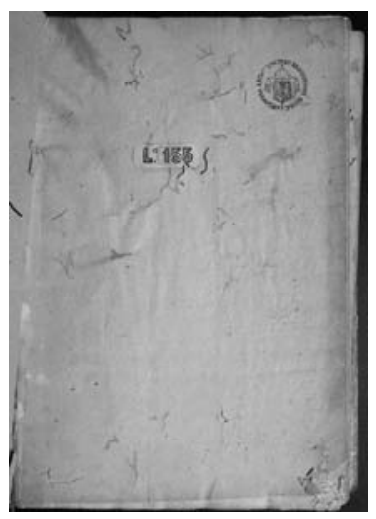

Figura 12: Falsa folha de rosto Fonte: Dietário (original)

O livro, com encadernação feita em percalina com bordas e lombada em couro, em um único volume (Fig. 13), data de época posterior (séc. XX).

\footnotetext{
${ }^{5}$ Entende-se como descrição extrínseca a apresentação minuciosa das características físicas da obra: tamanho do suporte e da mancha escrita, quantidade de fólios, tipo de letra, indicação de presença de letras ornadas e descrição das suas cacterísticas, tinta utilizada, quantidade de linhas escritas por fólio, estado de conservação do documento, indicação da presença de ornamentos e descrição das susas características, em suma, uma descrição detalhada das características externas da obra, deixando-se de fora, neste momento, o seu conteúdo e a sua língua.
} 


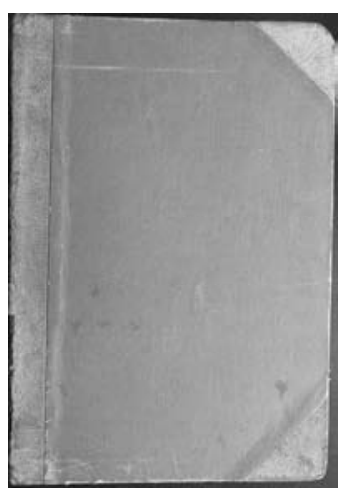

Figura 13: Encadernação

Fonte: Dietario (original)

Estranhamente, a encadernação da edição do Dietario elaborada por Silva Nigra é mais elegante que a do documento original (Fig. 14 e 15).
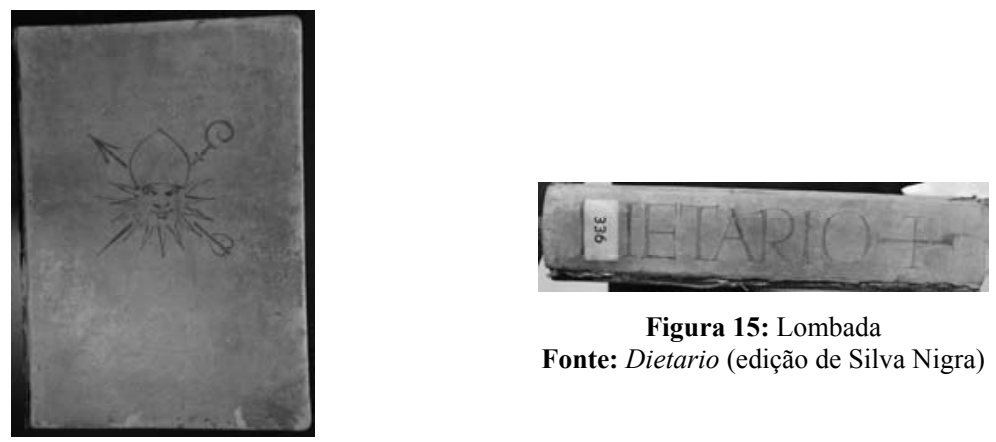

Figura 15: Lombada

Fonte: Dietario (edição de Silva Nigra)

Figura 14: Encadernação

Fonte: Dietario (edição de Silva Nigra)

A folha de guarda é verde, de um papel nada gracioso, como era de hábito em encadernações mais caprichadas. Em função de sua baixa qualidade, encontra-se bastante ressecado e quebradiço (Fig. 16). 


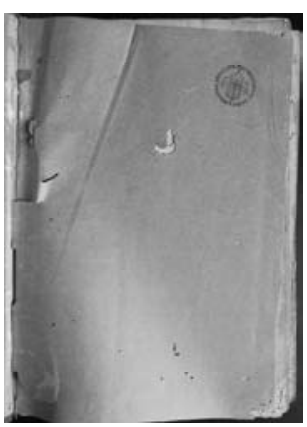

Figura 16: Folha de guarda Fonte: Dietário (original)

O documento apresenta 154 fólios escritos, em sua maioria, no recto e no verso, em tinta preta metalogálica, por vezes já descorada, e mais 32 fólios finais que não apresentam escrita. O papel, de gramatura média, apresenta uma bonita marca d'água, verjuras (Fig. 17).

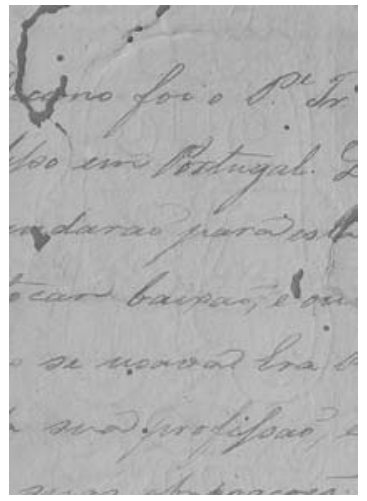

Figura 17: Marca d'água

Fonte: Dietário (original)

O volume sofreu a ação de insetos, encontrando-se, quase todos os fólios, com inúmeras falhas devido a cupins e brocas (Fig. 18).

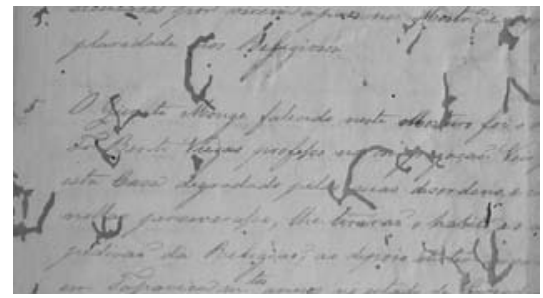


Figura 18: Fólio atacado por insetos

Fonte: Dietário (original)

Ainda, em diversos pontos, a tinta metalogálica corroeu o papel (Fig.19).

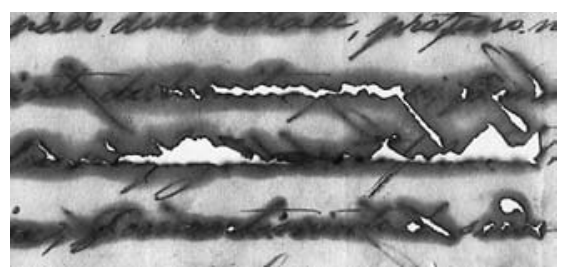

Figura 19: Corrosão causada pela tinta no documento Fonte: Dietário (original)

Nota-se também o escurecimento, por oxidação, de praticamente todo o suporte. Nos fólios finais do documento, a tinta utilizada desbotou consideravelmente, ganhando uma coloração amarelo-clara, o que também dificulta a leitura (Fig.20).

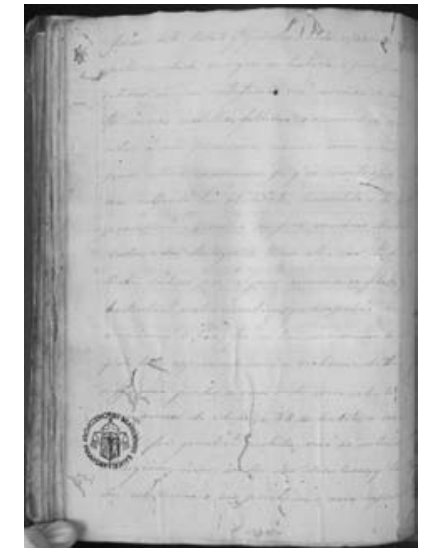

Figura 20: Tinta desbotada no documento Fonte: Dietário (original)

Boa parte dos fólios passou por um processo primitivo de restauro no qual se fazia a colagem de um papel de seda com cola comum por sobre o fólio original. Com o passar do tempo, este papel do suporte oxidou, o que o escureceu; e o papel de seda descolou do suporte, provocando bolhas de ar entre um material e outro, o que terminou por comprometer também a leitura (Fig.21). 


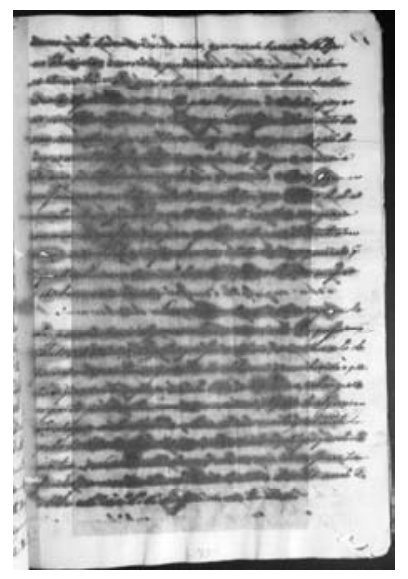

Figura 21: Restauro feito no documento Fonte: Dietário (original)

A relevância maior deste documento está no fato de que suas informações alcançam um período de cerca de 234 anos, relativos aos séc. XVI, XVII, XVIII e XIX, e embora referentes, todos, diretamente à vida dos Beneditinos da Bahia, trazem informações de caráter político, social, militar, econômico, genealógico, geográfico e histórico de grande importância para a história geral da Bahia e do Brasil.

\subsection{PROPOSTA PARA O TRABALHO DE EDIÇÃO}

Este documento será objeto de dois tipos diferentes de edição:

a) a primeira delas será uma edição diplomática, tendo critérios rigorosamente conservadores. Esta edição tem o objetivo de oferecer a especialistas dados linguísticos fiéis e completos. Esta se fará acompanhar de um levantamento detalhado das abreviaturas e das características da escrita de cada scriptor e de um breve estudo linguístico;

b) a segunda apresentará uma versão modernizada do texto do Dietario e está sendo realizada a pedido do próprio Mosteiro, com o intuito de divulgação do conteúdo do documento a um público mais amplo e para facilitar a sua leitura diária feita no refeitório da Abadia. 


\subsubsection{Critérios de Edição}

O trabalho que se realizou até o momento - e que agora está sob os cuidados de uma filóloga e duas alunas de Letras, em nível de iniciação científica - foi o cotejo da transcrição feita e fornecida já digitada em arquivo de Word por Dom Gregório Paixão, com o documento original, utilizando-se para isso os critérios de edição diplomática, adaptados às peculiaridades do documento. Além disso, fez-se, concomitantemente ao cotejo, o levantamento das características de cada um dos scriptores; uma descrição extrínseca do material e um estudo de todas as abreviaturas presentes ao longo do texto, destacando-as uma a uma e considerando-as nas suas especificidades, apontando, por exemplo, duas formas idênticas que, no entanto, divergem pela presença ou não de ponto.

Optou-se para este documento, em função dos objetivos estabelecidos, por uma lição conservadora, para qual foram utilizados os critérios expostos a seguir, elaborados de acordo com as necessidades surgidas ao longo das transcrições:

- respeita-se, dentro do possível, a disposição gráfica do texto na página. Para tal, toda a transcrição é feita dentro de tabelas em formato de arquivo .doc, o que evita desformatações acidentais. Tais tabelas deverão ser retiradas para a edição em formato digital;

- numeram-se as linhas dos fólios contando apenas aquelas preenchidas com escrita ou sinais muito particulares do scriptor. Desta forma, as linhas são numeradas de 5 em 5, a partir da primeira;

- a grafia original do texto é conservada na íntegra, mesmo nos casos em que fica claro o lapso do scriptor;

- as abreviaturas não são desdobradas na transcrição; no entanto, esta, como se disse, é acompanhada por um estudo detalhado das abreviaturas;

- na medida do possível, são respeitadas as separações e/ou ligações do documento original, no entanto, na maioria dos casos, o fato parece se dar simplesmente em função do processo de escrita da época, quando era hábito não levantar a pena do papel enquanto nela ainda houvesse tinta; 
- indica-se a partição silábica com o auxílio de hífen quando o scriptor assim o fizer, reservando-se o travessão maior para indicar o traço de preenchimento da linha, apenas quando este é utilizado no original; quando foi utilizado pelo scritor um hífen duplo (semelhante ao sinal de igualdade da matemática), assim este foi transcrito;

- observações adicionais do editor, por não serem numerosas, são expostas em notas de rodapé;

- notas marginais do scriptor são transcritas em fonte menor e nas suas respectivas margens, trabalho facilitado, na versão .doc, pelo uso de tabela;

- as alterações (rasuras, substituições, supressões etc.) realizadas ao longo da escrita (pelos próprios scriptores) são inseridas no texto da transcrição, utilizando-se para isso alguns operadores - por vezes tomados de empréstimo à crítica genética -, como os que se vêem a seguir:

$(\dagger)$ rasura ilegível;

[†] escrito não identificado;

(...) leitura impossível por dano do suporte;

/ / leitura conjecturada com base na leitura de Dom Clemente da Silva Nigra;

$<>$ supressão;

( ) rasura ou mancha;

$<\uparrow>$ supressão ilegível;

[ ] acréscimo;

$[\leftarrow]$ acréscimo na margem esquerda;

$[\rightarrow]$ acréscimo na margem direita;

[个] acréscimo na entrelinha superior;

$<>/ \backslash$ substituição por sobreposição; etc.

- na sua edição do documento, Silva Nigra e porteriormente Dom Matheus Ramalho da Rocha "dialogam" com o texto, inserindo algumas informações, corrigindo outras, colocando notas explicativas etc. Por se julgar estas informações por demais importantes para o conteúdo do textos, elas foram mantidas, utilizando-se para tal as seguintes indicações: APFL $=$ alteração posterior feita a lápis; $\mathrm{APFT}=$ alteração posterior feita a tinta; 
- da mesma forma, foi mantida a numeração dos fólios lançados posteriormente, por facilitarem, ao que parece, a localização dentro do texto. No entanto, como essa numeração se inicia apenas no fólio 2 recto, não há coincidência entre a contagem dos fólios e o número das páginas. Nesta edição, ambas aparecem indicadas;

- nos pontos em que a leitura foi impossível por dado no suporte, apresenta-se a transcrição feita por Silva Nigra, por ser a mais antiga e estar, portanto, cronologicamente mais próxima do original, que com o passar do tempo se desgasta cada vez mais. Nesses casos, informa-se em nota de rodapé o início e o final do trecho não cotejado.

\subsubsection{Etapas do trabalho}

São apresentadas a seguir a sequência das edições do Dietario. Para melhor compreensão, apresenta-se o mesmo fólio de cada uma delas: aquele em que são relatadas as informações biográficas do undécimo monge a falecer no Mosteiro, o Irmão Donado Frei Manuel, na seguinte seqüência:

1) documento original (Fig. 22);

2) edição de Silva Nigra (Fig. 23);

3) edição datilografada por Dom Gregório Paixão (Fig. 24);

4) edição digitada por Dom Gregório Paixão (Fig. 25);

5) edição preparada por Lose et al. (Fig. 26). 


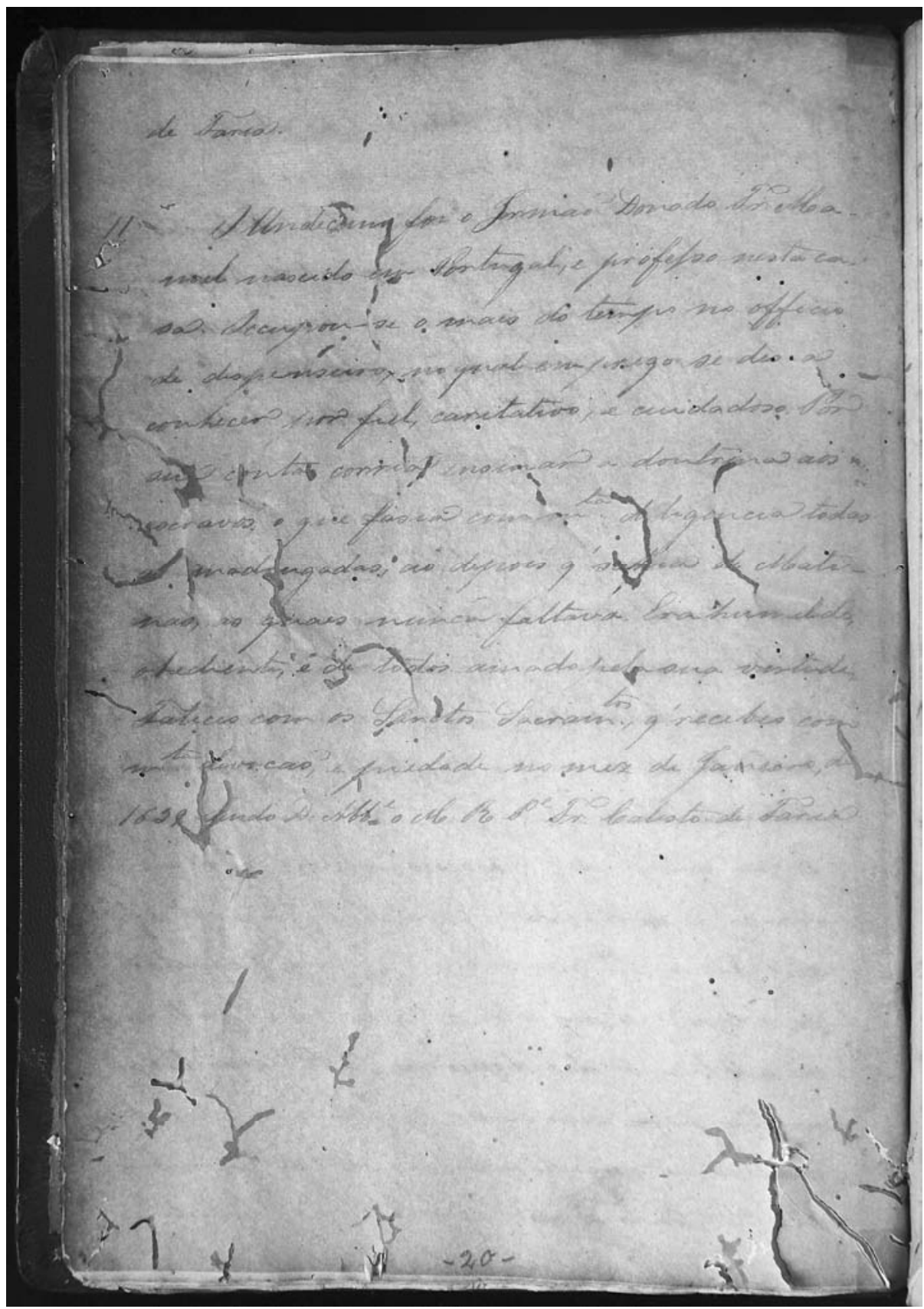

Figura 22: Fólio que apresenta o undécimo monge falecido Fonte: Dietario (original) 
guns annos, veir 6 conventual desta caza a $q^{l}$ servio nos imporegos de procunatos das demantas $e$ as dep das cazas. Foi Ablade da Gracea [ leito en Tibás ass

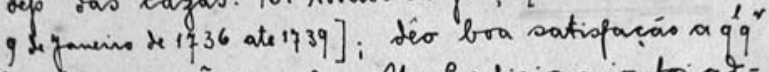
tos lngares, $\tilde{q}$ exeeviéo. Ho Conficionanio for atmiravel a sua Caride, estava prompto a tota, $\mathrm{eq}^{\text {gt }}$ ora. i chamaferm, ainita as depois que verria opminido de himina pezata funta de feno, $\bar{q}$ lhe sustin. ha huma perigoza quehatma, if $f \mathrm{~m}^{\text {tos }}$ an $^{0} \sigma$ ato menton. Falecieo com a gr tos dacram em sen perferto juizo com 82 amis de itate, e 39 de habito no $1^{2}$ de tameino de 1752 sento D. He M. M.R.QP ME: Fr. Yoiso de f. Maria. $)$

\section{2. de Tameino.}

11. "(9) Undecinno for $\sigma$ Humás Donado Fo. Manoel nascito em Portugal, e profefso mesta casa. Occomponqual emprego se deo a conhecer por fiel, canitativo, e cuidadoso. Por sua conta corria ensinar a dontrina ass escravos, $\sigma$ que fasia com $m^{\text {to }}$ digencia todas as matungatas, ar dypois o' sahia de Matinas, as quacs unnca faltava. Kra hnmilbe, obediente, $e$ de todos amado pela sma virtrite. Faleces com os Santos Sacramtos, q' recebes com $m^{\text {ka }}$ devocias, e pietade no mez de Janeino de 1639

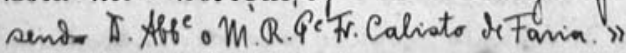

Figura 23: Fólio que apresenta o undécimo monge falecido Fonte: Dietario (edição de Silva Nigra) 
0 undécimo foi o irmão Donato Frei Manuel, nascido em Portugal e professo nesta casa. Ocupou-se o mais do tempo no ofício vo eispenseiro, no qual emprego se deu a conhecer por fiel, caritativo e cuidadoso. Por sua conta corria assinar a doutrina dos escravos, - que fazia com muita diligência todas as madrugadas, ao depois que saia das Matinas, as que nunca faltava. Era humilde, obediente e de todos amados pela sua virtude. Faleceu com os santos Sacramentos que recebeu com muita devoção e piedade no mês de janeiro de 1639، Sendo Dom Abade o Muito Reverendíssimo Padre, Frei Calisto de Faria.

$$
(\mathrm{DB}-11)
$$

Figura 24: Fólio que apresenta o undécimo monge falecido Fonte: Dietario (edição datilografada por Dom Gregório Paixão) 
profissão, e diligente na satisfação das suas obrigações; a affligia-se de q' se excusasse de trabalhar, quem tinha forças $\mathrm{p}^{\mathrm{a}} \mathrm{o}$ fazer. Viveo m.tos annos na Religião, freqüentando o Coro, e mais actos religiosos, em q. ${ }^{\text {to }}$ pode, não se utilisando das dispensas, q' a Religião the permittia pelos seus annos, e pelas suas moléstias. Faleceo este perfeito Religioso aos 9 de desembro de 1638. Sendo D.Abbe o M.R.Pe.Fr.Calisto de Faria.

11 - O Undécimo foi o Irmão Donado Fr.Manoel nascido em Portugal, e professo nesta casa. Ocupou-se o mais do tempo no officio de dispenseiro, no qual emprego se deo a conhecer por fiel, caritativo, e cuidadoso. Por sua conta corria ensinar a doutrina aos escravos, o que fasia com m. $^{\text {ta }}$ diligencia todas as madrugadas, ao depois q' sahia de Matinas, as quais nunca faltava. Era humilde, obediente, e de todos amado pela sua virtude. Faleceo com os Sanctos Sacram. ${ }^{\text {tos }}$ q' recebeo com m. ${ }^{\text {ta }}$ devoção, e piedade no mez de Janeiro, de 1639. Sendo D.Abb ${ }^{\mathrm{e}}$ o M.R.Pe.Fr.Calisto de Faria.

12 - O Duodécimo foi o P.Fr. Manoel de Mesquita nascido nesta Cide , professo neste Monsteiro. Seus virtuosos pays o mandarão aprender solfa, na qual ajudado de uma prfeita voz tanto se adiantou em pouco tp ${ }^{\circ}$, que $\mathrm{p}^{\mathrm{r}}$ esta, e outras prendas, de que era dotado, foi admitido ao santo habito com grande satisfação dos Religiozos. Viveu como perfeito Monge, exercendo ordinariam. te o emprego de cantor-mór, excuzando-se de outra $\mathrm{q} \cdot{ }^{1} \mathrm{q} \cdot{ }^{\mathrm{r}}$ occupação que o pudesse divertir deste santo, e louvável exercício. Já adiantado em annos padecia algumas moléstias habituaes, porem estas nunca o privarão da freqüência do coro, e mais actos conventuaes em quanto viveu. Occupado nos santos exercícios do seu estado, ao dep. ${ }^{\mathrm{S}}$ de recebidos os últimos Sacram. tos poz termo a sua exemplar vida em 17 de dezembro de 1639 sendo D.Abb o m. $^{\text {to }}$ R.P.Fr.Fram. ${ }^{\text {co }}$ da Aprezentação.

13 - O Décimo terceiro foi o Irmão Corista Fr.Felis da Cruz natural de Pernambuco, professo nesta caza. No pouco tempo, que os Monges logravão sua estimável companhia, deu a conhecer sua virtude, $\mathrm{p} .{ }^{\mathrm{r}} \mathrm{q}$ ' no exercício della gastava todo o tempo. Adoeceu de uma maligna, q' vencendo a todos os remédios da medicina, lhe tirou a vida, ficando a Religião privada dos serviços, q' prometia o seu préstimo por ser expedito, observante, e diligente. Foi o seu falecimento no mez de Dezembro de 1640 sendo sendo D.Abb ${ }^{\mathrm{e}}$ m. ${ }^{\text {to }}$ R.P.Fr.Francisco das Chagas.

14 - O Décimo quarto foi o Irmão Donato Fr.Pedro natura da Ilha Gracioza.Sempre este Monge deu em toda a sua dilatada vida uma prompta satifação aos empregos de q' o encarregava a obediência. No emprego de procurador, q' exerceu $\mathrm{p}^{\mathrm{r}} \mathrm{m}^{\text {tos }}$ annos acabou de mostrar a capacidade, q' tinha $p^{\mathrm{a}}$ qualquer ocupação laborioza. Os exercícios espirituaes pertencentes ao seu estado, erão os primeiros, a que satisfazia, assistindo com toda devoção aos officios divinos q. ${ }^{\text {do }}$ nelles se achava. Com estes católicos preparados revestidos de huma perfeita humildade se dispunha $\mathrm{p}^{\mathrm{a}}$ a morte, a $\mathrm{q}^{1}$, ao depois de recebidos os ultimos sacram. ${ }^{\text {tos }}$ lhe tirou a vida no mez de Janeiro de 1642 sendo D.Abb ${ }^{\text {e }}$ o M. ${ }^{\text {to }}$ R.P.Fr.Francisco da apresentação.

15 - O Décimo quinto foi o P.Fr.Placido da Cruz natural de Pernambuco professo nesta Caza. Era Religioso dotado de prendas, com as quaes sempre servio a Religião. Tocava orgão com destreza, e na muzica era perf. ${ }^{\text {to }}$. Todo o seu cuido se encaminhava $\mathrm{p}^{\mathrm{a}} \mathrm{q}^{\mathrm{O}}$ as

Figura 25: Fólio que apresenta o undécimo monge falecido

Fonte: Dietario (edição digitada de Dom Gregório Paixão) 


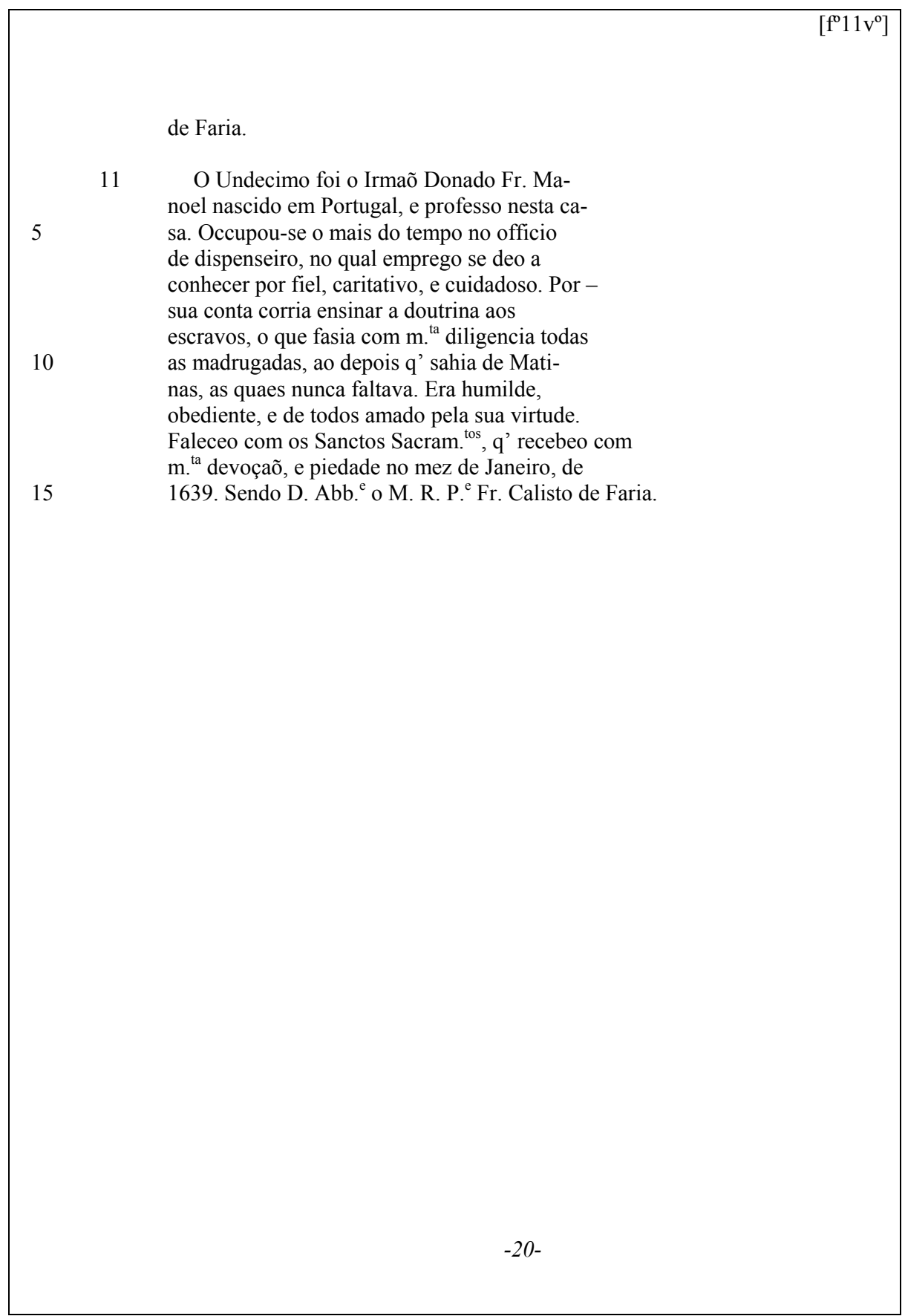

Figura 26: Fólio que apresenta o undécimo monge falecido Fonte: Dietario (edição Alícia Lose et al.) 


\subsection{CARACTERÍSTICAS INTRÍNSECAS ${ }^{6}$ : DIETARIO ORIGINAL}

Com o intuito de compreender essas características e proceder a uma edição rigorosamente conservadora do documento ora trabalhado, realizou-se a caracterização da grafia de cada scriptor que produziu o Dietario. Como este documento foi escrito ao longo dos anos, o volume apresenta traços de, pelo menos, cinco mãos diferentes, cada scriptor com características peculiares de grafia, formas específicas de abreviaturas, quantidade de linhas por fólio (Fig. 27), vocabulário etc. Em função disto, optou-se, para o trabalho de edição, por caracterizar, de maneira geral, a escrita de cada scriptor separadamente.
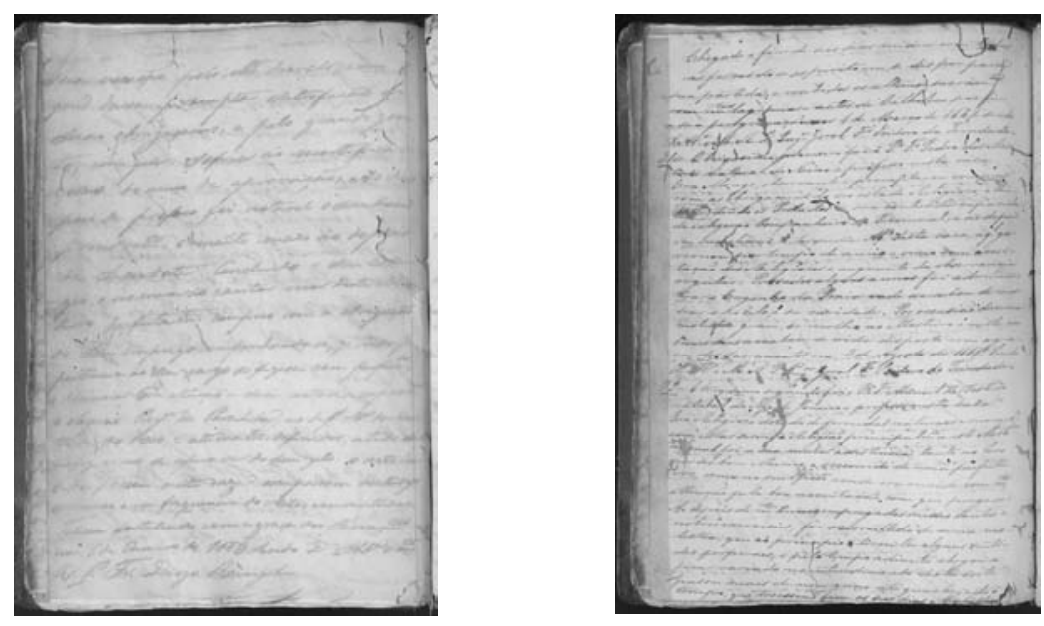

Figura 27: Diferenças entre os fólios

Fonte: Dietario (original)

Ao primeiro scriptor pertence o termo de abertura até a página 20. Essa contagem é relativa à numeração posterior feita a lápis. $\mathrm{Na}$ versão final, far-se-á também a remissão ao número de fólios. Em sua escrita:

- cada fólio tem, em média, 23 linhas escritas;

- as letras são um pouco inclinadas para a direita, bem definidas e organizadas;

\footnotetext{
${ }^{6}$ Características intrínsecas são definidas aqui como aquelas características ainda não ligadas à "língua", mas sim às peculiaridades "ortográficas" de cada scriptor. É importante fazer uma ressalva para o fato de que "ortografia", neste contexto, não deve ser pensada como a escrita correta, mas sim como a forma de escrever e de dispor e combinar os grafemas, criando, desta forma, fatos linguísticos a serem analisados. Como o Dietario é um texto escrito por várias mãos, a descrição destas características fez-se necesssária.
} 
- quando há $<$ ss $>$, o primeiro se apresenta longo e tem a grafia bastante semelhante a do $<\mathrm{p}>$ minúsculo;

- o $<\mathrm{Z}>$ é grafado dentro da regra das letras sem haste, semelhante à sua forma impressa e não à forma cursiva, portanto não apresenta a haste marcada;

- reclamo (característica de textos impressos e notariais): a última palavra do fólio anterior se repete, sistematicamente, como a primeira do fólio seguinte;

- a nasalidade é marcada com $<\sim>$;

- o til dos ditongos nasais encontra-se sistematicamente sobre a segunda vogal, ou, não raro, além desta, exemplo: aõ;

- em diversas letras, em especial $<\mathrm{r}>,<\mathrm{a}>,<\mathrm{u}>$ minúsculos, o traço final se estende até alcançar a parte superior da letra;

- há metátese (trocas de sílabas dentro de uma mesma palavra) algumas raras vezes, como em regilioso (por religioso);

- na página 11 o verbo por na terceira pessoa do pretérito, encontra-se grafada com a letra $<\mathrm{z}>$ ao final, da seguinte forma: poz;

- o <que>, embora apareça escrito algumas vezes, é, na maioria das ocorrências, abreviado por suspensão: <q'>;

- na página 11 encontra-se uma ligação porisso, fato relativamente escasso neste documento.

O segundo scriptor escreve das páginas 21 a 40 e são algumas de suas características:

- o $<$ s $>$ inicial ganha uma forma semelhante ao $<\mathrm{s}>$ maiúsculo, confundindo-se também com um $<$ D $>$ maiúsculo;

- o $<\mathrm{z}>$ passa a ter a sua haste inferior marcada, é escrito com letra cursiva dentro da regra das letras sem haste, semelhante à sua forma impressa;

- as sílabas com $<$ ss $>$ dobrados apresentam ambos grafados da mesma maneira;

- o reclamo já não aparece;

- em relação ao primeiro scriptor, o <que>, passa a ser, em um maior número de vezes, grafado por extenso, contudo sua abreviatura é ainda encontrada;

- passa a haver mais linhas escritas em cada fólio (de 25 a 30, em geral);

- a nasalidade é marcada também por $<$ n $>$ e não apenas por $\langle\sim>$, a exemplo de funcoens na página 23;

- na página 25 há metátese marcada em Pertendeu, na inversão de posição entre $<\mathrm{e}>\mathrm{e}<\mathrm{r}>$, na primeira sílaba, que, neste caso, pode representar uma variante 
Linguística do scriptor, pois essa é uma das formas comuns, ainda hoje, nas variantes menos tensas;

- $<$ um $>$ e $<$ uma $>$ são grafados com $<$ h $>$ : $<$ hum $>$ e $<$ huma $>$;

- a escrita apresenta letras mais graúdas e de traçado mais descuidado.

Parecem pertencer à mão de um terceiro scriptor as características da scripta lançada às páginas 41 a 93:

- a escrita apresenta um traçado mais fino e as letras são mais definidas e mais bem desenhadas;

- há mais linhas escritas por fólio, que variam entre 19 e 47, tendo em média 26 e 27 linhas;

- a abreviatura de Frei, que sistematicamente aparecia com o $<\mathrm{r}>$ escrito na mesma linha das demais letras, passa a apresentá-lo sobrescrito;

- nesse scriptor o <que> é escrito por extenso, havendo poucas ocorrências de sua forma abreviada;

- na página 41 Réligião é grafada com acento;

- a nasalidade é marcada ora por $<\mathrm{n}>$, ora por $<\sim>$;

- há mais rasuras e correções do que em relação aos scriptores anteriores;

- sistematicamente hum e he são grafados com $<\mathrm{h}>$;

- na página 48 lê-se pertendendo, caracterizando uma metátese que, neste caso, pode representar uma variante Linguística do scriptor, pois essa é uma das formas comuns, ainda hoje, nas variantes menos tensas;

- as palavras com $<$ ss $>$ na maioria das vezes, com raras exceções, apresentam o primeiro $<$ s $>$ longo e o segundo curto.

A partir do fólio 94 (p. 185 da numeração posterior), o texto revela traços pertinentes ao scriptor 4, sendo que uma considerável parcela de suas características gramaticais e gráficas assemelham-se às características do scriptor 5 . Os scriptores 4 e 5 se diferenciam mais pelos traçados das suas letras, coloração da tinta, disposição da mancha escrita por fólio do que pelos aspectos gramaticais que serão aqui descritos. Desta forma, é pertinente, portanto, proceder à descrição de ambos em conjunto. Acredita-se que a escrita presente desde a página 185 até a página 277 pertença ao scriptor 4; e da página 277 até a página 304 seja do scriptor 5 . A mão que encerra o texto apresenta-se diversa de todas as outras analisadas.

O scriptor 4 faz uso frequente das abreviaturas, sendo que o mesmo ocorre com o 5, que abrevia os vocábulos independentemente de suas classes gramaticais. 
Percebe-se a ocorrência de junção ou separação das palavras, geradas pela necessidade de não levantar a pena do papel enquanto houvesse tinta, traço característico dos dois scriptores.

Uma outra marca de ambos é a volta do reclamo (MARTINS, 2002), que deixou se ser usada desde o scriptor 2. Deve-se atentar também para o emprego da vírgula, sempre antecedendo o $<\mathrm{e}>$, conjunção coordenativa aditiva, atentando-se para o fato de que isso é possível quando a pontuação é retórica, indicativa de pausa para leitura.

É peculiar a separação silábica que não considera as fronteiras silábicas hoje estabelecidas. Ainda tratando da questão silábica, observa-se que vocábulos iniciados por uma sílaba simples - aquela que, segundo Silva (2000), tem somente o núcleo preenchido - ou aqueles que são formados por sílabas mediais simples, apresentam a duplicação da consoante da sílaba posterior.

Há, no campo lexical, uma variação do emprego das palavras, como o artigo indefinido feminino que ora grafa-se como $<$ huma $>$, ora grafa-se como $<$ uma $>$. Outra variação é de caráter vocálico, a exemplo de $<$ duente $>$ e $<$ doente $>$, $<$ premeiro $>$ e $<$ prịmeiro $>,<$ Deus $>$ e $<$ Deos $>,<\underline{\text { imprego }}>$ e $<$ émprego $>$. Tal grafia pode estar ligada à variação Linguística na realização das vogais átonas, podendo documentar a interferência da oralidade na escrita.

Têm-se alternâncias de caráter gráfico no emprego do $<\mathrm{c}>$, $<$ ç $><$ ss $>$ e $<$ s $>$ para o fonema [s]. Soma-se a isso a identificação da variação do uso do grupo $/ \mathrm{kt} />/ \mathrm{it} / \mathrm{em}$ palavras como < oictavo $>$ e $<$ oitavo $>$ - que, neste caso, parece ser uma contaminação da falsa grafia etimologizante e da grafia da forma corrente à época - , < benedictino $>$ e $<$ beneditino $>$ - isso, no entanto, pode se tratar de resultado de grafia de mãos inábeis.

O marcador nasal, na maioria das vezes, figura sobre a vogal final da sílaba final da palavra. Esse marcador é utilizado no verbo para indicar que ele está conjugado no pretérito imperfeito na terceira pessoa do plural. Ao tratar dos verbos, percebe-se que a terceira pessoa do singular do presente do indicativo, $[\varepsilon]$ tônico, é grafado como $<$ he $>$. 


\section{ABREVIATURAS PRESENTES NO TEXTO}

$$
\begin{aligned}
& 1^{\mathrm{o}}=\text { primeiro } \\
& 1^{\mathrm{os}}=\text { primeir } \mathrm{os} \\
& 4^{\mathrm{o}}=\text { quarto } \\
& 7 \mathrm{~b}^{\mathrm{ro}_{\mathrm{o}}}=\text { setembro } \\
& 7 \mathrm{br}^{\mathrm{o}}=\text { setembro } \\
& 8 .^{\text {bro }}=\text { outubro } \\
& 8 \mathrm{br}^{\circ}=\text { outubro } \\
& 9^{\text {bro }}=\text { novembro } \\
& 9 \mathrm{br}^{\mathrm{o}}=\text { novembro } \\
& \mathrm{A}^{\mathrm{be}}=\mathrm{Ab} a d \mathrm{e} \\
& \mathrm{Ab} .^{\mathrm{de}}=\mathrm{Ab} a \mathrm{de} \\
& \mathrm{Abb}=\mathrm{Abb} a d e \\
& \mathrm{Abb}^{\mathrm{e}}=\mathrm{Abb} a d \mathrm{e} \\
& \mathrm{Abb}^{\mathrm{es}}=\mathrm{Abb} a d \mathrm{es} \\
& \text { Abbe }=\text { Abbade } \\
& \text { Abd. }^{\mathrm{e}}=\mathrm{Ab} a \mathrm{de} \\
& \mathrm{Ab}^{\mathrm{e}}=\mathrm{Abade}
\end{aligned}
$$$$
\text { accertadam }^{\mathrm{e}}=\text { accertadamente }^{2}
$$$$
\text { accolhim }^{\text {to }}=\text { accolhimento }
$$$$
\text { accomet }^{\circ}=\text { accometido }
$$$$
\text { acomet }^{\mathrm{o}}=\text { acometido }
$$$$
\text { acontecim }^{\text {to }}=\text { acontecimento }
$$$$
\text { activid }^{\mathrm{e}}=\text { actividade }
$$$$
\text { adiantam. }{ }^{\text {to }}=\text { adiantamento }
$$$$
\text { admiravelm }^{\text {te }}=\text { admiravelmente }
$$$$
\text { afabilid }^{\mathrm{e}}=\text { afabilidade }
$$$$
\text { Agost }^{\circ}=\text { Agostenho }
$$$$
\text { agradecim. }{ }^{\text {to }}=\text { agradecimento }
$$$$
\mathrm{Ag}^{\text {to }}=\text { Agosto }
$$$$
\mathrm{Alm}^{\mathrm{da}}=\text { Almeida }
$$$$
\mathrm{am}^{\text {te }}=\text { amante }
$$$$
\text { am. }^{\text {te }}=\text { amante }
$$$$
\mathrm{am}^{\mathrm{e}}=\text { amante }
$$$$
\text { amisad. }^{\text {es }}=\text { amisades }
$$$$
\mathrm{Am}^{\mathrm{o}}=\mathrm{Amigo}
$$$$
\text { an. }{ }^{\mathrm{os}}=\text { an } n \text { os }
$$$$
\text { an. }{ }^{\mathrm{s}}=\text { annos }
$$$$
\text { An. }^{\text {to }}=\text { Antonio }
$$$$
\mathrm{a}^{\text {ns }}=\operatorname{anos}
$$$$
\mathrm{Ant}^{\mathrm{o}}=\text { Antonio }
$$$$
\mathrm{a}^{\text {os }}=\mathrm{a} n \text { os }
$$$$
\text { apaixonadam }^{\text {te }}=\text { apaixonadamente }
$$

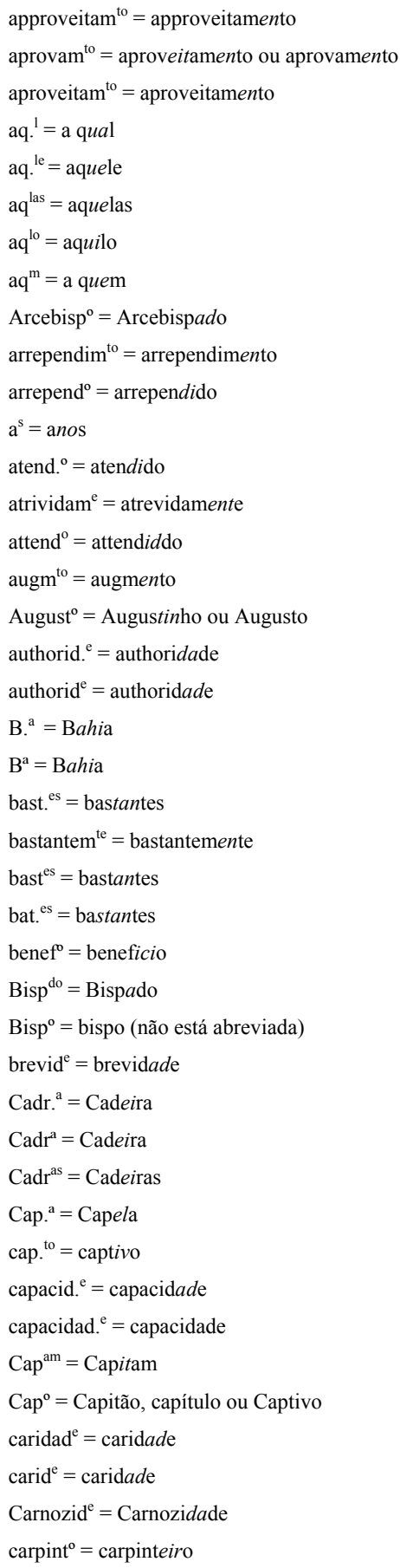




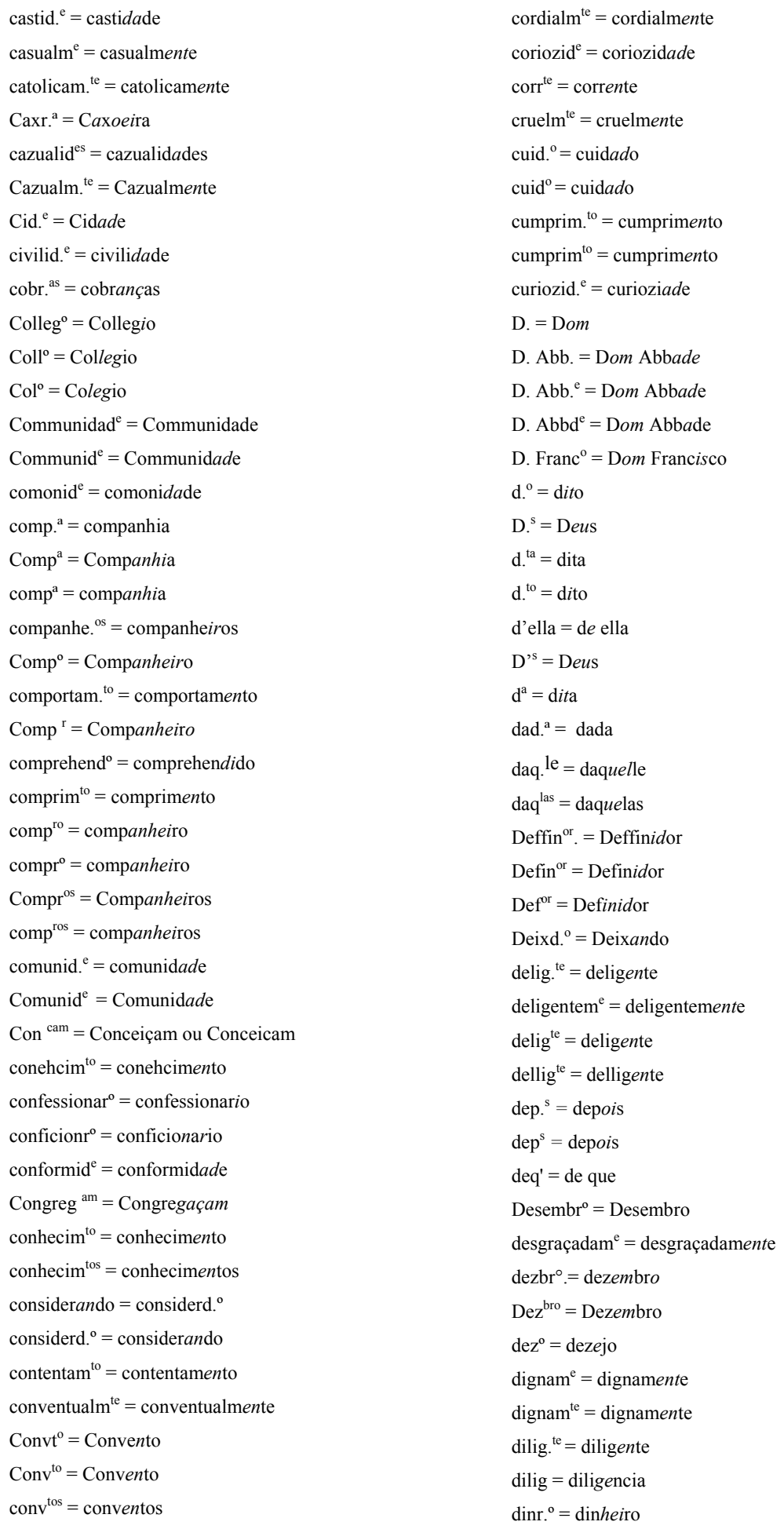




\begin{tabular}{|c|c|}
\hline directam $^{\mathrm{e}}=$ directamente & $\mathrm{fd}^{\mathrm{a}}=\mathrm{f} a z e n \mathrm{da}$ \\
\hline $\operatorname{dir}^{\text {to }}=$ direito & felicid $^{\mathrm{e}}=$ felicid $a d \mathrm{e}$ \\
\hline divertim $^{\text {tos }}=$ divertimentos & feliscid $^{\mathrm{e}}=$ feliscidade \\
\hline $\mathrm{d}^{\mathrm{o}}=$ dito & felizm $^{\text {te }}=$ felizmente \\
\hline Do $^{r}=$ Doutor & fengem. $.^{\text {to }}=$ fengemento \\
\hline $\mathrm{d}^{\mathrm{os}}=\mathrm{ditos}$ & festivid $^{\text {es }}=$ festivid $a$ des \\
\hline Dout $^{\mathrm{os}}=$ Doutores ou Doutos & Fever $^{\circ}=$ Fevereiro \\
\hline $\mathrm{D}^{\mathrm{r}}=$ Doutor & Fevr $^{\circ}=$ Fevreiro \\
\hline Dr. Fr. $=$ Doutor Frei & fidelid $^{\mathrm{e}}=$ fidelid $a d \mathrm{e}$ \\
\hline $\mathrm{D}^{\mathrm{r}}$. Fr. $=$ Doutor Frei & finalm ${ }^{\text {te }}=$ finalmente \\
\hline $\mathrm{dr}^{\mathrm{o}}=$ dinheiro & Finalm $^{\mathrm{e}}=$ Finalmente \\
\hline $\mathrm{D}^{\mathrm{s}}=\mathrm{D} e u \mathrm{~s}$ & $\mathrm{f}^{\mathrm{o}}=$ filho \\
\hline eff. $^{\text {tos }}=$ effeitos & Fr. $=$ Frei \\
\hline eficazm $^{\text {te }}=$ eficazmente & Fram ${ }^{\mathrm{co}}=$ Framcisco \\
\hline $\mathrm{ef}^{\mathrm{to}}=$ efeito & Franc $^{\mathrm{o}}=$ Francisco \\
\hline $\mathrm{em} \mathrm{q}^{\mathrm{to}}=\mathrm{em}$ quanto & freq $^{\text {te }}=$ freqüente \\
\hline $\mathrm{emp}^{\mathrm{o}}=\mathrm{empenho}$ & $\mathrm{f}^{\mathrm{to}}=$ feito \\
\hline emport $^{\mathrm{e}}=$ emportante & fudam ${ }^{\text {to }}=$ f $u$ damento \\
\hline $\mathrm{emq}^{\text {to }}=$ emquanto & fundam $^{\text {to }}=$ fundamento \\
\hline Encar ${ }^{\text {cam }}=$ Encarnaçam & $\mathrm{G}^{\mathrm{al}}=\mathrm{Geral}$ \\
\hline enfermid $^{\mathrm{e}}=$ enfermid $a d \mathrm{e}$ & geralm $^{\text {te }}=$ geralmente \\
\hline Eng $^{\mathrm{o}}=$ Engenho & Gl. Patri $=$ Gloria Patri \\
\hline entendim. ${ }^{\text {to }}=$ entendimento & gra. $^{\text {de }}=$ grande \\
\hline entendim $^{\text {to }}=$ entendimento & $\operatorname{grad}^{\mathrm{es}}=$ grandes \\
\hline Esp. $^{\circ}=$ Espirito & gradualm $^{\text {te }}=$ gradualmente \\
\hline esquecim $^{\text {to }}=$ esquecimento & gratuitam $^{\text {te }}=$ gratuitamente \\
\hline eternid. $^{\mathrm{e}}=$ eterni $d a \mathrm{de}$ & gravem $^{\text {te }}=$ gravemente \\
\hline eternid $^{\mathrm{e}}=$ eternid $a d \mathrm{e}$ & $\operatorname{gravid}^{\mathrm{e}}=$ gravidade \\
\hline $\mathrm{Ex}=$ Excelentíssimo & $\operatorname{grd} .^{\mathrm{e}}=\operatorname{grande}$ \\
\hline $\operatorname{exactam}^{\text {te }}=$ exactamente & humanid $^{\text {es }}=$ humanidades \\
\hline exemplarid. ${ }^{\mathrm{e}}=$ exemplarid $a d \mathrm{e}$ & humild $^{\mathrm{e}}=$ humild $a d \mathrm{e}$ \\
\hline $\mathrm{Ex}^{\mathrm{mo}}=$ Excelentíssimo & $\mathrm{id}^{\mathrm{e}}=\mathrm{id} a d \mathrm{e}$ \\
\hline Exm $^{\circ}=$ Exceletissimo & $\operatorname{Igr}^{\mathrm{a}}=$ Igreja \\
\hline extremid $^{\mathrm{es}}=$ extremid $a d \mathrm{es}$ & igualm $^{\text {te }}=$ igualmente \\
\hline f. $^{\text {os }}=$ filhos & imediatam $^{\text {te }}=$ imediatamente \\
\hline faculd ${ }^{\mathrm{e}}=$ faculd $a \mathrm{de}$ & imfermr $^{\circ}=$ imfermeiro \\
\hline falecim. ${ }^{\text {to }}=$ falecimento & impedim $^{\text {to }}=$ impedimento \\
\hline falescim ${ }^{\text {to }}=$ falescimento & indirectam ${ }^{\mathrm{e}}=$ indirectamente \\
\hline falicim $^{\text {to }}=$ falicimento & infalivelm $^{\mathrm{e}}=$ infalivelmente \\
\hline fallecim. ${ }^{\text {to }}=$ fallecimento & infalivelm $^{\text {te }}=$ infalivelmente \\
\hline fasendr $^{\circ}=$ fasendeiro & infelizm $^{\text {te }}=$ infelizmente \\
\hline faz. $^{\text {do }}=$ fazendo & infermid $^{\mathrm{e}}=$ infermid $a d \mathrm{e}$ \\
\hline fazd. ${ }^{\mathrm{a}}=$ fazenda & infermid $^{\text {es }}=$ infermi $d a$ des \\
\hline $\mathrm{faz}^{\mathrm{da}}=$ fazenda & injustam $^{\mathrm{e}}=$ injustamente \\
\hline faz $^{\text {das }}=$ fazendas & inst $^{\mathrm{es}}=$ instantes \\
\hline
\end{tabular}




$$
\begin{aligned}
& \text { instrum }^{\text {to }}=\text { instrumento } \\
& \text { instrum }^{\text {tos }}=\text { instrumentos } \\
& \text { insuficientem }^{\text {te }}=\text { insuficientemente } \\
& \text { inteiram }^{\mathrm{e}}=\text { inteiramente } \\
& \text { inteiram }^{\text {te }}=\text { inteiramente } \\
& \text { intelig }^{\text {te }}=\text { inteligente } \\
& \text { intellig }^{\text {te }}=\text { intelligente } \\
& \text { intendim }^{\text {to }}=\text { intendimento } \\
& \text { inutilm }^{\mathrm{e}}=\text { inutilmente } \\
& \text { Irmand }^{\mathrm{e}}=\text { Irmand } a d \mathrm{e} \\
& \mathrm{J}^{\circ}{ }^{\mathrm{o}}=\text { Junho ou Julho } \\
& \text { Janer }^{\mathbf{0}}=\text { Janero } \\
& \text { Janr. }^{\circ}=\text { Janeiro } \\
& \mathrm{Janr}^{\mathrm{o}}=\text { Janeiro ou Janero } \\
& \text { Jan }^{\text {ro }}=\text { Janeiro ou Janero } \\
& \mathrm{Jub}^{\mathrm{o}}=\mathrm{Jubilado} \\
& \text { juntam. }^{\text {te }}=\text { juntamente } \\
& \text { juntam }^{\mathrm{e}}=\text { juntamente } \\
& \text { justam }^{\mathrm{e}}=\text { justamente } \\
& \text { L. }{ }^{\mathrm{a}}=\text { Lisboa }
\end{aligned}
$$$$
\text { lastimozam }^{\mathrm{e}}=\text { lastimozamente }
$$$$
\mathrm{L}^{\text {cas }}=\text { Lembranças }
$$$$
\text { lembr. }{ }^{\mathrm{a}}=\text { lembrança }
$$$$
\text { lentam }^{\mathrm{e}}=\text { lentamente }
$$$$
\text { lentam }^{\text {te }}=\text { lentamente }
$$$$
\operatorname{Lex}^{\mathrm{a}}=\text { Lisboa }
$$$$
\text { liberalm }{ }^{\text {te }}=\text { liberalmente }
$$$$
\text { liberd }^{\mathrm{e}}=\text { liberd } a d \mathrm{e}
$$$$
\text { lic }^{\mathrm{a}}=\text { lincenca }
$$$$
\text { liç }{ }^{\mathrm{a}}=\text { licença }
$$$$
\text { livrem }^{\text {te }}=\text { livremente }
$$$$
\mathrm{Lx}^{\mathrm{a}}=\text { Lisboa }
$$$$
\text { M. }=\text { Mestre }
$$$$
\text { M. } \mathrm{P}^{\mathrm{e}} \text {. Ex. } \operatorname{Prov}^{\mathrm{al}} \mathrm{Fr}=\mathrm{M} u i \mathrm{Padre} \text { Excelentíssimo }
$$$$
\text { Provincial Frei }
$$

M. R. P = Mui Reverendo Padre

M. R. P. M Fr. $=$ Mui Reverendíssimo Padre Mestre Frei

M. R. P. M. $\mathrm{D}^{\text {or }}$ Fr. $=$ Mui Reverendíssimo Padre Mestre Doutor Frei

M. R. P. M. ${ }^{\mathrm{e}}{ }^{\mathrm{F}}{ }^{\mathrm{r}}=\mathrm{M} u i$ Reverendissimo Padre Mestre Frei

M. R. P. M. ${ }^{\mathrm{e}}$ Fr. $=$ Mui Reverendissimo Padre Mestre Frei
M. R. P. $\mathrm{M}^{\mathrm{e}}$. Ex. $=\mathrm{M} u i$ Reverendíssimo $\mathrm{P} a d r e$ Mestre Excelentíssimo

M. R. P. Preg. ${ }^{\text {or }}$ Fr. $=$ Mui Reverendo Padre Pregador Frei

M. R. P. Pregd ${ }^{\text {or }}=$ Mui Reverendo Padre Pregador

M. R. P. Preg ${ }^{\text {dor }}$ Fr. = Mui Reverendíssimo Padre Preg $a$ dor Frei

M. R. P. ${ }^{\mathrm{e}}=\mathrm{M} u i$ Reverendíssimo $\mathrm{P} a d r \mathrm{e}$

M. R. P. ${ }^{\mathrm{e}}=\mathrm{M} u i$ Reverendíssimo Padre

M. R. P. ${ }^{\mathrm{e}}$ Ex. Abb. ${ }^{\mathrm{e}}$ Fr. $=$ Mui Reverendissimo Padre

Excelentíssimo Abbade Frei

M. R. P. ${ }^{\mathrm{e}}$ Fr. $=$ Mui Reverendissimo Padre Frei

M. R. P. ${ }^{\mathrm{e}} \mathrm{M}^{\mathrm{e}}$ Fr. = Mui Reverendissimo $\mathrm{P} a d r \mathrm{e}$ Mestre Frei

M. R. P. ${ }^{\mathrm{e}}$ Preg. ${ }^{\text {or }}$ Geral $\mathrm{F}^{\mathrm{r}}$. $=\mathrm{M} u i$ Reverendissimo Padre Pregador Geral Frei

M. R. $\mathrm{P}^{\mathrm{e}} \mathrm{D} \cdot \mathrm{Abb}^{\mathrm{e}}=\mathrm{M} u i$ Reverendissimo Padre Dom Abbade

M. R. $\mathrm{P}^{\mathrm{e}}$. Ex. Prov ${ }^{\mathrm{al}}$ Fr. $=$ Mui ReverendíssimoPadre Excelentíssimo Provincial Frei

M. R. $\mathrm{P}^{\mathrm{e}} \cdot \mathrm{M}^{\mathrm{e}} \mathrm{D}^{\mathrm{or}} \mathrm{Jub}^{\mathrm{o}}=\mathrm{M} u i$ Reverendissimo Padre Mestre Doutor Jubilado

M. R. $\mathrm{P}^{\mathrm{e}} \cdot \mathrm{Pg}^{\text {or }} \mathrm{Fr}=\mathrm{M} u i$ Reverendíssimo $\mathrm{Padre}$ Pregador Frei

M. R. $P^{\mathrm{e}}$. Preg ${ }^{\mathrm{dor}}=\mathrm{M} u i$ Reverendíssimo $\mathrm{P} a d r \mathrm{e}$ Pregador

M. R. $P^{\mathrm{e}}$. Preg ${ }^{\mathrm{dor}}$ Fr. $=$ Mui Reverendíssimo Padre Preg $a$ dor Frei

M. R. $\mathrm{P}^{\mathrm{e}}$. Preg ${ }^{\text {dor }}$ Jub ${ }^{\mathrm{o}}$ Fr. $=\mathrm{M} u i$ ReverendissimoPadre Pregador Jubilado Frei

M. R. $\mathrm{P}^{\mathrm{e}} \cdot \operatorname{Preg}^{\text {or }} \mathrm{F} .=\mathrm{M} u i$ Reverendísimo Padre Pregador Frei

M. R. $\mathrm{P}^{\mathrm{e}}$. Preg ${ }^{\text {or }}$ Fr. $=\mathrm{M} u i$ Reverendíssimo Padre Pregador Frei

M. $\mathrm{R}^{\mathrm{e}} \cdot \mathrm{P}^{\mathrm{e}} \cdot \mathrm{M}^{\mathrm{e}} \mathrm{Jub}^{\mathrm{o}}$ Fr. $=\mathrm{M} u i$ Reverendíssimo Padre Mestre Jubilado Frei

$\mathrm{M}^{\text {co }}{ }^{=}$Março

$\mathrm{M}^{\text {co }}=$ Março

$\mathrm{M}^{\mathrm{e}}=$ Mãe ou Mestre

$\mathrm{m}^{\text {is }}=\mathrm{m} a$ is

$\mathrm{m}^{\mathrm{ma}}=$ mesma

$\mathrm{m} .{ }^{\mathrm{mo}}=$ mesmo

M. ${ }^{o}$ R. P. ${ }^{e}$ Preg. ${ }^{\text {or }}$ Geral F. ${ }^{\mathrm{r}}=$ Muito Reverendo Padre Pregador Geral Frei

m. ${ }^{\mathrm{s}}=$ mesmos ou mais 


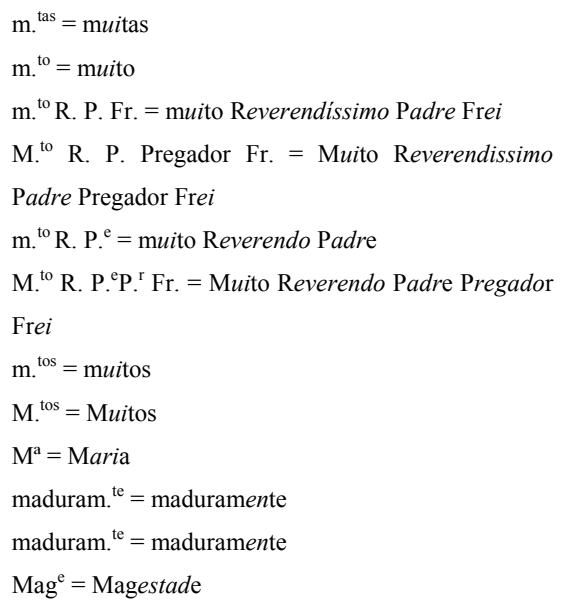

Magestad $^{\mathrm{e}}=$ Magestade

mand $^{\mathrm{e}}=$ mandante

md. ${ }^{\circ}=$ mundo

md. ${ }^{\circ}=$ mundo

md. ${ }^{\text {ou }}=$ mandou

md. $^{\text {ou }}=$ mandou

$\mathrm{M}^{\mathrm{e}}=\mathrm{M} \tilde{\mathrm{e}}$

$\mathrm{M}^{\mathrm{el}}=$ Manuel

$\mathrm{M}^{\mathrm{el}}$ de $\mathrm{S}^{\mathrm{to}} \mathrm{An}^{\text {to }}=$ Manuel de Santo Antonio

melhoram $^{\text {to }}=$ melhoramento

merecim $^{\text {to }}=$ merecimento

merecim $^{\text {tos }}=$ merecimentos

$\mathrm{M}^{\mathrm{es}}=$ Mestres

mes $^{\mathrm{ma}}=$ mesma

mil $\mathrm{r}^{\mathrm{s}}=$ mil réis

$\mathrm{m}^{\text {is }}=\mathrm{m} a$ is

$\operatorname{mocid}^{\mathrm{e}}=$ mocidade

Monstr $^{\mathrm{o}}=$ Monsteiro

$\operatorname{Montr}^{\circ}=$ Monteiro

moralid $^{\mathrm{e}}=$ moralida de

moralm $^{\mathrm{e}}=$ moralmente

mortalm $^{\mathrm{e}}=$ mortalmente

Most. ${ }^{\circ}=$ Mosteiro

Most. $^{\text {os }}=$ Mosteiros

Moste $^{\text {ro }}=$ Mosteiro

Mostr. $^{0}=$ Mosteiro

Mostr. $^{\text {os }}=$ Mosteiros

Most $^{\mathrm{ro}}=$ Mosteiro

movim $^{\text {to }}=$ movimento

$\mathrm{m}^{\mathrm{ta}}=\mathrm{m} u i \mathrm{ta}$

$\mathrm{m}^{\text {tas }} \mathrm{m}^{\mathrm{s}}=$ muitas mais $\mathrm{m}^{\text {te }}=$ mente (para formar advérbios, mas isolado em função das caracteristicas do traçado da escrita)

$\mathrm{M}^{\text {to }}$ R. P. = Muito Reverendo Padre

$\mathrm{m}^{\text {to }}$ R. P. Ex. Provincial Fr. $=$ muito Reverendíssimo

Padre Excelentíssimo Provincial Frei

$\mathrm{m}^{\text {to }} \mathrm{R}$. P. Exprovincial Fr. $=\mathrm{m}$ uito Reverendo $\mathrm{Padre}$

Excelentíssimo provincial Frei

$\mathrm{m}^{\text {to }}$ R. P. M. Fr. $=\mathrm{m}$ uito Reverendissimo Padre

Mestre Frei

$\mathrm{M}^{\text {to }}$ R. P. M. Fr. $=$ Muito Reverendo Padre Mestre

Frei

$\mathrm{m}^{\text {to }}$ R. P. $\mathrm{M}^{\mathrm{e}}$. $\mathrm{D}^{\text {or }}$. Fr. = muito Reverendo Padre

Mestre Doutor Frei

$\mathrm{M}^{\mathrm{to}}$ R. P. $\mathrm{M}^{\mathrm{e}}$. Fr. = Muito Reverendo Padre Mestre

Frei

$\mathrm{M}^{\text {to }}$ R. P. $\mathrm{M}^{\mathrm{e}}$. Jub ${ }^{\circ}$ Fr. =.Muito Reverendo Padre

Mestre Jubilado Frei

$\mathrm{m}^{\text {to }}$ R. P. Preg ${ }^{\text {or }}$. Fr. $=$ muito Reverendo Padre

Pregador Frei

$\mathrm{M}^{\text {to }}$ R. $\mathrm{P}^{\mathrm{e}}$. Preg ${ }^{\text {or }}$. Fr. $=$ Muito Reverendo Padre

Pregador Frei

$\mathrm{m}^{\text {to }} \mathrm{s}=$ muitos

mud. ${ }^{\circ}=\operatorname{mud} a d o$

mudam $^{\text {te }}=$ mudamente

mudam $^{\text {te }}=$ mudamente

$\operatorname{mud}^{\mathrm{o}}=\operatorname{mud} a d \mathrm{o}$

mutuam $^{\text {te }}=$ mutuamente

$\mathrm{N}=$ Nosso

N. M. P $\mathrm{P}^{\mathrm{e}} \cdot$ Ex. Prov ${ }^{\mathrm{al}}$ Fr. = Nosso Mui Padre Excelentíssimo Provincial Frei

N. M. R. Fr. = Nosso Mui Reverendo Frei

N. M. R. P. Fr. = Nosso Mui Reverendo Padre Frei

N. M. R. P. ${ }^{\mathrm{e}} \mathrm{Fr} .=$ Nosso Mui Reverendo Padre Frei

N. M. R. $\mathrm{P}^{\mathrm{e}}=$ Nosso Mui Reverendíssimo Padre

N. M. R. $\mathrm{P}^{\mathrm{e}} \cdot \mathrm{Ex}=$ Nosso Mui Reverendíssimo Padre Excelentíssimo

N. M. R. $\mathrm{P}^{\mathrm{e}}$. Ex. Prov ${ }^{\mathrm{al}}$ Fr. $=$ Nosso Mui Reverendo Padre Excelentíssimo Provincial Frei

N. M. R. $\mathrm{P}^{\mathrm{e}}$. Ex. Provi ${ }^{\mathrm{al}}$ Fr. $=$ Nosso Mui Reverendo Padre Excelentíssimo Provincial Frei

N. M. R. P ${ }^{\mathrm{e}}$. Ex. Provin ${ }^{\text {al }}$ Fr. $=$ Nosso Mui Reverendo Padre Excelentíssimo Provincial Frei

N. M. R. $\mathrm{P}^{\mathrm{e}} \cdot \mathrm{M}^{\mathrm{e}}$ Ex Prov $^{\mathrm{al}}$ Dor $=$ Nosso Mui

Reverendíssimo Padre Mestre Excelentíssimo

Provincial Doutor 
N. M. R. $\mathrm{P}^{\mathrm{e}} \cdot \mathrm{M}^{\mathrm{e}} \cdot$ Ex. Prov $^{\mathrm{al}}$ Fr. $=$ Nosso Mui

Reverendíssimo Padre Mestre Excelentíssimo

Provincial Frei

N. M. R. $\mathrm{P}^{\mathrm{e}} \cdot$ Preg $^{\text {or }}$ Fr. $=$ Nosso Mui Reverendíssimo Padre Pregador Frei

N. M. Reverendo Padre Exprovincial Fr. =

Nosso Muito Reverendo Padre Excelentíssimo provincial Frei

$$
\begin{aligned}
& \text { N. } P^{\mathrm{e}}=\text { Nosso } \text { Padre } \\
& \text { N. S. }{ }^{\text {ra }}=\text { Nossa } \text { Senhora } \\
& \text { N. Snr. }{ }^{\text {a }}=\text { Nossa } \text { Senhora } \\
& \text { N.S. }=\text { Nossa } \text { Senhora } \\
& \text { naq }^{\text {la }}=\text { naquela } \\
& \text { naq }^{\text {le }}=\text { naquele }
\end{aligned}
$$

Nascim ${ }^{\text {to }}=$ Nascimento

nat $^{\text {al }}=$ natal

Nativid $^{\mathrm{e}}=$ Natividade

naturalm ${ }^{\mathrm{e}}=$ naturalmente

necessid $^{\mathrm{e}}=$ necessid $a d \mathrm{e}$

nimiam $^{\mathrm{e}}=$ nimiamente (minimamente)

$\mathrm{n}^{\mathrm{o}}$. = número

nobr. $^{\text {za }}=$ nobreza

Nosso $\mathrm{m}^{\text {to }}$ R. P. Exprovincial Fr. $=$ Nosso $\mathrm{m} u$ ito

Reverendissimo Padre Excelentíssimo provincial

Nosso $\mathrm{m}^{\text {to }}$ Reverendo $\mathrm{P}^{\mathrm{e}}$. Ex. Provincial Fr. = Nosso

muito Reverendo Padre Excelentíssimo Provincial

Frei

not. $^{\mathrm{a}}=$ noticia

not. $^{\mathrm{a}}=$ noticia

novam $^{\mathrm{e}}=$ novamente

novam $^{\text {te }}=$ novamente

$\mathrm{Novb}^{\circ}=$ Novembro

Novbr $^{\mathrm{o}}=$ Novembro

Nov $^{\cos }=$ Noviços

$\operatorname{Nov}{ }^{\mathrm{s}}=$ Novos(não há abreviação)

O.S.B. $=$ Ordem de São Bento

obed $^{\mathrm{e}}=$ obediente

observ. $^{\text {te }}=$ observante

observan. ${ }^{\text {te }}=$ observante

observ $^{\text {te }}=$ observante

obst $=$ obstante

obst $^{\mathrm{e}}=$ obstante

occiozid $^{\mathrm{e}}=$ occiozid $a d \mathrm{e}$

ociosid $^{\mathrm{e}}=$ ociosidade

ociozid. $^{\mathrm{e}}=$ ociozid $a d \mathrm{e}$ offend $^{\mathrm{o}}=$ offendido

offerecim. ${ }^{\text {tos }}=$ offerecimentos

offerecim $^{\text {to }}=$ offerecimento

Olivr $^{\mathrm{a}}=$ Oliveira

opprim $^{\text {do }}=$ opprimido

Ordend $.^{\circ}=$ Orden $a$ do

ordinariam. ${ }^{\text {te }}=$ ordinariamente

ordinariam $^{\mathrm{e}}=$ ordinariamente

ornam. ${ }^{\text {to }}=$ ornamento

P. Fr $=$ Padre Frei

P. Fr. $=$ Padre Frei

P. M. R. P. Ex. Provincial Fr. = Padre Mestre

Reverendissimo Pregador Excelentíssimo Provincial

Frei

P. Preg ${ }^{\text {or }}$ Fr. $=$ Padre Preg $a d$ or Frei

p. $^{\mathrm{a}}=$ para

$\mathrm{P}^{\mathrm{e}}=$ Padre

P. ${ }^{\mathrm{e}}$ Fr. $=$ Padre Frei

$\mathrm{P}^{\text {es }}=$ Padres

p. ${ }^{\text {la }}=$ pela

p. ${ }^{\text {lo }}=$ pelo

p. $^{\text {los }}=$ pelos

$\mathrm{p}^{\mathrm{m}}=$ porem

$\mathrm{P}^{\circ}{ }^{\circ}=$ Primeir $\mathrm{o}$

p. ${ }^{\mathrm{r}}=\mathrm{p} a \mathrm{r} a$

p. ${ }^{\mathrm{r}}=$ por

p. ${ }^{\text {ro }}=$ primeiro

p. ${ }^{\text {ro }}=$ primeiro

p. ${ }^{\mathrm{s}}=$ pois

p. ${ }^{\text {te }}=$ parte

$\mathrm{p}^{\text {tes }}=$ partes

$\mathrm{p}^{\text {tes }}=$ partes

$\mathrm{p}^{\mathrm{a}}=\mathrm{p}$ ara

$\mathrm{p}^{\mathrm{a}} \mathrm{q}^{\prime}=$ para que

pac $^{\mathrm{a}} .=$ pacifica

$\mathrm{p}^{\mathrm{ar}}=$ particular

paraq' = para que

paraq' = para que

particularm $^{\mathrm{e}}=$ particularmente

particularm $^{\text {te }}=$ particularmente

Pass. ${ }^{\text {te }}=$ Passante

Pass $^{\text {te }}=$ Passante

$\mathrm{P}^{\mathrm{e}}$ Fr. $=$ Padre Frei

Pe. Fr. = Padre Frei

Pe. Fr. Fran ${ }^{\mathrm{co}}=$ Padre Frei Francisco 


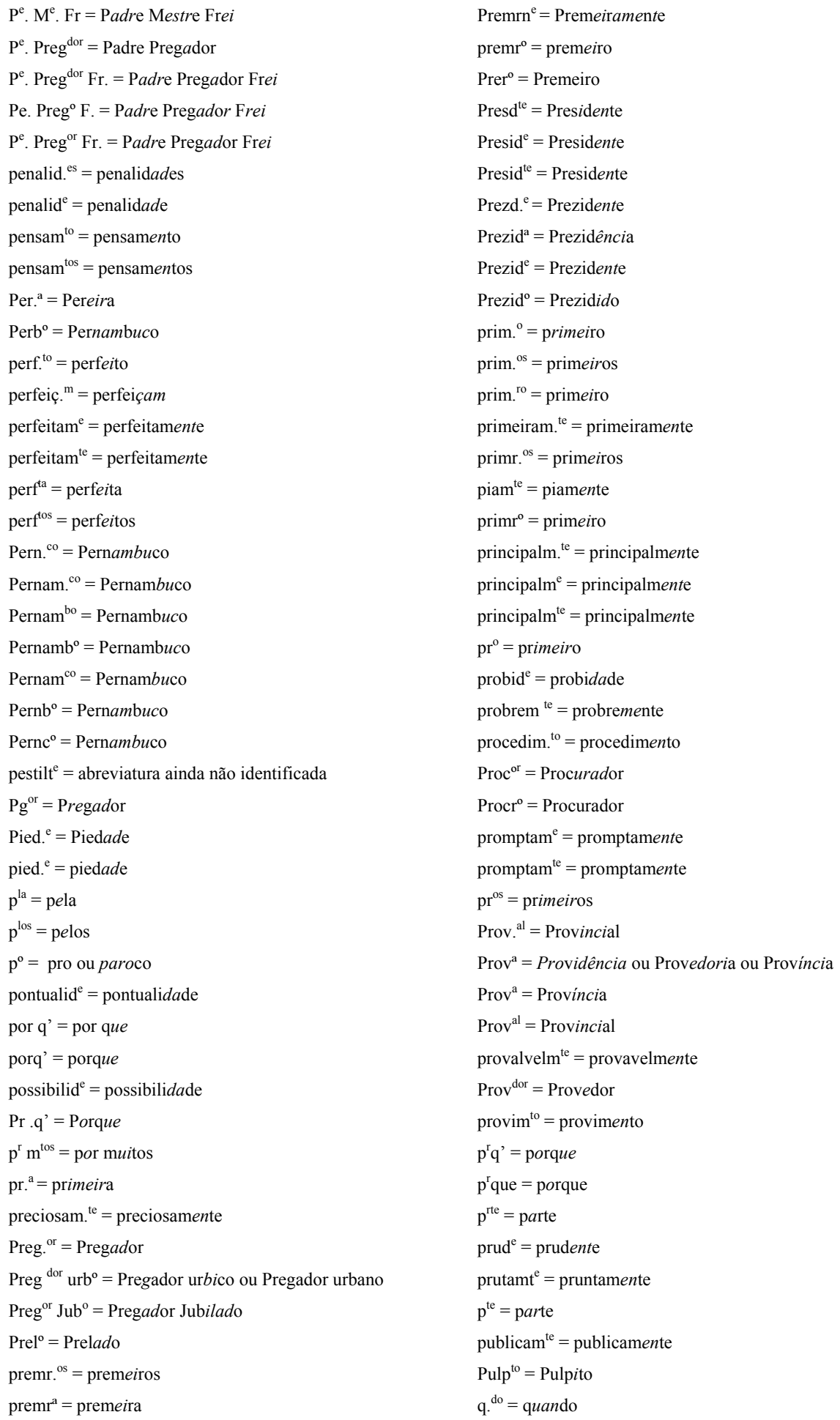




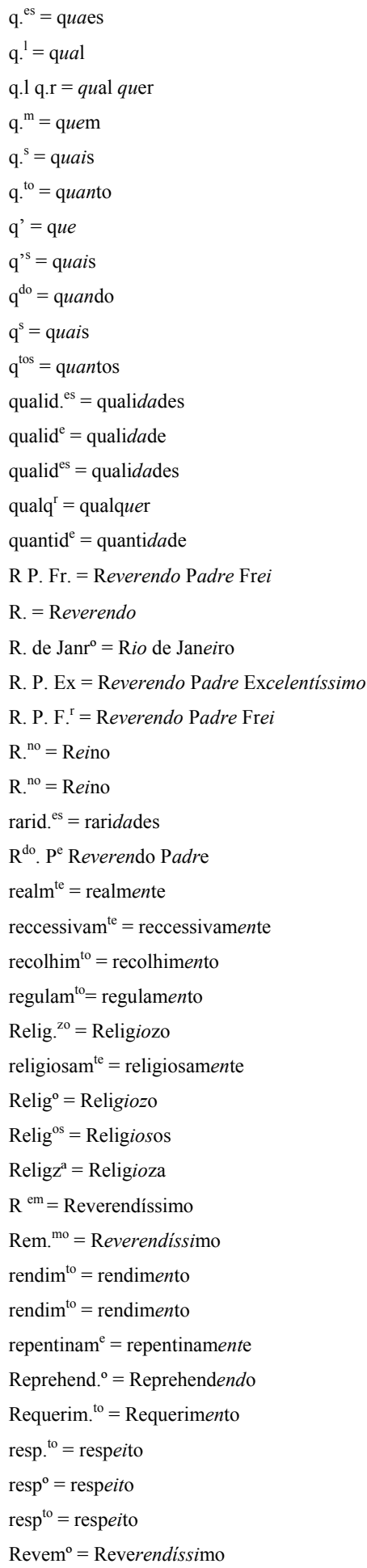

Revr $^{\text {do }} \mathrm{P}^{\mathrm{e}}$.Fr. $=$ Reverendo Padre Frei

Ribr $^{\mathrm{a}}=$ Ribeira

Ribr $^{\circ}=$ Ribeiro

$\mathrm{Rm}^{\circ}{ }^{\circ}=$ Reverendissimo

$\mathrm{R}^{\mathrm{o}}=\mathrm{R}$ eino

S. $=$ Santa

S. $=$ Santo

$\mathrm{S} .=\mathrm{S} \tilde{a} o$

$\mathrm{S} . \mathrm{Bern}^{\mathrm{do}}=$ São Bernardo

$\mathrm{S} . \mathrm{Franc}^{\mathrm{o}}=\mathrm{S} \tilde{a} o$ Francisco

S. Fran $^{\mathrm{co}} .=$ São Francisco

S. M. ${ }^{\mathrm{e}}=$ Santa Madre

S. $\mathrm{P}^{\mathrm{o}}=\mathrm{S} a \tilde{o} \mathrm{P} a u l \mathrm{o}$

$\mathrm{S} .{ }^{\mathrm{ta}}=$ Santa

$\mathrm{S}^{\text {to }}=$ Santo

$\mathrm{S}^{\mathrm{a}}=$ Silva, Silveira ou Sousa

sacram. ${ }^{\text {to }}=$ sacramento

Sacram. ${ }^{\text {tos }}=$ Sacramentos

sacram. ${ }^{\text {tos }}=$ sacramentos

Sacrament $^{\mathrm{os}}=$ Sacramentos

sagacid. ${ }^{\mathrm{e}}=$ sagacidade

salvam. ${ }^{\text {to }}=$ salvamento

Santid. $^{\mathrm{e}}=$ Santidade

Sapatr $^{\circ}=$ Sapateiro

saud. $^{\mathrm{e}}=$ saud $a d \mathrm{e}$

$\operatorname{seg}^{\mathrm{a}}=\operatorname{seg}$ und $\mathrm{a}$

segd. ${ }^{\mathrm{a}}=\operatorname{seg}$ unda

$\operatorname{seg}^{\mathrm{da}}=\operatorname{seg} u n \mathrm{da}$

$\operatorname{seg}^{\mathrm{da}}=\operatorname{seg} u n \mathrm{da}$

$\operatorname{seg}^{\mathrm{do}}=\operatorname{seg} u n$ do

$\operatorname{seg}^{\mathrm{e}}=$ seguinte

$\operatorname{seg}^{\text {te }}=$ seguinte

sent ${ }^{\mathrm{ca}}=$ sentenca

sentim $^{\text {to }}=$ sentimento

sentim $^{\text {tos }}=$ sentimentos

Septbr. ${ }^{\circ}=$ Septembro

sepul $^{\text {do }}=$ sepultado

sincerid. $^{\mathrm{e}}=$ sincerid $a d \mathrm{e}$

$\mathrm{Sm}^{\mathrm{a}}=$ Santissima

Sm. ${ }^{\mathrm{a}}=$ Santíssima

$\mathrm{S}^{\mathrm{ma}}=$ Santissima

$\mathrm{Sm}^{\mathrm{o}} \mathrm{P}^{\mathrm{e}}$. = Santíssimo Padre

Snr. $=$ Senhor

Sñr. $=$ Senhor

Snr. $^{\mathrm{a}}=$ Senhora 


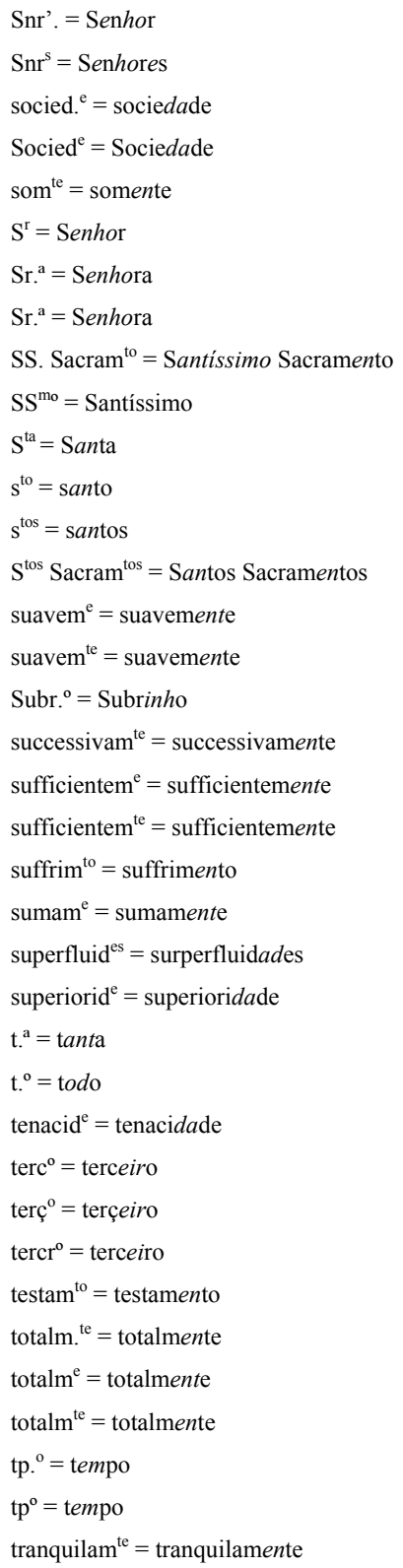

tranquillid $^{\mathrm{e}}=$ traquillida $\mathrm{de}$

trigesimo $7^{\circ}=$ trigesimo setimo

Trind $^{\mathrm{e}}=$ Trind $a d \mathrm{e}$

ultemam $^{\mathrm{e}}=$ ultemamente

ultimam. ${ }^{\mathrm{te}}=$ ultimamente

ultimam $^{\mathrm{e}}=$ ultimamente

ultim $^{\text {te }}=$ ultimamente

univercid $^{\mathrm{e}}=$ univercid $a \mathrm{de}$

universid. $^{\mathrm{e}}=$ universida de

urbanid. $^{\mathrm{e}}=$ urbanidade

$\mathrm{Urb}^{\circ}=\mathrm{Urbico}$ ou Urbano

utilidad. $^{\mathrm{e}}=$ utilid $a d \mathrm{e}$

utilid $^{\mathrm{e}}=$ utilid $a d \mathrm{e}$

v. g. = verbi gratia

$\mathrm{V}^{\mathrm{a}}=$ Vila

$\mathrm{v}^{\mathrm{a}}=$ vila

vaid $^{\mathrm{e}}=$ vaid $a d \mathrm{e}$

$\mathrm{Val}^{\mathrm{ca}}=$ Valenca

valim $^{\text {to }}=$ valimento

verd. $^{\text {es }}=$ verddades

verdad. $^{\text {ra }}=$ verdadeira

verdadeiram $^{\mathrm{e}}=$ verdadeiramente

verdadeiram $^{\text {te }}=$ verdadeiramente

verdadr. $^{\mathrm{a}}=$ verdadeira

verdadr $^{\circ}=$ verdadeiro

verd $^{\mathrm{e}}=$ verd $d a d \mathrm{e}$

verdr. $^{\mathrm{a}}=$ verdadeira

Vir. ${ }^{\mathrm{a}}=$ Vieira

$\operatorname{virt}^{\mathrm{es}}=$ virtudes

vocalm. $^{\text {te }}=$ vocalmente

voluntariam $^{\text {te }}=$ voluntariamente

$\operatorname{vontad}^{\mathrm{e}}=$ vontade

$\operatorname{vontad}^{\mathrm{e}}=$ vontade

vont $^{\mathrm{e}}=$ vontade

$\mathrm{V}^{\mathrm{r}}=$ Vieira

$\mathrm{Vr}^{\mathrm{a}}=$ Vieira 


\section{TRANSCRIÇÃO}

$\left[\mathrm{f}^{\mathrm{o}} 1 \mathrm{r}^{\mathrm{o}}\right]$

Dietario das vidas e mortes dos

Monges, q' faleceraõ neste Mosteiro de S.

Sebastiaõ da Bahia da ordem do Prin

cipe dos Patriarchas S. Bento no $<$ Prin $<[\uparrow$ Impe

rio $]>$ cipado $>\left[\uparrow\right.$ no] $\left[\uparrow \uparrow\right.$ Imperio] do Brasil. ${ }^{\urcorner}$

5

Em cumprim. ${ }^{\text {to }}$ ao decreto do $\left\langle\uparrow>\left[\uparrow \mathrm{SS}^{\mathrm{m}_{\mathrm{o}}}\right] \mathrm{P}\right.$. $^{\mathrm{e}}$

Urbano oitavo, protesto q' nestas vidas de Monges, q' escrevo, q. ${ }^{\text {do }}$ referir algum caso milagroso, algum beneficio especial de Dẽos; e quando disser, q' passaraõ a -

10 Bemaventurança, e da m. ${ }^{\mathrm{ma}}$ sorte quan do fallar algumas veses nesta palavra Santo, q' tudo isto he disendo respeito aos costumes, e nas acções, e naõ as pessõas, e q' tambem naõ paraq' se lhe dẽ outro credito, mais do que aquelle, que mereceo a fé humana.

7 Todas estas alterações aqui indicadas são feitas na escrita original, no entanto, posteriormente, foi

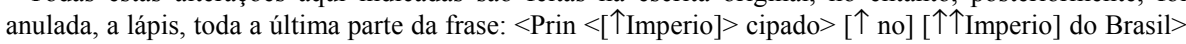
(APFL). 
Ao depois ${ }^{8}$ q' os Mosteiros Benedictinos do Reino de Portugal se unirão em um só corpo por ordem do Sñr. Cardeal Rei, ordenada uma congregaçaõ ${ }^{9}$ q' vivesse debaixo da cabeça de um Geral conforme a Bulla do Rm. ${ }^{010} \mathrm{P} .{ }^{\mathrm{e}}$ Pio Quinto, logo no segundo capitulo ao ${ }^{11}$ depois da reforma celebrada ${ }^{12}$ em Lisbôa no anno de $1575^{13}$, se concedeo faculd. ${ }^{\mathrm{e}}$ ao $\mathrm{Rm}$. ${ }^{\circ}$ eleito, paraq' este / sendo do agrado da Magestade / podesse mandar Monges á fundar Mostr. ${ }^{\mathrm{s}}$ nas partes ultra marinas. O Rm. ${ }^{{ }^{14}}$, q' entaõ era Fr. Placido de Villalobos, informado de q' esta Cidade da Bahia era a Capital do Bra sil, maduram. ${ }^{\text {te }}$ aconselhado, despachou no anno de $1580^{15}$ ao Irmaõ Donado Fr. Pedro de S. Bem to Religioso expedito, e intelligente com carta sua ao nobilissimo Senado da Camara, na q. 'representara o desejo q' tinha, de q' nesta Cidade se fundasse um Mosteiro de Monges Bentos, paraq' estes nesta quarta parte do Mundo se empregassem nos exercicios de virtude, e pied. ${ }^{\mathrm{e}}$, assim como estavaõ fasendo em toda Europa na sucessaõ de tantos seculos com grande utilidade da Igreja Catholica e adiant(...) $-1-$

\footnotetext{
${ }^{8}$ No original, Ao está riscado (anulado) e o $<\mathrm{d}>$ minúsculo de depois está sobrescrito para um $<\mathrm{D}>$ maiúsculo. (APFL)

${ }^{9}$ No original, vê-se a correção sobrescrita, alterando o $<\mathrm{c}>$ minúsculo para um $<\mathrm{C}>$ maiúsculo. (APFL)

${ }^{10}$ No original, $\mathrm{Rm}^{\mathrm{o}}$ encontra-se riscada (anulada), e, na entrelinha superior, foi acrescida a abreviatura de Santíssimo (SS). (APFL)

${ }^{11}$ No original, ao encontra-se (riscado) anulado. (APFL)

${ }^{12}$ Sobrescrito ao $<\mathrm{a}>$ encontra-se $u m<0>$. (APFL)

${ }^{13}$ Sobre o último número 5 , do ano de 1575 é sobrescrito o número 8 ., e na margem esquerda encontra-se a data de 187모, estando o último dígito sublinhado (APFL).

${ }_{15}^{14}$ Depois de $R m^{\circ}$, é escrita na entrelinha superior a palavra Geral. (APFL)

${ }^{15}$ Sobre o zero, de 1580 , está sobrescrito o número 1. (APFL)
} 
adiantam. ${ }^{\text {to }}$ espiritual das almas. Leo-se esta carta no Senado, e os Camaristas, q' entaõ eraõ; Joaõ Velho Galvaõ, Antonio da Costa, Gabriel Soares de Sousa, Fernando Pantoja; digo Fernando Vás, Antonio Fernandes Pantoja, aos quaes justam. ${ }^{\text {te }}$ devemos dar o titulo dos nossos primeiros Bemfeitores com grande gosto, e consolaçaõ sua, concederaõ a licença, q' da sua parte lhe tocava, insinuando ao Irmaõ Fr. Pedro de S. Bento, q' p. a a nova fundaçaõ pedisse ao Illustrissimo Sñr. D. Antonio Barreiros, dignissimo Bispo, q' entaõ era deste Bispado, uma Capella do glorioso Martire S. Sebastiaõ, q' existia neste lugar, em q' está fundado este Mosteiro, o dito Sñr ${ }^{16}$ sem q' pusesse duvida alguma, a entregou aos Monges Bentos com todos os seos preparos, concedendo juntam ${ }^{\text {te }}$ as licenças, q' dellas necessitavaõ p. ${ }^{\text {a }}$ nova fundaçaõ, na q. 'se mostrava interressado, por ter sido Prior de S. Bento de Avis no Reino de Portugal. Naõ duvidou o Capitaõ General Governador destes estados o Sñr. ${ }^{17}$ Lourenço da Veiga confirmar as ditas licenças, mas antes com $^{18}$

\footnotetext{
${ }^{16}$ Depois de Sñr,foi acrescentada, na entrelinha superior, a paravra Bispo. (APFL)

${ }^{17}$ Depois de $S \tilde{n} r$, foi acrescentada, na entrelinha superior, a paravra Bispo. (APFT)

${ }^{18} \mathrm{Na}$ margem direita, escrita na vertical, de baixo para cima, encontra-se a seguinte informação: Diego da Veiga falleceu em 4 de junho de 1581 (APFT).
} 
com $\mathrm{m}^{\text {to }}$ gosto concedeo tudo o q' nesta materia podia, e se assignou aos vinte cinco de Abril de 1$481^{19}$. Com estes prosperos principios q' já eraõ annuncios de felises progressos, voltou o Irmaõ Fr. Pedro p. ${ }^{a}$ o Reino a levar ao $\mathrm{Rm} .{ }^{\circ}$ a reposta do Senado, o qual recebendo esta noticia $\mathrm{p}^{\mathrm{a}}$ elle taõ desejada, ao depois de dar a Deos as devidas graças, entrou na diligencia de ir buscar sugeitos capases de corresponder as suas pretenções; na repeitavel pessoa do M. R. P. ${ }^{e}$ Fr. Antonio Ventura, e na sua perfeita observancia decobrio os requisitos necessarios p. $^{\mathrm{a}}$ uma empresa ${ }^{20}$, em q' tanto interessava, a honra de Deos, e utilidade das almas. Alcançada a provisaõ real, o nomeou por fundador, dando-lhe por companhe. ${ }^{\text {os }}$, e subditos oito Monges, cujos nomes saõ os seguintes, Fr. Pedro Ferraz, Fr. Joaõ Porcalho, Fr. Plácido da Esperança, Fr. Manoel de Mesquita, Fr. José, todos estes Sacerdotes; mais um Corista ordenado Subdiacono, chamado Fr. Francisco, e dous Donatos, Fr. Joaõ, e Fr. Bento, todos dotados de prendas, com q' servissem a Deos, e a Religiaõ. Correndo o anno de 1584. appa$-3-$

${ }^{19}$ Sobrescrito sobre o número 4, encontra-se o número 5. (APFL)

${ }^{20} \mathrm{O}<\mathrm{S}>$ está complementado com o alongamento relativo à letra $<\mathrm{z}>$ minúscula. (APFL) 
appareceraõ nesta terra aquelles mensageiros do Sñr. sem outra providencia, mais q' a divina, na qual trasiaõ toda a sua esperança, certificados q' nella tinhaõ um thesouro infalivel, no q. ${ }^{1}-$ haviaõ de achar o necessario $\mathrm{p}^{\mathrm{a}}$ conseguirem o fim dos seos louvaveis intentos, assim o experimentaraõ, q. $^{\text {do }}$ os moradores desta Cidade os foraõ receber com a caridade, veneraçaõ e respeito devido ao seo estado, as suas virtudes, e a seos annos. M. ${ }^{\text {tos }}$ e grandes foraõ os offerecim. ${ }^{\text {tos }}$ q' lhes fiseraõ as pessoas principaes da terra p. ${ }^{a}$ sua hospedagem, porem com attençaõ, q' deviaõ, se escusaraõ, e foraõ buscar a Capella, q' lhes estava destinada, recolhendo-se as suas casas a ella contiguas, as quaes redusidas a clausura, nella deraõ principio a um Mosteiro, q' pelo tempo adiante havia de ser o esplendor, e ornam. ${ }^{\text {to }}$ desta Cidade. Em breves tempos deraõ elles a $<$ acontecer $>$ /conhecer $\backslash$ aos habitadores da terra, q' a honra de $\mathrm{D}^{\mathrm{s}}$, e o zelo das suas almas era o fim unico, q' os trasia a estabelecer nesta quarta parte do Mundo uma Religiaõ taõ nobre, como esclarecida, porque - 
porque naquelles poucos Monges, deq' se ordenava a Comunidade, viraõ, e admiraraõ a observança da regra, e estatuos, a perfeiçaõ de culto, e das cerimonias, a frequencia dos pulpitos, e confessionarios, e finalm. ${ }^{\text {te }}$ o exemplo nas acções, e nas virtudes.

Do seo principio tem este Mosteiro florecido em suas lettras, e virtudes, porque sempre teve mestres, q' com as suas lettras acreditaraõ as cadeiras, Pregadores, q' com -

10 a sua eloquencia desempenharaõ os pulpitos, e confessores, q' com as suas instruções edificaraõ os penitentes. No Coro cantando os divinos officios com tanta devoçaõ, compostura, e decencia, q' parecia um anticipado ensaio, com que se preparavaõ na terra, para acompanharem os Coros dos Anjos daGloria. Agora neste Dietario se pertende dar uma breve noticia da vida, e da morte de cada um destes Monges em particular, p. ${ }^{\text {a }}$ ' se naõ perca de todo a memoria de uns Monges, q' tanto se empregaraõ no serviço, de Deos, e adiantam. ${ }^{\text {to }}$ das almas.

A vida, e a morte dos prim. ${ }^{\text {ros }}$ Monges q' fallecer- 
falleceraõ neste Monsteiro, q. ${ }^{\text {do }}$ para nos devia ser de saudosa memoria $p^{\text {a }}$ o agradecim ${ }^{\text {to }}$, e as suas louvaveis acções faserem-se recomendaveis a nossa lembrança p. ${ }^{\mathrm{a}}$ o exemplo, desapareceo a noticia de alguns delles, e as q' hoje se consertavaõ das mais antigas se devem ao inconsideravel disvello do M. R. P. ${ }^{\mathrm{e}}$ M. ${ }^{\mathrm{e}}$ Fr. José de Jesús Maria, e do M. R. P. ${ }^{e}$ Ex. Abb. ${ }^{e}$ Fr. Bernardo da encarnaçaõ, os quaes justam. ${ }^{\text {te }}$ se queixaõ de grande descuido, q' tem havido nesta matéria, porem esta falta se pode atribuir ou as hostilidades, dos Olan ${ }^{21}$. deses, q..$^{\text {do }}$ invadiraõ esta terra, ou porq' os nossos Monges antigos, as acções heroicas, mais se empenhavaõ em executa-las, do q' em escreve-las, e poderá ser q' melhor fortuna logrem sepultadas com suas cinsas, do q' por mal explicadas, perderem a gloria, com q' deviaõ ser applaudidas.

O primeiro Monge q' faleceo neste Monsteiro foi seo fundador, o M. R. P. ${ }^{\mathrm{e}}$ Fr. [个Antonio] Florencio, ${ }^{22}-$ Ventura. A vida, e a morte deste prim. ${ }^{\text {ro }}$ Prelado $-6-$

${ }^{21}$ Sobre o $<\mathrm{O}>$ maiúsculo estaõ sobrescritos um $<\mathrm{H}>$ maiúsculo e um $o$ minúsculo (APFL).

${ }^{22} \mathrm{O}$ nome Florêncio aparece riscado / anulado a lápis (APFL). 
Prelado, e fundador deste Monsteiro eraõ dignas de uma pena, q' com vivas expressões soubesse representar a posteridade, as heroicas acções do seo zelo, do seo trabalho, e do seo disvello. Em idade avançada se achava este perfeito regilioso, q. ${ }^{\text {do }}$ lhe deraõ a noticia, deq' elle era o nomeado p. ${ }^{\text {a }}$ fundador da Religiaõ Benedictina nos estados do Brasil, naõ deixaraõ de se lhe representar as difficuldades do emprego, porem elle fiado nos acertos da obidiencia, sem repugnancia se encarregou dos trabalhos, q' sabia, o esperavaõ por mar e por terra vencidos ${ }^{23}$ os prim. ${ }^{\text {ros }}, /$ dessendo $/{ }^{24}$ a esta terra, tomou posse das casas, e capella, q' lhe foraõ emtregues. Elegeo por seo Prior ao Pe. Fr. Pedro Ferraz, e presentes os mais religiosos, lhe repre(sem)tou a importancia do negocio, a q' vieraõ, e (o) tratrabalho, deque estavaõ encarregados, e como era ${ }^{25}$ fundar um Convento, q' Deos os tinha trasido a salvam. ${ }^{\text {to }}$ as terras taõ distantes, e os tinha posto em um lugar taõ sufficiente e acommodado, -

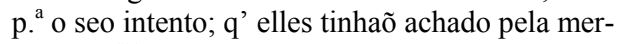
cê do $m .{ }^{\text {mo }}$ Sñr, as vontades dos moradores promptas para os ajudarem, agora da sua parte lhes

${ }^{23}$ vencidos foi substituído, por sobreposiçaõ, por .Vencidos (APFL).

${ }^{24}$ /dessendo/ está riscado e substituído, na entrelinha superior, por chegando (APFL).

${ }^{25}$ Após era foi acrescentado o de (APFL). 
lhes podia empenhar-se com todas as suas forças, primeiram. ${ }^{\text {te }}$ no serviço de Deos, e ao depois no trabalho da Religiaõ, p. ${ }^{\text {a }}$ q' estavaõ destinados. Efinalm. ${ }^{\text {te }}$ lhes advertia, q' a exemplaridade de suas vidas podia ser melhor attractivo, tanto das esmollas p. ${ }^{\text {a }}$ fundar o Mosteiro, como de Patrimonio p. ${ }^{a}$ sustentaçaõ dos Monges.

Estes, e outros paternaes avisos, e saudaveis conselhos receberaõ os Subditos com as lagrimas 10 nos olhos, e com o respeito devido a um Prelado, cheio do zelo da honra de D. ${ }^{\mathrm{s}}$ e adiantamento, da sua Religiaõ. Mandou dar principio a obra com tanto fervor, q' logo dẽo aconhecer a D. ${ }^{\mathrm{s}}$ dentro, e fora do Convento, q' o adotara de valor, e disposiçaõ p. ${ }^{\text {a }}$ cousas grandes. Já entre os Monges se naõ falla mais em descanço, todos trabalhos ${ }^{26}$, todos se disvellaõ, nenhum se isenta, estaõ promptos p. ${ }^{\mathrm{a}}$ tudo. Como a obra corria por conta de D. ${ }^{\mathrm{s}}$, em breves tempos se vio com grandes aumentos, de sorte q' o fundador em seus dias chegoua ver o Convento quasi completo, e com patrimonio sufficiente $p .^{\text {a }}$ sustentar os -

${ }^{26}$ Sobre $o s$ de foi sobrescrito $a \tilde{o}$ (APFL). 
os Religiosos, q' bastassem p. ${ }^{\text {a }}$ cumprir com as obrigações do côro, e outros actos de comunid. ${ }^{\mathrm{e}}$

Divulgada a fama pelas partes do Brasil, q' nesse tempo estavaõ discubertas do . $^{\text {to }}$ q' se empregavaõ aquelles perfeitos Religiosos nos divinos louvores de dia, e de noite, como tambem a grande aceitaçaõ, com q'estavaõ na opiniaõ de todos, adquerida naõ pelos caminhos da lisonja, mas sim pelos exercícios das virtudes, os moradores da Cidade do Rio de Janeiro solicitaraõ do M. R. P. ${ }^{\mathrm{e}}$ Fundador, lhes mandassem Monges $\mathrm{p}^{\mathrm{a}}$ nella levantarem um Monsteiro, $\mathrm{p}^{\mathrm{a}}{ }^{\mathrm{o}} \mathrm{o}$ q' queria concorrer com o necessário p. ${ }^{\mathrm{a}}$ lhe dar principio; elle condescendendo com os seos louv(avei)s desejos lhes mandou aquelles dous exemplares dapaciencia o P. ${ }^{\mathrm{e}}$ Fr. Pedro Ferraz, q' era o seo Prior, e o P. ${ }^{\mathrm{e}}$ Fr. Joaõ Porcalho por seo companheiro, os quaes partiraõ deste Monsteiro na opiniaõ mais bem fundada, no fim do anno de 1586. Naquella terra, aonde prim. ${ }^{\text {ro }}$ q' elles, tinha chegado a noticia das - 
das suas virtudes, desempenharaõ com acerto, das suas disposições, e com a exemplaridade das suas vidas, tudo, o q' se esperava da sua perfeita observancia.

Passados $7^{27}$ annos, e alguns meses em continuo trabalho de dia, e de noite, ao depois de deixar fundado um Monsteiro, estabelecido com patrimonio sufficiente p. $^{\mathrm{a}}$ a sua conservaçaõ, destituido já de forças p. ${ }^{a}$ a vida laboriosa, emtrou a preparar-se p. a morte, q' todos os dias esperava, foi delle aumentando uma molestia, q' padecia, e desenganado estarem, completos os seos dias, mandou chamar os Religiosos, e fasendo-lhe uma pratica, em q' lhes advertia como Prelado, e os avisava como Pai, a q' fossem perfeitos, se despedio de todos com m. ${ }^{\text {tas }}$ lagrimas, e elles com $\mathrm{m}^{\text {tas }}{ }^{\text {mais }} \mathrm{p} .{ }^{\mathrm{r}}$ se verem privados da compahia de um Prelado, q' por mar, e por terra sempre os tratava com amisade, e amor de Pai. Entregou ao seo Prior Fr. Placido da Esperança, o governo da casa, e dispondo-se com $\mathrm{m} .{ }^{\text {tos }}$ actos de piedade, e amor de D. , foi falecido com $-10-$

\footnotetext{
${ }^{27}$ Neste ponto, o suporte está danificado, e a informação do conteúdo (o número 7) foi acrescida a lápis, posteriormente (APFL).
} 
com a graça dos Sacram. ${ }^{\text {tos }}$, poz termo a sua perigrinaçaõ, deixando-nos no exemplo da sua ajustada vida um bem acertado dictame, $\mathrm{p}^{\text {. }}$ conseguimos a perfeiçaõ religiosa. Faleceo em 13 de Desembro de 1591. Governou tres annos como Abb. ${ }^{\mathrm{e}}$, tres como Presidente, por falecim. ${ }^{\text {to }}$ do seo sucessor o M. R. P. ${ }^{e}$ Fr. Luiz do Espirito Sancto, q' morreo vindo embarcado $p^{\text {a }}$ esta terra. Na pedra da sua sepultura se descobrem as lettras do seonome na porta da Sacristia, aonde foi emterrado com as honras devidas ao seo lugar, e a sua pessôa.

$2^{\circ}$ O Segundo monge falecido neste Monsteiro foi o $\mathrm{P}^{\mathrm{e}}$ Fr. Urbano professo na Congregaçaõ. Era religioso observante, e caritativo, e porisso foi mandado $\mathrm{p}^{\mathrm{a}}$ este Monsteiro, para q' nelle em companhia dos $\mathrm{m}^{\mathrm{s}}$ religiosos, se empregasse nos actos de caridade, e no serviço da Religiaõ; assim o praticou, emquanto viveo, frequentando o Côro, e mais actos da comunidade, obedencendo com promptidaõ, ao que the era mandado. Falecêo dis- 
disposto com os Santos Sacram. ${ }^{\text {tos }}$ em 7 de Agosto, de 1.602, sendo D. Abb. ${ }^{\mathrm{e}}$ o M. R. P. ${ }^{\mathrm{e}}$ Fr. Clemente das Chagas, q' era juntam. ${ }^{\text {te }}$ Provincial, assim como tambem o foraõ os seus tres Successores, e dahi por diante ficaraõ os Reverendissimos Provinciaes gosando p. ${ }^{\mathrm{r}}$ breve Pontifício todos os privilegios dos Dons Abb. es $^{\text {, }}$ sem o serem de casa alguma.

O Terceiro foi o N. M. R. Fr. Paulo Peixoto, professo na Congregaçaõ. Era religioso de vida exemplar, e de conhecida capacidade p. $^{\text {a }}$ occupar os lugares mais auctorisados da Religiaõ. Foi Abbade deste Mostro ${ }^{\circ}$ no seo governo fez as partes de bom Prelado, zelando a honra de D. , a observancia regular, e o patrimonio da Religiaõ. Certificados os Prelados Superiores do zelo, da prudencia, e da rectidaõ, com q' se houve na sua Abbadia, o ellegeraõ Providencial da Provincia, a qual naõ chegou a experimentar os eff. ${ }^{\text {tos }}$ da sua observancia, porq' no prim. ${ }^{\text {ro }}$ anno do seo governo acabou os dias de sua vida, tendo 
tendo recebido os ultimos Sacram. ${ }^{\text {tos }}$ Com $\mathrm{m}^{\text {tos }}$ acctos de catholico. Faleceo em 10 de Outubro de $1719^{28}$. Ignora-se o Prelado, q' nesse tempo governava.

54

O Quarto foi o Pe. Fr. Joaõ do Deserto professo na Congregaçaõ. Veio a esta Província mandado pelo R. ${ }^{\mathrm{mo}} \mathrm{p} .{ }^{\text {a }}$ nella exercer as prendas, de q' era dotado; desempenhou a sua obrigaçaõ, porq' socorrido de uma perfeita voz exercêo por $\mathrm{m} .{ }^{\text {tos }}$ annos o emprego de Cantormor, assistindo, e frequentando o Côro com tanta alegria, e consolaçaõ de sua alma, como quem sabia, q' este exercicio hé o mais nobre, o mais sancto, e o principal, de q. ${ }^{\mathrm{m}}$ pro-

15 fessa a vida religiosa. Com $\mathrm{m} .{ }^{\text {tos }}$ annos de idade, e os mais delles empregados no serviço de Dêos, e da Religiaõ, acabou a vida preparado com a graça dos Sacram. ${ }^{\text {tos }}$, no anno de 1$624^{29}$, sendo D. Abb. ${ }^{\text {e }}$ o N. M. R. P..$^{\mathrm{e}}$ Fr. Diogoda Silva.

Neste $\mathrm{m}^{\mathrm{mo}}$ anno, quando o Monstro já contava quarenta annos de fundaçaõ, invadiraõ os Olandese ${ }^{30}$ esta terra, e como eraõ

${ }^{28}$ Acima do dígito 7 encontra-se o dígito 6 (APFL).

${ }^{29} \mathrm{Na}$ margem esquerda, encontra-se um ponto de interrogaçaõ (APFL).

${ }^{30}$ Realmente não há concordância no original. 
eraõ uma infernal mistura de Luteranos, e Calvinistas, e prim. ${ }^{\text {ro }}$ objecto de suas dannadas intenções, foi o total estrago dos templos sagrados, aos quaes ao depois de roubados, e saqueados os arrasaraõ, deixando tudo assolado, e destruido; os Religiosos p. ${ }^{\text {a }}$ salvarem as vidas, se retiraraõ p. ${ }^{\mathrm{a}}$ o Certaõ, aonde padecendo $\mathrm{m}$. ${ }^{\text {tas }}$ necessidades, lamentavaõ a total destruiçaõ de um $\operatorname{Mostr}^{\circ}$ q' tanto lhes custara, assim andaraõ até q' as armas portuguesas, e castelhanas triunfando destes mortaes inimigos da fé catholica, os poseraõ em vergonhosa retirada no seguinte anno de 1.625.

Ao depois, q' a Portugal chegou a noticia, desta victoria, mandou o R. ${ }^{\text {mo }}$ novo Prelado, com mais 3 Religiosos e reedificar o Mostr ${ }^{\circ}$ e a convocar-se Monges, q' andavaõ dispersos; o Prelado parece ser o M. R. P. ${ }^{\mathrm{e}}$ Fr. Cosme de S. Tiago; um dos 3 Monges, era Fr. Paulo do Espírito Sancto grande Bemfeitor deste Mostr ${ }^{\circ}$, como se dirá na sua vida. Reedificado o Convento continuaraõ os Monges nos costumados exercicios, aumentando-se cada vez mais a regu- 
regular observança pelo maior numero de Religiosos, e maior adiantam. ${ }^{\text {to }}$ da casa, e assim tem perceverado, até este presente ano de 1776 , em q' se contaõ 56 Provinciaes $^{31}$, q' zelando a honra de Deos, e a observança regular acusta de $\mathrm{m}^{\text {to }}$ trabalho, por mar, e p. ${ }^{\mathrm{r}}$ terra tem conseguido uma attençaõ $\mathrm{m}^{\text {to }}$ distincta para esta Provincia entre os seculares por verem apaz nos Mostr. ${ }^{\text {os }}$ e exemplaridade nos $\operatorname{Re}<\mathrm{g}>/ 1 \backslash$ igiosos $^{32}$.

10

5 O Quinto Monge falecido neste Monsteiro foi o P. ${ }^{\mathrm{e}}$ Fr. Bento Viegas professo na Congregaçaõ. Veio p. ${ }^{a}$ esta Casa degradado pelas suas desordens, e como nellas preseverasse, lhe tiraraõ o habito, e o despediraõ da Religiaõ, ao depois de ter vivido em Taparica $\mathrm{m}^{\text {tos }}$ annos no estado de Sacerdote buscou o Monsteiro, o qual o recebeo, certificados os Monges, de q' estava emendado dos seos máos costumes, assim o mostrou, porque nestes poucos dias, que teve de vida, com as lagrimas, q' chorava, e com as penitencias, q' fasia, dava publica satisfaçaõ aos homens do escândalo, que lhes tinha causado, e procurava de D. ${ }^{\mathrm{s}}$ o perdaõ das culpas, com q' o tinha $-15-$

${ }^{31}$ Acima de Provinciais está escrito Conventos (APFL).

${ }^{32}$ Apresenta-se uma rasura original: sob o $<\mathrm{l}>$ encontra-se $<\mathrm{g}>$, provavelmente, à época tendou-se, em vão, eliminar este grafema por raspagem. 
tinha offendido; assim arrependido foi dar a sua conta no Tribunal divino no mez de Janeiro de $1626^{33}$ sendo D. Abb. ${ }^{\mathrm{e}}$ o M. R. P. ${ }^{\mathrm{e}}$ Fr. Cosme de S. Tiago.

56

O Sexto foi o P. ${ }^{\mathrm{e}}$ Fr. Mauro das Chagas professo na Congregaçaõ. Era Religioso observante, e exemplar, por ser bem instruido na arte da Musica, e compositor de solfa, o mandaraõ p. ${ }^{\mathrm{a}}$ este Mostr ${ }^{\circ}$. Empregou-se $p .{ }^{r}$ alguns annos no exercicio de Mestre de Capella, empenhando-se em q' todas as funções da Igreja, e côro, se fisessem com edificaçaõ dos Religiosos, e seculares. Instruio com grande disvello aos Monges juniores no Cantochaõ, desejando q' todos o soubessem na ultima perfeiçaõ. A custa do seo trabalho, deixou m. ${ }^{\text {tos }}$ discipulos, q' herdeiros de suas prendas serviraõ a Religiaõ, edificando aquem os ouvia e admirava. Occupado nestes, e outros louvaveis exercicios, encheo os seos dias no mez de Julho de 1629 sendo D. Abb. ${ }^{e}$ o M. R. P. ${ }^{\mathrm{e}}$ Fr. Cosme de S. Tiago.

O Septimo foi o Padre Fr. Isidoro da Visitaçaõ professo na congregaçaõ. Trabalhou $-16-$

\footnotetext{
${ }^{33} \mathrm{Na}$ margem esquerda, encontra-se um ponto de interrogaçaõ (APFL).
} 
$\left[\mathrm{f}^{\mathrm{o}} 10 \mathrm{r}^{\mathrm{o}}\right]$

trabalhou com grande disvello nas obras deste Mosteiro, em quanto teve forças p. ${ }^{a}$ o faser. Era obediente, zeloso, e caritativo, singularisando-se no grande cuidado, q' tinha dos enfermos, aos quaes repetidas veses visitava, animando-os á soffrer constantes as molestias, q' os affligiaõ; quando já os via agonisantes, com boas, e sanctas advertencias os ajudava naquella hora de angustias, á deixarem resignados esta vida caduca. Chegando o tempo determinado p. ${ }^{\text {a }}$ dar as suas contas, cuidou com todas as forças do seo espirito em se dispor p. $^{\mathrm{a}}$ receber os ultimos sacram. ${ }^{\text {tos }}$, e com a sua graça passou desta para outra vida no mez de Novembro de 1632, sendo D. Abb. o M. R. P. ${ }^{\mathrm{e}}$ Fr. Placido das Chagas.

O Oitavo foi o P. ${ }^{\mathrm{e}}$ Fr. Alexandre da Encarnaçaõ, professo na Congregaçaõ. Pouco se utilisou da Religiaõ do grande desejo, q' este Monge tinha de a servir, porq' todo o tempo, q' viveo neste Mostr. ${ }^{\circ}$, foi sempre padecendo, e penando; approveitaraõ porem os Religiosos, servindo-lhe de exemplo á constancia, e a pacien- 
paciencia, com q' sustentou p. ${ }^{\mathrm{r}} \mathrm{m} \cdot{ }^{\text {tos }}$ annos os lastimosos effeitos de uma incuravel, e trabalhosa molestia, mostrando-se sempre alegre, e conforme com aq. ${ }^{\text {le }}$ toque da maõ divina, dando a D. ${ }^{\mathrm{s}}$ repetidas graças pela esperança, em q' oposera da sua salvaçaõ. Posto em um estado digno de compaixaõ, nunca deixava de resar o officio divino de joelhos, ou na forma, q' podia, comprindo com todas as obrigações de Religioso, e satisfasendo a outras devoções, aq' se tinha obrigado. Ao depois de $\mathrm{m}^{\text {to }}$ padecer sempre sofredore sempre resignado o dispensou daq. ${ }^{\text {le }}$ purgatorio, em 10 de Janeiro de 1635 , sendo D. Abb. ${ }^{\text {e o M. R. }}$ P. ${ }^{\mathrm{e}}$ Fr. Placido das Chagas. ${ }^{34}$

159 O Nono Religioso, q' faleceo nesta Casa, foi, o irmaõ Donado Fr. Gonsalo natural das Ilhas, e professo neste Mostr. ${ }^{\circ}$. Já adiantado em annos buscou a Religiaõ, a qual o recebeo, e se utilisou do prestimo, q' tinha p. $^{\text {a }}$ a ser-

20 vir; o mais do tempo trabalhou na horta com zelo, e cuidado. Cumpria com as obrigações pertencentes á seo estado, naõ dei$-18-$

\footnotetext{
${ }^{34} \mathrm{Na}$ margem esquerda, encontra-se um ponto de interrogação (APFL).
} 
$\left[\mathrm{f}^{\mathrm{o}} 11 \mathrm{r}^{\mathrm{0}}\right]$

deixando de ouvir Missa todos os dias, obrigando juntam. ${ }^{\text {te }}, q^{\prime}$ também a ouvissem os escravos, que com elle trabalhavaõ. Destituido já de forças

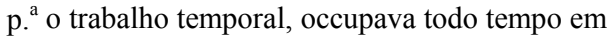
se dispor p. ${ }^{a}$ morte, q' sempre trasia na lembr. ${ }^{a}$ Falecceo preparado com agraça dos Sacram. ${ }^{\text {tos }}$ no mes de Julho de 1636, sendo D. Abb. ${ }^{\text {e o M. R. P. }}{ }^{\text {e }}$ Fr. Calisto de Faria. ${ }^{35}$

O Decimo foi o P. ${ }^{\mathrm{e}}$ Fr. Antonio da Encarnaçaõ professo em Portugal. Logo ao depois de Sacerdote mandaraõ para esta casa pela parte, q' tinha de tocar baixaõ, e outros instrum ${ }^{\text {tos }}$, de que nesse tempo se usava. Era Religioso observante, dos votos da sua profissaõ, e diligente na satisfaçaõ das suas obrigações; a affligia-se de q' se excusasse de trabalhar, quem tinha forças $\mathrm{p} .{ }^{\mathrm{a}} \mathrm{o}$ faser. Viveo $\mathrm{m}^{\text {tos }}$ annos na Religiaõ, frequentando o Côro, e mais actos religiosos, em q. ${ }^{\text {to }}$ pode, naõ se utilisando das dispensas, q' a Religiaõ lhe permittia pelos seus annos, e pelas suas moléstias. Faleceo este perfeito Religioso aos 9 de Desembro de 1638. Sendo D. Ab. ${ }^{e}$ o M. R. P. ${ }^{e}$ Fr. Calisto de -19 -

${ }^{35}$ No original, lê-se: $c f$. Doc. 12 Liv. Tombo (APFL). 
$\left[\mathrm{f}^{\mathrm{o}} 11 \mathrm{v}^{\mathrm{0}}\right]$

de Faria.

11 O Undecimo foi o Irmaõ Donado Fr. Manoel nascido em Portugal, e professo nesta ca-

5 sa. Occupou-se o mais do tempo no officio de dispenseiro, no qual emprego se deo a conhecer por fiel, caritativo, e cuidadoso. Porsua conta corria ensinar a doutrina aos escravos, o que fasia com $\mathrm{m}^{\text {ta }}$ diligencia todas as madrugadas, ao depois q' sahia de Matinas, as quaes nunca faltava. Era humilde, obediente, e de todos amado pela sua virtude. Faleceo com os Sanctos Sacram. ${ }^{\text {tos }}$, q' recebeo com $\mathrm{m} .{ }^{\text {ta }}$ devoçaõ, e piedade no mez de Janeiro, de 1639. Sendo D. Abb. ${ }^{\mathrm{e}}$ o M. R. P. ${ }^{\mathrm{e}}$ Fr. Calisto de Faria. 
12 O Duodécimo foi o P. Fr. Manoel de Mesquita nascido nesta Cid. ${ }^{\mathrm{e}}$, professo neste Monsteiro. Seus virtuosos Pays o mandaraõ a prender solfa, na qual ajudado deuma perfeita voz tanto se adiantou em pouco tp. ${ }^{\circ}$, que p. ${ }^{\mathrm{r}}$ esta, e outras [ $\uparrow$ prendas] de que era dotado, foi admitido ao santo habito com grande satisfaçaõ do Religiozos. Viveu como perfeito Monge, exercendo ordinariam. ${ }^{\text {te }}$ o emprego de cantor-mor, excuzando-se de outra q. ${ }^{1}$ q. ${ }^{\mathrm{r}}$ occupaçã̃ que o pudesse divertir deste santo, e louvável exercicio. Ja adiantado em annos padecia algumas moléstias habituais, porem estas nunca oprivaraõ da frequencia do Coro, e mais actos conventuais em quanto viveu. Occupado nos santos exercicios do seu estado, ao dep. ${ }^{\text {s }}$ de recebidos os ultimos Sacram. ${ }^{\text {tos }}$, poz termo a sua exemplar vida em 17 de dezembro de 1639 sendo D. Abb. ${ }^{\text {e o m }} .^{\text {to }}$ R. P. Fr. Fram. ${ }^{\text {co }}$ da Aprezentaçaõ.

2013 O Décimo terceiro foi o Irmaõ Corista Fr. Felis da Cruz natural de Pernambuco, professo nesta caza. No pouco tempo, que os Monges logravaõ sua estimavel companhia, deu a conhecer sua virtude, $p .^{\mathrm{r}} \mathrm{q}$ ' no exercicio della gastava 
todo o tempo. Adoeceu deuma maligna, q' vencendo a todos os remedios da medicina, lhe tirou a vida, ficando a Religiaõ privada dos serviços, q' prometia o seu prestimo por ser expedito, observante, e diligente. Foi o seu falecimento no mez de Dezembro de 1640 sendo D. Abb. ${ }^{\mathrm{e}}$ o M. R. P. Fr. Francisco das Chagas.

14 O Decimo quarto foi o Irmaõ Donado Fr. Pedro natura da Ilha gracioza. Sempre este Monge deu em toda a sua dilatada vida uma prompta satifaçaõ aos empregos $(\dagger)$ de q' o encarregava a obediencia. No emprego de procurador, q' exerceu p. ${ }^{\mathrm{r}} \mathrm{m}^{\text {tos }}$ annos, acabou de mostrar a capacidade, q' tinha $\mathrm{p}^{\mathrm{r}}$ qualquer occupaçaõ laborioza. Os exercicios espirituaes pertencentes ao seu estado, eraõ os primeiros, a que satisfazia, assistindo com toda devoçaõ aos officios divinos q. ${ }^{\text {do }}$ nelles se achava. Com estes catolicos preparados revestidos de huma perfeita humildade se dispunha p. ${ }^{\text {a }}$ morte, aq. ${ }^{1}$, aodepois $(\dagger)$ de recebidos os ultimos sacram. ${ }^{\text {tos }}$ lhe tirou a vida no mez de Janeiro de 1642 sendo D. Abb. o M. ${ }^{\text {to }}$ R. P. Fr. Francisco da Apresentaçaõ. 
$\left[\mathrm{f}^{\mathrm{0}} 13 \mathrm{r}^{\mathrm{0}}\right]$

15 O Decimoquinto foi o P. ${ }^{\mathrm{e}}$ Fr. Placido da Cruz natural de Pernambuco professo nesta caza.

Era Religioso dotado de prendas, com as quaes sempre servio a Religiaõ. Tocava orgaõ com destreza, e na muzica era perf. to $^{\text {. Todo o seu cuid. }{ }^{\circ} \text { se enca- }}$ minhava p. ${ }^{\text {a }}$ q' as funcoens do Coro, e Igreja se fizesse com toda a decencia, e perfeiçaõ. Contando ja m. ${ }^{\text {tos }}$ annos de idade, p. ${ }^{\text {a }}$ corôa dos seus virtuozos exercicios, foi acometido de umas grandes dores de cabeça, as q. ${ }^{\mathrm{s}}$ tolerou com grd. ${ }^{\mathrm{e}}$ paciencia; com huma resignaçaõ de perfeito Religiozo acabou a vida disposto com a graça dos Sacram. ${ }^{\text {tos }}$ no mez de dezbr. ${ }^{\circ}$ de 1642 sendo D. Abb. ${ }^{\mathrm{e}}$ o m. ${ }^{\text {to }}$ R. P. Fr. Bernardo de Braga.

$1516-\quad$ O Decimosexto foi o P. Fr. Lourenço da Purificaçaõ nascido nesta cidade, professo nesta caza.

Ao dep. ${ }^{\mathrm{s}}$ de concluir o seu collegio, o mandaraõ adminis trar a fazd. ${ }^{\text {a }}$ da Itapoam; na sua administraçaõ mostrou o zelo, q' tinha p. ${ }^{\text {a }}$ tratar dos bens da Religiaõ: ajudou $\mathrm{m}^{\text {to }}$ ao Monsteiro q' neste $\mathrm{tp}^{\mathrm{o}}$ andava com obraz, com grd. ${ }^{\text {e }}$ socorro de farinha, legumes, e frutas, q' todas as semanas remetia a custa do seu trabalho, e desvelo. Adoecendo de humas cezoens, e sendolhe aplicado o /remedio/ das sangrias, logo na pr. ${ }^{\text {a }}$ lhe traspassaraõ os nervos, e recolhendo-se ao Mostr ${ }^{\circ}$ embreves dias acabou a vida, ao dep. ${ }^{\mathrm{s}}$ de recebidos os Sacram. ${ }^{\text {tos }}$. Faleceu em $1^{\circ}$ de $\mathrm{M}^{\mathrm{co}}$ de 1643. sendo D. Abb. ${ }^{\mathrm{e}}$ o M. R. P. Fr. Bernardo 
17 O decimo septimo foi o Irmaõ corista Fr. Domingos do Rozario natural dos Ilheos, professo neste Monsteiro. No seu noviciado parece, q' este religiozo mais se despunha $p .{ }^{\mathrm{a}}$ morrer, do q' p. ${ }^{\mathrm{a}}$ professar, $\mathrm{p} .{ }^{\mathrm{s}}$ naõ dava ao seu corpo ne $/ \mathrm{m} /$ aquelle descanço, q' a Religiaõ permite aos Noviços p. ${ }^{\mathrm{a}}$ alivio das continuas mortificaçoens, e penalid. ${ }^{\text {es }}$, em q' se exercitaõ no anno da sua aprovaçaõ; p. $^{\mathrm{s}}$ todo otp ${ }^{\circ}$, lhe restava ao dep. ${ }^{\mathrm{s}}$ satisfazer as suas obrigaçoens, e empregava ao dep. ${ }^{\mathrm{s}}$ de professo lhe deraõ as bexigas, das quaes veio a morrer, tendo-se preparado, com todos os Sacram. ${ }^{\text {tos }}$, aos 3 de Abril de 1643 sendo D. Abb. ${ }^{\mathrm{e}}$ o M. R. P. M. ${ }^{\mathrm{e}}$ Fr. Bernardo de Braga.

18 O Decimo oitavo foi o Irmaõ Fr. Fran. ${ }^{\mathrm{co}}$ dos Anjos nascido em Itaparica. Neste Mosteiro foi admitido ao Noviciado, aonde poucos mezes dep. ${ }^{\mathrm{s}} \mathrm{da}$ sua entrada foi acometido das bexigas, avizados os Religiozos de q' eraõ mortaes, lhe foi dada a profissaõ, e consolado $\mathrm{p} .{ }^{\mathrm{r}}$ se ver no estado de Religiozo, encheu os seus dias em 9 de $\mathrm{J}^{\mathrm{o}}$ de 1646 sendo D. $\mathrm{Abb}^{\mathrm{e}}$ o M. R. P. $\mathrm{M}^{\mathrm{e}}$ Fr. Ignacio de S. Bento.

19 O Decimo nono foi o Irmaõ Donado $F[\dagger]$ Joze da Esperança natural do Reino professo nesta caza. Em premio do . $^{\text {to }}{ }^{\text {q }}$ trabalhou na 
$\left[\mathrm{f}^{\mathrm{o}} 14 \mathrm{r}^{\mathrm{0}}\right]$

5 reedificaçaõ deste Mosteiro, [ $\uparrow$ deu] lhe habito e corôa Monacal. Administrou a fazd. ${ }^{a}$ da Itapoam p. ${ }^{r}$ alguns annos, e na quellas partes adquirio uma molestia, de que veio a morrer disposto com os ultimos Sacramentos em 2 de M. ${ }^{\text {co }}$ de 1647 sendo D. Abbe o m. ${ }^{\text {to }}$ R. P. M.e Fr. Ignacio de S. Bento.

20 O Vigesimo foi o Irmaõ donado Fr. Miguel do Paraizo nascido nas Ilhas, professo nesta caza. No estado de secular trabalhou alguns annos nas obras deste Mostro. Pertendeu o $<\uparrow>$ [个habito] de Religiozo no estado de leigo e como sempre vivesse sem nota do seu procedim. ${ }^{\text {to }}$, foi-lhe concedido o q' dezejava dep. ${ }^{\mathrm{s}}$ de professo continuou no $\mathrm{m}^{\mathrm{mo}}$ exercicio de pedreiro com $\mathrm{m}^{\text {to }}$ zelo, e adiantam. ${ }^{\text {to }}$ das obras, naõ faltando a comprir com suas obrigaçoens, assistindo de noite a matinas, como neste tp. ${ }^{\circ}$ se praticava com os donados. Era humilde, e prompto em servir a q. ${ }^{1} \mathrm{q} .{ }^{\mathrm{r}}$ Monge, em particular sem m. ${ }^{\text {is }}$ interesse do q' obedecer. Faleceu com os Santos Sacram. ${ }^{\text {tos }}$ em 29 de Agosto de 1 $649^{36}$ Sendo D. Abb ${ }^{\text {e }}$ o m. ${ }^{\text {to }}$ R. P. M. ${ }^{\circ}$ Fr. Ignacio de S. Bento.

21 O Vigeimo p. ${ }^{\text {ro }}$ foi o P. Fr. Antonio de S. Paulo natural do Rio de Janeiro e professo nesta ca-[ $\left.\downarrow_{\text {za. }}\right]$ em

${ }^{36}$ A margem encontra-se um ponto de interrogação (APFL). 
As virtudes, e as prendas deste Religiozo o fizeraõ digno de uma atençaõ. $m .{ }^{\text {to }}$ destinta em q. ${ }^{1}$ q. ${ }^{\mathrm{r}}$ Mosteiro, que se achava. No tp. ${ }^{\mathrm{o}}$ de estudante aplicou-se com grd desvelo a muzica, e a varios instrumentos, principalm. ${ }^{\text {te }}$ a Arpa, q' tocava com destreza. Com estas prendas servio sempre a Religiaõ, principalm $^{\text {te }}$ a este Mosteiro, no q. ${ }^{1}$ foi sua maior assistencia. Ja de id avançada foi acometido de uma molestia, q' fazendo -se desprezível p. ${ }^{\mathrm{r}}$ pequena ou p. ${ }^{\mathrm{r}}$ desconhecida se adiantou com tanta pressa, q' naõ lhe valendo os remedios da medicina, acabou catolicam. ${ }^{\text {te }}$ o seu Desterro desposto com a graça dos Sacram. ${ }^{\text {tos }}$ em 6 de Septbr. ${ }^{\circ}$ de 1652 Sendo D. $\mathrm{Abb}^{\mathrm{e}} \mathrm{o} \mathrm{m}^{\text {to }}$ R. P. Fr. Mancio do Martires

22 O Vigesimo segundo foi o $\mathrm{P}^{\mathrm{e}}{ }^{\mathrm{e}} \mathrm{Fr}$. Paulo do $\mathrm{Esp}^{\circ} \mathrm{S}^{\text {to }}$ natural do $\mathrm{R}^{\mathrm{no}}{ }^{\text {, }}$, professo neste mosteiro. Nos seus principio naõ lhe faltou q' padecer, p. $^{\mathrm{r}} \mathrm{q}$ ' era colerico e de condiçaõ aspera, porem prompto e delig. ${ }^{\text {te }}$ na satisfaçaõ das suas obrigacoens. Ordend ${ }^{\circ}$ de Sacerdote, foi mudado $\mathrm{p}^{\mathrm{a}}$ Pernambuco, passados annos veio $\mathrm{p}^{\mathrm{a}}$ este, aonde perdendo a vida corporal, conseguio a do entendim. ${ }^{\text {to }}$ p. ${ }^{\mathrm{r}}$ saber repremir as suas paixoens, e sofreu constante os trabalhozos efeitos de huma cegueira taõ dilatada como foi a sua; visitava 
$\left[\mathrm{f}^{\mathrm{o}} 15 \mathrm{r}^{\mathrm{0}}\right]$

os enfermos como podia, e da mesma sorte, nos dias de festa se achava prezente as funçõens publicas p. ${ }^{a}$ ter a consolaçaõ de ouvir o q' naõ podia ver. Assim foi vivendo no purgatorio da sua cegueira conforme, e resignado, até q' chegada a hora da sua partida, foi dar contas a D. ${ }^{\mathrm{s}}$ preparado com a graça dos sacramen ${ }^{\text {tos }}$, em 5 de Agosto de 1660 sendo D. $\mathrm{Abb}^{\mathrm{e}} \mathrm{o} \mathrm{m}^{\text {to }} \mathrm{Re}$. P. FR. Mancio dos Martires. $2^{\mathrm{a}} \mathrm{vez}^{37}$

O vigesimo terceiro foi o P. Fr. Agostinho da Piedade nascido em Portugal, e professo nesta caza. Hum dos $\mathrm{m} .{ }^{\text {tos }}$ Monges, q' nesta provincia tem florecido em virtudes, e neste Mostr. ${ }^{\circ}$ acabaraõ perfeitam $^{\text {te }}$ as suas vidas foi um delles o P. Fr. Agostino da Pied. ${ }^{\text {e }}$ Logo q' professou a vida Religioza, considerando-se ja separado do md. ${ }^{\circ}$ dava a $\mathrm{D} .{ }^{\mathrm{s}}$ repetidas graças $p .{ }^{r}$ te-lo trazido ao estado, q' sempre desejava; assentou de naõ perder q. ${ }^{1}$ q. ${ }^{r}$ occaziaõ, q' se offerecesse p. ${ }^{a}$ merecer; teve $\mathrm{m}^{\text {tas }} \mathrm{p} .^{\mathrm{r}} \mathrm{q}$. estas naõ faltaõ a q. ${ }^{\mathrm{m}}$ quer aproveitar; nestes principios foi despondo um fudam ${ }^{\text {to }}$ solido $\mathrm{p}^{\mathrm{a}}$ as virtudes, em q' se havia de exercitar. Ordend. ${ }^{\circ}$ de Sacerdote apartou-se de todo o amor proprio, e principiou a mostrar a perfeiçaõ da sua ajustada vida. Como neste tp. ${ }^{\circ}$ a fazenda da Ita/poam era de grande utilidad. ${ }^{\mathrm{e}} \mathrm{p}^{\mathrm{a}}$ este Mostro $^{\mathrm{o}}{ }^{\beta 8}$

\footnotetext{
${ }^{37} \mathrm{Na}$ entrelinha encontra-se a recomendação " $c f . n$. 44" (APFL).

${ }^{38}$ A leitura desta linha foi recomposta a partir da transcriçaõ do original realizada por Dom Clemente Maria da Silva Nigra, antes que o manuscrito tivesse sido submetido ao processo de restauro, pois neste processo, as bordas do papel, por estares bastente puídas, foram cortadas, e, com isso, se perderam algumas linhas finais em fólios esparsos.
} 
Atendendo os Prelados a sua capacidad. ${ }^{\mathrm{e}}$ lhe encarregaraõ o governo dad. ${ }^{\mathrm{a}}$ fd. ${ }^{\mathrm{a}}$; nella assistio $\mathrm{m}^{\text {tos }}$ annos tanto $\mathrm{p}^{\text {lo }}$ zelo, com q' administrou os bens temporaes, como $\mathrm{p}^{\text {la }}$ caridad $^{\mathrm{e}}$, com q' tratava os escravos, e vigilancia, com q' assistia aos enfermos. Da Itapoam foi removida $\mathrm{p}^{\mathrm{a}}$ a Capella de N. S. da Graça neste tp. ${ }^{\circ}$ pertencente a este Mosteiro, achava-se ja adeantado em annos, e destituido de forças naturaes, porem da pouca q' tinha se aproveitou como se fosse muita, . $^{\text {a }}$ as empregar no serviço de N. S. Qualquer occupaçaõ era do seu gosto, porem o trato, e asseio da $\mathrm{Ca}$ pela queria q' corresse p. ${ }^{r}$ sua conta, naõ consentindo que escravo algum o ajudasse nem a varrer a Igreja. Diante daq. ${ }^{\text {la }}$ devotissima imagem passava os dias, e as noites, e sabia q' era perdido o tp. ${ }^{\circ}$, q' $^{\text {' }}$ se naõ empregava no serviço de D. ${ }^{\mathrm{s}}$ de sua May Sm. ${ }^{a}$ ou no exercicio das virtudes; o altar se via preciosam. ${ }^{\text {te }}$ ornado, com as esmolas adqueridas $p^{\text {la }}$ sua virtude, e p. ${ }^{\text {lo }}$ seu disvelo. Como neste tp ${ }^{\circ}$ corriaõ os necessitados, e aflictos com grd. ${ }^{\mathrm{e}}$ frequencia aquella Igreja a solicitar daquelle mar de graças o alivio dos seus trabalhos, e das suas molestias, conseguindo p. ${ }^{\text {la }}$ sua fe, e p. ${ }^{\text {la }}$ sua devoçaõ tudo o q' suspiravaõ: aquelles q' p. ${ }^{\mathrm{r}}$ impossibilitados naõ podiaõ ir 
$\left[\mathrm{f}^{\mathrm{o}} 16 \mathrm{r}^{\mathrm{0}}\right]$

implorar o socorro daquela soberanissima Rainha do Anjos mandaraõ pedir ao P. Fr. Agostinho o menino, q' a S. sustenta em seus braços; o P. tirando-o com toda areverencia, o entregava com toda a decencia, a q. ${ }^{\mathrm{m}}$ lho pedia; porem como algumas vezes se naõ lembrava, do q' fazia, p. $^{\text {la }}$ continua oraçaõ em q' andava, e p. ${ }^{\text {los }} \mathrm{m}^{\text {t.os }}$ annos q' tinha, q. ${ }^{\text {do }}$ voltava $\mathrm{p}^{\mathrm{a}}$ a Igreja, e via a falta do menino nos braços da Sr. ${ }^{a}$, ficava como louco, e olhando p..$^{a}$ os outros altares, vendo, q' o menino naõ estava na Igreja, com as lagrimas nos olhos, sahia pellas visinhanças, formando queixas de que tinha desaparecido o menino dos braços de sua Mãy Santissima, e que elle naõ se lembrava a q. ${ }^{\mathrm{m}}$ o tinha dado, perguntando com as palavras da Esposa $\mathrm{S}^{\text {ta }}$ a todos os que encontrava se sabiaõ a onde estava o amado da sua alma? Quem o tinha logo e entregava compadecido daquella virtuoza sincerid. ${ }^{\mathrm{e}} \mathrm{q}$ ' so se empregava em couzas Santas. Quando ja o $\mathrm{P}^{\mathrm{e}}$ se via na posse daq. ${ }^{\text {le }}$ celestial Tesouro, contente, Alegre, saudozo corria alevar a Snr. a a noticia de q' tinha aparecido a joia mais precioza dos seus santissimos braços; punha-o no altar e ao depois de lhe dar repetidos osculos nos pes, e de o adorar com reverentes genuflexoens, $\mathrm{p}^{\mathrm{a}}$ explicar a saud. ${ }^{\mathrm{e}}$ em q' o tinha posto a sua auzencia, lhe tomava uma amoroza satisfaçaõ de se ter auzentado da Igreja, Deixd. ${ }^{\circ}$ 
A companhia de sua May Santissima, q' com t. ${ }^{\circ}$ gosto o tinha em seus braços, e nelles o tinha le -vado p. ${ }^{\mathrm{r}}$ terras destantes, e caminhos trabalhozos p. ${ }^{\mathrm{a}}$ o livrar da morte q' lhe queriao dar os seus inimigos, e elle agora lhe fugia todas as vezes, q' queria. Reprehend. ${ }^{\circ}$ o menino com estas, e outra suavissamas palavras, que elle sabia compor, o restituia ao seu deliciozo trono, q' eraõ os braços da Snr. ${ }^{\mathrm{a}}$, e ajoelhado em terra se despedia satisfeito. Refere-se este cazo, p. ${ }^{\mathrm{a}}$ ver-mos ate onde chegaõ os pensam ${ }^{\text {tos }}$ nascidos da candida singeleza de hum varaõ sincero. Observava os votos da profissaõ com t. ${ }^{\text {a }}$ cautela, q' nunca se the ouviu palavra, q' naõ fosse decente, conservando-se casto ate amorte, como afirmava o seu companheiro nas virtudes o P. ${ }^{\mathrm{e}}$ Fr. Pedro de Jezus. Asua vontade era a dos Prelados, aos q. ${ }^{\mathrm{s}}$ sempre obedeceu gostoso, e delig. ${ }^{\text {te }}$ Era taõ am. ${ }^{\text {te }}$ da pobreza, q' ainda o $\mathrm{m}^{\text {is }}$ precizo lhe parecia superfluo: as paredes da sua cela se viaõ cobertas de riscos de carvaõ p. ${ }^{r}$ onde contava os rozarios, q' rezava, em a se naõ enganar na conta, q' pretendia; e estes eraõ os ornatos mais preciozos, em q' punha os olhos com m. ${ }^{\text {is }}$ gosto. Occupado nestes virtuozos exer cicios passava elle os dias, mezes, e annos; conhecendo já p. ${ }^{\text {la }}$ falta de calor, e p. ${ }^{\text {la }}$ sua $\mathrm{m}^{\text {ta }}$ idade q' se avisinhavaõ os seus ultimos dias, pediu q' o conduzissem p. ${ }^{\mathrm{a}}$ este Mosteiro a receber o pam dos Anjos em companhia dos Religiozos; poucos dias aodepois da sua chegada, lhe adminis travaõ os ultimos sacram. ${ }^{\text {tos }}$, q' rececbeu com m. ${ }^{\text {tos }}$ /actos de pied ${ }^{\mathrm{e}}$ e edificaçaõ dos assistentes;/ 
$\left[\mathrm{f}^{\mathrm{o}} 17 \mathrm{r}^{\mathrm{0}}\right]$

dahi apoucas horas pediu hum Senhor crucificado, e abraçando-se com elle, fazendo $\mathrm{m}^{\text {tos }}$ actos de contriçaõ, e pedindo perdaõ das suas culpas, acabou a sua penitente, e ajustada vida, deixando uma conjectura bem fundada aos circunstantes, de que sua alma fora gozar da vista de D. ${ }^{\mathrm{s}}$, tanto p. $^{\text {la }}$ formuzura, de q' se revestio ao depois de morto, como pelas virtudes em que se exercitou em quanto vivo. Foi o dia do seu falecim. ${ }^{\text {to }}$ em 2 de Abril de 1661 sendo D. Abb. ${ }^{\mathrm{e}} \mathrm{o}$ m. ${ }^{\text {to }}$ R. P. Fr. Diogo Rangel.

24 O Vigesimo quarto foi o Pe. Fr. Pedro de JEZUS $^{39}$ natural das Ilhas, profenso nesta caza. Os meios, q' D. ${ }^{\mathrm{s}}$ escolhe ${ }^{\mathrm{a}}{ }^{\mathrm{a}}$ trazer ao caminho da perfeiçaõ as creaturas remidas com o seu precioso sangue, saõ taõ admiraveis, q' deixaõ ao en tendim ${ }^{\text {to }}$ humano naõ so confundido, mas sim totalm. ${ }^{\text {te }}$ obrigado a reverenciar, e temer com um justo, e devido resp. ${ }^{\text {to }}$ a incomprehensivel elevaçaõ dos seus altissimos juizos. Hum dos exemplos desta doutrina foi o P. ${ }^{\mathrm{e}}$ Fr. Pedro de Jezus. Cazualm. $^{\text {te }}$ deu huma queda sendo Alferes em Pernambuco, q' alem de ficar maltratado em todo o corpo, quebrou uma perna; nesta aparente desgraça esteve a sua verdad. ${ }^{\text {ra }}$ fortuna $-31-$

\footnotetext{
${ }^{39} \mathrm{O}$ nome JEZUS encontra-se grafado em caracteres diferenciados, como era de hábito.
} 
p. ${ }^{\mathrm{r}} \mathrm{q}$ ' della tomou occaziao $\mathrm{p}^{\mathrm{a}}$ melhora de estado. Ao dep. ${ }^{\mathrm{s}}$ q'recuperou asaude perdida, pas sou-se a esta terra, e veio a este Mosteiro pedir o habito de Monge levado da exemplarid. ${ }^{\mathrm{e}}$, e ob servancia, q' via praticada no Mosteiro de Olinda; foi admetido naforma, q' dezejava: porem o inimigo tentador descobrindo naquelle animo uma propençaõ p. ${ }^{a}$ a virtude, temendo-se da guerra, q' p. $^{\mathrm{lo}}$ tp. $^{\circ}$ adiante lhe podia fazer, defendido com a cogulla Benedictina, empenhou as suas enfernaes astucias, p. $^{\mathrm{a}} \mathrm{o}$ vencer antes de o ver mais adiantado; por um livre motivo deixou o habito, e a Religiaõ; porem naõ se auzentou $\mathrm{p}^{\mathrm{a}}$ longe, $\mathrm{p} .{ }^{\mathrm{r}} \mathrm{q}$ 'se achava como prezo, sem saber p. ${ }^{\mathrm{r}}$ q. $^{\mathrm{m}}$; vivia em uma continua guerra com sigo $\mathrm{m}^{\mathrm{mo}}$; queria voltar, mas naõ sabia, q' o embaraçava; finalm. ${ }^{\text {te }}$ procurou segd. ${ }^{\text {a }}$ vez o ingresso, segd. ${ }^{\text {a }}$ vez vestiu o S. habito, e segd. ${ }^{\mathrm{a}}$ vez o deixou, com animo de nunca mais o pedir; porem enganou-se, p. $^{\mathrm{r}} \mathrm{q}$ ' naõ passaraõ-se m. ${ }^{\text {tos }}$ dias, q' naõ voltasse; terceira vez pediu, q' o admetissem, mas naõ foi atendido p. ${ }^{\mathrm{r}}$ inconstante; com este desengano tomou a resoluçaõ de se prostrar da parte de fora da portaria, aonde esteve trez dias com suas noites, dezejando q' o metessem debaixo dos pez q. ${ }^{\text {tos }}$ entrassem, e sahissem, até q' alguns Monges compadecidos intercederaõ p. ${ }^{r}$ elle; md. ${ }^{\text {ou }}$ o Prelado, q' se recolhesse e fosse trabalhar 
$\left[\mathrm{f}^{\mathrm{0}} 18 \mathrm{r}^{\mathrm{0}}\right]$

p. a a horta com os escravos; com grande gos-

to aceitou esta prova do seu espirito; assistio

$\mathrm{p}^{\mathrm{r}}{ }^{\mathrm{r}}$ alguns mezes em comp. ${ }^{\mathrm{a}}$ dos pretos, sem q'

delles se destinguisse no trabalho, e no sustento.

5 Desenganado o Prelado, e os Religiosos, q' elle triumfava

do enferno, e se despira do amor proprio, lhe vesti-

raõ o habito Monacal, $\mathrm{q}^{\prime} \mathrm{pl}^{\circ} \mathrm{tp}^{\circ}$ adeante acredi-

tou com as suas conhecidas, e relevantes virtudes.

Recolhido ao Noviciado chorava o tempo perdido, porem

10

elle cuidou em aproveitar naõ perdendo instante, q'

naõ empregasse em mortificações e penitencias que

com licença do seo Mestre accrescentava as que a Re-

ligiaõ determina. Ordenado de Sacerdote, todo se

empregava em cumprir com as obrigações de hum

15 taõ alto Estado; considerava a puresa com que deve chegar hum Ministro do $\mathrm{S}^{\mathrm{r}}$ ao Altar, e $\mathrm{p}^{\mathrm{r}}$ isso sempre achava diminuto o seo preparo e sempre insuficiente a sua disposiçaõ, naõ obst ${ }^{\mathrm{e}}$ ser este todo o seu desvelo. As devoçoens seraõ m. ${ }^{\text {tas }}$; a sua o- ${ }^{40}$ raçaõ continua, e as desceplinas ${ }^{41}$ taõ vigorosas, que as naõ largava, sem q' primeiro visse derramado copioso sangue. Era taõ parco, e austero, q' os seus manjares nunca se estenderaõ a carne, ou peixe, $\mathrm{p}^{\mathrm{r}}$ que huns mal guisados ligumes, e humas mal concertadas herva eraõ o q' sustentava aquella penitente vida. O voto da pobresa foi $\mathrm{p}^{\mathrm{a}}$ elle taõ recommendavel, que na sua cella naõ se viaõ mais do q' /humas imagens de Santos e huns livros espirituaes, e os ins/ $-33-$

\footnotetext{
${ }^{40}$ A partir deste ponto, até a linha 28 - última linha deste fólio -, a letra parece um pouco diferente, provavelmente apenas em função da troca de pena, por uma pena mais fina que a anterior, ou por maior capricho do scriptor, pois alguns grafemas bastante característicos permanecem com o mesmo traçado, o que faz com que se descarte a hipóteses de este trecho ter sido escrito por outra pessoa. Os traços $\operatorname{dos}\langle t\rangle$ saõ taõ sutis que quase naõ aparecem.

${ }^{41} \mathrm{O}<\mathrm{s}>$ medial é longo.
} 
trum $^{\text {tos }}$ das suas penitencia; em certos dias da semana se apertava $p .{ }^{r} \mathrm{~m} .{ }^{\text {tas }}$ horas com um largo celicio, q' $\mathrm{p}^{\mathrm{r}}$ sua aspereza o punha em hum lastimozo estado. Assistia nos actos conventuaes, principalm $^{\text {te }}$ no Coro, e Igreja com tanta modestia,

e compostura, q' mudam ${ }^{\text {te }}$ advertia $\langle\uparrow\rangle$ [ $\uparrow$ a reverencia], com que devem estar os Monges na prezença de $\mathrm{D}^{\mathrm{s}}, \mathrm{q}^{\text {do }}$ occupados nos seus louvores. Assim foi passando esse perfeito $<\mathrm{m}>$ /M $\backslash$ onge q' naõ obstante as suas rigorozas penitencias, foi della $<\mathrm{d}>/ \mathrm{t} \mid \mathrm{ada}, \mathrm{p} .{ }^{\mathrm{a}}$ nos desenganar-mos, q' o exercicio das virtudes naõ diminue $<\dagger>$ os annos, mas sim os augumenta. Ja p. ${ }^{\text {la }}$ sua m. $^{\text {ta }}$ id..$^{\mathrm{e}}$ desamparado da natureza, mas naõ da graça, cahio p. ${ }^{r}$ uma vez na cama, aonde se acabou de purificar p. ${ }^{\mathrm{r}}$ meio de uma delatada molestia sofrida com admiravel paciencia, até q' chegou o tp ${ }^{\circ}$ de trocar esta $p^{\text {la }}$ outra vida; se despio p. ${ }^{\text {a }}$ a sua partida p. ${ }^{\mathrm{r}}$ um modo admiravel. Em dia de Pascoa levantou-se da cama, foi a cella do Prelado pedir-lhe licença p. $^{\text {a }}$ dizer missa, o q. ${ }^{1}$ admirado com aquella novid. ${ }^{\mathrm{e}}$, com brandas palavras o aconselha, q' melhor seria ouvilla, $p$. $^{\text {r q' }}$ ' estava totalm $^{\text {te }}$ destituido de forças p. ${ }^{\text {a }}$ dizel-a, porem p. ${ }^{\text {lo }}$ naõ privar d'uma consolaçaõ taõ santa, considerd. ${ }^{\circ}$ q' saõ grd. ${ }^{\text {es }}$ as forças da divina graça, p. $^{a}$ q' um homem cheio de fe em D. , possa executar 
$\left[\mathrm{f}^{\mathrm{o}} 19 \mathrm{r}^{\circ}\right]$

emprezas superiores as forças da natureza, mandou um Monge, q' o acompanhasse, e lhe assistiu no altar ate o fim da missa; ao dep. ${ }^{\mathrm{s}}$ acabou de celebrar com aquella devoçaõ, e ternura, de q' Deus foi testemunha, recolheu-se a cella, e entrou a despor-se $\mathrm{p}^{\mathrm{a}}$ a ultima despedida. Tirou primieram. ${ }^{\text {te }}$ aquelle aspero celicio, q' trazia a raiz da carne p. ${ }^{a}$ q' naõ fosse visto, lavou aquelle corpo, q' tantas vezes tinha triumfado dos tres inimigos da alma; vestiu o seu habito, e recostando-se na cama; mandou buscar um paõ, poz junto a si uma vella benta, e hum caderno de oraçoens convenientes $\mathrm{p}^{\mathrm{a}}{ }^{\mathrm{a}}$ os agonizantes; ja tudo prompto solicitou do Prelado p. ${ }^{\mathrm{r}}$ meio do enfermeiro, q' o mandasse ungir; quizeraõ demorar a sua < purificaçaõ > [ $\uparrow$ petiçaõ] p. ${ }^{a}$ o dep. ${ }^{\mathrm{s}}$ do refeitorio, em q' se achavaõ os Monges, $\mathrm{p}{ }^{\mathrm{r}}$ verem havia poucas horas tinha acabado de dizer missas, porem atendendo aos seus rogos, lhe administraraõ o sacram. ${ }^{\text {to }}$ da extrema-unçaõ; concluídas todas as ceremonias daquelle ultimo acto, pedio q' o enterrassem com o m. ${ }^{\text {mo }}$ habito, q' tinha vestido; e despedindo-se dos Religiozos, agradeçendo a caridade, que tinhaõ uzado com elle toda a vida, pegou de um Senhor Crucificado, e abraçando-se com elle, the rendeu os ultimos obzequios, pedindo-lhe perdaõ das suas culpas, e de o naõ ter servido como pedia o estado de Catolico, e de Religiozo, que 
professara: ultimam. ${ }^{\text {te }}$ faz. ${ }^{\text {do }} \mathrm{m}^{\text {tos }}$ actos de piedade, e amor de D. ${ }^{\mathrm{s}}$, entrando em uma leve agonia, poz termo a sua penitente vida nos braços dos Religiozos, q' todos sentiraõ a sua morte, $\mathrm{p}^{\mathrm{r}}{ }^{\mathrm{r}}$ se verem privados da comp. ${ }^{\mathrm{a}} \mathrm{de}$ hum Monge, q' sempre os edificara, e nunca os offendera. As pobres alfaias q' se acharaõ na sua cela, se repartiraõ entre os Religiozos como preciozo espolio de um varaõ virtuozo. Conta-se, q' uma enferma ja ungida, tendo noticia da morte deste Religiozo, mandara pedir ao Mosteiro alguma couza, de q' elle tivesse uzado em vida, e chegando-lhe as maõs umas contas p. ${ }^{\mathrm{r}}$ onde elle rezava, lançando-as no pescoço recuperara saude, e ainda vivera $p .{ }^{\mathrm{r}}$ alguns annos. Foi o dia do seu falecim. ${ }^{\text {to }}$ e de Páscoa aos 17 de abril de 1661 sendo D. Abb. ${ }^{\mathrm{e}} \mathrm{o} \mathrm{m}^{\text {to }}$ R. P. M. ${ }^{\mathrm{e}}$ Fr. Bento Rangel.

25 O vigesimo quinto foi o N. M. R. P. Fr. Bernardo de Braga Exprovincial natural da m. ${ }^{\text {ma }} \mathrm{Cid}^{\mathrm{e}}$; professo <neste Mosteiro> /na Congregaçaõl. Era Religiozo observante, e dotado de prendas, como as quaes servio a Religiaõ, e lhe adquirio avultados creditos nas Cadr ${ }^{\text {as }}$, e nos pulpitos; ainda se conservaõ alguns sermoens impressos, nos q. ${ }^{\text {es }}$ se descobre a sua erudiçaõ ,e o seu zelo. 
Certificados os Prelados superiores dos talentos que dotado, p. ${ }^{\text {a }}$ qualquer emprego, o ellegeraõ Abb. ${ }^{\mathrm{e}}$ deste Mosteiro; a experiencia mostrou o acerto da elleiçaõ $\mathrm{p} .{ }^{\text {lo }} \mathrm{m} .{ }^{\text {to }} \mathrm{q}$ ' trabalhou no aumento temporal, e espiritual desta caza.

Concluido o seu triênio foi elevado ao lugar de Provincial; desempenhou com acertaçaõ o seu emprego, vizitando a provincia com grande utilid. ${ }^{\text {e }}$ dos Mosteiros, e trabalho

10 seu; concluido o seu governo, recolheu-se a esta caza, na qual passou o resto dos seus dias, empregando-se na pratica das virtudes, q' sempre exercitara dep. ${ }^{\mathrm{s}} \mathrm{de}$ Religiozo. Achava-se no engenho da Praia preparando-se p. ${ }^{a}$ pregar umas tardes da quaresma, aonde caindo $p .{ }^{\mathrm{r}}$ umas escadas, ficou tam maltratado, q' recolhendo-se ao Mostr. ${ }^{\circ}, \log$ ao depois q' pregou as Domingas, ou algumas dellas, entrou a experimentar os efeitos da queda; desenganado, q' morria, cuidou com todas 
as forças do seu espirito em purificar a sua conciencia, e recebidos os ultimos sacram. ${ }^{\text {tos }}$ com $\mathrm{m} .{ }^{\text {ta }}$ devoçaõ e lagrimas, deixou rezignado esta vida mortal aos 9 de Março de 1662 sendo D. Abb. ${ }^{\mathrm{e}}$ o M. R. P. M. ${ }^{\mathrm{e}}$ Fr. Diogo Ra $<1>[\uparrow n] g e l$.

$2<5>/ 6 \backslash$ O vigesimo sexto foi o . $^{\mathrm{e}}$ Fr. Gaspar da Assumpçaõ natural do Reino, professo nesta caza. Foi Religiozo dotado de uma candida singeleza, e de uma vida exemplar. A humildade, e a obediência foraõ os principios, em q' estabeleceu a conducta da sua bem ajustada vida. Em qualquer parte q' se achava servia a Religiaõ com fidelidade e promptidaõ. No emprego de Fazendeiro passou grande parte da vida, tanto pelo zelo, com que administrava os bens da Religiaõ, como pela caridade, que uzava com os escravos, 
e vigilança, com que assistia aos enfermos. Ja adiantado em annos, recolheuse ao Mosteiro, aonde empregou todo o seu cuidado em se dispor para a sua conta final. Adoeceu gravemente, e dezenganado, que estavaõ completos os seus dias, recebidos os santos sacramentos, pagou o tributo de nascido, aos 20 de Agosto de 1662 sendo D. Abb. o M. R. P. ${ }^{\mathrm{e}} \mathrm{M}^{\mathrm{e}}$ Fr. Diogo Rangel.

27. O Vigesimo septimo foi o M. ${ }^{\text {to }}$ R. P. ${ }^{\text {e }}$ P. ${ }^{\mathrm{r}}$ Fr. Bento da Cruz natural do Reino, professo nesta caza. Logo do seu noviciado mostrou ser verdadeira a 
sua vocaçaõ pelo m. $^{\text {to }}$ disvelo, com que dava prompta satisfaçaõ as suas obrigaçoens, e pelo grande gosto, com que sofria as mortificaçoens do anno de aprovaçaõ; Ao depois de professo foi notavel o seu bom procedim. $^{\text {to }}$, e muito mais ao depois de Sacerdote. Concluido o seu collegio, o nomearaõ cantor mor deste Mosteiro; perfeitam. ${ }^{\text {te }}$ comprio com a obrigaçaõ do seu emprego, empenhando-se q' tudo q' pertencia ao seu cargo se fizesse com perfeiç. ${ }^{\mathrm{m}}$, e dicencia. Em atençaõ a sua notoria capacid. ${ }^{\mathrm{e}}$ o elegeraõ Prezd. ${ }^{\mathrm{e}}$ da Parahiba, ao dep. ${ }^{\mathrm{s}} \mathrm{Ab}^{\mathrm{e}}$ do Mosteiro do Rio, e ultimam. ${ }^{\text {te }}$ difinidor; a tudo satisfez como se esperava do seu zelo: o resto da vida pasou nesta caza, occupado em virtuozos exercicios, e na frequencia do Actos conventuaes. Faleceu fortalecido com a graça dos sacram. ${ }^{\text {tos }}$ em 8 de Janeiro de 1663 sendo D. Abb. ${ }^{\text {e o }}$ m. ${ }^{\text {to }}$ R. P. Fr. Diogo Rangel. 
$28=\quad$ O vigesimo oitavo foi o muito R. P. F. ${ }^{r}$ Antonio da Esperança, nascido em Pernambuco, professo neste Mosteiro. A humildade, e obediência deste Monge lhe preparaõ um caminho suave para viver ate a morte sem trabalhos nem disgosto que lhe perturbassem a paz, e quietaçaõ interior de sua Alma, sempre foi prompto em obedecer, e diligente em executar o que lhe mandavaõ sem inquirir os motivos, averigoar as causas ou offerecer disculpas. Foi muitos annos Mordomo nesta Caza com geral contentamento e satisfaçaõ dos Religiozos e utilidade do Mosteiro, naõ faltando no meio de tantas obrigaçoens de satisfazer as occupaçoens do seu estado a seo tempo, e as suas horas. Distituido de forças naturaes para a vida laborioza empregava todas as suas forças do espirito em se preparar para a Eternidade. Vendose accomettido de uma molestia grave, e que esta se adiantava para lhe tirar a $v i<\uparrow>d a$, tratou de se dispor com repetidos actos de contricçaõ, e com as graças dos Sacramentos, os quaes recebidos com grande devoçaõ se partio des ${ }^{42}$ mundo em 7 de Maio de 1663 sendo D. Ab. ${ }^{\text {de }}$ o M. R. P. M. ${ }^{\mathrm{e}}$ F. ${ }^{\mathrm{r}}$ Diogo Rangel.

$29=\quad$ O vigesimo nono foi o P. F. ${ }^{\mathrm{r}}$ Ambrozio do Espirito Santo. Nascido no Reino, professo nesta casa. Foi resoluto, de animo intrepido e grandes forças naturaes, das quaes nunca se aproveitou para offender a pessoa alguma so sim para servir a Réligiaõ, e favorecer aq ${ }^{\mathrm{m}}$ delle se vallia no que era justo. Passado o conde de Castello melhor por esta terra para a conquista da Colonia informado do seo valor, o levou por seo capellaõ e nisso esteve a sua feli $<1>/ c$ lidade, porque ficando prisioneiro dos Castelhanos pelos varios successos da guerra metido em uma apertada prisaõ, dentro em uma

$$
-41-
$$

\footnotetext{
${ }^{42}$ Muito provavelmente, isso foi ocasionado por um descuido do scriptor, não constituindo, portanto, um ato de língua.
} 
fortalesa situada nas margens do Rio da Plata, o P. ${ }^{\mathrm{e}}$ ajudado do seo valore sua industria com muito trabalho e grande perigo o tirou da Fortalesa por uma mina subterranea e o poz a salvo nas terras de Portugal.

Deste Monge se contaõ alguns casos que the acconteceraõ revestidos de umas circunstancias que parece lhe diminuem o credito, escreva-se porem a sustancia delles para que naõ fique a tradiç̧aõ, privada da posse em que se acha ha muitos annos.

O primeiro caso, he, que achando se este Religioso na Capitania do Espirito Santo indo de passagem para o Rio de Janeiro; huma noite estando conversando uns moradores da terra, que era mal assombrado o caminho por onde se subia para uma alta Penha na qual estava uma Ermida de N. S. ${ }^{\text {ra }}$ O P. ${ }^{\text {e }}$ ouvindo a conversa para os tirar daquelles prejuisos, disse que elle iria a aquellas horas ate o mais alto da Penha onde estava a Ermida, e para signal tocaria o sino da mesma capela, e sem mais demora se poz a caminho, porem a poucos passos se encontrou com um espantozo vulto, que mudando-se em varias formas o fora accompanhando ate o lugar destinado; chegou a capela e querendo tocar o sino, achou embaraçado na corda outro vulto de mais horrenda figura que o primeiro; sempre lançou maõ da corda e tocou o sino, porem ao mesmo tempo aquelle animal immundo o impelio com tanta força, e violencia, que no mesmo instante veio pelos ares cahir a porta da mesma casa aonde o estavaõ esperando: admirados todos de verem o P. ${ }^{\mathrm{e}}$ junto a si logo que ouviraõ o sino, elle 
sem turpaçaõ alguma lhes referio o que havia passado. Dizia o dito P. ${ }^{\mathrm{e}}$ que N. S. ${ }^{\text {ra }}$ com aq. ${ }^{1}$ se apegara quando lançou maõ a corda, o livrara de algum grande perigo que lhe podia succeder; e este he o unico e sufficiente motivo que nos pode persuadir a darmos credito ao successo referido.

O segundo caso foi: que naõ podendo este Religiozo em uma noite adormecer se levantara pelas 11 horas, e sahira para um eirado que ficava perto de sua cella aonde costumavaõ conversar $\mathrm{o}^{43}$ Religiozos nas horas permitidas, e vendo que estava la outro Religiozo, se chegara a elle a saber quem era, e conhecendo ser um Monge que havia dias tinha morrido, lhe perguntara que vinha ca buscar, ao q' o defunto respondeo que vinha solicitar o perdaõ de uma restituiçaõ em que estava a hum Religiozo de um pouco de dinheiro que achara dentro em uma bolsa que lhe cahira indo elle para a horta em uma tarde dispensada, e como naõ restituiu e nem pedio perdaõ em vida, agora por divina permissaõ vinha fazer esta diligencia.

O P. tomando por sua conta o seo disencargo foi dar parte ao Prelado e ao Religiozo do que tinha passado, e conseguido o perdaõ de um e outro voltou com a resposta ao defuncto o q. ao depois de the agradecer o beneficio que the 30 fizera desaparecera.

O terceiro caso, he, que a este Religiozo veio pedir um Monge falecido, que quizesse o accompanhar no coro a rezar o officio Divino pelas faltas que nelle tinha commettido, por se naõ inclinar ao Gl. Patri na forma que devia, e que o $\mathrm{P}^{\mathrm{e}}\left[{ }^{\mathrm{e}}\right.$ 个ao q o $\mathrm{P}^{\mathrm{e}}{ }^{\mathrm{P}}$ ] annunindo propoz-se fazer $-43-$

\footnotetext{
${ }^{43}$ Realmente, no original, não há concordância de número; o artigo está no singular e o substantivo está no plural.
} 
$<$ de um $>$ [ $\uparrow$ no espaço de um] anno desde huma hora da noite ate as duas, [ $\uparrow$-e depois disso deixou de assistir o religiozo [ $\downarrow$ fallecido a essas obrigações] Estes saõ os casos que se conta succederaõ a este Monge. O q' se he ou naõ, verdade, Deos o sabe.

Neste Mosteiro fez a sua maior assistencia, ao qual sempre servio com promptidaõ e zelo. Naõ molestava, nem offendia pessoa alguma, porque era prudente, e amigo da paz. Já adiantado em annos adoeceo de uma febre maligna que dando lhe tempo para se preparar com $\mathrm{m}^{\text {tos }}$ actos de Catholico, e com a graça dos Sacramentos em breves dias lhe tirou a vida. Foi o dia do $\mathrm{se}^{44}$ fallecimento aos 19 de Março de 1664 sendo D. A. ${ }^{\text {be }}$ o M. R. P $^{\mathrm{e}}$. M. ${ }^{\mathrm{e}}$ F. $^{\mathrm{r}}$ Francisco da Visitaçaõ.

$30=\quad$ O trigesimo foi o muito R. P. ${ }^{\mathrm{e}}$ F. ${ }^{\mathrm{r}}$ Paulo de Jezus, natural do Reino, e professo neste Mosteiro, a vida deste Religiozo foi exemplar. Logo de seu ingresso na Religiaõ sempre as suas acçoens se encaminhavaõ para o serviço de Deos, e deste Mosteiro, era dotado de genio affavel cortez e politico em tudo o que se naõ oppunha a observancia Regular. Viveo na graça dos Prelados pelo seo recto procedimento, e pela sua perfeita observancia. Depois de ter servido esta caza $\mathrm{m}^{\text {tos }}$ annos no Coro, Altar e outros empregos em geral satisfaçaõ vendo que este Mosteiro naõ tinha Engenho nem posses para o fabricar entrou a ponderar os meios por onde poderia conseguir que o tivesse sem dispendio da Religiaõ. Deos lhe descobrio os caminhos para

${ }^{44}$ Exatamente assim se encontra no original. 
completar o seo desejo, deu parte ao Prelado e mais Religiozos do seu intento, pedindo as terras da Lagem, que pouco antes nos tinha dado Gonçalo Annes. Foi ouvida a sua proposta mas naõ muito attendida pelas impossibilidades que se representavaõ dos animos de menos valor que o seo, conseguida comtudo a licença, cheio de fe em Deos, tomando sobre si o dinheiro para a fabrica, foi dispondo tudo com taõ bom successo, que em menos annos do que se esperava se vio este Mosteiro de posse de um Engenho completo, accabado e satisfeito todo o dinheiro, que o P. ${ }^{\mathrm{e}}$ seo fundador tinha tomado para o estabelecer. Já adiantado em annos pedido ao Prelado lhe mandasse successor, entregando-lhe o Engenho, lhe pedio com as lagrimas nos olhos tratasse os escravos com muita caridade na saude e na doença, na vida e na morte, e da

20 mesma sorte soccorresse ${ }^{45}$ aos pobres que delle se valessem, segurandolhe que em $\mathrm{q}^{\text {to }}$ assim fizesse o Engenho havia de render e Deos o havia de ajudar, assim succedeo, e assim se utilizou este Mosteiro de avultados rendimentos pelo 25 espaço de muitos annos. O resto da vida empregando-se em louvaveis exercicios, e frequencia dos actos Conventuaes em q. ${ }^{\text {to }}$ pode, na vida e na morte foi tratado, do Prelado e dos Religiozos com o respeito e Caridade que merecia, o seo zelo e sua virtude. Foi Monge que sempre acreditou o seo habito e sua Religiaõ tanto dentro como fora do Mosteiro.

${ }^{45} \mathrm{O}$ segundo $<\mathrm{s}>$ aparece grafado como $<\rho>$ longo. 
5 $31^{47}=$

Chegado o fim de seos dias cuidou com todas as forças do $\mathrm{se}^{46}$ espirito em se dispor para sua partida, e recebidos os ultimos sacram. ${ }^{\text {tos }}$ com m. ${ }^{\text {tas }}$ lagrimas e actos de Catholico, poz fim a sua peregrinaçaõ aos 4 de Março de 1667 sendo D. Ab. ${ }^{\mathrm{e}}$ o M. R. P. ${ }^{\mathrm{e}}$ Preg. ${ }^{\text {or }}$ Geral F $\mathrm{F}^{\mathrm{r}}$. Izidoro da Trindade. $\mathrm{O}$ trigesimo primeiro foi o P. ${ }^{\mathrm{e}}{ }^{\mathrm{F}}$. ${ }^{\mathrm{r}}$ Pedro dos Martires natural do Reino e professo nesta caza. Era Monge, observante e prompto em comprir com as obrigaçoens do seo estado Religiozo; atten$<$ os Prelados $>$ dendo os Prelados a sua conhecida capacidade o elegeraõ Companheiro do Provincial, e ao depois em sua eleiçaõ intermedia $\mathrm{Ab} .^{\mathrm{e}}$ desta caza, aq. ${ }^{1}$ governou por tempo de anno e meio com acceitaçaõ dos Religiozos e aumento da observancia regular. Passados alguns annos foi administrar o Engenho da Praia onde accabou de mostrar o seo zelo, e sua caridade. Por occasiaõ de uma molestia grave, se recolheo ao Mosteiro e nelle em breves dias accabou a vida disposto com a graça dos sacramentos em 3 de Agosto de 1668. Sendo D. Ab o M. R. P. ${ }^{\mathrm{e}}$ Preg. ${ }^{\mathrm{or}}$ Geral F. ${ }^{\mathrm{r}}$ Izidoro da Trindade. $32^{48}=\mathrm{O}$ trigesimo segundo foi o $\mathrm{P}^{\mathrm{e}}{ }^{\mathrm{e}} \mathrm{F} .{ }^{\mathrm{r}}$ Manoel do Desterro natural do Rio de Janeiro e professo nesta caza. Era Religiozo dotado de prendas naturaes e moraes; com ellas servio a Religiaõ principalm ${ }^{\text {te }}$ a este Moste $^{\text {ro }}$ no qual foi a sua maior assistencia, tanto no Coro por ser bom Muzico, e soccorrido de uma perfeita voz, como no pulpito aonde era ouvido com $\mathrm{m}^{\text {ta }}$ attençaõ pela boa acceitaçaõ com que pregava. Ao depois de $\mathrm{m}^{\text {tos }}$ annos empregados nesses santos $\mathrm{e}$ nobres exercicios, foi accomettido de uma molestia, que ao principio $\langle\dagger\rangle$ tirou-lhe alguns sentidos corporaes, e pelo tempo adiante chegou a ficar variado no entendimetno, desta sorte passou mais de um anno ate que chegado o tempo, que tivessem fim os seos dias e trabalhos

$$
-46-
$$

\footnotetext{
${ }^{46}$ Exatamente assim se encontra no original.

${ }^{47}$ No original, o número 31 está sublinhado com caneta hidrocor verde.

${ }^{48}$ No original, o número 32 está sublinhado com caneta hidrocor verde.
} 
por conta do Ceo correo o prepara para sua partida, porque huma noite as dez horas foraõ avisar o Prior, da parte do Prelado, para que fosse confessar ao P. ${ }^{\mathrm{e}}$ F. ${ }^{\mathrm{r}}$. Manoel do Desterro. este aviso nem foi do Prelado, nem se soube quem o dera, entrando o Prior na cella do enfermo o achou em seo perfeito juizo fez huma confiçaõ geral com muitas lagrimas e muitos repetidos actos de contricçaõ, ao depois de absolvido perdeo a falla, e dahi a poucas horas a vida. Foi o dia do seu fallecim ${ }^{\text {to }}$ em 6 de Dezembro de 1668 sendo D. Ab. ${ }^{\mathrm{e}}$ o M. ${ }^{\mathrm{o}}$ R. P. ${ }^{\mathrm{e}}$ Preg. ${ }^{\text {or }}$ Geral F. ${ }^{\mathrm{r}}$ Izidoro da Trindade.

33 O trigesimo terceiro foi o P. ${ }^{\mathrm{e}} \mathrm{F} .{ }^{\mathrm{r}}$ Bernardino dos Reis natural de Bastos professo nesse Mosteiro. Foi Religiozo de huma vida penitente, e perfeitam ${ }^{\text {te }}$ observante dos votos de sua profissaõ. Todo o tempo que lhe restava das obrigaçoens da Religiaõ, empregava na liçaõ dos livros espirituaes. Sempre estava recolhido, e assim sempre viveo descançado. A este Religiozo succedeo estando no Confessionario, chegar a confessar se huma Mulher indisposta para o Sacramento; com boas palavras e bons concelhos a despedio sem absolviçaõ, porem ella querendo accrescentar o numero de suas maldades, the respondeo que se naõ absolvia clamava que elle a estava solliscitando; ficou o Religiozo angustiado e afflicto, porem neste tempo appareceo hum Monge que nunca se soube quem foi com hum recado do Prelado que o chamava a toda a 30 pressa, promptam $^{\text {te }}$ se levantou e foi buscar o Prelado, do qual se soube que naõ tinha mandado tal avizo; conheceo o P. ${ }^{\mathrm{e}}$ q' por este meio $\mathrm{D}$. ${ }^{\mathrm{s}}$ o tinha livrado da infamia que o esperava. Nos ultimos annos de sua dilatada vida padeceo algumas molestias para coroa de suas virtudes. Faleceo aos ${ }^{49}$ com a graça do Sacramento em 31 de Dezembro de 1669 sendo D. Ab. ${ }^{\mathrm{e}}$ o M. ${ }^{\circ}$ R. P. ${ }^{\mathrm{e}}$ Preg. ${ }^{\text {or }}$ Geral /F. ${ }^{\mathrm{r}}$ Pedro do Espirito Santo./

${ }^{49}$ Exatamente assim se encontra no original. 
$34=\mathrm{O}$ trigesimo quarto foi o $\mathrm{P} .{ }^{\mathrm{e}}{ }^{\mathrm{F}}{ }^{\mathrm{r}}$ Joaõ Lopez natural do Reino, e professo nesta caza. Buscou a Religiaõ adiantado em annos, e ja no estado de Sacerdote, tinha huma fazenda em Sergipe do Conde aonde assistia; pela amizade, que tratava com o P. ${ }^{\mathrm{e}} \mathrm{F} .{ }^{\mathrm{r}}$ Paulo de Jezus fundador do Engenho da Praia sabendo delle a perfeiçaõ e a observancia em que viviaõ os Monges deste Mosteiro, pertendendo ser admitido em o numero delles, conseguio o q' desejava, pelas noticias q' havia do seo recto procedimento, doou esta Caza com 8 escravos que possuia, e profeçando a vida Religioza com grande consolaçaõ e alegria de sua alma viveo quatro annos em companhia dos Monges, e dando a Deos $\mathrm{m}^{\text {tas }}$ graças, sempre viveo $\mathrm{m}^{\text {to<s }}$ satisfeito, no fim delles adoecendo gravemente, e conhecendo se a doença de morte, para ella se dispoz com todos os Sacram ${ }^{\text {tos }}$ e ultim ${ }^{\text {te }}$ com muitos actos de contricçaõ accabou a sua ajustada vida em 2 de Março de 1672 sendo D. Abb. ${ }^{\mathrm{e}}$ o M. R. P. ${ }^{\mathrm{e}} \mathrm{Preg}^{\text {or }}$ Geral F. ${ }^{\mathrm{r}}$ Pedro do Espirito Santo.

$35^{50} \quad \mathrm{O}$ trigesimo quinto foi o $\mathrm{F}^{\mathrm{r}}{ }^{\mathrm{A}}$ An. ${ }^{\text {to }}$ Catelam professo no Mosteiro de N. S. ${ }^{\text {ra }}$ do Monserrate de Cataluna, natural do Reino de Castella; com licença de seos Prelados veio para America a tirar esmollas para remediar as necessidades de suas obrigaçoens, que tinha nesta cidade assistio alguns annos em caza de hum seo Parente vivendo como Religiozo sem nota de seo procedim. ${ }^{\text {to }}$ Vendo-se accomettido de huma molestia grave, se recolheo a este Mosteiro e nelle veio a morrer entre os Religiozos preparado com a graça dos Sacramentos aos 3 de Maio de 1672 sendo D. Abb $^{\mathrm{e}}$ o M. R. P. ${ }^{\mathrm{e}}$ Preg $^{\text {or }}$ Geral F. ${ }^{\mathrm{r}}$ Pedro do Espirito Santo.

$36=$ O Trigesimo sesto foi o P. ${ }^{\mathrm{e}}{ }^{\mathrm{F}}{ }^{\mathrm{r}}$ Gregorio Per. ${ }^{\mathrm{a}}$ nascido no Reino, professo nesta Caza. Era Religiozo de huma candida singeleza, humilde e obediente. Servio a Religiaõ no Coro e no púlpito ate onde chegavaõ suas forças. Foi Prior em Pernambuco, recolhido a este Most. ${ }^{\circ}$ padeceo $\mathrm{m}^{\text {tos }}$ annos molestias incuraveis do que veio ultimam. ${ }^{\text {te }}$ a ficar entrevado, com $-48-$

${ }^{50}$ APFL. 
paciência de justo sofria as grandes e continuas dores procedidas das chagas que se lhe abriraõ no corpo, ao depois de $\mathrm{m}^{\text {to }}$ padecer sempre resignado e conformi accabou a sua trabalhoza vida disposto com a graça dos Sacramentos, e com repetidos actos de Catholico, aos 25 de $8 .^{\text {bro }}$ de $1673=$ sendo D. Abb. ${ }^{e}$ o M. R. P. ${ }^{e}$ Preg. ${ }^{\text {or }}$ Geral Fr. Pedro do Esp. ${ }^{\circ}$ Santo. ${ }^{51}$

$37=\mathrm{O}$ trigesimo $7^{\circ}$ foi o $\mathrm{P} .{ }^{\mathrm{e}}$ Preg. ${ }^{\text {or }} \mathrm{F} .{ }^{\mathrm{r}}$ Bazilio da Ascençaõ nascido no Reino e Professo nesta Caza. Logo no seo principio mostrou que ${ }^{52}$ buscado a Religiaõ para servir, assim o praticou emq. ${ }^{\text {to }}$ viveo, porq' sempre trabalhou sem descanço, em quan. ${ }^{\text {to }}$ teve fo $<\dagger>$ /rlças para o fazer.Como era notorio o seo zelo o mandaraõ por companheiro do fundador do $\mathrm{Most}^{\circ}$ de Santos aonde accabou de mostrar a capacidade que tinha para qualquer emprego, foi Abb. ${ }^{\mathrm{e}}$ do $\mathrm{Most}^{\mathrm{o}}$ de S. Paulo Presidente do Hospicio do Parnahiba, e por $\mathrm{m} .{ }^{\text {tas }}$ vezes vizitador dos Conventos q' temos por aquellas partes a tudo satisfazia como se esperava da sua perfeita observancia. Já nos seos ultimos annos voltou para este Mosteiro a disporse para a Morte que todos os dias esperava para maior estimulo do seo preparo. Cahio enfermo, e desenganado q' era chegada a sua hora recebidos os ultimos sacram. ${ }^{\text {tos }} \mathrm{com}$ signaes bem indicantes da sua contriçaõ encheo os seos dias em 20 de Junho de 1674 sendo Prezid. deste Most. ${ }^{\circ}$ o M. R. P. ${ }^{\mathrm{e}}$ F. ${ }^{\mathrm{r}}$ An. ${ }^{\text {to53 }}$ da Trindade.

38 O trigesimo oitavo foi o Irmaõ Donato F. ${ }^{\mathrm{r}}$ Macario de S. Joaõ, natural do Reino de Castella. Foi admettido ao S. Habito, no estado de leigo tanto pelo seo bem procedim. ${ }^{\text {to }}$, como por ter sufficiente noticia de Architectura. Trabalhou nis ${ }^{54}$ ate morrer com grande zelo e disvelo. Em premio do seo merecim. ${ }^{\text {to }}$ lhe deraõ o habito e coroa Monachal. Deixou disposta em parte a planta deste Most. ${ }^{\circ}$ e da Igreja nova com a clareza necessária $p .^{a}$ sua execuçaõ. Faleceo depois de Sacramentado aos 3 de Abril de 1676 sendo Prezid. ${ }^{\text {e }}$ desta Caza o M. R. P. ${ }^{\text {ePreg. }}{ }^{\text {or }}$ F. ${ }^{\mathrm{r}}$ An. ${ }^{\text {to5 }} \mathrm{da}$ Trindade.

39 O trigesimo nono foi o M. R. P. ${ }^{\mathrm{e}}{ }^{\mathrm{F}}{ }^{\mathrm{r}}$ Constatino da Aprezentaçaõ, nascido em Portugal professo nesta Caza nella foi Conventual toda a sua vida.

\footnotetext{
${ }^{51}$ Há um ponto de interrogação, de cabeça para baixo, na margem esquerda e o nome do monge está sublinhado. (APFL)

${ }_{53}$ Contrário ao que seria de se esperar, não há o verbo ter (mostrou que tinha buscado) nesta sentença.

${ }^{53}$ Há um ponto de interrogação, de cabeça para baixo, na margem esquerda e o nome do monge (An. ${ }^{\text {to }}$ está sublinhado. (APFL)

${ }^{54}$ Percebe-se a falta, por pressa ou por discuido do scriptor, da sílaba final da palavra nisto.

${ }^{55}$ Há um ponto de interrogação, de cabeça para baixo, na margem esquerda e o nome do monge (An. ${ }^{\text {to }}$ está sublinhado. (APFL)
} 
Conventual $^{56}$ porque naõ quizeraõ os Prelados que ficasse privada da assistencia de hum monge taõ exemplar e observante. Logo do seo noviciado mostrou que D. ${ }^{\mathrm{s}}$ o tinha destinado para Religiozo por q' sempre foi prompto em obedecer diligente em executar o q' the mandavaõ sem imquirir os motivos, averiguar as causas, ou offerecer disculpas; para o Coro era taõ dilligente que nunca foi visto que entrasse tarde, ou faltasse a elle, e da mesma sorte em todos os actos conventuaes, e funçoens Religiozas, a sua composiçaõ, o seo recolhimento, a sua perfeita observancia lhe adquiriraõ huma attençaõ muita distincta naõ so entre os Religiozos, mas tambem entre os Seculares. Certificado os Prelados da sua ajustada vida, com doze annos de habito o elegeraõ

15 Mestre de Noviços; neste emprego o conservaraõ por espaço de dezoito annos, e merecia que o conservassem por toda a vida pelos grandes fructos que colheo a Religiaõ do seo disvello.Tratava dos seos Noviços como Mestre e como Pai, instruindo-os no S. ${ }^{\text {to }}$ temor de Deos na 20 observancia dos estatutos, e leis da Religiaõ, e na pratica de todas as virtudes, porque em todas os fazia exercitar, sendo elle o primeiro que com seo exemplo os animava, com sua doutrina os dirigia a serem observantes. Sempre os accompanhava nos actos Conventuaes com tanta modestia, e compustura, que naõ se conhecia qual delles era o Mestre senaõ pelo lugar em que o viaõ; persuadia 1 he $\mathrm{e}^{57}$ com tanto espirito as obrigaçoens pertencentes ao estado religiozo, q' $\mathrm{m}^{\text {tos }}$ de seos discipulos ao depois que foraõ Prelados se aproveitavaõ de

30 muitos dos seos avizos para o acerto dos seos governos, e bastava saberse q' algum Religiozo fora discípulo deste Mestre, p. ${ }^{\text {a }}$ o julgarem observan. ${ }^{\text {te }}$, e perf. ${ }^{\text {to }}$, foi duas vezes Prior deste Most. ${ }^{\circ}$ para naõ parecer que falta a obediencia, de outras Prelazias que se offereceraõ sempre se recuzou, $p .{ }^{r}$ se julgar pela sua humildade sem os requisitos $\mathrm{p}^{\mathrm{a}}{ }^{\mathrm{a}}$ as exercer. Ao depois de passar m. ${ }^{\text {tos }}$ an. ${ }^{\text {os }}$ occupando os dias e as noites em Religiozos exercicios, e rigorozas penitencias as q's ajuntava um trabalhozo Cilicio, trez dias antes de morrer recolheose a sua cella a prepararse com as ultimas 40 disposiçoens para sua partida e recebidos os sacramentos da Igreja com $m .{ }^{\text {tos }}$ actos de Catholico concluio os seos dias este observante e perfeito Religiozo deixando os Monges saudozos e sentidos por se verem privados

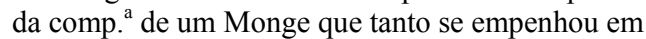
$-51-$

\footnotetext{
${ }^{56}$ Esta palavra encontra circulada. Ato feito na mesma época da escrita do texto.

${ }^{57}$ Não há concordância de número.
} 
acreditar a Religiaõ com suas virtudes e edificar os Religiozos com seos exemplos; foi o dia do seo fallecim. ${ }^{\text {to }}$ em 9 de $8{ }^{\text {bro }}$ de 1676 . Sendo D. Abb. ${ }^{\text {e o M. R. P. }}{ }^{e}$ Preg. ${ }^{\text {or }}{ }^{\text {F. }}$. Joaõ de Souzas ${ }^{58}$ o q' ${ }^{\text {, }}$ lhe fez as exéquias cantan-

5 do elle a Missa, e o mais q' se costuma nos officios de Religi-

40. O quadragegiso foi o P. ${ }^{\mathrm{e}} \mathrm{F} .{ }^{\mathrm{r}} \mathrm{Joa}$ V Vir. ${ }^{\mathrm{a}}$ natural desta Cid. ${ }^{\mathrm{e}}$ professo neste Most. ${ }^{\circ}$ Era Monge de bom procedim. ${ }^{\text {to }}$ e dilig. ${ }^{\text {te }}$ em cumprir com as obrigaçoens pertencentes a sua profiçaõ. Nos seos principios padeceo alguns trabalhos e disgostos por ser de condiçaõ dura, passados alguns an. ${ }^{\text {os }}$ se foi ordenar ao Reino, e no regresso o mandaraõ para os Most. ${ }^{\text {os }}$ do Sul, aonde servio a Religiaõ, no que permettiaõ suas forças; ja adiantado em annos voltou para este Most. ${ }^{\circ}$ e nelle terminou sua carreira aos 16 de julho de 1677 sendo D. Abb. ${ }^{e}$ o M. R. P. ${ }^{\mathrm{e}}$ Preg. ${ }^{\text {or }}$ F. ${ }^{\mathrm{r}}$ Joaõ de Souza.

$41=$ O quadragesimo prim. ${ }^{\circ}$ foi o Irmaõ F. ${ }^{r}$ Phillipe dos S.$^{\text {tos }}$ nascido em Portugal, professo nesta caza. Na idade de quarenta 7 an ${ }^{\text {os }}$ buscou a Religiaõ, desenganado das inconstancias da cousas terrenas; porem $\mathrm{D} .^{\mathrm{s}}$ lhe dilatou a vida para o servir e louvar, como tambem para confuzaõ dos mais fortes, porq' sendo um homem simples e de pouca industria de tal sorte se adiantou nas virtudes q' parecia, q' todas as acçoens q' obrava se encaminhavaõ a mostrar os caminhos que deve seguir aquelle que quizer ser perfeito. Ao depois de professo foi mandado trabalhar na horta, recebeo com $\mathrm{m} .{ }^{\text {tos }}$ gostos este humilde emprego, e nelle se exercitou em $\mathrm{q}^{\text {,to }}$ teve forças p. ${ }^{\mathrm{a}}$ exercer, de noite se recolhia a clausura, e se conversava com o seo M. ${ }^{\mathrm{e}}$ de virtudes o P. ${ }^{\mathrm{e}}$ F. ${ }^{\mathrm{r}}$ Pedro de Jesus o qual o admettia por companheiro de suas particulares penitencias, emprestava algumas vezes o seo colete de Cilicio do q" uzava. Dispensado já pelos seos an. ${ }^{\text {s }}$ do trabalho da horta, de todo se entregou a dispor-se para sua conta final, as manhãs as gastava pelo Coro, e tribunas, [ $\uparrow$ servindo] as mais das missas que se diziaõ na Igreja, as tardes e as noites passava de joelhos na sua pobre cella orando ou mental ou vocalm. ${ }^{\text {te }}$, chorando lagrimas e pedindo mizericordia nestes santos exercicios. Continuou deste modo ate morrer, sendo o exemplo da sua vida o melhor ditame que nos podia deixar p. $^{\text {a }}$ conseguirmos a perfeiçaõ Religioza. Faleceo com os Sacram. ${ }^{\text {tos }}$ da Igreja em 22 de Maio de 1678 sendo D. Abb. ${ }^{e}$ o M. R. P. ${ }^{\text {e }}$ Preg. ${ }^{\text {or }}$ F. Joaõ de Souza.

$$
-51-
$$

\footnotetext{
${ }^{58}$ No mais das vezes, o nome desse religioso aparece sem $\mathrm{o}<\mathrm{S}>$ final.
} 
$42=\quad$ O quadragesimo segundo foi o M. R. P. ${ }^{e} M^{e}{ }^{e} F \cdot{ }^{r}$ Mauro da Assunpçaõ, natural do Rio de Janeiro professo na mesma caza. Logo no seo Noviciado fechou este Religiozo as portas a ociosidade, empregando se sempre em exercicios, em compaciveis com a Cella, porque nos seos prim. ${ }^{\text {os }}$ an ${ }^{\text {os }}$ se applicou a liçaõ da S ta Regra, Ceremonias, e livros spirituaes; ao depois de Collegial, cuidou em satisfazer suas obrigaçoens com tanto disvello que no fim dos estudos o elegeraõ Pass. ${ }^{\text {te }}$ ao depois M. ${ }^{\text {e }}$ de Theologia, adquirindo creditos $\mathrm{m}^{\text {to }}$ distinctos para a Religiaõ pela geral satisfaçaõ com q' dava a conhecer o seo talento, tanto nas Cadeiras como nos pulpitos. Foi Prior em Pern. ${ }^{\text {co }}$ sendo Pass. ${ }^{\text {te }}$, e no Rio de Janeiro sendo Lente. Ao depois de Jubilado com licença do Rev. ${ }^{\text {mo }}$ se passou a procurar a Provedoria da Fazenda Real p. ${ }^{\text {a }}$ um seo Irmaõ. Concluido o seo negocio, como tambem algumas das prudencias da $<\uparrow>/ P \backslash$ rovincia, q' lhe recomendaraõ os Prelados della, voltou para este Mosteiro, o qual pouco aproveitou do seo grande prestimo, $\mathrm{p} .{ }^{\mathrm{r}} \mathrm{q}$. a morte o privou da vida, recebidos so Sacram. ${ }^{\text {tos }}$ da Igreja, em 18 de Dezembro de 1678. Sendo D. Ab. ${ }^{\mathrm{e}}$ o M. R. P. ${ }^{\text {e }}$ Preg. ${ }^{\text {or }}$ F. ${ }^{\mathrm{r}}$ Joaõ de Souza.

$43^{59}=$ o quadragesimo terceiro foi o M. R. P. ${ }^{e}$ F. ${ }^{r}$ An ${ }^{\text {to }}$ da Natividade, natural da $\mathrm{Ci}^{\text {de }}{ }^{\text {da }} \mathrm{B} .{ }^{\mathrm{a}}$ professo neste Mosteiro. Era Monge dotado de $\mathrm{m} .{ }^{\text {tas }}$ prendas naturaes, e moraes, com as quaes servio e acreditou a Religiaõ e sua pessoa. Admitido ao Collegio de Philosophia, como tinha feliz memoria, e era incansavel na applicaçaõ aos estudos, tanto se aproveitou nos exercicios literarios, e foraõ taõ felizes os seos progressos, que logo no fim do Collegio fazendo Actos de Passante, foi [个nomeado] provido em uma Cadeira de Filosophia, na qual accabou de mostrar a capacid. ${ }^{\mathrm{e}}$ indubitavel para as letras; pelo tempo adiante conseguio o nome de gra. ${ }^{\text {de }}$ Theologo, e de Preg. ${ }^{\text {or }}$ insigne. Como as suas letras se realsavaõ com a pratica da virtude, p. ${ }^{\mathrm{r}}$ q. ${ }^{1}$ sempre foi observan. ${ }^{\text {te }}$, composto, prud $^{\text {te }}$ e bem instruido nos estatutos e leis da Religiaõ, o elegeraõ D. Abb. ${ }^{\mathrm{e}}$ do Rio de Janeiro, a experiencia mostrou o acerto da eleiçaõ pelo $\mathrm{m}^{\text {to }}$ que trabalhou no spiritual do Mosteiro. No Cathalogo dos Prelados daquella Caza se da uma gra. ${ }^{\text {de }}$ not. ${ }^{\text {a }}$ q' augmentou as obras do Convento, porque as pincipaes e de mais custo se fizeraõ no seo trieno, concluido elle se retirou para este Most. ${ }^{\circ}$, o qual pouco tempo logrou a sua proveitoza assistencia, porque, passados poucos mezes

\footnotetext{
${ }^{59} \mathrm{O}$ número está sublinhado com caneta hidrocor verde. (APFT)
} 
depois de sua chegada foi accomettido de huma mo-

$\left[\mathrm{f}^{\mathrm{0}} 28 \mathrm{r}^{\mathrm{0}}\right]$ lestia grave, que conhecendo ser a ultima, cuidou em se dispor com toda as forças do seo spirito para a sua partida. Faleceo em 7 de Julho de 1679 tinha quarenta e tres annos de idade e vinte sete de habito, sendo D. Ab. ${ }^{\mathrm{e}}$ o M. ${ }^{\circ}$ R. P. ${ }^{\mathrm{e}}$ P. ${ }^{\mathrm{r}}$ Fr Marcos do Desterro.

$44^{60}-$ O quadragesimo quarto foi o P. ${ }^{\mathrm{e}} \mathrm{F} .{ }^{\mathrm{r}}$ Paulo do Esp ${ }^{\circ} \mathrm{S} .^{\text {to }}$ do qual naõ se descobrio outra noticia da sua vida senaõ o seo nome na pedra da sepultura, he queixa sem remedio lamentar este discuido. Foi Religiozo Sacerdote, podemos inferir chegou a ser admittidos a estes estados taõ perfeitos, por que o naõ desmerecia o seo procedim. ${ }^{\text {to }}<$ Fas $>$ Faleceu em 12 de Agosto de 1680 sendo D. Ab. ${ }^{\mathrm{e}}$ o M. R. P. ${ }^{\mathrm{e}}$ Preg. ${ }^{\text {or }}$ F. ${ }^{\mathrm{r}}$ Marcos do Desterro.

Antonio da Trindade, natural de Itaparica termo deste Arcepispado ${ }^{62}$ da Bahia. Do seo Noviciado sahio este Religiozo taõ bem instruido no caminho das virtudes, e perfeiçaõ Religioza, q' bem mostrava ser discipulo daquelle grande $\mathrm{M}$. ${ }^{\mathrm{e}}$ que bem soube ser dos seos Noviços; vivia totalm ${ }^{\text {te }}$ separado da communicaçaõ com os homens, de sorte que ficando sua Patria pouco distante Cidade ${ }^{63}$; poucas vezes voltou a ella ao depois de Religiozo, dizendo que sua caza era a Religiaõ, e seos parentes os seos Irmaõs Religiozo, como era Religiozo observante e prudente o elegeraõ Prezidente desta Caza, por deixaçaõ que tinha feito della o seo $\mathrm{Abb}^{\mathrm{e}}$ o M. R. P. ${ }^{\mathrm{e}}$ Fr. Mauro da Trindade, no acerto se esperava da sua perfeita observancia. Passados an. ${ }^{\text {s como nelle concorriaõ os pre- }}$ dicados para exercer o lugar supremo da Religiaõ, o elegeraõ Provincial desta Provincia no prim $^{\circ}$ capitulo celebrado nesse $\mathrm{Most}^{\circ}$ no an..$^{\circ}$ de 1679 a eleiçaõ deste Religiozo mostrou o acerto do Capitulo. Com geral acceitaçaõ foi recebido dos Religiozos

\footnotetext{
${ }^{60} \mathrm{O}$ número está sublinhado com caneta hidrocor verde. (APFT)

${ }^{61} \mathrm{O}$ número está sublinhado com caneta hidrocor verde (APFT). Há também na entrelinha superior a seguinte indicação $c f .22$ (APFL).

62 É exatamente assim que aparece no original.

${ }^{63}$ É exatamente assim que aparece no original.
} 
os quaes o estimavaõ como Pai, e o respeitvaõ como prelado taõ benemerito; p. $^{\mathrm{m}}$ no mesmo tempo, q' dignam ${ }^{\text {te }}$ se achava exercendo o seo emprego com hum anno, e alguns mezes de governo foi accomettido de huma infermidade mortal, e conhecendo ser esta, a q' lhe determinava os seus dias, recomendando aos subditos, que se achassem prezentes a lembrança do rigor da quella ora, e a vigilança com que deviam andar pela sua incerteza, tendo recebidos todos os Sacramentos, pagou o tributo de nascido aos 20 de Maio de 1681, sendo D. Abade o $\mathrm{m}^{\text {to }}$ R. P. Pregador Fr. Marcos do Disterro. Foi sepultado na Sacristia com as honras devidas ao lugar, que occupava.

46 O Quadragesimo sexto foi o P. Fr. Joaõ Baptista. As suas memorias estaõ sepultadas com as suas sinzas; $p^{r}$ que naõ se descobrio noticia alguma da sua vida, que suppomos havia de ser ajustada ao estado de Religiozo, e de Sacerdote. Falecêo em 13 de Abril de 1682, sendo D. Abade o $\mathrm{M}^{\text {to }}$ R. P. ${ }^{\mathrm{e}}$ Pregador Fr. Bento da Victoria.

$47^{64}$ O Quadragesimo septimo foi o $\mathrm{m}^{\text {to }}$ Reverendo P. Provincial Fr. Ignacio da Purificaçaõ, natural da Cidade do Porto, professo neste Mosteiro, como discipulo, que foi, da quelle grande Mestre de Noviços, de q. ${ }^{\mathrm{m}}$ já se fallou, e p..$^{\text {la }}$ boa educaçaõ com q' foi criado nos premr. ${ }^{\text {os }}$ annos, em todo tempo mostrou este religiozo nas suas acções o feliz progreço de taõ bons principios, detodos era estimado p. ${ }^{\text {la }}$ sua obervancia, $\mathrm{p}^{\text {lo }}$ seu zêllo e $\mathrm{p}^{\text {lo }}$ seu prestimo. Ordenado sacerdote, foi admettido ao Collegio no Rio de Janr. ${ }^{\circ}$ ao depois de fazer actos de paçante, e constituio lente de Theologia, ou p. ${ }^{\mathrm{r}}$ falta de saude, ou por algum desgosto, que tivesse, deixou a cadr ${ }^{\mathrm{a}}$, e com licença do Rem. ${ }^{\text {mo }}$ se passou ao Reino; na viagem foi cap. ${ }^{\text {to }}$ de Mouros, e resgatado da quella dura escravidam, chegou a sua Patria, aonde assistio alguns tempos, edificando com o seu ajustado procedimento, todos aq $q^{\text {les }}$ com $\mathrm{q}^{\mathrm{m}}$ tractava. Brevemente voltou $\mathrm{p}^{\mathrm{a}}{ }^{\mathrm{e}}$ este Most $^{\mathrm{o}}$, aonde foi recebido com muito gosto dos Religiozos, p. ${ }^{\mathrm{r}}$ se verem na posse da comp. ${ }^{\mathrm{a}}$ de hum monge, que tanto desejavaõ, como era exemplar, e cuidadozo, o mandaraõ estabelecer na barra de S. An. ${ }^{\text {to }}$ huma quinta 
$\mathrm{p}^{\mathrm{a}}$ divertimento dos Religiozos, nos dias, que a Religiaõ o $\mathrm{p}<0>$ /er $\backslash$ mitte, fundou a quinta, e nella assistia com aquella modestia, e compustura, que se esperava da sua perfeita observancia.

Era muito amante da sua Provincia; e por ella padecêo muitos trabalhos. Na mesma quinta foi prezo $\mathrm{p}^{\mathrm{r}}$ decreto real a requerimento dos Padres da Provincia, e p. ${ }^{\text {a }}$ Lisbôa remettido p..$^{\text {lo }}$ crime, que lhe formaraõ de separador da Provincia; porem nenhum trabalho foi capaz de lhe diminuir a sua constancia, antes animava aos Monges, que o acompanharaõ na prizaõ, a naõ desistirem de p. ${ }^{\mathrm{r}}$ em liberdade a sua Provincia. Chegado a Lisboa, vendo que a cauza da Provincia tinha corrido a revería ${ }^{65} \mathrm{p}^{\mathrm{r}}$ falta de Procurador, se partio para Roma, em Companhia do $\mathrm{m}^{\text {to }}$ R. P. F Leaõ de S. Bento, aonde conseguiraõ o breve, $p{ }^{\text {a }}$ que os filhos da Provincia fossem Prelados nella; $\mathrm{p}^{\mathrm{r}}$ que antes deste tempo os Monges da congregaçaõ, he que a vinhaõ governar. Nestas viagens taõ bem dilatadas padecêo este Religiozo $\mathrm{m}^{\text {tos }}$ disgostos, $\mathrm{m}^{\text {tas }}$ contradiçoes, e $\mathrm{m}^{\text {tos }}$ trabalhos. Em premio dos seus avultados merecimentos quizeraõ os Padres capitulares, que occupasse os lugares mais auctorizados da Religiaõ, mas elle sempre se escuzou, dizendo, que naõ padecera trabalhos por ambiçaõ dos governos, mas sim $\mathrm{p}^{\mathrm{r}}$ patrocinar a razaõ, e pelo zêllo da Provincia; ultimam ${ }^{\mathrm{e}} \mathrm{p}^{\mathrm{r}}$ satisfazer os Repetidos rogos dos Monges asseitou o ser Provincial, e foi o segundo elleito na Provincia. Governou anno, e meio com geral acceitaçaõ dos Religiozos $\mathrm{p}^{\mathrm{r}} \mathrm{q}$ ' todos lhe viviaõ obrigados $\mathrm{p} .^{\text {los }}$ muitos serviços, que fazia, e fizera a Religiaõ, e faria muitos mais, se a morte o naõ privasse da vida no tempo em que andava mais cuidadozo no seu augmento espiritual, e temporal. Enfermou gravemente, e dezenganado q' a moléstia vencia a todos os remedios, que lhe applicavaõ, dispondo-se com todos os Sacram. ${ }^{\text {tos }}$, e com muitos actos de Catolico, deixou rezinado este vale de mizerias em 13 de Dezembro de 1682 sendo D. Abd. ${ }^{\mathrm{e}}$ o M. ${ }^{\text {to }}$ R. P. Pregador F Bento da Victoria, Foi sepultado na

${ }^{65}$ É exatamente assim que aparece no original. 
Sacristia com as Seremonias devidas ao lugar q' exercitava.

$48^{66}=$ O quadragesimo oitavo foi o M. $\mathrm{R}^{\mathrm{do}} \mathrm{P}^{\mathrm{e}} \mathrm{Fr}$. Martinho de Jezus natural do Rio de Janeiro. $<\mathrm{Ne}>$ Noticia que se pode descubrir deste Religiozo he que servio assistindo sempre dentro do Mosteiro, porque era bom Musico, e soccorrido de huma perfeita voz a qual empregava nos divinos louvores com grande alegria, e consolaçaõ da sual Alma. Faleceo em 24 de Agosto de 1683 sendo D. Abb. ${ }^{\mathrm{e}}$ o $\mathrm{M}^{\mathrm{o}}$ R. $\mathrm{P}^{\mathrm{e}}$. Preg $^{\text {or }}$ Fr. Bento da Victoria. $49^{67}=\mathrm{O}$ quadragesimo nono foi o $\mathrm{P}^{\mathrm{e}}$ Fr Joaõ Gondim natural do Reino professo neste Mosteiro. Na virtude, e humildade estabeleceo este Religiozo a conducta da sua vida, aborrecia $<_{0}$ ocio $>$ [ $\uparrow$ o vicio] capital principio de $\mathrm{m}^{\text {tos }}$ desordens: os seus pensamentos sempre foraõ humildes e so desejava obedecer, e servir, e assim passou toda a sua vida, sem que aspirasse outra couza, sempre frequentou o Coro, e mais actos Conventuaes, e $\mathrm{m}^{\text {to }}$ mais na sua velhice. Desamparado da Natureza, $<$ porque passava $>$ /porque passava $\backslash$ de 80 annos, mas fortalecido com a graça dos Sacram ${ }^{\text {tos }}$ accabou a vida em seo perfeito juizo, com tantos annos de preparo quantos tinha de Religiozo. Faleceo aos 30 de Junho de 1683 sendo D. Abb ${ }^{\mathrm{e}}$ o M. R. P. Preg ${ }^{\text {or }}$ $\mathrm{F}^{\mathrm{r}}$ Bento da Victoria.

$50^{68}$ O Quinquagesimo foi o P. ${ }^{e}$ Fr. Bernardo de Santa Maria. Ignorase a terra, em que nascêo, e a caza em que professou. Era Religiozo exemplar, modesto, e humilde. O tempo, que lhe restava das obrigações Religiozas o gastava na liçaõ de livros espirituaes, tanto p. ${ }^{\mathrm{a}}$ se adiantar nas virtudes, como p. ${ }^{\mathrm{a}}$ evitar a ociozid. ${ }^{\mathrm{e}}$, officina de abominações. Faleceo neste Mostro $^{\circ}$ em 7 de Julho de 1683, sendo D. Abd ${ }^{\mathrm{e}}$ o $\mathrm{M}^{\text {to }}$ R. P. Preg. ${ }^{\text {or }}$ Fr. Bento da Victoria.

\footnotetext{
${ }^{66}$ Como estava bastante desbotada no original, a numeração foi "reforçada" com caneta hidrocor verde. (APFT)

${ }^{67}$ Como estava bastante desbotada no original, a numeração foi "reforçada" com caneta hidrocor verde. (APFT)

${ }^{68}$ Como estava bastante desbotada no original, a numeração foi "reforçada" com caneta hidrocor verde. (APFT)
} 
$51^{69}$ O Quinquagesimo primr. ${ }^{\circ}$ foi o P. F. Luis de Souza, nascido em

$\left[\mathrm{f}^{\mathrm{0}} 30 \mathrm{r}^{\mathrm{0}}\right]$ Lisboa de geraçaõ illustrissima, professo no Mostro de S Martinho de Tibãens. Ao depois de viver alguns annos na Religiaõ, se fez apostada ${ }^{70}$, largando o habito se passou a França, e assentando praça de Soldado, melitou nos exercitos de Luiz Cardozo ${ }^{71} \mathrm{p}^{\mathrm{r}}$ espaço de vinte annos. Chegado o tempo de conhecer o máo estado, em q' andava, voltou p. ${ }^{\mathrm{a}} \mathrm{Lx} .{ }^{\mathrm{a}}$ e recolhido no Palacio do Arcebispo seu Parente, vestio o abito, e buscou o Mosteiro, aonde foi recebido com alegria, e conçolaçaõ dos Religiozos, entre os quaes vivêo alguns annos sentindo, e chorando o tempo perdido.

Como nesse tempo corria a fama das virtudes, em q' floricia esta Provincia, a qual os Padres da Congregaçaõ dava o tituto ${ }^{72}$ de S. ${ }^{\text {ta }}$ Para ella se passou este Religiozo, levado do dezejo de viver na Companhia de Religiozos taõ exemplares. Passados alguns annos o mandaraõ os Prelados administrar huma fazenda, q' tivemos no Itapecurú; neste emprego servio a Religiaõ com zelo e aos Seculares com exemplo, e administraçaõ dos Sacramentos. Huma occaziaõ querendo preparar huma espingarda p. ${ }^{a}$ seu devertimento, naõ advertindo q' estaria carregada, de repente se disparou; e passando-lhe o chumbo a garganta, cahio em terra como morto, porem com a diligencia da cura, que lhe fizeraõ conseguio alguma melhora. Recolhido ao Mostr. ${ }^{\circ}$ ainda vivêo quatro annos, occupando os dias, e as noites em virtuozos exercicios, dourando com as suas penitencias os erros passados. Falecêo fortalecido com a graça dos Sacram ${ }^{\text {tos }}$, e pedindo perdam a D. ${ }^{\mathrm{s}}$ e aos homens, enchêo os seus dias em 30 de Agosto de 1684, sendo D. Abd. ${ }^{\mathrm{e}}$ o M. ${ }^{\text {to }}$ R. $\mathrm{P}^{\mathrm{e}}$ Pregador Fr Bento da Victoria. Ao seu interro assistio o Marquez das Minas, e seu Subr. ${ }^{\circ}$ com toda a nobr. ${ }^{\mathrm{za}} \mathrm{da} \mathrm{Cid}^{\mathrm{e}}$. O Quinquagesimo seg ${ }^{\text {do }}$ foi o m. ${ }^{\text {to }}$ R. P. Pregador Fr Leaõ de S. Bento natural da $\mathrm{Cid}^{\mathrm{e}}$. do Porto, professo neste Mosteiro. Logo no seu noviciado mostrou este Religiozo ser verdadr ${ }^{\mathrm{a}}$ a sua vocaçaõ p. $^{\text {la }}$ promptidaõ, obediencia, e humildade, com q' satisfazia a todas as suas obrigações, e p..$^{\text {lo }}$ grande gosto, com que levava, e soffria as mortificações

\footnotetext{
${ }^{69}$ Como estava bastante desbotada no original, a numeração foi "reforçada" com caneta hidrocor verde. (APFT)

${ }^{70}$ No original, encontra-se a "correçaõ" feita por Dom Clemente da Silva Nigra, emendando $<\mathrm{d}>$ por $<\mathrm{t}>$ (APFL).

${ }^{71} \mathrm{Na}$ entrelinha superior, acima de Cardozo, encontra-se a seguinte indicação $<$ XVI $>$ XIV. (APFL)

${ }^{72}$ No original realmente não se vê a concordância verbal e a palavra titulo encontra-se grafada com $<\mathrm{t}>$ no lugar do $<\mathrm{l}>$.

${ }^{73}$ Como estava bastante desbotada no original, a numeração foi "reforçada" com caneta hidrocor verde. (APFT)
} 
e penalidades da Religiaõ. Ordenado de Sacerdote foi admetido ao Colegio da Filozofia no Rio de Janr. ${ }^{\circ}$, e nelle a custa do seu disvello sahio taõ aproveitado, que suposto naõ quizesse seguir as Cadêras, foi p..$^{\text {lo }}$ tempo adiante hum pregador de grande nome, procurado de todos nas occaziões de maior impenho; e da mesma sorte no Conficionario, aonde fazia as $\mathrm{p}^{\text {tes }}$ de bom ministro, $\mathrm{p}^{\mathrm{a}} \mathrm{o}$ q' estava sufficientem $^{\mathrm{e}}$ instruido na sciencia, doutrina, e liçaõ dos livros convenientes, e necessarios p. ${ }^{\mathrm{a}}$ exercer estes santos, e nobres impregos. Sua Provincia, e a razaõ, era $\mathrm{m}^{\text {to }}$ amadas $^{74} \mathrm{p}^{\mathrm{a}}$ elle, e naõ levando a bem que viessem governa-la os Padres da congregaçaõ alcançou hum breve Apostolico p. ${ }^{\text {a } q u e ~ o s ~ f i l h o s ~ d ' e l l a ~ f o s s e m ~ o s ~ s e u s ~ P r e l a d o s ; ~ n a o ̃ ~}$ lhe faltou que padecer $p .{ }^{r}$ esta diligencia; $p .{ }^{r}$ que a Requerim ${ }^{\text {to }}$ dos Padres da Congregaçaõ foi prezo p. ${ }^{\mathrm{a}} \mathrm{Lx} .{ }^{\mathrm{a}} \mathrm{p} .{ }^{\mathrm{r}}$ hum decreto real junto com mais 12 Religiozos; porem chegando a barra de Liboa, teve occaziaõ de avizar a hum seu Irmaõ Religiozo Trino de grd $^{\mathrm{e}}$ respeito na Côrte, o qual a toda preça conseguio nôvo decreto, no qual se determinava, que os Religiozos prezos fossem p. ${ }^{\mathrm{a}}$ o Mosteiro da ordem de Sister, p. ${ }^{a}$ de lá serem ouvidos, pouco depois chegaraõ os nossos Monges do Mosteiro de Lisbôa com grilhões e algemas acompanhados de Ministro de Justiça p. ${ }^{a}$ os levarem em ferros p. ${ }^{a}$ o dito Mosteiro; mas aprezentando-lhe o P. ${ }^{\mathrm{e}}$ Fr. Leaõ o breve encontrado os deixou confuzos, e admirados. Recolhidos ao Mosteiro dos Bernardos frequentavaõ as horas do côro, e mais actos Conventoaes com tanta devoçaõ, e modestia, que o Rm. ${ }^{\circ}$ Geral dos Monges de Sister $\mathrm{m}^{\text {tas }}$ vezes lhes offerecêo $\mathrm{o}^{75}$ seus Mostr $^{\text {os }} \mathrm{p}^{\mathrm{a}}{ }^{\mathrm{a}}$ nelles ficarem trocando as cogullas brancas p. ${ }^{\text {las }}$ pretas. O Muito Reverendo P. Fr. Liaõ no Pulpito mostrou a sua erudiçaõ, o seu talento, pregando a N. Sr ${ }^{\mathrm{a}}$ do Desterro padroeira d'aquelle Mostro . D'aquella corte partio p. ${ }^{a}$ Roma, e de Roma p. ${ }^{a}$ este Mostr. ${ }^{\circ}$, aonde foi recebido com aplauzo devido ao seu zello, e ao seu trabalho. Foi o $4^{\circ}$ Provincial eleito p. $^{\text {la }}$ Provincia, e hum dos mais cuidadozos no .seu augmento espiritual, e temporal. Ao dep. ${ }^{\mathrm{s}} \mathrm{de} \mathrm{m}^{\text {to }}$ trabalhar, e padecer p. $^{\text {la }}$ boa reputaçaõ da sua Provincia, e conseguido o breve,

\footnotetext{
${ }^{74}$ No original, realmente, naõ é feita a concordância numérica.

${ }^{75}$ É exatamente assim que aparece no original.
} 
que tanto dezejava, . $^{\text {a }}$ que fosse governada . $^{\text {los }}$ filhos d'ella, entrou a cuidar com maior disvello no ponto mais principal, q' era a salvaçaõ da sua alma. Separou-se de toda a comunicaçaõ, e recolhido na sua Cella gastava os dias, horas em actos de Piedade e Religiaõ. Recebêo os ultimos Sacram ${ }^{\text {tos }}$ com ${ }^{\text {tas }}$ lagrimas, e actos de Catolico, naõ cessando os Religiozos de o acompanharem com $\mathrm{m}^{\text {tos }}$ mais, sentidos de se verem privados da Companhia de hum Monge, a q. ${ }^{\mathrm{m}}$ se reconheciaõ taõ obrigados. Ao seu Corpo deraõ huma honrada sepultura com assitencia da Nobreza desta Cidade, pegaraõ do Esquife os Prelados das Religiões, e todos sentidos da falta, que faz a huma Comunid ${ }^{\mathrm{e}}$, hum homem iminente como era o nosso Padre Fr. Leaõ de S. Bento. Falecêo em 12 de Janr. $^{\circ}$ de 1688, sendo D. Abd. ${ }^{\mathrm{e}}$ o M. ${ }^{\text {to }}$ R. P. Pregador Fr. André da Cruz.

53 O Quinquagesimo terç foi o M. ${ }^{\text {to }}$ R. P. ${ }^{\text {e }}$ Pregador Fr. Bento da Victoria natural da Cidade de $\mathrm{Braga}^{76}$; duvida-se se foi professo na Congregaçaõ, ou na Provincia. Foi Religiozo de vida exemplar, recolhido, amante do Silencio, e totalmente separado das couzas terrenas, empregando-se som ${ }^{\text {te }}$ na observancia dos votos, e preceitos regulares, na pratica das virtudes, e Santo temor de Deos. Ao dep ${ }^{\mathrm{s}}$ de ter exercido $\mathrm{p}^{\mathrm{r}}$ alguns annos dignamente o emprego de $\langle\uparrow>$ /Mestre $\backslash$ de Noviços foi elleito Abade do Rio de $\operatorname{Janr}^{\mathrm{o}} \mathrm{p}^{\mathrm{a}}$ evitar alguma relaxidaõ, que introduziraõ alguns Monges menos observantes; Deos o ajudou, e com o exercicio da sua Passiencia, p. ${ }^{\mathrm{r}}$ que naõ lhe faltou que suffrer ${ }^{77}$, vio tudo restituido ao estado que dezejava. Evitou os guizados particulares, de que uzavaõ alguns Monges naõ sem nota, e escandalo dos mais observantes. Aos actos conventoaes todos se ajuntavaõ, e concorriaõ, $\mathrm{p}^{\mathrm{r}}$ que elle era o pr. $^{\mathrm{mo}}$ Concluido o seu trienio, e restituido aq. ${ }^{\text {le }}$ Motr. ${ }^{\circ}$ a huma perfeita observancia, acabou ${ }^{78}$ vida tocada de huma Epidemia, que $-59-$

\footnotetext{
${ }^{76}$ No texto original, aparece riscada a palavra Braga e substitui pela abreviatura $\mathrm{Lx}^{\mathrm{a}}$ (APFL).

${ }^{77}$ Encontra-se grafado realmente com $<\mathrm{u}>$.

${ }^{78}$ No documento, aparece inserido o artigo a (APFL).
} 
laborava nesta terra, a que chamaraõ a bixa, tendo recebido os ultimos Sacram. ${ }^{\text {tos }}$ com devoçaõ, que esperava-se da sua piedade, e perfeita observancia. Falecêo em 25 de Janr ${ }^{\circ}$ de 1688 sendo $\mathrm{Abd}^{\mathrm{e}} \mathrm{o}$ m. ${ }^{\text {to }}$ R. P. ${ }^{\mathrm{e}}$ Pregador Fr. André da Cruz.

$-60-$ 
$54^{79}$ O Quinquagesimo quarto foi o Padre Fr. Joaõ de Christo nascido no Reino, e professo nesta caza. Foi Religiozo de conhecida vitude neste Mosteiro, e nesta Provincia. Era de todo de uma candida singelesa, e humildade e sinceridade, os seos pensamentos eraõ taõ ajustados, que dezejava, que os homens so se empregassem no que fosse para honra de Deos, e utilidade espiritual do proximo, e como naõ podia persuadir estes taõ sanctos desejos com palavras, $\mathrm{p}^{\mathrm{r}}$ ser naturalm. ${ }^{\text {te }}$ timido, e humilde, o fazia com obras, empregando-se continuamente em virtude os exercicios; $p^{r}$ que no choro naõ faltava hora alguma, ainda ao depois que as suas molestias, e annos o dispensa raõ deste exercicio. Para todos os actos conventuaes era dos primeiros, e sempre prompto para suprir alguma falta que sucedesse; se $\mathrm{p}^{\mathrm{r}}$ acaso vio algum descuido nas ceremo nias ou menos modestia em algum Religiozo, todo se angusti ${ }^{80}$ nhava $^{81}$ [个ava] como se fora elle o culpado, Era de tal sorte inimigo da occiosidadi, que naõ sofria gastar tempo, que naõ fosse bem empregado. Nos /vottos/ da sua profissaõ era /taõ exacto/, que $\mathrm{m}^{\mathrm{s}}$ parecia ser pobre, casto, e obdiente $\mathrm{m}^{\mathrm{s}}$ por natureza, ,do que $\mathrm{p}^{\mathrm{r}}$ obrigacaõ. Elegeraõ o $\mathrm{Abd}^{\mathrm{e}}$ da Paraiba, recebeo a quella noticia como se naõ fora com elle, e certificado ${ }^{82}\left[\uparrow\right.$ certificado] $\mathrm{p}^{\text {los }}$ Directores da sua conciencia, que naõ /peccava/ escusandose d'aquella Prelasia, para logofez/renuncia/ d'ella.

do cincoenta annos de Idade, e mais de trinta de Religioso;

\section{Contan} um dia sentindo-se ameacado da epedimia chamada bi-

\footnotetext{
${ }^{79}$ A partir desse ponto a leitura foi reconstituída com base na transcrição feita por Silva Nigra.

${ }^{80}$ A partir desse ponto, o cotejo com o original volta a ser feito.

${ }^{81}<\mathrm{nh}>$ sublinhado e tracejado o resto da palavra.

${ }^{82}$ A palavra está sublinhada com tracejado.
} 
cha como a sua obediencia era taõ cega parecendo, que nada podia faser, foi a cella do Prelado pedir-lhe licen ca para morrer, e antes disto para dizer missa, e commun gar $\mathrm{p}^{\mathrm{r}}$ viatico, e ultimamente para se ungir, alcancando todas estas licenças, foi diser Missa, errender os ultimos ob séquios ao Sñr. Sacramentado. Pelas tres horas da tarde pe dio o Sacramento da unçaõ,e chegando os Monges para lhe administrar aquelle Sacramento, querendo-lhe tirar um cilicio, com que o acharaõ apertado, pedio, e rogou,que lhe naõ tirassem o seo companheiro de trinta annos, ao de pois de ungido concluidas as mais cerimonias religiosas entregou o seo espirito nas maõs do seu Creador para lo grar as eternas felicidades da Gloria, como piamente julgou. Foi o dia do seu falecimento em $\underline{30}$. de janeiro de 1688

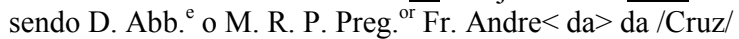

$55 \mathrm{O}$ Quinquagesimo quinto foi o $\mathrm{P}^{\mathrm{e} .}$ Fr. Gregório Macha do professo nesta caza, e nascido em Portugal. Era Religioso desembaraçado, e diligente para as suas obrigacoens, (†ouvio) a porém com pouco gosto os conselhos, que lhe davaõ, e elle bem necessitava. Achando-si no engenho da Praÿa no tempo das festas que nelle se fasiem, querendo ver como se faria o ascucar subio a cavallo $\mathrm{p}^{\mathrm{r}}$ huma escada de pedra que vai para as casas das caudeiras, e quando foi a descer com a $\mathrm{m}^{\text {ta }}$ pressa com que subio e cahindo pe las 
${ }^{83}$ escadas abaixo quebrou ambas as pernas, ficando mor=

$\left[\mathrm{f}^{\mathrm{0}} 33 \mathrm{r}^{\mathrm{o}}\right]$ to sem sentido; recolheo-se ao Mostro ${ }^{\circ}$, e nelle viveo exem plarmente $\mathrm{p}^{\mathrm{r}} \mathrm{m}^{\mathrm{s}}$ annos; $\mathrm{p}^{\mathrm{r}}$ que todo o tempo passava na sua cella occupado em virtuosos exercicios com $\mathrm{m}^{\text {tos }}$ tra balhos, e dores apegadas as suas moléstias, chegava a Capel= la de S. Bernardo a ouvir missa, e commungar nos mais dos Domingos, e dias santos, e neste purgatorio foi viven do resignado, e conforme, até que sentindo-se ameaçado do mal contagiozo, que chamavaõ a bicha, pedindo os santos Sa cramentos, e recebidos com $\mathrm{m}^{\text {tas }}$ lagrimas, e actos de Catholi co, acabou os seos dias no 1 de Agosto de 1688 sendo D. Abb ${ }^{\text {de }}$ o $\mathrm{M}^{\text {to }}$ R.P. $\mathrm{M}^{\mathrm{e}}$. Fr. Ruberto de Jesus.

56 O quinquasesimo sexto foi o Pe. Fr. $\mathrm{An}^{\text {to }}$ dos Martires. Deste Monge naõ ficaraõ outras noticias $\mathrm{m}^{\mathrm{s}}$ do que a perseveran ça na Religiaõ sendo D. Abbde o $\mathrm{M}^{\mathrm{e}}$ R.P. $\mathrm{M}^{\mathrm{e}}$. Fr. Ruberto de Jesus até a sua morte que foi no anno de 1688 .

57 O quinquagesimo septimo foi o Irmaõ Donado Fr. José de Je sus nascido nos Ilheos Arcebispado desta Cidade, professo nes te Mostr ${ }^{\circ}$, era cazado, e abundante de bens temporaes; $p^{r}$ certa temporalidade, que lhe succedeo se refugiou neste Mostr ${ }^{\circ}$, e agradando da vida religioza, $\mathrm{p}^{\mathrm{r}}$ consentimento de sua Mulher professou o instituto Monachal no habito de Lei $-63-$

${ }^{83}$ A leitura de todo esse fólio foi baseada na transcrição feita por Silva Nigra. 
go fazendo doaçaõ a esta casa dos bens, que lhe /tocavaõ/ nas par tilhas, sem que para si reservasse coisa alguma; a sua vida foi de um Religioso verdadr ${ }^{\circ} \mathrm{m}^{\text {to }}$ desenganado, e de to do separado da communicaçaõ com os homens. Exerceo $\mathrm{p}^{\mathrm{r}} \mathrm{m}^{\text {tas }}$ /vezes/ o emprego de $\mathrm{M}^{\mathrm{e}}$ das obras com grande utilidade des te Mostr ${ }^{\circ}$. Nunca foi para o seu trabalho sem que primei $\mathrm{ram}^{\text {te }}$ ouvisse uma ou mais missas, e satisfisesse as obriga çoens pertencentes a seo estado que professava, occupado nestes virtuosos exercicios, foi accomettido do mal dabicha,

$10 \mathrm{e} /$ recebidos/ os ultimos sacramentos com $\mathrm{m}^{\text {ta }}$ devoçaõ aca /bou a sua vida/ em $\underline{27}$ de Septembro de $\underline{1689}$ sendo D. Abb. $\mathrm{M}^{\text {to }}$ R. P. M. Fr. Ruberto de Jesus.

58 O quinquagesimo oictavo foi o Irmaõ Fr. Bento da Pi edade, inferese que este Religioso faleceo no anno de 1689 pelo lugar que occupa a sua sepultura, delle naõ ficou outra noticia $\mathrm{m}^{\mathrm{s}}$ que o seu nome na pedra que cobre as suas cinsas. He escusado lamentar estes descuidos $\mathrm{p}^{\mathrm{r}} \mathrm{q}$ ' he quei xa sem remedio.

$59 \mathrm{O}$ /quinquagesimo/ nono foi o Pe. Fr. Fran ${ }^{\text {co }}$ da Trinda /de natural da Cidade do/ Porto professo nesta casa. Era Religiozo modesto observante sofrido adaptado de pren /das/ com que servia a Religiaõ; porém naõ se utilisou /ella/ 
muito tempo da sua conhecida capacidade, e prestimo $\mathrm{p}^{\mathrm{r}}$. que

$\left[\mathrm{f}^{\mathrm{0}} 34 \mathrm{r}^{\mathrm{0}}\right]$ logo dep ${ }^{\mathrm{s}}$ de Sacerdote se lhe abrio uma ferida na perna incuravel, que pelo tempo adiante chegou a meter compai xaõ a quem a vida, e horror, a ${ }^{\text {ma }}$ naturesa; porém como $\mathrm{D}^{\mathrm{s}}$ naõ permite nas creaturas tralbahos que excedaõ as suas forças, lhe suavisava as intoleraveis dores que a toda a hora o atormentavaõ, mostrando-se contente, e alegre satis feito com aquelle toque da maõ divina, dando-lhe $\mathrm{m}^{\text {tas }}$ gracas pela esperancaem que o punha de salvar, etao

10 depois de $\mathrm{m}^{\text {to }}$ padecer sempre constante, e resignado encheo os dias de sua penosa perigrinação, preparado com a gra ça dos Sacramentos em $\underline{30}$ de Outubro de $\underline{1689}$ sendo D. Abb o $\mathrm{M}^{\text {to }}$ R.P. $\mathrm{M}^{\mathrm{e}}$. Fr. Pascual do Espirito/Sancto/.

60 /O sexa/gesimo foi o Irmaõ Noviço Fr. Dionisio de S. Bento, sete dias ao depois que vestio o $\mathrm{s}^{\mathrm{to}}$ habito, sintindo-se tocado do mal da bicha fez profíssaõ perante o Prelado, e recebidos os $\mathrm{S}^{\text {tos }}$ sacramentos com $\mathrm{m}^{\text {tas }}$ lagrimas de contriçaõ e arrepen dimento acabou a vida no estado que desejava aos 17 de Maio de 1691 . Sendo D. Abb o M ${ }^{\text {to }}$ R.P. M M $^{\mathrm{e}}$. Fr. Pascoal do Espirito Sancto.

61 O sexagesimo primro foi o Irmaõ Noviço Fr. Antonio de S. Bento natural de Bastos Arcebispado de Braga. Com dois meses de noviciado nos quaes mostrou verda deira a sua vocaçaõ fez também profissaõ nas 
maos do Prelado e desenganado o que morria, ao depo is que recebeo tdos os Sacramentos com $\mathrm{m}^{\text {ta }}$ piedade $\mathrm{e}$ devoçaõ, pedio um Sñr. curcificado, e fazendo $\mathrm{m}^{\text {tos }}$ actos de contriçaõ acabou os seus dias ferido do $\mathrm{m}^{\mathrm{mo}} \mathrm{mal}$ da bicha em $\underline{20}$ de Maio de $\underline{1691}$ sendo D. Abbd ${ }^{\mathrm{e}}$ o $\mathrm{M}^{\text {to }}$ R.P. $\mathrm{M}^{\mathrm{e}}$. Fr. Pascoal do Espirito Sancto.

62 O sexagesimo segundo foi o Irmaõ Donado fr. Bento do Rosário nascido em Portugal professo neste Mostro em premio do $\mathrm{m}^{\text {to }}$ que servio a esta casa, tanto na fasen da da Itapoam, como no emprego de Mordamo lhe de raõ o habito, e coroa Monacal. Tambem servio de Pro curador dando sempre a satisfaçaõ, que se esperava do seu zello e verdade. Nunca principiou trabalho $\mathrm{p}^{\mathrm{r}} \mathrm{ma}$ ior que se lhe apresentasse a necessidade sem que primr ${ }^{\circ}$ ouvisse Missa e satisfizesse as obrigacoens Religiosas. Ao depois de ter servido a D. ${ }^{\mathrm{s}}$ Religiaõ $\mathrm{m}^{\text {to }}$ annos [foi $\uparrow$ ] accom mettido do mal da bicha. Faleceo em 30 de Ouctubro de $\underline{1691}$ sendo D. $\mathrm{Abb}^{\mathrm{e}}$ o $\mathrm{M}^{\text {to }}$ R. Pe. Preg ${ }^{\underline{\text { or }}}$. Fr. Manoel do Nascimento.

2063 O sexagerimo terceiro foi o Pe. Fr. Baltazar de $\mathrm{S}^{\text {ta }}$ Cathari na natural da Cidade do Rio de $\mathrm{Janr}^{\circ}$ professo nesta ca za. Entre outras virtudes foi admiravel na obediencia e guarda do silencio, e recolhimento $\mathrm{p}^{\mathrm{r}}$ que da sua cella unicamente sahia $\mathrm{p}^{\mathrm{a}}$ os actos conventuaes, aos quaes nun 
${ }^{84}$ faltava; ordenado sacerdote, foi mandado $\mathrm{p}^{\mathrm{a}}$ o Collegio q' se abrio em N. Snr ${ }^{\mathrm{a}}$ da Graça, passado algum tempo voltou a este Mostr ${ }^{\circ}$ tocado do mal da bicha para buscar a sepul tura; faleceo fortalecido com a graça dos Sacramentos aos $\underline{3}$ de Mayo de 1692 sendo D. Abbd o $^{\text {to }}$ R. P. Preg ${ }^{\text {or }}$. Fr. Ma noel do Nascimento.

64 O sexagesimo quarto foi o P. Fr. Domingos de S. Amaro na tural desta cidade, e professo neste Mostr $^{\circ}$ Do Noviciado sahio este Monge taõ instruido $\mathrm{p}^{\mathrm{a}} \mathrm{o}$ estado de Monge, que naquelles poucos annos de Idade que tinha, e nos poucos dias se professo, que contava bem se mostrou ser sua vocaçaõ verdadeira. Ao depois que se ordenou de Sacerdote, tendo ja dez annos de Religiaõ, pela sua perfeita observancia o fez o Prelado seu Sub Prior; a tudo as tisfez como se esperava da sua Religiaõ, e Capacidade. Admettido ao Collegio da Graça cuidou em se aplicar aos estudos com tanto disvello, que todo o tempo, que restava aos actos conventuaes, o empregava na liçaõ das suas postillas, porem naõ chegou a Religiaõ a gozar dos fructos do seu dis vello, $\mathrm{p}^{\mathrm{r}}$ que ferido do mal contagiozo, se recolheo a este Mostr ${ }^{\mathrm{o}}$ onde acabou a vida com a graça dos Sacramentos aos 7 de Mayo de 1692 sendo D. Abbd $^{\text {e o }}$ M $^{\text {to }}$ R. P. Preg ${ }^{\text {or }}$. Fr. Manoel do Nascimento.

${ }^{84}$ A leitura desta fólio foi baseada na transcrição de Silva Nigra. 
$65 \quad{ }^{85} \mathrm{O}$ sexagesimo quinto foi o P. Fr. Jacinto do Desterro natural d'esta Cidade da $\mathrm{B}^{\mathrm{a}}$ professo neste Mostr ${ }^{\circ}$. Pella boa educaçaõ que a este seu Filho deraõ os sés virutosos Paes naõ lhe foi dificultoso o exercicio das Virtudes e mortificaçoens da Religiaõ, $\mathrm{p}^{\mathrm{r}}$ que desde o seu noviciado mostrou que tinha sido creado para Religiozo, obediencia sem Repugnancia, e tudo que pelos Prelados lhe era mandado, executava com diligencia. Cuidou $\mathrm{m}^{\text {to }} \mathrm{em}$ adquirir huma perfeita noticia de $\mathrm{S}^{\text {ta }}$ Regra, ceremonias, e consituiçoens e assim estava prompto para desfazer qualquer duvida, que se offerecia. Foi Regliozo de $\mathrm{m}^{\text {ta }}$ madureza, piedade e zeloso do patrimonnio da Religiaõ, de tal sorte que as demandas $\mathrm{m}^{\mathrm{s}}$ importantes que se moviaõ contra o Mostro elle se encarregava d'ellas, e sempre com bom successo conseguia o que desejava; o seu procedimento era exemplar, a sua vida ajustada, como Corista noviço e Padre, e quando esta vaõ doentes os visitava com licença do seu $\mathrm{M}^{\mathrm{e}}$ dando algumas esmolas para remediar suas necessidades. Quando a Religiaõ começava a primiar os seus merecimentos obriga ções mais autorisadas, adoeceo da epidemia chama bicha, a $\mathrm{q}^{1}$ em breves dias o privou da vida tendo-se confessado repetidas vezes e receebido os $\mathrm{m}^{\mathrm{s}}$ Sacramentos com $\mathrm{m}^{\text {tos }}$ actos de catholico, e de Religiozo. Foi o dia do seu falecimento aos 31 de Maio de 1692 sendo D. Abbd $^{\text {e }}$ o M $^{\text {to }}$ R. P. Preg ${ }^{\text {or }}$. Fr. $\mathrm{M}^{\mathrm{el}}$ do Nascimento.

$-68-$

\footnotetext{
${ }^{85}$ A leitura desse fólio foi baseada na transcrição de Silva Nigra. No original, este fólio apresenta 27 linhas, no entanto, como não foi possível seguer conferir a disposição do texto na página, isso foi feito de forma arbitrária, evitando a divisão de palavras entre as linhas.
} 
$66{ }^{86} \mathrm{O}$ sexagesimo sexto foi o Irmaõ converso $\mathrm{An}^{\text {to }}$ Pereira natu

$\left[\mathrm{f}^{0} 36 \mathrm{r}^{\circ}\right]$ /ral/ do Reino disem que d'entre a Prov ${ }^{a}$ do Douro, e Minho, era homem nobre e Senhor de um morgado em sua terra. Por occaziaõ de certo desgosto se ausentou para o Brasil sem outra providencia $\mathrm{m}^{\mathrm{s}}$ que a divina, e nella trasia tudo, como elle expe rementou, $\mathrm{p}^{\mathrm{r}}$ que $\mathrm{D}^{\mathrm{s}}$ lhe descubrio o caminho, e os meios pra conseguir com felicidades tudo que desejava, tinha promettido servir a N.Snr ${ }^{a}$ em terras estranhas no habito de hermitaõ; chegando q' foi a esta terra desembarcando na Praya sem $\mathrm{m}^{\mathrm{s}}$ guia, que o do Ceo, foi caminhando até a capella de N. Sn do Montserrate, que nes te tempo estava solitaria, entrou para dentro, e pondo os olhos naquella augustissima Rainha dos Anjos, prostrado $\mathrm{p}^{\mathrm{r}}$ terra, ao de pois que os suspiros, e lagrimas lhe deraõ lugar para articular vozes, the deo repetidas graças, e louvores $\mathrm{p}^{\mathrm{r}}$ se chegar a ver 15 na posse do que tanto desejava e apetecia.

Ao depois que con seguio licença do administrador da Capella, cheio de consolaçaõ, e alegria, com todas as forças do seu espirito se occupou no servico da $\mathrm{Snr}^{\mathrm{a}}$, até a Morte vestido de Hermitaõ. Atodos os rumeiros que visitavam aquelle sanctuario servia com rara humildade, ajustan do a todos com a sua vida, e recto procedimento. Era admi ravel na virtude da paciencia, $p^{r} q^{\prime}$ a todos soffria e agradava, e $\mathrm{p}^{\mathrm{r}}$ isso de tal sorte lhe grangeou as vontades que sem elle pe dir lhe offereciaõ grandiosas esmolas, das $\mathrm{q}^{\mathrm{s}}$ mandou faser a coroa de Ouro, que hoje possue aquella soberana $\mathrm{Snr}^{\mathrm{a}}$ e outras preciosas alfaias, que o tempo gastou, e algumas ain

${ }^{86}$ A leitura desse fólio foi baseada na transcrição de Silva Nigra. 
da se conservaõ.

$\left[\mathrm{f}^{\mathrm{0}} 36 \mathrm{v}^{\mathrm{0}}\right]$

Esta Capella foi fundada pr D. Franc ${ }^{\circ}$ de Sou

sa hoje Marques di Minas, em comprimento de um voto que fez pelo

bom sucesso e descobrimento das esmeraldas de que veio encarre

5 gado, vindo governar os estados do Brasil, e como aquella

caza sempre foi /amante/ da Religiaõ Benedictina, passados

alguns /annos/ depois de fundada a Capella, fez doaçaõ della

a este Mostr $^{\circ}$ com todas as insençoens, e haveres, que possuia

tambem se passou para nas o Irmaõ Antonio Pereira ao qual

10 se deo habito converso, /e/ nelle continuou no $\mathrm{m}^{\mathrm{mo}} \mathrm{s}^{\text {to }}$ servico de /servir/ a N. Snr. ${ }^{2}$. Ja adiantado em annos se abrio uma cha ga no rosto, que lhe deo $\mathrm{p}^{\mathrm{r}} \mathrm{m}^{\text {to }}$ occasiaõ /de merecer pela cons/ tancia com que sofria as dôres que lhe causava; d'ella veio a morrer fortalecidos com a graça dos Sacramentos, deixando a esse Mostr ${ }^{\mathrm{o}}$ a preciosa reliquia de $\mathrm{S}^{\text {to }}$ Lenho, unica prenda que para si reservou de tudo quanto possuia. Foi sepul tado entre os Religiosos em $\underline{15}$ de $9^{\text {bro }}$ de $\underline{1692}$ sendo D. $\mathrm{Abb}^{\mathrm{e}}$ o $\mathrm{M}^{\text {to }}$ R. Pe. Preg ${ }^{\text {or }}$. Fr. Manoel do Nascimento.

67 O sexagesimo septimo foi o Irmaõ Novico Fr. Lucas de Assum pcaõ, natural de S. Joaõ de Fos do Douro. A sua humild ${ }^{\mathrm{e}}$ e obediencia promettiaõ grandes progressos na Religiaõ, porém a Divina Providencia dispos a que melhor esta va para sua alma, permittindo com os dois meses de habi to o levar desta vida para a sempiterna, depois de recebi dos os Sacramentos, e feita/profissaõ na maõ do Prelado/ Fa 
${ }^{87}$ em 26 de Junho de 1693 sendo D. Abbd ${ }^{\text {e }}$ o M ${ }^{\text {to }}$ Rever $^{\text {do }}$. P. Preg ${ }^{\text {or }}$. Fr. Manoel do Nascimento.

68 O sexagesimo oitavo foi o P. Fr. Romualdo de $\mathrm{S}^{\text {ta }}$ Catharina natural dessa Cidade da $\mathrm{B}^{\mathrm{a}}$ professo nesta caza, nos an nos de seu coristado procedeo admiravelm ${ }^{\text {te }}$ comprido com as suas obrigaçoens principalmente no Choro, suprindo a fal ta dos cantores por ser dotado de uma voz perfeita, e bas tantem $^{\text {te }}$ instruido no cantochaõ, ordenado de sacerdote descahio em tantas desordens que lhe deraõ sentença de expulsaõ; no estado de clerigo secular naõ deixou o costume de Religiozo, em quanto ao vestido, e ao fausto $\mathrm{p}^{\mathrm{r}}$ que nunca usou de fivellas nem vestidos curiosos; $\mathrm{p}^{\mathrm{r}} \mathrm{m}^{\mathrm{s}}$ annos exerceo o emprego de cantor mor na Sé Archiepiscopal satisfazendo a sua obrigaçaõ com agrado do $\mathrm{Ill}^{\mathrm{mo}}$ Cabido. Ja no fim da vida procurou a Religiaõ, que o recebia com $\mathrm{m}^{\text {to }}$ gosto. Na vespera que ha via de tomar segunda vez o habito, lhe deo um estopor, q' o privou de todos os sentidos, recolhido d'esta sorte ao Most ${ }^{\text {ro }}$ nelle encheo os seus dias ao depois de ungido. Foi o dia do seu falecimento em 26 de septembro de 1693 sendo D. Abb o $\mathrm{M}^{\text {to }}$

69 O sexagesimo non foi o Pe. Fr. Pedro de S. Francisco natural do Reino, sendo collegial no Rio de Janeiro, por dexaçaõ que fez dos estudos foi governar uma fazenda a que administrou com zello e felicidades, passado para este Mostr ${ }^{\circ}$ onde servio $-71-$

${ }^{87}$ A leitura desse fólio foi baseada na transcrição de Silva Nigra. 
a Religiaõ, ate onde chegavaõ suas forcas. Era Religioso

perfeito, e como tal acabou a sua vida com os $\mathrm{s}^{\text {tos }} \mathrm{sa}$ cramentos, e $\mathrm{m}^{\text {tos }}$ actos de Religiaõ. Faleceo em $\underline{30}$ de Ouctubro $^{88}$ de 1694 sendo D. Abb o ${ }^{\text {to }}$ R. P. Preg ${ }^{\text {or }}$. Fr. Man el do Nascimento.

$70 \mathrm{O} /$ septuagesimo/ foi o $\mathrm{M}^{\text {to }}$ R. P. $\mathrm{M}^{\mathrm{e}}$. Jub ${ }^{\mathrm{o}}$ Fr. Jeronimo de S. Bento nascido na Cidade do Porto professo nesta casa. A capacidade d'este Religioso para a vida Mo nastica logo se fes notoria do seu Noviciado principiou bem, e acabou melhor, desempenhado com as suas theoricas virtudes, e erelevantes procedimentos tudo o que d'elle se es perava. No fim de seu Collegio lhe entregaraõ uma cadeira de Theologia no Rio de Janeiro na qual adquerio honra para a Religiaõ e credito para sua pessoa, ao depois foi nomeado $\mathrm{M}^{\mathrm{e}}$ de Philosophia no Collegio da graca, que neste tempo era granja /deste/ Mosteiro, aonde acabou de mostrar sua erudiçaõ e talen to. No pulpito foi um fiel/despensciro/ da palavra divina, procura $<\uparrow>/$ do $\backslash$ de todos nas occasioeñs de maior empenho, no confessionario fasia as partes de bom $/ \mathrm{mi} /$ nistro, para o que estava sufficientemente instrui do na siencia, doutrina, e liçoens de livros conveni entes, e necessario para cumprir e /executar/ estes $\mathrm{s}^{\text {tos }} \mathrm{e}$ nobres spiritu digo empregos. Reconhecendo os Prelados $\mathrm{a} /$ capacidade/ indubitavel que tinha para qualq ${ }^{\mathrm{r}}$

occu

${ }^{88} \mathrm{O}<\mathrm{t}>$ está grafado sem o traço horizontal. 
occupaçaõ o admitiraõ aos governos, e lugares $\mathrm{m}^{\mathrm{s}}$ auctorisa dos d'esta Religiaõ. Primeiram ${ }^{\text {te }}$ o elegeraõ D. $\mathrm{Abb}^{\mathrm{e}}$ de Per nambuco, no governo espiritual, e temporal d'este Mostr ${ }^{\circ}$ mostrou a vigilância, e cuidado, Monge $\mathrm{o} / \mathrm{m}^{\mathrm{s}} /$ observan tte, e de Prelado o $\mathrm{m}^{\mathrm{s}}$ solicito; constando-lhe que o seu Pri or em sua ausencia se descuidava da [ $\dagger$ ] sua obrigaçaõ /com/ o detrimento da observancia religiosa, /examina/ da a verdade o privou do lugar $/ \mathrm{p}^{\mathrm{r}} /$ ver que indignamente occupava, naõ obstantemente uma amisade $\mathrm{de}^{\text {to }}$ annos que havia em ambos. Naquella terra foi consultado em matérias pertecente ao governo d'aquelles estados, e o seu voto de todos foi attendido com preferencia, concluido /o/ seu trienio com grd $^{\mathrm{e}}$ credito da Religiaõ, e satisfaçaõ dos secula res, foi eleito provincial d'esta Provincia recolheo-se a este Mostr ${ }^{\circ}$

15 a tomar posse como neste tempo se costumava; foraõ as suas disposicoens em seis meses que governou bem acertadas tanto para o espiritual, como $\mathrm{p}^{\mathrm{a}}$ o temporal, porem naõ teve a Prov ${ }^{\mathrm{a}}$ /fortuna/ de experimentar as felicidades que esperava; $\mathrm{P}^{\mathrm{r}}$.q'. quan do completava meio anno de seuaplausivel governo foi acco mettido de um estupor, que o privou das siencias, e /movimento/ /dos/ braços, accudirao lhe com os remedios porém, sem effeito al gum; $\mathrm{p}^{\mathrm{r}}$ que a força da molestia vencia a todos, entendeo que que estava chegado a termo de seus dias, cuidou em se dis por para a sua conta final, recebidos os ultimo Sacramentos com muitas lagrimas, e os Monges que o vestiaõ /derrama/ raõ $\mathrm{m}^{\text {tas }} \mathrm{m}^{\mathrm{s}}$ pela falta de um Prelado que /servira/ todo o tem 
po de credito a esta Prova ${ }^{\mathrm{a}}$ Esperou com $\mathrm{m}^{\text {tos }}$ actos de

catholico /a ultima/ hora, e se /signando/ novamente do Sñr suavemente espirou aos $\underline{30}$ de Maio de $\underline{1695}$ sendo D. Abb o $\mathrm{M}^{\text {to }}$ R. P. $\mathrm{M}^{\mathrm{e}}$ Fr. José da Natividade. Foi sepultado com as honras devidas ao lugar, que exercia, com a asistencia da nobreza d'esta Cidade.

71 O septuagesimo primeiro foi o $\mathrm{M}^{\text {to }}$ R.P.Missionario Aposto lico Fr. Matias de S. Bento natural da Cidade de Braga, professo neste Most ${ }^{\text {ro }}$, abracou com tanto affecto a vida Re ligiosa, que em tudo que obrava e fasia /se/ manifes tava uma fiel correspondência, e vocaçaõ divina. Ao de pois de professo, e ordenado sacerdote, foi admirado ao Col legio de Philosophia, e neste exercicio se applicou com tanto disvello, que no fim dos estudos supposto, que naõ fisesse op posiçaõ as Cadeiras, era taõ notoria a sua capacidade que o seu $\mathrm{M}^{\mathrm{e}}$, e seus companheiros o atribuiaõ a um tal de sapego as honra da terra, mas o seu intento era buscar a $\mathrm{D}^{\mathrm{s} 89}$ por outro caminho $\mathrm{p}^{\mathrm{r}}$ que como era bom organista $\mathrm{e}$ melhor musico, quiz empregar estas prendas nos /divinos/ lou vores sabia, que o Chorô era o emprego $\mathrm{m}^{\mathrm{s}}$ nobre de um Reli gioso, este foi o que esculheo, este foi o que buscou. Foi $\mathrm{m}^{\text {to }}$ an nos $\mathrm{M}^{\mathrm{e}}$ de capella, e Cantor mor accudindo a todas as su as obrigaçoens com $\mathrm{m}^{\text {ta }}$ promptidaõ, e com $\mathrm{m}^{\text {to }}$ gosto, empe nhado-se que todas as pencoens pertencentes a seu emprego, satisfizessem com $\mathrm{m}^{\text {ta }}$ perfeiçaõ, e decencia. Passados $\mathrm{m}^{\text {tos }}$ $-74-$

\footnotetext{
${ }^{89}$ A grafia desta palavra apresenta-se de forma muito peculiar, tendo um traçado semelhante a um $<\mathrm{R}>$, antecedido de alguma outra forma não identificada. Esta grafia foi lida e transcrita originalmente como abreviatura de Deus. Por parecer coerente com o sentido da frase, mateve-se essa leitura.
} 
${ }^{90}$ annos nestes louvaveis exercicios, querendo buscar a $\mathrm{D}^{\mathrm{s}}$ por

$\left[\mathrm{f}^{\mathrm{0}} 39 \mathrm{r}^{\mathrm{0}}\right]$ $\mathrm{m}^{\text {tos }}$ caminhos, e servir ao próximo mas matérias mais interes santes ao bem das suas almas, alcançou um breve de Missi onario Apostolico, e com elle partio para o certaõ a pregar as verdades divinas com tanto espirito e aproveitamento dos seus moradores que em breve tempo teve a consolaçaõ de ver os avultados fructos do seu disvello, $\mathrm{p}^{\mathrm{a}}$ que concurria da sua patê com exemplo, com dourina, e obras, $\mathrm{p}^{\mathrm{r}}$ que no confessionário era taõ previdente, e caritativo, que naõ so de dia

10 mas tambem grande parte da noite nelle se occupava em ouvir de confissaõ ao povo, que de parte mui distante o bus cava, movido da sua prudencia, e virtude, conseguimos $\mathrm{p}^{\mathrm{r}}$ aquellas terras o nome de bom Religioso, e de bom confessor, e de bom missionario. de para instruir algumas almas no caminho da perfeiçaõ, o elegeraõ Mestre de Noviços, chegada que foi a noticia, se recolheo a toda pressa a executar os preceitos da obediencia e conhecido o pres timo para este emprego, concluidos os tres annos, voltou para as partes para continuar no seu exercicio, depois de alguns an nos chegouo a este Mostro a noticia de sua morte geralm ${ }^{\text {te }}$ sentida pelos habitantes dáquellas terras, na consideraçaõ que perdiaõ um taõ grande director das suas almas, os seus ossos foraõ tran feridos para o claustro em 23 de Ouctubro de 1695 sendo D. Abb. o $\mathrm{M}^{\text {to }} \operatorname{Rev}^{\mathrm{o}} \mathrm{P} . \mathrm{M}^{\mathrm{e}}$ Fr. José da Naividade.

$-75-$

${ }^{90}$ A leitura deste fólio foi feita com base na transcrição de Silva Nigra. 
$72 \mathrm{O} /$ septuagesimo/ segundo foi o $\mathrm{P}^{\mathrm{e}}$. Fr. Rodrigo do Espiritu santo, natural d'esta Cidade professo nesta casa. Nos an nos que o mundo costumava com $\mathrm{m}^{\mathrm{s}}$ efficacia as suas imprudentis maximas o despresou, elle buscando a Re ligiaõ Benedictina, a qual foi admetido pelas esperan cas que os seus costumes permettiaõ, e as suas prendas o /recommendavaõ/; empregou todas as forças em comprir com as suas obrigacoens, e dava signaes evidentes de felis progresso, assim como succedeo, $\mathrm{p}^{\mathrm{r}}$ que na perfeita ex ecucaõ com que se havia nos preceitos religiosos, eno cuidado com que observava os votos da profissaõ, mos trava a eficacia da sua vocaçaõ, e a firmesa do /seu/ espirito, concluidos os seus estudos, servio a este Motr $^{\circ}$ no choro no pulpito, e confessionário sem nunca /alegar disculpas/, que o /escuzassem/ deste louvaveis, e $\mathrm{s}^{\text {tos }}$ exercicios; mas como elle sabia agradar aos homens, no que era juso, e ser político sem faltar a observancia, sendo necessario a esta Provincia mandar um Re ligioso a Corte de Lex ${ }^{\mathrm{a}}$ a tratar das dependencias della, /fiseraõ eleiçaõ nelle/, e mandaraõ o confiado na sua capacidade, e entelligencia, desempenhar o conceito q' delle tinhaõ formado, dando completa expediçaõ aos ne gocios mais importantes, a que fora mandado, ultima mente $^{91}$ voltou $\mathrm{p}^{\mathrm{a}}$ este Mostr $^{\mathrm{o}}$ constituido na dignida de de D. Abb. in partibus, o que alcançou da $\mathrm{s}^{\text {ta }}$ se apostolica porém naõ sendo recebido como desejava

${ }^{91} \mathrm{O}$ traço horizontal do primeiro $<\mathrm{t}>$ não está grafado. 
se retirou a viver em huma fasenda d'esta cidade, passados

$\left[\mathrm{f}^{\mathrm{0}} 40 \mathrm{r}^{\circ}\right]$ bastantes annos, vendo-se accommettido de uma molestia grave, querendo se recolher ao Mostro ${ }^{\circ}$, naõ o podendo faser por empedimento da infirmidade, ao depois de morto foi condusido para ser sepultado entre os Religiosos como ti nha pedido, e sempre desejara. Foi o dia do seu enterro aos 23 de Novb $^{\circ}$ de 1698 sendo D. Abb o M ${ }^{\text {to }}$ R P. Fr. Theodoro da Purifaçaõ.

$<6>/ 7 \backslash 3$ O septuagesimo trerceiro foi o Padre Fr. Fernando Felis Mon ge de $\mathrm{S}$. Bernardo, natual d'esta Cidade da $\mathrm{B}^{\mathrm{a}}$ de gera çaõ illustre. Foi mandado por seus Paes para $\mathrm{Lx}^{\mathrm{a}} \mathrm{em}$ ordem de se empregar nos empregos dignos de seu Nascimento, chegando a aquella corte /tomou/ o louvavel desejo de aban donar as /honras/ do mundo, e recolher-se em uma Reli giaõ, a todas antepos a de $\mathrm{S}$. Bern ${ }^{\text {do }}$ e nella professou a vida Religiosa, pelo tempo adiente chegou a conseguir a custa do seu disvello /o nome/ de bom $\mathrm{M}^{\mathrm{e}}$ e fama de bom pregador; $\mathrm{p}^{\mathrm{r}}$ rasaõ, que se naõ /sabem/, voltou para sua patria, e recolheo-se neste Most $^{\text {to }}$ e nelle viveo alguns annos, ao depois foi assistir em huma fasenda dos seus parentes, vivendo sempre ajusatado aos votos, que professou na dita fasenda encheo os dias, e sendo condusido a este Mostr ${ }^{\circ}$ depois de morto, foi sepultado no Claustro aos 8 de mar /ço/ de $\underline{1699}$ sendo D.Abb ${ }^{\mathrm{e}}$ o R P. Fr. Theodoro da Purificaçaõ. 
/7/4 O septuagesimo quarto foi: o P.Fr. Joaõ de $\mathrm{S}^{\text {ta }}$ Maria natural d'esta Cidade professo neste Mostro ${ }^{\circ}$. No seculo era tratado com es timacaõ $\mathrm{m}^{\text {to }}$ distinta pelas prendas de que foi dotado, $\mathrm{p}^{\mathrm{r}}$ que era o Musico mais dextro daquelles tempos, no tocar, e cantar principalmente no organo. Pedio o nosso habito ao qual foi admetido com $\mathrm{m}^{\text {to }}$ gosto, e satisfacaõ dos Religiosos, naõ se pelas /suas/ prendas mas tambem pelo seu recto procedim ${ }^{\text {to }}$. Ao depois de professo se authorisou a Religiaõ $\mathrm{p}^{\mathrm{r}}$ mais annos do seu conhecido prestimo, e elle com $\mathrm{m}^{\text {to }}$ gosto servia, e ser viria até a morte, se lhe naõ fosse necessario assistir na companhia de seus Irmaõs, que $\mathrm{p}^{\mathrm{r}}$ falecimento de seus Pais ficaraõ sem outro abrigo $\mathrm{m}^{\mathrm{s}}$ do que o seu Irmaõ; em sua com panhia viveo alguns annos despendendo tudo, o que queria pelas suas ordens, em redime ${ }^{92}$ remediar as suas /indig/ gencias. Ja adiando em annos foi /accomettido/ de /u/ ma febre maligna, que dando-lhe tempo para se dispor com os ultimos sacramentos the tirou a vida nos fins do anno de 1699 sendo D. $\mathrm{Abb}^{\mathrm{e}}$ o $\mathrm{M}^{\text {to }} \mathrm{R} \mathrm{P}$. Fr. Theodoro da Purificaçaõ.

$2075 \mathrm{O}$ septuagesimo quinto foi o Pe. $\mathrm{Preg}^{\circ} \mathrm{F}$. Rafael da Trindade natural desta Cidade professo neste Mostr ${ }^{\circ}$. seus verda deiros Paes o crearaõ no temor de $\mathrm{D}^{\mathrm{s}}$ e o mandaraõ estu dar grammatica, e philosophia; aproveitou o tempo por que dos seus principios sempre evitou a /ociosid $/$ foi admettido ao $\mathrm{s}^{\text {to }}$ habito, e nelle professou a vida monas

${ }^{92}$ A palavra está sublinhada. 
tica com aceitacaõ dos Religiosos, ordenado de sacerdote teve

$\left[\mathrm{f}^{\mathrm{0}} 41 \mathrm{r}^{\circ}\right]$ o seu Collegio na Graça, donde sahio taõ aproveitado que mereceo ser ser moneado Preg ${ }^{\text {or }}$ desempenhou esta obriga çaõ com $\mathrm{m}^{\text {to }}$ credito da sua pessoa, e do seu habito; po

5 rem, como o estudo, e applicacoens dos livros eraõ /maiores/ que as suas forças veio a descahir em uma tísica, e sendo the necessario mudar de ares por concelhos do Medi cos se embarcou para a Villa de Cairú, aonde assistio alguns tempos com poucas esperancas de melhoras. Os Religiosos

10 de S. Fran ${ }^{\text {co }}$ daquella Villa pela noticia que tinhaõ da sua capacidade, lhe encommendaraõ o sermaõ do Patriarca, naõ se escusou, e subindo ao púlpito, no $\mathrm{m}^{\mathrm{mo}}$ tempo, que es tava pregando com o seu costumado espirit; lancando gol phes de sangue pela boca acabou a sua vida no $\mathrm{m}^{\mathrm{mo}}$ pul

15 pito, deixando o auditorio confuso, e sentido com este re pentino accidente, foi sepultado no $\mathrm{m}^{\mathrm{mo}}$ convento, e pas sados alguns annos foraõ os seus ossos tranferidos para o nosso clautro em $\underline{17}$ de $8 \mathrm{br}^{\circ}$ de $\underline{1699}$ sendo D.Abb o $\mathrm{M}^{\text {to }}$ R P. Preg ${ }^{\text {or }}$. Fr. Theodoro da Purificaçaõ.

2076 O septuagesimo sexto foi o Irmaõ Noviço Fr. Joaõ de S. Agosti nho natural a Braga. Pela sua humild e pelo seu prestimo me receo este Irmaõ ser aprovado em todos os votos de fazer a sua profissaõ solemne; porém já no ultimo mez seu novici ado fes profissaõ nas maos do Prelado, por occasiaõ de uma molestia grave disposto com a graça dos Sacramentos em 
$\underline{3}$ de Março de 1701 sendo D.Abb o M $^{\text {to }}$ R P. Preg ${ }^{\text {or }}$. Fr. The odoro da Purificaçaõ.

77 O septuagesimo septimo foi o P. Fr. Alcuino de Jesus, natu ral do Reino professo nesta casa; ao depois de cumprir com diligencia, e cuidado as obrigaco ens do choristado, foi ad mettido ao Collegio da Graça, e nelle $\mathrm{m}^{\mathrm{s}}$ se aplicou aos ser vicos da Religiaõ, que aos estudos; feitos os seus actos de Pre gador, como era intelligente zelloso do patrimonio da Religiaõ, o mandaraõ administrar a fasenda da Itapo am, deo provas sufficientes de sua capacidade pelo bom acerto da sua administraçaõ, e pela utilidade que resul tou ao Mostr ${ }^{\circ}$ do seu trabalho; na $^{\text {ma }}$ fasenda adoeceo gravemente, e recolhendo-se a buscar os remedios que ne cessitava, como a molestia vencia a todos que aplicavaõ, cuidou em se dispor para a sua partida com $\mathrm{m}^{\text {tos }}$ actos de contriçaõ, com a graça dos sacramentos, que recebeo com $\mathrm{m}^{\text {tas }}$ devoçoens, e amor de $\mathrm{D}^{\mathrm{s}}$. Foi o dia de sua morte em 20 de Fevr ${ }^{\mathrm{o}}$ de 1700 sendo D.Abb ${ }^{\mathrm{e}}$ o $\mathrm{M}^{\text {to }}$ R P. Preg ${ }^{\text {or }}$. Fr. Theodoro da Purificaçaõ.

$2078 \quad{ }^{93} \mathrm{O}$ septuagesimo oitavo foi o Pe. Fr. Franc ${ }^{\mathrm{o}}$ da Visita çaõ natural de canaves Bispado do Porto, e professo nesta casa. Foi Religioso modesto observante e na turalm ${ }^{\text {te }}$ humilde, rasaõ por que os Prelados depois de sacerdote, o cnservaraõ $\mathrm{m}^{\text {tos }}$ annos no officio de $-80-$

${ }^{93}$ A partir desse ponto, a leitura tem por base a transcrição de Silva Nigra. 
porteiro, recebia os hospedes com $\mathrm{m}^{\text {ta }}$ politica, e os pobres com muita carid ${ }^{\mathrm{e}}$ os quaes por $\mathrm{m}^{\text {to }}$ tempo lamentarao sua falta. Occupado neste, e outros louvaveis exercícios o elegeraõ D. Abb ${ }^{\mathrm{e}}$ da Paraíba, tomou posse para cum prir com o preceito que obrigava, e fasendo logo renuncia do lugar, voltou a esta casa a continuar no exerci cio mais humildes da Religiaõ; por q' so estes apeteci a, e desejava, naõ obstante o seu desapego aos lugares auctorisados, o fiseraõ $\mathrm{M}^{\mathrm{e}}$ de Noviço, aceitou com a con diçaõ de nunca mais se lembrassem delle para emprego algum, assim o fiseraõ deixando the todo o tempo livre para se emcommendar a $\mathrm{D}^{\mathrm{s}}$ e tratar da salvaçaõ da sua alma. Seguio os actos conventuaes em quanto teve forcas para faser, e considerandose ja visinho a morte, cuidou com todas as forças do seu espirito para a sua hora final; e sendo accomettido da ultima enfermidade, se preparou para a sua conta final, que foi dar no tribunal divino, em $\underline{18}$ de $\mathrm{Janr}^{\circ}$ de 1702. Sendo D. $\mathrm{Abb}^{\mathrm{e}}$ o M $^{\text {to }}$ R P. Preg ${ }^{\text {or }}$. Fr. Francisco das Chagas.

79 O septuagesimo nono foi o Padre Fr. Anselmo da Trinda /de/ natural do Reino professo nesta casa, a promptidaõ com que este Religioso satisfasia as suas obrigacoens e o /zelo/ com que tratava o patrimonio da Religia $\mathrm{o}=$ brigou ao Prelados desta casa a entregarem o go verno, e administraçaõ de uma fasenda que temos 
no Tapicurú; naquella parte procedeo como devia,

vivendo ajustado com a observancia do estado, que pro fessava, ao depois esta fazenda se vendeo, como estava acostumado a viver no retiro foi assistir na Capella de S. Franc ${ }^{\circ}$ na praya da Itapoam ja de idade avancada se recolheo ao Mostr $^{\circ}$ appremido de uma /molestia/ que naõ obdecendo ao remedios, o pri vou /da/ vida tendo-se disposto com as repetidas confiçoens com agraca dos sacramentos, e com $\mathrm{m}^{\text {tos }}$ actos de Catholicos $^{94}$ faleceo em $\underline{7}$ de Maio de $\underline{1702}$ sen do D.Abb ${ }^{\mathrm{e}} \mathrm{M}^{\text {to }}$ R P. Preg ${ }^{\text {or }}$. Fr. Franc ${ }^{\mathrm{o}}$ das Chagas.

80 O oitagesimo foi o M.R.P.M Fr. Christovaõ da lus natural /d'es/ ta cidade de geraçao nobre e professo neste Mostr ${ }^{\circ}$ observan do seu pai o despreso com que este Filho tratava as coisas do Mundo, observaraaõ entre si que elles o creavaõ para Religio so, naõ se enganaraõ; pois naõ esperava elle mais que a ida de para ser; buscou a Religiao Benedictina a qual o aceitou sem demora por ver os progressos que promettia costumes tao virtuosos, e annos tao diminutos desempenhou com as suas virtudes, e com o seu taõ ajustado procedimento tudo o que delle se esperava, /concluido/ seu noviciado onde mostrou a efficacia de sua /vocaçaõ,/ passados alguns annos foi admetido ao collegio de Philosophia, e Theologia don de sahio taõ aproveitado que /feitos/ os actos de passante o nomearaõ $\mathrm{M}^{\mathrm{e}}$ de Philosophia, foi exercer este emprego no Mostr ${ }^{\circ}$ de Olinda Pernambuco adquerindo creditos $\mathrm{m}^{\text {to }}$ distin

${ }^{94} \mathrm{O}$ traço horizontal do $<\mathrm{t}>$ não está grafado. 
ctos para sua pessoa, e para seu habito, neste exercicio conti nuou até receber o titulo de Magisterio. ${ }^{95}$

Certificados os prelados su periores da sua capacidade do seu prestimo, e da sua interesa o elegeraõ D. $\mathrm{Abb}^{\mathrm{e}}$ do Rio de $\mathrm{Janr}^{\mathrm{o}}$ Partio para (aquella Cidade) tomando posse da caza(...) naõ lhe faltaraõ occasioens de exerci tar a sua paciencia, porém, como o /seu animo era superior/ a todos os trabalhos, nem huma contradiçaõ ou trabalho foi capas de o perturbar a quietaçaõ do seu espirito, por que tudo sofria constante, contando que a honra de $\mathrm{D}^{\mathrm{s} 96}$ e a observancia re gular se adiantassem, pois isso era todo o seu cuidado, e unico fim aque se encaminhavaõ o seu incancavel disvello, consegui o, o que ententava, por que o Senhor defendia a sua casa, con cluido o seu trienio deixando o Mostr ${ }^{\circ}$ desempenhado, con credito e reputacaõ de sua Religiosa pessoa; passados poucos annos o elegeraõ Prov ${ }^{\text {al }}$ e neste lugar ultimo acabou de mostrar o seu zelo, e a sua Religiaõ, vizitou a provincia reformando o que lhe parecia ser necessario para o adientamento da observancia regu lar; no regresso para este Mostr $^{\circ}$ foi accometido de um estu por, que lhe deo lugar para chegar a terra; porém fasendo a barba de tal sorte lhe agravou a molestia que em poucas ho ras acabou a vida. Foi igualm ${ }^{\text {te }}$ sentida a sua morte pe los Religiosos, e seculares, pelas suas letras, e virtudes, foi o di a do seu Falecimento em $\underline{31}$ de Agosto de 1702 sendo D. Abb o $^{\text {to }}$ R. P. Preg ${ }^{\text {or }}$ Fr. Franc ${ }^{\circ}$ das Chagas.

81 O oitagesimo primeiro foi o P.Preg ${ }^{\text {or }}$ Fr. Nicolao dos Mar tires $-83-$

\footnotetext{
${ }^{95}$ Nessas primeiras linhas, a tinta está mais clara.

${ }^{96}$ A grafia desta palavra apresenta-se de forma muito peculiar, tendo um traçado semelhante a um $<\mathrm{R}>$, antecedido de alguma outra forma não identificada. Esta grafia foi lida e transcrita originalmente como abreviatura de Deus. Por parecer coerente com o sentido da frase, mateve-se essa leitura.
} 
tires natural desta Cidade da Bahia professo neste Mostr $^{\circ}$ entrou na Religiaõ de poucos annos e nella viveo $\mathrm{m}^{\text {tos }}$, cumprindo perfeitamente com as obrigacoens do seu esta ${ }^{97}$ do principam ${ }^{\text {te }}$ na /frequencia/ do Choro em quanto pode su bir as escadas. Obrigado da caridade, e do zelo que tinha da /prefeita/ observancia reprehendia o que era necessario, e avi sava o que era precioso, ninguem se queixava antes se confor mava com o que elle disia, obdiencia o que elle mandava; por que viaõ nelle os bons exemplos, procediaõ aos bons con celhos, para nenhum trabalho se negou excepto os da prelasias porque $\mathrm{p}^{\mathrm{r}}$ espaco de cicoenta annos e $\mathrm{m}^{\mathrm{s}}$ que viveo na Reli giaõ so uma vez acceitou o lugar de Prior e por outra o de companheiro, e da hi por diante todo o seu cuidado se em caminhava a dispor-se com todas as forças do seu espirito para a sua conta final, passava de oitenta annos $\mathrm{q}^{\text {do }}$ foi accomettido de uma leve enfermidade, a que bastou para lhe tirar a vida disposto com a graca dos Sacramentos foi o dia do seu falecimento em $\underline{21}$ de septembro de 1702 sendo D. Abb o $\mathrm{M}^{\text {to }}$ R.P. Fr. Franc ${ }^{\mathrm{o}}$ das Chagas.

2082 O oitagesimo segundo foi o P. Preg ${ }^{\text {or }}$ Fr. Manoel do Desterro na tural da Cidade de Arrifana de Souza, professo neste Mostro .

Ao depois de passados os annos de corista sempre trabalhando e /obe/ decendo foi admetido ao collegio de Philosophia na Prezid ${ }^{\mathrm{a}} \mathrm{da}$ Graça, e no fim delle recolhido /aeste/ Mostr ${ }^{\circ}$ o nomearaõ mor domo, e neste emprego servio alguns annos a esta caza com geral satisfaçaõ dos Religiosos, e aceitaçaõ dos Prelados e

\footnotetext{
${ }^{97} \mathrm{O}$ traço horizontal do $<\mathrm{t}>$ não está grafado.

${ }^{98} \mathrm{O}$ traço horizontal do $<\mathrm{t}>$ segue até $\mathrm{o}<\mathrm{l}>$, fazendo-o assemelhar-se a outro $<\mathrm{t}>$.
} 
e utilid ${ }^{\mathrm{e}}$ da Religiam, $\mathrm{p}^{\mathrm{r}}$ que sabia distribuir o Patrimonio com zello, Prudencia, e fidelid ${ }^{\mathrm{e}}$, mostrando-se em tudo caritativo com os pobres, com os infermos, e com os Escravos. Adoecêo de huma molestia dilatada, e retirando-se $\mathrm{p}^{\mathrm{a}}$ huma fazenda com licen ça dos Prelados, e concelho dos Medicos nella enchêo os seus dias em 6 de Maio de 1703, foi sepultado no claustro sendo D. Abb o $\mathrm{M}^{\text {to }}$ R.P. Pregador F. Franc ${ }^{\mathrm{o}}$ das Chagas.

83 O oitagesimo tercr ${ }^{\circ}$ foi o $\mathrm{P}^{\mathrm{e}}$. Fr. Sebastiaõ das Chagas natural do Reino, professo na congregaçaõ, eno estado de Leigo, ao dep $\mathrm{p}^{\mathrm{s}} \mathrm{de}$ ter servido alguns annos a Religiaõ, em alguns mostr ${ }^{\text {os }}$ enten /tou-se ordenar de Sacerdote, e como naõ podesse conseguir, o q'/ dezejava $\mathrm{p}^{\mathrm{r}}$ /meios lícitos, auzentando-se/ da Religiaõ, ordenou-se de Salto; $\mathrm{p}^{\mathrm{m}}$ /antes de exercer as ordens/, o prenderaõ, e suspenço $\mathrm{p}^{\mathrm{r}}$ huma sentença, o mandaraõ degradado $\mathrm{p}^{\mathrm{a}}$ esta $\operatorname{Prov}^{\mathrm{a}}$ com o habito pardo, e corôa fexada. No Rio de Janr ${ }^{\circ}$ o despencaraõ da Centença $\mathrm{p}^{\mathrm{a}} \mathrm{q}^{\prime}$ podesse ${ }^{99}$ uzar das suas ordens e o mandaraõ $\mathrm{p}^{\mathrm{a}}$ esta caza ${ }^{100}$ onde logo dep ${ }^{\mathrm{s}}$ da sua Chegada, sendo accomettido de huma loucura furioza em breves tempos acabou lastimozam ${ }^{\mathrm{e}}$ a vida em 28 de Janer $^{\circ}$ de 1704, sendo D. Abd ${ }^{\mathrm{e}}$ o M. R. P. Pregador Fr. Emilianno da $\mathrm{M}^{\mathrm{e}}$ de $\mathrm{D}^{\mathrm{s}}$.

/84/ O oitagesimo quarto foi o M.R.P.M ${ }^{\mathrm{e}}$. Fr.Bened ${ }^{\circ}$ de S. /Ber/ nardo, natural de Pern ${ }^{\text {co }}$; e professo ${ }^{101}$ no Mostr ${ }^{\mathrm{D}}$ de Olinda, $/$ logo/ no seu Noviciado foi este Religiozo tractado do seu Mestre com attencaõ distincta /entre os $\mathrm{m}^{\mathrm{s}} /$ condiscipulos $\mathrm{p}^{\text {la }}$ Diligencia ${ }^{102}$ e promptidaõ com q'/satisfazia/ as suas obrigações, e $\mathrm{p}^{\text {los }}$ indicios, que dava de felizes progressos ${ }^{103}$, passados, poucos $-85-$

\footnotetext{
${ }^{99}$ A palavra está grafada com o primeiro $<_{\mathrm{S}}>$ longo.

${ }^{100}$ Embaixo da palavra há um traço semelhante a uma vírgula.

${ }^{101}$ A palavra está grafada com o primeiro $<\mathrm{s}>$ longo.

${ }^{102}$ Embaixo da palavra há um traço semelhante a uma vírgula.

${ }^{103} \mathrm{O}<\mathrm{S}>$ está sendo grafado longo com freqüência.
} 
annos ao dep ${ }^{\mathrm{s}}$ de professo como era notoria a felicid $\mathrm{e}^{\mathrm{e}}$ do seu engenho foi admetido aos estudos no colegio do R. de Janro; nelles se aplicou com tanto desvello, e excedêo com tanta/vantagem/ aos outros condiscipulos, que no fim do seu $\mathrm{Col}^{\circ}$ merecêo ser promovido em huma Cadr ${ }^{\mathrm{a}}$ de Filosofia, na $\mathrm{q}^{\mathrm{l}}$ se dêo a conhecer $\mathrm{p}^{\mathrm{r}} \mathrm{M}^{\mathrm{e}}$ de bom nome, e grande fama, com a m ${ }^{\text {ma }}$ asseitaçaõ lêo Theologia, e com tanto /aproveitamento/ dos seus Discipulos, que d'ellas sahiraõ cinco mestres, que $\mathrm{p}^{\text {lo }}$ tempo adiante, acreditaraõ a sua Religiaõ, e as suas Pessoas. Ao dep ${ }^{s}$ de jubilado, se entregou aos exercicios de piedade, em q'foi exemplar, em $\mathrm{q}^{\text {tol04 }}$ teve forças $\mathrm{p}^{\mathrm{a}} \mathrm{o}$ exercer; $\mathrm{p}^{\mathrm{m}}$ como era buscado dos seus discipulos, q' sempre o respeitavaõ, como Mestre, e o attendiaõ como a /Religiozo, de $\mathrm{q}^{\mathrm{m}}$ recebiam/ bons con= selhos $\mathrm{p}^{\mathrm{r}}$ suspeitas mal fundadas, alguns (.sugeitos) inimigos da Paz o acuzaraõ, e aos seus Discipulos $\mathrm{p}^{\mathrm{r}}$ separadores da Prova; donde lhe rezultaraõ $\mathrm{m}^{\text {tos }}$ disgostos, etrabalhos, de sorte q'vendo-se privado $\mathrm{p}^{\mathrm{r}}$ huma sentença de voto, e do lugar, e condenado a pre= zaõ se refugiou em certo convento, donde recorrêo ao $\mathrm{Rm}^{\circ}$, que vendo a nullidade da /Sentença/, o restituiu) ao seu lugar, nome $=$ ando juntam $\mathrm{e}^{\mathrm{r}} / \mathrm{compr}^{\mathrm{o}} / \mathrm{de}$ visitador geral, o $\mathrm{q}^{\mathrm{l}}$ aproveitando-se dos seus concelhos reduziraõ a provincia ao seu antigo explen= dor, e regular observancia, mas ainda lhe restava mais que padecer; $\mathrm{p}^{\mathrm{r}}$ que achando-se em Pernamb ${ }^{\circ}$; o buscaraõ $2 \mathrm{~Pa}=$ dres Amaristas $\mathrm{p}^{\mathrm{a}}$ que fosse Juis, e executar de hum breve da /Sé/ Apostolica, em /ordem a recolhessem/ ao convento, donde fo= raõ despidos; $\mathrm{p}^{\mathrm{r}}$ naõ quererem viver /sugeitos/ a huns estatutos novam $^{\mathrm{e}}$ estabelecidos $\mathrm{p}^{\mathrm{r}}$ hum /Padre/ da $\mathrm{m}^{\mathrm{ma}}$ congregaçaõ parecendo a este Religiozo, que /naõ haveria/ duvida na sua execu çaõ, se lhe poz o Exm ${ }^{\circ}$ Bispo, e chegando /as/ couzas atermos $-86-$

${ }^{104} \mathrm{O}$ traço horizontal do $<\mathrm{t}>$ não está grafado. 
foi preciso $\mathrm{p}^{\mathrm{r}}$ censuras ao $\operatorname{Exm}^{\mathrm{o}}$ Bispo, e este fulminalas con

$\left[\mathrm{f}^{\circ} 45 \mathrm{r}^{\circ}\right]$ tra o Religiozo, e da mesma sorte interdicto pessoal, e ao dep $p^{\mathrm{s}}$ local e sendo sentenciado a couza a favor da Patente contraria, $q^{\text {do }}$ odito Religiozo estava/de partida/ $\mathrm{p}^{\mathrm{a}}$ Roma, /descahindo em huma lou/ cura, foi remetido $\mathrm{p}^{\mathrm{a}}$ este Mostr ${ }^{\mathrm{o}}$ aonde acabou a vida, poucos me zes ao deps que em Pernambuco falecera o seu Contrario. /Foi o dia/ da sua morte em 18 de Fevr ${ }^{\circ}$ de 1704, sendo D.Abade deste Mostr ${ }^{\circ}$. o Nosso R.P. Ex.Provincial Fr. Emiliano da Madre de Deos.

85 O oitagesimo quinto foi o P.Fr. Jeronimo de S.Ivo, natural da $\mathrm{V}^{\mathrm{a}}$ de Vianna, professo neste Mostr ${ }^{0}$ levado da sua vocaçaõ, deixou es= te Religioso o Mundo na idade de 32 annos, pedio o Santo habito; e nelle professou a vida Religioza, em breve tempo alcançou ser ordenado de Sacerdote; porem fazendo-se lhe insofrivel a frequencia do côro, e dos mais actos, e mortificações Religiozas, pedio q' oman dassem $\mathrm{p}^{\mathrm{a}}$ o Mostr ${ }^{\mathrm{o}}$ da Paraiba, aonde tivesse mais descanço e me nos trabalhos, mas como ainda o pouco lhe parecia $\mathrm{m}^{\text {to }}$, deixan= do o Convento, e largando o habito, se passou ao Reino, donde veio prezo $\mathrm{p}^{\mathrm{a}}$ esta caza, e conhecendo o seu erro, ao dep $^{\mathrm{s}}$ de satisfei tas as penitencias, reformou a sua vida, satisfazendo com $\operatorname{grd}^{\mathrm{e}}$ conçolaçaõ atodas as obrigações do seu estado, sendo o $1^{\circ}$ que se acha va no côro, e mais actos da Religiaõ, assim foi vivendo, athé que chegando a sua hora, deixou este mundo pedindo perd/aõ/a Deos, e aos homens, ao dep ${ }^{\mathrm{s}}$ de recebidos os Sacram ${ }^{\text {tos }}$ com $\mathrm{m}^{\text {tos }}$ actos de Catholico. Foi o dia da sua morte aos 28 de Março de 1704, sendo D.Abd ${ }^{\mathrm{e}}$ o M.R.P./M/ Ex/p/rovincia/l Fr. Emiliano da $\mathrm{M}^{\mathrm{e}}$ de $\mathrm{D}^{\mathrm{s}}$. 
natural desta Cidade, professo neste Mostr $^{\circ}$ Era Religiozo

prompto, e expedicto $\mathrm{p}^{\mathrm{a}}$ comprir com as suas obrigações: $\mathrm{p}^{\mathrm{r}}$ certa

cazualid $^{\text {es }}$ o meteraõ no lugar destinado $\mathrm{p}^{\mathrm{a}}$ castigar culpas, $\operatorname{do}[\uparrow \uparrow] \mathrm{de}$ otiraraõ passados trez dias, e quando ja subia $\mathrm{p}^{\text {la }}$ escada abuscar a Cella do Prellado foi acometido de hum assidente, e caindo em ter$\mathrm{ra} / \mathrm{dando} / \mathrm{com}$ a Cabeça em hum degráo de pedra, no mesmo lugar aca/b/ou a vi/d/a com grande sentim ${ }^{\text {to }}$ do Prelado, e mais $R e$ ligio/z/os, que prezenciaraõ aquelle lastimozo successo. Foi o dia da sua morte em 25 de Abril de 170/4/, sendo D.Abd ${ }^{\mathrm{e}}$ o N.M.R.P ${ }^{\mathrm{e}}$. Ex Provincial Fr. Emiliano da $\mathrm{M}^{\mathrm{e}}$ de Deos.

87 O oitogesimo septimo foi o M.R.P.Pregadador Fr. Bento da Vitori a natural de Viana, professo neste Mostr ${ }^{\circ}$ Hum dos $m^{\text {to }}$ Religio zos, que neste Mostro dezempenharaõ ao brigaçaõ, em q' os poz o estado da vida Monacal, foi este Monge; $p^{r}$ que logo dos seus prin= cipios fexou as portas aocciozid ${ }^{\mathrm{e}}$; e cuidou no adiantam $^{\text {to }}$ das virtudes; aplicando quanto podia aos meios convenientes, $\mathrm{p}^{\mathrm{a}}$ os conseguir, era naturalm ${ }^{\mathrm{e}}$ humilde, obediente, e composto em todas as suas ações satisfazendo cuidadozo as obrigações do seu estado, e sempre vi= gilante na observancia dos votos, q' profeçara. Exercêo $p^{\mathrm{r}}$ alguns annos o emprego de Sacristaõ, e nelle se discobrio a sua cabacid ${ }^{\text {e }}$; o seu zello, e a sua vigilancia. Foi admetido aos estudos, e tirou d'elles o adiantamento, q' se fez notorio, no pulpito, e Confissionario. $\mathrm{Ce} / \mathrm{r} /$ tificado a Religiaõ ${ }^{105}$ do seu merecim ${ }^{\text {to }}$ foi eleito em D.Abade deste Mostr ${ }^{\circ}$. no $2^{\circ}$ Capitulo, q' se fez nesta Provincia. Desempe $=$ nhou o seu lugar com geral acce/i/taç/ã/o dos seus subditos. Conservando o convento na sua perf/e/ita /o/bservancia, sendo o seu /ex/emplo as vozes m ${ }^{\mathrm{s}}$ eficazes, com q' o pers/u/adia. No seu /Triênio/ $-88-$

${ }^{105} \mathrm{O}<\mathrm{r}>$ inicial desta palavra está grafado de um modo diferente do apresentado anteriormente. 
se fizeraõ obras emportantes, como foraõ o portico da Igreja nova, o côro e outras mais, que se podem ver no Catalogo dos Prelados desta Caza. Concluio felizmente o seu Governo, buscou o $\mathrm{Re}=$ tiro $^{106}$ da sua Cella, e de todo entregue aos exercicios de hum perfeito Religiozo, nenhuma couza lhe importava mais do que tractar do importan/t/e negocio da sua salvacaõ.

A caridade $\mathrm{p}^{\mathrm{a}}$ com os infermos, e necessitados, era a corôa esta naõ menos a exercitava em soccorrer aos vivos, como taõ bem aos mortos, aplicando muitos sufragios pelas $\mathrm{Al}=$ mas, e tendo especial cuidado, de que nenhum Religiozo fale $=$ cido ficasse prejudicado da quelles suffragios, q' a Religiaõ costuma fazer $\mathrm{p}^{\text {los }}$ Monges defuntos, e assim nos 30 dias seguintes da sua morte, nunca dizia missa sem q' premeiro ficasse na certeza, de que a missa do trintario estava dita, ou infalivelm ${ }^{\mathrm{e}}$ se havia de dizer, este cuidado naõ tiveraõ com elle no seu trintario; $\mathrm{p}^{\mathrm{m}}$ o Céo teve; $\mathrm{p}^{\mathrm{r}}$ que esquecendo hum dia se lhe dizer a Missa, quando se advertio o discuido era já perto do meio dia, sen= tio-se ${ }^{107}$ a falta; mas esta a suprio hum Monge das Brotas, que casualm $^{\mathrm{e}}$ chegou a esta hora, occupado nestes, /eou/tros virtuozos exercicios, sentindo que se lhe augmentava huma molestia, que havia tempos padecia, cuidou em purificar a sua conci= encia com repetidas confições, e recebidos com $\mathrm{m}^{\text {tas }}$ lagrimas /os/ ultimos Sacramentos trocou avida mortal $\mathrm{p}^{\text {la }}$ eterna aos 22 de $\mathrm{Fevr}^{\mathrm{o}}$ 1704, sendo D.Abd ${ }^{\mathrm{e}}$ o N.M.R.P ${ }^{\mathrm{e}}$.Ex.Provincial Fr. Emiliano da $\mathrm{M}^{\mathrm{e}}$ de Deos.

$88 \mathrm{O}$ /oitgesimo/ oitavo foi o P. Fr. An/s/elmo da Anunciaçaõ, natural /do/ Reino, professo nesta Caza. A prudencia deste Religiozo a paz interior $-89-$

\footnotetext{
${ }^{106} \mathrm{O}<\mathrm{r}>$ inicial desta palavra está grafado de um jeito diferente, que aparece também em outras palavras.

${ }^{107} \mathrm{O}$ traço horizontal do $<\mathrm{t}>$ não está grafado.
} 
em que vivia, obom animo, com que supportava $q^{1}$ quer cazua lidade, que se offerecia, lhe alargaraõ a vida, e augmentaraõ as virtudes. Ordenado de Sacerdote o mandaraõ $\mathrm{p}^{\mathrm{r}}$ companheiro do Padre Fr. Joaõ do Espirito Santo o tomar posse das nossas terras de porto seguro, $\mathrm{p}^{\mathrm{r}}$ aquellas partes se demoraraõ alguns annos, /servindo/ de exemplo, e utilidade, aquelle povo, que $\mathrm{p}^{\mathrm{r}} \mathrm{m}^{\text {tos }}$ tempos chorava a sua falta. Recolhidos ao Mostro ${ }^{0} \mathrm{p}^{\mathrm{a}}$ que naõ estivesse acciozo o seu prestimo, o mandou o $\mathrm{Rm}^{\circ} \mathrm{p}^{\mathrm{r}}$ companheiro do $\mathrm{m}^{\mathrm{mo}}$ Fr. Joaõ do Espirito Santo a fundar hum hospicio na comarca de S. Paulo, em huma terra chamada Jundiahy, $p^{a}$ ella se par tiraõ fiados na Divina providencia, e nella acharaõ as vontades do moradores promptas $\mathrm{p}^{\mathrm{a}}$ os ajudar athé aonde chegassem as su as possibilidades, principiaraõ a obra, e chegaraõ ao Estado, de q' ain da de prezente se conserva. Adqueriraõ $\mathrm{p}^{\mathrm{a}}$ seu patremonio 10 legoas de terra, das quaes estivemos de posse 70 annos athe que anno de 1731 o Governador de S. Paulo Antonio da S ${ }^{\text {a Cardêra }}$ a destribuio a varias pessoas, fundando-se em naõ estarem confirmadas $\mathrm{p}^{\text {la }}$ Magestade. Ao dep ${ }^{\mathrm{s}}$ de trabalhar sem descanço mais de $30 \mathrm{an}^{\mathrm{s}}$ na quellas partes no serviço de Deos, e da Religiaõ, pedio licença $\mathrm{p}^{\mathrm{a}}$ se reccolher a este Mostro a buscar a Sepultura, $\mathrm{p}^{\mathrm{r}}$ que ja paçava de $80 \mathrm{a}^{\mathrm{s}}$ foi-lhe concedida, e nesta caza veio a completar 90 de idade, e mais de 70 de Religiaõ. Falecêo dezamparado da natureza, mas naõ de graça conseguida $\mathrm{p}^{\mathrm{r}}$ meios dos Sacram ${ }^{\text {tos }}$ que todos recebêo, disposto como perfeito Religiozo. Foi o dia da sua morte em $1^{\circ}$ de Agosto 1705 sendo D.Abade o N.M.R.P. Exprovincial Fr. Emiliano da Madre de Deos. 
natural do Reino, pofesso nesta caza, experimentando o pouco fructo, que no Secolo tirava do seu trabalho, e dizinganado de que só hé bem pago, quem serve a Deos buscou a Religiaõ já adiantado em annos $\mathrm{p}^{\mathrm{a}}$ nelle o servi; assim o fez; $\mathrm{p}^{\mathrm{r}}$ que trabalhou sem discan ço athé a morte. Os exercicios pertencentes ao seu estado, eraõ os premeiros, a que satisfazia naõ principiando trabalho algum, sem que premr ${ }^{\circ}$ ouvisse missa, e se encomenda/ss/e a Deos, era oficial de Pedreiro, e neste officio trabalhou, em quanto teve forças nas obras novas deste Mostr ${ }^{\circ}$. Adiantado em annos foi acomettido de huma febre maligna, que lhe tirou a vida, disposto com a gra ça dos Sacramentos, que todos recebêo com $\mathrm{m}^{\text {tos }}$ actos de Catolico. Foi o dia do seu falecim ${ }^{\text {to }}$ em 17 de Agosto de 1706, sendo D.Abade o Nosso Padre Exprovincial Fr. Emiliano da $\mathrm{M}^{\mathrm{e}}$ de Deos.

90 O Nonagesimo foi o muito R. Padre D. Abade actual Fr. Antonio da Santa, digo da Silva, natural d/e/sta Cidade de geraçaõ illustre, e professo no Mostr $^{\circ}$ de S. Marthinho de Tibaens. Foi chamado $\mathrm{p}^{\mathrm{a}}$ a corte de Lisboa, na idade de $15 \mathrm{an} / \mathrm{n} / \mathrm{os}$, $\mathrm{p}^{\mathrm{a}}$ que vivendo na Companhia de seus progenitores, conseguisse $\mathrm{p}^{\text {lo }}$ tempo adiante os impregos dignos de seu nascimento, mas como Deos o chamava $\mathrm{p}^{\mathrm{r}}$ outro caminho, disprezando todas as honras que o mundo lhe offerecia, pedio o habito de Monge, e nelle professou a vida Religi= oza, no dito Mostr ${ }^{\circ}$ de Tibaéns, ao depois de passar os annos /de/ Corista, e colegial, ordenado de Sacerdote, ofeito Pregador, foi $\mathrm{m} / \mathrm{a} / \mathrm{nda}$ do $\mathrm{p}^{\mathrm{a}}$ o Mosteiro de Lisboa, aonde se achava, quando naquella corte apareceraõ presos aquelles dous exemplares da constancia e da paciencia, Fr. Leaõ de S. Bento, e Fr. Ignacio da Porificaç/a/õ com os mais companheiros $\mathrm{p}^{\text {la }}$ causa da Provincia, como já se dice/,/ 
elle logo que vio huns Monges taõ exemplares, taõ constantes, e de tantas prendas, entrou na diligencia de se passar a esta sua Patria, e selhar-se ${ }^{108}$ nesta Provincia, conseguio o que desejava, e em= barcando-se $\mathrm{p}^{\mathrm{a}}$ este Mosteiro, nelle foi recebido com geral acceita= çaõ e contentam ${ }^{\text {to }}$ dos Monges. Era Religiozo de prendas, prudente, e observante p. ${ }^{\text {las }}$ quais se fez digno /de/ empregos autorizados, que exerceo com/cred/ito da sua pessoa, e adiantamento da observancia geral. Foi companheiro procurador da Congregaçaõ, difinidor, e ultimam ${ }^{\mathrm{e}}$ Abade desta graça, digo deste Mosteiro, o qual imprego naõ chegou a experimentar ${ }^{109}$ os acertos das suas bem acertadas dispozicoes, $\mathrm{p}^{\mathrm{r}}$ que logo nos premeiros meses do seu Governo, achando-se na fazenda de Itapoam, a dar principio a vizita, que pertendia fazer de todas ellas, foi acometido de huma molestia taõ forte, que dando-lhe tempo $\mathrm{p}^{\mathrm{a}}$ se recolher ao Mosteiro, e para se dispor com os ultimos Sacramentos, o privou da vida com grande sintimentos dos seus subditos, aos quaes tinha merecido o amor de Pai, e respeito ${ }^{110}$ de Prelado; p. $^{\text {s }}$ os governava com suavidade, brandura, e justiça. Falecêo com $\mathrm{m}^{\text {tos }}$ signaes de Pre distinado aos 25 de Novembro de 1707.

\footnotetext{
${ }^{108}$ Há um retângulo em torno da palavra, feito a tinta, com um tracejado trêmulo. Parece ter sido feito muito próximo da época em que o texto original foi escrito, pois a tinta é muito semelhante, mas não parece ser a mesma.

${ }^{109} \mathrm{O}<\mathrm{i}>$ está grafado com algo semelhante a um crochê.

${ }^{110} \mathrm{O}<\mathrm{r}>$ está grafado de um modo diferente dos anteriores; assemelha-se aqui a um $<\mathrm{Z}>$ maiúsculo.
} 
91 O nonagesimo primeiro foi o N.M.R.Pe. Ex.Provincial /Fr/.

Gaspar das Neves nascido na Cidade de Braga de Paes nobres, e professo nesta casa. He certo que todos aquelles que p/rofes/ saraõ a vida Religiosa estaõ obrigados a procurarem ser per/fei/ tos, e adiantarem-/se n/as vir ${ }^{\text {tes }}$ caminhando do bem para o milhor, este celestial dictame, pella $\mathrm{m}^{\mathrm{ce}}$ de Deos e vemos pr/atica/ do neste Mosteiro desde o seu principio; porem huns /se//deraõ/ mais a conhecer q' outros pelos lugares que occuparaõ, e pelos em/pre/ gos q' exerceraõ; o M.R.P ${ }^{\mathrm{e}}$.Fr. Gaspar das Neves, pelos lugares, q' servio, e pelos empregos q' exerceo se deo a conhecer $\mathrm{p}^{\mathrm{r}}$ hum Religi oso perfeito, observante, e deligente; tudo mostrou nas occupações q' logo de seo principio lhe encarregaraõ os /Prelados/ desta Casa, como foraõ de /porteiro/, de Subprior, e outros mais q' /todos ex/ erceo com o zelo q' se esperava da sua perfeita observancia; $p^{r}$ este motivo o elegeraõ Prezid de Sorocaba, aonde os Secu/lares/ experimentaraõ a sua Carid ${ }^{\mathrm{e}}$ e os Religiosos as suas virt ${ }^{\mathrm{es}}$. No trienio seg ${ }^{\mathrm{e}}$ sahio D. $\mathrm{Abb}^{\mathrm{e}}$ de S. Bento de Olinda e /ul/ timam ${ }^{\text {te }}$ Prov $^{\text {al }}$ nestes empregos mostrou o /desejo/ /q'/ o acom panhava do aumento espiritual e/tem/poral d/os seos súbditos/ aos quas sempre amou [个amou] como Pay e estimou c/omo Prelado./ Dispunha com hum taõ elegante methodo /as Cartas dos/ $\mathrm{R}^{\mathrm{mos}}$ $\mathrm{P}^{\text {es }}$. Geraes, q' no fim /do seu/ Provinciado foi /chamado a/ Con greg $^{\text {am }}$ para votar em /Capi/tulo, e p $\mathrm{p}^{\mathrm{a}}$ o fazere $/ \mathrm{m} /$ Geral oque naõ teve $\mathrm{ef}^{\mathrm{to}} \mathrm{p}^{\mathrm{r}}$ algumas contradições, que se offereceraõ e no= /meado/ Visitador Geral desta Prov ${ }^{\mathrm{a}}$ voltou para este Mosteiro, on/d/e passou o resto da Vida frequentando /os actos/ 
${ }^{111}$ Religiosos,/e dispondo-se $\mathrm{p}^{\mathrm{a}}$ a morte com todas as forças do seo /espi/=

$\left[\mathrm{f}^{\mathrm{0}} 48 \mathrm{v}^{\mathrm{0}}\right]$ /rito/, adoeceo de huma febre lenta q' fasendo-se despresi/vel/

/no p/rincipio se adiantou de sorte q' vencendo atodos os remedios,

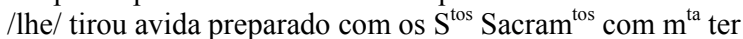
nura e devoçaõ aos 13 de Maio de 170/8./ Sendo Prezid ${ }^{\circ}$ o M.R. $/ \mathrm{Pe} /$. .Fr.Joaõ dos /A/njos.

192/ O Nonagesimo segundo foi o N.M.R.P . $^{\mathrm{e}}$ Ex Prov ${ }^{\mathrm{al}}$ Dor $/ \mathrm{Ru} /$ berto de Jesus nascido na $\mathrm{V}^{\mathrm{a}}$ de S.Antonio no Recife de Pernambuco professo neste Mostr. ${ }^{\circ}$ Seos virtuosos o crea $=$ raõ no temor de Deos, /e o/ guiaraõ pelo caminho da Vir/tu/ de; cuidando em q' vivesse separado de companhias que the podessem /corrom/per os seos bons costumes; mandaraõ -o /applicar/ ao estudo de Grammatica /sahio taõ/ perfeito La/tino/ q' os P. ${ }^{\text {es }}$. da Compa se empenharaõ em o persuadir a vistir a rou /peta/ de S. Ignacio, para este embarcou-se $\mathrm{p}^{\mathrm{a}}$ esta Cid. ${ }^{\mathrm{e}}$, porem variando de parecer veio a este $\operatorname{Mostr}^{\mathrm{o}}$ pedir o habito de Monge. Examinou o Pre/lado/ a sua sciencia, a sua vida, e os seos cos tumes e achando-o merecedor do beneficio que pedia, lhe con cedeo o que desejava. /Recolhido ao Noviciado/ logo nelle /se/ mostravaõ indicios manifestos $\mathrm{d} / \mathrm{a} / \mathrm{s}$ virtudes q' haviaõ de resplandecer na Religiaõ, era modesto, composto, e humil $\mathrm{de}, \mathrm{fu} / \mathrm{g} / \mathrm{ia}$ a ociosidade, sempre solicito, e naobservancia re gular sempre prompto.

Ao /depois/ de professo como era brando e pacifi/co/ e prudente /mandaraõ/ o servir o officio de /dispenceiro,/ $\mathrm{h} / \mathrm{u} / \mathrm{ma}$ /occasiaõ//recolhendo-se/ das onse $\mathrm{p}^{\mathrm{a}}$ /a meia noite ouvin-/ $-94-$

\footnotetext{
${ }^{111}$ A tinta da mancha escrita do recto passou integralmente para o verso comprometendo bastante a leitura.

${ }^{112}$ APFT, caneta hidrográfica verde.
} 
${ }^{113}$ do hum estrondo de açoutes em huma parte oculta e querendo examinar de mais perto quem se açoitava vendo q' o vi nhaõ buscando a passos apressados, se recolheo a cella, porem nella foi asperam ${ }^{\text {te }}$ aceitado sem saber $p^{r} q^{m}$ ficou taõ desmai ado q' so no dia sege tomou a si, depois deste successo naõ se contentando com as penitencias e mortificações q' a Religiaõ determina, accresentou outras q' sempre prati cou em $\mathrm{q}^{\text {to }}$ viveo. Ordenado de Sacerdote como era dotado de feliz memoria e agudo engenho, foi admetido ao Collegio de Philophi= a no Rio de Janeiro aonde mostrou a capacidade indubita= bel que tinha $\mathrm{p}^{\mathrm{a}}$ as Letras; no fim delle foi eletio Passante, e lhe deraõ a $\mathrm{Cadr}^{\mathrm{a}}$ de Philosophia e Theologia, resultan= do do seu trabalho tanta gloria $\mathrm{p}^{\mathrm{a}} \mathrm{o}$ seo nome $\mathrm{q}^{\text {to }}$ credito

$15 \quad \mathrm{p}^{\mathrm{a}}$ a sua Religiaõ.

Depois de concluidas as leituras recebido o graõ de Magisterio se recolheo a este Mostr $^{\circ}$ onde o exem plo que nos deixou com a sua ajustada vida, merecia ser para nos de eterna lembrança; vivia como $\mathrm{Re}=$

20 ligioso exemplar cumprindo perfeitam ${ }^{\text {te }}$ com as obrigações da sua profissaõ; e quando pellos seos annos e pelos seos privi= legios estava izento das mais penosas, entaõ he que as pra ticava com maior disvello, naõ faltando a hora alguma do couro, e nas meridianas era o que ordinariamente pre sidia. Sempre foi hum dos mais zelosos do explendor e au mento da Religiaõ, era qualificador do $\mathrm{S}^{\text {to }}$ officio e pela(...) $-95-$

${ }^{113}$ A leitura deste fólio foi baseada na transcrição feita por Silva Nigra. 
${ }^{114}$ sua diligncia fes com que nesta nossa Igreja se collocas se a Imagem de S. Pedro Martyr, e nella se lhe fizesse a sua festa. No pulpito foi hum digno Ministro da doctrina Evangelica, e $\mathrm{p}^{\mathrm{r}}$ isso dos seos Sermões sempre tirava o fructo que pertendia q' hera o aproveitam ${ }^{\text {to }}$ dos seos ouvintes sen= do os seos irreprehensiveis costumes e Rhetorica mais eloquen te com q' os movia $\mathrm{p}^{\mathrm{a}}$ onde dezejava; vendo esta Cidade in= festada com huma doença q' o Diabo poz o nome de Caya subindo ao pulpito declamou com tanto espirito e fervor q' em breves tempos se vio extinta aquella peste de en= tre as Creaturas. Para desempenho dos maiores assum ptos sempre foi procurado $\mathrm{p}^{\mathrm{a}}$ subir aos pulpitos desta Cidade; pregando em $\mathrm{S}^{\text {ta }}$ Theresa no primeiro dia da sua Igreja nova, dando-se $\mathrm{p}^{\mathrm{r}}$ offendido hum Religioso do Carmo de $\mathrm{m}^{\text {to }} \mathrm{q}$ 'ouvio exagerar as virtudes da reforma no dia $\mathrm{seg}^{\mathrm{e}}$, subindo ao pulpito intentou deslustra-lo com alguns imprudentes dicterios; mas com confusaõ sua $\mathrm{p}^{\mathrm{r}} \mathrm{q}$ ' todos conheceraõ q' aquelles ditos eraõ effeitos de inve $=$ ja q' naõ podia eclipsar (digo) de inveja de hum resplandor q' naõ podia eclipsar.

Reconhecido pella religiaõ o seo zelo as suas letras e as suas virtudes $\mathrm{p}^{\mathrm{r}}$ falecimto do M.R.P $\mathrm{P}^{\mathrm{e}}$. Fr. Ignacio da Purificaçaõ convocados s Capitulares nes te Mostr $^{\circ}$ o elegeraõ Provincial foi o terceiro eleito pella Pro= vincia. Mostrou-se neste lugar que era verdadeiro Prelado e verdadeiro Pay $\mathrm{p}^{\mathrm{r}} \mathrm{q}$ 'naõ só adiantava a

${ }^{114}$ A leitura deste fólio foi baseada na transcrição feita por Silva Nigra. 
/observancia, sendo nos actos conventuaes o primeiro se naõ/

$\left[\mathrm{f}^{\mathrm{0}} 50 \mathrm{r}^{\mathrm{0}}\right]$ que cuidava do Subditos com carid ${ }^{\mathrm{e}}$, e amor principalm ${ }^{\text {te }}$ dos infermos aos quaes visitava repetidas veses $\mathrm{p}^{\mathrm{a}}$ evitar toda a falta ou descuido q' podesse haver. Como ja era notorio o talento de que Deo/s/ o doutara $\mathrm{p}^{\mathrm{a}}$ os empregos mais $\mathrm{Au}=$ thorisados da Religiaõ, e ofructo q' colhia do acerto das suas disposições, no quarto Capitulo celebrado na Prov ${ }^{\mathrm{a}}$ no anno de 1688 o elegeraõ D.Abb ${ }^{\mathrm{e}}$ deste Mostro ${ }^{\mathrm{O}}$, foi geralm ${ }^{\mathrm{e}}$ aplaudi= da esta eleiçaõ tanto dos Seculares como dos Religiosos $\mathrm{p}^{\mathrm{r}} \mathrm{q}$ ' enchia os lugares com todas as circunstancias e /pre/= dicados de hum exelente Prelado; porem pouco tempo $/ \mathrm{lo} /=$ graraõ a consolaçaõ de renderem obediencia a hum Pre= lado taõ benemerito $\mathrm{p}^{\mathrm{r}} \mathrm{q}$ 'passados quatro meses /entre/ gou a Casa ao D.Abb eleito pela congregaçaõ, e se recolhe= o ao retiro da sua cella continuando no exercicio do /couro/ e mais actos Religiosos, como sempre fizera; mas $\mathrm{q}^{\text {do }}$ esperava ver-se devertido da sua quietaçaõ foi mandado $\mathrm{pe}=$ la Religiaõ a Corte de Lex a p/a/trocinar a /causa//dos disimos/ que se tinha declarado contra nos; fallou em audiencia ao /Sñr/. D. Pedro Segundo q' entaõ felixmente reinava, expondo-lhe com tanta eficácia as rasões que tinha es= te Mosteiro $\mathrm{p}^{\mathrm{a}}$ inplorar a sua clemencia, que ouvidas e attendidas $\mathrm{p}^{\mathrm{r}}$ aquelle piedoso Monarcha mandou passsar hum decreto contrario a Ordem do conselho, no $\mathrm{q}^{1}$ se mandava ao Procurador da Corôa Franc ${ }^{\mathrm{co}}$ Lamberto 
que confiscasse a este Mostr $^{\circ}$ todos os bens q' necessiari= os fossem para pagamento dos disimos.

Aodepois de conseguir o decreto real a nosso favor edemorar-se na quella cor $\mathrm{p}^{\mathrm{r}}$ alguns tempos /aonde/ adquerio pelas suas letras muitas estimações, e honras $\mathrm{m}^{\text {to }}$ distintas entre as pessoas de maior authoridade, recolheo-se a este Mosteiro cheio de a= plausos deixando os Monges da Congregaçaõ bem intei rados do /seos avultados/merecimentos; da congreça q' lhe determinacaõ $\mathrm{p}^{\mathrm{a}}$ a sua sustentaçaõ em Lisboa troxe dous Calices de prata dourada q' ainda existem e hum p/re/ c/ioso véo) de hombros, de que $\mathrm{p}^{\mathrm{r}} \mathrm{m}^{\mathrm{s}}$ annos se utilisou a $/ \mathrm{Sa}$ christia./ Ultimamente foi condecorado com o emprego de /Vi/= sitador Geral da Provincia, e suposto q' já se acha-se /desti/ tuido de forças $\mathrm{p}^{\mathrm{a}}$ esta Laboriosa ocupaçaõ naõ recusou o trabalho fiado na asistencia do Céo; visitou todos os /Mos/ teiros da $\operatorname{Prov}^{\mathrm{a}}$ /z/elando a honra de Deos e a observancia da $\mathrm{Re}=$ gra; /nas visitas de tal sorte ajustava o amor de/ Pay com /a severidade de/ Juiz, que /naõ/ ficando culpa sem /castigo,/ ${ }^{115}$ nem falta sem reprehensaõ ninguem castigado sem mostrava queixo o nem reprehendido escandalisado, $p^{r} q^{\prime}$ viaõ que a justica hia acompanhada com a misericordia e o castigo com a piedade. ${ }^{116}$

Concluída asua visita, e oseo gover no ficou neste Mosteiro que entre todos sempre foi $\mathrm{p}^{\mathrm{a}}$ elle /o mais desejado./ Já naõ cuidava em outra cousa $-98-$

\footnotetext{
${ }^{115}$ A partir dessa parte a leitura tese como base a transcrição de Silva Nigra.

${ }^{116}$ Deste ponto em diante volta-se a fazer o cotejo.
} 
mais do que na Morte $\mathrm{p}^{\mathrm{a}}$ a qual se dispunha com todas as

$\left[\mathrm{f}^{\mathrm{0}} 51 \mathrm{r}^{\mathrm{o}}\right]$

forças do seo espirito. Era devotissimo de N.S. da Graça

a qual visitava todos os Sabbados e disia a Missa

no seo Altar com a devoçaõ e piedade com q' sempre celebra-

va; pela estreita amisade q' tinha com D. Joaõ de Lan=

castro; alcançou algumas joias de grande preço e es

timaçaõ $\mathrm{p}^{\mathrm{a}}$ aquella soberana $\mathrm{Snr}^{\mathrm{a}}$ Tambem foi de

votissimo do N.P $P^{\mathrm{e}}$ S. Bernardo e $\mathrm{p}^{\mathrm{r}}$ sua conta corri=

a todos os annos a sua festa; adquerio $\mathrm{p}^{\mathrm{a}}$ a sua

Cappella huma alampada e galhetas de prata e

varias cortinas. Celebrava todos os dias o Santo Sacri

ficio da Missa para que gastava todo o tempo ao depois q' sahia de Matinas, em si dispor com muitos actos de piedade de Catholico e de Religio= so. Era taõ amante do silencio que mais parecia inclinaçaõ da naturesa do que desempanho da Obrigaçaõ; nem em toda sua vida se ôvio palavra que naõ fosse decente. Na sua cella naõ tinha $\mathrm{m}^{\mathrm{s}}$ do que o preciso e tudo ajustado com o voto de pobre $=$ sa. Foi Religioso que sempre amou a justiça e aborreceo a maldade. Trabalhou sempre no ser= viço de Deos e da Religiaõ, $\mathrm{p}^{\mathrm{r}}$ que desde o seo no= viciado fechou as protas a ociosidade athe a $\mathrm{m} / \mathrm{o} / \mathrm{r}$ - 
te. Chegado o tempo de receber o premio dos seos trabalhos, foi a= cometido de hum estupor que o privando de todos ${ }^{117}$ os sentidos só o deixou illeso de ouvir encheo este repen= tino accidente de confusaõ e magoa aos Religosos, pelo desengano em q' os deixou, de que era e verdugo de hu= ma vida taõ dezejada; assim passou alguns $\mathrm{di}=$ as proferindo em palavras truncadas louvores a $\mathrm{D}^{\mathrm{s}}$ e a Sua May $S^{\text {ma }}$ de sorte que quando algum Mon= ge pertendia ouvil-o principiava Deus in adjutorium meum intende, eja elle continuava Domine ad ad= juvandum me festina, e proseguia resando de N.Snr ${ }^{\mathrm{a}}$ na forma que podia. Desta sorte louvando ao Sñr. a= bou $^{118}$ a vida este perfeito Religioso e verdadeiro Mon= ge aos $9^{119}$ de Maio de 1708 sendo Prezidente desta ca=

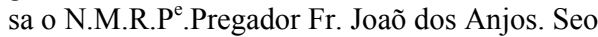
corpo foi enterrado dentro da Sacristia onde lhe deraõ decorosa sepultura.

93 O Nonagesimo terceiro foi o Irmaõ Noviço Fr. Mano el de S. Lourenço natural de Passo de Sousa Bispado de Arrifama. No oitavo mes do seo Noviciado adoeceo gra= vemente, e desenganado que estaraõ conpletos os seos dias fasendo a sua profissaõ nas maõs do Prelado e dis posto com a graça dos Sacram ${ }^{\text {tos }}$ deixou esta vida /aos/ 30 de Agosto de 1708 sendo Prezid ${ }^{\mathrm{e}}$ o M.R.P ${ }^{\mathrm{e}}$.Preg ${ }^{\text {or }}$ $-100-$

${ }^{117} \mathrm{O}$ traço horizontal do $<\mathrm{t}>$ não está grafado.

${ }^{118}$ Há um carimbo, que se estende por três linhas, com a seguinte inscrição: "ARCHIVVM ARCHICCENOBII. BRASILIENSIS BAHIAE".

${ }^{119} \mathrm{O}$ escrito está sob o carimbo. 
Fr. Joaõ dos Anjos.

$\left[\mathrm{f}^{\mathrm{0}} 52 \mathrm{r}^{\mathrm{0}}\right]$

94 O Nonagesimo quarto foi o $\mathrm{P}^{\mathrm{e}}$. Fr. Alexandre de S. Bento natural do Reino professo /no/ Mosteiro das

Brotas. Era Religioso naturalm ${ }^{\mathrm{e}}$ humilde e $\mathrm{o}=$ bediente, tratava-se /com tanto/ despreso q'/j/á parecia dejenerar de /Sinceridade. Ao depois de/ Sacer= /dote, como era de recto procedim ${ }^{\text {to }} /$ foi mandado $\mathrm{p}^{\mathrm{r}} / \mathrm{Compa} /$ nheiro de Fr. Joaõ Camuge administrador das fazendas do certaõ, a este obedecia com tanta promptidaõ como /se/ fosse seo Prelado. Todos os annos /vinha/ ao Mos= teiro conduzir as boiadas ou trazer em dinheiro o pro= ducto das ditas fazendas, e consta de Livros antigos que /houve/ anno em que trasia seiscentos mil reis. Ado= /eceo/ de huma /mali/gna, e recolhedo-se ao Convento de S. Francisco da Villa do Penedo acabou a vida com todos os Sacramentos e nelle lhe deraõ a Sepultura.

Os seos ossos foraõ /transfiridos/ $\mathrm{p}^{\mathrm{a}}$ /o nosso/ Claustro aos 22 de Septembro de 1712 sendo D. Abb ${ }^{\mathrm{e}}$ o N.M.R. $\mathrm{P}^{\mathrm{e}}$. Pregador $\mathrm{G}^{\mathrm{al}}$ Fr. Dionisio de S. José.

$2095 \quad \mathrm{O}$ Nonagesimo quinto foi o $\mathrm{P}^{\mathrm{e}}$. Pregador Fr.

Alberto da Purificaçaõ natural d'esta $\mathrm{Cid}^{\mathrm{e}}$ profes $=$ so neste Mosteiro. De seu Noviciado sahio tambem /instroido/ $\mathrm{p}^{\mathrm{a}}$ a vida Religiosa, que nenhuma mortifi $-101-$ 
$\mathrm{ca}<\mathrm{s}>/$ ç $\backslash$ aõ, $\mathrm{pe}<\mathrm{l}>/ \mathrm{n} \backslash \mathrm{alid}^{\mathrm{e}}$, ou preceito se lhe fasia difficultoso; mas antes com muito gosto, e consolaçaõ sua; cumpria a tudo, ao q' se julgava obrigado, sempre sugeitou sem repugnancia a sua vontade a dos Prelados ${ }^{120}$, e se affli$\mathrm{g} / \mathrm{i} / \mathrm{a}$ quando naõ podia satisfazer como dezejava. Teve o seu C/o/l1 $1^{\circ}$ na Graça; e recolhido a este Mostr ${ }^{\circ}$ seguia /aos/ actos de Communid ${ }^{\mathrm{e}}$, com grande exemplo dos Religiosos, pela modestia, e compustura, com q' nelles assis= tia. Era recolhido, evitando todas as praticas, e conver= $\mathrm{sa} /$ ções/, em q' naõ achava utilid $\mathrm{p}^{\mathrm{a}}$ o seu adiantam ${ }^{\text {to }}$. Passados b/as/tantes annos dentro do Mostr ${ }^{\circ}$, lhe foi ne/ce/ssario assistir em Companhia de suas Irmãs honestas, q' por falescim ${ }^{\text {to }}$ de seus Pais, se achavaõ faltas do necessa $=$ ri/o/ $\mathrm{p}^{\mathrm{a}}$ passarem a vida; alcançou /Br/eve Apostólico, para as socorrer, e acompanha-las, e assim o fez viven= do em comp ${ }^{\text {a }}$ d'ellas; com natural procedim ${ }^{\text {to }}$, sem nũ $=$ ca perder o de/choro/ devido a sua Profiçaõ; os seus passeios só se encaminhavaõ $\mathrm{p}^{\mathrm{a}}$ este Mostr $^{\mathrm{o}}$ aonde vinha dizer Missa quazi todos os dias. Chegando finalm ${ }^{\text {te }}$ o termo dos seus dias, $\mathrm{a} /$ doe/ceu de huma mali $<\mathrm{g}>$ ana, que dando-lhe tempo para se recolher ao Convento, e de Receber os ultimos Sacram $^{\text {tos }}$, o privou da vida em 22 de Agosto de 1712 s/e/ndo D. Abb ${ }^{\mathrm{e}}$ o $\mathrm{M}^{\text {to }} \mathrm{R}^{\mathrm{do}} \mathrm{P}^{\mathrm{e}}$ Pregador Jub ${ }^{\mathrm{o}}$ Fr. Dionisio de S. José.

${ }^{120} \mathrm{O}<\mathrm{l}>$ está grafado com o traço horizontal como se fosse $<\mathrm{t}>$. 
96 O Nonagesimo sexto foi o Irmaõ Corista Fr. Pedro da Nati-

$\left[\mathrm{f}^{\mathrm{0}} 53 \mathrm{r}^{\mathrm{0}}\right]$

${ }^{121}$ vidade nascido nesta Cidade professo neste Mosteiro. Poucos annos logrou este Monge o estado de Religioso q' sempre desejava, porem esse pouco, q' passou de dous annos o soube aproveitar taõ diligente e cuidadoso que naõ passou hora nem instante que naõ empregasse em algum louvavel e virtuoso exercicio conducente $\mathrm{p}^{\mathrm{a}}$ a honra de Deos e salvaçaõ da Sua Alma; de sorte que naõ faltou $\mathrm{q}^{\mathrm{m}}$ naõ se admirasse em ver virtudes taõ relevantes em annos taõ diminutos. Adoeceo de huma molestia q' se fasendo despresivel ao principio em breves dias se adiantou de sorte que logo se declarou mortal, cuidou em se dispor com a graça dos Sacram ${ }^{\text {tos }} \mathrm{p}^{\mathrm{a}}$ receber o ul timo golpe que esperou taõ resignado e contrito como se esperava de huma vida taõ pefeita. Faleceo aos 24 de Maio de 1713. Sendo D. Abb ${ }^{\mathrm{e}}$ o N.M.R.P. Preg $^{\text {or }}$ Fr. Dionisio de S. José deixando aos seus contemporanios saudosos na consideracaõ de perderem de companhia um Monge, que tanto os animara com seu exemplo a serem perfeitos, e a todos os Religiosos sentidos $\mathrm{p}^{\mathrm{r}}$ se verem pri= vados de hum Irmaõ q' prometia $\mathrm{m}^{\text {tas }}$ honras e /cre/dito.

97 O Nonagesimo septimo foi o M.R.P. ${ }^{\mathrm{e}} \cdot \mathrm{M}^{\mathrm{e}} \mathrm{D}^{\text {or }} \mathrm{Jub}^{\mathrm{o}}$ Fr. José da Natividade. Este Religioso, cuja memoria será $\mathrm{p}^{\mathrm{a}}$ nos de Saudosa lembrança, logo de seo pr/in/$-103-$

${ }^{121}$ A leitura dessas linhas foram baseadas na transcrição de Silva Nigra. 
principio procurou acreditar ao seo habito e a sua $\mathrm{Re}=$

ligiaõ, $<\mathrm{p}^{\mathrm{r}}$ todos os caminhos, alcançaõ, digo $>$ alcancou o que dezejava $\mathrm{p}^{\mathrm{r}}$ que /foi/ hum dos filhos mais benemeritos des ta Cidade. Nasceo na Cidade do Rio de Janeiro de $\mathrm{Pa}=$ ys /vir/tuosos os quaes o crearaõ e tambem o outro $\mathrm{f}^{\mathrm{o}} \mathrm{q}^{\text {' }}$ foi Monge nosso no temor de Deos e observancia dos divinos preceitos; em idade competente o mandaraõ $\mathrm{p}^{\mathrm{a}}$ os /pateos/ estudar Grammatica, e ao depois Filoso= phia onde deo a conhecer a felicidade do seo inge $=$ nho, e da sua memoria. Chegado o tempo de escolher estado pedio o habito de Monge q' lhe foi concedido pe $=$ la noticia que havia de seos costumes e sua capa $=$ cidade; foi noviço no Rio de Janr ${ }^{\circ}$, e naquelle Mostro ${ }^{\circ}$ professou com geral approvaçaõ dos Religiosos, e continuando no ex ercicios da observancia regular, o resto do tempo, que per mite a Religiaõ aos Juniores $\mathrm{p}^{\mathrm{a}}$ descanço do continuo tra balho, em se occupaõ, o empregava na liçaõ dos Livros, principalm ${ }^{\text {te }}$ de Filosofia, na qual era graduado; estu dou Theologia no $\mathrm{m}^{\mathrm{mo}}$ Mostr $^{\mathrm{o}}$, e de edificaçaõ $\mathrm{p}^{\mathrm{a}}$ os Reli giosos, e exercitava-se em $\mathrm{m}^{\text {tas }}$ obras de piedade. Soccorrren do na forma, q' podia aos necessitados, e aos enfermos. Ao depois de assistir alguns annos neste Mostr $^{\circ}$, abrio se-lhe huma pequena chaga no peito, q' $\mathrm{p}^{\text {lo }}$ tempo adiante veio a degenerar em hum monstruoso cancro; soffreo com 
$\mathrm{m}^{\text {ta }}$ passiencia este toque da maõ de $\mathrm{D}^{\mathrm{s}}$, offerecendo as in toleraveis dores, q'padecia em satisfaçaõ das suas culpas. $Q^{\text {do }}$ ja se achava neste estado, lhe chegou a noticia de q' elle era o Prov. ${ }^{\text {al }}$ recebeo-a como se naõ fora com elle, nem chegou a tomar posse, $\mathrm{p}^{\mathrm{r}} \mathrm{q}$ ' só cuidava em despor $\mathrm{p}^{\mathrm{a}}$ dar contas a $\mathrm{D}^{\mathrm{s}}$ agravou se a molestia, e recolhendo-se $/ \mathrm{p}^{\mathrm{a}} \mathrm{p}^{\mathrm{te}} /$ interior aq $\mathrm{aq}^{\mathrm{le}}$ tu mor $^{122}$ pestilt ${ }^{\mathrm{e}}$, reconheceo ser chegado ofim dos seus dias. Pedio os $\mathrm{S}^{\text {tos }}$ Sacram ${ }^{\text {tos }}$, q' recebeo com grd ${ }^{\mathrm{e}}$ ternura, e edificaçaõ /dos/ assistentes; e continuando em fervorosos actos de Amor de $\mathrm{D}^{\mathrm{s}}$ morreo com ${ }^{\text {tos }}$ signaes de predestinado aos $9 \mathrm{de}$ Abril de 1714 sendo D. Abb $^{\mathrm{e}}$ o M.R.P. . Preg $^{\text {dor }}$ Geral Fr. Di onisio de S.José. O Governador q' entaõ era Pedro de Vas concellos the veio honrar o seu cadaver com a catholica ceremonia de lhe botar agua benta com bastantes demonstraçoens de sentim ${ }^{\text {tos }}$, a $\mathrm{m}^{\text {ma }}$ ceremonia fez o Sñr. Bispo de Angola, q' se achava na terra; o Snr Arcepis bo D.Sebastiaõ Monteiro o vesitou na sua doença, e as prin cipaes pessoas da $\mathrm{Cid}^{\mathrm{e}}$; e das Religioens assistiraõ o seu feneral e olevaraõ a sepultura com as honras devidas a sua pessoa, e ao seu lugar.

2098 O Nonagesimo oictavo foi o $\mathrm{P}^{\mathrm{e}}$. Preg ${ }^{\text {dor }}$ Fr. Agostinho da $\mathrm{S}^{\text {ta }}$ Monica natural da $\mathrm{Cid}^{\mathrm{e}}$ do Porto professo no $\mathrm{Mostr}^{\circ}$ /do/ Rio. Era Religioso deligente, prompto, e cuidadoso. veio $/ \mathrm{ma} /$ ndado $\mathrm{p}^{\mathrm{a}}$ esta ${ }^{123}$ esta casa, aonde satisfez aos empregos, q' lhe encommendaraõ os Prelados, como foraõ de sachristaõ, mordomo, e outros com zello, e fideli dade. No coro era frequente, do $\mathrm{q}^{1}$ era pouco despensa

${ }^{122} \mathrm{O}$ traço horizontal do $<\mathrm{t}>$ não está grafado.

${ }^{123}$ A palavra está repetida e sublinhada. 
do $\mathrm{p}^{\mathrm{r}}$ ser bom musico e socorrido de huma vos admi ravel. Tocava varios instrumentos, e nunca se escusou de servir a Religiaõ com as prendas de que era dotado; huma tarde dispensado estava se divertindo com outro Monge no jogo das tabolas; levantando-se para hir asua cella e ja recolhido nella cahio $\mathrm{p}^{\mathrm{r}}$ terra $<\mathrm{t}>/$ flican $=$ do prevado de todos os sentidos; ajuntaraõ-se alguns Religiosos e dahi a poucos instantes rebentando-lhe hum apostema enterior ficou restituido aos seos sen= tidos; teve lugar para se confessar duas veses eao depois de ungido espirou nos braços dos assisten= tentes aos 22 de Janeiro de 1715 sendo D. $\mathrm{Abb}^{\mathrm{e}} \mathrm{o}$ M.R.P ${ }^{\mathrm{e}}$.Pg ${ }^{\text {or }}$ Fr. Antonio da Trindade Ramos.

$99 \mathrm{O}$ No $<\mathrm{g}>/$ nlagesimo $^{124}$ nono foi o $\mathrm{P}^{\mathrm{e}}$. Fr. Prudencio da As= sumpçaõ antural de $\mathrm{S}$. Joaõ de Fós professo Nesta casa. Depois de ter servido a este Mosteiro com as prendas de que era doutado, foi admetido a/o/ Collegio no Rio de janeiro, porem agradando-se mais do exercicio do couro do que da assistencia das Aulas voltou $\mathrm{p}^{\mathrm{a}}$ esta casa a c/o/ntinuar no emprego de cantor mór q' ja em outro tempo tinha exercido. Tendo já em= pregado muitos annos nestes e outros louvaveis ex= ercicios compadecido da necessidade em que /vi/viaõ hu= mas irmãs $\mathrm{p}^{\mathrm{r}}$ falecim ${ }^{\text {to }}$ de seo pai $\mathrm{q}^{1}$ as tinha man= $-106-$

${ }^{124}$ Há um $<\mathrm{x}>$ grafado na parte superior da palavra, na entrelinha. (APFT, com caneta hidrocor preta) 
mandado vir para esta Cidade deixando a Companhi= a dos Monges foi viver em companhia della em or= $\mathrm{dem}$ a socorrelas pelas esmolas adqueridas pellas $\mathrm{su}=$ as ordens; asssim viveo alguns annos sem nota de seo procedimento athé que sendo accometido de huma molestia grave acabou a vida naõ tendo os Religios noticia da molestia senaõ depois de morto. Veio $\mathrm{p}^{\mathrm{a}}$ este Mosteiro $\mathrm{p}^{\mathrm{a}}$ ser /dado/ a sepul tura /aos/ 19 de Maio /de/ 1715 sendo D.Abb o M.R. $\mathrm{P}^{\mathrm{e}}$.Preg ${ }^{\text {or }}$ Fr. Amtonio da Trind ${ }^{\mathrm{e}}$ Ramos.

100 O Centesimo foi o M.R.P ${ }^{\mathrm{e}}$ D.Abb ${ }^{\mathrm{e}}$ actual deste Mos teiro Fr. Antonio da Trindade Ramos natural desta Cidade da Bahia professo nesta casa. Logo de seo Novi= ciado se fes merecedor de huma attençaõ $\mathrm{m}^{\text {to }}$ destinta dos seos Mestres edos seos Prelados por verem a prom= tidaõ com que satisfazia as suas obrigações, e a hu= mildade com que obdecia aos seos preceitos. Estudou Philosophia e Theologia no Collegio da Graça e fei= tos os actos de Preg ${ }^{\text {or }}$ voltou para esta casa a qual servio no coro, pulpito, e/co/nficionario com satis façaõ de sua Pessoa e credito de seo habito. Tambem servio de Mordomo com fidelidade, e zelo, e supos= 
to experimentasse alguns disgostos que lhe deraõ com o pretexto de produlario, a retidaõ e ajuste de suas contas mostrou a verdade; $p^{r}$ que naõ se $a=$ chou gasto que naõ fosse em beneficio dos Religi= osos, dos pobres, e dos infermos.

Attendida a sua capacidade o elegeraõ em D.

$\mathrm{Abb}^{\mathrm{e}}$ deste Mosteiro, neste emprego mostrou o $\mathrm{q}^{\text {to }}$ desejava /o/ adiantamento espiritual e temporal do Mostei/ro/ e dos subditos a/os/ quas ama/v/a como Pai e estimava como Prelado. Era caritativo para com os pobres e os infermos zelava com $/ \mathrm{gr} / \mathrm{ande}$ cuidado o patrimonio do Mosteiro emuito mais a observancia regular; naõ chegou porem a Religiaõ a utilisar-se d/o/ acerto de todas as suas dis posições $\mathrm{p}^{\mathrm{r}}$ que acabou a vida antes de acabar o tri enio: achava-se com dous annos de governo quando adoecendo de huma febre maligna, dentro em trez dias foi desenganado que estava no ultimo de sua vi= da; recebeo o aviso com grande comformidade, man= dou chamar os Religi/o/sos e entregando ao seo Pri= or pedio os santos Sacram ${ }^{\text {tos }}$ os quaes recebidos com muita piedade e devoçaõ passadas poucas horas 
${ }^{125}$ pagou o tributo de nascido aos 4 de Septembro de 1716 em que contava 68 annos de id e 45 de habito. Foi se= pultado no cruseiro da Igreja com as honras devidas ao lugar que occupava.

101 O Centesimo primeiro foi o Pe. Fr. Joaõ de S. Bento Camu= ge Hamburguez de Naçaõ professo neste Mostr ${ }^{\circ}$. Este $\mathrm{Re}=$ ligioso, que foi hum grande bemfeitor desta casa mor= reo sendo administrador da fasenda da Ilha grande no Rio de S. Francisco, foi enterrado no convento dos Fran= ciscanos da $\mathrm{V}^{\mathrm{a}}$ do Penedo. Ao depois de Sacerdote $\langle\uparrow>$ $<\dagger>$ governou aquella fazenda, nella assistio muitos annos com grande utilidade deste Mostr $^{\circ}$ ao qual socorria e ajudava com grandes remessas de mantimentos duas vezes no anno alem das boyadas que mandava todos os annos ou producto dellas, e hou= ve occasiaõ que mandou seis centos mil $\mathrm{r}^{\mathrm{s}}$ com consta de livros antigos. Era Religioso Authorisado e naquellas partes adquerio honra e estimaçaõ das pessoas princi= paes da terra e de todos sempre foi tratado com respei= to. Faleço com id ${ }^{\mathrm{e}}$ avançada trabalhando $\mathrm{p}^{\mathrm{a}} \mathrm{D}^{\mathrm{s}}$ e para nos.

102 O centesimo segundo foi o Pe. Fr. Francisco da Concei= çaõ natural de Lessa de Matusinhos. Foi Monge de vir= tude conhecida e de vida exemplar. Morreo com $\mathrm{m}^{\mathrm{s}}$ de 80 annos de Religiaõ e sempre dentro de Mosteiro exce= $-109-$

${ }^{125}$ A leitura deste fólio baseada na transcrição de Silva Nigra. 
ptuando treze annos q' foi $\mathrm{Abb}^{\mathrm{e}}$ de S.Paulo donde /tornando/

a /voltar $\mathrm{p}^{\mathrm{a}}$ esta casa escusou-se/ athé a morti de $\mathrm{q}^{1} \mathrm{q}^{\mathrm{r}} \mathrm{em}$

prego, que o podesse devertir da /fre/quencia do Chôro ao [个qual] nunca

faltou em quanto poude subir as escadas; observou com

toda cautella os votos da sua profissaõ comprindo /com di/

/ligencia/ todas as obrigações pertencentes ao $/ \mathrm{seo} / \mathrm{est} / \mathrm{a} / \mathrm{do}$; pas=

sados mais de 60 annos em louvaveis exercicios quando já

caminhava $\mathrm{p}^{\mathrm{a}}$ os 90 de idade desamparado da naturesa

e fortalecido com a gr/a/ça dos Sacramentos suavem ${ }^{\text {te }} /$ espi/

rou em 9 de Novembro de 1717 sendo D.Abb ${ }^{\mathrm{e}}$ o M.R.P.

$/ \mathrm{M}^{\mathrm{e}}$. Fr. Mauro da Incarnaçaõ.

103 O Centesimo terceiro foi o $\mathrm{P}^{\mathrm{e}}$. Preg ${ }^{\text {or }}$ Fr. Miguel de $/ \mathrm{S}$. Escolas/= tica natural d'esta Cidade da Bahia filho de Pais abundan tes e honestos. Pass/a/dos os annos de Corista cump/r/indo com as suas obrigações athé onde chegava a sua possibilidade foi /adme/tido ao Collegio neste Mosteiro onde professa/r/a. Feitos os actos de Pregador foi mandado para o Mos/teiro/ da Graça, onde foi Prior, e mordomo zeloso, e v/ig/i/la/nte; $\mathrm{p}^{\mathrm{r}}$ falecimento de seu Pay alcançou breve Apostolico $\mathrm{p}^{\mathrm{a}}$ viver em Comp ${ }^{a}$ de sua May e tratar das dependensias de $\mathbf{s u}=$ a casa; nella viveo alguns annos sem nota de seo pr/oce/ dimento, mas antes sempre ajustado com os votos da sua profissaõ. Adoeceo gravem ${ }^{\text {te }}$ buscou o Mostro como Religi oso, que era, e recebidos os ultimos Sacram $^{\text {tos }} /$ encheo os seos/ di $-110-$

\footnotetext{
${ }^{126}$ Foi inserida na margem esquerda a numeração referente ao monge (103), com caneta hidrocor verde. (APFT)
} 
${ }^{127}$ as em 21 de Agosto de 1718 sendo D. Abb ${ }^{\text {e o M.R.Pe.M }}{ }^{\mathrm{e}}$. Fr. Mauro da Encarnaçaõ.

104 O Centesimo quarto foi o Irmaõ Corista Fr. Balthasar de Sta Gertrudes natural desta Cidade professo nesta casa. Esos Pays eraõ abundantes dos bens da terra e tementes a Deos o levaraõ do seo principio pelo caminho das virtudes; e chegado o tempo de tomar estado, sabendo que este seo $\mathrm{f}^{\mathrm{o}}$ só apetecia o estado de Monge, concorreraõ com grande gosto para satisfaserem o seo louvavel dezejo; conseguio o que desejava, vestindo o nosso habito com grande consolaçaõ sua; ao depois de professo mostrou a eficacia de sua vocaçaõ pela promptidaõ e deligencia com que satisfasia as obrigações de Religioso.

Naõ se aproveitou a Religiaõ, $\mathrm{p}^{\mathrm{r}} \mathrm{m}^{\text {to }}$ tempo do seo prestimo, $p^{r}$ q' acabou a vida quando principiava a mostrar os effeitos da sua capacidade. Seos Pays doaraõ a este Mosteiro as terras da Piedade, e o jogo chamado de Antas e todas as benfeitorias das terras. Faleceo preparado com a graça dos Sacram $^{\text {tos }}$ aos 19 de Dezbr ${ }^{\circ}$ de 1718 sendo D.Abb ${ }^{\text {e }}$ M.

20 R.Pe.Fr. Mauro da Encarnaçaõ. ${ }^{12}$

105 Ocentesimo quinto foi o Pe. D. Rozendo de Souza nascido em Lex $^{\mathrm{a}}$ irmaõ do Exm $^{\circ}$ Márquez das Minas professo $\langle\nmid\rangle$ no Mostr ${ }^{\circ}$ de Tibães. Teve bons principios na Religiaõ athe conseguir o estado de Sacerdote, dahi $\mathrm{p}^{\mathrm{r}}$ deante descahindo pouco a pouco da observancia regular chegou a termos q' foi sentenciado a despirem-lhe o $-111-$

\footnotetext{
${ }^{127}$ A leitura deste fólio foi feita com base na transcrição de Silva Nigra.

${ }^{128}$ Foi inserida próxima à margem esquerda a numeração referente ao monge (105), com caneta hidrocor verde. (APFT)
} 
habito, e como aquella illustrissima casa sempre foi /aman/=

te da Religiaõ Benedictina $\mathrm{p}^{\mathrm{a}}$ lhe naõ /causarem/ hum taõ grande desgosto em sua pres/ença o mandaraõ/ para esta ca sa para nella se excutar a sentença; porem chegando es= ta not/ici/a ao g/o/vernador destes estados $\mathrm{An}^{\text {to }}$ Luiz da /Cama/ ra /C/oitinho primo de tal Religioso, alcançou dos Prelados que manda/ssem/ fazer esta deligencia em algum Mos teiro mais remoto $\mathrm{p}^{\mathrm{a}}$ naõ padecer esta injuria; foi /remetido/ $\mathrm{p}^{\mathrm{a}}$ S.Paulo e lá se fez a execuçaõ. Redusido já ao estado de Sacer= dote Secular veio $\mathrm{p}^{\mathrm{a}}$ a V/i/lla de Santos, onde escapando de hum /tiro/ $\mathrm{p}^{\mathrm{r}}$ ocasiaõ de jogo se $\mathrm{r} / \mathrm{e} /$ tirou $\mathrm{p}^{\mathrm{a}}$ esta cid $\mathrm{cid}^{\mathrm{e}}$ da $\mathrm{B}^{\mathrm{a}}$ nella $[\dagger]$ muitos [ $\dagger$ ] exercitandosse na obra de Piedade $\mathrm{p}^{\mathrm{a}}$ com

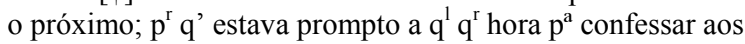
$\mathrm{m} /$ orib/undos animando-os com $\mathrm{m}^{\text {ta }} / \mathrm{pru}$ )dencia a /deixa/ rem resignados este valle de miserias. Ao $/ \mathrm{mei} / \mathrm{o}$ dia vin/ha/ /do/ Mostro /procurar/ a ra/ça/õ q' lhe /deraõ/ p $^{\mathrm{r}}$ esmola. Já adi $/ \mathrm{na} / \mathrm{tad} / \mathrm{o} / \mathrm{em}$ annos achando-se mortalm ${ }^{\mathrm{e}}$ infermo, $/ \mathrm{reco} /=$ lhe/o-se/ ao Mosteiro e ao depois de se ter confessa/do/ com $\mathrm{m}^{\text {tas }} / \mathrm{lag} /$ rimas, e recebidos os mais Sacram ${ }^{\text {tos }}$ como Chatholico poz fim a sua perig/ri/naçaõ aos 18 de Agosto de 17 /19/ sendo D.Abb o M.R.P. .Preg $^{\text {or }}$ Fr. Mauro da /Encarna/ caõ.

/106/ O Centesimo sexto foi o $\mathrm{P}^{\mathrm{e}}$. Preg ${ }^{\text {or }}$ Fr. Innoce/ncio/ de $\mathrm{S}^{\text {ta }}$ Joana natural desta Cidade professo nesta Casa. Era Mon ge bem /consertado/ nas suas acções e costumes; /ao/ depois de /professo exerceo/ o officio de infermeiro $\mathrm{p}^{\mathrm{r}}$ bast ${ }^{\mathrm{es}}$ annos 
com muita carid/a/de e passiensia, onde lhe naõ faltaraõ occasiões de /mere/cer das quaes se aproveitava trabalhando e servindo /a/ toda hora e em todo tempo; Ao depois de Sa/cer/dote teve o seo Coll ${ }^{\circ}$ na Graça e no fim delle foi a Portu= gal a certas ${ }^{129}$ dependencias; na Congreg ${ }^{\text {am }}$ servio a sua assis= tencia de edificaçaõ aos Monges aos quaes deixou saudosos na sua retirada. Foi Presid ${ }^{\mathrm{e}}$ da Graça e recolhido a este Mosteiro seguia o coro e actos de communidade sem que al= gumas molestias que padecia lhe servissem de escusa para se izentar delles. Adoeceo de huma mali $<\mathrm{g}>$ na taõ for $=$ te q' vencendo a todos os remedios q' se lhe applicaraõ aca= bou avida com todos os Sacramentos aos 13 de Outubro de 1719 sendo D. $\mathrm{Abb}^{\mathrm{e}}$ o M.R.P ${ }^{\mathrm{e}}$.M $\mathrm{M}^{\mathrm{e}}$.Fr.Mauro da Encar= nacaõ.

15 /107/ O Centesimo septimo foi o $\mathrm{P}^{\mathrm{e}}$. Fr. Pantaleaõ de /S./ Bento natural da Cidade do Porto professo no Rio de Janeiro. Ao depois de terservido aquelle Mosteiro com as prendas de que era doutado como eraõ ser bom $/ \mathrm{mu} /$ sico o tocar varios instrum ${ }^{\text {tos }}$ com destresa, veio muda do $\mathrm{p}^{\mathrm{a}}$ esta Casa, na $\mathrm{q}^{1}$ continuou o mesmo exercício $\mathrm{p}^{\mathrm{r}}$ bastantes annos; pedindo licença $\mathrm{p}^{\mathrm{a}}$ ir a Villa de Jagoaripe lá o acometeo a morte e foi sepultado na $\mathrm{m}^{\mathrm{ma}}$ Freguesia sendo D.Abb o M.R.P ${ }^{\mathrm{e}}$.M M $^{\mathrm{e}}$.Fr.Mauro da Encar ${ }^{\text {cam }}$. $-113-$

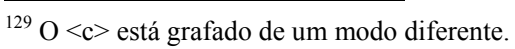


108 O Centesimo oitavo foi o $\mathrm{P}^{\mathrm{e}}$.Fr. Paulo da $\mathrm{Con}^{\text {cam }}$ natu

ral da Cidade do Porto professo no Rio de Janeiro. Ao depois de ter o seo noviciado naquelle Mostr $^{\circ}$ e taõ bem /oseo/ Coristado teve o seo $\mathrm{Coll}^{\circ}$ na Graça, no fim delle pelo seo zelo e capacid ${ }^{\mathrm{e}}$ foi mandado administrar a nossa fazenda do Rio de S.Fran cisco; poucos annos assistio naquellas partes, $\mathrm{p}^{\mathrm{r}} \mathrm{q}$ ' $\mathrm{ado}=$ ecendo de huma mali $<\mathrm{g}>$ na em breves dias acabou a /vida/ sendo D.Abb ${ }^{\mathrm{e}}$ o M.R.P. ${ }^{\mathrm{e}}$. $\mathrm{M}^{\mathrm{e}}$ Fr. Mauro da Encarnaçaõ.

109 O Centesimo nono foi o $\mathrm{P}^{\mathrm{e}}$. Fr. Leandro natural da Cidade do Rio de Janr ${ }^{\circ}$ professo nesta casa. Neste lugar se fas memoria deste Religioso q' se naõ sabe com certesa o tempo em q' elle morreo; ainda que parece seria em na= nos antecedentes; foi administrador da nossa fazenda de Mataquerŷ onde assitio $\mathrm{p}^{\mathrm{r}}$ alguns annos sem nota do seo procedim ${ }^{\text {to }}$, e com aceitaçaõ dos Seculares $\mathrm{p}^{\mathrm{r}}$ que ato $=$ dos servia com oseo prestimo e seo trabalho: porem um delles mais ingrato, q' valeroso em huma quarta $\mathrm{fr}^{\mathrm{a}}$ de cinza the deo hum tiro caminhando $\mathrm{p}^{\mathrm{a}}$ a $\mathrm{V}^{\mathrm{a}}$ de $\mathrm{S}$. Franc $^{\mathrm{co}}$ de q' veio a morrer; foi enterrado no Convento dos Religiosos Franciscanos que lhe fiseraõ as exequias com toda honra compadecidas de taõ lastimozo cazo. Debaixo d'este $\mathrm{m}^{\mathrm{mo}}$ numero de fas memoria do $\mathrm{P}^{\mathrm{e}}$. Fr. Belchior da Trindade falecido no $\mathrm{m}^{\mathrm{mo}}$ certaõ do qual $-114-$ 
naõ ficou outra not ${ }^{\mathrm{a}}$ mais do que oseo nome.

$\left[\mathrm{f}^{\mathrm{0}} 59 \mathrm{r}^{\mathrm{0}}\right]$

110 O Cente/s/imo decimo foi o M.R.P ${ }^{\mathrm{e}}$.D. Abb $^{\mathrm{e}}$ actual deste $\operatorname{Mostr}^{\circ}$ o $\mathrm{P}^{\mathrm{e}}$. $\mathrm{M}^{\mathrm{e}}$. Fr. Mauro da Encarnaçaõ natural des= ta cid $^{\mathrm{e}}$ professo nesta casa. Com geral aprovaçaõ dos $\mathrm{Mo} / \mathrm{n} / \mathrm{ges}$ professou a vida Religiosa pelos felises progres= /sos/ que prometia a sua capacidade, e os seos bons, costu= $/ \mathrm{m} /$ es. Ordemnado de Sacerdote foi mandado para o Coll ${ }^{\circ}$ do Rio de Janr ${ }^{\circ}$ e nelle se applicou com tanto disvello aos /exe/rcicios literarios ${ }^{130}$, que no fim/dos/ estudos mereceo ser eleito passante, ena Theologia seg ${ }^{\text {te }}$ provido na $\mathrm{Cadr}^{\mathrm{a}} \mathrm{de}$ Vesporas nesta sciencia a maior de todas continuou athé jubil/a/r-se com boa reputaçaõ da sua pessoa, e credito do seo habito. Ao depois como era doutado de pren= das pelas quaes se fasia respeitado tendo jubilado-se hum dos $\mathrm{Abb}^{\text {es }}$ daquelle Mosteiro interessado no adian= tamento da observancia regular lhe rogou quizesse ser Prior; naõ recusou, e conseguio o D. Abb $\mathrm{p}^{\mathrm{r}}$ este meio fa= zer hum trienio applausivel como elle ao depois $\mathrm{m}^{\text {tas }}$ veses o/di/sia. Naõ foi necessaria outra prova da sua capacidade $\mathrm{p}^{\mathrm{a}}$ ser eleito em $\mathrm{D} \cdot \mathrm{Abb}^{\mathrm{e}}$ desta casa no trieni= o seg ${ }^{\mathrm{e}}$, ouvio a not ${ }^{\mathrm{a}}$ com desagrado, $\mathrm{p}^{\mathrm{r}} \mathrm{q}^{\prime}$ pela sua humil= dade se julgava sem os requesitos necessarios $\mathrm{p}^{\mathrm{a}}$ as Prela $=$ sias; deixou aquelle Mostr ${ }^{\circ}$ onde assistio mais de trin $-115-$

\footnotetext{
${ }^{130} \mathrm{O}$ traço horizontal do $<\mathrm{t}>$ se estende sobre $\mathrm{o}<\mathrm{l}>$, fazendo-o assemelhar-se a este.
} 
trinta annos e aos Monges saudos/os/ de perderem a comp ${ }^{\mathrm{a}}$ de hum Monge que nunca soube offendel-os.

Chegado a esta casa tomou posse do seo governo com grande satisfaçaõ dos Religiosos pelas no ticias q' tinhaõ de suas prendas, continuou o seo /trie/ nio com admiraveis disposições encaminhadas /ao au/ mento espiritual e temporal do Mostr ${ }^{\circ}$. No engenho /de/ S.Caetano mostrou oseo zelo no $\mathrm{m}^{\text {to }} \mathrm{q}$ ' trabalhou $\mathrm{p}^{\mathrm{a}} \mathrm{a}$ sua fundaçaõ; $\mathrm{p}^{\mathrm{a}} \mathrm{co} / \mathrm{m} /$ os súbditos era prud $\mathrm{e}^{\mathrm{e}} \mathrm{e}$ caritativo, sentido de ver algum pouco consolado e satisfeito, naõ faltou com tudo hum subdito indigno de taõ bom Prelado que fasendo-se-lhe insofrivel o zelo da observancia regular, lhe deo alguns desgostos, desauthorisando com palavras in= jur/iosas/ aquelle a $\mathrm{q}^{\mathrm{m}}$ devia respeitar pelas suas virt ${ }^{\mathrm{es}}$ letras, e lugar. Porem no mesmo tempo q' este zeloso Pre= lado empregava todas as forças $\mathrm{p}^{\mathrm{a}}$ satisfase $<\mathrm{r}>$ as obrigacões do lugar q' occupava, adoeceo de huma molestia que já pa= decia /porem/ agora elle a conheceo $\mathrm{p}^{\mathrm{r}}$ mortal pela força com que lhe repetio e entrando em hum desengano das cousas temporaes só cuidava em se dispor para asua conta fi nal; entregou o governo ao seo Prior, pedio os Santos Sa cramentos, os quaes recebidos com $\mathrm{m}^{\text {tas }}$ lagrimas dos $\mathrm{Re}=$ ligiosos q' assistiaõ, encheo os seos dias aos 18 de Fevereiro de $-116-$ 
1720. Ao seo funeral assistiraõ os Prelados das Religiões

$\left[\mathrm{f}^{\circ} 60 \mathrm{r}^{\circ}\right]$ pelos /quaes foi/ dado a /se/pultura dentro da Sacristia.

111 O Centesimo undecimo foi o $\mathrm{P}^{\mathrm{e}}$. Preg ${ }^{\text {or }}$ Fr. Joaõ do Sacram ${ }^{\text {to }}$ natural da $\mathrm{Cid}^{\mathrm{e}}$ do porto professo neste Mostro ${ }^{\circ}$. Foi admetido ao $\mathrm{S}^{\text {to }} /$ habito/ pelas prendas de que era doutado $\mathrm{p}^{\mathrm{r}} \mathrm{q}^{\text {' era hum }}$ /dos//m/elhores mu/s/icos, e organistas /daquelle/ tempo, pó rem as virtudes q' elle exercitou o fiseraõ mais estima= /vel nos/ olhos de $\mathrm{D}^{\mathrm{s}}$ e dos homens; observava com toda a cau/tela/ os votos da sua /profiss/aõ; a sua assistencia no/c/oro foi continua, e/vigilante/ em satisfaser as /suas/o/br/igações. Deixou /admiraveis/ exempos da sua hu= mildade e passiencia; achando /em/ certo Mostr ${ }^{\circ}$ das $\operatorname{Prov}^{\mathrm{a}}$ já depois de Preg ${ }^{\text {or }} \mathrm{p}^{\mathrm{r}}$ ocasiaõ /hum/ leve dito, hum Monge dando-se $\mathrm{p}^{\mathrm{r}}$ offendido, mais att/rev/ido q' animoso deo-lhe hu= ma $\mathrm{gr}^{\mathrm{de}} /$ bofet/ada, e cuidando os q' assitiaõ q' elle tomasse huma grande vingança daquella injuriosa acçaõ naõ só per/du/rou, porem tambem interpôs oseo respeito para que o Monge naõ fosse castigado. Por falecim ${ }^{\text {to }}$ de hum seo /Irmaõ lhe/ adveio huma gr ${ }^{\text {de }}$ herança da qual deo hu= ma grandiosa esmolla a Sacristia e oresto dividio em= tre os pobres, re/ser/vando $\mathrm{p}^{\mathrm{a}}$ si huma avultada terça esta= belecida em humas casas q' $\mathrm{p}^{\mathrm{r}}$ sua morte ficaraõ $\mathrm{p}^{\mathrm{a}} / \mathrm{o} /$ Mostr ${ }^{\circ}$. Foi nove annos $\mathrm{M}^{\mathrm{e}}$ de Noviços e merecia que fosse toda avida pela boa educaçaõ e exemplo q' lhe dava. Adoeceo de huma molestia desconhecida $\mathrm{p}^{\mathrm{a}}$ se lhe appli= carem os remedios competentes, porem conhecida $\mathrm{p}^{\mathrm{a}}$ elle 
deo ordem a procurar os remedios de sua alma. Faleceo aos 2 de Abril de 1720 com todos os Sacram ${ }^{\text {tos }}$ sendo D. Abb $^{\text {e }}$ o M.R.P. Preg $^{\text {or }}$ Fr. August ${ }^{\mathrm{o}}$ da Encarnaçaõ.

112 O Centesimo duo decimo foi o $\mathrm{P}^{\mathrm{e}}$.Fr. Manoel de JE SUS Ma q' ao depois mudou em Fr. /Feliciano//de S./ Miguel $/ \mathrm{na} / \mathrm{tu} / \mathrm{ral} /$ das visinhanças da $\mathrm{Cid}^{\mathrm{e}}$ do Porto pro= fesso nesta Casa. Servio a Religiaõ athe onde chegavaõ as suas forças, e desejava que fossem maiores para /mais a ser/ vir. Teve o /s/eo Coll ${ }^{\circ}$ na Graça e no fim delle reco/lhido//nes/ te Mosteiro exerceo o emprego de Sacristaõ mór $\mathrm{p}^{\mathrm{r}}$ algũ tempo com geral acei/t/açaõ dos Prelados e Religi/os/os. Foi Prezid $^{\mathrm{e}}$ do Mostr $^{\circ}$ da Graça, e voltando para esta casa escusando-se dos lugares authorisados da Religiaõ só cui $=$ dava no emport ${ }^{\mathrm{e}}$ negocio de salvar a sua alma, freqüen= tou os actos conventuaes com $\mathrm{m}^{\text {ta }}$ prom/pti/daõ athe ficar impedido $\mathrm{p}^{\mathrm{r}}$ huma molestia grave de duas chagas incuraveis, q' lhe deraõ $\mathrm{m}^{\text {to }} \mathrm{q}$ ' padecer, e merecer. Faleceo com a graça dos Sacram ${ }^{\text {tos }}$ em 26 de Janr $^{\circ}$ de 1721 sem= do D.Abb ${ }^{\mathrm{e}}$ o M.R.P. .Ex.Prov $^{\mathrm{al}}$ Fr. José de S. /Jeronimo./

20113 O Centesimo decimo terceiro foi o $\mathrm{P}^{\mathrm{e}}$. Fr. Ant ${ }^{\circ}$ de $\mathrm{S}$. Bento natural de S.Paio Dantas Arci/b/ispado de Braga. Era destituido de forcas naturaes porem dotado de hum espirito capas de empreender cousas grandes nos annos /an/ tecedentes ao seo $\mathrm{Coll}^{\circ}$ satisfasia assuas obrigações com prom ptidaõ e diligencia, naõ admitindo nem ainda aquelle breve descanço q' permite a Religiaõ aos Juniores $\mathrm{p}^{\mathrm{a}}$ ali $-118-$ 
vio do seo continu/o/ trabalho. Estudou Philosophia, e

Theologia no Rio de Janr ${ }^{\circ}$ com tanta applicaçaõ q' no fim do $\mathrm{Coll}^{\circ}$ fasendo a sua oposiçaõ mereceo ser provido /em/ huma Cadr ${ }^{\mathrm{a}}$ de Philosophia no Mostro de Pern ${ }^{\text {co }}$ /venci/das varias contradições q' se offereceraõ principiou /a/ sua leitura e nella continuou com felicidade $\mathrm{p}^{\mathrm{r}}$ $/ \mathrm{hu} / \mathrm{m}$ anno, porem como a sua applicaçaõ aos estudos excedesse a sua possibilidade, veio adecahir em huma tisica conhecida de sorte qeu dei $/ \mathrm{x} /$ ando a $\mathrm{Cadr}^{\mathrm{a}}$ retirou -se $\mathrm{p}^{\mathrm{a}}$ este Mostr $^{\mathrm{o}}$ a buscar alguma melhora nos ares da terra mas como a molestia ja estava adiantada vencendo atodos os remedios della veio a morrer com tan tos $a^{\mathrm{s}}$ de preparo $\mathrm{q}^{\text {tos }}$ tinha de Religiaõ. Faleceo forta lecido com a graça dos Sacram ${ }^{\text {tos }}$ em 15 de Fevereiro de 1721 sendo D.Abb ${ }^{\mathrm{e}}$ o N.M.R.P ${ }^{\mathrm{e}}$.Ex.Prov ${ }^{\mathrm{al}}$ Fr. José de S.Jeronimo.

114 O Centesimo decimo quarto foi o Irmaõ corista Fr. A= nastacio de $S^{\text {ta }}$ Quiteria nascido nesta cid ${ }^{\mathrm{e}}$ professo nes= te Mostr $^{\circ}$. Era naturalm ${ }^{\mathrm{e}}$ triste, e melancolico, de sorte que só era visto nos actos conventuaes, e todo o mais tem= po passava recolhido na sua cella occupado na liçaõ de alguns livros, e outros exercicios honestos separando-se to $=$ talm $^{\mathrm{e}}$ de toda communicaçaõ ainda d/os/ seos Compr ${ }^{\text {os }}$ 
promptam $^{\mathrm{e}}$ satisfasia as suas obriga/ç/ões em quanto naõ ficou empredido $\mathrm{p}^{\mathrm{r}}$ huma molestia trabalhosa e dilatada mandaraõ-no $\mathrm{p}^{\mathrm{a}} \mathrm{o}$ Rio de Janr ${ }^{\mathrm{o}}$, $\mathrm{p}^{\mathrm{a}}$ ver se conseguia algũas melhoras com a mudança de ares; porem adiantando-se cada ves mais a molestia voltou para esta sua patri a onde viveo poucos dias; achava-se em casa de seos $\mathrm{Pa} / \mathrm{ys} /$ q' o mandaraõ à embarcaçaõ em que tinha chegado, mas elle pedindo huma e $\mathrm{m}^{\text {tas }}$ veses q' o mandassem $\mathrm{p}^{\mathrm{a}}$ oseo Mos= $\operatorname{tr}^{0}$ espirou à porta $\mathrm{d} / \mathrm{a} /$ Sacristia $\mathrm{q}^{\mathrm{do}}$ se vinha recolhendo. Foi o dia do seo falecim ${ }^{\text {to }}$ aos 12 de Marco de 1721 sendo D. $\mathrm{Abb}^{\mathrm{e}}$ o N.M.R.P ${ }^{\mathrm{e}}$.Ex.Prov ${ }^{\mathrm{al}}$ Fr. José de S. Jeronimo.

115 O Centesimo decimo quinto foi o $\mathrm{P}^{\mathrm{e}}$. Fr. Gonçalo da $\mathrm{Con}^{\text {cam }}$ natural de Pern ${ }^{\text {co }}$, a sua casa o foraõ procurar os Religi osos para que fosse taõbem Religioso da nossa Ordem, ven= do nelle as prendas, q' o fasiaõ merecedor deste offerecim ${ }^{\text {to }} ;$ com $^{\text {to }}$ gosto condescendeo com as suas vontades e sem demora se recolheo ao noviciado onde procedeo como delle se esperava, professou com geral approvaçaõ e $\mathrm{p}^{\mathrm{r}}$ espaco de muitos na= nos servio a Religiaõ com as $\mathrm{p}^{\text {tes }} \mathrm{q}$ ' tinha de bom music/o/ e tocar alguns instrum ${ }^{\text {tos }}$ de q' se usava com dextresa. Era Religioso exemplar e defensor da liberd ${ }^{\mathrm{e}}$ da $\operatorname{Prov}^{\mathrm{a}}$ e $\mathrm{p}^{\mathrm{r}}$ isso foi preso com os Monges q' tambem foraõ $\mathrm{p}^{\mathrm{a}}$ Portugal pe 
la causa da mesma Prova ${ }^{a}$ Como já se visse livre da prisaõ veio para este Mostr ${ }^{\circ}$, e delle passou a Pernan= buço; onde obrigado da necescidade em que viviaõ algũs seos parentes alcançou lic ${ }^{\mathrm{a}} \mathrm{p}^{\mathrm{a}}$ chegar a minas em ordem a adquerir alguma cousa $\mathrm{p}^{\mathrm{a}}$ os arremediar; adquerio o /q/ue julgava sufficiente, e se recolheo aeste Mostr ${ }^{\circ}$; porem perdendo $\mathrm{q}^{\text {to }}$ tinha $\mathrm{p}^{\mathrm{r}}$ certa $/ \mathrm{cu} /$ sualidade, que se offereceo, $\mathrm{fi}=$ cou vivendo na pobresa que professara, dando Graças a $D^{s} p^{r}$ o livrar de hum taõ perigoso embaraço $\mathrm{p}^{\mathrm{a}}$ oseo estado, e só sentia o tempo que perdéra de servir/a/ Religiaõ em $\mathrm{q}^{\text {to }}$ viveo fora della. E assim dezenganado passou o resto da vida que foi dilatada; adoeceo de huma leve infermid ${ }^{e}$ da qual veio a morrer caminhando $\mathrm{p}^{\mathrm{a}}$ os setenta de Religiaõ e $\mathrm{m}^{\mathrm{s}}$ de oiten= ta de idade natural. Faleceu com todos os Sacram ${ }^{\text {tos }}$ aos 6 de Abril de 1721 sendo D.Abb ${ }^{\mathrm{e}}$ o N.M.R.P ${ }^{\mathrm{e}}$.Ex.Prov ${ }^{\mathrm{al}}$ Fr. Jo= sé de S. Jeronimo.

116 O Centesimo decimo sexto foi o $\mathrm{P}^{\mathrm{e}}$. Fr. Manoel de $\mathrm{S}^{\text {ta }}$ Rosa natural do reconcavo desta $\mathrm{Cid}^{\mathrm{e}}$ prof $<\mathrm{f}>/ \mathrm{e} /$ sso no Mostr ${ }^{\mathrm{O}}$ de Pern ${ }^{\mathrm{co}}$. Naquella casa viveo alguns an ${ }^{\mathrm{s}}$ satisfazendo $\mathrm{c} / \mathrm{o} / \mathrm{m}$ promptidaõ as suas obrigações, veio mudado para /este Mos/ $\operatorname{tr}^{\circ}$ onde pello tempo adiante e pela força de seo genio /ad/querio trabalhos e inimigos; de sorte q' lhe foi necessario embarcar-se para o Mostro de Olinda e delle passar-se a Corte Lisboense onde alcançou hum breve no qual lhe concederaõ os privilegios de Preg ${ }^{\text {or }} \mathrm{Jub}^{\mathrm{o}}$. Voltou seg ${ }^{\mathrm{a}}$ ves $\mathrm{p}^{\mathrm{a}}$ esta casa, e foi admiravel a mudança de sua 
vida e areforma de seos costumes: separou-se totalm ${ }^{\text {e }}$ de

toda communicaçaõ com os homens, desejando ser despre= sado $p^{r}$ todos, entregou-se aos exercicios das virt ${ }^{\mathrm{es}}$ e assim passaou o resto da vida. Adoeceo de huma hidropisia, e conhecendo que amolestia era incuravel preparou= -se para sua conta final, a $\mathrm{q}^{1}$ foi dar no tribunal Divino aos 3 de Agosto de 1721 sendo D.Abb ${ }^{\text {e }}$ N.M.R. $P^{\mathrm{e}}$.Ex.Prov ${ }^{\text {al }}$ Fr. José de S. Jeronimo.

117 O Centesimo decimo septimo foi o $\mathrm{P}^{\mathrm{e}}$. Fr. Marcos de Jesus natural d'esta $\mathrm{Cid}^{\mathrm{e}}$ de Pais virtuosos e professo neste Mos $\operatorname{tr}^{\circ}$. Ao depois de ter sirvido a esta casa no côro e outros offi= cios q' lhe foraõ emcomendados; foi $\mathrm{m} / \mathrm{u} /$ dado $^{\mathrm{a}} \mathrm{o}^{\mathrm{o}} \mathrm{Mostr}^{\mathrm{O}}$ de S.Paulo onde assistio $\mathrm{m}^{\text {tos }}$ annos deixando varios exemplos de Obediencia e humildade. Por occasiaõ de alg/u/= mas molestias voltou $\mathrm{p}^{\mathrm{a}}$ esta casa e nella o fiseraõ $/ \mathrm{Su} / \mathrm{b}=$ prior e $\mathrm{M}^{\mathrm{e}}$ de Juniores, deo a satisfaçaõ que se esperava do seo zelo; porem como as queixas q' padecia se aumenta= raõ cadaves $\mathrm{m}^{\mathrm{s}}$ conhecendo q' se avisinhava a morte; cui= $\mathrm{do} / \mathrm{u} / \mathrm{em}$ se dispor para receber o ultimo golpe, q' esperou re= /signa/do e conforme, e recebendo os ultimos $\operatorname{Sacram}^{\text {tos }} \mathrm{a}=$ cabou a vida com trinta e cinco an ${ }^{\mathrm{s}}$ de habito aos $2 / 5 /$ de $7 b^{\text {ro }}$ de 1721 sendo D.Abb ${ }^{\text {e }}$ o N.M.R.P ${ }^{\mathrm{e}}$.Ex.Prov ${ }^{\text {al }}$ Fr. Jo sé de S. Jeronimo. 118 - O Centesimo decimo oitavo foi o $\mathrm{P}^{\mathrm{e}}$.Preg ${ }^{\text {or }}$ Fr. August ${ }^{\circ} \mathrm{d} / \mathrm{a} \mathrm{A} /$ ppresentaçaõ natural da Cajahiba termo deste Arcebisp ${ }^{\prime /}$ da $\mathrm{B}^{\mathrm{a}}$ e proffesso neste Mostro ${ }^{\circ}$ Teve o seo Coll ${ }^{\circ}$ no Convento 
da Graça; ao depois de Preg ${ }^{\text {or }}$ foi mandado $\mathrm{p}^{\mathrm{a}}$ o Mostro de Pern $^{\mathrm{co}}$

$\left[\mathrm{f}^{\circ} 63 \mathrm{r}^{\circ}\right]$ onde assistio poucos tempos $\mathrm{p}^{\mathrm{r}} \mathrm{q}^{\text {' voltou }} \mathrm{p}^{\mathrm{a}}$ este /Mostr\% a satis fazer as /p/enitencias q' lhe foraõ impostas $\mathrm{p}^{\mathrm{r}}$ certas causu alidades, q' lá lhe succederaõ; desta casa se ausentou $\mathrm{p}^{\mathrm{a}} \mathrm{o}$ $\mathrm{Rei} / \mathrm{n} / \mathrm{o}$, e alcancando perdaõ da fuga, alcançou tambem li= /cen/ça $\mathrm{p}^{\mathrm{a}}$ hir a Minas; e recolhendo-se $\mathrm{p}^{\mathrm{a}}$ este Mostr ${ }^{\mathrm{o}}$ foi ad= ministrar a fasenda da Petinga, onde os escravos experimen taraõ asua Carid ${ }^{\mathrm{e}}$ eos Seculares as suas virtudes. Era devo= tissimo de N.S.da Purificação; e com li/cença da/ Religiaõ deu huma preciosa coroa de ouro a huma devotissima Ima= gem da mesma Snr ${ }^{\text {a }}$ na $\mathrm{V}^{\text {a }}$ de $\mathrm{S}^{\text {to }}$ Amaro. $\mathrm{P} /$ or/ causa de hu= /ma hidropisia/ buscou o Mostr ${ }^{\circ}$ e desen/ganado/ que a moles= tia era /incurável/; des/pois-se como Catholico/ e R/e/ligioso $\mathrm{p}^{\mathrm{a}}$ a ultima hora; recebeo os Santos Sacram ${ }^{\text {tos }}$ e com a sua gra $=$ ça encheo os seos dias sendo diffenidos aos $3 \mathrm{de} / \mathrm{Dez}^{\text {bro }} / \mathrm{de} 1721$ $/ \mathrm{t} / \mathrm{endo}$ de idade $58 \mathrm{an}^{\mathrm{s}}$ e de habito 38. Sendo D.Abb ${ }^{\mathrm{e}}$ o M.P $\mathrm{P}^{\mathrm{e}}$.Ex. Prov $^{\text {al }}$ Fr. José de S. Jeronimo.

119 O Centesimo decimo nono foi o $\mathrm{P}^{\mathrm{e}}$. Fr. Boa/ventura/ de $\mathrm{S}^{\text {ta }}$ Quiteria /natural/ desta Cidade de $\mathrm{F}^{\mathrm{o}} \mathrm{de} \mathrm{Pa} / \mathrm{i} / \mathrm{s}$ ho/nestos no seu/ ingresso na Relig/iaõ se chamou Fr. Valintim de/ S. Ber $\mathrm{n}^{\mathrm{do}}$ que depois /mudou/ em o /nome/ que fica dito. Assistio dous annos neste $/ \mathrm{Mos} / \mathrm{tr}^{\mathrm{O}} / \mathrm{em}$ estado d/e /Secu/lar para su $-123-$ 
prir a falta de organista que nesta occasiaõ havia, /ao de/

$\mathrm{p}^{\mathrm{s}} \mathrm{d} / \mathrm{e} / \mathrm{ad} / \mathrm{m} /$ ettido ao $\mathrm{S}^{\text {to }}$ habito, e nelle professou a vida Religio

$\mathrm{sa}$; ja professo foi continuando no exercicio de organista, e seguin

do a communidade em todos os seus actos; ordenado de /Sacer/ dote enfermou de huma febre lenta, que veio degenerar em uma tisica; estando em sua casa curando-se, sen/tindo-se/ mortal, pedio que o recolhessem ao Mostro ${ }^{\circ}$ e ja dentro /del/ le espirou, ,tendo cinco annos de habito. Era D.Abb o $/ \mathrm{N} . /$ M.R./Pe/.Ex.Provin ${ }^{\text {al }}$ Fr. Jose de S. Jeronimo. Foi o /dia/ do seu falecimento em $\underline{28}$ de Desembro de 1721.

/120/ O Centesimo vigesimo foi o P.Preg ${ }^{\text {or }} \mathrm{Fr} . \mathrm{An}^{\text {to }}$ da Graça na/tu/ral de Basto professo neste casa passados os annos /de seu coristado/ /estudou/

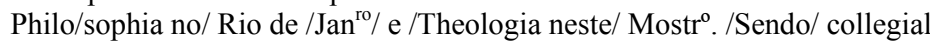
Theologo foi Subp/e/rior, e notario; no fim do Coll ${ }^{\circ}$ o fiseraõ /Procurador/ das demandas; a todos e $<\mathrm{f}>/$ s $\mid$ tes empegos deo boa satisfaçaõ, $\mathrm{p}^{\mathrm{r}} \mathrm{q}^{\text {' era deli }}$ gente, e /cui/dadoso. Attendido os seus merecim ${ }^{\text {tos }}$ o elegeraõ D.Abb /das Bro/ttas, ao dep ${ }^{\mathrm{s}}$ procurador geral nesta occupaçaõ foi /acc/ome= ttido de uma molest $/ \mathrm{i} / \mathrm{a}$ grave que naõ obdecendo aos remedios que lhe aplicaraõ /o/ privou da vida $\mathrm{q}^{\mathrm{do}} \mathrm{ja}$ a jun/ta geral o ti/nha eleito em $\mathrm{Abb}^{\mathrm{e}}$ da /Graça/. /Faleceo com todos os Sacramentos/ em 12 de Maio de $1723 \mathrm{com} / 26$ an/nos de /ha/bito sendo D.Abb ${ }^{\mathrm{e}}$ o $/ \mathrm{N} /$. $\mathrm{M}^{\text {to }}$ R.P.Ex./Provincial/ Fr. /José de S/.Jeronimo. 
/121/ O Centesimo vige/s/imo primr $^{\mathrm{o}}$ foi o $\mathrm{P}^{\mathrm{e}}$. Agostinho Ribr ${ }^{\circ}$ Cleri

$\left[\mathrm{f}^{\mathrm{o}} 64 \mathrm{r}^{\mathrm{0}}\right]$ go secular natural d'esta Cid ${ }^{\mathrm{e}}$. Era Snr'. e administrador da Capella de S.Gonçalo, e do Rio vermelho, e de todas aq ${ }^{\text {las }}$ terras visinhas, vivia com $\mathrm{m}^{\text {ta }}$ edificaçaõ dos seculares, os quaes sen tiraõ por $\mathrm{m}^{\text {to }}$ tempo a sua falta. Tinha particular devoçaõ a /N./Snr ${ }^{\mathrm{a}}$ dos Mares, e em sua capella de S.Gonçalo huma devotissima imagem da $\mathrm{m}^{\mathrm{ma}} \mathrm{Snr}^{\mathrm{a}}$, e todos os annos lhe fasia sua festa. Sempre foi $\mathrm{am}^{\text {te }}$ da Religiaõ, e sempre tratou os Religiosos com $\mathrm{m}^{\text {ta }}$ estimaçaõ: o seu desejo era viver na comp $^{\text {a }}$ dos Monges, aos visitava repetidas veses. Antes de morrer fez deixaçaõ de todos os bens terrenos, e fazendo de de todos elles doaçaõ a este Mostr ${ }^{\circ}$.; n'elle veio se recolheo ja enfermo, e n'elle acabou avida com a graça dos Sacram ${ }^{\text {tos }}$, q' tinha recebido ${ }^{131} \mathrm{com} \mathrm{m}^{\text {ta }}$ devoçaõ, e pied ${ }^{\mathrm{e}}$. Foi sepultado /no/ claustro amortalh/ado/ na cogula, com todos os sufragios, q' se fazem aos Monges falecidos; $p^{r} q^{\prime}$ esta era huma das verbas do seu testam ${ }^{\text {to }}$ tudo se lhe fez, e tudo merecia. Foi o dia /do/ falecim $^{\text {to }}$ em 6 de Fever $^{\circ}$ de 1724 sendo D.Abb ${ }^{\mathrm{e}}$ o /N.M.R./ $\mathrm{P}^{\mathrm{e}}$.Ex.Prov ${ }^{\mathrm{al}}$ Fr. Antonio da Trind $^{\mathrm{e}}$. 122 - O Centesimo vigesimo seg ${ }^{\mathrm{d} o}$ foi o N.M.R ${ }^{\mathrm{e}}$. $P^{\mathrm{e}}$.Ex.Prov ${ }^{\mathrm{al}}$ Fr. Cos me de S.Damiaõ natural da $\mathrm{Cid}^{\mathrm{e}}$ do Porto, professo n'este Mostro. Logo q' entrou, no seu novicido deu a conhecer a sua virtude, $\mathrm{p}^{\mathrm{r}} \mathrm{q}$ ' nos exercicios della empregava todo $-125-$

${ }^{131} \mathrm{O}$ último $<\mathrm{O}>$ da palavra esta envolto por um círculo feito com tinta mais escura. 
o tempo. Ja com sete annos de Religiaõ o mandava ordenar de Sarcerdote; foi the necessario hir a Galisa, $\mathrm{p}^{\mathrm{r}} \mathrm{q}$ ' em Portugal naõ havia Bispos $\mathrm{p}^{\mathrm{r}}$ occasiaõ das guerras q' se moveraõ na aclamaçaõ do D.Joaõ quarto. Re colhido no Mostro de S.Martinho de Compostela acreditou a sua Prov ${ }^{\mathrm{a}}$ com seu recto procedim ${ }^{\text {to }}$ recebendo $\mathrm{m}^{\text {tos }} \mathrm{fa} / \mathrm{vo} /$ res do D. $A b b^{\mathrm{e}}$ e mais Religiosos d'aq ${ }^{\text {le }}$ Mostr $^{\mathrm{o}} \mathrm{p}^{\mathrm{r}} \mathrm{q}^{\prime}$ o jul gavaõ digno de todo benefício. Ao depois de ordenado voltou $\mathrm{p}^{\mathrm{a}}$ esta casa e d'ella foi mandado $\mathrm{p}^{\mathrm{a}} \mathrm{o}$ Colleg ${ }^{\mathrm{o}} / \mathrm{d} / \mathrm{o}$ Rio de Janr ${ }^{\circ}$ no fim dos estudos, como era conhecido o seu zelo lhe encommendaraõ o governo das faz ${ }^{\text {das }}$ de Igua sú, e camosim aonde asssitio $\mathrm{m}^{\text {tos }}$ anos com grd ${ }^{\mathrm{e}}$ edificaçaõ dos seculares, e utilid da Religiaõ. Contando ja quaren ta $a^{\text {os }}$ de habito, buscou esta casa $p^{\text {a }} n$ 'ella esperar a morte. A sua vida era exemplar, $p^{r} q^{\prime}$ frequentava os actos con ventuaes como $\mathrm{q}^{1} \mathrm{q}^{\mathrm{r}}$ dos Juniores, sem se utilisar das dis /pe/nsas, q' lhe permetiaõ os seus annos, e ao molestias ${ }^{132}$; /neste/ tempo, em ja naõ cuidava em outra coisa mais do q' na sua conta final veio eleito $\mathrm{Abb}^{\mathrm{e}}$ da Parahy ba; foi tomar posse da casa, $\mathrm{p}^{\mathrm{r}}$ satisfazer o preceito da obediencia, e renunciando o lugar voltou $\mathrm{p}^{\mathrm{a}}$ este Mostr ${ }^{\circ}$, a continuar nos seus virtuosos exercicios, mas querendo os Prelados superiores, q' a sua exemplarid ${ }^{\mathrm{e}}$

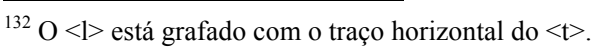


se fisesse mais publica, o elegeraõ Prov ${ }^{\text {al }}$ desta Provincia; $q^{\text {do }}$ teve a noticia da eleiçaõ, disia, q' entre as $\mathrm{m}^{\text {tas }}$, e graves molestias que tinha padecido, e padecia, esta era maior de todas. Governou com grd $^{\mathrm{e}}$ acerto, e visitando a Prov ${ }^{\mathrm{a}}$ deixou varias dis posiçoens todas encaminhadas $\mathrm{p}^{\mathrm{a}} \mathrm{o}$ augm $^{\text {to }}$ espiritual, e tem poral dos Mostros. No fim do seu trienio foi viver no retiro da Graça empregando todas as forças do seu espirito em se dispor $\mathrm{p}^{\mathrm{a}}$ eternid ${ }^{\mathrm{e}}$. Quando ja contava oitenta anno de id ${ }^{\mathrm{e}}$ e setenta de Religião; sentindo totalm ${ }^{\text {te }}$ destituido de forças naturaes, e q' as suas queixas ja lhe naõ permitiaõ $\mathrm{m}^{\text {tos }}$ dias de vida, veio $\mathrm{p}^{\mathrm{a}}$ este Mostro e dentro em poucos dias terminou a sua perigrinaçaõ disposto com a graça dos Sacram $^{\text {tos }}$, e com $\mathrm{m}^{\text {tos }}$ actos de perfeito Religioso. Foi o dia do seu falecim ${ }^{\text {to }}$ em 21 de Junho de 1724 sendo D. Abb $^{\mathrm{e}}$ o N M.R.P ${ }^{\mathrm{e}}$.Ex.Prov ${ }^{\mathrm{al}}$ Fr. Ant ${ }^{\mathrm{o}}$ da Trind $\mathrm{e}^{\mathrm{e}}$.

$123 \mathrm{O}$ centesimo vigesimo terc ${ }^{\circ}$ foi oIrmaõ Donado Fr. /Antonio/ de Jesus natural de Regalados Arcebispado de Braga professo no Mostro de Pernambuco. Ao depois de ter servi do aquelle Mostr ${ }^{\circ}$; veio mudado $\mathrm{p}^{\mathrm{r}}$ obediencia $\mathrm{p}^{\mathrm{a}}$ esta casa a $\mathrm{q}^{1}$ tambem servio com fidelid $\mathrm{p}^{\mathrm{r}}$ ser zeloso e delig ${ }^{\text {te }}$ em fazer o q' lhe era mandado. Assistio alguns annos, em as nossas terras pertencecntes ao Eng $^{\circ}$ das Vapacarocas, $\mathrm{p}^{\mathrm{a}}$ deffender 
e impedir q' naõ entrassem $\mathrm{p}^{\mathrm{r}}$ ellas os visinhos, q' moravaõ perto das suas extremid ${ }^{\text {es}}$; entando porem def fende-las $\mathrm{p}^{\mathrm{r}}$ huma $\mathrm{p}^{\mathrm{te}} \mathrm{q}$ ' avisinhavaõ com hum homem poderoso chamado D.Joaõ Mascarenhas, no $\mathrm{m}^{\mathrm{mo}}$ campo, em q' se achava, cruelm ${ }^{\text {te }}$ o mataraõ na occa siaõ da contenda, os deffensores da $\mathrm{p}^{\text {te }}$ contraia; ao /de/ pois de morto o foraõ buscar os Religiosos, q' admi= nistravaõ o Eng $^{\circ}$ di S.Caetano, e lhe deraõ a sepultura na Capella do Unhatá d'onde os seus osso foraõ tras ladados $\mathrm{p}^{\mathrm{a}}$ o nosso claustro. Succedeo este lastimoso caso em 15 de Fever $^{\mathrm{o}}$ de 1724 sendo D.Abb ${ }^{\mathrm{e}}$ o N.M.R.P. .Ex. $^{\mathrm{e}}$ Prov $^{\text {al }} F r$. An $^{\text {to }}$ da Trind ${ }^{\mathrm{e}}$.

124 O centesimo vigesimo quarto foi o N.M.R.P ${ }^{\mathrm{e}}$.Ex.Prov ${ }^{\text {al }}$ Fr. $\mathrm{M}^{\mathrm{el}}$ dos Anjos nascido de Pais nobres nas visinhãças de Guimaraens, professo n'este Mostro teve os primr ${ }^{\text {os }}$ annos de seu coristado, ao depois, foi $\mathrm{p}^{\mathrm{a}} \mathrm{o}$ Rio de Janr ${ }^{\mathrm{o}}$ /estudar/ Filosofia, e Theologia; voltando $\mathrm{p}^{\mathrm{a}}$ esta casa me receo o nome de bom Pregador $\mathrm{p}^{\text {la }}$ satisfaçaõ, com q' era ouvido nos Pulpitos, a custa do seu disvello, e applicaçaõ dos livros conducentes $\mathrm{p}^{\mathrm{a}}$ seu ministério; no confessionario era freq ${ }^{\text {te }} p^{\text {a } o ~ q ' ~ e s t a v a ~ s u f f i c i e n t e m ~}{ }^{\text {te }}$ instruido nas materias moraes. Attendida sua capacid ${ }^{\mathrm{e}}$; occupou 
alguns lugares authorisados da Religiaõ; primeiram ${ }^{\text {te }}$ foi

$\left[\mathrm{f}^{\mathrm{0}} 66 \mathrm{r}^{\circ}\right]$ mandado $\mathrm{p}^{\mathrm{r}}$ visitador comissario do Rio de $\mathrm{Janr}^{\circ} \mathrm{e}$ mais conv $^{\text {tos }} \mathrm{d}^{\prime} \mathrm{aq}^{\text {las }} \mathrm{p}^{\text {tes }}$, ja devolta $\mathrm{p}^{\mathrm{a}}$ este Mostr ${ }^{\mathrm{o}}$ encontrando-se com hum navio de levantados, q' crusavaõ os mares do Sul, $p^{r}$ elles foi preso junto com hum Padre da Comp ${ }^{\mathrm{a}}$, a q $\mathrm{q}^{\mathrm{m}} \operatorname{logo}$ mataraõ a sua visita, e querendo lhe fazer o $\mathrm{m}^{\text {mo }}$ rogou $\mathrm{p}^{\mathrm{r}}$ elle hum dos $\mathrm{m}^{\text {mos }}$ piratas, e assim /esc/apou da morte porem tam maltratado com outras violencias, q' ainda na s/u/a chegada ao Mostr $^{\circ}$ vi-

10 nha bastante $\mathrm{m}^{\text {te }}$ molestado. Recolhido na sua cella foi continuando nos seus exercicos do coro pulpito, e confessionario; porem querendo a Reli giaõ utilisar-se do seu prestimo, o elegeraõ $\mathrm{Abb}^{\mathrm{e}}$ do Mostr ${ }^{\circ}$ de Pernambuco, e governou com tanto acerto, q' naõ foi necessario outra prova $\mathrm{p}^{\mathrm{a}}$ no trienio seg ${ }^{\text {te }} \mathrm{o}$ elevarem ao lu gar de Prov ${ }^{\text {al }}$; era ja de id ${ }^{\mathrm{e}}$ avançada, e opprimido de varias molestias, mas nem $\mathrm{p}^{\mathrm{r}}$ isso se poupou ao trabalho do seu em prego; visitou a Prov ${ }^{\mathrm{a}}$ com bast ${ }^{\text {te }}$ incommodo da sua saúde, e com grd utilid $^{\mathrm{e}}$ da observancia regular. Conclu ido o seu trienio, entrou adispor $\mathrm{p}^{\mathrm{a}}$ amorte, $\mathrm{aq}^{1}$ sempr/e/ tr/as/ia na lembr ${ }^{\mathrm{a}} \mathrm{p}^{\mathrm{a}}$ maior estimulo do seu preparo. Oi tenta annos de $\mathrm{id}^{\mathrm{e}}$ e mais de setenta de habito contava este Religioso, $\mathrm{q}^{\text {do }}$ huma das suas antias molestias o privou 
da vida disposto com a graça dos Sacram ${ }^{\text {tos }}$, e com m ${ }^{\text {tos }}$, actos de Religioso. Faleceu em 22 de Maio de 1725 sendo D. $\mathrm{Abb}^{\mathrm{e}}$ o N.M.R.P ${ }^{\mathrm{e}}$.Ex.Prov ${ }^{\text {al }}$ Fr. $\mathrm{An}^{\text {to }}$ da Trind ${ }^{\mathrm{e}}$.

125 O centesimo vigesimo quinto foi o $\mathrm{P}^{\mathrm{e}}$. Fr.Amaro de S.Do mingos natural d'esta $\mathrm{Cid}^{\mathrm{e}}$ de $\mathrm{Pais}$ virtuosos professo n'este Mostro . Ja ordenado de Sacerdote foi admittido ao Collegio do Rio de Janro; fez deixaçaõ dos estudos, passou $\mathrm{p}^{\mathrm{a}}$ o Mostr ${ }^{\circ}$ de S.Paulo, e alcançando licença foi $\mathrm{p}^{\mathrm{a}}$ Minas aonde assistio alguns annos sem nota do seu procedim ${ }^{\text {to }}$. Recolheu se a esta casa $\mathrm{aq}^{1}$ deu a sua esmola, e remedi ou as necessid ${ }^{\mathrm{e}}$ de alguns seus parentes. Como tinha deixado huma fazenda $p^{r}$ onde andou, $q^{\text {do }}$ seg $^{\text {da }}$ vez voltava $p^{\mathrm{a}} \mathrm{Mi}$ nas, adispor d'ella; na villa da Cachoeira foi acommettido de huma molestia tam violenta q' dando-lhe som ${ }^{\text {te }}$ lugar de procurar o Mostro ${ }^{\circ}$ n'elle veio acabar a sua vida com a /gr/aça dos Sacram ${ }^{\text {tos }}$, aos 24 de Julho de 1725 sendo $\mathrm{D}<0>/ . \mathrm{Abb}^{\mathrm{e}}$ o N.M.R.P. ${ }^{\mathrm{e}}$. Ex.Provi ${ }^{\mathrm{al}}$ Fr. Antonio da Trind ${ }^{\mathrm{e}}$.

/126/ O centesimo vigesimo sexto foi o $\mathrm{P}^{\mathrm{e}}$.Preg ${ }^{\text {dor }}$ Fr. José de $\mathrm{S}^{\text {to }}$ Ant ${ }^{\mathrm{o}}$ natural de Matusinhos; professou n'esta casa, e teve o seu Collegio em N.Snr ${ }^{\mathrm{a}}$ da Graça. Encheo o lugar de Pregador com grd ${ }^{\mathrm{e}}$ satisfaçaõ, e louvores dos ouvintes. Passados alguns annos foi 
mudado $\mathrm{p}^{\mathrm{a}}$ o Rio de Janr ${ }^{\circ}$; e $\mathrm{p}^{\mathrm{r} 133}$ occasiaõ de alguns desgostos,

deixando o habito, se fez Apostata; e foi assistir na villa de Cai rú, aonde $\mathrm{p}^{\mathrm{r}}$ hum officio vil adquiria o necessario $\mathrm{p}^{\mathrm{a}}$ passar avida; porem naõ se dando $\mathrm{p}^{\mathrm{r}}$ seguro, se metteo ao interior do certaõ aonde acommettido de huma maligna acabou avida tendo setenta e trez annos de id $\mathrm{d}^{\mathrm{e}}$. Faleceo no anno de $1725 \mathrm{e}$ n'elle chegou a noticia triste de sua vida, e morte. Era D.Abb ${ }^{\mathrm{e}}$ o N.M.R.P. ${ }^{\mathrm{e}}$ Ex.Provil ${ }^{\text {al }}$ Fr. Antonio da Trind ${ }^{\mathrm{e}}$.

127 O centesimo vigesimo septimo foi o M.R.P. .Preg $^{\text {dor }}$ Fr. $\mathrm{M}^{\mathrm{el}}$ do Nascim ${ }^{\text {to }}$ natural do reconcavo d'esta Cid ${ }^{\text {e }}$ filho de Pais nobres professo n'este Mostro ${ }^{\circ}$. Foi Religioso de $/ \mathrm{m}^{\text {ta }}$ authorid ${ }^{\mathrm{e}} \mathrm{e}$ credito $\mathrm{p}^{\mathrm{a}}$ a nossa prov ${ }^{\mathrm{a}}$, principalm ${ }^{\text {te }} \mathrm{p}^{\mathrm{a}}$ esta casa; n'ella viveo $\mathrm{m}^{\text {tos }}$; annos sempre trabalhando tanto em Prelado, como em

15 Subdito. Era prudente, parco, e caritativo, nunca bebeo vinho, nem comeo outros majares, q' naõ fossem os do Refetor/io/, assim ao jantar, como a noite. Frequentava o coro com $\mathrm{grd}^{\mathrm{e}} \mathrm{de} / \mathrm{vo} / \mathrm{çaõ}$, exemplo dos Monges, q' todos o respeitavaõ em $\mathrm{q}^{1} \mathrm{q}^{\mathrm{r}} \mathrm{p}^{\mathrm{te}}$ o uviaõ. Reprenhendia os Juniores $\mathrm{q}^{\text {do }}$ via alguma $<\mathrm{P}>/$ flalta; e ainda aos $\mathrm{m}^{\text {mos }}$ Prelados advertia alguns descuidos; ninguem se q/u/eixava, todos the obedeciaõ $\mathrm{p}^{\mathrm{r}}$ saberem, q' n'elle os bons exemplos precediaõ os bons concelhos. Este Monge de tantas prendas, e virtudes moraes, foi dos q' foraõ presos a Port/u/ $-131-$

${ }^{133} \mathrm{O}<\mathrm{r}>$ da abreviatura não está grafado. 
gal $\mathrm{p}^{\text {la }}$ causa da Prov ${ }^{\mathrm{a}}$ padeceo $\mathrm{m}^{\text {tos }}$ trabalhos, e asua cons tancia em soffrelos admirava, e confundia aos $\mathrm{m}^{\text {mos }} \mathrm{q}$ ' lhe causavaõ.

Ao depois q' de alguma sorte se compuseraõ as causas entre a Prov ${ }^{\mathrm{a}}$, e a Congreg ${ }^{\mathrm{am}}$, voltou $\mathrm{p}^{\mathrm{a}}$ este Mostr ${ }^{\mathrm{o}}$ aonde foi recebido com grd $^{\mathrm{e}}$ contentam $^{\text {to }}$ dos Monges, $\mathrm{p}^{\text {la }}$ esperança em $\mathrm{q}^{\mathrm{n}}$ as pôs daq ${ }^{1}$ os filhos da Prov ${ }^{\mathrm{a}}$. Haviaõ de ser os Prelados dos Mostr'; e con tinuando nos exercicios de hum perfeito Religioso, como os seus merecim ${ }^{\text {tos }}$ de justiça pediaõ os maiores empregos da Re ligiaõ o elegeraõ D.Abb ${ }^{\text {e }}$ d'esta casa; esta eleiçaõ foi ouvida com $\operatorname{grd}^{\mathrm{e}}$ aplauso de todos, os q' o /c/onheciam tomou posse dolugar e cuidou em /con/servar o Mostr ${ }^{\circ}$ em pas, e sem deminuiçaõ da observancia regular, mas antes se empenhava no adianta $\mathrm{m}^{\text {to }}$; animando com seu exemplo aos seus subditos a serem observantes, e perf ${ }^{\text {tos }}$; a todos tra/ta/va como Pais, e Prelado benigno, prudente, e attencioso. Em todo o seu trienio traba lh/ou/ sem descanço; mandou duas lâmpadas de prata q' hoje vimos na capella mór, e foraõ as primr ${ }^{\text {as }}$ q' appareceraõ n'esta $\mathrm{Cid}^{\mathrm{e}} \mathrm{daq}^{\text {la }}$ forma. Mandou tambem açoalhar o coro, revocar todas as paredes da Igreja, efazer a primr ${ }^{\mathrm{a}}$ ordem de $\mathrm{Cadr}^{\mathrm{as}} \mathrm{e}$ as grades do $\mathrm{m}^{\mathrm{mo}}$ coro. Mandou vir de $\mathrm{Lx}^{\mathrm{a}}$ hum sino grd $^{\mathrm{e}}$ e de $\mathrm{m}^{\text {to }}$ boas vozes. $/ \mathrm{No} / \mathrm{seu}$ tempo adveyo a as christia a preciosa reliquia do $S^{\text {to }}$ Lenho, q' n'ella se conser $-132-$ 
va; outras obras de utilid ${ }^{\mathrm{e}}$, se fiseraõ no seu trienio $\mathrm{p}^{\mathrm{a}}$ a $\operatorname{Igr}^{\mathrm{a}} \mathrm{ep}^{\mathrm{a}}$

$\left[\mathrm{f}^{\circ} 68 \mathrm{r}^{\circ}\right]$ o Mostr ${ }^{\circ}$, e $\mathrm{p}^{\mathrm{a}}$ as fazendas das q'uaes se dará noticia no $\mathrm{Ca}$ talogo dos Prelados d'esta Casa. No seg ${ }^{\text {do }}$ anno doseu triênio, se hospedou neste $\operatorname{Mostr}^{\mathrm{o}}$ o $\mathrm{Ex}^{\mathrm{mo}}$ Arcebispo o Snr'. D.Joaõ Franco de Olivra ${ }^{a}$, na sua chegada a esta terra, aonde ao depois de assistir n'elle trez dias d'elle foi tomar posse da Sé Archiepiscopal $\mathrm{m}^{\text {to }}$ satisfeto da grande /za/ com q' foi hospedado. Concluido o seu governo conservou sempre o respeito devido a sua Religiosa Pessoa. Foi exami nador synodal $\mathrm{f}^{\mathrm{to}} \mathrm{p}^{\mathrm{lo}} \mathrm{Snr}$ '. D. Sebastiaõ Montro ${ }^{\circ}$ a Vide, o $\mathrm{q}^{1}$ sem pre o tratou com huma attençaõ $\mathrm{m}^{\text {to }}$ destinta. Era cordialm ${ }^{\text {te }}$ devoto de S.Caetano e ao seu zelo se deve o augm ${ }^{\text {to }}$ de sua Ca pella. Ainda ao depois viveo $\mathrm{m}^{\text {tos }}$ annos, os quaes gastou na preparaçaõ de sua ultima jorn/ada/, até chegando a ultima hora, disposto com todos os Sacram ${ }^{\text {tos }}$ encheo os seus dias aos 27 de $7 \mathrm{br}^{\circ}$ de $1725 \mathrm{q}^{\text {do }}$ ja passava de mais de noventa annos de $\mathrm{id}^{\mathrm{e}}$, e mais de setenta de Religioso. Era D.Abb ${ }^{\mathrm{e}}$ o N.M.R.P. Ex.Prov ${ }^{\text {al }} F r . A n^{\text {to }}$ da Trind ${ }^{\mathrm{e}}$.

128 Neste trienio faleceo na fazenda da Ilha grd ${ }^{\mathrm{e}}$ do Rio de S. Fran ${ }^{\text {co }}$ o $P^{\mathrm{e}}$. Fr. Dionisio, o q pertence o numero de centesim/o/ v/ig/esimo oitavo, era natural do Arcebispado de Braga, e professo n'esta casa. Vestio o nosso habito ja com 27 annos de id ${ }^{\mathrm{e}}$, ao depois de ordenado de Sacerdote foi administrar $-133-$ 
a q $q^{\text {la }}$ fazenda aonde encheo os seus dias; está sepultado no convento de S.Fran ${ }^{\text {co }}$ da Villa do Penedo.

Entre os Monges falecidos está sepultado o $\mathrm{P}^{\mathrm{e}}$. Joaõ Neves Vigário da Villa de Camamú, q' p ${ }^{\text {la }}$ devoçaõ q' tinha a nossa Religiaõ alcançou este beneficio do N.M.R.P. ${ }^{\mathrm{e}}$.Ex.

Prov $^{\text {al }}$ Fr. Antonio da Trind ${ }^{\mathrm{e}}$ D.Abb ${ }^{\mathrm{e}}$ ' entaõ era d'esta casa. $\mathrm{Na} \mathrm{m}^{\text {ma }}$ sepultura foi enterrado vinte annos ao depois $\mathrm{R}^{\text {do }}$. $\mathrm{P}^{\mathrm{e}}$. Luiz Per ${ }^{\mathrm{a}}$ Torres de S.P ${ }^{\mathrm{o}}$ novo, Sacerdote bem pro cedido, e de vida exemplar, o $\mathrm{q}^{1}$ tambem conseguio este bene ficio $\mathrm{p}^{\text {lo }} \mathrm{m}^{\mathrm{mo}}$ principio de ser devoto, e am ${ }^{\text {te }}$ da nossa Reli giaõ Benedictina.

129 O centesimo vigesimo nono foi o M.R.P P.Preg $^{\text {or }}$ F.Caetano de S.Domingos natur/al/ de S.Paio de Seide Arcebispado de Braga, professo n'esta casa. Estudou Filosofia nos pa tios da Comp ${ }^{\mathrm{a}}$ e n'elle se formou; teve a sua Theologia no Mostro da Graça; no fim do Collegio foi mudado $\mathrm{p}^{\mathrm{a}}$ o Mostr ${ }^{\mathrm{o}}$ de Pern ${ }^{\mathrm{co}}$ aonde assistio $\mathrm{m}^{\text {tos }} / \mathrm{a} / \mathrm{nnos}$ servindo a Religiaõ no coro, pulpito, e confessionário; e outros empregos, q' fiaraõ da sua capacid ${ }^{\mathrm{e}}$ voltando $\mathrm{p}^{\mathrm{a}}$ este Mostr ${ }^{\mathrm{o}}$ 'elle foi Prior, e Presid $\mathrm{p}^{\mathrm{e}} \mathrm{p}^{\mathrm{r}}$ morte do D. $A b b^{e}$, concluido o seu trienio veio eleito D. $\mathrm{Abb}^{\mathrm{e}}$ de O linda em todos estes lugares se houve com prudência 
e zelo do augm ${ }^{\text {to }}$ espiritual, e temporal de ambos os Mostros

$\left[\mathrm{f}^{\mathrm{o}} 69 \mathrm{r}^{\mathrm{0}}\right]$ No trienio $\mathrm{seg}^{\text {te }}$ occupou o lugar de Definidor, e principiou a experimentar humas intoleraveis dores, a q' chamaõ de pedra, as quaes the deraõ $\mathrm{m}^{\text {tas }}$ occasioens de merecer $\mathrm{p}^{\text {la }}$ passiencia, com q' as supportava; d'ellas veio aca bar avida, tendo se confessado repetidas vezes acompa nhando as vezes com as lagrymas, recebidos os ultimos Sacram $^{\text {tos }}$ com $_{\text {grd }}{ }^{\text {e }}$ edificaçaõ dos Religiosos. Foi o dia do seu falecim ${ }^{\text {to }}$ aos 27 de Janr $^{\circ}$ de 1726. Sendo D.Abb ${ }^{\text {e }}$ N. M.R.P ${ }^{\mathrm{e}}$.Ex.Prov ${ }^{\text {al }}$ Fr. Antonio da Trind ${ }^{\mathrm{e}}$.

130 O centesimo trigesimo foi o $\mathrm{P}^{\mathrm{e}}$. Preg ${ }^{\text {dor }}$ Fr. Joaõ da Emcarnaçaõ natural d'esta $\mathrm{Cid}^{\mathrm{e}} / \mathrm{p} /$ rofesso n'este Mostro ${ }^{\circ}$. Era Religioso passifico, afavel, e de prestimo $\mathrm{p}^{\mathrm{a}}$ favorecer aos q' se valiaõ do seu patrocinio, $\mathrm{p}^{\mathrm{r}} \mathrm{q}$ ' sempre logrou estimaçaõ entre os Religiosos, e seculares. Foi devotissimo de N.Snr ${ }^{\mathrm{a}}$ da Conc ${ }^{\mathrm{am}}$, e confessava elle, q' $\mathrm{p}^{\mathrm{r}}$ intençaõ da $\mathrm{m}^{\text {ma }} \mathrm{Snr}^{\mathrm{a}}$ escapara de morrer afogado embarcando -se $\mathrm{p}^{\mathrm{a}}$ a faz ${ }^{\mathrm{da}}$ do Iguassú no Rio de Janer ${ }^{\mathrm{n}}$ aq $^{\text {le }}$ Mostr $^{\mathrm{o}}$ Filosofia e Theologia estudou, e voltando $\mathrm{p}^{\mathrm{a}}$ este foi $\mathrm{M}^{\mathrm{ee} /}$ /de/ Novicos, eno treino seg ${ }^{\text {te }}$ nomeado Presid ${ }^{\text {te }}$ de hum[ $[<\mathrm{a}>]$ /das/ provincias de S.Paulo a q ${ }^{1}$ renunciou. Por morte de seu Pai q' era homem de grd ${ }^{\mathrm{e}}$ megocio, foi viver em 


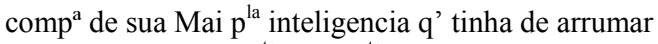
contas; poz tudo corr ${ }^{\text {te }}$ com $\mathrm{m}^{\text {to }}$ desembaraço, e boa disposiçaõ; satisfazendo com toda fidelid ${ }^{\mathrm{e}}$ as heranças, e legitimas de seus Irmaõs, e suas Irmans Religioas. Nas festas solennes vinha assistir as Matinas, e da $\mathrm{m}^{\text {ma }}$ sorte $\mathrm{p}^{\text {la }}$ semana $\mathrm{S}^{\text {ta }} \mathrm{A}$ commettido de huma molestia grave, buscou a comp ${ }^{\mathrm{a}} \mathrm{dos}$ Religiosos, aonde veio morrer com todos os Sacram $^{\text {tos }}$ em 16 de Agosto de 1726. Tendo 42 annos de id e 25 de habito sendo D.Abb ${ }^{\mathrm{e}}$ o N.M.P ${ }^{\mathrm{e}}$.Ex.Prov ${ }^{\mathrm{al}}$ Fr. Ant ${ }^{\mathrm{o}}$ da Trind ${ }^{\mathrm{e}}$.

10131 O centesimo trigesimo primr $^{\circ}$,/ foi o $\mathrm{P}^{\mathrm{e}}$. Fr. Francisco de $\mathrm{S}^{\text {ta }}$ Gertrudes nascido em Lisboa de Pais nobres professo n'este Mostro ${ }^{\circ}$. Era Religioso sincero, timido, e obediente. Sendo admitti do ao Coll $^{\circ}$ no Mostr $^{\circ}$ de Pernambuco, vendo q' ti/nh/a pou co adiantam ${ }^{\text {to }}$, e pouco fructo de sua applicaçaõ dos estu dos, fez deixaçaõ d'elles, e foi administrar huma fazenda Religiaõ; d'ella se auzentou $\mathrm{p}^{\mathrm{r}}$ occasiaõ de alguns desgostos, passados alguns tempos buscou o Mostr ${ }^{\circ}$, e sendo sen tenciado conforme as suas culpas veio mudado $\mathrm{p}^{\mathrm{a}}$ esta ca sa satisfazer as penitencias, como era pouco desembara çado $\mathrm{p}^{\mathrm{a}}$ satisfazer suas obrigações, o mandaraõ $\mathrm{p}^{\mathrm{a}}$ comp ${ }^{\mathrm{o}}$ do $\mathrm{P}^{\mathrm{e}}$. $\mathrm{q}^{\prime}$ governava o nosso Eng $^{\mathrm{o}}$ da Praia; alguns annos assistio em sua comp $p^{\mathrm{a}}, \mathrm{p}^{\mathrm{r}} \mathrm{q}^{\prime}$ naõ desmerecia o seu bom 
procedim $^{\text {to }}$. Adoeceo de huma postema principiada de hua ${ }^{134}$

$\left[\mathrm{f}^{\circ} 70 \mathrm{r}^{\circ}\right]$ grd ${ }^{\mathrm{e}}$ queda, q' deu, da q $\mathrm{q}^{1}$ fez pouco caso; recolheo-se ao Mos $\operatorname{tr}^{\circ}$ e desenganado q' estavaõ completos os seus dias, entrou a

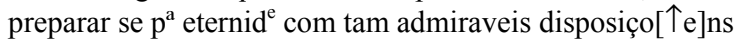
q' deixando bem edificados os Religiosos suavem ${ }^{\text {te }}$ espirou no mes de $7 b^{\circ}$ de 1726. Sendo D.Abb ${ }^{\mathrm{e}}$ o N.M.P. ${ }^{\mathrm{e}}$.Ex.Prov ${ }^{\mathrm{al}}$ Fr. Ant ${ }^{\mathrm{o}}$ da Trind ${ }^{\mathrm{e}}$.

132 O centesimo trigesimo seg ${ }^{\text {do }}$ foi o M.R.P. ${ }^{\mathrm{e}}$. $\mathrm{M}^{\mathrm{e}}$.Fr.Thomaz da Conc $^{\text {am }}$ nascido na Villa de Cairú de Pais honestos, professo nesta Casa. Levado da sua vocaçaõ, pedio o habito de Mon ge ao $\mathrm{q}^{1}$ foi admittido, $\mathrm{p}^{\mathrm{r}} \mathrm{q}$ ' n'elle concorriaõ os requisitos ne cessarios $\mathrm{p}^{\mathrm{a}} \mathrm{o}$ estudo Religioso, era bom grammatico e de re cto procedim ${ }^{\text {to }}$. Estudou Filosofi/a,/ e Theologia no Collegio do Rio de Janr ${ }^{\circ}$ e applicou com tanto disvello aos exercicios

15 literarios, q' mereceo o elegessem $\mathrm{M}^{\mathrm{e}}$ no fim dos estudos foi provido em huma Cadr ${ }^{\mathrm{a}}$ de Theologia no Mostro de Pern ${ }^{c o}$ a q $q^{1}$ deu satisfaçaõ, q' se esperava do seu trabalho. Tendo ja recebido o gráo de Magisterio acceitou a ser Prior naq ${ }^{\text {la }}$ casa $p^{\text {la }}$ eficacia com q' o D.Ab/b / reptidas vezes lhe rogou, o quisesse acompanhar no seu trienio: porem como padecia varias molestias sem esperança de melhoras naq ${ }^{\mathrm{la}}$ terra, buscou $\mathrm{p}^{\mathrm{r}}$ con $-137-$

${ }^{134} \mathrm{O}<\mathrm{u}>$ está grafado com $<\sim>$. 
selhos os ares da Patria, e recolhido a este Mostro conti nuando as suas queixas sem deminuiçaõ lhe abrevi araõ avida; $\mathrm{p}^{\mathrm{r}}$ poucos tempos; ao depois da sua che gada completou os seus dias em 21 de Julho de 1727. Quando contava trinta e cinco annos de id ${ }^{\mathrm{e}}$; e dezeceis de Religiaõ faleceo com todos os Sacram ${ }^{\text {tos }}$ sendo D.Abb ${ }^{\mathrm{e}}$ o M.R.P.Pregd ${ }^{\text {or }}$ Ciprianno da Conc ${ }^{\text {am }}$.

133 O centesimo trigesimo terceiro, foi o Irmaõ Donado Fr. Gregorio do Paraizo natural do Reino professo n'esta

casa. Foi $\mathrm{m}^{\text {tos }}$ annos conventual do Mostr ${ }^{\circ}$ da Graça ao $\mathrm{q}^{1}$ servio com $\mathrm{m}^{\text {to }}$ zelo, adquirindo $\mathrm{m}^{\text {tas }}$ esmolas $\mathrm{p}^{\mathrm{a}} \mathrm{o}$ seu augmento, e sustentaçaõ. Adoeceo de humas cesoens, e d'ellas veio a morrer n'este Mostro ${ }^{\circ}$ com to dos os Sacram ${ }^{\text {tos }}$ aos 13 de Maio de 1727 sendo D. Abb $^{\mathrm{e}}$ o M.R.P ${ }^{\mathrm{e}}$.Pregd ${ }^{\text {or }}$ Ciprianno da Conc $^{\text {am }}$.

134 O centesimo trigesimo quarto foi o M.R.P $P^{\mathrm{e}} \cdot \mathrm{M}^{\mathrm{e}} \mathrm{Fr}$. José de Jesus Maria nascido na villa de Cairú de Pais nobres professo n'este Mostro ${ }^{\circ}$. Foi Religioso de $\mathrm{m}^{\text {to }}$ prestimo e de notoria capacid $\mathrm{p}^{\mathrm{e}} \mathrm{p}^{\mathrm{a}}$ servir a Religiaõ naõ se negando a trabalho algum, q' fosse em utilid d'ella. $\mathrm{P}^{\mathrm{a}}$ se ordenar de Sacerdote foi em Buenos Ayres 
e no ingresso ficou no Rio de Janr ${ }^{\circ}$, aonde estudou Filosofia e Theologia; no fim do Coll ${ }^{\circ}$ fez actos de passante, e conhe cida a capacid ' q' tinha para os exercicios literarios foi provido na cadr ${ }^{\mathrm{a}}$ de Filosophia, e ao depois em huma de Theologia; ${ }^{+}$no fim do seu Collegio digo ${ }^{+}$e nesta divina sci encia recebeo o gráo de Magisterio, ao depois de deffendidas as suas conclusoens com boa reputaçaõ de sua pesso a, e credito da Religiaõ. Foi o primr ${ }^{\mathrm{o}}$ chronista, q' deu principio a Chronica da Prov ${ }^{\mathrm{a}}$, revolvendo com $\mathrm{m}^{\text {to }}$ trabalho os cartorios dos Mostr ${ }^{\text {os }}, \mathrm{p}^{\mathrm{a}}$ descobrir as noticias de sua fun daçaõ, e as vidas dos primr ${ }^{\text {os }}$ Monges, q' n'elle faleceraõ; n'este Mostro escreveo as vidas, e as mortes dos primr ${ }^{\text {os }}$ qua renta e quatro, q' nelle morreraõ. Foi comp ${ }^{\text {ro }}$ e Secretario do $\operatorname{Prov}^{\text {al }} / \mathrm{e} /$ D.Abbe do Mostro de Pern ${ }^{\text {co }}$ e 5 conseguindo licença $\mathrm{p}^{\mathrm{a}}$ se recolher n'esta casa, fez viagem $p^{r}$ terra; $p^{r}$ aq ${ }^{\text {les }}$ caminhos vinha fazendo missaõ, e confeçan do sem perdoar trabalho algum, q' necessario fosse $\mathrm{p}^{\mathrm{a}}$

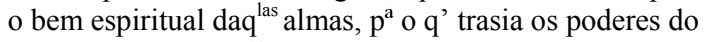
Snr'. Bispo de Pern ${ }^{\mathrm{co}}$ D.José Fialho; chegando a nossa faz ${ }^{\text {da }}$ da Ilha grd ${ }^{\mathrm{e}}$, foi admittido de hum estupor, q' em breve/s/ dias privou-o da vida. Está sepultado no Conv ${ }^{\text {to }}$ de S. Fran $^{\mathrm{co}}$ na villa do Penêdo. Falecêo em 14 de Fever ${ }^{\circ}$ de 1729 sendo D. $\mathrm{Abb}^{\mathrm{e}}$ o M.R.P . Pregd $^{\mathrm{or}}$. Fr. Ciprianno da Conc ${ }^{\mathrm{am}}$. $-139-$ 
135 O centesimo trigesimo quinto foi o $\mathrm{P}^{\mathrm{e}} \mathrm{Preg}^{\mathrm{dor}}$ Fr. Angelo

da Assumpçaõ, nascido na villa de Guimaraens de

Pais honestos professou n'este Mostro com o no=

me de Fr. Manoel da Conc ${ }^{\mathrm{am}}$ ao dep $\mathrm{de}^{\mathrm{s}}$ mudou p $\mathrm{p}^{\mathrm{a}}$ o q' fica

dito. Era Religioso modesto, e observante, teve o seu Coll ${ }^{\circ}$ no Rio de Janr ${ }^{\circ}$, e ao depois de Preg ${ }^{\text {dor }}$ administrou algumas faz ${ }^{\text {das }}$ do $\mathrm{m}^{\text {mo }}$ Mostr $^{\mathrm{o}}$ com $_{\text {grd }} \mathrm{e}^{\mathrm{e}}$ zello, e fide $\operatorname{lid}^{\mathrm{e}}$. Passados alguns annos foi $\mathrm{p}^{\mathrm{r}}$ comp $^{\mathrm{o}}$ do Presid $^{\text {te }}$ de Jundiahy, aonde assistio pr dilatados tempos, com grd $^{\text {es }}$ edificaçoens dos seculares, aos quaes administrava os Sacram ${ }^{\text {tos }}$ na vida e na morte com zello, e carid ${ }^{\mathrm{e}}$. Ja nos seus ultimos annos se recolheo a este Mostr ${ }^{\circ}$ a esperar a morte, $\mathrm{p}^{\mathrm{r}}$ se achar enfermo de huma mo lestia contagiosa, a $\mathrm{q}^{1}$ lhe deu $\mathrm{m}^{\text {tas }}$ occasiões pade cer, e de merecer. Faleceo com todos os Sacram ${ }^{\text {tos }}$ em 13 de Maio de 1729. Sendo D.Abb ${ }^{\mathrm{e}}$ o M.R.P.Pregd ${ }^{\text {or }} \mathrm{Fr}{ }^{135}\left[\rightarrow \mathrm{Cip}^{\text {ra }}\right.$ da Conceiçaõ. $]$

136 O centesimo trigesimo sexto foi o N.M.R.P ${ }^{\mathrm{e}}$. Ex.Prov ${ }^{\text {al }}$ Fr. Jo sé de $\mathrm{S}^{\text {ta }}$ Catharina nascido n'esta $\mathrm{Cid}^{\mathrm{e}}$ de Pais nobres, e abundantes, professo n'este Mostro . Era Religioso ex pedito, intellig ${ }^{\text {te }}$ e bem instruido nos estudos, freqüentava o confessionario com prudencia e carid $^{\mathrm{e}}<\mathrm{P}>$ pregava com $\mathrm{m}^{\text {ta }}$ satisfaçaõ. Conhecia a sua capacid ${ }^{\mathrm{e}}$ e eleva

${ }^{135}\left[\rightarrow \mathrm{Cip}^{\text {ra }}\right.$ da Conceiçaõ. $]$ (APFL) 
raõ aos empregos mais authorizados da ordem. Exerceo o lu gar de Prov ${ }^{\text {dor }}$ da Prov $^{\mathrm{a}}$ e no trienio seg ${ }^{\text {te }}$ foi eleito em D.Abb do Rio, descançou hum trienio e sahio eleito Prov ${ }^{\text {al }}$ encheo es tes lugares com bastante credito da sua pessoa e augm ${ }^{\text {to }}$ da Religiaõ. Padeceo alguns disgostos, porem o seu animo era superior a todas na contradiçoens; bem se experimentou na constancia, com q' soffreo hum falso testemunho, q' lhe levan taraõ, athe q' o m ${ }^{\text {mo }}$ q' o tinha arguido, inte[个eira]riorm ${ }^{\text {tel } 136}$ lhe resti tuio o credito, desdisendo-se repetidas vezes, e pedindo-lhe public/am/te ${ }^{\text {te }}$ perdaõ na vida, e na morte. $O$ resto da vida foi continuando opprimido de algumas molestias, q' adiantando com os annos o privaraõ da vida disposto com agraça dos

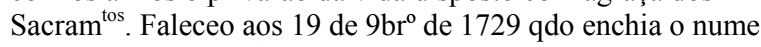
ro de 63 annos de id e 45 de Religiaõ. Foi sepultado a porta da Sachristia sendo D.Abb ${ }^{\mathrm{e}}$ o M.R.P. Preg $^{\mathrm{er}}$ Fr. Cipriano da $\mathrm{Conc}^{\mathrm{am}}$.

137 O centesimo trigesimo septimo foi o N.M.R.P ${ }^{\mathrm{e}}$.Ex.Prov ${ }^{\text {al }}$ Fr. Emeliano da $\mathrm{M}^{\mathrm{e}}$ de Deos natural da $\mathrm{Cid}^{\mathrm{e}}$ Porto de Pay honestos, professo neste Mostro ${ }^{\circ}$. Foi admittido ao nosso ha bito $\mathrm{p}^{\text {la }} \mathrm{p}^{\text {te }} \mathrm{q}$ ' tinha de musico ajudado de hum perf ${ }^{\text {ta }}$ voz. Era humilde, e prompto na satisfaçaõ de suas obrigações. Com septe annos de habito, foi $\mathrm{p}^{\mathrm{a}}$ o Rio estudar Filosofia, e Theologia, antes de concluir o Coll ${ }^{\circ}$, veio mudado $\mathrm{p}^{\mathrm{a}}$ esta ca

$-141-$

${ }^{136}[\uparrow$ eira $](A P F L)$ 
sa, aonde assistio freqüentado o coro, e mais actos da Communida[ $\uparrow \mathrm{e}] \mathrm{d}^{\mathrm{e}}$ athé q' foi nomeado Procurador geral da Prov ${ }^{\mathrm{a}}$ n'este emprego se descobrio a inteligência, e desembaraço, q' tinha $\mathrm{p}^{\mathrm{a}}$ occupar lugares mayores. Elegerão-no em D.Abbe d'esta casa, q' governou com grd' acerto, e maior fortuna: no trienio seg ${ }^{\text {te }}$ foi Definidor $1^{\circ}$ e ultimam ${ }^{\text {te }}$ Prov $^{\text {al }}$ em todos estes lugares mostrou /hum/ zello singular a observancia Religiosa, e utilid ${ }^{\mathrm{e}}$ do Mostr $^{\mathrm{o}}$, principal $\mathrm{m}^{\text {te }}$ desta Bahia aonde foi a sua maior assistencia.

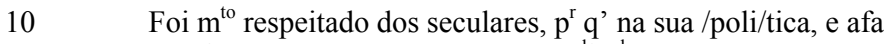
bilid ${ }^{\mathrm{e}}$, reconhecia hum predicado, $\mathrm{p}^{10} \mathrm{q}^{1}$ se fazia merece dor de toda a estimaçaõ dos $\mathrm{Snr}^{\mathrm{s}}$ Governadores, e pessoas mais authorisadas desta $\mathrm{Cid}^{\mathrm{e}}$ alcançou com grd $^{\mathrm{e}}$ credito de sua pessoa attrahir-lhe os animos $\mathrm{p}^{\mathrm{r}}$ uma attençaõ $\mathrm{m}^{\text {to }}$ destrin cta; d'elles conseguio $\mathrm{m}^{\text {tos }}$ favores $\mathrm{p}^{\mathrm{r}}$ a Religiaõ, $\mathrm{p}^{\mathrm{a}}$ todos aq $\mathrm{q}^{\text {les }}$, q' se valliaõ do seu resp ${ }^{o}$ Padeceo $\mathrm{p}^{\mathrm{r}}$ alguns annos a trabalho sa molestia de gota, d'onde em algumas occasioens 1 he ${ }^{137}$ re sultava acerbissimas dores, as quaes soffria com grd ${ }^{\mathrm{e}}$ confor mid $^{\mathrm{e}}$ e admiravel passiencia; assim foi passado o resto

20 da vida até q' de todo opprimido da queixa e destituido das forças naturaes, vendo q' era chegado o ultimo de seus dias recebendo com $\mathrm{m}^{\text {tos }}$ actos catholicos os ultimos Sacram ${ }^{\text {tos }}$ deixou resignado esta vida mortal em 27 de Março de

${ }^{137} \mathrm{O}<\mathrm{h}>$ está grafado com o traço horizontal do $<\mathrm{t}$. 
1730 sendo D. $\mathrm{Abb}^{\mathrm{e}}$ o M.R.P. Preg $^{\text {or }}$ Fr. Cyprianno da Conc $^{\mathrm{am}}$.

138 O centesimo trigesimo oictavo foi o $\mathrm{P}^{\mathrm{e}}$.Preg ${ }^{\mathrm{dor}} \mathrm{Fr}$. Antonio Les sa natural de Matosinhos, professo neste Mostr ${ }^{\circ}$. Era Re ligioso de bons costumes, e obserservante ${ }^{138}$ dos votos, q' professou. Satisfazia perfeitam ${ }^{\text {te }}$ as suas obrigaçoens; poucos tempos ao depois de Pregador pedio licença $\mathrm{p}^{\mathrm{a}}$ hir a villa de $\operatorname{Mara}^{139}[\uparrow a]$ gogipe pregar huns sermoens, $\mathrm{na}^{\mathrm{ma}}$ terra foi acom mettido de huma maligna, q' em poucos dias lhe tirou avida; dizem, q' os Religosos de S.Fran ${ }^{\mathrm{co}}$ lhe deraõ a sepultura no seu convento de [†Paragu]assú. Faleceo sendo D.Abb ${ }^{\mathrm{e}}$ o M.R.P.Preg ${ }^{\mathrm{dor}}$ Fr. Cyprianno da Conc ${ }^{\mathrm{am}}$.

139 O centesimo trigesimo nono foi o $\mathrm{P}^{\mathrm{e}}$. Preg ${ }^{\text {dor }}$ Fr. $\mathrm{M}^{\mathrm{el}}$ de $\mathrm{S}^{\text {to }} \mathrm{An}^{\text {to }}$ natural da $\mathrm{Cid}^{\mathrm{e}}$ do Rio de Janr ${ }^{\mathrm{o}}$, e professo no $\mathrm{m}^{\mathrm{mo}} \mathrm{Mostr}^{\mathrm{o}}$. Nos seus ultimos votos sahio reprovado, e despedido $\mathrm{p}^{\mathrm{r}}$ seu $\mathrm{M}^{\mathrm{e}}$ de entre os Religosos, $/ \mathrm{nem} / \mathrm{p}^{\mathrm{r}}$ isso desmaiou no espirito da sua vocaçaõ; recorreo a Sé Apostolica, e tambem ao $\mathrm{R}^{\mathrm{mo}}$ e alegando o seu dir ${ }^{\text {to }}$ julgou se $\mathrm{p}^{\mathrm{r}}$ sent ${ }^{\mathrm{ca}}$, $\mathrm{q}^{\prime}$ completo o tempo de noviciado o admittissem a profissaõ; ao dep ${ }^{\mathrm{s}}$ de professo veio $\mathrm{p}^{\mathrm{a}}$ este Mostro ${ }^{\mathrm{o}}$, e nelle viveo com $\mathrm{m}^{\text {ta }}$ exem plarid $^{\mathrm{e}}$, seguindo com grd ${ }^{\mathrm{e}}$ consolaçaõ, e alegria todos os actos da comunid ${ }^{\mathrm{e}}$. Ao dep ${ }^{\mathrm{s}}$ de Preg ${ }^{\mathrm{dor}}$ foi administrar afaz ${ }^{\mathrm{da}}$

${ }^{138}$ A sílaba $<$ ser $>$ foi escrita duas vezes no original.

${ }^{139}[\uparrow a](A P F L)$ 
da ilha grd $^{\mathrm{e}}$ no Rio de S.Fran ${ }^{\mathrm{co}}$, aonde mostrou o seu zello, e fidelid $\mathrm{e}^{\mathrm{e}} ; \mathrm{p}^{\mathrm{r}}<\mathrm{al}>$ occasiaõ de algumas molestias recolheo-se ao Mostro ${ }^{\circ}$, e n'elle foi nomeado Superior com satisfaçaõ dos Religiosos, aos $\mathrm{q}^{\mathrm{s}}$ desejava agradar sem prejuiso da observancia, e diciplina regular. A doeceo de hum trabalhoso flacto, q' empedindo lhe ares piraçaõ algumas vezes o deixava $\mathrm{p}^{\mathrm{r}} / \mathrm{morto} /$; em hũa occasiaõ q' experimentou maior ataque, sahio da cella pedindo em altas vozes, q' lhe acudissem com os Sacram $^{\text {tos }}, p^{r}$ q' estava espirando; a toda pressa chegou o Prior e dando absolviçaõ dentro de poucos inst ${ }^{\mathrm{es}}$ the cahio morto nos braços. Faleceo em 21 de Julho de 1730 sendo D.Abb ${ }^{\mathrm{e}}$ o N.M.R.P ${ }^{\mathrm{e}}$.Ex.Prov ${ }^{\text {al }}$ Fr. Joaõ Baptista da Cruz.

$15140 \quad$ O centesimo quadragesimo foi o $\mathrm{P}^{\mathrm{e}}$. Preg ${ }^{\text {dor }}$ Fr. Martinho da Assumpçaõ, nascid/o/ n'esta Cid ${ }^{\mathrm{e}}$ de Pais nobres, professo n'este Mostr ${ }^{\circ}$. Movido de huma inclina çaõ, q' logo d'esde os seus primr ${ }^{\text {os }}$ annos teve a nossa Religiaõ, conseguindo a licença de seus Pais, pedio o nosso $\mathrm{S}^{\text {to }}$ habito, o $\mathrm{q}^{1}$ foi admettido na id ${ }^{\mathrm{e}}$ de quinse annos, professou $\mathrm{p}^{\text {lo }}$ os votos de todos os Monges, $\mathrm{p}^{\mathrm{r}} \mathrm{q}^{\text {' }}$ nelle observaraõ os requisitos necessarios $\mathrm{p}^{\mathrm{a}}$ o estado 
Religoso. No choristado viveo sempre assustado as leis da Religiaõ e obediencia aos seus Prelados, e aos seus Mestres, com seis annos de habito foi $\mathrm{p}^{\mathrm{a}}$ o Collegio da Graça, estudar Filosofia e no fim de Theologia feitos os actos de Pregador, voltou $\mathrm{p}^{\mathrm{a}}$ este Mostr ${ }^{\mathrm{o}}$ aonde perfeitam $^{\text {te }}$ satisfazia as suas obrigaçoens. Passados poucos annos deixando-se vencer de huma tentaçaõ de ver terras estranhas $\mathrm{q}^{\mathrm{do}} \mathrm{ja}$ naõ tinha liberd ${ }^{\mathrm{e}} \mathrm{p}^{\mathrm{a}}$ o fazer embarcou-se $\mathrm{p}^{\mathrm{a}} \mathrm{Lx}^{\mathrm{a}}$; chegando aq ${ }^{\text {la }}$ Cor te ao depois q' vio, o q' desejava alcançou perdaõ da fuga hum bre ve de Pregador Urbico, e com elle se embarcou $\mathrm{p}^{\mathrm{a}}$ esta $\mathrm{Cid}^{\mathrm{e}}$, e recolhido ao Mostr ${ }^{\circ}$ o mandaraõ Convetual da Parahiba; o D.Abb ${ }^{\mathrm{e}}$ a/ttend/en do a pobresa, em $q^{\text {to }} n$ 'este tempo se achava aq ${ }^{\text {la }}$ casa $p^{\text {la }}$ invazaõ Olandesa o mandou $\mathrm{p}^{\mathrm{a}}$ Minas adquirir algumas esmolas $\mathrm{p}^{\mathrm{a}}$ be neficio do Mostr ${ }^{\circ}$ naõ conseguio, o q' desejava, $p^{r} q^{\prime}$ poucos tempos ao depois de chegar aparagem $\mathrm{p}^{\mathrm{a}}$ onde caminhava descahio em hum total esquecim ${ }^{\text {to }}$ de todas as cousas, de sorte q' naõ sabia $q^{\text {do }}$ era Domingo, ou dia $\mathrm{S}^{\mathrm{to}}$, nesta forma buscou o Rio de $\mathrm{Janr}^{\mathrm{o}} \mathrm{d}^{\prime}$ 'onde o embarcaraõ $\mathrm{p}^{\mathrm{a}}$ esta Casa, na $\mathrm{q}^{1}$ acabou a sua vida logo ao dep $\mathrm{p}^{\mathrm{s}}$ da sua chegada. Faleceo em primr ${ }^{\circ}$ de $7 b^{\circ}$ de 1730 tento de id ${ }^{\mathrm{e}}$ 45 annos, e de habito 30. Era D.Abb ${ }^{\mathrm{e}}$ o N.M.R.P ${ }^{\mathrm{e}}$.Ex.Prov ${ }^{\mathrm{al}}$ Fr. Jo aõ Baptista da Cruz.

141 O centesimo quadragesimo primr ${ }^{\circ}$ foi o $\mathrm{P}^{\mathrm{e}}$. Preg ${ }^{\text {dor }}$ Fr.José d'As sumpçaõ natural d'esta $\mathrm{Cid}^{\mathrm{e}}$ da $\mathrm{B}^{\mathrm{a}}$ de Pais honestos, e professo 
n'este Mostro . Era prompto em satisfazer as suas obrigaçoens ${ }^{140}$

e cuidava com dilig ${ }^{\text {cia }}$ na execuçaõ dellas; causava porem

disgosto aos Prelados, e aos $\mathrm{M}^{\mathrm{es}} \mathrm{p}^{\mathrm{r}}$ ser de huma condiçaõ aspe ra. Ordenado de Sacerdote, o admittiraõ ao Collo de Pernambuco, aonde naõ só se mostrou pouco sofrido, mais tambem deso bediente; no principio da Theologia; adoeceo do mal de S.Lasaro; deixaraõ-no continuar os estudos, $\mathrm{p}^{\mathrm{r}}$ naõ lhe causarem alguns disgostos prejudiciaes aq ${ }^{\text {la }}$ molestia; feito Preg ${ }^{\text {dor }}$ veio $\mathrm{p}^{\mathrm{a}}$ este $^{\mathrm{a}}$ Mstr $^{\mathrm{O}}$ e d'elle foi governar a faz ${ }^{\text {da }}$ da Itapuam, parecendo-lhe q' naq ${ }^{\text {las }}$ $\mathrm{p}^{\text {tes }}$ passaria com mais alivio; porem em breves tempos se /lhe/ augmentou o mal, de sorte q' aberto em chagas ficou cheio de bixos; avisado o Prelado o estado em q' se achava este Monge, mandou hum Religioso, q' fosse buscar; che gou o $\mathrm{P}^{\mathrm{e}}$. a faz $\mathrm{z}^{\mathrm{da}} \mathrm{e}$ achando em huma lastimosa figura, lhe advertio, q' se confessasse; confesçou-se com $\mathrm{m}^{\text {tos }}$ signaes de arrependim ${ }^{\text {to }}$ e passadas poucas horas trocou esta $p^{\text {la }}$ outra vida na id de 42 , e de habito 21 foi condusido $\mathrm{p}^{\mathrm{a}} \mathrm{o}$ Moste/y/ro aonde lhe deraõ a sep/u/ltura aos 28 de Junho de 1731 sendo D.Abb o N.M.R.P ${ }^{\mathrm{e}}$.Ex.Prov ${ }^{\mathrm{al}}$ Fr. Joaõ Baptis ta da Cruz.

142 O centesimo quadragesimo seg $^{\text {do }}$ foi o M.R.P. Preg $^{\text {dor }}$ Fr. Dionisio de S.José, nascido nesta $\mathrm{Cid}^{\mathrm{e}}$ de Pais nobres

${ }^{140} \mathrm{O}<\mathrm{e}>$ está grafado com $<\sim>$. 
e abundantes professo neste Mostr $^{\circ}$. Logo dos $/ \mathrm{s} /$ eus primr $^{\text {os }}$ annos foi creado no temor de $\mathrm{D}^{\mathrm{s}}$, elevado $\mathrm{p}^{\text {lo }}$ caminho da per feiçaõ, e p $\mathrm{p}^{\mathrm{a}} \mathrm{q}$ ' logo dos seus principios se exercitasse em bons costu mes, lhe vestiraõ a cogula Benedictina da $q^{1}$ usou athe os dez annos de id $^{\mathrm{e}}$ no tempo competente o mandaraõ aprender al gumas artes liberaes, prendas dignas de hum homem bem nascido. Foi bom Grammatico, e excellente Musico; e huma das melhores vozes q' teve este Mostr ${ }^{\circ}$. Admittido ao Noviciado profes sou com grd $^{\text {e }}$ cont $<t>/ e \backslash$ ntam $^{\text {to }}$ seu, e satisfaçaõ dos Religiosos $\mathrm{p}^{\text {las }}$ prendas de q' era dotado; procedeo ${ }^{141}$ [个 como] se esperava de sua /boa/ e ducaçaõ, e bons costumes. Nos estudos se applicou com tanto desvello, q' no $<\mathrm{f}>$ /cloro do Collegio, mereceo q' lhe nomeado Preg ${ }^{\text {dor }}$ urb $^{\mathrm{o}}$; neste exercicio conseguio hum bom nome, $\mathrm{p}^{\mathrm{r}}$ ser dotado de todos os predicados, q' constitue hum Orador excellente. Inteirados os

15 Prelados Superiores da sua capacid ${ }^{\mathrm{e}}$ o elegeraõ D.Abb ${ }^{\mathrm{e}}$ deste Mostro tendo 22 annos de habito; foi a noticia desta eleiçã̃ ouvida com gosto nesta terra, na concideraçaõ de verem pre miadas os merecim ${ }^{\text {tos }}$, govern/o/u com acerto, e boa disposiçaõ; naõ se livrou porem de q' the dessem alguns encargos, d'onde lhe resulta raõ algumas penitencias, as quaes satisfez como humilde, e obe diente: na hora de sua morte declarou q' as satisfizera $\mathrm{p}^{\text {lo }}$ amor de Deos, $\mathrm{p}^{\mathrm{r}} \mathrm{q}$ ' nos encargos q' lhe deraõ naõ se achava convencido nem culpado. Ao depois de Jub ${ }^{\circ}$ buscou o Mostr ${ }^{\circ}$ das Brottas $\mathrm{p}^{\mathrm{a}}$ viver

${ }^{141}$ [ $\uparrow$ como] (APFL) 
em retiro, e separado de tudo, o q' lhe podesse perturbar a paz, e quietaçaõ do seu espirito. Passados alguns annos sentindo-se molestado em huma perna, buscou este Mostro ${ }^{\circ}$, aonde ja naõ naõ achou remedio $\mathrm{p}^{\mathrm{a}}$ a queixa, q' padecia, q' se disse ser hua ${ }^{142}$ postema; administraraõ os $\mathrm{S}^{\text {tos }} \mathrm{Sacram}^{\text {tos }} \mathrm{q}$ ' recebeo com $\mathrm{m}^{\text {ta }} \mathrm{de}$ voçaõ, e ternura; pedio q' lhe dessem hum Snr. Crucificado, e a-

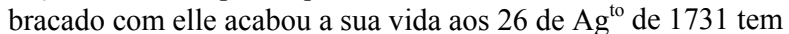
do de id ${ }^{\mathrm{e}}$ cincoenta e sete, e de habito 41. Era D.Abb ${ }^{\mathrm{e}}$ o N.M.R. $\mathrm{P}^{\mathrm{e}}$.M $\mathrm{M}^{\mathrm{e}}$.Ex.Prov ${ }^{\mathrm{al}}$ Fr. Joaõ Baptista da Cruz.

$10143 \mathrm{O}$ centesimo quadragesimo tercr ${ }^{\mathrm{o}}$, foi o $\mathrm{P}^{\mathrm{e}}$. Collegial Fr. Joaõ d'As sumpçaõ nascido na Villa de $\mathrm{S}^{\text {tos }}$ de Pais honestos, e ricos, profes so no Mostro de S.Paulo. Teve o seu Coll ${ }^{\circ}$ de Filosofia no Mostr ${ }^{\circ}$ de Olinda, e a Theologia n'esta casa, poucos annos se utilisou a Religiaõ do seu conhecido prestimo, $\mathrm{p}^{\mathrm{r}} \mathrm{q}$ ' humas bexigas encuraveis o privaraõ da vida, disposto com todos os Sacram ${ }^{\text {tos }}$ aos 12 de Agosto de 1732 sendo D.Abb ${ }^{\mathrm{e}}$ o N.M.R.P ${ }^{\mathrm{e}}$. Ex.Prov ${ }^{\mathrm{al}}$ o Dr. Fr. Joaõ Baptista da Cruz.

144 O centesimo quadragesimo quarto foi o $\mathrm{P}^{\mathrm{e}}$. Fr. José de $\mathrm{S}$. Boaventura natural da $\mathrm{Cid}^{\mathrm{e}}$. de Braga professo no Mostr $^{\mathrm{o}}$ de Pernam ${ }^{\mathrm{co}}$. Era Religioso obediente, e humil de, e cincero. Foi Presid ${ }^{\text {te }}$ em Jundiahy, e Definidor da $-148-$

${ }^{142} \mathrm{O}<\mathrm{U}>$ está grafado com $<\sim>$. 
Provincia, ao depois de ter servido a Religiaõ $\mathrm{p}^{\mathrm{r}}$ estes Mos $\operatorname{tr}^{\mathrm{os}} \mathrm{p}^{\mathrm{r}}$ onde assistio, retirou $\mathrm{p}^{\mathrm{a}}$ o Mostr ${ }^{\mathrm{O}}$ da Graça; passados an nos acomettido de huma molestia grave, buscou esta casa $\mathrm{p}^{\mathrm{a}}$ morrer entre os Religiosos, q' na doença o trataraõ com carid ${ }^{\mathrm{e}}$; e na $/ \mathrm{m} /$ orte lhe deraõ a sepultura como Religioso, e Irmaõ q' era, do q' nunca se soube q' o offendesse, ou molestasse Mõ ge algum em todo o tempo da sua vida. Faleceo com todos os Sacram $^{\text {tos }}$ em 28 de Fever ${ }^{\circ}$ de 1733. Sendo D.Abb ${ }^{\mathrm{e}}$ o N.M.R. Ex.Prov $^{\text {al }}$ o $D^{r}$. Fr. Joaõ Baptista da Cruz.

$10145 \mathrm{O}$ centesimo quadragesimo quinto foi o M.R.P. Preg $^{\mathrm{d}}$.r. Fr. Fran cisco das chagas nascido na villa de Amarante de Pais nobres professo neste Mostr $^{0} \mathrm{p}^{\mathrm{a}}$ se ordenar de Sacerdote foi ao Rei no, aonde entre os Monges da Congregaçaõ acreditou a sua Prov $^{\mathrm{a}}$; tanto com a sua perfeita observancia, e recto procedim ${ }^{\text {to }}$, co mo tambem $\mathrm{p}^{\text {las }}$ boas auzensias, q' fez dos Monges d'ella; no re gresso foi ter o seu Collo ao Rio de Janro; no depois de Preg ${ }^{\text {dor }}$ foi administrar a fazenda de Iguasú; aonde deo a conhecer ${ }^{143}$ a sua carid ${ }^{\mathrm{e}}$, e o seu zello: naõ menos caritativo, e zeloso se mostrou na $v^{\text {a }}$ de Sorocaba, em q' foi Presid ${ }^{\text {te }}$. Cuidando com grd $^{\mathrm{e}}$ desvello do augmento daq ${ }^{\text {la }}$ Presidencia, q'prin cipiava entaõ. Passados alguns annos foi eleito em D.Abb ${ }^{\mathrm{e}}$ do Mostr $^{\circ}$ de Pernambuco, e como o lugar era maior, se des cobrio sua capacidade $\mathrm{p}^{\mathrm{a}}$ os empregos da Religiaõ, no seu $-149-$

${ }^{143}$ A sílaba $<$ cer $>$ foi $($ APFL $)$ 
trienio se fiseraõ obras importantes, como foraõ hum Dor

mitorio $\mathrm{n} / \mathrm{o} / \mathrm{vo}$, e outras mais $\mathrm{p}^{\text {los }}$ os Engenhos. Mandou bus

car a Portugal ornamentos preciosos, de $\mathrm{m}^{\text {to }}$ custo $\mathrm{p}^{\mathrm{a}}$ a Sachris

tia, naõ faltando com o preciso, e ne necessario $\mathrm{p}^{\mathrm{a}}$ a sustenta çaõ, e provim ${ }^{\text {to }}$ de quarenta Monges, $\mathrm{q}^{\prime}$ tevi $\mathrm{p}^{\mathrm{r}}$ subditos, e da $\mathrm{m}^{\text {ma }}$ sorte com as esmolas dos Pobres, aos quaes liberal $\mathrm{m}^{\text {te }}$ os mandava soccorrer na Portaria. Concluido o seu tri enio sem deixar empenhos, veio $\mathrm{p}^{\mathrm{a}}$ este Mostr ${ }^{\mathrm{o}}$ occupado no lugar de Defenidor, no trienio seguinte o elegeraõ $\mathrm{Abb}^{\mathrm{e}} \mathrm{d}$ 'esta casa, aq $\mathrm{q}^{\mathrm{l}}$ governou com grd $^{\mathrm{e}}$ acerto, e adiantam ${ }^{\text {to }}$ no espiritual e temporal. Fizeraõ-se $\mathrm{mt}^{\text {as }}$ grad $^{\mathrm{es}}$ obras, das quaes se dara noti cia no Catalogo dos Prelados d'esta casa. Foi tambem Visitador primr $^{\mathrm{o}}$, e seg ${ }^{\mathrm{da}}$ vez Defenidor. Passou n'este Mostro o resto da vi da conservando sempre o respeito, e attençaõ devida á sua pessoa, e aos seus annos. Foi Relgioso $\mathrm{m}^{\text {to }} \mathrm{am}^{\text {te }}$ da Prova ., exem plar, e observante frequentando os actos da comunid ${ }^{\mathrm{e}} \mathrm{em}^{\text {to }}$ teve forças $\mathrm{p}^{\mathrm{a}} \mathrm{o}$ fazer, sem se approveitar das dispenças permi ttidas $^{144}$ aos seu annos, e as suas molestias. Huma leve en fermid $^{\mathrm{e}}$ o privou da vida $\mathrm{p}^{\mathrm{r}}$ se achar ja na id ${ }^{\mathrm{e}}$ de no venta e dous annos. Faleceo com todos os Sacram ${ }^{\text {tos }}$ aos 13 de Agosto $^{145}$ de 1733 sendo D.Abb ${ }^{\mathrm{e}}$ o N.M.R.P. ${ }^{\mathrm{e}}$. Preg ${ }^{\text {dor }}$ Fr. Basilio das Neves. [Ainda existe a lapide tumular no nosso claustro, que indica o mez de Agosto como o da sua morte. $]^{146}$

146 O centesimo quadragesimo sexto foi o M.R.P. Preg $^{\text {dor }}$

\footnotetext{
${ }^{144} \mathrm{O}$ início das linhas 18,19 e 20 está sob um carimbo.

$145<$ de Agosto $>$ foi (APFL)

${ }^{146}$ [Ainda existe a lapide tumular no nosso claustro, que indica o mez de Agosto como o da sua morte.] (APFL)
} 
Fr. Alvaro da $\mathrm{M}^{\mathrm{e}}$ de Deos natural da $\mathrm{Cid}^{\mathrm{e}}$ do Porto /pr/ofes/s/o neste Mostr $^{\circ}$. Nos annos do Choristado servio nesta casa com $\mathrm{m}^{\text {ta }}$ satisfa çaõ aq ${ }^{\text {les }}$ empregos q' correm $\mathrm{p}^{\mathrm{r}}$ conta dos Juniores, $\mathrm{p}^{\mathrm{a}}$ se ordenar de Sa cerdote foi a Portugal, e chegado a Prov ${ }^{\mathrm{a}}$ foi admittido ao $\mathrm{Coll}^{\circ}$ no Rio de Janr ${ }^{\circ}$. Ao depois de Preg ${ }^{\text {dor }}$ veio mudado $\mathrm{p}^{\mathrm{a}}$ este Mostr ${ }^{\circ}$ aonde foi Prior cuidadoso edellig ${ }^{\mathrm{te}}$ na observancia regu lar. Tambem foi Secretario e compro do Prov $^{\text {al }}$, ultimam ${ }^{\text {te }}$ $\mathrm{Abb}^{\mathrm{e}} \mathrm{da}^{147}$ Parahyba trabalhando naq ${ }^{\text {la }}$ casa sem descanço, $\mathrm{p}^{\mathrm{r}} \mathrm{q}^{\text {' }}$ deo principio a capella maior, sendo lhe preciso abrir profun dos alicerces $\mathrm{p}^{\mathrm{a}}$ ficar com segurança, deixou-a fora do ali cerce em altura de vinte palmaz: aliviou o Mostro em $\operatorname{grd}^{\mathrm{e}}$ $\mathrm{p}^{\text {te }}$ do emp ${ }^{\mathrm{o}}$ em q' achou, fez outras obras de utilid $\mathrm{e}$ e bene $\mathrm{f}^{\mathrm{o}} \mathrm{p}^{\mathrm{a}}$ a casa, e retirando-se $\mathrm{p}^{\mathrm{a}}$ este Mostr ${ }^{\circ}$ foi governar a faz ${ }^{\mathrm{da}}$ o Rio Vermelho d'onde veio doente de cezoens, q' ajuntando se com hum flacto, q' padecia acabou a sua vida com gra ças dos Sacram $^{\text {tos }}$ aos 2 de Desembr ${ }^{\circ}$ de 1733 com 53 annos de $i^{\mathrm{e}}$., e trinta e seis de habito. Sendo D.Abb ${ }^{\mathrm{e}}$ o M.R.P. ${ }^{\mathrm{e}}$. Preg ${ }^{\text {dor }}$ Fr. Basilio das Neves.

147 O centesimo quadragesimo septimo foi o M.R $R^{\mathrm{e}} \cdot \mathrm{P}^{\mathrm{e}} \cdot \mathrm{M}^{\mathrm{e}} \mathrm{Jub}$ Fr.Fernando da Trind ${ }^{\mathrm{e}}$ nascido em $\mathrm{Lx}^{\mathrm{a}}$ de Pais honestos professo neste Mostro ${ }^{\circ}$. Foi Religioso dotado de $\mathrm{m}^{\text {tas }}$ pren das naturaes, e moraes e com ellas servio a Religiaõ,

${ }^{147}$ Entre $<$ da $>$ e $<$ Parahyba $>$ há um escrito não identificado. 
adquirindo-lhe honra e credito; bom musico, e bom La tino; escrevia e contava admiravelm ${ }^{\text {te }}$., $p^{\text {lo }}$ tempo adiante foi bom $\mathrm{M}^{\mathrm{e}}$ e bom Prelado. Leo Theologia no Rio de Janr ${ }^{\mathrm{o}}$ e ao depois Filosofia, empenhandose em q' os seus discipu los fossem sabios, e virtuosos. Foi Prior neste Mostro., e jun $\operatorname{tam}^{\text {te }}$ de trez $<$ de trez $>$ popilos, q' $p^{\text {lo }}$ tempo adiante bem se lhe deraõ a conhecer, $\mathrm{p}^{\mathrm{r}}$ discipulo de hum taõ $\operatorname{grd}^{\mathrm{e}} \mathrm{M}^{\mathrm{e}}$., $\mathrm{p}^{\mathrm{r}}$, q' alem de os instruir na pratica das virtudes, tambem lhes ensinou grammatica e musica. Adiantou $\mathrm{m}^{\text {to }}$ a Irmand $^{\mathrm{e}}$ de N.Snr ${ }^{\mathrm{a}}$ do Pilar, da $\mathrm{q}^{1}$ foi Capelaõ alguns annos. Por mor te ou deixaçaõ do $\mathrm{Abb}^{\mathrm{e}}$ daq ${ }^{\text {la }}$ casa, o elegeraõ Presid ${ }^{\text {te }}$., ao depois veio eleito em $\mathrm{Abb}^{\mathrm{e}}$ entrou no seu governo com grd ${ }^{\mathrm{e}}$ satisfaçaõ dos Subditos, ${ }^{\mathrm{r}}$ q' o exemplo lhes dava de Religiaõ, e virtude pro dusia nelles admiraveis effeitos vivendo todos dignam ${ }^{\text {te }}$. Como $\mathrm{p}^{\text {tes }}$ de hum corpo, q' tinha huma tal cabeça; porem o ini migo da paz fazendo-lhe insofrivel a sua quietaçaõ, excitou algumas discordias, das quaes the resultaraõ disgostos, e tra balhos, q' soffria, e dissimulava como prudente, e virutoso. No meio do seu trienio deixou o Mostro e passou a Portugal; /e de/ sejo de ver terras tambem foi a Roma Sim grande Mo/n/ ge, perfeito Mestre, q' fallou com o Pontifice he falso beijou os pes [ $\uparrow$ beijou os pes] $]^{148}<$ do $>$ do Pontifice, e lhe perguntou com q' lingua queria q' lhe fallasse, ao q' respondeo o $\mathrm{Sm}^{\mathrm{o}} \mathrm{P}^{\mathrm{e}}$., q' na Por 
tuguesa q' gostava de a ouvir. Concedeo lhe /v/ari/a/s indul gencias e com a sua abençaõ se recolheo ao Reino e do Reino buscou o Mostro de Pernambuco. Pouco

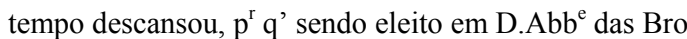
ttas, com grande fortuna daquelle Conv ${ }^{\text {to }}$ veio tomar posse delle; governou como se esperava de sua observan cia, e zelo. No fim do seu trienio retirou $\mathrm{p}^{\mathrm{a}} \mathrm{o}$ Mostr $^{\mathrm{O}} \mathrm{da}$ Graça $\mathrm{p}^{\mathrm{a}}$ empregar o resto das forcas no serviço da $\mathrm{q}^{\text {la }}$ casa. Passados alguns annos adoeceo de cesoens, como ja es tava em id avançada, logo conheceo q' estavaõ cheios os seus dias recolheo se a este Mostr ${ }^{\circ}$ a esperar a $q^{1}$ chegou com tantos annos de preparo, como tinha de Religioso $p^{r}$ q' sempre foi observante, austero, e penitente.

Faleceo aos 23 de $\mathrm{Janr}^{\circ}$ disposto com a graça dos Sacra $\mathrm{m}^{\text {tos }}$ no anno 1734 , Tendo de idade setenta e seis annos e de habito sesenta. Era D.Abb ${ }^{\mathrm{e}}$ o M.R.P. ${ }^{\mathrm{e}}$.Preg ${ }^{\mathrm{dor}}$ Fr. Basilio das Neves.

148 O centesimo quadragesimo oictavo foi o M.R.P.Preg ${ }^{\mathrm{d}}$. $\mathrm{Jub}^{\mathrm{o}} \mathrm{Fr}$. José de Nasareth nascido na $\mathrm{Cid}^{\mathrm{e}}$ do Porto, pro fesso neste Mostr ${ }^{\circ}$. Era Religioso obediente zeloso, e $\mathrm{am}^{\mathrm{e}}$ da paz. Nesta casa teve o seu Collegio de Filosofia 
e hum anno de Theologia no fim da $\mathrm{q}^{1}$ alcançou breve de Pregador, e pela Religiaõ foi nomeado $\mathrm{Urb}^{\circ}$., encheo o tempo da sua jubilaçaõ, e ficou neste Mostro . Seguindo os actos conventuaes a q' era obrigado, naõ se escusou porem de ser Prior, encar regando-se de grd $^{\mathrm{e}}$ parte do trabalho da casa, no tempo q' exercia este lugar com satisfaçaõ dos Re ligiosos, e obser adiantam ${ }^{\text {to }}$ da observancia, adoeceo de huma molestia, q' parecendo leve, lhe tirou avi da mais depressa do q' se esperava. Faleceo aos 12 de Junho de 1734. Sendo D.Abb ${ }^{\mathrm{e}}$ o M.R.P ${ }^{\mathrm{e}}$.Preg ${ }^{\text {dor }}$ Fr. Ba silio das Neves. 
149 O Sentecesimo quadragesimo nono foi o $\mathrm{P}^{\mathrm{e}}$. pregador Fr. Joaõ de $\mathrm{S}$.

/Anna/ nascido nesta Cidade de Pais nobres, profeço no Mos= teiro do Rio de Janr ${ }^{\circ}$. Naquelle Mosteiro assistio muitos annos sem nota do seu procedimento; mas antes com edi= ficaçaõ, [ $\uparrow$ dos Religiosos] aos quais servia, e amava sem nunca os offender, ou molestar; e com razaõ se mostraraõ sentidos, quando se retirôu $\mathrm{p}^{\mathrm{a}}$ esta caza. Foi 'foi' procurador da Província, e $\mathrm{Abb}^{\mathrm{e}}$ do Mos= /teiro/ das Brottas; e em ambos os empregos se mostrou diligente, e cuidadozo em cumprir com a sua obrigaçaõ, e dahi $\mathrm{p}^{\mathrm{r}}$ /dian/te se escuzou de outros lugares, e recolhendo-se a este Mos= teiro só cuidava em se dispor $\mathrm{p}^{\mathrm{a}}$ a sua conta final; freqüenta $=$ va os actos de communidade, etinha particulares devoções, e /exe/rcicios, a que nunca faltava, assim foi passando o resto da vida; athe que infermando gravemente, ao depois de rece= /bidos/ os ultimos Sacramentos, co/m/pletou os seus dias com huma morte admiravel aos olhos dos homens. Faleceo aos 13 de Junho de 1734 sendo D.Abb o Padre Mestre R.P.Pre gador Frei Bazilio das Neves.

150 O Sentesimo quinquagesimo foi o P.Pregador Fr. Leaõ da Pied ${ }^{\mathrm{e}}$. natural desta Cidade da Bahia, e professo neste Mosteiro. era Religiozo obediente, e prompto $\mathrm{p}^{\mathrm{a}}$ satisfazer as Obrigações pertencentes ao seu estado. Estudou Filosofia nos pateos, e The= ologia nesta caza. Servio a Religiaõ em alguns empregos: como foi o de mordomo, eoutros mais, com zêlo, e fidelidade. Foi $\mathrm{Abd}^{\mathrm{e}}$. das Brotas, aonde os seus subditos experimentaraõ a sua Caridade, eos Siculares a sua virtude. Recolhido a es= te Mosteiro, nelle vivêo bastantes annos, empregando-se em religiosos, e louvaveis exercicios. Falecêo com a graça dos Sacra= ment/os e/m 17 de Novembro de 1734 send D.Abbade o P.M. 
R.P.Pregadôr Frei Bazilio das Neves.

$\left[\mathrm{f}^{\mathrm{0}} 79 \mathrm{v}^{\mathrm{0}}\right]$

151 O Sentesi $/ \mathrm{m} / \mathrm{o}$ quinquagesimo $\mathrm{premr}^{\mathrm{o}}$ [ $\uparrow$ foi] o P.M.R.P.Ex.Provincial Fr. A/n/t/ô/nio da Trindade, nascido em hum lugar chamado cavalois do Arcebispo de Braga de geraçaõ nobre, profeço neste mosteiro em premio da sua vocaçaõ foi admitido ao Noviciado, quando já contava vinte $\mathrm{a}^{\mathrm{s}}$ de idade, concluido elle profeçôu a vi= da religioza com aceitaçaõ dos Monges, $\mathrm{p}^{\mathrm{r}}$ que o julgaraõ $\mathrm{co} / \mathrm{m} /$ os predicados necessarios $\mathrm{p}^{\mathrm{a}} \mathrm{o}$ estado Monacal. Teve o seu colégio na Graça, e nomeado pregador veio $\mathrm{p}^{\mathrm{a}}$ este $\mathrm{Mostr}^{\mathrm{o}}$., aonde $\mathrm{se}=$ guia os actos de Communid ${ }^{\mathrm{e}}$ com edificaçaõ, e bom exemplo dos Religiozos. Exercêo aocupaçaõ de mordomo, eneste premr ${ }^{\circ}$ imprego se foi discubrindo a sua $/$ capac/id $\mathrm{p}^{\mathrm{a}}$ cousas grandes. Passou a prior desta caza, satisfazendo com grande zêlo as obriga $=$ ções do seu lugar, no trienio seguinte, elegeraõ $\mathrm{Ab}^{\mathrm{e}}$ das Brottas,

15 e sendo que os reditos de /ca/za eraõ diminutos mandou dar $\mathrm{prin} / \mathrm{cip} /$ io ao dormitorio nôvo, eo vio completo no seu tempo sem gravar o Mosteiro com empenhos. Naõ o deixaraõ dis= cançar; $\mathrm{p}^{\mathrm{r}}$ que viaõ os grandes fructos, $\mathrm{q}^{\prime}$ a Religiaõ colhia dos seus gover/n/os. Foi compr ${ }^{\circ}$ elogo Abade do Rio de Janr ${ }^{\circ}$. Neste em prego mostrou hum grande cuidado na observancia Reli= gi/oza/, eda utilidade temporal; mandou comprar quarenta escrav/o/s p $\mathrm{p}^{\mathrm{a}}$ beneficios das fazend $/ \mathrm{a} / \mathrm{s}$ efez $\mathrm{m}^{\text {tas }}$ obras necessarias $\mathrm{p}^{\mathrm{a}}$ augmento do Mosteiro. Pelo disvello com que se houve nes/tas/ duas Prelazias, merecêo ser elevado ao lugar de Provincial, vi= 25 zitando a Provincia deixou o nome de bom prelado $\mathrm{p}^{\text {lo }}$ accer to com que se houve nas suas dispozições; $\mathrm{e}^{\text {la }}$ benignida/de/ com que tractava aos súbditos $\mathrm{p}^{\mathrm{r}}$ que sem faltar as obri gações de Juiz, a todos amava: como Pai: Deraõ lhe hum 
Trienio $\mathrm{p}^{\mathrm{a}}$ discançar do trabalho ao Provincialado, e na junta

$\left[\mathrm{f}^{\mathrm{0}} 80 \mathrm{r}^{\mathrm{0}}\right]$ seguinte o ellegeraõ Prelado deste Mosteiro. Bem quise/ra/ elle escu zar-se deste imprego; $\mathrm{p}^{\mathrm{m}}$ os preceitos, com que se vio obrig/ado, lhe/ naõ deraõ lugar a izentar-se deste nôvo trabalho. Tomou posse do lugar, e com era já bem notoria a sua capacid ${ }^{\mathrm{e}} \mathrm{p}^{\mathrm{a}}$ os gover= nos todos o respeitaraõ, e lhe obedeceraõ como a hum Prelado be $=$ nemerito, que sempre tractava aos subditos com caridade, e $\mathrm{a}=$ mor Paternal. Ultimamente o elegeraõ segunda vez os voga $=$ es da junta Geral em Provincial, lembrados do grande accerto com que governara a premr ${ }^{\mathrm{a}}$. Neste lugar dêu as ultimas provas da sua capacidade $\mathrm{p}^{\mathrm{a}}$ os lugares, que sempre enchera com hon= ra, com respeito, com accerto. Os seus governos sempre foraõ felizes, e sempre plauziveis. O Seu intento era q' o Patrimonio dos Mosteiros se gastasse no culto Divino, na sustentaçaõ dos Monges, e nas esmollas aos Pobres, $\mathrm{p}^{\mathrm{r}} \mathrm{q}$ ' julgava accertadam ${ }^{\mathrm{e}}$, que estes dispendios naõ atrazavaõ as Cazas, mas antes augmen= tavaõ. Cuidôu em que aobservancia Religiosa se concervasse no seu ponto, sem $\mathrm{p}^{\mathrm{r}}$ isso faltar aos subditos com os favores, beneficios, que se naõ opunhaõ aos estatutos da Religiaõ. Era de Estatura mais, que mediana, que incultava respeito, $\mathrm{aq}^{\mathrm{m}}$. o via, parecia severo na presença, e era todo benigno, e Cheo de piedade. No fim do seu ultimo governo se deixou ficar neste Mosteiro, o $\mathrm{q}^{1}$ sempre teve afortuna, que grande parte dos Religiosos mais beneme= ritos da Provincia o honrassem com as suas cinzas. Passados alguns annos em louváveis exercicios, achando-se no Engenho da Pra/ia/ sentio-se molestado nas costas, e discobrindo-se the hũ tumor pestilentento, a que chamaõ intraz atoda apreça se re= colheo a/o/ Mosteiro, naõ abuscar/r/emedio pa a queixa, que já 
o naõ tinha; mas sim a cuidar nas ultimas desposições $\mathrm{p}^{\mathrm{a}}$ a sua conta final. Pedio os ultimos Sacramentos aos quaes recebêo com $\mathrm{m}^{\text {tos }}$ actos de Catolico; edahi a poucas horas espirou, dei xando /aos/ Religiosos saudades, e sentidos $\mathrm{p}^{\mathrm{r}}$ se verem privados da Companhia de hum monge, que sempre os governôu com prudencia, rectidaõ, e inteira. Falecêu em 13 de $9 \mathrm{br}^{\circ} 1734 \mathrm{com}$ $64 \mathrm{a}^{\mathrm{s}}$ de idade, e $43 \mathrm{a}^{\mathrm{s}}$ de habito. Seu Corpo foi sepultado na Sacristia com as honras devidas ao seu lugar. Era D. $\mathrm{Abb}^{\mathrm{e}}$ o P. M. o $\mathrm{R}^{\mathrm{mo}}$ P.Pregadôr Fr. Bazilio das Neves.

$10152 \mathrm{O}$ sentesimo quiquagesimo segundo foi o P.M.R ${ }^{\mathrm{mo}}$.Pregador Fr. Cypriano da Conceição natural da Cidade de Braga filho de Pais honestos, professo nesta caza. Era Religiozo expedito, e diligente em cumprir com as suas obrigações. Teve o seu Collegio no Rio de $\mathrm{Janr}^{\mathrm{o}}$. e ao depois de pregador veio $\mathrm{p}^{\mathrm{r}}$. conventual deste Mosteiro, aonde naõ faltava ao côro pulpito, e confecionario, e aos mais actos da Religiaõ. Ajudava $\mathrm{m}^{\text {to }}$. aos Procuradores das Deman= das, $\mathrm{p}^{\mathrm{a}}$. o que lia, e revolvia com $\mathrm{m}^{\text {ta }}$ coriozid $^{\mathrm{e}}$ os Titulos das terras, e todos os papeis do cartorio, conseguindo $\mathrm{p}^{\text {lo }}$ tempo adiante hua ${ }^{149}$ taõ grande noticia das fazendas, das terras e das propriedades do Mosteiro, que disfzia, e declarava todas as duvidas, q' se /offe-/ reciaõ em q quer destas materias. Foi Abd do Mosteiro de Parahiba, e dêo provas taõ manifestas da sua Capacidade, que passado $\mathrm{hu}^{150}$ trienio, em q' occupou olugar de Deffin ${ }^{\text {or }}$. o elegeraõ $\mathrm{Ab}^{\mathrm{e}}$ desta ca $=$ za, dêo a satisfaçaõ que se esperava de seu zelo, o seu trienio foi abundante, e nelle se concluiu o Dormitorio nôvo, e se fize= raõ $\mathrm{m}^{\text {tas }}$ obras nos Mosteiro, enas fazendas, das quaes se dará /maior/ noticia no Catalogos dos Prelados desta Caza. Quando encheo o numero de $56 \mathrm{an}^{\mathrm{s}}$. de idade, e 33 de Religiaõ foi acometido /de/ huma molestia, que dando-lhe tempo $\mathrm{p}^{\mathrm{a}}$ se dispôr $/ \mathrm{com} /$

${ }^{149} \mathrm{O}<\mathrm{u}>$ está grafado com $<\sim>$.

${ }^{150} \mathrm{O}<\mathrm{u}>$ está grafado com $<\sim>$. 


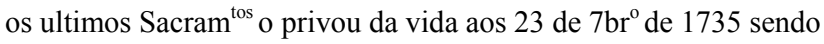
D. Abade o P.M.R.P.Pregador Fr. Bazilio das Neves.

153 O Centesimo quinquagesimo terc ${ }^{\text {o }}$; que falecêo sendo conve/ntual/ desta caza foi o $\mathrm{P}^{\mathrm{e}}$. Pregadôr Fr. Columbano de S.Bernardo ${ }^{151}$ natural da Cidade do Porto professo neste Mosteiro. Ao deps que este Monge $\mathrm{p}^{\mathrm{r}}$ espaço de $\mathrm{m}^{\text {tos }}$ an $^{\mathrm{s}}$ experimentou o Material affecto, com que a Religiaõ tracta aos seus filhos na vida, e na morte, e elle da sua parte lhe correspondêo, como filho agradecido, servindo a no Pulpito, no Conficionario, principalmente no Côro $\mathrm{p}^{\mathrm{r}}$ ser $\mathrm{mu}=$ zico destro, succurrido de huma perfeita voz, compadecido da pobreza de huns seus Parentes foi aminas acabar a vida nas maõs dos Negros fugido; huns paçageiros lhe deraõ sipultura no mesmo lugar, aonde desgraçadam ${ }^{\mathrm{e}}$ foi morto. Os seus ossos foraõ trasladados $\mathrm{p}^{\mathrm{a}} \mathrm{o}$ caustro /sendo/ D. $\mathrm{Abd}^{\mathrm{e}} \mathrm{o}$ P.M.R.P. Pregadôr Fr. Ba/zilio/ das Nev/es/.

154 O Centesimo quinquagesimo quarto foi o Irmaõ Curista Fr. Pedro da Conceiçaõ, natural desta Cidade da $\mathrm{B}^{\mathrm{a}}$ professo neste mostei= ro poucos annos logrou este Monge o estado, que sempre deze $=$ java, que era o de Religiozo; porem neste pouco tempo dêo aco= nhecer a efficacia da sua vocaçaõ, $\mathrm{p}^{\text {lo }}$ coidado, com q' se applicava aos exercicios da Religiaõ, ep ${ }^{\text {la }}$ prompta satisfaçaõ, com q' cum= pria as suas obrigações. Morrêo tizico tendo se disposto com repe= tidas confições, e com os mais Sacram ${ }^{\text {tos }}$ aos 3 de Dezembro 1735 quando contava $19 \mathrm{an}^{\mathrm{s}}$ de idade incompletos, e $2 \mathrm{a}^{\mathrm{s}}$ e alguns mezes de Religiaõ. Era D.Abd ${ }^{e}$ o P.M.R.P.Pregador Fr. Bazilio das Neves.

151 "No livro Velho do Tombo assina com. S.Escolastica" fl. 158v (380-51) 
$155 \mathrm{O} /$ Centesimo quinquagesi/mo quinto foi o $\mathrm{m}^{\text {to }}$ R.P.M.Fr. Antonio

da Con/ceiçaõ natural/ desta Cidade, eprofesso neste Mosteiro. Oiten

ta /annos de peregrinaçaõ/ neste mundo contôu este Religiozo, d/esoi/

to /emcompletos na caza/ de Seus Pais, e Secenta, e dois carregando

o jugo do Senhôr dentro da Religiaõ. Dêo Theologia no Mos

teiro da Graça, eneste tomou o gráo de $\mathrm{Do}^{\mathrm{r}}[\uparrow \mathrm{Hra}]$ Monge

virtuozo, e exemplar. Foi difinidor, e $\mathrm{Ab}^{\mathrm{e}}$ da Graça, a $\mathrm{q}^{\mathrm{l}}$ abadia

renunciôu no fim do premr $^{\circ}$ anno, e recolhido aeste Mosteiro

nelle passou o resto da vida, exercitando em obras de pied ${ }^{\mathrm{e}}$.

Zelava a honra de Deus, ecredito da Religiaõ, sendo elle o q'

primr $^{\circ}$ praticava [ $\leftarrow$ aquilo q' persuadia; foi admiravel a sua virtude, e paciencia].

Levantaraõ-lhe em huma occaziaõ hũ

falço testemunho, aonde intentavaõ convence-lo de inconti

nente, em materia grave, e supposto que padecesse pouco no seu

credito, $\mathrm{p}^{\mathrm{r}}$ que em breves /dias se/ manifestou a verdade; elle /andou/

prompto em soffrer, e perduar aos seus injustos offensores. Já com

o pezo de muitos an ${ }^{\mathrm{s}}$, edevarias molestias descaindo das pou=

cas forças, que lhe restavaõ, eo premio de huma dôr de Cabe-

ça acompanhada de hum mortal fastio côpletou onumero dos

seus dias, fortalecido com a graça dos Sacram ${ }^{\text {tos }}$, que todos rece $=$

bêo em seu perfeito juizo aos 17 de Julho de 1736 sendo D.Abd ${ }^{\mathrm{e}} \mathrm{o} \mathrm{m}^{\text {to }}$

reverendo P.Pregador Fr. Bazilio das Neves.

156 O Centesimo quinquagesimo sexto foi omuito R.P.D.Abd ${ }^{\mathrm{e}}$ actu

al deste e Mostr ${ }^{\circ}$ o Doctor Fr. Anastacio ${ }^{152}$ da Assumpçaõ nascido

na Cidade do Porto de Pais nobres, professo no Mosteiro do R/io/

de Janr ${ }^{\circ}$. Na mesma caza teve o seu Collegio, eaplicando-se

com grande desvellos aos exercicios literatios dignamente

merecêo, que o ellegessem passante. Dêo Theologia no Mos=

[Foi irmaõ do R.P.Preg ${ }^{\mathrm{or}}$. Fr. Brenardo da Encarnação. 220. pg.217.] ${ }^{153}$

$-160-$

${ }^{152}$ Sobre $<$ Anastacio $>$ há um $<\mathrm{x}>$ (APFL)

${ }^{153}$ [Foi irmaõ do R.P.Preg ${ }^{\text {or }}$. Fr. Brenardo da Encarnação. 220. pg.217.] (APFL). 
teiro de Olinda, e na quella Divina Sciencia tomôu o gráo de

Doctor. Veio mudado $\mathrm{p}^{\mathrm{a}}$ esta caza, e passados poucos annos atten= dida a sua capacidade, o ellegeraõ Diffinidor deste lugar, pas= sou a compro ${ }^{\circ}$, e Secretario da Provincia, eno trienio seguinte o ellegeraõ a junta geral D.Abd ${ }^{\mathrm{e}}$ desta caza. Pouco tempo se aproveitôu ella das accertadas dispozições, com que dêo princi= pio ao seu governo em 4 mezes incompletos, que governôu pagôu dous mil cruzados, que se devia a misericordia a juros; algumas dividas mais, que passaraõ de trezentos mil $\mathrm{r}^{\mathrm{s}} \mathrm{p}^{\mathrm{a}} \mathrm{Sa}$ cristia mandou fazer huma Cazula rica $\mathrm{p}^{\mathrm{a}}$ uzo dos Prelados, etrez mais de damasco pa uzo dos Religiozos. Achava-se no Engenho de S.C/ae/tano $\mathrm{p}^{\mathrm{a}}$ dar pri/nci/pio avizita das Fazendas, sentio novi= dade grande em hum flacto q' padecia; e conhecendo o perigo retirou-se $\mathrm{p}^{\mathrm{a}} / \mathrm{o} / \mathrm{E} / \mathrm{ngen} / \mathrm{ho} / \mathrm{da}$ Praia;/ /adiantou/-se a molestia com tanta preça, q' dan/do-lhe/ tempo a confessar-se, e ungir-se emi= diatamente lhe tirou avida. Contava $50 \mathrm{a}^{\mathrm{s}}$ de idade etrinta e tres de Religiaõ. No Mosteiro das Brottas lhe deraõ huma decoroza Sipultura na Capella mor, sendo D.Abd daquella caza o nosso $\mathrm{m}^{\text {to }}$ R.P.Ex.Provincial Fr. Antonio da Luz.

157 O Centesimo quinquagesimo septimo foi o Nosso $\mathrm{m}^{\text {to }}$ Reverendo $\mathrm{P}^{\mathrm{e}}$. Ex.Provincial Fr. Manoel do Espirito Santo, natural da Cidade de Lisboa, professo neste Mosteiro, foi a vida deste Religiozo verdadeiram $^{\mathrm{e}}$ vida de Monge; $\mathrm{p}^{\mathrm{r}}$ que logo do seu Noviciado se empe $=$ nhou em apartar de si todo o affecto a couzas terrenas, depe $=$ /dindo-se do amor/ proprio, e só cuidadozo na observancia /dos preceitos Divinos,/ e votos da profiçaõ. Ao depois de Sacerdote foi admetido ao Collegio, applicando-se mais 
/ao exercicio das/ virtudes, do que das letras, escolhendo antes ser /bom Sacerdote,/ ebom Religozo, do que bom Mestre. Empregava /maior parte do/ tempo no estudo da Theologia moral, do q' se /aproveitou $\mathrm{p}^{\mathrm{a}}$ exer/cer dignam ${ }^{\mathrm{e}}$ o misterio de Confeçar, e regular a seus costumes; completos dez annos de habito, ofez o D.Abade seu superior ${ }^{154}$, ejustam ${ }^{\mathrm{e}} \mathrm{M}^{\mathrm{e}}$ de Novicios, evidente prova da sua capacidade, $\mathrm{p}^{\mathrm{r}}$ que naquelles Saudozos tempos este imprego só se fiava de religiosos exemplares. Já com $20 \mathrm{a}^{\mathrm{s}}$ de Religiaõ /veio/ eleito em $\mathrm{Ab}^{\mathrm{e}}$ das Brottas, lugar, que encheo, como se esp/era/ va da sua exemplaridade, e do seu zelo. Nos lugares de /vizi/ tador geral, e Provincial desta Provincia, que taõ bem /occu/= pou, hé inexplicavel o seu disvello na reforma $/ \mathrm{dos} / \mathrm{custu}=$ mes, no adiantam ${ }^{\text {to }}$ da observancia regular, e na bôa un/iaõ/, epaz entre os religiozos; /tu/do conseguio; $\mathrm{p}^{\mathrm{r}}$ que o seu exem= plo precedia as suas auctoridades digo acertadas dis/pozi/= ções. Ultimam ${ }^{\mathrm{e}}$ foi elleito em $\mathrm{Abd}^{\mathrm{e}}$ do Rio de $\mathrm{Janr}^{\mathrm{o}}$ recebêo esta noticia; como se naõ fora com elle, escuzou-se com justificado motivo, de que naõ queria morrer governan= do, pedi/n/do com toda a umildade ao $\operatorname{Rem}^{\mathrm{mo}}$, q' lhe permi tisse o resto dos dia $\mathrm{p}^{\mathrm{a}}$ o preparo da morte. Da hi $\mathrm{p}^{\mathrm{r}}$ diante só cuidôu em se dispor $\mathrm{p}^{\mathrm{a}}$ a Eternidade. Seguia os actos de communid $^{\mathrm{e}}$ com grande edificaçaõ dos Religioszos; Tinha $\mathrm{m}^{\text {tas }}$ devoções particulares, a que naõ faltava, uzava em alguns dias de hum aspero Cilicio, e naõ se dispençava de religiozas disciplinas, em quanto pode levantar obraço $\mathrm{p}^{\mathrm{a}}$ o executar. F/azia/ $\mathrm{m}^{\text {tas }}$ esmólas aos Pobres, sem que elles soubessem /de onde lhe/ vinhaõ. Já nas vesperas de sua morte pedio licença 
ao Prelado $\mathrm{p}^{\mathrm{a}}$ dispender algumas couzas, que lhe restavaõ do q' adquirira $\mathrm{p}^{\text {las }}$ suas ordens, concedida ella deixôu duzentos mil $\mathrm{r}^{\mathrm{s}}$ $\mathrm{p}^{\mathrm{a}}$ que do sêu rendim ${ }^{\text {to }}$ se concervasse assêza $/ \mathrm{hu} / \mathrm{ma}$ lampada diante da immagem do Senhor crucificado, que está no côro, de quem sempre foi devotissimo, dêo huma avultadda esmol= la $\mathrm{p}^{\mathrm{a}} \mathrm{o}$ orgaõ, que entaõ se fez, emandôu incarnar /o/ Santo Christo, que está no altar das Angustias.Enfermôu de hũa Erzipella, que recolhendo-se $\mathrm{p}^{\mathrm{a}}$ aparte do Coraçaõ, dava poucas esperanças de obedecer aos remedios, que lhe aplicavaõ. Dispo/z/se com todos os Sacramentos, esperôu dizignado a ultima ho= ra, e chegado o dia oitavo do mez de $7 b^{\circ}$ de $17 \underline{3} 6$ Enchêo os seus dias com huma morte semelhante a sua vida, na mesma occaziaõ em que tinha chegado das Brottas anoticia da mor= te do Abade d/e/sta caza om ${ }^{\text {to }}$ reverend/o/ $\mathrm{P}^{\mathrm{e}}$. /Mestre/ Fr. Anastacio da Assumpçaõ.

$158 \mathrm{O}$ centesimo /qu/inq/uage/simo o/c/tavo foi o P.Fr. Joaõ do Nascim ${ }^{\text {to }}$. natural desta Cidade, professo n/este Moste/iro. Com trinta $a^{\mathrm{s}}$ de idade buscou a Religiaõ, aqual recebêo $\mathrm{p}^{\text {la }}$ noticia, que ha= via do sêu bom procedim ${ }^{\text {to }}$. Ordenado de Sacerdote, f/a/zendo-se lhe inso/ffrivel/ a observancia desta caza, pedio q' o mandas= sem $\mathrm{p}^{\mathrm{a}}$ a graça aonde assitio alguns tempos servindo ao Mos= teiro, no q' podia, passôu-se $\mathrm{p}^{\mathrm{a}}$ as Brottas, e da hi a poucos a $\mathrm{a}^{\mathrm{s}}$; adoecendo de huma hydropizia, buscôu este mostr ${ }^{\mathrm{o}} \mathrm{p}^{\mathrm{a}}$ nell/e/ se curar; $\mathrm{p}^{\mathrm{m}}$ naõ naõ /obede/cendo amolestia aos remedios conve $=$ /nientes por viatico, e $\mathrm{p}^{\mathrm{r}}$ concelhos im/prudentes foi $\mathrm{p}^{\mathrm{a}} / \mathrm{a} /$ caza de $/ \mathrm{hum} /$ /curador com promessa de saûde;/ da mesma ca/z/a veio morto a /por/ /taria no mez de Novembro de/ 1736 sendo Prezidente o $\mathrm{m}^{\text {to }}$ R.P. Pregador Fr. /Bernardo/ da Em/car/naçaõ. 
$159 \mathrm{O} /$ Centesimo/ quinquagesimo nono foi o $\mathrm{m}^{\text {to }}$ Reverendo P.Pregador $\mathrm{Urb}^{\circ} \mathrm{Fr}$. Lourenço da Conceiçaõ natural da Villa de Viana pro= /feço neste/ mosteiro. No fim do seu collegio, que teve no Mosteiro /de Pernam/buco, merecêo ser nomiado Pregador Urb ${ }^{\circ}$. Exercêo /o seu//lugar/ com satisfaçaõ, e aplauzo, os mais dos Annos do seu /exercicio/ esteve nesta caza. Foi Mestre de Juniores, defini dor. Era Religiozo modesto, eprompto em cumprir com as obrigações. Padecia suas queixas, huma dellas, que mais o opremia o privou da vida, preparado com a graça dos $\mathrm{Sa} / \mathrm{cra} /$ mentos aos 11 de Janer ${ }^{\circ} 1737$ sendo Prezidente o ${ }^{\text {to }}$ R.P.Prega dor Fr. Bernardo da Encarnaçaõ.

160 O Centesimo sexagesimo foi o P.Pregador Fr. Grigorio da $\mathrm{Ma}=$ dre de Deos, nascido nesta Cidade da $\mathrm{B}^{\mathrm{a}}$ da Pais nobres, profes= so neste Moste/iro/. Na idade de dezoito $a^{\mathrm{s}} \mathrm{p}^{\mathrm{a}}$ dezanove pedio o habito Monacal, ao q' foi admetido, $\mathrm{p}^{\text {lo }}$ conhecim $^{\text {to }}$ que tinha/õ/ os Religiozos dos seus bons costumes, e nelle pro/fe/çou a vida/re/ ligioza com geral /satisfaçaõ/ de todos. Como dos seus pri $/ \mathrm{m}^{\mathrm{ros}} /$ annos foi creado em sugeiçaõ, e temor de Deos, sem repugnan= cia /abraçou/todas as penalidades, e mortificações, que na $\mathrm{Re}=$ ligiaõ representaõ deficultozas, a falta de bons principios, /ne/ nhum acto de Religiaõ lhe era molesto, ninhum preceito dificultozo. Nesta caza teve o seu Collegio, e feitos os seus a/ctos/ de pregador satisfazia cuidadozo as obrigações do Pulpito, de /con/ficionario, e do côro. Por mor/te d/e hum seu parente lhe foi /preciso/ chegar ao Certaõ, a cobrar hu/ma he/rança per= tencente a su/a/ caza, na Ritirada $\mathrm{p}^{\mathrm{a}}$ o Mosteiro foi ac/o/me= tido de /huma/ maligna taõ forte, que em /trez/ dias lhe 
tirou a vida, tendo-se confeçado com hum Religiozo de S.Francis

$\left[\mathrm{f}^{\circ} 84 \mathrm{r}^{\circ}\right]$ co, o qual lhe assistio athé a ultima hora. Seu Corpo foi dado a Sepultura em huma Igreja, que ficava perto, $p^{\text {lo }}$ mesmo Reli= giôzo, e mais Sacerdotes, que se achavaõ prezentes; e Chegôu a noticia do seu falicim ${ }^{\text {to }}$ a este Mosteiro, em 22 de Março de 1737 sendo Prezidente o muito R.P.Pregador Fr. Bernardo da Encarnaçaõ.

161 O Centesimo Sexagesimo primeiro foi o P.Pregador Fr.Caetano de S.José natural desta Cidade, professo nesta caza. Estudôu Filosofia, e Theologia no Rio de Janro; e feito pregador veio muda= do $\mathrm{p}^{\mathrm{a}}$ este Mosteiro, nelle vivêo alguns annos, satisfazendo com promptidaõ as suas obrigaçoes, vencido de huma tentaçaõ auzen= tou-se do Mosteiro, enunca mais se soube delle, athé que pas= sados muitos /annos/ chegôu /aesta/ /caza/ atriste noticia, de que morrera nas partes do Maranhaõ, aonde vivêo perto de trinta annos junto de hum Rio, adquirindo alguma couza $\mathrm{p}^{\mathrm{a}}$ susten= tar-se $\mathrm{p}^{\text {lo }}$ oficio de /Barqueiro./ Chegôu esta noticia sendo Pre= zidente o muito Reverendo $P^{\mathrm{e}}$.Pregadôr Fr.Bernardo da Encarnaçaõ.

20162 O Centesimo sexagesimo segundo foi o P. Pregador Fr.Agostinho do Nascimento natural de Pernanbuco, professo no Mosteiro de Olinda. Sendo Corista auzentou-se da Religiaõ; passados alguns annos, busocu o Mosteiro, satisfazendo com toda a umil= dade as /pe/nitencias, que lhe foraõ dadas, $\mathrm{p}^{\text {la }}$ sua fuga. Dahi

$25 \mathrm{p}^{\mathrm{r}}$ diante /vivêo/ exemplarmente, e chorando otempo perdido, /e dando prompta execução/ as obrigações Religiozas. Foi procurador, geral da Provincia, econcluido o seu tempo foi mudado 
$\mathrm{p}^{\mathrm{a}}$ o Mosteiro das Brottas, $\mathrm{p}^{\mathrm{r}}$ occaziaõ de huma queixa interior, voltou $\mathrm{p}^{\mathrm{a}}$ esta caza abuscar os remedios convenientes $\mathrm{p}^{\mathrm{a}}$ a sua molestia. Hum dia estando assentado ameza, repentina $=$ mente cahio $\mathrm{p}^{\mathrm{r}}$ terra, e rebentando-lhe huma postema $\mathrm{p}^{\text {la }} / \mathrm{boca} /$ imidiatamente acabou a vida ao depois de ungido sendo D.abade o nosso $\mathrm{m}^{\text {to }}$ R.P.Exprovincial Fr. Jozé de S.Jeronimo.

163 O Sentesimo sexagesimo terceiro fio o P.Frei Francisco do Ruzario nas= cido nesta Cidade de pais honestos, professo neste Mosteiro. Teve /o seu/ Colegio em Pernanbuco, e nomesmo tempo exercêo aoccupaç/aõ/ de Mordomo. Ao dep ${ }^{\mathrm{s}}$ de Pregador, voltou $\mathrm{p}^{\mathrm{a}}$ esta caza, a qual servio com zêllo, efedelidade em algumas officinas, que lhe encaregaraõ. Foi Prezidente do Hospicio de Jundihahy, aon= de os seus vizinhos expe/rime/ntaraõ a su $\mathrm{Ca} / \mathrm{rida} / \mathrm{de}$, e o seu pres= timo. Ultimamente foi governar as nossas fazendas do Rio de S.Francisco com grande utilidade do Mosteiro, em huma dellas foi accomettido de huma /ma/ligna, de que veio a mor rer, sem que the desse tempo a buscar os remedios convenien tes $\mathrm{p}^{\mathrm{a}}$ a vencer. Ao dep $\mathrm{p}^{\mathrm{s}}$ de morto foi conduzido $\mathrm{p}^{\text {los }}$ Escravos ao Convento de S.Francisco, aonde lhe deraõ Sepultura aos 13 de Maio de 1740 sendo D.Abd ${ }^{\mathrm{e}}$ o nosso exprovincial Fr. Jo= zé de S.Jeronimo.

164 O Sentesimo sexagesimo quarto foi o nosso o R.P.Provincial o Doctor Fr. Roque da Assumpçaõ natural /da Cidade/ do Por= to, professo neste Mosteiro. Da sua Patria se embarcou pa esta Cidade a esperar o cumprim ${ }^{\text {to }}$ da sua promessa, que o Revem $^{\circ}$ lhe tinha feito, de que havia de ser Monge Benedictino 
nesta Província. Passados alguns mezes chegou a patenta, e sen=

$\left[\mathrm{f}^{\circ} 85 \mathrm{r}^{\circ}\right]$ do admittido ao noviciado, nelle dêo repetidas provas de felizes progreços; profeçou $\mathrm{p}^{\mathrm{r}}$ votos de todos os Monges, e da hi a poucos an ${ }^{\mathrm{s}}$ foi admettido ao Collegio no Rio de Janeiro. Applicou-se com tantos disvellos aos exercicios literarios, que nas concluzões publi $=$ /cas,/ que muitas vezes defendêo. Logo dêo a conhecer afelicidade $/ \mathrm{da} /$ sua memoria, e agudeza do seu engenho. No fim do Coll ${ }^{\circ}$ o ellegeraõ passante; ep ${ }^{a}$ que naõ estivesse por muito tempo ocul= to do seu talento, o proveraõ em huma Cadeira de Filozofia no Mosteiro de Olinda; e /sendo/ que n'aquella Cidade sempre floreceraõ nas Religiões Mestres de grande nome, entre todos /con/ceguio elle huma attenç/aõ/, elugar $\mathrm{m}^{\text {to }}$ distinto. Lêo Theolo= gia, enella se dôctorou, deixando Discipulos dignos de hum tal Mestre; como foi o Nosso $\mathrm{Rm}^{\circ}$ Pinna, que tanto acreditou o ha= bito com as suas let/ras/, evertudes, e outros mais. Pulpi= to foi hum dos mais oradores excellentes dos seus tempos, a sua eloquencia era duas vezes bôa, e admiravel, huma $\mathrm{p}^{\text {la }}$ sua re $=$ gularidade, e boa dispoziçaõ, outras $\mathrm{p}^{\text {los }}$ affectos, que della rezul= tavaõ aos seus ouvintes; $\mathrm{ep}^{\mathrm{r}}$ isso nesta Cidade, e na de Pernan= buco sempre foi procurado $\mathrm{p}^{\mathrm{a}}$ o dizimpenho dos maiores as $=$ sumptos. Na Theologia moral sempre os seus pareceres foraõ houvidos com Respeito, e attendidos com preferencia. Sempre olhôu com dizapego $\mathrm{p}^{\mathrm{a}}$ os lugares da Religiaõ, nem delles ca= recia, $\mathrm{p}^{\mathrm{a}}$ conseguir honras $\mathrm{m}^{\text {to }}$ destintas das maiores pessôas da terra, /aonde q/uer q' se achava. Foi Abd em Pernanbuco e pro= vincial. Já no fím da vida. As suas letras eraõ realçadas com exercicios victoriozos, em q' gastava a maior parte do tem= po. Era devotissimo de S.Anna, e tinha particulares devoções, 
a que nunca faltava. Sempre rezou de juelhos o officio Divi= vino, nunca deixou de vizitar a Igreja. No dia de Istaçaõ dispoz na tribuna huma viaçacra, que freqüentava $\mathrm{p}^{\text {la }}$ qua $=$ resma, e alguns dias do anno. Finalmente foi grande prega $=$ dor, grande Mestre, e perfeito religiozo. A/cha/va-se no quinto mez do seu governo, $q^{\text {do }}$ ajuntando-lhe hum nova molestia, aoutas, que padecia, conhecendo o perigo, em q' estava, cuidou em se pre= parar $\mathrm{p}^{\mathrm{a}}$ a jornada da Eternid ${ }^{\mathrm{e}}$, pediu o $\mathrm{S}^{\mathrm{r}}$ por viatico, e vestido com o seu habito o esperou fora da sua cella com ahumild ${ }^{\mathrm{e}}$., e respei $=$ to devido ataõ Suberana $\mathrm{Ma} /$ ges/tade, ao dep ${ }^{\mathrm{s}}$ de o receber com gr $^{\text {de }}$ ternura, e actos de amor pedio o ulimo Sacram $^{\text {to }}$; e com a gra $=$ ça de todos pagou o tributo de /todos/ nascido em 3 de Abril 1740, tendo de idade setenta, /ehum/ anno, e de habito 44 foi Sepul= tado na Sacristia com/as honras/ devidas a sua pessoa, e ao seu lugar sendo D.Abd ${ }^{\mathrm{e}}$ onosso $\mathrm{m}^{\text {to }}$. R.P.Exprovincial Fr. Jozé de S.Jeronimo.

165 O Centesimo sexagesimo quinto foi o $\mathrm{m}^{\text {to }}$ R.P.Pregador Fr. Mano= el da Gloria professo neste Mosteiro. Deixado a sua Patria com grande gosto seu, se embarcôu $\mathrm{p}^{\mathrm{a}}$ o Brazil com Patente de $\mathrm{Rm}^{\circ}$ a sacrificar a Deus a sua liberdade na Religiaõ Bene $=$ Dictina, e com o mesmo gosto vivêo nella athé morrer sem= pre contente, e sempre satisfeito com o seu estado. Era reli= gioso perfeitamente observante, zêllozo, e de grande presti= mo $\mathrm{p}^{\mathrm{a}} \mathrm{q}^{1} \mathrm{q}^{\mathrm{r}}$ imprego da Religiaõ. Achando-se conventual do Mosteiro do Rio o mandaraõ a minas a tractar de al= gumas dependencias importantes, e de /utilidade/ $\mathrm{p}^{\text {a }} \mathrm{aq}^{\text {le }}$ mosteiro, com o seu respeito, e com o seu/trab/alho con/seg/uio com presteza, e felicidade ofim, que dezejava. 
Utilizou-se a Religiaõ do seu prestimo $\mathrm{p}^{\mathrm{a}}$ varios impregos, aos quaes satisfez como se esperava da sua capacide; e do seu zello. Foi Abd ${ }^{\mathrm{e}}$ da Parahiba, procurdor geral, difinidor. Ultimamente, feito $\mathrm{Abd}^{\mathrm{e}}$ do Rio de Janro; do q naõ tomou posse, $\mathrm{p}^{\mathrm{r}}$ que amorte lhe tirôu avida, quando a Religiaõ esperava colher o fructo mais sazonado da suas prendas, e vertudes. Falecêo disposto com a graça dos Sacram ${ }^{\text {tos }}$ em 22 de Julho de /1742/ sendo D.Abd ${ }^{\mathrm{e}}$ o Nosso $\mathrm{m}^{\text {to }}$ R.P.Exprovincial Fr. Jozé de S.Jeronimo.

10166 O Sentesimo sexagesimo sexto foi o $\mathrm{M}^{\mathrm{to}}$ R.P.Pregador Fr.Lourenço /se/ S.Jozé natural da Freguezia de S.Maria de Ferreiros Arce= bispado de Braga, professo neste Mostr ${ }^{\circ}$.Era Religioso de louvaveis /cos/tumes, amante da Religiaõ, e zellozo da observancia geral. /Occup/ou alguns impregos de honras, como fora o de Mestre de Noviços, Procurador geral da congregaçaõ, e Abade da Graça, da qual Abadia naõ chegou a tomar posse, $\mathrm{p}^{\mathrm{r}}$ se achar já opprim ${ }^{\mathrm{do}}$ da molestia, que o privôu da vida. Falecêo preparado com os ul= /timos/ Sacramentos em 2 de Fevr ${ }^{\circ}$ de 1743 sendo D.Abbe o Nosso $\mathrm{m}^{\text {to }}$ R.P.Exprovincial Fr. Jozé de S.Jeronimo.

20167 O Centesimo sexagesimo septimo foi o Muito Revr ${ }^{\text {do }} P^{\mathrm{e}}$.Fr.Joaõ de S.Bento, nascido nesta Cidade de Pais nobres, professo neste Mosteiro. Ao depois que enchêo os annos de Corista= do com exemplo, e edificaçaõ foi mudado $\mathrm{p}^{\mathrm{a}}$ omosteiro de Pernanbuco. Naquella caza $\mathrm{p}^{\mathrm{r}}$ certa cazualid ${ }^{\mathrm{e}}$ de pouca conci= deraçaõ /se au/zentou do Mostro ${ }^{\circ}$, efeitas varias diligencias nunca se /pode/ discobrir noticia delle, athé que passado hum anno soube-se que estava junto do mesmo Mosteiro 
escondido em caza de hum pobre, o qual o sustentava com esmollas, que hia pedir na portaria. recolhêo-se, efoi da hi $\mathrm{p}^{\mathrm{r}}$ diante Religioso de vida exemplar, a sua maior assistencia foi nes= ta caza, servindo sempre de contador, e depositario $\mathrm{p}^{\text {lo }}$ prestimo, /que/ $\mathrm{p}^{\mathrm{a}}$ isso tinha, era $\mathrm{m}^{\text {to }}$ recolhido, e tam amante do Cilencio, que poucas vezes se via fora da Cella, e muitas menos fóra do Mosteiro ${ }^{155}$ aonde vivia. Fugia de todas as com verçações, ao mesmo tempo, que a sua era agradável, e descen= te. Ja nos ultimos annos da vida se retirou $\mathrm{p}^{\mathrm{a}} \mathrm{o}$ Mosteiro da Graça, aonde vivia totalm ${ }^{\mathrm{e}}$, separado da communicaçaõ com os homens. Veio eleito em procurador geral da Provin= /cia, e dahi/ apoucos tempos lhe deraõ humas Cezões, $\mathrm{p}^{\text {las }}$ quaes /se vio obrigado,/ abuscar a caza de hum seu Cunhado, aon= de acab/ôu/ avida, tendo recebido o Sacramento da unçaõ ao depois de morto foi trazido ao Mosteiro, aonde lhe deraõ Sepultura no $1^{\circ}$ de Julho de 17/4/4, sendo D.Abade o Nosso Muito Reverendo $\mathrm{P}^{\mathrm{e}}$.Ex Provincial Fr. Antonio da Luz.

168 O Centesimo sexagesimo oitavo foi omuito Reverendo P.Prega= dor Jubilado Fr. Raimundo de S.Miguel, nascico nesta Cidade de Pais virtuosos, profeço neste Mosteiro. Como nes= ta caza oridnariamente assistiaõ os nossos Reverendissimos provinciaes, emuitos Religiosos autorizados, todos elles empe $=$ nhados, em que as funções Religiozas, principalmente as do côro, e altar se fizessem com exemplo, e edificaçaõ dos $/$ Secula/= res, buscavaõ sugeitos prendados, a quem dessem o habito de Monges, $p^{a}$ que este Mosteiro tivesse Religiozos, q' sustentassem o explendor, com q' sempre florecera do seu principio; $-170-$

${ }^{155}$ Há uma palavra rasurada entre $<$ mosteiro $>$ e $<$ aonde $>$ que não pode ser identificada por dano no suporte. 
$\mathrm{p}^{\mathrm{a}}$ este imprego taõ agradavel a Deos foi admetido ao Novicia/do/

o Religiozo, de q' se falla, $\mathrm{p}^{\mathrm{r}}$ ser dotado de prendas, que o faziaõ di= gno deste beneficio. Era bom Gramatico, bom Muzico, etocava al= guns instrum ${ }^{\text {tos }}$, que acompanhavaõ o canto cham, com estas par= tes servio a Religiaõ, naõ só no tempo, em q' era obrigado, ao coro, $\mathrm{m}^{\mathrm{s}}$ taõ bem ao dep ${ }^{\text {s }}$, que $\mathrm{p}^{\text {los }}$ seus privilegios ficôu dispençado d'elle.

Teve o seu Colegio no Rio de Janr ${ }^{\circ}$, enofim d'elle, foi nomiado pre= gador urbano. Exercêo este imprego com aplauzo, e asseitaçaõ; $\mathrm{p}^{\mathrm{r}}$ q' nelle concorriaõ os requizitos nesseçarios $\mathrm{p}^{\mathrm{a}}$ este misterio. Foi procurador geral da Provincia, e $\mathrm{M}^{\mathrm{e}}$ de Noviços, aos quaes ins= truio em tudo, q' era necessario $\mathrm{p}^{\mathrm{a}}$ serem perfeitos, e observantes. Nos seus premr ${ }^{\text {os }}$ annos admettio alguns divertim ${ }^{\text {tos }}$ que supposto naõ fossem pecaminosos, naõ eraõ permitidos ao seu estado, ao de $\mathrm{p}^{\mathrm{s}}$, o chorou athé amorte, como se fossem horrendos delictos. Foi ad= miravel a reforma dos seus custumes, e a imenda da sua vida.

Dispio-se do amor proprio, e disapropriou-se, de $\mathrm{q}^{\text {to }}$ tinha, em $\mathrm{q}^{\text {to }} \mathrm{po}=$ dia discobrir a mais leve sombra da vaid ${ }^{\mathrm{e}}$, na sua Cella em outro tempo bem ornada, naõ se via $\mathrm{m}^{\mathrm{s}} \mathrm{q}$ ' imagens devotissima de $\mathrm{al}=$ guns $\mathrm{S}^{\text {tos }}$. Hum $\mathrm{S}^{\mathrm{r}}$ crucificado, e os instrum ${ }^{\text {tos }}$ das suas penitencias, e dos seus castigos. Nesta murtificada, epenitente passou bastantes annos. Tudo nelle eraõ ações de piedade, tudo exercicios de virtudes. Nos dias antecedentes da sua morte $\mathrm{p}^{\mathrm{r}}$ obedecer asseitou ser prior desta caza, adiantou a observancia regular, e frequentava os actos de comunide de dia, e de nôte, e desta sorte o seguiaõ todos $\mathrm{p}^{\mathrm{r}}$ verem q' elle era opremr ${ }^{\circ}$. Naõ se escuzando ao mesmo tempo de pregar humas tardes da quaresma, /de cujo/ exceço dizem que principiara a molestia; de q' veio amorrer. Adoecêo de hum defluxo, que caindo no 
no peito, em poucos tempos veio aparar em huma tizica, avizado

$\mathrm{p}^{\mathrm{r}}$ este meio, de q' se avizinhava a sua morte, $\mathrm{p}^{\mathrm{r}} \mathrm{q}^{\prime}$ a molestia adiantava-se /com paços apreçados,/ separôu-se de toda a comunicaçaõ com os homens, de sorte, que /nem a vi/zita de hum Irmaõ Secular, aq ${ }^{\mathrm{m}}$ amava quiz admettir nas $\mathrm{m}^{\text {tas }}$ vezes, que o procurava $\mathrm{p}^{\mathrm{a}}$ se dispidir, o seu tracto era com Deos, e com os seus Santos. Sentindo-se totalm ${ }^{\text {e distitui= }}$ do de forças, pedio os santos Sacramentos, os q $\mathrm{q}^{\mathrm{s}}$ recebêo com tantas lagrimas, e ternura, q' cauzou nos assistentes grandes effeitos de $\mathrm{Pi}=$ edade, e deficaçaõ. Dispidio-se de todos, recomendando-se nas suas orações, preparada a sua alma $\mathrm{p}^{\mathrm{a}}$ a sua partida, taõ bem quiz preparar o corpo para a sepultura, pedio agoa $\mathrm{p}^{\mathrm{a}}$ se lavar, e rôpa lavada $\mathrm{p}^{\mathrm{a}}$ se vestir. Recostou-se na cama, e disse ao imfermr ${ }^{\mathrm{o}}$., q' fizesse signal com os massos, acudiraõ os monges, e perguntando hum se tiria tempo $\mathrm{p}^{\mathrm{a}}$ dizer missa $\mathrm{p}^{\mathrm{a}} \mathrm{o}$ depois ajudar na ultima hora, respon= dêo, q' sim. Da hi a poucos minutos pedio hum santo Christo, e ren= dendo-lhe os ultimos obsequios, com $\mathrm{m}^{\text {tas }}$ lagrimas, e actos de contriçaõ, procurando taõ bem o patrocinio de Maria Sanctissima, en= trando em huma leve agonia espirou, tendo de idade 54 an= nos, e de habito 36. Foi o dia do seu falecim ${ }^{\text {to }}$ em 19 de Junho de 1746. Era D.Abd ${ }^{\mathrm{e}}$ o Nosso Muito R.P.Exprovincial Frei Antonio da Luz.

169 O Centesimo sexagesimo nono foi o P.Joaõ de S.Boavinura, que ao depois mudou em Graça, natural da Provincia do minho, e professo neste Mosteiro. Achava-se nesta Cidade ja na idade de 30 annos, levado de hum louvavel dezejo de se recolher em Religiaõ, principiôu a tomar lições de Gramatica com /hum/ Mestre particular, pedio o nosso habito, ao que foi admetido; $\mathrm{p}^{\mathrm{r}}$ impenhos, a que se naõ podia faltar com facilidade; 
$\mathrm{p}^{\text {lo }}$ mesmo empenho alcançou ordenar-se de sacerdote, logo ao dep/ois/

$\left[\mathrm{f}^{\mathrm{0}} 88 \mathrm{r}^{\mathrm{0}}\right]$ de professo, paçados poucos tempos, buscou /o/ Prelado, dizendo que se naõ podia acomodar com huma vida detanto trabalho de dia, e denôte, que o mandasse $\mathrm{p}^{\mathrm{a}}$ huma caza, aonde houvesse mais dis= canço. Foi $\mathrm{p}^{\mathrm{r}}$ conventual da Graça, e ao depois da parahiba, naõ podendo com o $\mathrm{m}^{\text {to }}$ nem com o pôco, se auzentou $\mathrm{p}^{\mathrm{a}} \mathrm{o}$ Certam, aonde acabou disgraçadamente a vida de hum tiro, que lhe deraõ. Chegou a noticia da sua morte aeste Mosteiro sendo D.Aba= de o Nosso $m^{\text {to }} R$. Padre Ex Provincial Fr. Antonio da Luz.

$10170 \quad$ O Centesimo septuagesimo foi o Muito reverendo Padre D. Abd em partibus Fr. Francisco de Jezus Maria, nascico nes/ta/ Cidade, e professo neste Mosteiro, levado da sua vocaçaõ, /profeçou/ a vida Monastica, Teve o seu Collegio no Rio de Janer ${ }^{\circ}$; eja feito prega= dor, voltou $\mathrm{p}^{\mathrm{a}}$ esta caza, a $\mathrm{q}^{\mathrm{l}}$ servio, e as mesmas $\mathrm{p}^{\mathrm{r}}$ onde andou athe onde chegavaõ as suas forças, passados alguns annos, ou $\mathrm{p}^{\mathrm{r}}$ expe $=$ rimentar algumas dificuldades na penalidades da Religiaõ, ou $\mathrm{p}^{\mathrm{r}}$ outros motivos, que lhe pareciaõ justificados, procurou o Autori= $\mathrm{zad} / \mathrm{o} /$ titolo de Abade em partitus; constituido nesta dignidade foi viver em caza de seus Pais, aonde assistio bastante tempo sem nota do seu procedim ${ }^{\text {to }}$ na mesma caza foi accometido de hũa maligna, que em sinco dias lhe tirou avida, preparado com os Santos Sacram $^{\text {tos }}$. Ao depois de morto o mandaraõ seus paren= tes $\mathrm{p}^{\mathrm{a}}$ o Mosteiro, que recebido, como religiozo foi dado a Sepul tura na Capella mór sendo D.Abd ${ }^{\mathrm{e}}$ o $\mathrm{M}^{\text {to }}$ R.P.Fr.An ${ }^{\text {to }}$ da Luz.

25171 O Centesimo sexagesimo $\left[\uparrow\right.$ septuagesimo ${ }^{156}$ premeiro foi o Muito reverendo $\mathrm{P}^{\mathrm{e}}$. $\mathrm{M}^{\mathrm{e}}$. Doctor Fr. Ruberto de Jezus, nascido nesta Cidae da $\mathrm{B}^{\mathrm{a}}$ $-173-$

${ }^{156}[\uparrow$ septuagesimo $](\mathrm{APFL})$ 
/pr/ofesso neste Mostr ${ }^{0}$ entre os muitos Religiosos filhos desta Cida= de da Bahia, que com as suas prendas, eas suas letras acredita $=$ raõ a Patria, em que nasceraõ, e a Religiaõ que profeçaraõ, en= tramos ao Mui/to/ Reverendo Padre Mestre Doctor Fr. Ruperto de Jezus. Neste Mosteiro teve o seu Colegio de Filosofia, logo no seu prin= cipio discobrio nelle o seu Dôctimo Mestre huma tal comprehen= çaõ e sutileza do entendim ${ }^{\text {to }}$ que entre todos os seus discipulos, era elle o mais estimado. Foi $\mathrm{p}^{\mathrm{a}}$ Cuimbra estudar Theologia, e applicôu-se com tanto disvello a esta sciencia Divina, que assim dentro do Mosteiro, como na Universidade merecêo hu= ma attençaõ muito distincta dos seus Mestres. Fez todos os se= us actos com grande aplauzo; e graduando se doctor na $\mathrm{m}^{\mathrm{ma}}$ universidade, conseguio o nome de grande Mestre. Quando ja coidava em $/ \mathrm{serritar} / \mathrm{p}^{\mathrm{a}}$ a sua Provincia teve offerecim ${ }^{\text {tos }}$ de Pessôas grandes, que se ficasse na univercid ${ }^{\mathrm{e}}$ lhe prometiaõ o seu fa= vor $\mathrm{p}^{\mathrm{a}}$ os seus adiantam ${ }^{\text {tos }}$. Rezolvêo-se com tudo a buscar a sua Patria $\mathrm{p}^{\mathrm{r}}$ motivos justificados. Recolhido a este Mostro ${ }^{\mathrm{o}}$, continuou a leitura de Theologia athé a sua jubilaçaõ, freqüentava as aulas, e sempre as suas duvidas, e argumentos foraõ ouvidas com attençaõ e respeito. Naõ só nas Caderas conseguio o nome de grande Mestre, mas taõ bem nos pulpitos $\mathrm{d} / \mathrm{e} \mathrm{ex} /=$ cellente orador, porem nesta Cidade sempre foi procurado, e escolhido $\mathrm{p}^{\mathrm{a}}$ dezimpenhos das maiores solemnidades. As Igre $=$ jas, eos Templos $p^{r}$ maiores que fossem sempre se viaõ cheias das Pessôas principaes, quando pregava o Padre Mestre /Frei/ Roberto, a eloquencia era nelle natural, avoz clara, e preciti $=$ vel, dotado em ponto $\mathrm{m}^{\text {to }}$ subido de todos aquelles predicados, 
que constituem hum orador completo. Como tinha hum enten

$\left[\mathrm{f}^{\circ} 89 \mathrm{r}^{\circ}\right]$ $\operatorname{dim}^{\text {to }}$ claro, e subtil, em em comprehender as sciencias, aq' se applica= va, nos seus dôctissimos pareceres de discobriaõ respostas bem funda= das no direito civil, e canonico. Ao depois de a/s/sistir muitos an= nos nesta caza com grande credito no seu nome, e da sua Reli= giaõ foi $\mathrm{p}^{\mathrm{r}}$ conventual do Mosteiro da Graça, continuando no mesmo exercicio da predica; $\mathrm{p}^{\mathrm{r}}$ que $\mathrm{p}^{\mathrm{r}}$ mais longe q' estivesse, lá era procurado. Alguns annos antecedentes a sua morte, com licença da Religiaõ foi viver em companhia de seu Pai, que já naquelle tempo, necessitava da Companhia d'aquelle filho, $p^{a}$ o amparar. Em huma occaziaõ, que nesta terra se fez huma grande festa a S.Gonçallo Garcia, elle foi o procu= rado $\mathrm{p}^{\mathrm{a}}$ orador, na vespera da festividade, em tempo, que andava cuidando no Sermaõ com o seu costumado disvello, achando-se recolhido no seu quarto, foi accometido de huma apoplexia, que o privou de todos os sentidos, ali o foraõ achar, passadas algumas horas, sem movimento algum, veio avi= zo ao Mosteiro, atoda pressa, accudiraõ os Religiozos, e o con= duziraõ n'aquelle estado $\mathrm{p}^{\mathrm{a}}$ huma Cella, aonde pella duas horas da nôite, emmodeceo de tôdo, aquela dôcta lingua, que por espaço de muitos annos, tinha sido nesta Cidade hum suavissimo orgaõ dos Sagrados Evangelios. Falecêo aos 4 de $8 b^{\circ}$ de 1746 , quando contava 60 annos de idade, e 35 de habito, era prezidente desta caza o Muito R.P.Prega= dôr Fr. Leonardo de S.Jozé.

172 O Sentesimo /septua/gesimo segundo foi o $\mathrm{M}^{\text {to }}$ R.Pregador Fr. Agost ${ }^{\mathrm{o}}$ da Encarnaçaõ nascido nesta Cidade da Bahia, profess/o/ 
nesta caza A experiencia tem mostrado ser $\mathrm{m}^{\text {to }}$ util a huma

communidade, hum /ve/lho impertenente, sendo virtuozo; tudo têve este Monge, $/ \mathrm{s} /$ empre foi $^{157}$ ao dep de velho, imper= tenente naõ sendo menos /proveitozo/ com as suas impertenen cias, do que exemplar com as suas virtudes, $\mathrm{p}^{\mathrm{s}}$ hé serto quando as impertenencias saõ fundadas em bons principios sempre se encaminhaõ pa obem. Em toda a sua vida q' foi dilatada, frequentou os actos Conventuaes, empenhando em q'tudo $\mathrm{fi}=$ zesse-se com perfeiçaõ $\mathrm{d} / \mathrm{e} /$ cencia, e gravid $^{\mathrm{e}}, \mathrm{q}^{\text {do }}$ via $\mathrm{q}^{1} \mathrm{q}^{\mathrm{r}}$ discuido, ou falta de seremonias, tudo eraõ afflições, tudo eraõ quexas. Levado de hum zêllo Santo, reprehendia, estranhava o que devia ser istranhado, e reprehendido, sempre se fazia, o q' elle dezejava; $\mathrm{p}^{\mathrm{r}}$ que só pertencia, o que era justo. Nos $\mathrm{Pa}=$ /treos/ da Companhia, se gradoou em artes, e na Graça ouvio Theologia. Ocupou na Religiaõ alguns impregos de honra, aos quaes satisfez, como se esperava da sua per= feita obervancia. Falecêo em 27 de Agosto de 1743 [6] ${ }^{158}$, sendo D.Abd ${ }^{\mathrm{e}}$ o Nosso R.P.Exprovincial Fr. Antonio da Luz. $[\rightarrow$ Este devi vir antes do precedente. $]^{159}$

173 O Centesimo Septuagesimo terc ${ }^{\circ}$ foi o Padre Fr. Salvador da Trindade, natural da Cidade do Rio de Janeiro, professo no Mosteiro da mes ${ }^{\mathrm{ma}}$ Cidade. Era Religioso de prestimo, e capacidade $\mathrm{p}^{\mathrm{a}}$ qualquer imprego. No Mosteiro do Rio adminis $=$ trou algumas fazendas com zello, e fidelidade. Nesta caza servio de porteiro, lugar, em q' mostrou a sua Caridade, e/pa/ci= encia; taõ bem foi procurado $<r>$ das demandas, e do exceço, com q' se aplicou as dependencias do Mostro., naõ se resg APFTuardando $-176-$

${ }^{157}$ Há um escrito não identificado entre $<$ foi $>$ e $<$ ao $>$.

158 [6] (APFL)

${ }^{159}[\rightarrow$ Este devi vir antes do precedente. $]$ (APFL) 
/dos/ ardores do sol, q $\mathrm{q}^{\text {do }}$ julgava q' asim /era/ precizo $\mathrm{p}^{\mathrm{a}}$ bem da Religiaõ,

$\left[\mathrm{f}^{\mathrm{9}} 90 \mathrm{r}^{\mathrm{0}}\right]$ lhe rezultou huma maligna, q' naõ se dando a conhecer, $\mathrm{p}^{\mathrm{a}}$ se lhe $\mathrm{a}=$ plicarem os remedios convenientes, della veio a morrer em breves di= as, falecêo em 24 de $8 b^{\circ}{ }^{o} 1746$, sendo D.Abade o Nosso $M^{\text {to }}$ R.P.M ${ }^{\mathrm{e}}$.Fr. Matheos da Encarnaçaõ Pina.

5174 O Centesimo septuagesimo quarto, que fallecêo neste Mostr ${ }^{\circ}$ foi o Padre Fr. Caetano de Santa Gertudes, nascido nesta Cidade dePa= is nobres, professo nesta Caza. Era Religiozo diligente, e prom= pto em cumprir as obrigações do seu estado. Logo ao depois de Sacerdote principiou a sentir os effeitos de huma mo= lestia, que pello tempo adiante, veio a discahir em huma Tizica, a sim infermo foi $\mathrm{p}^{\mathrm{a}}$ o Mosteiro da Graça, aonde /ex/ercêo o impreg $<\mathrm{a}>/ \mathrm{o} \mid<\mathrm{do}>$ de Mordomo; porem como a quexa se fosse adiantando, buscou este Mosteiro, no qual, depois de sustentar com grande pacia APFT paciencia, os trabalhos d'aquella di= latada enfermidade, veio a morrer fortalecido com a graça dos Sacramentos em 21 de Março de 1747, tendo de idade 29 annos, e de habito 10. Era D.Abd ${ }^{\mathrm{e}}$ o Nosso $\mathrm{M}^{\text {to }}$ R.P.M $\mathrm{M}^{\mathrm{e}}$. Exprovincial Frei Matheos da Encarnaçaõ, Pina.

175 O sentesimo septuagesimo quinto o P.Pregador Fr.Rafael do Es= pirito santo, natural da Cidade de Lisbôa, professo neste Mostei= ro. Teve o seu Colegio no Rio de Janeiro, enofim delle foi governar a fazenda de Maricá, n'aqual assistio muitos annos, $\mathrm{p}^{\text {la }}$ boa $\mathrm{sa}=$ tisfaçaõ, que dav/a/ da sua administraçaõ. Ao depois veio mu= dado $\mathrm{p}^{\mathrm{a}}$ esta caza, na qual $\mathrm{p}^{\text {la }}$ boa noticia, que havia do seu prestimo, servio a Religiaõ pelo mesmo imprego de fazendero -177 - 
na ilha grande de S.Francisco, nella taõ bem assistio mui= tos annos $\mathrm{p}^{\mathrm{la}}$ boa satisfaçaõ, que dava da sua bôa administraçaõ Athé que destituido de forças $\mathrm{p}^{\mathrm{a}}$ a vida laborioza, se recolhêo ao Mosteiro a cuidar no importante negocio da sua salvaçaõ, ainda servio de porteiro alguns tempos com edificaçaõ dos $\mathrm{Se}=$ culares. Faleceo com $61 \mathrm{an}^{\mathrm{s}}$ de idade, e 42 de habito aos 21 de Dezembro de 1747 sendo D.Abd ${ }^{\mathrm{e}}$ o Nosso $\mathrm{M}^{\text {to }}$ R.P.M $\mathrm{M}^{\mathrm{e}}$ Ex.Pro= vincial Fr. Mathêos ${ }^{160}$ da Encarnaçaõ Pina.

176 O Centesimo septuagesimo sexto foi o $\mathrm{P}^{\mathrm{e}}$. Pregador F.Francisco de $\mathrm{S}$.Thomé, nascido nesta Cidade de Pais honestos. Era Religio $=$ zo /si/ncero obediente, e omilde, no Conficionario taõ Cheio taõ cheio deprudencia, e Carid ${ }^{\mathrm{e}}$ que a toda hora o achava prompto qual q $\mathrm{q}^{\mathrm{r}} \mathrm{q}^{\prime}$ o buscava. Muitos annos foi compahêro $\mathrm{d} / \mathrm{os} /$ fazenda/r/ios pe $=$ la docilidade do seu genio, e pela diligencia com q' acodia aos iscravos infermos na vida, e na morte. Tocado de huma moles= tia contagioza se recolhêo ao mostro ${ }^{\circ}$, e nelle vivêo bastantes annos, sofrendo com paciencia os lastimos[个os] effeitos daquella dilatada, etrabalhoza infirmidade, foi-se augmentando a quexa, e co= nhecendo operigo, confeça se repetidas vezes, e recebidos os mais $\mathrm{Sa}=$ cramentos com $\mathrm{m}^{\text {tas }}$ lagrimas, enchêo os seus dias ao 23 de Abril de 1748, tendo 65 annos de idade, e 43 de habito, que vistio neste Mosteiro. Era D.Abade o Nosso $\mathrm{M}^{\text {to }}$ R.P.Mestre Fr. Matheus da Encarnaçaõ Pina.

177 O Centessimo septuagesimo septimo foi o $\mathrm{P}^{\mathrm{e}}$. Pregador Fr.Ancel= mo do Paraizo professo neste Mosteiro. /A sua maior/ assistencia foi nesta caza, aq ${ }^{1}$ sempre servio com zello, deligencia, freqüentava o co= /ro/, e mais actos de Comunidade com exemplo, e edificaçaõ. Administrou $-178-$

${ }^{160} \mathrm{O}$ traço horizontal do $<\mathrm{t}>$ não está grafado. 
$/ \mathrm{p}^{\mathrm{r} / \text { muitos annos a nossa fazenda de Jaguaripe com grande utilid }} \mathrm{e}^{\mathrm{e}}$

$\left[\mathrm{f}^{\circ} 91 \mathrm{r}^{\circ}\right]$ deste Mosteiro, ao $\mathrm{q}^{1}$ soccorrêo repitidas vezes com $\mathrm{m}^{\text {tos }}$ milheiros de tijollos, telhas, lenhas, e outras muidezas, como estêras $\mathrm{p}^{\mathrm{a}}$ os Escra $=$ vos, piassabas $p^{\mathrm{a}}$ os Engenhos, que tudo se acabôu com a sua falta. Adoecêo de hum flacto trabalhozo, que em hum ataque mais violento o privou da vida com 66 annos de idada, e 44 de habi= to. Falecêo na mesma fazenda, na Igreja Matris foi dada a Sepul= tura, sendo D.Abade o N.M.R.P. ${ }^{\mathrm{e}}$.Exprovincial Fr. Matheus da Encarnaçaõ Pina.

10178 O Centesimo seputagesimo oitavo foi o $\mathrm{P}^{\mathrm{e}}$.Frei Manoel da Concei= çaõ, nascido nesta Cidade de geraçaõ nobre, professo nesta caza. Era Religiozo humilde, e obediente, e prompto $\mathrm{p}^{\mathrm{a}}$ servir a R/el/ig/ia/õ/,/ athé aonde chegavaõ as suas forças administrou a fazenda da Itapoam, digo de jaguaripe, aonde vevia sem nota do seu procedim ${ }^{\text {to }}$, e com edificacaõ dos Siculares, que o amavaõ como vezinho, q' o socco= rriaõ na vida, e na morte, como as Cazas, em q' morava, eraõ ve $=$ lhas, repentinam ${ }^{\mathrm{e}}$ cahiraõ em huma note tormentoza, sem lhe dar tempo, aque se retirasse; seu Corpo tirado de entre as Ruinas, foi sepultado na Igreja da Villa de Jagoaripe, succedêo este las= timozo cazo, sendo D.Abade o Nosso $\mathrm{m}^{\text {to }}$ R.P.Mestre ExProvin= cial Fr. Matheus da Em/carna/çaõ Pina.

179 O Centesimo Septuagesimo non $/ \mathrm{o} /$ foi o $\mathrm{m}^{\text {to }}$ R.P.M $\mathrm{M}^{\mathrm{e}} \cdot \mathrm{D}^{\text {or }}$. Fr. Bonifacio da Conceiçaõ natural desta Cidade d[个e] Pais virtuozos, professo neste Mosteiro. Foi este Religiozo de louvaveis custumes, observante, e de vida exemplar; taõ amante da Virtude da Castidade, que nunca /se lhe/ ouvio palavras menos decente, nem diante d'elle ninguem se atrevêo a proferila; era dado a oraçaõ, recolhido, e sempre occu= pado em liçaõ, que lhe apr/ov/eitasse $\mathrm{p}^{\mathrm{a}} \mathrm{si}$, e $\mathrm{p}^{\mathrm{a}}$ o proximo, evitava 
todas as converças, que o podessem devertir do seu intento, q' era n/aõ/ offender a Deos, nem as sua Creaturas. Estudou Filozofia no Mos= teiro de Olinda e Theologia em Coimbra. Nesta sagrada scien cia se gradoôu, e recebêo a borla de Dotor na $\mathrm{m}^{\mathrm{ma}}$ univercidad/e,/ ao depois de ter satisfeito aos seus actos com grande aplauzo. Recolhêo-se $\mathrm{p}^{\mathrm{a}}$ este Mostro ${ }^{\mathrm{o}}$, e delle o mandaraõ ler Filozofia no $\mathrm{Col}^{\mathrm{o}}$ do Rio, principiou a sua leitura com acceitaçaõ, chegando ao /fim/ do $1^{\circ}$ anno, o inimigo da paz fazendo se lhe insuffrivel a sua quietaçaõ, excitou algumas discordias, que lhe cauzaraõ bast ${ }^{\mathrm{es}}$ disgostos; fez dizistencia da $\mathrm{Cadr}^{\mathrm{a}}$, e retirou-se $\mathrm{p}^{\mathrm{a}}$ esta caza, aonde continuou a leitura de Theologia, athé conseguir a sua jubilaçaõ. $\mathrm{Al} /$ guns/ annos antecedenes a sua morte foi a porto seguro $\mathrm{p}^{\mathrm{a}} \mathrm{se}$ en= Teirar, e fazer hum calcolo certo das nossas terras $\mathrm{p}^{\mathrm{r}}$ duvidas, que se offereceraõ nesta materia, como era amante da solidaõ, e re= tiro, dexou-se ficar n'aquella fazenda, na $\mathrm{q}^{1}$ trabalhou insencavel= mente $\mathrm{p}^{\mathrm{a}}$ dar principio a Capella, e cazas, em que assistisse algũ Religiozo, que admenistrasse a dita fazenda. Foi a sua satisfaçaõ, n'aquellas partes de grande utilidade $\mathrm{p}^{\mathrm{a}}$ a Religiaõ, e $\mathrm{p}^{\mathrm{a}}$ aquelle Po vo; $\mathrm{p}^{\mathrm{r}}$ que com a sua prudencia compunha discordias, e com a sua Caridade acodia aos infermos. A sua morte teve principio em hũa queda, q' dêo da qual naõ fazendo /cazo/, della veio a morrer, naq ${ }^{\text {le }}$ dizerto, quando contava 53 annos de idade, e 34 de habito. Chegou a noticia da sua morte sendo D.Abade o N.M.Reverendo Padr/e/ Exprovincial Fr. Matheus da Encarnaçaõ Pina.

180 O Centesimo oitagesimo foi o M.R.P.M.D ${ }^{\text {or }}$ Fr. Antonio de S. Bento natural da Cidade de Coimbra, professo neste Mosteiro. No seu noviciado mostrou a boa educaçaõ, que deraõ seus virtuo zos, Pais, $\mathrm{p}^{\mathrm{r}}$ que com toda a humildade, e deligencia obedecia a todas 
as determinações de seu Mestre. Prefessou $\mathrm{p}^{\mathrm{r}}$ votos de todos os Monges, e dezimpenhou as obrigações do Coristado com agrado dos seus superi ores. Foi admetido ao Colegio no Rio de Janr ${ }^{\circ}$., e logo nos seus principios dêo a conhecer a felicidade da sua memoria, e de seu talento; aprovei= tou-se da capacidade, que Deos lhe dera com tanto disvello, que no fim dos estudos dignamente o ellegeraõ passante. Veio para este Mosteiro, aonde freqüentou as aulas com credito da Religiaõ, e da sua pessoa, e $\mathrm{p}^{\mathrm{a}}$ que o seu talento brilhasse a todas as luzes, naõ foi menor diligencia, que fez para conseguir o nome de bom Pregador, que adquerio a custa do seu trabalho.

Passados poucos annos foi ler Theologia no Rio de Janr ${ }^{\circ}$; e côcluida a sua leitura, foi chamado $\mathrm{p}^{\mathrm{a}}$ ler filozofia neste Mosteiro, foi recebido com gosto dos Religiozos, e dos discipulos, que todos os dias esperavaõ a sua chegada. Continuou o Colegio com geral ac= ceitaçaõ, e no mesmo tempo se gradoôu em Theologia athé entaõ naõ se tinha doutorado. Nas ferias do segundo anno, pedio licença $\mathrm{p}^{\mathrm{a}}$ hir pregar huns sermões, e juntam ${ }^{\text {te }}$ para tomar algum discan $=$ ço do continuo trabalho do seu inprego; Chegando a hum lugar chamado pernamerim, recolhendo-se em caza de huma sua Tia, abrazado do sol da mesma hora entrou alançar $\mathrm{p}^{\text {la }}$ boca repedidas golfadas de sangue: accudiraõ-lhe com alguns remedios, q' nada aproveitaraõ; $\mathrm{p}^{\mathrm{r}}$ que amolestia vencia a todos, tinha-se confeçado, e celebrados nomesmo dia do premr $^{\circ}$ ataque, e no quarto acabou a vida com $36 \mathrm{an}^{\mathrm{s}}$ de idade, e 20 incompletos de habito. Foi interra= do no Mostr $^{\circ}$ das Brotas, vizinhos d'aquellas partes. A noticia da sua morte foi geral sintida, principalmente dos seus discipulos, $\mathrm{p}^{\mathrm{r}}$ ser este o segundo golpe, que experimentaraõ, em menos de $2 \mathrm{an}^{\mathrm{s}}$ $/$ na/ falta de 2 Mestres, que perderaõ dignos de todo o respeito, e at= 
tençaõ, e sem duvida se faria mais sencivel, se naõ tivessem a fortuna, terceiro Mestre, que dignam ${ }^{\text {e }}$ occupou olugar de ambos com avulta= dos creditos da Religiaõ, e do seu nome. Era D.Abd ${ }^{\mathrm{e}}$ o Nosso M.R. P. Exprovincial Fr. Matheus da Encar/nação/ Pina.

181 O Centesimo oitagesimo oitagesimo premr $^{\circ}$ foi om $^{\text {to }}$ R.P.Pregador Fr. Leonardo de S.Jozé, natural desta Cidade de Pais nobris pro fesso neste Mostro . Todo o tempo em q' vivêo este Religiozo, se utilizou a Religiaõ do seu prestimo, $\mathrm{p}^{\mathrm{r}}$ q' nunca se escuzou de a servia, no q' podia. Era naturalmente pacifico, obed ${ }^{\mathrm{e}}$, e recolhido. Teve o seu collegio no Mosteiro de Olinda, e nomiado pregador, foi $\mathrm{p}^{\mathrm{r}}$ conventual da Para= hiba, aonde teve a occupaçaõ de Prior, aq deu inteira satisfaçaõ. Passados alguns $a^{\mathrm{s}}$ veio mudado $\mathrm{p}^{\mathrm{a}}$ esta caza, frequentava $\mathrm{o}$ côro o pul= pito, e conficionro; e todos os actos de comunid ${ }^{\mathrm{e}}$ com diligencia, e zêllo. Governou o $\mathrm{Eng}^{\mathrm{o}}$ de S.Caetano, e sendo chamado $\mathrm{p}^{\mathrm{a}}$ supprior, e $\mathrm{M}^{\mathrm{e}}$ de $\mathrm{Ju}=$ niores, exercêo estas occupações com adiantam ${ }^{\text {to }}$ da observancia, e aprovam ${ }^{\text {to }}$ dos Discipulos. Por morte do Prior, ficou em seu lugar, e sendo o D.Ab ${ }^{\mathrm{e}}$ elevado ao lugar de Provincial, ficou prezedindo o Mostro ${ }^{\mathrm{r}} \mathrm{p}^{\mathrm{r}}$ alguns $\mathrm{me}=$ zes, athé a chegada do novo Prelado, oq ${ }^{1}$ taõ bem escolhêo $\mathrm{p}^{\mathrm{a}}$ seu prior, $\mathrm{p}^{\text {la }}$ noticia, que teve da sua exemplaridade, quando completava hum an noo nesta occupaçaõ foi accometido de huma molestia grave, e conhe= cendo operigo, se dispoz com os San/t/os Sacram ${ }^{\text {tos }}$, e com a sua graça trocou esta $\mathrm{p}^{\text {la }}$ outra vida aos 3 de Julho de 1748, sendo D.Abd ${ }^{\mathrm{e}}$ o N. M.R.P.M ${ }^{\mathrm{e}}$ Fr. Matheus da Encarnaçaõ Pina.

182 O Centesimo oitagesimo seg ${ }^{\text {do }}$ foi o M.R.P.Pregador Fr. $\mathrm{An}^{\text {to }}$ dos Sera fins, nascido na $\mathrm{Cid}^{\mathrm{e}}$ do Porto, professo nesta caza. A humild ${ }^{\mathrm{e}}$, a obediencia, e a mancidaõ a este Religiozo lhe preparavaõ hum caminho suave 
$\mathrm{p}^{\mathrm{a}}$ viver sem trabalhos, e sem disgostos; sempre foi prompto, em obedecer, ede= ligentem ${ }^{\mathrm{e}} \mathrm{em}$ executar, o q' lhe mandavaõ sem formar quexas, nem all/e/ gar $^{161}$ disculpas. Foi Collegiado em Pernambuco, e nomiado Preg ${ }^{\text {or }}$ veio $\mathrm{mu}=$ dado $\mathrm{p}^{\mathrm{a}}$ este Mostro ; ao $\mathrm{q}^{1}$ servio muitos annos, principalm ${ }^{\mathrm{e}}$ no altar, e no côro, do $\mathrm{q}^{1}$ era pouco dispençado $\mathrm{p}^{\mathrm{r}}$ ser bom muzico, correndo otempo, o fizeraõ pre $=$ zidente do nosso Mostro ${ }^{\circ}$. de Sorrocaba, aonde trabalhou sem discanço $\mathrm{p}^{\mathrm{a}}$ tirar aq ${ }^{\text {la }}$ caza dos informes principios, em q' estava. Taõ bem foi $\mathrm{Ab}^{\mathrm{e}}$ da Graça, que governou 4 annos com zêlo e fidelid ${ }^{e}$. Ultimam ${ }^{e}$ recolhido a esta caza, nella passou o resto da vida occupando otempo em Religi= ozos exercicios, sem faltar aos actos de comunid ; q' nunca deixou de $\mathrm{se}=$ guir, em $\mathrm{q}^{\text {to }}$ teve forças $\mathrm{p}^{\mathrm{a}} \mathrm{o}$ fazer, como era Monge exemplar lhe encarre $=$ garaõ a educaçaõ dos noviços $\mathrm{p}^{\mathrm{r}}$ alguns tempos, cuidou $\mathrm{m}^{\text {to }}$ em os instru= ir nos exercicios da Religiaõ, e das virtudes, empenhando-se em q' fossem perfeitos, eobservantes. Achava-se com $74 \mathrm{an}^{\mathrm{s}} \mathrm{de}^{\mathrm{i}} \mathrm{e}^{\mathrm{e}}$., e 48 de habito, $\mathrm{q}^{\mathrm{do}}$ oppre= mido de huma molestia trabalhoza, enchêo os seus dias preparado com a graça dos sacram ${ }^{\text {tos }}$ aos 19 de Janr $^{\circ}$. de 1749, sendo D.Abd ${ }^{\mathrm{e}}$ o N.M.R. P.M.ExProvincial Fr. Matheus da Encarnaçaõ Pina.

183 O Centesimo oitagesimo tercr ${ }^{\circ}$ foi o Irmaõ Donado Fr. $\mathrm{M}^{\mathrm{el}}$ de S.Bento natu ral de Travanca Arcebispado de Braga, professo neste Mostr ${ }^{\circ}$. Era $[\rightarrow \text { antes de }]^{162}$ $[\leftarrow \text { ser }]^{163}$ Religiozo[, $]^{164}$ oficial de Sapatr eneste officio trabalhou $\mathrm{m}^{\text {tos }}$ an $^{\mathrm{s}}$ no $\mathrm{Col}^{\circ}$. Benedictino de Coimbra, $\mathrm{q}^{\text {do }}$ ja contava $45 \mathrm{an}^{\mathrm{s}} \mathrm{de}^{\mathrm{e}} \mathrm{d}^{\mathrm{e}}$ pedio o habito de Mon= ge no humilde estado de Leigo, como era de recto procedim ${ }^{\text {to }}$, e de vida exem= plar foi attendida a sua petiçaõ, deixando na sua elleiçaõ o Mostro; aon= de queria vestir o habito, escolhêo esta caza $\mathrm{p}^{\text {las }}$ noticias, q' tinha da sua observancia, e regu/la/ridade, conseguio oq' dezejava, embarcou-se $\mathrm{p}^{\mathrm{a}}$ es= ta terra naõ abuscar as requezas temporaes, $\mathrm{m}^{\mathrm{s}}$ sim a caza de $\mathrm{D}^{\mathrm{s}} \mathrm{p}^{\mathrm{a}}$ s/al/var a sua alma. Recolh/ido/ na Religiaõ considerando-se ja separado $-183-$

\footnotetext{
${ }^{161} \mathrm{O}$ primeiro $<\mathrm{a}>$ da palavra foi escurecido a lápis posteriormente.

${ }^{162}[\rightarrow$ antes de $]$ (APFL)

$163[\leftarrow$ ser] (APFL)

164 [,] (APFL)
} 
do mundo, q' sempre aborrecera, dava a Deos repetidas graças $\mathrm{p}^{\text {lo }}$ trazer ao /e/stado que desejava. Assentou de naõ perder $\mathrm{q}^{\mathrm{l}} \mathrm{q}^{\mathrm{r}}$ occaziaõ, que se offere $=$ cesse $\mathrm{p}^{\mathrm{a}}$ merecer, teve $\mathrm{m}^{\text {tas }} \mathrm{p}^{\mathrm{r}} \mathrm{q}^{1}$ estas nunca faltavaõ, aquem as quer ap= proveitar. Nestes principios foi dispondo hum fundam ${ }^{\text {to }}$ solido $\mathrm{p}^{\mathrm{a}}$ firme assento das virtudes, em q' se havia de exercitar. Ao dep ${ }^{\mathrm{s}}$ de professo traba= lhou $\mathrm{m}^{\text {tos }} \mathrm{a}^{\text {ns }} \mathrm{p}^{\text {lo }}$ seu officio com agrado dos Prelados, e satisfaçaõ dos Religiozos. Tinha as horas repartidas, de sorte que naõ lhe faltava otem= po $\mathrm{p}^{\mathrm{a}}$ as suas obrigações, nem subejava $\mathrm{p}^{\mathrm{a}}$ estar ociozo, como sucede a todos, q' sabem repartir. Foi-se adiantando nos annos, e taõ bem nas vir= tudes, athe que destituido $\mathrm{d} / \mathrm{a} / \mathrm{s}$ forças necessarias $\mathrm{p}^{\mathrm{a}}$ as obrigações labori/o/sas, de todo se entrgou avida contemplativa, gastando os dias, e as notes nas tribunas, no côro, ou prostrado, ou de juelhos, pedindo entre lagrimas, e suspiros perdaõ, clemencia, e piedade. Confeçava-se todos os dias, q' a $R e=$ ligiaõ tem determinado, e algumas mais, que a devoçaõ lhe pedia, ouvia a maior parte das missas, que se diziaõ na Igreja, e fazia $\mathrm{m}^{\text {tas }} \mathrm{e}$ gran= des penetencias em lugares occultos, ou em horas, q' naõ precentidas. Quatro annos antes da sua morte caio $\mathrm{p}^{\mathrm{r}}$ huma vez na cama de sor= te q' nunca mais levantou, senaõ em braços alheios, levou este Purga= torio com admiravel paciencia, dando a Deos repetidas gracias $\mathrm{p}^{\mathrm{r}}$ este beneficio, naõ deixou de continuar o exerci/c/io da Confiçaõ, e da sagrada comunhaõ, pedindo $\mathrm{aq}^{\mathrm{m}}$ lhe carregasse $\mathrm{p}^{\mathrm{a}}$ a capella de S.Bernardo, to $=$ dos os Domingos, e dias santos, e isto ainda ao dep ${ }^{\mathrm{s}}$ de corpo lhe abri raõ algumas, q' lhe faziam mais penoso omovim ${ }^{\text {to }}$. Nunca se quexou da falta, que experimentasse, mas antes sempre respondia, q' nada lhe faltava, $q^{\text {do }}$ era perguntado. Parece que este infe/rm/o foi hum, dos $\mathrm{q}^{\prime} \mathrm{D}^{\mathrm{s}}$ escolhêo $\mathrm{p}^{\mathrm{a}}$ confuzaõ dos fortes. $78 \mathrm{an}^{\mathrm{s}}$ de idade, e 32 de habito contava este perfeito Religiozo, $\mathrm{q}^{\mathrm{do}} \mathrm{D}^{\mathrm{s}}$ foi servido ti/ra/lo ${ }^{165}$ deste mundo, sentio a/lgu/ãs

${ }^{165} \mathrm{O}<\mathrm{l}>$ está grafado com o traço horizontal do $<\mathrm{t}>$. 
184 Osentesimo octogesimo quarto foi o nosso $\mathrm{m}^{\text {to }}$ R.P.Ex.Provincial Fr.Joze de S.Jeronimo, nascido na $\mathrm{Cid}^{\mathrm{e}}$ do Porto de Pais honestos. No Mostro ${ }^{\mathrm{o}}$. de Pern ${ }^{\mathrm{co}}$. vestio ohabito de Monge, e nelle professou a vida Religioza, $q^{\text {do }}$ completa va $/ 16 /$ an $^{\text {s; }}$ e alguns dias, naõ obstante ser a id taõ diminuta, logo nos seus principios dêo aconhecer q' buscava a Deos com Espirito; $\mathrm{p}^{\mathrm{r}} \mathrm{q}$ ' seguia aobservancia regulár com todo disvello. Teve o seu Colegio no Rio de Ja= $\mathrm{nr}^{\mathrm{o}}$; eno fim d'elle com licença da Religiaõ foi a sua Patria vizitar aos seus Pais, e dispedir-se d'elles $\mathrm{p}^{\mathrm{a}}$ sempre Voltou $\mathrm{p}^{\mathrm{a}}$ o Mostr ${ }^{\mathrm{o}}$ do Rio, a onde seguia os actos da Religiaõ com tanto exemplo, e vivia com tanta mo= destia, q' logo foi attendido pa occupar os impregos autorizados da Prov ${ }^{\mathrm{a}}$. Premrn ${ }^{\mathrm{e}}$. onomearaõ procurador da Congregaçaõ, lugar, q' dizimpe $=$ nhou com diligencia, e dizimbaraço. No trienio seguinte o elle $=$ geraõ $\mathrm{Abd}^{\mathrm{e}}$. do $\mathrm{Mostr}^{\circ}$ de Olinda com grande fortuna d'aquellacasa, $\mathrm{p}^{\mathrm{r}}$ que achando 8 mil cruzados de impenho, logo cuidou em aliviala d'aquella oppressaõ, pagando $\mathrm{q}^{\text {to }}$ devia; $\mathrm{p}^{\mathrm{m}}$ o seu maior disvello foi o culto Divino, e observancia regular; $\mathrm{p}^{\mathrm{a}} \mathrm{q}$ ' naõ faltava aos Religi ozos com o necessario, na saude, e nas duenças. As esmollas, que /fazia/ aos pobres, eraõ muitas, e avultadas. Nos actos de comunid ${ }^{\mathrm{e}}$ e a mortificaçaõ era o premr ${ }^{\mathrm{o}} ; \mathrm{p}^{\mathrm{r}}$ que sabia q' a prezença dos Prelados, he q' mais obriga aos subditos, $\mathrm{p}^{\mathrm{a}} \mathrm{o}$ imitarem. Concluido felizm ${ }^{\mathrm{e}}$ o seu trienio, veio $\mathrm{p}^{\mathrm{a}}$ este Mostr ${ }^{\mathrm{o}}$ occupar o imprego de Definidor, /em/ q' sahio provido. Discançou 3 an'; $^{\mathrm{s}}$ ep ${ }^{\mathrm{a}}$ q' naõ estivesse a sua 
$\left[\mathrm{f}^{\circ} 94 \mathrm{v}^{\circ}\right]$

notoria capacid ${ }^{\mathrm{e}}$ sem exercicio na Junta Geral o ellegeraõ em $\mathrm{Ab}^{\mathrm{e}}$ desta casa, governou com grande accerto; $\mathrm{p}^{\mathrm{r}}$ que todo o seu cuidado era a honra de Deos, aobservancia regular, a quietaçaõ e paz en= tre os Religiozos. Concluido este trienio com a mesma felicid ; que oprmr $^{\mathrm{o}}$ fazendo $\mathrm{m}^{\text {tas }}$ obras de ultilid ${ }^{\mathrm{e}}$; como se dirá em seu lugar; $\mathrm{ep}^{\mathrm{a}}$ q' toda a Prov ${ }^{a}$ experimentasse os effeitos da sua prudencia, da sua capa= cid $^{\text {e; }}$ e da sua Religiaõ, o ellegeraõ provincial, d'ella; cuidou em governar sem perturbaçaõ; esupostos q' nas suas vizitas naõ deixasse culpa sem castigo, nem falta sem reprehençaõ, nem $\mathrm{p}^{\mathrm{r}}$ isso o castigado

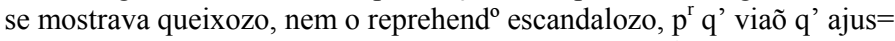
tiça a cumpanhava a mizericordia. Segunda vez foi $\mathrm{Ab}^{\mathrm{e}}$ desta ca za, no seu governo continuou com om ${ }^{\text {mo }}$ zelo, ecom om ${ }^{\text {mo }} /$ cuid $^{\circ} /$, efez obras de importancia, eacerto, como consta do seu estado. Ultiman ${ }^{\mathrm{e}}$ foi $\mathrm{M}^{\mathrm{e}}$ de Noviços, suposto que já se achava cheio de Molestia, e carre= gados de $\mathrm{a}^{\mathrm{s}}$; naõ se escuzou da occupaçaõ com grd $^{\mathrm{e}}$.utilid ${ }^{\mathrm{el} 66}$; e $\operatorname{adiantam}^{\text {to }}$ dos seus discipulos. Foi Religiozo devida exemplar, observante, e de recto procedim ${ }^{\text {to }}$. Murtificava-se com Religiozas penitencias de ci licios, deceplinas. Sabia de semular agravos, e com facilid ${ }^{\mathrm{e}}$ admetia os mesmos de $\mathrm{q}^{\mathrm{m}}$ era offend ${ }^{\circ}$. Quando ja de todo dizimbaraçado de go= vernos, gastava todo tempo em oraço ${ }^{167}$ es na reza do officio Devino, e varias devoçoes particulares, que nunca dexava de satisfazer; $\mathrm{Ce}=$ lebrava todos os dias com $\mathrm{m}^{\text {tas }}$ devoções, e pied ${ }^{\mathrm{e}}$; purificando a sua con= ciencia com repetidas conficoes, e actos de amor de Deos; Era duente de Erizipellas, $\mathrm{ep}^{\mathrm{r}}$ mais /annos/ padecêo, rezignados os effeitos desta trabalhoza molestia, em occaziaõ, q' o acometeo com maior força oprivou da vida disposto, como perfeito Religiozo com $72 \mathrm{a}^{\mathrm{s}}$ de id $^{\mathrm{e}}$ e 56 de habito em 19 de $8 b^{\circ}$ de 1750 , sendo D.Abd ${ }^{\mathrm{e}}$ o N.M.R.P. $\mathrm{M}^{\mathrm{e}}$ Exprovincial Fr. Joaõ de S.Maria. Foi sepultado na Sacris= tia com as honrras devidas de hum /Pai/ da Provincia.

\footnotetext{
${ }^{166}$ Não há o traço horizontal do $<\mathrm{t}>$

${ }^{167} \mathrm{O}$ marcador de nasalidade encontra-se sobre $\mathrm{o}<\mathrm{e}>\mathrm{em}$ todas as palavras que formam o plural com $<$ ões $>$.
} 
185 O Centesimo octogesimo quinto foi om $^{\text {to }}$ R.P.Preg ${ }^{\text {or }}$ Fr. $\mathrm{An}^{\text {to }}$ da Victo $=$ ria, nascido em hum lugar chamado Patativa de geraçaõ nobre, professo no Mostr ${ }^{\circ}$ das Brotas. Veio $\mathrm{p}^{\mathrm{a}}$ esta caza passar os professo do seu /curistado/, levado de hum louvavel $\mathrm{dez}^{\mathrm{o}}$ de viver, aonde era maior a observancia, e mais apartada a clauzura, ordenado de Sacerdote, e feito Pregador; como era dizimbaraçado, e intelig ${ }^{\text {te }}$ o mandaraõ admi $=$ nistrar algumas fazendas da Religiaõ, dêo a satisfaçaõ, q' se /espe $=$ rava/ do seu zelo. Foi Abade das Brottas, e no trienio seg ${ }^{\text {te }}$ procurador da Provincia, ambos os lugares dezimpenhou com acceitaçaõ. No ultimo anno de sua occupaçaõ, adoecêo de huã hidropizia, que naõ obedecendo aos Remedios, q' se lhe applicaraõ no Mostr ${ }^{\circ}$ foi $\mathrm{p}^{\mathrm{a}}$ caza de huma sua Tia, aonde naõ contava $50 \mathrm{a}^{\mathrm{s}}$; digo conse= guindo milhoras em breves dias acabou a vida, $\mathrm{q}^{\text {do }}$ contava $50 \mathrm{a}^{\mathrm{s}}$ de idade, e 33 de Religiaõ, sendo D.Ab o N.M.R.P. . $^{\mathrm{e}}{ }^{\mathrm{e}}$ Ex Provincial Fr. Joaõ de S.Maria.

186 O Centesimo octagesimo sexto foi o $\mathrm{P}^{\mathrm{e}}$.Fr. Ignacio da Assumpçaõ, natural desta $\mathrm{Cid}^{\text {e }}$; filho de Pais virtuozos, abundantes, e senhores de bastantes terras, que doaraõ a este Mostro; ; professo nesta caza. Quarenta e dois a vivêo este Religiozo, ao de $\mathrm{p}^{\mathrm{s}} \mathrm{q}^{\mathrm{s}}$ dignam $^{\mathrm{e}}$ vestio oha $=$ bito de Monge, os 2 ultimos conventual da Graça, eos 40 neste Mos $\operatorname{tr}^{\circ}$ todos occupados no imprego $\mathrm{m}^{\mathrm{s}}$ nobre, e mais Santo do Religiozo, que hé o coro, naõ quiz, nem teve occupaçaõ, q' o devertisse deste $S^{\text {to }}$ exercicio, em todo este tempo; e supposto q' algumas occaziões lhe entregassem a portaria, nunca faltava a Mathinas. Para os $\mathrm{m}^{\mathrm{s}}$ actos de Comunid ${ }^{\mathrm{e}}$; era dos premr $^{\text {os }}$. Nunca molestou, nem offen dêo Mong e algum, taõ bem vivêo descançado, e sem discordias; $\mathrm{p}^{\mathrm{r}} \mathrm{q}$ ' nunca pertendêo, o q' outros intentavaõ. Era Religiozo, e am ${ }^{\mathrm{e}}$ do Scilencio 
e as suas palavras eraõ poucas, e boas; lingua na verd ${ }^{\mathrm{e}}$ digna de

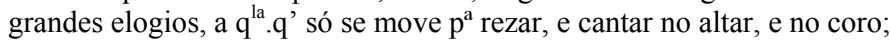
passados os $40 \mathrm{a}^{\mathrm{s}}, \mathrm{q}$ ' ja se disse, nesta forma devvida, buscou o retiro da graça, $\mathrm{p}^{\mathrm{a}}$ de todo viver separado dos homens, eno fim de $2 / \mathrm{a}^{\mathrm{s}} / / \mathrm{ado}$ ecêo/ de humas sezões, que pertendia levar de pé, assim molestado, veio a este $\operatorname{Mostr}^{\circ}$ na occaziaõ da Pascoa do Espirito S. digo de Ressu= rreiçaõ a comprimentar os Religiozos; na volta passou $\mathrm{p}^{\mathrm{r}}$ cauza de hum seu parente, e amigo, e sintindo de humas sezões mais fortes, deixou-se ficar em sua caza, e n'ella completou os seus di= as com gr $^{\text {des }} \operatorname{sintim}^{\text {tos }}$ dos Religiozos, q' todos o estimavaõ $\mathrm{p}^{\text {las }}$ suas virtu= des. Falecêo em 6 de Abril 1751, foi sepultado, entre os Monges deste Mostro ; sendo D.Ab ${ }^{\mathrm{e}}$ o N.M.R.P.Ex.Prov ${ }^{\text {al }}$ Fr. Joaõ de $\mathrm{S}^{\text {ta }}$ Maria.

187 O Centesimo oitagesimo septimo foi o M.R.P.Ex.F.M ${ }^{\mathrm{e}}$ anoel da Con=

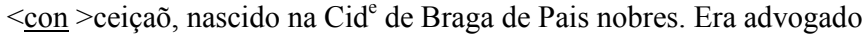
de cauzas com rectidaõ, e verdade, $\mathrm{p}^{\mathrm{r}}$ occaziaõ de certo disgosto se rezolvêo a dexar o mundo, e todas as estimações, q' n'elle se po= de conseguir, pedio o habito de Monge, e imbarcando-se $\mathrm{p}^{\mathrm{a}}$ o $\mathrm{Bra}=$ zil, foi vestido no Mostr ${ }^{\circ}$ de S .Paulo, aonde passou. Passados alguns anos, veio $\mathrm{p}^{\mathrm{r}}$ conventual desta caza, a $\mathrm{q}^{1}$ servio nos impregos de Procurador das demandas, e ao deps das cazas. Foi Abade da Graça; dêo boa satisfaçaõ a $\mathrm{q}^{1} \mathrm{q}^{\mathrm{r}}$ dos lugares, q' exercêo. No conficionario foi admiravel as ua Carid ${ }^{\mathrm{e}}$; estava prompto atoda, $\mathrm{eq}^{1} \mathrm{q}^{\mathrm{r}}$ ora, q' o cha= massem, ainda ao depois que vevia opprimido de huma pezada funda de ferro, q' lhe surtinha huma perigoza quebradura, q' $\mathrm{p}^{\mathrm{r}} \mathrm{m}^{\text {tos }}$ an $^{\mathrm{s}} \mathrm{o}$ atormentou. Falecêo com agr ${ }^{\mathrm{ca}}$ dos Sacram ${ }^{\text {tos }}$ em seu $<\uparrow>$ per $=$ feito juizo com 82 annos de idade, e 39 de habito no $1^{\circ}$ de /Janeiro/ 
de 1752 sendo D.Ab ${ }^{\mathrm{e}}$ o N.M.R.P.M $\mathrm{M}^{\mathrm{e}}$ Fr. Joaõ de $\mathrm{S}^{\text {ta }}$ Maria.

188 - O Centesimo oitagesimo oitavo foi o M.R.P.Pregador Fr. Pedro de S.

Caetano Pontes nascido em Maçarellos, professo neste Mostro ; Era

Religiozo Prud ${ }^{\mathrm{e}}$; e soffrido, dava perfeita execuçaõ as suas obrigações, efazia com $\mathrm{m}^{\text {to }}$ gosto, e dizimbaraço tudo, oq' lhe mandavaõ. Foi Prezid ${ }^{\mathrm{e}}$. no Conv $^{\text {to }}$ de $\mathrm{S}^{\text {tos }}$ com grd ${ }^{\text {e }}$ edificaçaõ dos Seculares, que todos o respeitavaõ $\mathrm{p}^{\mathrm{la}}$ sua Religiaõ, e politica. Como os Prelados desta Prov ${ }^{\mathrm{a}}$ discobrirdo n'elle capacid ${ }^{\mathrm{e}} \mathrm{p}^{\mathrm{a}} \mathrm{q}^{\mathrm{l}} \mathrm{q}^{\mathrm{r}}$ imprego oescolherdo Proc ${ }^{\text {or }}$ Geral da mesma Prov ${ }^{\mathrm{a}}$ com assistencia na congregaçaõ, embarcou-se $\mathrm{p}^{\mathrm{a}} \mathrm{Lx}^{\mathrm{a}}$; e $\mathrm{qd}^{\mathrm{o}}$ principia $=$ va exercer o seu imprego, se lhe offereceraõ varias contradicões, de sorte que $\mathrm{p}^{\mathrm{a}}$ bem de Just $\mathrm{t}^{\mathrm{a}}$ lhe /foi/ nesceçario recorrer alegancia, aonde teve sentenca a seu favor, no q' pertendia. Assistio alguns annos na côrte, naõ lhe faltaraõ trabalhos, e disgostos, os $\mathrm{q}^{\mathrm{s}}$ padecia constante, e rezigna $=$ do. Falecêo no Mostro de $\operatorname{Lx}^{\mathrm{a}}$ com $65 \mathrm{a}^{\mathrm{s}}$ de id ${ }^{\mathrm{e}}$ e de habito 46 no anno de 1751, sendo D.Ab ${ }^{\mathrm{e}}$ o N.M.R.P $\mathrm{P}^{\mathrm{e}} \mathrm{M}^{\mathrm{e}}$ Ex.Provincial Fr. Joaõ de $\mathrm{S}^{\text {ta }}$ Maria.

189 O Centesimo oitagesimo nono foi o $\mathrm{P}^{\mathrm{e}}$.Pr ${ }^{\text {or }}$ Fr. Joaõ da $\mathrm{M}^{\mathrm{e}}$ de Deos nascido em ponte de lima de geraçaõ nobre, professo neste Mostr ${ }^{\circ}$. Era $/ \mathrm{Rlz}^{\mathrm{o}} \mathrm{do}=/$ tado de hum animo brando, e pacifico. No seu Coll ${ }^{\circ}$ foi dos q' sahiraõ mais approvados, o que bem deu a conhecer no pulpito, econficionr ${ }^{\circ} \mathrm{fa}=$ zendo a sua obrigaçaõ com prudencia, e boa acceitaçaõ. Neste Mosteiro foi Procurador das cazas, eno da Graça: Administrou huma fazenda no certaõ com zêlo, e fidelidade. Na id ${ }^{\mathrm{e}} \mathrm{de} / 46 / \mathrm{a}^{\mathrm{s}}$; e trinta de Abito foi acomet ${ }^{\mathrm{o}}$ de hú estupor, do q' veio a morrer, ao dep ${ }^{\mathrm{s}}$ de Sacramentado em 22 de $7 \mathrm{br}^{\circ} 1752$, sendo D.Ab ${ }^{\mathrm{e}}$ o N.M.R.P $P^{\mathrm{e}}$ Ex.Provincial Fr. Joaõ de $\mathrm{S}^{\text {ta }}$ Maria.

190 O Centesimo nonagesimo foi o $\mathrm{M}^{\text {to }} / \mathrm{R}^{\mathrm{e}} \mathrm{P}^{\mathrm{e}} \cdot \mathrm{M}^{\mathrm{e}}$ Fr. Leandro/ do Disterro, natu= ral desta Cidade, filho de Pais virtuozos, professo neste Mostr ${ }^{\circ}$. Aperfeita 
$\left[\mathrm{f}^{\circ} 96 \mathrm{v}^{\circ}\right]$

observancia deste Religiozo, na sua bond $\mathrm{e}^{\mathrm{e}}$; aquietacaõ da sua con= ciencia, e obom animo, com q' suffria $\mathrm{q}^{1} \mathrm{q}^{\mathrm{r}}$ cazualidade, q' se offerecia, lhe alargaraõ avida, e o adiantaraõ nas virtudes, Lêo Theologia no Rio de Janr ${ }^{\circ}$ com acceitaçaõ, e n'ella se doutorou, ao dep sempre vivêo n'este Mostro ; trabalhando como servo fiel athe a morte. No Pul= pito, e conficionario fazia a sua obrigaçaõ com zêlo, e deligencia. A sua converça era delicioza, $\mathrm{p}^{\mathrm{r}}$ que era descente, e honesta. Naõ teve na Religiaõ outro imprego mais o q' o servilla, fugindo do enganozo explendor das Prelazias[ $\uparrow$ como] de hum formidavel precepicio, era tractado $\mathrm{p}^{\text {los }}$ Prelados com respeito, e sempre o attenderaõ $\mathrm{p}^{\mathrm{r}}$ que se fazia digno de todo o beneficio. Dous anno antes da sua mor= te ficou totalm esquecido das couzas deste mundo e só lhe lem= bravaõ de algumas passagens de /Escritura/, que $\mathrm{m}^{\text {tas }}$ vezes, $<$ que $\mathrm{m}^{\text {tas }}$ vezes $>$, repetia, com as quais dava graça a Deos, $\mathrm{p}^{\text {los }}$ beneficios recebidos. Nas vesperas da sua morte tornou a seu juizo, e recebendo os San= tos Sacram ${ }^{\text {tos }}$; com grande devoçaõ e conhecim ${ }^{\text {to }}$, enchêo os seus dias em 24 de Novembro de 1754, na occaziaõ, emq' na Igreja se estava cantando o officio dos nossos Irmaõs defuntos, sendo elle, o q' /aodep $/$ de Mestre, cantou sempre a Missa deste dia $\mathrm{p}^{\mathrm{r}}$ sua devoçaõ. Contava $74 \mathrm{a}^{\mathrm{s}}$ de $\mathrm{id}^{\mathrm{e}}$ de Religiozo 52. Era D.Ab ${ }^{\mathrm{e}}$ o N.M.R.P.M $\mathrm{M}^{\mathrm{e}} \mathrm{Ex}=$ Provincial Fr. Joaõ de Santa Maria.

191 O Centesimo nonagesimo pr $^{\circ}$ foi o $\mathrm{P}^{\mathrm{e}}$.Pregador Fr.Manoel da $\mathrm{Na}=$ tividade Passsos, nascido nesta Cid $^{\text {e }}$ de Pais abundantes, enobres. Foi Religiozo de exemplar procedimento, e pureza, de costumes bons, alcancou licença $\mathrm{p}^{\mathrm{a}}$ estudar Filozofia, e Theologia na Congre= gaçaõ, o q' naõ teve effeito; $\mathrm{p}^{\mathrm{r}} \mathrm{q}$ ' chegando a $\mathrm{Lx}^{\mathrm{a}}$ foi acometido de huã molestia perigoza; e voltando $\mathrm{p}^{\mathrm{a}}$ este $\mathrm{Mostr}^{\mathrm{o}}$; nelle teve o seo $\mathrm{Col}^{\circ}$. Ao dep ${ }^{\mathrm{s}}$ de Pregador foi /administrador/ da fazenda do Rio vermelho, aonde em poucos mezes adquerio humas Sezoes amalignadas, das ${ }^{168}$ $\mathrm{q}^{\mathrm{s}}$ veio amorrer no Mostr ${ }^{\mathrm{o}}$ preparado com todos os Sacram ${ }^{\text {tos }}$ no $1^{\circ}$ de Dezembro $-190-$

${ }^{168}$ A marcaçaõ da página esta na entrelinha superior da última linha. 
de 1754, sendo D.Ab ${ }^{\mathrm{e}}$ o M.R.P.M ${ }^{\mathrm{e}}$ Fr. Joaõ de Santa /Maria/, tendo de $i^{\mathrm{e}} 36 \mathrm{a}^{\mathrm{s}}$ e 14 de Abito.

192 O Centesimo nonagesimo segundo foi om $^{\text {to }}$ R.P. $P^{\mathrm{e}} \cdot \mathrm{M}^{\mathrm{e}}$ Fr. Salvador dos Santos, nas cido de Pais honestos nesta $\mathrm{Cid}^{\mathrm{e}}$ da $\mathrm{B}^{\mathrm{a}}$, professo neste Mos= teiro. A sua boa educaçaõ, a pureza dos seus costumes, e as suas pren= das bem conhecidas $\mathrm{p}^{\text {los }}$ Religiozos deste Mostro ; como vizinho, q' era, ep ${ }^{\text {la }}$ assistencia, que n'elle fazia, o fizeraõ digno $<0>$ de q' lhe vestissem o ha $=$ bito de Monge; e n'elle professasse a vida Religioza. Dizimpenhou o q' d'elle se esperava, satisfazendo perfeitam ${ }^{\mathrm{e}}$ as obrigações de bom $\mathrm{Co}=$ rista, $p^{r}$ estar bem instruido na Gramatica, na muzica, e seremoni= as da Religiaõ. Ordenado de Sacerdote, alcançou licença $\mathrm{p}^{\mathrm{a}}$ /estudar/ na Congregaçaõ, ouvio Artes no Mostr ${ }^{\circ}$ de Bastos, e Theologia no Colegio de Coimbra, aplicou-se com tanto disvello, que feitos os seus actos de Pasçante o nomearaõ Mestre de Theologia no Rio de Janr ${ }^{\circ}$ aonde principiou a sua leitura, e a veio continuar nesta /caza, na q⿳亠丷厂 defendêo as suas concluzões publicas com aceitaçaõ, e/credito da sua/ pessoa. Nesta sagrada sciencia, tomou o gráo de Doctor, e ficando nes= te Mostr $^{\circ}$, frequentava as Aulas, nas q $\mathrm{q}^{\mathrm{s}}$ sempre foraõ attendidos os seus argumentos. A sua vida era exemplar, empenhando na /observancia/ religioza sempre advertia o q' lhe parecia necessário; assim foi passando alguns annos athé ${ }^{169}$ que fazendo-se a sua capacid ${ }^{\mathrm{e}}$; elegeraõ $\mathrm{M}^{\mathrm{e}}$ de Noviços, escuzou-se deste imprego $p^{\mathrm{r}}$ motivos justificados. No Trienio seg ${ }^{\mathrm{te}}$ veio elei= to em D. $A b^{\text {e }}$ da Grça, e q ${ }^{\text {do }}$ continuava na quelle governo com utilid do Monstro o removeraõ $\mathrm{p}^{\mathrm{a}}$ a caza de Pernanbuco, com om ${ }^{\mathrm{mo}}$ imprego de $\mathrm{Ab}^{\mathrm{e}}$ Os $1^{\text {os }} 2$ an $^{\text {s }}$ foi aplauzivel o seu governo, tanto $\mathrm{p}^{\text {lo }} /$ augmento/ espiritual, como $\mathrm{p}^{\text {lo }}$ temporal do $\mathrm{d}^{\mathrm{o}}$ Mostr $^{\mathrm{O}}$; em q' cuidava com zêlo, q' lhe recomendava a sua per $=$

feita observancia, os súbditos con tudo satisfeitos, os pobres, e os seculares todos n'elle achavaõ a caridade e o patrocínio.

${ }^{169}$ Não há o traço horizontal do $<\mathrm{t}>$. 
/Passados/ dous annos, / e alguns mezes nesta armonia, e quietaçaõ, o in= nimigo da paz exitou entre elle, e alguns subditos huma turmen ta taõ grande e [ $\uparrow$ de] discordias, que nunca mais se pode serenar athe o fim do trienio; haviaõ parsia[ $\uparrow 1 \mathrm{li}]$ dades, enredos, murmuraçaõ, e dictos, q' chega= vaõ athe o Palacio do $\operatorname{Exm}^{\circ}$ Bispo, o prelado vendo q' lhe faltavaõ alguns dos Subditos com a obediencia devida ao seu lugar, ecom o resp ${ }^{\text {to }}$ devido a sua pessoa, naõ incontrando meio, com q' podesse aquietar a $\mathrm{q}^{\text {la }}$ tem= pestade, recorreo ao Prelado supperior, $\mathrm{p}^{\mathrm{a}}$ que lhe desse providencia; principiaraõ os juramentos, e as devaças athé o fim do ultimo anno, /bem se concluir/ couza alguma. Neste tempo chegou a noticia das /eleições/, nas quais vinha nomeado companheiro, retirou-se $\mathrm{p}^{\mathrm{a}}$ esta caza, edep ${ }^{\mathrm{s}}$ de alguns mezes, recebeo ordem do $\mathrm{Rm}^{0} ; \mathrm{p}^{\mathrm{a}} \mathrm{q}^{\prime}$ aparecesse na congegaçaõ, a responder os incargos, que lhe tinha recultado das devaças: embarcou-se: e chegando ao Mostr ${ }^{\circ} \mathrm{de} \mathrm{Lx}^{\mathrm{a}}$ bem dêo aco= /nhecer que na/ sua religioza Peçôa, naõ podiaõ ter logar similhan= tes dizordens, porem naõ sendo attend ${ }^{\circ}$ como dezejava, se retirou $\mathrm{p}^{\mathrm{a}} \mathrm{o}$ Convt ${ }^{0}$ de Bethlem dos $\mathrm{P}^{\text {es }}$. Jeronimos, $\mathrm{p}^{\mathrm{a}}$ que com mais dizimbara $=$ ço tratasse da saua justiça, n' aq ${ }^{\text {le }}$ convento, assistio alguns tempos, athé q' sendo accomet ${ }^{\circ}$ de huma molestia trabalhoza, avizado do pe $=$ rigo, pedio que o mandassem $\mathrm{p}^{\mathrm{a}}$ o seu $\mathrm{Most}^{\mathrm{o}}$; recolhidon'elle, foraõ admiraveis as dispozições com q' se preparôu $\mathrm{p}^{\mathrm{a}}$ a sua conta final, Confeçou-se algumas vezes, pedio perdaõ a todos os Monges, assim

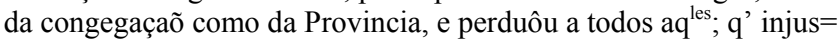
$\operatorname{tam}^{\mathrm{e}}$ lhe cauzaraõ tantos disgostos, e trabalhos; disapropriou se detu= do nas maõs do Prelado, e pedindo oultimos Sacrament ${ }^{\text {os }}$, q' recebêo com grd devoçaõ, e ternura, acabôu a sua peregrinaçaõ aos $7 \mathrm{de}$ Dezembro 1752 , sendo D.Ab ${ }_{;}^{\mathrm{e}} \mathrm{d}^{\mathrm{a}} \mathrm{aq}^{\mathrm{le}}$ Montr $^{\mathrm{o}}$ o M.R.P. Pregador Geral 
$\left[\mathrm{f}^{\mathrm{0}} 98 \mathrm{r}^{\mathrm{0}}\right]$

Fr.Marcelino da $\mathrm{M}^{\mathrm{e}}$ de Deos, tinha 50 annos de idade, e 33 incomple= inconpletos de Religiaõ.Chegou a noticia de sua morte no mez de Ja=

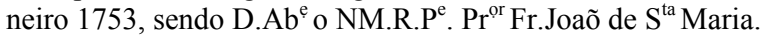

193 O Centesimo nonagesimo terc ${ }^{\mathrm{o}}$ foi o $\mathrm{P}^{\mathrm{e}}$.Fr.Manoel da Encarnaçaõ, nascido em $\mathrm{Lx}^{\mathrm{a}}$ de pais honestos, com os quais se embarcou pa o Brazil, o com elles foi viver na villa de Camamu, professo neste Mostr $^{0} ; a_{0} \mathrm{q}^{1}$. servio com zêllo, e promptidaõ $\mathrm{m}^{\text {tos }}$ annos, principalm ${ }^{\mathrm{e}}$ no altar, e côro $\mathrm{p}^{\mathrm{r}}$ ser $\mathrm{m}^{\text {to }}$ bom muzico, e tocar arpa com $\mathrm{m}^{\text {to }}$ destreza. Era Religiozo pacifico, observante, e reco=

lhido. Por $\mathrm{m}^{\text {tos }} \mathrm{a}^{\mathrm{s}}$ padecêo huma molestia traballhoza, que lhe naõ per= metia discanço em hora alguma.Com licença de Religiaõ foi viver na dita $\mathrm{V}^{\mathrm{a}}$ em q' assistiraõ os seus Parentes, aonde experimentava algum ali= vio, a sua assistencia, $n^{\prime} \mathrm{aq}^{\text {la }}\left[\uparrow\right.$ Villa]foi de $\mathrm{m}^{\text {ta }}$ utilid $\mathrm{p}^{\mathrm{e}} \mathrm{p}^{\mathrm{a}}$ os moradores, aos $\mathrm{q}^{\mathrm{s}}$ adminis $=$

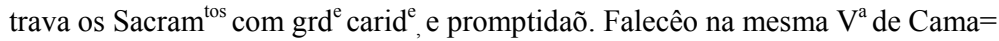
mu com $84 \mathrm{a}^{\mathrm{s}}$ de id ${ }^{\mathrm{e}}$; e 61 de habito em 19 de Março [ $\uparrow$ de] 1753, sendo D.Abade o N.M.R.P. ${ }^{\mathrm{e}} \mathrm{M}^{\mathrm{e}}$.Exprovincial Fr.Joaõ de Santa Maria.

194 O Centesimo nonagesimo quarto foi o $\mathrm{P}^{\mathrm{e}}$.Pregador Fr.Placido de S.Anna, nascido /no/ mar avista de terras da $\mathrm{B}^{\mathrm{a}}$, vindo seus Pais imbarcados $\mathrm{p}^{\mathrm{a}}$ esta $\mathrm{Cid}^{\mathrm{e}}$; professo nesta caza. Ao dep ${ }^{\mathrm{s}}$ de graduado em artes, nas aulas da $\mathrm{Com}=$ panhia foi $\mathrm{p}^{\mathrm{a}}$ a univercid ${ }^{\mathrm{e}}$ estudar Leis; $\mathrm{p}^{\mathrm{m}}$ disagradando=se d'aquella vida, buscou a Religiaõ Benedi[个ict]na, e n'ella professou o estado de Monge, ordenando de Sacerdote, ouvio Theologia neste Mostro ; eno fim d'ella di= gnam $^{\mathrm{e}}$ o numiaraõ Pregador Urbano. Exercêo este imprego com geral acceitacaõ, tanto nesta caza, como em Pernanbuco. Quando pregava as Domingas da quaresma nesta nossa Igreja, /concorria/ tanto pôvo que era necessario porem-se guardas nas portas $\mathrm{p}^{\mathrm{a}}$ evitar algumas disor= dens, q' podia acontecer. Algumas vezes foi ao Certaõ pregar missaõ; e pro punha com exprecões taõ claras, e valentes a doutrina Evangelica 
$\left[\mathrm{f}^{\mathrm{0}} 98 \mathrm{v}^{\circ}\right]$

que suavem ${ }^{\mathrm{e}}$ movia aos ouvintes $\mathrm{p}^{\mathrm{a}}$ as reformas das suas vidas; dias, e notes inteiras gastava em ouvir confições geraes, $\mathrm{p}^{\mathrm{a}} \mathrm{o}$ que era buscado de $\mathrm{m}^{\text {to }}$ lon= ge. Reconcelhava inimigos, compunha discordias, e naõ perduava $\mathrm{q}^{1} \mathrm{q}^{\mathrm{r}}$ trabalho $\mathrm{p}^{\mathrm{a}}$ converçaõ das Almas: $\mathrm{p}^{\mathrm{r}} \mathrm{m}^{\text {tas }}$ terras foi hum fiel dispen= ceiro da palavra do Senhor. Achava $=$ se na $V^{a}$ da Jacobina preg $<\mathrm{u}>$ ando humas tardes da quaresma, com o seu custumado esperito na $3^{\mathrm{a}}$ foi accometido de huma febre taõ forte, que em breves dias lhe tirou a vida. Foi sepultado na Igreja de S.Miguel no Arraial de S.An ${ }^{\text {to }}$, $\mathrm{p}^{\mathrm{a}}$ onde se tinha retirado no mez de Marco 1753, sendo D.Ab ${ }^{\mathrm{e}}$ o N. M.R.P. . $^{\mathrm{e}}$. Ex Provincial Fr. Joaõ de Santa Maria.

O Centesimo nonagesimo quinto foi o $\mathrm{P}^{\mathrm{e}}$.Fr. Ignacio da Conceiçaõ, 195 filho de Pais honestos desta $\mathrm{Cid}^{\mathrm{e}}$. Foi muzico dos mais excellentes, que neste tempo havia, e assim $\mathrm{p}^{\mathrm{r}}$ esta e outras prendas, era estima= do da Pessoas mais auctorizadas desta terra, e ainda dos mesmos principais, que a governavaõ. Achando-se ja na id ${ }^{\mathrm{e}}$ de $40 \mathrm{a}^{\mathrm{s}}$, renun= ciando todas estas honras, e outras $\mathrm{m}^{\text {tas }}$ conveniencias q' lhe faziaõ, acceitou o offerecim ${ }^{\text {to }}$ o Provincial, e entaõ era $\mathrm{p}^{\mathrm{a}}$ que fosse Religiozo Vestio o habito de Monge.Servio a Religiaõ com as suas prendas, e otempo que lhe restavaõ das suas obrigações, sempre o im= pregou: aexercicios honestos, como era obordar, e pintar, do q' ti= nha sufficiente noticia adquirida $\mathrm{p}^{\mathrm{r}}$ sua curiozid ${ }^{\mathrm{e}}$. Retorôlla veneravel imagem do $\mathrm{S}^{\text {to }}$ Christo do coro com aperfeiçaõ, q' sevê. A mitra mais precioza, q' tem a Sachristia hé toda a obra sua. Nestes, e outros louvaveis exercicios passou alguns annos neste Mostro ${ }^{\circ}$ e no $\mathrm{m}^{\mathrm{mo}}$ continuou nas Brottas $\mathrm{p}^{\mathrm{a}}$ aonde foi $\operatorname{mud}^{\mathrm{o}}$. Quando contava 57 an $^{\mathrm{s}}$ de id $\mathrm{id}^{\mathrm{e}}$, e 15 de Religiaõ adoecêo de huma hidropizia, e recolhendo-se a esta caza $p^{\text {a }}$ cuidar na sua saude, naõ conseguindo as milhoras, q' espirava, mas antes dizinganado q' morria, se dispoz como bom Catholico, e bom Religiozo pa a sua ultima hora. Falecêo 
$\left[\mathrm{f}^{\mathrm{p}} 99 \mathrm{r}^{\circ}\right]$

em 3 de Dezembro 1753, sendo D.Abade o /N.M.R.P. ${ }^{\mathrm{e}} \mathrm{M}^{\mathrm{e}}$. Ex Provincial/ Fr. Antonio da Luz.

196 O Centesimo nonagesimo sexto foi o $\mathrm{P}^{\mathrm{e}}$. Fr. Manoel da Conceiçaõ, natural da Praça de Monçaõ, professo neste Mostro . Pouços annos logrou este Monge o estado q' sempre dezejava, q' era o de Religiozo, $p^{r}$ q' logo q' se ordenou de sacerdote, adoecêo de huma molestia, $\mathrm{q}^{\prime}$ veio a disgene= rar em huma tizica; naõ foi dilatada; $\mathrm{p}^{\mathrm{r}}$ que $o \mathrm{~m}^{\text {to }}$ sangue, $\mathrm{q}^{\prime}$ lança va $\mathrm{p}^{\text {la }}$ boca em poucos tempos o chegou ao ultimo ponto do seu dias, recebêo os ultimos Sacram ${ }^{\text {tos }}$ com $\mathrm{m}^{\text {ta }}$ devoçaõ, ecomo perfeito Religiozo, q' era com $\mathrm{m}^{\text {tos }}$ actos de contriçaõ suavem ${ }^{\mathrm{e}}$ espirou no mez de Agosto 1754, sendo D.Ab ${ }^{\mathrm{e}}$ o N.M.R.P. $\mathrm{P}^{\mathrm{e}}$. Ex Provincial Fr. Antonio da Luz.

197 O sentesimo nonagesimo septimo foi o $P^{\mathrm{e}}$.Fr.Fran ${ }^{\mathrm{co}}$ de $S{ }^{\text {ta }}$. Elena, nascido de Pais nobres, e abundantes, nesta $\mathrm{Cid}^{\mathrm{e}} \mathrm{da} \mathrm{B}^{\mathrm{a}}$; os $\mathrm{q}^{\mathrm{s}}$ deixaraõ algu= mas terras a este Mostro ${ }^{\circ}$ como já sedice em outro lugar, professo nesta caza. Ao dep ${ }^{\mathrm{s}}$ de ter servido este Mostro ${ }^{\circ}$ no tempo de Corista, eno estado de Sacerdote, com promptidaõ, e deligencia se Auzentou p ${ }^{\mathrm{a}}$. o certaõ, aon= de assistio vinte $\mathrm{a}^{\mathrm{s}}$ no fim delles se recolhêo em virtude de hum per= daõ geral concedido aos fugetivos, e Apostatas; recolhido ao Mostr ${ }^{\circ}$ os Prelados se aproveitaraõ do seu prestimo $\mathrm{p}^{\mathrm{a}}$ administrar algumas

198 O centesimo nonagesimo oitavo foi o $P^{\mathrm{e}}$.Pregador Fr. Ignacio de Santa reiras em Jaguaripe. Adoecendo de huma hidropizia, veio morrer em Comp $^{\text {a dos Religiozos com os Sacram }}{ }^{\text {tos }}$ da Igreja aos 13 de Abril 1755 sendo D. $\mathrm{Ab}^{\mathrm{e}}$ o N.M.R.P. ${ }^{\mathrm{e}}$. Ex.Provincial Fr. Antonio da Luz.

Izabel, natural desta $\mathrm{Cid}^{\mathrm{e}} \mathrm{da} \mathrm{B}^{\mathrm{a}}$; depais honestos, professo nesse Mostr ${ }^{\mathrm{o}}$. Sempre este Monge servio a Religiaõ com zelo, e promptidaõ, em q ${ }^{1}$ quer $-195-$ 
parte q' se achava; nesta caza foi a sua maior assistencia, e n'ella foi $\mathrm{Pi}=$ or alguns tempos, comprindo perfeitam ${ }^{\mathrm{e}}$ com as obrigações do seu lugar, Padecêo $\mathrm{p}^{\mathrm{r}} \mathrm{m}^{\text {tos }}$ annos grandes dores cauzadas de huma chaga /incu= $\mathrm{ravel} /$, que se the abrio em huma perna, d'ella veio amorrer forta= liscido com agraça dos Sacramentos em 26 de Abril, de 1756, sendo D.Abade o Nosso $\mathrm{M}^{\text {to }} \mathrm{R}^{\mathrm{do}} \mathrm{P}^{\mathrm{e}}$. Ex Provincial Fr.

Antônio da Luz.

199 O Centesimo nonagesimo nono foi o M.R.P.Definidor Fr.Mano el do Nascimento, natural da Cidade de Lisbôa, professo neste Mosteiro. Ao depois de passar nesta caza alguns annos de seu Coristado, foi manda $<\mathrm{d}>$ do estudar Filozofia no Rio de Janeiro, e Theologia neste Mosteiro, no fim do seu Collegio foi nomiado pregador Urbano $\mathrm{p}^{\text {la }}$ capacidade, que n'elle observavaõ para otal exercicio, correndo o tempo, o elegeraõ Procurador de Geral da Provincia, tractou das dependencias da Religiaõ, como se esperava do seu zelo. No trienio seguinte sahio elleito em D.Abbade de Olin= da, embarcou-se $\mathrm{p}^{\mathrm{a}}$ a quella terra, e tomando posse do Mosteiro, em todos os 3 annos, trabalhou sem discanço, fizeraõ-se obras importantes, como foi a torre e outras mais, q' elle assistia a toda a ho= $\mathrm{ra}, \mathrm{p}^{\mathrm{a}}$ que a sua prezença adiantasse o serviço. Naõ faltava aos actos da Communidade $\mathrm{p}^{\mathrm{a}}$ que tudo se fizesse com perfeiçaõ devida. Concluio o seu trienio em asseitaçaõ, e aplauzo, voltou $\mathrm{p}^{\mathrm{a}}$ esta caza a oc= cupar o imprego de Definidor, em que veio provido. Em huma noi= te $\mathrm{p}^{\text {las }}$ oito oras sahio a confecar-se, e recolhido $\mathrm{p}^{\mathrm{a}}$ a Cella, sentindo huma novidade grande, procedida de huma quebradura, q' ha= via annos the cauzava grandes molestias, echamou $\mathrm{p}^{\mathrm{r}}$ dois Religio $=$ zos; os quais lhe asssitiraõ athe as 10 oras da mesma noite, em que foi accometido da molestia, que lhe tirou a vida ao 15 de junho 
de 1756, sendo D.Abade o Nosso Muito $\mathrm{R}^{\mathrm{do}} \mathrm{P}^{\mathrm{e}}$. Ex Provincial Fr. Antônio da Luz.

200 O Ducentesimo foi o irmaõ Donado Fr.Belchior da Encarna= çaõ nascido de Pais honestos na Villa de Mirandela, professo nesta caza. Era official de Sapateiro, e nelle servio a este Mosteiro com agrado dos Religiozos, em quanto teve forças para trabalhar. Nunca principiou trabalho sem que primeiro ou= visse Missa; e satisfizesse as obrigações de Religiozo. Era muito ca= ritativo $\mathrm{p}^{\mathrm{a}}$ os infermos, e do grande cuidado, com q' assistio a hum tizico, dizem que adquerira a mesma molestia, ed'ella veio amorrer, preparado com agraça dos Sacramentos, e com muitas lagrimas, e actos de Contriçaõ, como verdadeiro Cato= lico aos 7 de Oitubro 1756, sendo D.Abbade o Nosso Muito R. P . Ex Provincial Fr. Jerônimo da Assumpçaõ. ria natural do Reino, professo nesta caza. Embarcou-se para o Brazil em ordem adquirir alguma couza, com que honestamente passa-se a vida. Foi para o Sertam da Bahia, aonde vivêo alguns annos; porem como Deos o tinha para outro fim, deixando aquelles dizertos, veio para esta Cidade, e buscando este Moseiro, ja adiantado em idade, pedio humildemente o habito no estado de Leigo, foi attendida a sua petiçaõ; $\mathrm{p}^{\mathrm{r}}$ que discobriraõ nel le bastantes indicios de virtude, e semceridade. Ao de $\mathrm{p}^{\mathrm{s}}$ de professo, o mandaraõ governar as nossas fazendas no districto da Villa de mata queri, passados tres annos 
e quazi, seis mezes, veio ao mosteiro; e queixando-se da falta de Missa para elle, e para os Escravos; $\mathrm{p}^{\mathrm{r}}$ ficar a Igreja em distancia de muitas leguas, o mandaraõ ordenar de Sa cerdote, voltou $\mathrm{p}^{\mathrm{a}}$ as ditas fazendas, e n'ella assistio muitos annos pela boa conta, que dava, e pelo seu bom procedimento. Considerando-se já destetuido das forças necessarias $\mathrm{p}^{\mathrm{a}}$ a quelle trabalho, pedio licença, e recolhêo-se a este Mosteiro.

A sua vida era exemplar. Frequen tava os Actos conventuaes; como qualquer Junior; fugia de toda a estimaçaõ, e todo o seu impenho era que as su as ações se encaminhassem para a honra, e serviço de Deos, e da Religiaõ. Era amante da pobreza, e alguma co[ $\uparrow u] z a, q u e$ adqueria, occultamente destribuia pelos Pobres. Ja com oitenta annos de idade, e quarenta de bom Religiozo foi accometido de hum estupor, do que veio a morrer em 19 de Abril 1757, sendo D.Abbade o Nosso Muito R. P $\mathrm{P}^{\mathrm{e}}$. Ex provincial Fr. Jeronimo da Assumpçaõ. -198 - 
202 O Ducentesimo segundo foi o Irmaõ Fr.Virissimo do Espirito Santo natural de Rendufe /Arcebispa do/ de Braga, professo nesta Casa. Trinta, e oito annos servio este Religioso a este Mostr ${ }^{\circ}$ com ge ral satisfaçaõ dos Prelados, e dos Religiosos, e uti lidade da Religiaõ, os mais delles no emprego de mordomo, sabia destribuir o patriminio com zêlo, prudencia, e fidelid ${ }^{\mathrm{e}}$, porq' evitando todas as superfluid ${ }^{\text {es }}$, naõ faltava com o necessario dos emfermos, aos pobres, aos escravos, á tempo, e á horas, satisfasendo a todos, sem desconsolar a nenhum: era prutamt $\mathrm{e}^{\mathrm{e}}$ adequeiro, e $\mathrm{p}^{\mathrm{a}}$ satisfazer a tudo com promptidaõ, tinha as horas repartidas, as primr ${ }^{\text {as }}$ do dia era $\mathrm{p}^{\mathrm{a}}$ /ouvir Missa, satisfaser as suas devoções, e re/ zas, a q' era obrigado pela sua profissaõ. /Tinha/ grande credito emtre os homens abonados desta terra, de sorte q' estavaõ promptos $\mathrm{p}^{\mathrm{a}}$ fi 
fiarem delle tudo o q' quisesse, tudo merecia pela verdade, com q' os tratava, e pela prom ptidaõ com que os satisfasia $<\tilde{o}>$. Na carreira de tan tos annos naõ lhe faltaraõ occasioens̃ de exer citar a sua paciencia, porem nem uma lhe pode alterar o animo, $\mathrm{p}^{\mathrm{a}} \mathrm{q}^{\text {' se mostrasse me- }}$ nos soffrido. Era obediente, humilde, e de bom procedim $^{\text {to }}$; e porisso sempre mereceo dos Pre lados, e dos Religiosos uma attençaõ $\mathrm{m}^{\text {to }}$ dis tinta.Padeceo por alguns annos um flato, q' bastantem $^{\text {te }} \mathrm{o}$ atormentava, principalm ${ }^{\text {te. }}$ nas occasioens̃ de lúa, foi-se lhe aumentando, até q' de todo opprimido com a violencia $\mathrm{da}<\mathrm{d}>$ /S $\backslash$ ua suffocaçaõ perdeo a sua vida com setenta e nove ${ }^{170}$ annos de idade, e 38 de habito, a sua morte foi geralm ${ }^{\text {te }}$ sentida, naõ é entre os Religiosos, mas ainda dos Seculares, q' todos conheciaõ o seo prestimo, e sua capacid ${ }^{e}$.

\footnotetext{
${ }^{170}$ O nove está sob o carimbo do ARCHIVVM ARCHICCENOBII BRASILIENSIS BAHIAE que se estende das linhas 15 a 17.
} 
capacidade. Faleceo aos de 1757. Sendo D.Abb o N. M. R. $P^{\mathrm{e}}$. ExProv ${ }^{\mathrm{al}}$ Fr. Jeronimo da Ascençaõ.

$203 \mathrm{O}$ du $</$ ode $/>$ cente $\left[\downarrow_{\text {simo }}\right]$ terceiro foi o $\mathrm{P}^{\mathrm{e}}$.Pregador Fr. Franc ${ }^{\text {co }}$ de $\mathrm{S}^{\text {ta }}$ Luzia nascido nesta Cidade de Pais honestos, professo neste Mostr'. Pelas prendas, q' tinha de organista, e musico, e pela perfeiçaõ de seos costumes foi admettido ao estado de Monge,ao qual sempre viveo ajustado, observandocom a cautella os vottos, q' professara, e tudo mais q' a Religiaõ determina. Pelos Mostr ${ }^{\text {os }}$ por onde andou, servia a Religiaõ com grande gosto, e cuidado. Nesta Casa aonde foi maior a sua assistencia, servio $\mathrm{m}^{\text {tos }}$ annos de Cantor mór, e Mestre da Capella, procurando com diligencia, q' todas as funcções do Côro, e Igreja se fisessem com toda a perfeiçaõ, decencia, e gravidade, $\mathrm{e} / \mathrm{p}^{\mathrm{a}}$ / ter os melhores Musicos sempre promptos $\mathrm{p}^{\mathrm{a}}$. quando delles necessitava, fasia com elles algumas despesas a custa do seo Peculio. Frequentava o côro com promptidaõ, e confessionario com carid ${ }^{\mathrm{e}}$, e tambem no pul- 
pulpito desempenhava a sua obrigaçaõ. Ao depois de ter servido à Religiaõ trinta, e oito annos sempre dentro do Mostr ${ }^{\circ}$., quan do enchia sincoenta, e seis annos de idade natural, foi accomettido de um repentinoaccidente, q' dando lhe tempo $\mathrm{p}^{\mathrm{a}}$ se absolver e ungir, o privou da vida em 3 de $8 b^{\circ}$ vesporas do Patriarcha S.Franc ${ }^{\circ}$, de $\mathrm{q}^{\mathrm{m}}$ era devotissimo, de 1758 Sendo D.Abb o N. M. R. $\mathrm{P}^{\mathrm{e}}$. ExProv ${ }^{\mathrm{al}}$ Fr. Jeronimo da Ascençaõ.

204 O Ducentesimo quarto foi o Padre Fr. Antonio Manoel, natural desta Cidade, professo neste Mostr ${ }^{\circ}$. Enchendo os annos de Corista, comprin do com /as/ suas obrigações prompto, e diligente, ordenado Sacerdote, pouco se aproveitou a Religiaõ do $\mathrm{m}^{\text {to }} \mathrm{q}$ ' podia faser, porq' saindo-lhe das q' chamaõ carnal, em uma parte do rôsto, do qual fasendo pouco caso, de tal sorte se veio a agravar, q' foi o instrum ${ }^{\text {to }}$ q' lhe tirou a vida aos 12 de Fevr ${ }^{\circ}$ de 1759. Sendo D.Abb o N. M. R. P e ExProv $^{\text {al }}$ Fr. Jeronimo da Ascençaõ 
$\left[\mathrm{f}^{\mathrm{o}} 103 \mathrm{r}^{\mathrm{0}}\right]$

da Ascençaõ, e tinha quatro annos de habito, e 24 de idade natural.

205 O ducentesimo quinto foi o padre Fr.Felis da Piedade, natural da villa de Asurar Bisp ${ }^{\text {do }}$ do Porto. Na idade de 22 annos incompletos,

profissou a vida Religiosa neste Mostr ${ }^{\circ}$, no $\mathrm{q}^{1}$. assistio, até q' ordenado Sacerdote, foi manda do $\mathrm{p}^{\mathrm{a}}$ o Rio de Janeiro estudar Philosophia, no quarto mez do primr $^{\circ}$ anno fez deixaçaõ do Collegio, e voltando $\mathrm{p}^{\mathrm{a}}$ esta Casa, o mandaraõ governar a fasenda do Unhatá, aonde assis tio /perto/ de $s</$ el $>$ icenta annos com edificaçaõ dos Seculares, por ser Religoso de vida exemplar, esmol[er], e caritativo. Destituido ja de todas as forças naturaes, e pertubado dossentidos, recolheo-se a este $\operatorname{Mostr}^{\circ}$ no qual acabou a vida com a graça dos Sacram ${ }^{\text {tos }}$ aos 9 de Abril de 1759 tendo noventa annos de idade, e secenta e nove de habito. Era D. $\mathrm{Abb}^{\mathrm{e}}$ o N. M. R. $\mathrm{P}^{\mathrm{e}}$. Ex.Prov ${ }^{\mathrm{al}}$ Fr. Jeronimo da Ascençaõ.

206 O ducentesimo sexto foi o M.R.P. ${ }^{\mathrm{e}}$.Preg ${ }^{\text {or }} \mathrm{Fr}$. $-203-$ 
Fr. Bazilio das Neves natural da Cidade deArrifana de Sousa, de Pais virtuosos. Professou nesta Casa, e logo nos seos principios mostrou q' havia de ser Religoso, exemplar, recolhido, e observ ${ }^{\text {te }}$, assim o mostrou, e assim o foi toda a sua vida. Teve o seo $\mathrm{Coll}^{\circ}$ no Mostro do Rio, e concluido elle recolheo-se a esta Casa, vivendo no seo costumado reco 1 him $^{\text {to }}$,e e servindo a Religiaõ, no q' promet tiaõ as suas forças, e lhe davaõ lugar as su as molestias. Attendido o seu prestimo o elegeraõ em D.Abb ${ }^{\mathrm{e}}$ deste Mostro o qual gover nou com paz, e satisfaçaõ dos seos Subditos. No seo triennio se fiseraõ algumas obras de utilidade, e necessarias. Como foi mandar forrar a Igreja, e outras mais q' cons taõ do estado. Acabou o seo lugar recolhen do-se na sua cella, e deixando-se de tudo. Só cuidava em dispor-se como bom Catholico $\mathrm{p}^{\mathrm{a}}$ a tremenda viagem da morte, atéq' chegando a sua ultima hora, disposto com a graças dos Sacram ${ }^{\text {tos }}$ deixou este Mundo 
Mundo aos 12 de Junho de 1759 q do $^{\text {enchia oi- }}$ tenta e quatro annos de $i^{\mathrm{e}}$, e 66 de Religiaõ Sendo D.Abb ${ }^{\mathrm{e}}$ o N. M. R. P ${ }^{\mathrm{e}}$. Ex.Prov ${ }^{\mathrm{al}}$ Fr. Jeronimo da Ascençaõ.

$5207 \quad$ O ducentesimo septimo foi o Irmaõ Donado Fr.Constantino, natural da Cidade do Porto, professo neste Mosteiro. Era Religioso obediente, eprompto em servir, no que lhe mandava.Naõ se utilisou por $\mathrm{m}^{\text {to }}$ tempo a Religiaõ do seo prestimo, porq' morreo tizico com cinco annos incompletos de habito, confessou-se e recebeo o N. por viatico com grande devoçaõ, e antes de se acabar de ungir espirou-no dia decimo de $7 b^{\circ}{ }^{\circ}$ de 1759 Sendo D.Abb o N. M. R. P $\mathrm{P}^{\mathrm{e}}$. Fr. Jeronimo da Ascençaõ.

208 O Ducentesimo oitavo [foi] o $\mathrm{P}^{\mathrm{e}}$.Preg ${ }^{\text {or }}$ Fr.Ignacio da Encarnaçaõ, natural desta Cidade professo neste Mostro ${ }^{\circ}$, no $\mathrm{q}^{1}$ teve alguns annos de Corista, satisfasendo as suas obrigações com promptidaõ, e diligencia. Teve o seo coll ${ }^{\circ}$. no Mostro de Perna[ $\uparrow \mathrm{m}]$ buco, e feito Pregador pouco exercicio teve deste emprego pelos seos- 
seos trabalhos, e suas molestias. Passados $\mathrm{m}^{\text {tos }}$ annos veio morrer neste Mostro ${ }^{\circ}$, sendo conventual da Graça, preparado com os sacra $\mathrm{m}^{\text {tos }}$ da Igreja, e com assistencia dos Religiosos, no anno de 1760 Sendo D.Abb o N. M. R. $P^{\mathrm{e}}$. ExProv ${ }^{\text {al }}$ Fr. Jeronimo da Ascençaõ.

209 O Duentesimo nono foi o M.R.P. ${ }^{\mathrm{e}}$. ${ }^{\mathrm{e}}$.Fr. José de Santa Rosa natural ${ }^{171}$ natural de Joaõ da Foz digo de Foz de Pais honestos, professo neste Mostr ${ }^{\circ}$, nelle teve o seo Coristado dando uma prompta satisfaçaõ as suas obrigações, q' lhe pertenciaõ; $\mathrm{Na}$ Graça estudou Filosophia, no Rio de Janeiro teve a sua Theolgoia, no fim do seocoll $^{\mathrm{o}}$ o elegeraõ Pass ${ }^{\text {te }}$ por ordem do $\mathrm{R}^{\mathrm{mo}}$. Lêo Theologia com aceitaçaõ, porq' era estudioso, e dotado de um entendim ${ }^{\text {to }}$. claro. Passados annos veio eleito em D.Abb ${ }^{\mathrm{e}}$ do $\mathrm{Mostr}^{\mathrm{o}}$ da Parahiba, tomou posse do lugar, e governou com acerto, e credito da Religiaõ, e da sua pessôa, desenganando aos $\mathrm{R}^{\mathrm{mos}} \mathrm{Ge}$ raes, q' nunca mais se lembrassem delle

${ }^{171}$ A palavra $<$ natural $>$ está sublinhada e entre parênteses (APFL). 
delle para emprego da Religiaõ, assim o fiseraõ, e elle $\mathrm{m}^{\text {to }}$ satisfeito teve uma vida dilatada e livre dos trabalhos, q' dahi havia de resultar. Assistio $\mathrm{m}^{\text {tos }}$ annos nesta Casa, servindo a no q' lhe mandavaõ, era $\mathrm{m}^{\text {to }}$ recolhido, observante, e amigo da paz, frequentava os actos convertuaes, em $\mathrm{q}^{\text {to }}$ teve forças $\mathrm{p}^{\mathrm{a}}$ a faser, eas missas de N.Snr ${ }^{\mathrm{a}}$., e a comopletas nunca faltava, em q ${ }^{\text {to }}$ pode subir as escadas do Coro. Faleceo fortificado com a graça dos Sacram ${ }^{\text {tos }}$, em 2 de Maio de 1761, tendo 70 annos deReligiaõ, e oitenta, e seis de idade Sendo D. $\mathrm{Abb}^{\mathrm{e}}$ o N. M. R. P ${ }^{\mathrm{e}}$. Ex Prov ${ }^{\mathrm{al}}$ Fr. Jeronimo da Ascençaõ.

$15210 \quad$ O Ducentesimo decimo foi o M.R.P. e $^{\mathrm{e}} \mathrm{M}^{\mathrm{e}}$ .Fr. Bento da Graça, natural da Cidade de Olinda, e professo neste Mostro da ${ }^{\text {ma }} \mathrm{Cid}^{\mathrm{e}}$. Logo de seo ingresso da Religiaõ fechou as portas a occiosidade, occupando todo tempo, q' lhe restava das obrigações religiosas, em exer cicos conducentes $\mathrm{p}^{\mathrm{a}} / \mathrm{o}$ seu/ adiantam ${ }^{\text {to }}$. Foi admettido ao Collegio no Mostro do Rio, aonde debaixo 
debaixo de disciplina de um /grande/ Mestre, mostrou a capacidade, q' tinha $\mathrm{p}^{\mathrm{a}}$ as lettras, tanto nas conclusões particulares, e publicas, q' defendia, como na boa intelligencia, e penetraçaõ das materias, q' estudava. Fez actos de Passante, e no seguinte deo Theologia com grande applauso, e nesta se doutorou, e pa q' a Religiaõ se utilisasse do seo concedido prestimo por $\mathrm{m}^{\text {tos }}$ caminhos veio eleito em D.Abb ${ }^{\mathrm{e}}$ do Mostro . de S.Paulo, sendo uns dos Prelados, q' trabalharaõ no adiantam ${ }^{\text {to }}$, espiritual, e temporal da ${ }^{172}$ quella casa. Mandou faser a torre da Igreja, applicando com tanto calor a execuções de suas disposiçõens ${ }^{173}$, e q' em poucos meses se vio perfeita, e acabada a obra, q' havia tantos annos, esperava a sua diligencia. Governou com zêlo, respeito, e credito, porq' todos o attendiaõ, como Prelado, q' enchia o seo lugar. No trienio immediato veio nomeado Compro ${ }^{\mathrm{o}}$, e Secretario do $\mathrm{R}^{\mathrm{mo}}$ Provincial, achando de visita neste Mosteiro, agravando-se lhe uma molestia $-208-$

${ }^{172}$ A palavra estava grafada assim: "da quella", houve depois uma ligação a lápis.

${ }^{173} \mathrm{O}$ til sobre $\mathrm{o}<\mathrm{S}>$, o que é frequente nesse scriptor. 
molestia /antiga/, </q' $>>$ padecia, della veio a morrer disposto com $\mathrm{m}^{\text {tos }}$ actos de Catholico, e com a graça dos Sacram ${ }^{\text {tos }}$. aos 14 de Julho de 1761, quando a Religiaõ principiava a colher os fructos mais sazonados do seo conhecido prestimo. Era D.Abb ${ }^{\mathrm{e}}$ o M. R. $\mathrm{P}^{\mathrm{e}}$. Preg ${ }^{\text {or }}$ Fr. José de $S^{\text {ta }}$ Thereza.

211 O Ducentesimo undecimo foi o M.R.P. ${ }^{\mathrm{e}}$.Pregador Fr. Bernardino de S.Miguel, natural desta Cidade de Pais honestos, vestio o habito Monachal neste Mostr $^{\circ}$ com o nome de Fr. Miguel, q' ao depois mudou em Fr. Bernardino. No seo noviciado mostrou, q' tinha sido creado $\mathrm{p}^{\mathrm{a}}$. a Religiaõ, porq' era humilde, obediente, e cuidadoso, cuidou em adquerir uma completa noticia ahi, e ceremonias da Religiaõ, e sempre estava prompto $\mathrm{p}^{\mathrm{a}}$. desfaser, qualquer duvida, /q'/ se lhe fasia. Foi Religioso de exemplar procedim ${ }^{\text {to }}$, de $\mathrm{m}^{\text {ta }}$. maduresa, e zêlo, foi algumas veses ao Certaõ com licença dos Prelados, aonde acreditou a sua pessôa, e o seo habito. Duas veses occupou o lugar de Prior nesta casa com adi- 
$\operatorname{adiantam}^{\text {to }}$ da observancia regula/r,/ e zelo da Religiaõ. No Rio de Janeiro foi Sacristaõ mór, cuidando com grande disvello, em q' todas ás funções, q' 'he pertenciaõ, se fisesse com $\mathrm{m}^{\text {ta }}$ decencia e gravidade. Attendido o seo merecim ${ }^{\text {to }}$ o proveraõ em $\mathrm{Abb}^{\mathrm{e}}$. de Perna[m]buco com grande fortuna da quella Casa, porq' elle, e o seo antecessor se empenharaõ em aliviar aquelle Mosteiro da oppressaõ, em q' se achava com dividas antigas. No fim de seo trienio se recolheo a esta Casa, aqual servio no Engenho da Praia, e na capella de Montecerrate com zelo, e disvello. Passados bastantes annos em religiosos exercicios, vendo q' se avisinhava asua hora, $\mathrm{p}^{\mathrm{a}}$. ella se dispoz como bom Catholico, e Religioso. Faleceo em 22 de Outu/bro de/ 1761. Sendo D.Abb o M. R. P P $^{\mathrm{e}}$ Preg ${ }^{\text {or }}$. Fr. José de $S^{\text {ta }}$ Thereza. Fr.Antonio de S.Bento natural da Cidade do Porto, professo nesta Casa. Naõ desme- 
desmereceo este Religioso ser admettido a profissaõ por ser diligente, edesembaraçado $\mathrm{p}^{\mathrm{a}}$ servir a Religiaõ, e pelo desejo q' tinha de fazer as suas obrigações com perfeiçaõ. Frequentava o Coro, e o Confessionario com diligencia, e caridade; pregava com satisfaçaõ, e fasia o q' lhe mandavaõ com zelo, e diligencia, governou o Engenho de S.Caetano com grande utilidade do Mostr ${ }^{\circ}$. Foi Procurador geral, $\mathrm{Abb}^{\mathrm{e}}$. das Brottas, e Compr ${ }^{\circ}$., satisfez a estes empregos, como se esperava da sua capacid ${ }^{\mathrm{e}}$. O resto da vida passou nesta Casa com exemplo, e edificaçaõ. Padeceo por bastantes tempos uma molestia trabalhosa, da qual veio acabar a vida dis posto como perfeito Religioso em 2 de Março de $17<5>/ 612$ Sendo D.Abb ${ }^{\mathrm{e}}$ o M. R. $\mathrm{P}^{\mathrm{e}}$. Preg $^{\text {or }}$ Fr. José de $\mathrm{S}^{\text {ta }}$ Thereza.

213 O Ducentesimo [ $\uparrow$ decimo] /terceiro/ foi o $\mathrm{P}^{\mathrm{e}}$.Fr.Benedicto, de $\mathrm{S}^{\text {to }}$ Antonio natural des $<\uparrow>|\mathrm{ta}|^{174}$ Cidade, de geraçaõ esclarecida, e nobre, professo neste Mosteiro Deixadas todas as honras, e requesas mun 
mundanas, vestio a Cogula Benedictina, $\mathrm{m}^{\text {tas }}$ ve ses buscada $<\mathrm{s}>$ pelos Emperadores, Reis, e grandes de terra, de quem sabemos haverem renunciado coroas, e sceptros $\mathrm{p}^{\mathrm{a}}$ a vestirem. Era Religioso humilde, caritativo, e natural $/ \mathrm{m}^{\text {te }} /$ compadecido dos necessitados, $\mathrm{p}<\mathrm{r}>$ atrocinando com o seo respeito a todos, os q' buscavaõ ao seo amparo. Assistio por mais annos administrando uma fasenda sua com licença da Religiaõ. Foi Conventual das Brottas, e neste Mostro ${ }^{\circ}$ acabou a sua vida, disposto com $\mathrm{m}^{\text {tos }}$. actos de Catholico, e Religioso, pedindo com $\mathrm{m}^{\text {tas }}$. lagrimas misericordia a Deos, e perdaõ aos homens, aos 27 de Fevr ${ }^{\circ}$. de 1763 Sendo D.Abb ${ }^{\mathrm{e}}$ o M. R. P ${ }^{\mathrm{e}}$. Preg ${ }^{\text {or }}$ Fr. José de $\mathrm{S}^{\text {ta }}$ Theresa.

214 O Ducentesimo quatorze foi o $\mathrm{P}^{\mathrm{e}}$. Preg ${ }^{\text {or }} \mathrm{Fr}$. Franc $^{\circ}$. Xavier de $\mathrm{S}^{\text {ta }}$ Maria, nascido nesta Cidade de Pais honestos, professo neste Mosteiro. No seo noviciado procedeo como se esperava dos seos bons costumes, e da bôa 
boa educaçaõ, /c/om q' fora creado, professou com geral aceitaçaõ dos Religiosos, q' observaraõ a/s/ esperanças, q' promettia a sua capacidade,modestia, e compostura, naõ se enganaraõ por q' sendo bons os seos principios, foraõ melhores os seos progressos. Foi Religioso humilde, e obediente, em tudo exemplar, se[r]vio sempre a Religiaõ, em qualquer Mostr ${ }^{\circ}$, em q' se achava, com zelo, promptidaõ, e diligencia, /e/ supposto q' pela sua humildade naõ seguis se as cadeiras, $\mathrm{p}^{\mathrm{a}}$ as quaes tinha capacidade indubitavel, no pulpito conseguio o nome de bom Preg ${ }^{\text {or }}$, por ser dotado das prendas, = naturaes, e moraes, e de todos [os] $<$ ap $>$ predicados, q' constituem um Orador completo. No confes /sionário/ era prudente, e caritativo, e $\mathrm{p}^{\mathrm{a}}$ todos /os/ actos da Religiaõ sempre foi o mais prompto, e diligente. Faleceo com a graça $/$ dos/ Sacram ${ }^{\text {tos }}$. aos 3 de Julho de $176<2>/ 3 \backslash$. Sendo D. $/ \mathrm{Abb}^{\mathrm{e}} /$ o M. R. $\mathrm{P}^{\mathrm{e}}$. Preg ${ }^{\text {or }}$ Fr. José de $\mathrm{S}^{\text {ta }}$ Thereza.

215 O Ducentesimo [ $\uparrow$ decimo] quinto foi o $\mathrm{P}^{\mathrm{e}}$. Collegia $<\dagger>/ 1$ 
Collegia $<$ r $>/ \backslash$ Fr. Franc ${ }^{0}$ da Natividade natural desta Cidade, de Pais virtuosos, professo neste Mostr ${ }^{\circ}$. Era Religioso obediente, humilde, e temente a $\mathrm{D}^{\mathrm{os}}$ e como tal compria perfeitam ${ }^{\text {te }}$ com as suas obrigações, ordenou se de /Sacer/dote, já com principio de sua (f) / t lisica, celebrava com $\mathrm{m}^{\text {ta }}$. devoçaõ, e piedade, porem adiantando-se a molestia, della veio a morrer ao depois de recebidos os Santos Sacram ${ }^{\text {tos }}$, com $\mathrm{m}^{\text {tos }}$. actos de Catholico, em 4 de Agosto de 1764, contando vinte e seis annos de idade, e nove de Religiaõ. Era D.Abb o M. R. $P^{\mathrm{e}}$. Preg ${ }^{\text {or }} \mathrm{Jub}^{\mathrm{o}}$. Fr. Fillippe da Nativid ${ }^{\mathrm{e}}$. cio de $\mathrm{S}^{\text {ta }}$ Anna, nascido nesta Cidade, de Pais honestos, professo nesta Casa. Era Religioso expedito, e diligente, e de prestimo $\mathrm{p}^{\mathrm{a}}$ servir a Religiaõ em qualquer emprego. Teve o seo Coll ${ }^{\circ}$. neste Mostr ${ }^{\circ}$. aonde mostrou capacidade indubitavel $\mathrm{p}^{\mathrm{a}}$ exercicios litterarios, os quaes naõ seguio tam 
tanto pelas molestias, q' padecia, como por alguns embaraços, q' se offereceraõ. Foi nomeado Pregador $\mathrm{Urb}^{\circ}$, q' tambem naõ continuou pelas suas queixas; foi por Conventual das Brottas, e naquelle Mosteiro foi Prior, taõ bem assistio algum tempo na Graça, e voltando $\mathrm{p}^{\mathrm{a}}$ esta Casa nella veio a morrer preparado com a graça dosSacram $^{\text {tos }}$ da penitencia, e Eucharistia, q' recebeo porviatico com $\mathrm{m}^{\text {tos }}$ actos de contriçaõ, e lagrimas de penitente, e arrependido. Faleceo aos dezenove de Julho de 1764. Sendo D.Abb ${ }^{\mathrm{e}}$ M. R. P ${ }^{\mathrm{e}}$. Preg ${ }^{\text {or }} \mathrm{Ju}-$ bilado Fr. Filippe da Natividade. ${ }^{175}[\rightarrow$ (Este precedeu o precedente na morte.)]

217 O Ducentesimo decimo septimo foi o Irmaõ Donado Fr.Franc ${ }^{\circ}$ da $\mathrm{S}^{\text {ta }}$ Rita nascido nesta $\mathrm{Cid}^{\mathrm{e}}$ Conventual do Mostr ${ }^{\circ}$ da Graça. Era official de carpint ${ }^{\circ}$, e com o seo officio, e outros empre gos servio aquella casa com zelo, e cuidado, e /esses/ poucos annos, q' viveo depois de Religioso, veio morrer, neste Mostr $^{\circ}$., disposto com a graça dos Sacram $^{\text {tos }}$, e as sistencias ${ }^{176}$ dos Religiosos em 7 do mes de Julho de 1765. Sendo D.Abb ${ }^{\mathrm{e}}$ o M.

-215 -

${ }^{175}$ APFL

${ }^{176}$ APFT Silva Nigra ligou a lápis o $<$ as $>$ ao $<$ sistencia $>$. 
M. R. P. Preg ${ }^{\text {or }}$ Jubilado Fr. Fi/li/ppe da Nativid ${ }^{\mathrm{e}}$.

218 O Ducentesimo decimo oictavo foi o $\mathrm{P}^{\mathrm{e}}$.Fr.Adrianno de $\mathrm{S}^{\text {ta }}$. Escolastica natural da vesinhança da Cidade do Porto, professo nesta Casa. Nos annos de Corista, e alguns tempos ao depois de Sacerdote, foi Sacristaõ menor, tratando com $\mathrm{m}^{\text {ta }}$ limpesa, e asseio tudo, o q' estava a seo cargo, e corria por sua conta. Foi mandado pela obediência administrar a nossa fasenda de gado no rio de S.Franc ${ }^{\circ},<\mathrm{a}>$ onde assistio dezoito annos, removido $\mathrm{p}^{\mathrm{a}}$. o Mostr ${ }^{\mathrm{o}}$., compria com as obrigações com diligencia, e cuidado, até q' pór duvidas, q' houveraõ a respeito da posse do Prelado desta Casa, foi remettido $\mathrm{p}^{\mathrm{a}}$. Lisboa, e dahi $\mathrm{p}^{\mathrm{a}}$ o Mostr ${ }^{\mathrm{o}}$ de Tibaens ${ }^{177}$, /enelle/ faleceo aos 18 de Agosto de 1765. Sendo D.Abb ${ }^{\mathrm{e}}$ desta casa, donde era conventual, o M. R. P P $^{\mathrm{e}}$ Preg ${ }^{\text {or }}$ Jubilado Fr. Filippe da Natividade.

219 O Ducentesimo decimo nono foi o $\mathrm{P}^{\mathrm{e}}$.Fr. Ma$-216-$

${ }^{177} \mathrm{O}$ traço de nasalidade encontra-se sobre $\mathrm{o}<\mathrm{S}>$. 
Manoel de S.Bernardo natural da Cidade do Por-

$\left[\mathrm{f}^{\mathrm{o}} 110 \mathrm{r}^{\mathrm{0}}\right]$ to, professo neste Mostro . Ao depois de Sacerdote, foi ao Reino, e voltando $\mathrm{p}^{\mathrm{a}}$ sua Provincia, assistio em alguns Mosteiros della, fasendo as /suas/ obrigações na forma q' podia. A sua maior assistencia foi nesta Casa, e nella morreo preparado com os Sacram ${ }^{\text {tos }}$ da Igreja, aos 2 de $7 b^{\circ}$ de 1765 , com oitenta annos, e alguns meses de idade, e sessenta incompletos de Religiaõ. Era D.Abb ${ }^{\mathrm{e}}$ o M. R. P ${ }^{\mathrm{e}}$. Preg ${ }^{\text {or } J u b i-~}$ lado Fr. Filippe da Natividade.

220 O Ducentesimo vigesimo foi o M.R.P ${ }^{\mathrm{e}}$.Preg ${ }^{\mathrm{or}}$ Fr.Bernardo da Encarnaçaõ, nascido na $\mathrm{Ci}$ dade do Porto, de Paes nobres, professo no Mostr ${ }^{\circ}$ do Rio de Janeiro. Ao depois q' desempanhou o nome de bom corista com o seo procedim $^{\text {to }}$, e pela promptidaõ com q' satisfasia as suas obrigações, foi mandado pelos Padres, digo pelos Prelados, ordenar-se de Sa cerdote em Buenos Ayres, junto com outros Religiosos, restituido ao $\operatorname{Mostr}^{\circ}$ continuou 178 $-217-$

${ }^{178}$ Foi irmão do $\operatorname{Rev}^{\mathrm{mo}} . \mathrm{Abb}^{\mathrm{e}}$.Fr. Antonio da Assumpção 156. pg.160 (APFT) 
continuou o seo coll ${ }^{\circ}$, e com bastante intelligencia, e percepçaõ das materias q' estudava, escusou-se de faser actos de Passante, porq' a sua inclinaçaõ o chamava $\mathrm{p}^{\mathrm{a}}$. o exercicio da predica, pregava com acceitaçaõ, concluindo seos sermões, com doutrinas moraes, e conducentes $\mathrm{p}^{\mathrm{a}}$. o approveitam ${ }^{\text {to }}$. dos ouvintes. Algumas veses sahio apregar missaõ pelas visinhanças, mais incultas do Rio de Janeiro, junto com outro Monge, aonde as suas doutrinas eraõ ouvidas com $\mathrm{m}^{\text {ta }}$ attençaõ, e reformas de costumes.

O Exmº. Bispo do Rio de Janeiro informado de seo zelo $\mathrm{p}^{\mathrm{a}}$. o bem das almas, o nomeou. Vigario da Freguisia da Conceiçaõ no districto da Villa de S.Vicente, neste emprego mostrou a sua grande caridade $\mathrm{p}^{\mathrm{a}}$. com os seos fregueses, porq' na/õ s/ó exercitava as obrigações de Parach/o/ Vigilante na administraçaõ dos Sacram ${ }^{\text {tos }}$, mas tam bem as de Pais, fasendo $\mathrm{m}^{\text {ta }}$ ismolla aos 
$\left[\mathrm{f}^{\mathrm{o}} 111 \mathrm{r}^{\mathrm{o}}\right]$

aos necessitados, patrocinando aos desvalidos,e /edificando/ a todos com o seo exemplo, e com o seo recto procedim ${ }^{\text {to }}$; e por esta rasaõ, choraraõ todos por muitos tempos a sua ausencia, na sua retirada $\mathrm{p}^{\mathrm{a}}$. o Mosteiro. Attendidos estes predicados, q' o fasiaõ digno $<\mathrm{s}>$ de honrosos empregos, o elegeraõ $\mathrm{D}$. $\mathrm{Abb}^{\mathrm{e}}$. do Mostro ${ }^{\mathrm{o}}$. da Parahiba, e ao depois de Olinda, nestes lugares mostrou um grande cuidado da honra de $\mathrm{D}^{\mathrm{s}}$, e culto divino; da observancia regular, e / doutiabidade / natural. Tambem foi alguns tempos Presidente deste Mostr $^{\circ}$, porem por algumas duvidas, q' se offereceraõ a respeito da sua Presidencia, seretirou $\mathrm{p}^{\mathrm{a}}$. Portugal, e na volta $\mathrm{p}^{\mathrm{a}}$. esta. Provincia o nomearaõ Chronista mór, e sem duvida com grande accerto, porq' foi o segundo, q' continuou em escrever as vidas dos Monges, q' faleceraõ nesta Casa, principiando pela vida de Fr. Paulo do Espirito Santo, q' foi o quadragesimo quarto falecido neste Mostr ${ }^{\mathrm{o}}$, sendo este o /nu/ mero, /em/ q' tinha ficado o prim ${ }^{\text {ro }}$ Cronista o M.R. $\mathrm{P}^{\mathrm{e}}$.M $\mathrm{M}^{\mathrm{e}}$.Fr. José de Jesús Maria, ele chegou até o numero de duzentos, e desazete, a custa de mui- 
$\left[\mathrm{f}^{\mathrm{o}} 111 \mathrm{v}^{\mathrm{o}}\right]$

muito trabalho, e $\mathrm{m}^{\text {to }}$ disvello em des cobrir noticias antigas, humas adqueridas por traduçaõ; outras pela incançavel applicaçaõ a leitura de $\mathrm{m}^{\text {tos }}$. livros velhos e papaeis antigos, tanto deste, commo de outros Mostr $^{\mathrm{os}}$. da Provincia. Passou $\mathrm{m}^{\text {tos }}$. annosnesta fadiga, porq' occupava grande parte do tempo em comprir com as obrigações necessarias do seo estado, e satisfaser as suas particulares devoções, aqual naõ faltava, como era appli,car todos os meios $\mathrm{p}^{\mathrm{a}}$. lucrar as indulgencias, q' a Igreja concede aos fieis pela $<\mathrm{G}>/ \mathrm{Q}$ luaresma, e outros dias do anno, occupado nestes religiosos, e nobres exercicios o achou a infermid ${ }^{\mathrm{e}}$, q' $^{\prime} \mathrm{o}$ privou da vida, disposto com a graça dos Sacram $^{\text {tos }}$. aos 17 de Julho de 1766, contanto mais de oitenta annos de idade, e mais de sessenta de religiaõ. Era D.Abb ${ }^{\mathrm{e}}$ o M. R. $\mathrm{P}^{\mathrm{e}}$. Prov ${ }^{\mathrm{al}}$ Fr.Jeronimo da Ascençaõ.

221 O Ducentesimo vigesimo primr ${ }^{\circ}$ foi o N.M. R.P. ${ }^{\mathrm{e}}$.Ex.Prov ${ }^{\mathrm{al}} \mathrm{Fr}$. Antonio da Luz, natural de S.Joaõ da Foz professo neste Mostro ${ }^{\circ}$ Logo 
$\left[\mathrm{f}^{\mathrm{o}} 112 \mathrm{r}^{\mathrm{o}}\right]$

Logo nos annos seguintes depois da sua profissaõ, em q' exercitava as obirgações de Corista, mostrou a capacidade, e prestimo, q' tinha $\mathrm{p}^{\mathrm{a}}$. servir a Religiaõ. Passado o tempo de seo $\mathrm{Coll}^{\circ}$, sendo nomeado Pregador, exerceo por tres annos o emprego de Mordorno nesta Casa com satisfaçaõ dos Prelados, contentam ${ }^{\text {to }}$ dos Religiosos, e zelo do patrimonio da Religiaõ. Certificados os Prelados Superiores da sua capacidade e elegeraõ Presidente de Sorocaba, naquelle hospicio trabalhou com tanto disvello, q' as obras mais avultadas, q' nelle apparecem, se deve a sua deligencia, ecuidado. E como seo merecim ${ }^{\text {to }}$. pedia lugares maiores, veio eleito em D.Abb ${ }^{\mathrm{e}}$ das Brottas, naquelle Mostro ${ }^{\circ}$ expirimentaraõ os Subditos a grandesa do seo animo, e os estranhos hoje os he feito de sua caridade, deste emprego passou ao lugar de Comp ${ }^{\mathrm{r}}$, sendo este trabalhoso pelas distancias dos Mostros, foi visitar os mais remotos, pelo impidi/ $\mathrm{m}^{\text {to }} / \mathrm{de}$ uma molestia, com q' se achava o $\mathrm{R}^{\mathrm{mo}} \operatorname{Prov}^{\text {al }}$ desse tempo. Fez as suas visitas com $\mathrm{m}^{\text {ta }}$ paz, naõ dispensando o castigo, aonde achava culpas. Descançou algum tempo, mas para q' naõ estivessem sem exercicio o seo 
seo prestimo, o elegeo a Junta Geral em D.Abb ${ }^{\mathrm{e}}$ desta $\mathrm{Ca}$ sa, foi esta eleiçaõ ouvida com grande gosto dos Religiosos, e tambem dos Seculares, porq' uns, e outros o julgavaõ dignos de cousas grandes, tomou posse do lugar, e pelas $<$ as $><$ cer $>$ /acer $\mid$ tadas disposições, com q' principiou o seo governo, já senaõ esperava mais, q' felicid ${ }^{\mathrm{es}}$ no seo progresso. O seo principal intento era o culto divino e a observancia Monastica, $\mathrm{p}^{\mathrm{a}}$ o q' escolheo um Prior, capaz de corresponder a sua pertençaõ e conseguio o q' desejava, porq' o seo trienio foiplausivel; mereceo uma attençaõ $\mathrm{m}^{\text {ta }}$. distincta dos ministros, e pessoas grandes desta Cidade, porq' sabia obsequiar a todos sem exceder os limites da profissaõ religiosa, e por este motivo sempre os achou promptos $p^{a}$. favorecerem a Religiaõ, $q^{\text {do }}$ assim o pedia a necessidade de seo patroci $<\mathrm{n}>$ nio. Deu principio as obras da Capella mór, $\mathrm{p}^{\mathrm{a}}$. as quaes ajuntou avultadas esmollas tanto dentro da Cidade, como pelo reconcavo, e vesinhanças della $<\mathrm{s}>$; fez outras obras importantes, das quaes se dará noticia no $2^{\circ}$ Cathalogo dos Prelados desta casa. Concluido felizm ${ }^{\text {te }}$ o seo triennio 
triennio foi elevado ao lugar de Prov ${ }^{\text {al }}$. para q' todos os-

$\left[\mathrm{f}^{\mathrm{o}} 113 \mathrm{r}^{\mathrm{0}}\right]$ Mostr $^{\text {os }}$. da Provincia experimentassem os effeitos das suas acertadas determinações; a todos visitou a custa do $\mathrm{m}^{\text {to }}$. trabalho; mas elle naõ se escusava, de nenhum, $\mathrm{q}^{\mathrm{do}}$ assim o recomendava a utilidade da Reli giaõ; nas sua visitas, o q' mais lhe interessava, era a perfeiçao do culto divino, a paz, e a boa ceremonia entre os Religiosos, a perfeita observancia das leis, e estatutos da Religiaõ. No fim do seo governo se retirou $\mathrm{p}^{\mathrm{a}}$. a Capella de N.S. do Montecerrate a discançar das continuas fadigas a tantos annos, deraõ um triennio $\mathrm{p}^{\mathrm{a}}$. discançar; e no seginte $\mathrm{o}$ elegeraõ segunda vez em D.Abb ${ }^{\mathrm{e}}$ desta Casa; tomou posse, e supposto q' as suas forças, ja naõ eraõ $\mathrm{p}^{\mathrm{a}}$. tanto pêso, sempre trasia diante dos olhos o adiantam ${ }^{\text {to }}$ espiritual, e temporal do Mostro ${ }^{\circ}$, acabou o seo triennio, e ficou nesta Casa a esperar a morte, q' $\mathrm{p}^{\mathrm{a}}$. estimulo do seo preparo sempre trasia diante dos olhos. Assistia aos actos da Religiaõ, q' lhe davaõ lugar as suas molestias, e na sua cella se empregava em virtuosos exercicios, considerando nas inconstancias, e variedades das cousas terrenas, vivia $\mathrm{m}^{\text {to }}$. $\mathrm{sa}$ tisfeito; ainda q ${ }^{\text {do }}$ por descuido, dos q' o serviaõ ex $-223-$ 
experimentava alguma falta. Já de idade avança da, avisado por uma molestia de q' estavaõ comple tos seos dias, preparado com a graça dos Sacram ${ }^{\text {tos }}$ e com $\mathrm{m}^{\text {tos }}$ actos de Religioso, pagou o tributo de nascido aos 17 de Julho de 1766. Sendo D.Abb o M.R.P. Ex Prov ${ }^{\text {al }}$ Fr. Jeronimo da Ascençaõ.

222 - O Ducentesimo vigesimo segundo foi o $\mathrm{P}^{\mathrm{e}}$.Fr. Jozé de $\mathrm{S}$.

Bento natural de Landim, professo no Mosteiro de Pernabuco. Era religioso diligente, e desimbaraçado, e assim sempre servia a Religiaõ, emqualquer parte q' se achava com satisfaçaõ, e agrado dos Prelados. Neste Mostr ${ }^{\circ}$. administrou por alguns annos a fasenda da Ilha grande no Rio de S.Franc ${ }^{\circ}$, na qual fez umas casas boas, e capases de assistirem os Religiosos, q' até esse tempo as naõ tinha sufficientes. Recolhendo-se ao Convento foi mandado $\mathrm{p}^{\mathrm{a}}$. oCertaõ a faser suas cobr ${ }^{\mathrm{as}}$. $\mathrm{a} /$ tes*/tamen[ $[\mathrm{z}]$ taria pertencentes, aqual por falecim ${ }^{\text {to }}$. de nosso grande Bemfeitor Franc ${ }^{\circ}$ Barcell/ar/ corria por conta desta Casa. Achando no districto do Paracatú $\mathrm{p}^{\mathrm{a}}$. executar esta diligencia, foi acommetido de umas sezões malignas, q' foraõ o verdugo de sua vida. Chegou a este Mostro ${ }^{\circ}$. a no- 
noticia de sua morte no mez de Julho de 1766. Sendo

$\left[\mathrm{f}^{\mathrm{o}} 114 \mathrm{r}^{\mathrm{0}}\right]$ D.Abb ${ }^{\mathrm{e}}$ o M.R.P ${ }^{\mathrm{e}}$. Ex Prov ${ }^{\mathrm{al}}$ Fr. Jeronimo da Ascençaõ.

223 - O Ducentesimo vigesimo terceiro foi o M.R.P. .Preg $^{\text {or }}$ Fr. José de $\mathrm{S}^{\text {ta }}$. Theresa nascido em Lordello junto ao Porto, professo nesta casa. Foi mandado $\mathrm{p}^{\mathrm{a}}$. o Coll ${ }^{\mathrm{o}}$. do Rio de Janeiro, e no fim delle occupou alguns empregos com satisfaçaõ, principalm ${ }^{\text {te }}$. o de Procurador das casas, q' exerceo por mais annos com promptidaõ, delligencia, e fidelidade, mudado $\mathrm{p}^{\mathrm{a}}$. este Mosteiro, servio na $\mathrm{m}^{\text {ma }}$; occupaçaõ com o seo costumado zêlo, no triennio seguinte veio provido na $\mathrm{Ab}-$ badia desta Casa, cuidando com disvello no adi$\operatorname{antam}^{\text {to }}$ da observancia regular, e culto divino,tambem applicou todas as forças $\mathrm{p}^{\mathrm{a}}$. o augmento temporal do Mostro . no tempo do seo governo, no fim delle por certas contendas, q' houveraõ arespeito da posse do seo Sucessor, foi remettido $\mathrm{p}^{\mathrm{a}}$. o Reino, e passados alguns annos, encheo os dias no Mostr ${ }^{\circ}$. de Tibaens em 9 de Agosto de 1768. Sendo D.Abb ${ }^{\mathrm{e}}$. desta Casa, donde era Conventual, o N.M.R.P ${ }^{\mathrm{e}}$. Fr. Jeronimo da Ascençaõ. 
224 - O Ducentesimo vigesimo quarto foi o $\mathrm{P}^{\mathrm{e}}$.Fr. Joaõ de

$\left[\mathrm{f}^{\mathrm{0}} 114 \mathrm{v}^{\mathrm{0}}\right]$

$\mathrm{S}^{\text {to }}$ Antonio, nascido nesta Cidade, de Pais honestos, professo neste Mostro . Ao depois q' encheo os annos de Corista, comprindo perfeitam ${ }^{\text {te }}$ com as suas obrigações, foi estudar, Filosophia, e Theologia em nosso collegio de Olinda, aonde com a $\mathrm{m}^{\text {ma }}$. promptidaõ satisfasia ao exercicio de Colleg[ $\uparrow \mathrm{i}] \mathrm{al}$, voltando $\mathrm{p}^{\mathrm{a}}$. esta $\mathrm{Ca}$ sa com licença dos Prelados, frequentava o Coro, e mais actos religiosos com diligencia, e cuidado. Administrou por mais annos a nossa fasenda doRio vermelho com edificaçaõ dos moradores das quellas partes, e utilidade do Mostro . Foi Prior desta Casa sem dimimuiçaõ da observancia re ligiosa, mas antes com adiantam ${ }^{\text {to }}$ della, Achava-se já adiantado em annos, e por duvidas, q' se exercitaraõ a respeito da posse de um Prelado eleito desta Casa, foi remettido a[o] Reino, e no Mostro . de Titaens acabou a sua perigrinaçaõ em 23 de Outubro de 1768. Sendo D.Abb o N.M.R.P ${ }^{\mathrm{e}}$. Ex Prov $^{\mathrm{al}}$ Fr. Jeronimo da Ascençaõ. 225 - O Ducentesimo vigesimo quinto foi o M.R.P. Preg ${ }^{\text {or }}$.Fr.Miguel da Conceiçaõ, natural da 
da Cidade do Porto, professo neste Mostro ${ }^{\circ}$ Todo tempo q' viveo este Monge, se utilisou a Religiaõ doprestimo q' tinha $\mathrm{p}^{\mathrm{a}}$. a servir; servio-a no Côrocom a parte, q' tinha de Musico bem instruido, principalm ${ }^{\text {te }}$. no canto chaõ; no pulpito pregando, com satisfaçaõ, e applauso, nas fasendas governando com zêlo, e fidelidade. Informados os Prelados Superiores da sua capacidade $\mathrm{p}^{\mathrm{a}}$. qualquer emprego, della se approveitaraõ $\mathrm{p}^{\mathrm{a}}$. o exercicio de muitos. Foi $\mathrm{Abb}^{\mathrm{e}}$. da Graça, Procurador Geral da Província, $\mathrm{Abb}^{\mathrm{e}}$. de Pernâbuco, Mestre de Noviços, $\mathrm{Abb}^{\mathrm{e}}$. do Rio de Janeiro, Defin ${ }^{\text {or }}$,e Compr ${ }^{\circ}$; em todos estes lugares deo a satisfaçaõ q' se esperava de seo zêlo, e da sua perfeita observancia, porq' era Religioso observante, desenteressado, e zeloso, achava-se neste Mostro ${ }^{\circ}$, quando vendo se acommettido de uma molestia maior, do q' outra q' padecia, conhecendo q' o perigo era mortal, cuidou em se dispor $\mathrm{p}^{\mathrm{a}}$. a ultima hora, com $\mathrm{m}^{\text {to }<\mathrm{s}>}$ actos de contriçaõ, e com a graça dos $\mathrm{S}^{\text {tos }}$. Sacram ${ }^{\text {tos }}$, q' recebeo com $\mathrm{m}^{\text {ta }}$ devoçaõ, e ternura, no dia seguinte espirou, deixando $<$ s $>$ aos Monges sentidos, porq' nunca soube offende-los, no Rio 
Rio de Janeiro foi geralm ${ }^{\text {te }}$. sentida a sua morte, por estar já eleito $\mathrm{Abb}^{\mathrm{e}}$. daquelle Mosteiro. Faleceo em 7 de Novembro de 1768. Sendo D. $\mathrm{Abb}^{\mathrm{e}}$ o N.M.R.P ${ }^{\mathrm{e}}$. Ex Prov ${ }^{\mathrm{al}}$ Fr. Jeronimo da Ascençaõ. 
226 - O Ducentesimo vigesimo sexto foi o $\mathrm{P}^{\mathrm{e}}$.Fr.Andre do Espirito $\mathrm{S}^{\text {to }}$

$\left[\mathrm{f}^{\mathrm{o}} 116 \mathrm{r}^{\mathrm{0}}\right]$ natural d'esta Cidade, professo neste Mostr ${ }^{\circ}$. Foi conventual em varios Mostros . da Provincia, em todos elles sirvio a Religiaõ até onde chegava a sua possibilidade. Nesta Casa assestio o $\mathrm{m}^{\mathrm{s}}$, de tempo, frequentando o Choro, e os $\mathrm{m}^{\mathrm{s}}$ actos da Religiaõ com promptidaõ, e diligencia. Ao depois de sexagenario, o mandaraõ para o Convento das Brottas, no qual ainda viveo alguns annos; veio para este Mos$\operatorname{tr}^{\circ}$. a buscar alguns remedios para uma molestia, que pade cia; porém naõ conseguindo melhoras, della veio a mor rer, fortalecido com a graça do Sacram ${ }^{\text {tos }}$, em $\underline{3}$ de Fevro ${ }^{\circ}$. de $\underline{1769}$ sendo D.Abb ${ }^{\mathrm{e}}$ o N.M.R.P. ${ }^{\mathrm{e}}$. Ex Prov $^{\text {al }}$ Fr. Jeronimo da Ascençaõ. 227 - O Ducentesimo vigesimo septimo foi o Irmaõ Donado Fr. Bartolome $<\mathrm{u}>/ \mathrm{o} \backslash$ de Jesus conventual do Mostr ${ }^{\mathrm{0}}$ das Brottas, ao de pois de ter servido aquella caza com $\mathrm{m}^{\text {to }}$ trabalho, $\mathrm{m}^{\text {to }}$ zelo, $\mathrm{e}$ $\mathrm{m}^{\text {ta }}$ felicidade, por espaço de $\mathrm{m}^{\text {tos }}$ annos, vendo-se accommettido de uma enfermidade grave, buscou este Mostr ${ }^{\circ} \mathrm{p}^{\mathrm{a}}$ lhe appli car os remedios convenientes; porém vencendo a molestia a todos, della acabou a vida preparado com a graça dos Sacram ${ }^{\text {tos }} \mathrm{em}$ $\underline{6}$ de Abril de 1769. Sendo D.Abb ${ }^{\mathrm{e}}$ o N.M.R.P. ${ }^{\mathrm{e}}$. Ex Prov $^{\text {al }}$ Fr. Je ronimo da Ascençaõ.

228 - O Ducentesimo vigesimo oictavo foi o P.Fr.Joaõ Damasceno Preg $^{\text {or }}$. de S.Jozé nascido na Villa de Maragogipe de Pais honestos. Ao deps. de completo o seu anno de noviciado se demorou a sua profissaõ, $\mathrm{p}^{\mathrm{r}}$ algumas duvidas, que se offereceraõ; porém a- 
veriguando-se, a naõ desmerecia; $\mathrm{m}^{\mathrm{s}}$ antes se fasia digno d'ella $\mathrm{p}^{\text {los }}$

seus bons custumes, e recto procedimento; professou neste Mostr ${ }^{\circ}$. a vi

da Religiosa com aq ${ }^{\text {le }}$ gosto $\mathrm{q}^{\mathrm{r}}$ desejava. Teve o seu Collegio nes

ta caza, e no fim delle exercêo a occupaçaõ de mordomo

com zello, e satisfaçaõ. Como era Religioso de Prestimo $\mathrm{p}^{\mathrm{a}} \mathrm{q}^{\mathrm{l}} \mathrm{q}^{\mathrm{r}}$.

emprego foi mandado pela obdiencia a governar a fazen

da da Ilha grande no Rio S.Franc ${ }^{\circ}$. porém pouco tempo

se utilisou o Mostro do seu disvello, porque dentro de poucos ans.

acabou a vida naq ${ }^{\text {las }}$. partes. Foi enterrado no convento de S.

Fran $^{\text {co }^{\circ}}$. da Villa do Penedo com a caridade custumada d'aq ${ }^{\text {les }}$

Religiosos. Faleceo em 20 de Abril de 1769. Sendo D. $\mathrm{Abb}^{\mathrm{e}}$

o N.M ${ }^{\text {to }}$.R.P. e $^{\mathrm{e}}$ Ex Provin ${ }^{\mathrm{al}}$ Fr. Jeronimo da Ascençaõ.

229 - O Ducentesimo vigesimo nono foi o Irmaõ Donado Fr. Balha

zar de S.Bento nascido na Provincia de Transmontes pro

15

fesso nesta caza. Movido da sua vocaçaõ pedio o habito de

Monge no humilde estado de Leigo, ja adiantado em an .

foi attendida a sua petiçaõ, porq' nelle observaraõ a capaci

dade que o fasia merecedor d'este officio. Sempre assestio nes

20

te Mostro ${ }^{\circ}$ ao qual servio $\mathrm{m}^{\text {tos }}$ annos em ambos os engenhos

e outras fasendas da Religiaõ, trabalhando de dia e denoi

ti, quando assim o recomendava a necessidade do tra

balho, naõ deixando de satisfaser as obrigaçoens do seo es

tado $\mathrm{p}^{\mathrm{r}} \mathrm{m}^{\mathrm{s}}$ cançado que estivesse. Carregado de ans. e

detistuido de forças para a vida laboriosa recolheo

se ao Mostro ${ }^{\circ}$ a entregar-se de todo aos exercicios espirituaes

nesta vida passou alguns ans. até que chegasse o termo 
de seus dias, faleceo com os $\mathrm{S}^{\text {tos }}$ Sacramentos da Igreja assesti

$\left[\mathrm{f}^{\mathrm{o}} 117 \mathrm{r}^{\mathrm{0}}\right]$

5

10

15 do dos Religiosos em $\underline{15}$ de de Desembr ${ }^{\circ}$ de 1769 Tendo de idade 8/9*/ an e cincoenta incompletos de Religiaõ Salvo erro Era D.Abb ${ }^{\mathrm{e}}$ o M.R.P ${ }^{\mathrm{e}}$. Preg ${ }^{\text {or }}$ Fr. Bartholomeo dos Martires.

230 - O Ducentegimo trigesimo foi o M.R.O.Preg ${ }^{\text {or }}$ Fr. Bar tholomeo dos Martires nascido na Prova ${ }^{\mathrm{a}}$. de Alibres Bis pado do Porto professo nesta casa. Era Religiozo observan te recolhido, e amigo da Paz, e de conhecido prestimo para o serviço da Religiaõ, teve o seu Collegio no Rio de Janr ${ }^{\circ}$. e con cluido elle admnistrou $p^{r} m^{\text {tos }}$ annos o Engenho da Ilha perte ${ }^{179}[n]$ cente ao $\mathrm{m}^{\mathrm{mo}}$. Mostr ${ }^{\circ}$. tratava com toda cari $<\mathrm{di}>$ dade os escra vos na saude, e na doença, e edificou de tal sorte, os visi nhos com o seu recto procedimento, e com as esmolas, que fasia aos que della necessitavaõ, que todos lamentaraõ na sua ausencia a sua retirada. Foi Prior no Mostro do Rio, e antes de acabar o seu triênio o elegeraõ D.Abb ${ }^{\mathrm{e}}$ da Paraiba, encheo o seu lugar com aplauso, e utilidade da caza; ao deps. foi Procurador geral, $\mathrm{Abb}^{\mathrm{e}}$ de Pernam buco, $\mathrm{Abb}^{\mathrm{e}}$ d'este Mostro ${ }^{\circ}$. em huma eleiçaõ entermedia. Todos os seus governos foraõ acertados, e aplausiveis, porq' zela va com todas as forças a honra de $\mathrm{D}^{\mathrm{s}}$. e a observancia regu lar, e o patrimonio dos Mostros. Quando ultimamente oc= cupava o lugar de $<\mathrm{de}>/ \mathrm{De} \mid<\mathrm{t}>/$ f inidor, frequentando os actos conven tuaes com a desisaõ, e exemplo dos Religiosos foi accomettido de uma molestia, aq ${ }^{1}$. veio a declarar-se em uma poplexia 
que dando-lhe lugar para se dispor com a graça $\mathrm{do}^{180}[\mathrm{~s}]$ Sacra

$\left[\mathrm{f}^{\mathrm{0}} 117 \mathrm{v}^{\mathrm{o}}\right]$ mentos, e lagrimas de contriçaõ o privou da vida em $\underline{26}$ de Janr ${ }^{\circ}$. de 1773. Sendo D.Abb ${ }^{\mathrm{e}}$ o M.R.P ${ }^{\mathrm{e}}$. Preg ${ }^{\text {or }}$

$\mathrm{Jub}^{\circ} \mathrm{Fr}$. Calisto de S.Caetano. aõ de $\mathrm{S}^{\text {ta }}$ Maria nascido na corte-de-Lx ${ }^{\mathrm{a}}$. de Paes virtuosos professo neste Mostr $^{\circ}$ pela molestia obdiencia promptidaõ com que no seu noviciado executava as suas obrigaçoens logo nelle desc $<$ r $>$ ubriraõ os Religiosos $<\underline{\text { uma }>}$ uma capacidade indu bitavel para a vida de Monge, assim o mostrou em toda a sua vida por que sempre viveo recolhido separado das prati cas, que pudiaõ resultar offensa a $\mathrm{D}^{\mathrm{s}}$. ao próximo. Era verda deiram ${ }^{\text {te }}$ observante dos votos da sua profissaõ, e zelozo da hon= ra de $\mathrm{D}^{\mathrm{s}}$ e do proximo, o que bem mostrou os lugares q' exerceo na Religiaõ fasendo-se exemplar das virtudes, e aos seus subditos; no Coll ${ }^{\circ}$. do Rio leo Theologia com aceitaçaõ, e sendo ao $\mathrm{m}^{\text {mo }}$. tempo. Prior; dava prompta satisfacaõ as obrigacoens da aula e do Choro; no $\mathrm{m}^{\mathrm{mo}}$. Mostr ${ }^{\circ}$. tomou o grao de $\mathrm{D}^{\mathrm{r}}$. e nesta caza continuou a leitura de Theologia moral ate seguir a jubilaçaõ.

Informados os Prelados Superiores da sua capacidade para encher $\mathrm{q}^{1} \mathrm{q}^{\mathrm{r}}$ lugar auctorizado da Religiaõ, o elegeraõ primeiram ${ }^{\text {te }} \mathrm{em} \mathrm{Abb}^{\mathrm{e}}$ do Mostro ${ }^{\mathrm{o}}$. da Paraiba, satisfes a este emprego como se esperava da sua perffeita observancia, e do seu conhecido zelo. Foi em segundo lugar cmpanheiro do Prov ${ }^{\text {al }}$. e no trienio seguinte $\mathrm{Abb}^{\mathrm{e}} \mathrm{de}$ S.Paulo o que renunciou $\mathrm{p}^{\mathrm{r}}$ motivos justificados, descan $-232-$

${ }^{180}$ APFL 
çou algum tempo, e veio eleito em D.Abb ${ }^{\mathrm{e}}$ desta caza com gran

de fortuna della $\mathrm{p}^{\mathrm{r}}$ que no seu tempo faleceo um seu Irmaõ chamado Franc ${ }^{\circ}$. Balcelon homem de negocio, abundante de bens temporaes, e de virtude conhecida, o qual como temente a $D^{\mathrm{s}}$ querendo que ficasse $\mathrm{p}^{\mathrm{r}}$ sua morte bem empregado, o q' tinha sido bem adquerido aplicou no seu testamento, $\mathrm{q}^{\text {to }}$ pos suia para as obras da nossa capella mor, ao $\left[\uparrow \mathrm{dep}^{\mathrm{s}}\right]$ de feitas algu mas disposicoens de menos ponderaçaõ, com esta taõ $\operatorname{grd}^{\mathrm{e}} \mathrm{e}$ avultada esmola continuaraõ as ditas obras que haviaõ $m^{\text {to }}$ tem po estado paradas, o subiraõ a uma concideravel altura, na qual esperaõ o seu complemento para $\mathrm{q}^{\mathrm{do}}$. $\mathrm{D}^{\mathrm{s}}$ o tem determinado, con cluido o seu trienio, foi chamado a congregaçaõ para responder a uns encargos, que lhe deraõ de se haverem transitado, e mudado de habito do seu tempo dois Religiosos de certas Religio ens, que se achavaõ refugiados neste Most $^{\circ}$. Chegou a Lex ${ }^{\mathrm{a}} \mathrm{e}$ ou vidas as suas resoens naõ so o julgou o $\mathrm{Rm}^{\circ}$. Sem culpa alguma, mas antes inteirado da sua religiosa vida, e da sua perfei ta observancia, o mandaraõ retirar para sua Provincia, e no trienio seguinte o elegeraõ a junta geral Prov ${ }^{\mathrm{al}}$. della Visi tou todos os Mostr ${ }^{\mathrm{os}}$. zelando a honra de $\mathrm{D}^{\mathrm{s}}$. e a obcer vancia regular, deixando acertadas disposicoens aos Reli giosos digo aos Prelados para o bom governo do seu Mostro no espiritual, e temporal, concluido o tempo do seu Provin= cialado deixou-se ficar nesta caza, continuando nos seus reli giosos exercicios, com $\mathrm{m}^{\text {tos }}$ actos de piedade, com a edificaçaõ dos Religiosos, aos quaes sempre deo bons exemplos com as prati cas de virtudes, em que se exercitava. Ja de idade avança 
da comecou a queixar-se de uma dor que o atormentava

$\left[\mathrm{f}^{\mathrm{o}} 118 \mathrm{v}^{\mathrm{o}}\right]$ sem desçanço, aqual naõ obedecendo aos remedios, que lhe apli cavaõ se foi adientando, de sorte, que em menos de um anno o poz em estado mortal conhecendo o perigo em que estava, pedio os $\mathrm{S}^{\text {tos }}$ Sacramentos aos quaes recebidos com $\mathrm{m}^{\text {tos }}$ actos de piedade, e amor de $\mathrm{D}^{\mathrm{s}}$. pegando em um Snr. crucificado pedindo-lhe perdaõ das suas culpas, d'ahi a poucas horas, dei xou rezigna $<\mathrm{n}>$ do esta vida mortal em 14 de Abril de 1773. Sendo D.Abb ${ }^{\text {e }}$ o N.M.R.P. ${ }^{\mathrm{e}}$. Ex.Prov ${ }^{\text {al }}$ Preg $^{\text {or }}$ Jubila do Fr. Calisto de S.Caetano, Seu corpo foi sepultado na Sa cristia com as honras devidas a seu lugar.

232 - O ducentesimo trigesimo Seg ${ }^{\text {do }}$. foi o Irmaõ Donado Fr. José da Conceçaõ natural das Ilhas professo neste Mostro ${ }^{\circ}$ ja de idade avançada pedio o habito de Monge no humil de estado de Leigo para empregar o resto dos seus dias no servico de $\mathrm{D}^{\mathrm{s}}$. recolhido na Religiaõ, como era notorio o seu bom procedimento conseguio o beneficio, que desejava. Ao de pois de professo ainda viveo $\mathrm{m}^{\text {tos }}$ annos servindo a Religiaõ em tudo o, que lhe era mandado: principalm ${ }^{\text {te }}$ no emprego de adegueiro com grande satisfaçaõ dos Prelados, e agrado dos Religiosos $\mathrm{p}^{\text {lo }}$ seu zelo, $\mathrm{p}^{\text {la }}$ sua prudencia, e $\mathrm{p}^{\text {la }}$ sua feli cidade, era Religioso temente a $\mathrm{D}^{\mathrm{s}}$. recolhido, e poucas, e boas palavras, ja destituido de forças, o isentarao das occu pacoens trabalhosas, e recolhido na sua pobre sella de todo se empregou nas praticas do exercicios conducentes para sua salvaçaõ, ouvia Missa todos os dias, naõ faltando a confissaõ, e sagrada communhaõ nos dias determinados; assim $-235-$ 
foi vivendo religiosam ${ }^{\text {te }}$, ate que sendo accometido de uma

$\left[\mathrm{f}^{\mathrm{0}} 119 \mathrm{r}^{\mathrm{0}}\right]$ $\operatorname{grd}^{\mathrm{e}}$. poplixia, em breves dias, acabou a vida em 26 de Abril de 1773 Sendo D. Abb ${ }^{\mathrm{e}}$ o N.M.R.P. Ex.Prov ${ }^{\mathrm{al}} \mathrm{Jub}^{\mathrm{o}}$

Fr. Calisto de S.Caetano. 233 - O Ducentesimo trigesimo tercr ${ }^{\circ}$. foi o Irmaõ Donado Fr. Domingos da Conceiçaõ natural do Reino, professo neste Mostr ${ }^{\circ}$. buscou a Religiaõ adiantado em $a^{\mathrm{s}}$. nella foi recebido $\mathrm{p}^{\text {las }}$ boas enforma coens do seu procecdimento, e por ser bom official de $\mathrm{p} / \mathrm{r}^{*}$ /edreiro, mos trou ser verdra ${ }^{\mathrm{a}}$. a sua vocaçaõ na prompta satisfaçaõ que dava as obrigacoens do seu estado e do seu officio, passados bastantes annos oc= cupado no servico de $\mathrm{D}^{\mathrm{s}}$ e do Mostro ${ }^{\mathrm{o}}$. adoeceo de uma molestia con tagiosa, e encuravel, $q^{\prime} p^{r}$ alguns an ${ }^{\mathrm{s}}$. lhe deo $\mathrm{m}^{\text {to }}$ que, padecer na $\mathrm{pac}^{\mathrm{a}}$. e conformidade divina, achava o alavio pare lhe refrige rar as dores que dedia e de noite lhe atromentavaõ; acabou os seus dias com $\mathrm{m}^{\text {tos }}$ actos de ${ }^{181}$ Catholicos, e de Religioso, em $\underline{30}$ de $\mathrm{Ma}=$ io de $\underline{1775}$. Sendo Sendo D. Abb o N.Revm ${ }^{\circ}$ Ex.prov .al $^{\text {al }}$ Calisto de S Caetano, representava ter para cima de secenta an ${ }^{\mathrm{s}}$ de $\mathrm{i}=$ dade. 234 - O Ducentesimo trigesimo quarto foi o N.R ${ }^{\mathrm{mo}} \mathrm{P}$. Ex Provinci al Fr. Jeronimo da ascençaõ da Freguesia da Cidade Penna flos; foi noviço neste Mostro . e nelle professou, teve o seu Coll ${ }^{\circ} \mathrm{em}$ Pernanbuco, e no fim delle foi mudado para o Convento do Rio de Janr ${ }^{\circ}$. onde foi Subprior, administrou algumas fasen das, nas $\mathrm{q}^{\mathrm{s}}$ deo a conhecer a capacidade que tinha para ser vir a Religiaõ em qual $\mathrm{q}^{\mathrm{r}}$ emprego, entra para a Religiao de poucos an ${ }^{\mathrm{s}}$ e nella viveo $\mathrm{m}^{\text {tos }}$ sempre trabalhando sem des canco com desvello, zelo, felicidade ou nas fasendas que adminis $-235-$

${ }^{181} \mathrm{O}<\mathrm{t}>$ está sem o traço horizontal. 
$\left[\mathrm{f}^{\mathrm{o}} 119 \mathrm{v}^{\mathrm{0}}\right]$

trou pelos Mostros da Provincia ou nos lugares da Religiaõ, que administrou $\mathrm{p}^{\mathrm{r}} . \mathrm{m}^{\text {tas }}$. vezes, e $\mathrm{p}^{\mathrm{r}} \mathrm{m}^{\text {tos }}$ annos. Foi Presidente em Santos. Abb ${ }^{\mathrm{e}}$. em S.Paulo, na Paraiba ${ }^{182}$ duas vezes, nestes Mostr ${ }^{\circ}$ Proc $^{\text {or }}$. geral da Provincia do Rio de Janr ${ }^{\circ}$. e ultimamente Provincial, com todos estes empregos, ajudado de saude, que sempre logrou, fre quentava os actos conventuaes de dia e denoite anima[ $\uparrow \mathrm{n}] \mathrm{do}$ com a sua prezenca aos subdi $<\mathrm{d}>/ \mathrm{t} l o s$, e servindo de exemplo a todos, pois viaõ um Prelado, que todo o seu disvello era o augmento espiritu al, e temporal das casas que governava; adoeceo de um tubercu lo, que sem remedio lhe tirou a vida em $\underline{23}$ de Abril de 1777 .

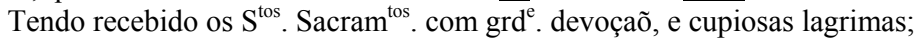
tinha de idade natural oitenta e seis ans. emcompletos. Era D. Abb. deste Mostro ${ }^{\circ}$ o M.R.P.M.Jub o Dr.Fr. Pascual da Ressur reiçaõ. 235 - O Ducentesimo trigesimo quinto Monge que faleceu neste Mostr ${ }^{\circ}$ foi o M.R.P.P.Fr. Miguel Jesus Maria nascido nesta cidade, e professo nesta casa, foi collegial em Pernanbuco, e no fim delle voltou para es te Mostr $^{\circ}$ no qual assistio toda sua vida que foi dilatada por $\mathrm{m}^{\text {tos }}$ annos Sacristam maior, e $\mathrm{m}^{\text {tos }} \mathrm{m}^{\mathrm{s}}$ Mestre de Caristas que pela boa aceitaçaõ com que exercia estes empregos, era bem instrido nas cerimonias da Religiaõ, e as fasia praticar com a perfeiçaõ dividida; $\mathrm{p}^{\mathrm{r}} \mathrm{m}^{\mathrm{s}}$ de $40 \mathrm{an}^{\mathrm{s}}$ frequentou o Coro de dia, e denoite nelle fasia $\mathrm{m}^{\text {tas }}$ veses as obrigacoens de cantor, por que alem de ser dotado de voz perfeita, tinha sufficen tem $^{\text {te }}$ intelligencia de Cantoxaõ.Foi Prior desta caza algumas veses, Definidor segd ${ }^{\circ}$ alguns meses Presd ${ }^{\text {te }}$ os $\mathrm{m}^{\text {tos }}$ an $^{\mathrm{s}}$ lhe tiraõ a vida,em $\underline{23}$ de $8 \mathrm{br}^{\circ}$ de $\underline{1777}$. Disposto a graça dos $-236-$

\footnotetext{
${ }^{182}$ Duas vezes está escrito entre uma barra (/) e um sinal de igualdade (=).
} 
$\left[\mathrm{f}^{\mathrm{o}} 120 \mathrm{r}^{\mathrm{0}}\right]$

Sacramentos, er D.Abb ${ }^{\mathrm{e}}$.deste Mostro ${ }^{\circ}$ M.R.P.M.Jub ${ }^{\circ}$.Fr.Pascoal da Re ssureiçam.

236 - O Ducentesimo trigesimo sexto foi o Irmaõ Donado Fr. Cosme de S.Da miaõ nascido nesta Cidade foi $\mathrm{m}^{\text {tos }}$ an ${ }^{\mathrm{s}}$ militar nesta Praca a sua as $=$ sistencia nesse $\operatorname{Mostr}^{\circ}$ era frequente, $\mathrm{p}^{\mathrm{r}}$ que tinha $\mathrm{m}^{\text {tos }}$ parentes Religiosos, $\mathrm{a}=$ companhou um delles que foi ser D.Abb ${ }^{\mathrm{e}}$ da Paraiba naq ${ }^{\text {la }}$ casa recebeo o habito e fes profissaõ no estado de Leigo, voltou para esta Casa, e admi nistrou algumas granjas em $\mathrm{q}^{\text {to }}$ teve forças para o trabalho. Faleceo fortalecido com a graca dos $\mathrm{S}^{\text {tos }} \operatorname{Sacram}^{\text {tos }} \mathrm{em} \underline{9}$ de Maio de $\underline{1778}$ com $\mathrm{m}^{\mathrm{s}}$ de $60 \mathrm{an}^{\mathrm{s}}$ de idade. Sendo Abb o M.R.P.M.Jub Fr. Pascoal da Resurreiçaõ.

237 - O Ducentesimo trigesimo septimo foi o M.R.P.P.Fr.An ${ }^{\text {to }}$ do Rosario natural da Cidade do Porto, neste Mostr ${ }^{\circ}$ teve o seu noviciado, e fes a sua profissaõ foi collegial no Rio de $\mathrm{Janr}^{\circ}$ e no fim delle sendo man dado para esta Caza administrou algumas fazendas com zello, fidelid ${ }^{\mathrm{e}}$ naõ se escusando de trabalhar para beneficio do Mostro ainda $\mathrm{qd}^{\circ}$ as forcas ja naõ permitiaõ por falta de saude, foi $\mathrm{Abb}^{\mathrm{e}}$ do Mostro da Gra ça, e neste lugar deo a conhecer a capacid ${ }^{\mathrm{e}}$ que tinha para os empregos da Religiaõ. Faleceo sendo M.de Nov ${ }^{\text {os }}$ disposto como bom Religioso em $\underline{10}$ de Junho de 17778 . tinha quarenta e tres an ${ }^{\mathrm{s}}$ de idade, era $\mathrm{Abb}^{\mathrm{e}}$ d'esta caza e M.R.P.M.Jub ${ }^{\circ}$ S.P.Pascoal da Resurreicaõ. 238 - O Ducentesimo trigesimo oictavo foi o M.R.P.Ex $\mathrm{Abb}^{\mathrm{e}}$ Fr Fran ${ }^{\mathrm{co}}$ [个Inácio!] da

Piedade $\mathrm{P}^{\text {to }}$ nasceo nesta $\mathrm{Cid}^{\mathrm{e}}$ professou neste Mostr ${ }^{\mathrm{o}}$. Foi Religo= so de conhecido pretimo para servir a Religiaõ nos $\operatorname{Mostr}^{\text {os }}$ aon de foi conventual, neste foi a sua Maior assistencia aonde exer ceo varios empregos com zello, e satisfaçaõ. Foi $\mathrm{Abb}^{\mathrm{e}}$ do $\mathrm{Mostr}^{\circ}$ da Gra ça com grande utilidade d'aquella caza dando-lhe uma avuta 
tada esmola com que se fes a capella mor da Igreja nova; segun

$\left[\mathrm{f}^{\mathrm{o}} 120 \mathrm{v}^{\mathrm{0}}\right]$ da vez o elegeraõ $A b b^{\mathrm{e}}$ do Mostro ${ }^{\mathrm{o}}$, renunciou o lugar por se achar impossibilitado para o exercer: pellas suas ordens, e pella sua boa economia ajuntou um avultado epeculio, q' por sua morte ficou a esta Casa. Faleceo com 80 an ${ }^{\mathrm{s}}$ de Id emcompletos, ao dep $\mathrm{d}^{\mathrm{e}}$ de Forta lecido com a graca dos Sacram ${ }^{\text {tos }}$ em $\underline{30}$ de Junho de 1778. Era Abb d'este Mostr $^{\circ}$ o M.R.P.M.Jub ${ }^{\circ}$ Fr. Pascoal da Resurreiçaõ.

239 - O Ducentesimo trigesimo nono Monge que faleceo neste Mostr $^{\circ}$ foi o N.R ${ }^{\mathrm{mo}}$ P.Ex Prov ${ }^{\text {al }}$ Fr. Joaõ da Trindade filho da $\mathrm{Cid}^{\mathrm{e}}$ do Porto professo nesta casa, foi collegial no Rio de Janr ${ }^{\circ}$, e no fim delle veio mudado $\mathrm{p}^{\mathrm{a}}$ este Mostr ${ }^{\mathrm{o}}$ era Religioso observante, e exemplar compor to nas suas accoens, e $\mathrm{p}^{\mathrm{r}}$ isso digno, e merecedor dos empregos que ex erceo na Religiaõ com retidaõ, e justica. Foi $\mathrm{Ab}^{\mathrm{e}}$ de $\mathrm{Nov}^{\mathrm{cos}}$ Prer $^{\mathrm{o}}$ geral, duas vezes $\mathrm{Abb}$ em Pernanbuco e ultimamente Prov ${ }^{\mathrm{al}}$ en cheo os seus dias com $\mathrm{m}^{\text {tos }}$ actos de contriçaõ, disposto com os Sacra $\mathrm{m}^{\text {tos }}$ da Igreja em $\underline{20}$ de Janr ${ }^{\circ}$ de $\underline{1780}$ tendo de idade $75 \mathrm{an}^{\mathrm{s}} \mathrm{e}=$ $\mathrm{ra} \mathrm{Abb}^{\mathrm{e}}$ deste Mostro e M.R.P.M.Jub ${ }^{\mathrm{o}}$ Fr. Pascoal da Resurreiçaõ. 240 - O Ducentesimo quadragesimo foi o R.P.Fr.Manoel da Encar naçaõ natural da $\mathrm{Cid}^{\mathrm{e}}$ do Porto, professo no Mostro do $\mathrm{R}^{\circ}$ foi Collegial em Pernanbuco, e antes de acabar o Coll ${ }^{\circ}$ foi remo vido $\mathrm{p}^{\mathrm{a}}$ esta caza aonde viveo $\mathrm{p}^{\mathrm{r}}$ alguns an ${ }^{\mathrm{s}}$ nos exercicios da vida Monastica, uma trabalhosa molestia que sofreo com grande paciencia lhe tirou a vida com pouco $\mathrm{m}^{\mathrm{s}}$ de trin= ta $a^{\mathrm{s}}$ de id ${ }^{\mathrm{e}}$. Faleceo com todos os Sacramentos em $\underline{6}$ de Abril de 1781. Sendo D.Abb ${ }^{\mathrm{e}}$ d'este Mostro o M.R.P.Preg ${ }^{\text {or }}$ Fr. An ${ }^{\text {to }}$ de S.José Val ${ }^{\text {ca }}$. 
241 - O Ducentesimo quadragesimo $\mathrm{p}^{\text {ro }}$ foi o R.P.Prego ${ }^{\mathrm{r}}$ Fr.Bernardo

$\left[\mathrm{f}^{\mathrm{o}} 121 \mathrm{r}^{\mathrm{o}}\right]$ da crus filho da Cidade de Braga professo nesta Caza em Per nambuco teve o seu Collegio, onde foi tambem Subprior, manda do para este Mostro $^{\circ}$ nelle administrou as fasendas $\mathrm{m}^{\mathrm{s}}$ remotas com zelo fi= delidade, e satisfaçaõ era Monge exemplar, temente a $D^{\text {s183 }}$ e por isso respei tado dos seculares aos $\mathrm{q}^{\mathrm{s}}$ servia tanto no confessionar ${ }^{\mathrm{o}}$ como em outros exercicios de carid ${ }^{\mathrm{e}}$ sem faltar ao respeito divido ao seu habito, e a sua Religiaõ passados $\mathrm{m}^{\text {tos }}$ an $^{\mathrm{s}}$ e ja cançado de viver entre seculares, se recolheo ao Mostro aonde encheo os seos dias disposto como perf ${ }^{\text {to }}$ Religioso em $\underline{7}$ de Novbr ${ }^{\circ}$ de 1781. Sendo Abb o N.R ${ }^{\text {mo }}$ P. Ex Prov ${ }^{\text {al }} F r$. An ${ }^{\text {to }}$ de S.Jose Val ${ }^{\text {ca }}$. 242 - O Ducentesimo quadragesimo segd ${ }^{\circ}$ foi o M.R.P.Preg ${ }^{\text {or }}$ urbico Fr. $\mathrm{Ant}^{\mathrm{o}}$ de $\mathrm{S}^{\text {ta }}$ Margarida natural da Cidade do Porto, professo nes= ta Caza, em Pernam ${ }^{\text {bo }}$ teve o Collegio de Philosophia, e neste Mostro o de Theologia no fim delle pertendeo o emprego de Preg ${ }^{\text {or }}$ urbico q' de boa vontade lhe foi concedido pela sua notoria capacidade, desen penhou com aq ${ }^{\text {la }}$ aceitaçaõ, o lugar, e redito da Religiaõ e da sua pessoa, no fim do seu exercicio foi accomettido de uma moles tia grave, que em breves dias lhe tirou a vida com notavel sentimentos dos Religiosos $\mathrm{p}^{\mathrm{r}}$ se verem perdido da companhia de um Monge exemplar, observ ${ }^{\text {te }}$ e de capacid ${ }^{\mathrm{e}}$ indubitavel para servir a Religiaõ. Foi o seu falecimento em $\underline{29}$ de Janr ${ }^{\circ}$ de $\underline{1783}$ tinha de id $d^{\mathrm{e}}$ natural $48 \mathrm{an}^{\mathrm{s}}$. Era $\mathrm{Abb}^{\mathrm{e}}$ deste Mostro o N. $\mathrm{R}^{\mathrm{mo}} \mathrm{P}$. Ex Provincial Fr. An ${ }^{\text {to }}$ de S.Jose Val ${ }^{\text {ca }}$. 243 - O Ducentesimo quadragesimo terc ${ }^{\circ}$ foi o R.P.Preg ${ }^{\text {or }} F r . M^{\text {el }}$ de $\mathrm{S}^{\text {ta }}$ Theresa, filho da Cidade de Braga professo nesta casa con= cluido seu Coll ${ }^{\circ}$ que teve no rio de Janr ${ }^{\circ}$ foi mandado $\mathrm{p}^{\mathrm{a}}$ S.Paulo e naquelle Mostro as suas Presidencias servio a Religiaõ $\mathrm{p}^{\mathrm{r}} \mathrm{m}^{\text {tos }}$ an $^{\mathrm{s}}$ voltando para esta Caza com o emprego de Procurador geral e nofim do trienio se passou ao Most ${ }^{\text {ro }}$ de Pernamb ${ }^{\circ}$ ao $\mathrm{q}^{1}$ servio com o seu cos tumado zelo, ultimamente veio nomeado Mestre de Novicos $\mathrm{p}^{\mathrm{a}}$ esta Ca $-239-$

\footnotetext{
${ }^{183}$ Embora, no original, a grafia desta palavra se assemelhe a um $<\mathrm{BE}>$, o sentido evidente dela é Deus, portanto, optou-se por assim transcrevê-la.
} 
za aonde trabalhou no servico da Religiaõ sem descanço; faleceo em

$\left[\mathrm{f}^{\mathrm{o}} 121 \mathrm{v}^{\mathrm{0}}\right]$ $\underline{7}$ de Março de $\underline{1783}$ disposto com a graça dos $\mathrm{S}^{\text {tos }}$ Sacramentos tendo de id natural 68 an $^{\mathrm{s}}$. Era D.Abb ${ }^{\mathrm{e}}$ deste Mostr $^{\mathrm{o}}$ o N.R ${ }^{\mathrm{mo}}$ P.Ex Pro= vincial Fr. An ${ }^{\text {to }}$ de S.Jose Val ${ }^{\text {ca }}$. 244 - O Ducentesimo quadregesimo quarto foi o Irmaõ Donado Fr. Manoel da Trindade filho do Reino, professo nesta caza, reco= lhendo a esta caza ja adiantado em id ${ }^{\mathrm{e}}$ nella viveo $\mathrm{m}^{\text {tos }}$ annos sem= pre trabalhando com alegria zello fidelidade, era Monge humilde prudente e sofrido, nas officinas em que ordinariam ${ }^{\text {te }}$ se occu pava, nunca offendeo a um escandalisou a ninguem ainda $\mathrm{m}^{\text {mo }}$ aos escravos, huma leve enfermidade lhe tirou a vida de todos dese jada. Faleceo fortalecido com a graça dos Saccramentos em $\underline{4}$ de Abril de 1783. com 80an de idade encompletos. Era D.Abb ${ }^{\mathrm{e}}$ des te Mostr ${ }^{\mathrm{o}}$ o N.R ${ }^{\mathrm{mo}}$ P.Ex Prov ${ }^{\text {al }}$ Fr. An ${ }^{\text {to }}$ de S.Jozé Val ${ }^{\mathrm{ca}}$. 245 - O Ducentesimo quadregesimo quinto foi o N.R ${ }^{\text {mo }}$ P.Ex Prov ${ }^{\text {al }}$ Preg ${ }^{\text {or }}$ $\mathrm{Jub}^{\circ}$ Fr. Calisto de S.Caetano filho desta Cidade professo neste Mostr ${ }^{\circ}$ teve o seu Coll ${ }^{\circ} \mathrm{em} \mathrm{Pernb}^{\circ}$ e mudado para esta caza nella foi a sua maior assistencia nos dilatados $a^{\mathrm{s}}$ que $\mathrm{D}^{\mathrm{s}}$ lhe conservou de vi da era Monge dotado de boas prendas umas naturais, e outras adque ridas com ellas servio sempre a Religiaõ nos seus $\mathrm{m}^{\mathrm{s}}$ nobres em pregos, como sao o Pulpito, Choro, e altar naõ se escuzando em $\mathrm{q}^{\text {to }}$ teve forcas destes louvaveis e $S^{\text {tos }}$ exercicios occupou os lugares $\mathrm{m}^{\mathrm{s}}$ au ctorizados da Religiaõ; $\mathrm{p}^{\mathrm{r}}$ que assim o recommendavaõ seus me recimentos, alguns trienios foi procurador geral da Provincia $\mathrm{M}^{\mathrm{e}}$ de Novicos $A b b^{\mathrm{e}}$ da Graça $A b b^{\mathrm{e}}$ da Paraiba Provincial ultimam ${ }^{\text {te }}$ $\mathrm{Abb}^{\mathrm{e}}$ deste $\mathrm{Mostr}^{\mathrm{o}}$ nos seus ultimos $\mathrm{an}^{\mathrm{s}}$ foi viver em retiro na $\mathrm{Ca}=$ pella de Monte Serrate, donde se recolheo a Cella avisado de uma molestia que o privou da vida em 4 de Abril de 1784 disposto com a graça dos ultimos Sacramentos. Faleceo com 83 an $^{\text {s }}$ de idade. 
Sendo D.Abb ${ }^{\mathrm{e}}$ o N.R ${ }^{\mathrm{mo}}$ P. Ex Prov $^{\mathrm{al}}$ Fr. Antonio de S.José Val ${ }^{\mathrm{ca}}$.

$\left[\mathrm{f}^{\mathrm{o}} 122 \mathrm{r}^{\mathrm{0}}\right]$

246 - O Ducentesimo quadragesimo sexto, que faleceeo em Porto seguro conven

tual d'este Mostro foi o R.P.P. ${ }^{\mathrm{r}}$.Fr Joaquim da Natividade, era filho

do Rio de Janr ${ }^{\circ}$ professo nesta caza, no Rio de Janr ${ }^{\circ}$ teve o seu Collo ${ }^{\circ}$ e sendo muda

do para este Mostr $^{\circ}$ nelle e no das Brottas servio a Religiaõ no q' permitia a su a possibilid ${ }^{\mathrm{e}}$. Foi mandado administrar a fasenda do Porto seguro aonde as sistio alguns an exercendo juntamente o emprego de $\mathrm{Vg}^{\mathrm{r}}$ em uma Povo= açaõ de Indios, era Monge caritativo, e vigilante, como tal estimado de toda visinhanca. Faleceo em $\underline{13}$ de Dezembro de 1784 assistido com alguns Sacerdotes d'aquellas partes, tinha $48 \mathrm{an}^{\mathrm{s}} \mathrm{de}^{\mathrm{i}} \mathrm{d}^{\mathrm{e}}$ chegou a noticia do seu falecim ${ }^{\text {to }}$. Sendo D.Abb ${ }^{\text {e }}$ o N.M.R.P. Ex Prov ${ }^{\text {al }} F r$. $A^{\text {to }}{ }^{\text {te }}$ S.José Val ${ }^{\text {ca }}$. 247 - O Ducentesimo quadragesimo septimo foi o R.P.P.Fr José da $\mathrm{M}^{\mathrm{e}}$ de $\mathrm{D}^{\mathrm{s}}$ filho da Vila nova do Porto, professo neste Mostro digo no de $\operatorname{Perb}^{\circ} \mathrm{p}^{\mathrm{a}}$ es te Most $^{\text {to }_{0}}$ voltou dep ${ }^{\mathrm{s}}$ de ordenado Sacerdote, e dep ${ }^{\mathrm{s}}$ de ter ido a sua Patria. Neste Mostr ${ }^{\circ}$ teve o seu Collo era Monge caritativo, sincero, e humilde, administrou fasendas da Religiaõ $\mathrm{p}^{\mathrm{r}} \mathrm{m}^{\text {tos }}$ an ${ }^{\mathrm{s}}$ sem nota al guma do seu procedimento, naõ se soube que este Religiozo dissesse algumas palavras, que offendessem ou molestassem a seu Proximo e se lhe davaõ occasiaõ para isto tudo dissimulava com prudencia; e paciencia. Faleceo no Engenho das Tapaccrocas em $\underline{10}$ de Marco de $\underline{1}<\underline{8}>/ \underline{7} \backslash \underline{85}$ representava ter id $\mathrm{d}^{\mathrm{e}} 70 \mathrm{an}^{\mathrm{s}}$. Era $\mathrm{Abb}^{\mathrm{e}}$ deste Mostr ${ }^{\mathrm{o}}$ o N.R ${ }^{\text {mo }}$.P. Ex Prov ${ }^{\text {al }}$ Fr. An ${ }^{\text {to }}$ de S.José Valença.

248 - O Ducentesimo quadragesimo oictavo foi o N.R ${ }^{\mathrm{mo}}$ P.M.Ex Prov ${ }^{\mathrm{al}}$ $\mathrm{D}^{\mathrm{or}}$ Jubilado Fr. Alexandre da Purificaçao $\mathrm{Vr}^{\mathrm{a}}$ era Filho de $\mathrm{Pen}^{\mathrm{co}}$ neste Mostr $^{\mathrm{o}}$ professou, e teve seo Coll $^{\circ}$ no fim delle foi mudado $\mathrm{p}^{\mathrm{a}}$ o Mostro ${ }^{\mathrm{o}}$ de $\mathrm{Per}^{\mathrm{co}}$

$\mathrm{p}^{\mathrm{a}}$ exercer os empregos de Prior, $\operatorname{Procr}^{\mathrm{o}}$ e Pass $^{\text {te }}$ jubilou, e veio tomar o graõ de Magisterio nesta Caza, $\mathrm{p}^{\mathrm{a}} \mathrm{q}^{\prime}$ o seu prestimo naõ estivesse sem exerci cio veio eleito em $\mathrm{Abb}^{\mathrm{e}}$ da Paraiba no trienio seguinte $\mathrm{Def}^{\mathrm{or}} \mathrm{pr}^{\mathrm{o}} \mathrm{ul}$ 
timamente Prov ${ }^{\text {al }}$. Era Monge bem instruido mas leis, e cerimo

$\left[\mathrm{f}^{\mathrm{0}} 122 \mathrm{v}^{\mathrm{0}}\right]$ nias, e assim com vigilancia, e disvello as fasia praticar tanto no tempo do seu governo como fora delle; $\mathrm{p}^{\mathrm{a}} \mathrm{q}$ ' de todos era atendidos, no Pulpito, e Cadr ${ }^{\mathrm{a}}$. acreditou a Religiaõ; e a sua pessoa; no seus ulti mos an ${ }^{\mathrm{s}}$ buscou e retiro das Brotas, onde se dispos $\mathrm{p}^{\mathrm{a}}$ a morte com re petidos exercicios de virtudes e caridades, fasendo $\mathrm{m}^{\text {tas }}$ esmolas aos pobres daqeulla visinhança que $\mathrm{p}^{\mathrm{r}} \mathrm{m}^{\text {tos }}$ an ${ }^{\mathrm{s}}$ choraraõ a sua ausen cia, sentindo-se de todo oprimido de uma molestia, que padecia, recolheo-se a este Mostr ${ }^{\circ}$ e fasendo-se nelle comventual, disposto com a graca dos Sacramentos com $\mathrm{m}^{\text {tos }}$ actos de Catholico e Religioso, encheo os seus dias em $\underline{4}$ de Fevr ${ }^{\circ}$ de $\underline{1786}$. tendo de idade 64 an $^{\text {s }}$ encompletos. Era D. Abb ${ }^{\mathrm{e}}$ deste Mostro o N.R ${ }^{\mathrm{mo}}$.P. Ex Provincial Fr. $A n^{\text {to }}$ de S.Jozé Valença.

15

20

249 - Entre todos os esquecidos pareceme, que naõ havera outro como o P.Fr.Felis natural do Rio de Janr ${ }^{\circ}$ o qual foi musico, e entreme tida naõ me lembre se de orgaõ ou de rebeca o qual deps que veio de $\mathrm{Lx}^{\mathrm{a}}$ e o conhecido de vista neste $\mathrm{Mostr}^{\mathrm{o}}$ no $\mathrm{q}^{\mathrm{al}}$ acabou a vida entrou a padecer umas quenturas pelo corpo das quaes veio a cobrirssde ${ }^{184}$ mal de S.Lasaro $\mathrm{p}^{\mathrm{r}}$ cuja causa foi separado de seos Irmaõs a mor $-242-$

${ }^{184}$ Está assim no original. 
rer apartado d'elles em uma casinha que havia na horta até acabar

$\left[\mathrm{f}^{\mathrm{0}} 123 \mathrm{r}^{\mathrm{0}}\right]$ a vida. Naõ sei que crime tinha feito, $\mathrm{p}^{\mathrm{r}}$ que ouvi entaõ diser, que aquella doenca era castigo $p^{\text {lo }}$ que elle havia feito. Se foi assim ou naõ, eu naõ affermo; $\mathrm{m}^{\mathrm{s}}$ podemos tomar exemplo, e louvar e $\mathrm{D}^{\mathrm{s}} \mathrm{p}^{\mathrm{r}}$ que $\mathrm{q}^{\text {to }} \mathrm{m}^{\mathrm{s}}$ padeceo nesta vida teria menos, que padecer na outra, trouxa $\mathrm{m}^{\text {to }}$ selfa para este Mostr ${ }^{0}$ toda em letra redonda como entaõ se usava em Lex ${ }^{\mathrm{a}} \mathrm{p}^{\mathrm{r}}$ que ainda que parecesse bem a musica, do q' nesse tempo se usava nestas partes do Brazil, era obra de uma mera curiosidade, mas naõ composta conforme as regras d'arte; $\mathrm{p}^{\mathrm{s}}$ nenhum era compositor de perfeiçaõ. Veio de horta dep $^{\mathrm{s}}$ de morto, e se lhe deo sepultura nos claustros.

250 - Naõ ha de ser menos esqeucido o P.Fr. Fran ${ }^{\text {co }}$ Gama natural d'esta Cidade Musico, e organista deste Mostro em o q tambem foi $\mathrm{M}^{\mathrm{e}}$ de Capella $\mathrm{m}^{\text {tos }}$ annos, e tambem Cantor, e Musico; eu ainda assisti o seu officio de corpo presente, deixou no seculo um seu Irmaõ Secular, que tambem era musico, e Organista, e como ainda viveo bastantes ans e foi conhe cido de alguns dos nossos Religiosos, por elle pode ser $\mathrm{m}^{\mathrm{s}}$ bem lebrado o dito Monge defuncto. $-251-\mathrm{Naõ}$ he bem que fique em eterno esquecimento o $\mathrm{P}^{\mathrm{e}}$.Fr. Bento natural de Portugal a $\mathrm{q}^{\mathrm{m}}$ eu conheci perfeitam ${ }^{\mathrm{te}}$ o qual tocava charamel= llinha principalmente quando se contava o Te Deum nas Mati= nas no Choro, e $\mathrm{qd}^{\mathrm{o}}$ se cantava o Magnificat, e Benedictus, e fa= berdaõ com tal istrumetno tanto lustrava nosso Choro neste tempo, que os Religiosos de S.Franc $c^{\circ}$ naquellas matinas $\mathrm{m}^{\mathrm{s}}$ solem nes, dep ${ }^{\mathrm{s}}$ que acabavaõ de cantar as suas, punhaõ se nas janellas de suas Cellas $\mathrm{p}^{\mathrm{a}}$ ouvirem a consonencia, que fazia a nossa dita xara $=$ milinha, e as voses dos nossos P.P. hoje porem naõ havera $\mathrm{q}^{\mathrm{m}}$ quei ra ouvir nosso canto $\mathrm{p}^{\mathrm{r}}$ que alem de estar a Choro taõ falto de vozes se encommenda a dois Choristas os $\mathrm{q}^{\mathrm{s}}$ naõ tem voses cheias e $\mathrm{p}^{\mathrm{r}}$ isso naõ se ouvem os outros parece, que seguem o canto Ceciliano cantan 
$\left[\mathrm{f}^{\mathrm{0}} 123 \mathrm{v}^{\mathrm{o}}\right]$

do som $^{\text {te }}$ com as voses do coraçaõ $\mathrm{p}^{\mathrm{s}}$ os $\mathrm{m}^{\mathrm{s}}$ delles nem abrem as bocas $\mathrm{qd}^{\mathrm{o}} \mathrm{se}$ canta. Como era velho, fortalecido com as gracas dos Sacramen tos morreo.

252 - Tambem $p^{\mathrm{r}}$ mim naõ ha de perder-se a memoria de um Irmaõ Leigo que nunca ouvi nem $<\mathrm{S}>/\left.\mathrm{b}\right|^{185} \mathrm{em}$ sei o nome d'elle, o qual ou esti vesse como ajudador de Monge ou assistia na capella do Ina tá, e $\mathrm{p}^{\mathrm{r}}$ acaso se achasse nella indo acompanha $<$ ndo $>/ \mathrm{r} \backslash$ ao Monge, que $<$ que $>$ hia disforcar-se das terras que nos havia tomado $\mathrm{p}^{\mathrm{r}}$ es sas partes o Fidalgo D.Joaõ Mascarenias sahiraõ os escravos do dito Fidalgo com varias armas contra os dois Monges, e logo cru elmente mat/araõ/ a dito Leigo, e Sacerdote valendo-s de Cavallo em q' estava montado, livrou a vida vindo a carreira reco $=$ lher-se na dita Capella; $\mathrm{p}^{\mathrm{r}}$ essa causa foi a $\mathrm{Lx}^{\mathrm{a}}$ o $\mathrm{R}^{\mathrm{mo}}$ Fr.Roque de Assumpsaõ $<$ mandado $>$ mandado $\mathrm{p}^{\mathrm{r}}$ esse Mostr $^{\mathrm{o}}$ a queixar-se a q sua $\mathrm{Mag}^{\mathrm{e}}$ do que tinha feito o Fidalgo nomeado; e q' resultou foi $\mathrm{El}=$ Rei mandou-o buscar preso, mais depois que chegou a côrte mor reo antes de sahir a sentenca, e como morrio o reo tambem acabou-se a demmanda, no dia em q' o Geral do Mostr ${ }^{\circ}$ re ce/beo o/ aviso do que havia succedido, tinha vindo o dito Fidalgo ouvir o sermaõ, que se fasia; mas ja se tinha recolhido com o General, e entaõ ouvio diser a alguns Monges como desejava. Mas sendo aq ${ }^{\text {le }}$ sitio taõ saudavel para outros, succedeo-lhe o contrario, $\mathrm{p}^{\mathrm{r}}$ que o $\mathrm{m}^{\mathrm{mo}}$ foi ir para elle, $\mathrm{q}^{\prime}$ entrar a adoecer com doencas gravissimas, o que o perseguiraõ até a morte, naõ lhe va lendo o cuidado, com que elle tiveraõ os Medicos, a a boa assistencias que lhe fiseraõ os seus parentes. Finalm ${ }^{\text {te }}$ ouvindo diser ao Medico que naõ tinha remedio entrou para o $\operatorname{Mostr}^{\circ}$ pedindo logo os Sacra mentos, e sem demora se pos logo a morrer pedindo ao $\mathrm{P}^{\mathrm{e}}$. que the assistia o ajudasse. Tanto que espirou entraraõ tambem a dobrar os sinos de S.Fran ${ }^{\mathrm{co}} \mathrm{p}^{\mathrm{r}} \mathrm{q}^{\prime}$ tinha um Irmaõ Difinidor actual 
que di(sia) ser Prelado futuro, no dia seguinte tanto os Religio

$\left[\mathrm{f}^{\mathrm{o}} 124 \mathrm{r}^{\mathrm{o}}\right]$

sos de S.Franc ${ }^{\circ}$ como do Carmo vierao assistir o seu officio; $\mathrm{p}^{\mathrm{r}} \mathrm{q}^{\mathrm{q}}$

no Carmo tinha também um [个Primo] P.M.; e naõ so esses, mas também o ${ }^{\text {mo }}$ Provincial de S.Franc ${ }^{0}$ o levou sobre os seos hombros a sepultura. Foi chorado a sua morte; $\mathrm{p}^{\mathrm{r}}$ que neste Mostr $^{\mathrm{O}}$ ainda conservava verdadeiros amigos. Tinha particular devoçaõ com N.P.S.B ${ }^{\text {to }}$ e assim desejava que a festa de seo dia se fisesse com a grandeza possivel, e o mesmo na Semana Santa, q' sempre a celebrou até onde podia chegar as suas forças servindo de Sacristaõ mor. Faleceo a 11 de Julho de $\underline{17}[85]^{186}$ 85. sendo D. $\mathrm{Abb}^{\mathrm{e}}$ o $^{\text {to }}$ R.P.Preg ${ }^{\text {or }}$ Fr. Antonio de S.José Valença. 253 - Segue-se a vida, e morte do R ${ }^{\text {do }}$ P.Fr. Matheus de S.An na natural desta Cidade, filho de Pais honrados, que vie raõ do Reino para esta Cidade, os quas o crearaõ no temor de $\mathrm{D}^{\mathrm{s}}$ mandando o instruir nas escolas, e aprender a lingua latina, que soube sufficientem ${ }^{\text {te }} \mathrm{e}$ alcancando uma patente para ser Religioso nosso tomou o habito /neste/ Mostr ${ }^{\circ}$, e nelle foi novico, mostrando no tempo do seu novi ciado a grande vocaçaõ com que veio ser Religioso $\mathrm{p}^{\text {lo }} \mathrm{m}^{\text {to }} \mathrm{com}$ que se entregava a virtudes; e professando teve o seu Coris tado neste Mostr ${ }^{\circ}$, continuando sempre nas costumadas vir tudes religosas, e sendo $\mathrm{m}^{\text {to }}$ diligente no comprimento de suas obrigacoens $\mathrm{p}^{\text {la }}$ que era $\mathrm{M}^{\text {to }}$ estimado dos Religiosos. $\mathrm{De}=$ pois de ordenado de Sacerdote viveo $\mathrm{m}^{\text {tos }}$ annos neste Mostr ${ }^{\circ}$ Foi tambem Colligial do Mostr ${ }^{\circ}$ da Graça alguns annos, e tambem das Brotas, e tornando para este Mostr ${ }^{\circ}$ foi man 
dado para a nossa Olaria de S. Antonio das Barreiras de

$\left[\mathrm{f}^{\mathrm{0}} 124 \mathrm{v}^{\mathrm{o}}\right]$ Jaguaripe onde esteve $\mathrm{m}^{\text {tos }}$ annos. Depois tomou $\mathrm{p}^{\mathrm{a}}$ este Mostro aonde o fizeraõ Subprior, e mestre dos Irmaos Coristas, cujo car go exerceo até o fim da vida. Este Monge era dos mais cari tativos, e diligentes no comprimento da sua obrigaçaõ do confes sionario do $\mathrm{q}^{\mathrm{l}}$ acodia com $\mathrm{m}^{\text {ta }}$ diligencia sem que nunca negasse a confissaõ a penitente algum, dos que lhe pediaõ tal vez $\mathrm{p}^{\mathrm{a}}$ se livrar decahir em culpa grave, em que $<\mathrm{d}>$ /clcahem os Sacerdotes negligentes de administrarem este Sacra mento a $\mathrm{q}^{\mathrm{m}}$ the pede como dizendo $\mathrm{m}^{\text {tos }}$ Dout $^{\text {os }}$ principalm ${ }^{\text {te }}$ Barufaldo titulo 18. $\mathrm{n}^{\mathrm{o}} .3$ disendo $\mathrm{p}^{\mathrm{r}}$ estas palavras= Confessarius peceabit enim graviter, si risputat audire ponitentem, quando hic obligatur ad confessionem. Si est Parachus peccabit contra justitiam: si est simplex sa cerdos approbatus peccabit contra caritatim $\mathrm{V}^{\mathrm{r}}$ Finalm ${ }^{\text {te }}$ este Monge cheio de virtudes, e merecimentos faleceo neste Mostr $^{\circ}$ aos $\underline{28}$ de Janeiro de 1790 . Sendo D. Abb $^{\mathrm{e}}$ o M.R. $\mathrm{P}^{\mathrm{e}}$.Preg ${ }^{\text {or }}$ Fr. An ${ }^{\text {to }}$ da Encarnacaõ Penna. 
$\left.\mathrm{f}^{\mathrm{0}} 125 \mathrm{r}^{\mathrm{0}}\right]$

254 - Segue-se a vida e, morte do Irmaõ Fr. $\mathrm{An}^{\text {to }}$ de Santa Anna Buticario. Este Religiozo era natural de Lamego,e sendo moço de $18 \mathrm{an}^{\mathrm{s}}$ veio $\mathrm{p}^{\mathrm{a}}$ esta terra procurar algum meio de ganhar a vida; o vindo a este Mostr ${ }^{\circ}$ fallou ao $R^{\text {do }}$ P.Fr. Jozé de Jezus Boticario; $p^{a} q^{\prime}$ o recebesse $p^{r}$ seu discipulo, afim de lhe encinar od ${ }^{\text {to }}$ officio, assim o fez o $\mathrm{d}^{\text {to }} \mathrm{P}^{\mathrm{e}}$. $\mathrm{P}^{\text {lo }}$ ver $\mathrm{m}^{\text {to }}$ esperto, e agil $\mathrm{p}^{\mathrm{a}} \mathrm{od}^{\text {to }}$ officio, e logo veio $\mathrm{p}^{\mathrm{a}}$ a sua companhia, e lhe en= signou od ${ }^{\text {to }}$ officio em poucos $a^{\mathrm{s}}$. Dep ${ }^{\mathrm{s}}$ alcançou Patente $\mathrm{p}^{\mathrm{a}}$ ser Religio $=$ zo leigo, e tomando o habito foi proceguindo com o seu Noviciado, do $\mathrm{q}^{1}$ fugio $\mathrm{p}^{\mathrm{a}}$ fora do Mostr ${ }^{\mathrm{o}}$, mas em breves dias logo conhecêo o mal, q' ti= nha feito, e tornando a procurar o Mostro ${ }^{\circ}$ andou prostando-se $\mathrm{p}^{\text {los }}$ as portas de todos os Monges, pedindo-lhe q' lhe tornassem a receber n'a sua comp $\mathrm{p}^{\mathrm{a}} \mathrm{p}^{\mathrm{s}}$ ja estava arrepend ${ }^{\circ}$ do mal, q' tinha feito, ao q' sentio toda a comonid ${ }^{\mathrm{e}}$; e $\mathrm{p}^{\mathrm{r}}$ isso o tornaraõ a asseitar, o foi continuando com o seu noviciado; athe q' professou. Dep ${ }^{\mathrm{s}}$ foi porceguindo n'a sua occupa= çaõ de Boticario, e passados alguns $\mathrm{a}^{\mathrm{s}}$ mandou pedir huma licença ao $\mathrm{Rm}^{\mathrm{o}} \mathrm{P}^{\mathrm{e}}$ Geral $\mathrm{p}^{\mathrm{a}}$ abria corôa Monacal, e trazer Cogullas, e vindo /conseguio*/ od $^{\text {to }}$ effeito, e andou de corôa aberta, e cogulla alguns $a^{\mathrm{s}}, \mathrm{m}^{\mathrm{s}} \mathrm{dep}^{\mathrm{s}}$ saben= do-se q' ad ${ }^{a}$ licença era falça, mandaraõ-lhe prohibir, que andasse de cogulla, oq' inteiram ${ }^{\mathrm{e}}$ comprio. Sempre continuou na $\mathrm{d}^{\mathrm{a}}$ sua occupaçaõ de Boticario; e nella ficou $\mathrm{p}^{\mathrm{r}}$ morte $\operatorname{dod}^{\text {to }} \mathrm{P}^{\mathrm{e}}$. Fr. Jozé Boticario. Tinha $\mathrm{m}^{\text {to }}$ zelo com a Butica, e grd ${ }^{\mathrm{e}}$ cuidado no seo augmento, adquerindo em al= guns annos o partido de alguns Religozos, e cazas particulares, em ordem a augmentar no seu rendim ${ }^{\text {to }}$. Este Irmaõ taõ bem foi compre= hend ${ }^{\mathrm{o}}$ no Crime, $\mathrm{q}^{\prime}$ cometteraõ outros Religiozos; $\mathrm{p}^{\mathrm{r}}$ recuzarem a posse de serto $\mathrm{Abb}^{\mathrm{e}}$ deste Mostro $; \mathrm{p}^{\text {lo }}$ q' veio decreto Rial $\mathrm{p}^{\mathrm{a}}$ irem prezos $\mathrm{p}^{\mathrm{a}}$ o Reino, ecomo

este $\mathrm{d}^{\mathrm{O}}$ Irmaõ estava no Rio de Janr ${ }^{\mathrm{o}}$; lá lhe mandaraõ in/tim/ar a dita 
ordem, e logo se embarcou p. ${ }^{\mathrm{a}}$ este Mostro; e daqui foi logo p..$^{\mathrm{a}}$ Lisboa, seguin do a derrota dos mais, q' ja tinhaõ partido, e chegando a corte de Lisboa, logo o remetteraõ $\mathrm{p}^{\mathrm{a}}$ Tibães, onde o meteraõ no carcere, e tronco do d. ${ }^{\circ}$ Mos $=$ $\operatorname{tr}^{\circ}$ juntam $^{\mathrm{e}}$ com alguns dos mais Religiosos, q' naõ tiveraõ o d. ${ }^{\circ}$ castigo ca no Brazil, mas passados alguns tempos; elle $\mathrm{p}^{\text {lo }}$ socorro dos seus amigos fugio do Tronco $\mathrm{p}^{\mathrm{a}}$ Galiza, e $\mathrm{p}^{\mathrm{r}}$ lá andou $\underline{9}$ mezes, e tendo noticia q' os $\mathrm{Re}=$ ligiosos estavaõ $\mathrm{p}^{\mathrm{a}}$ vir $\mathrm{p}^{\mathrm{a}}$ o Brazil, tomou o seu Padrinho de $\operatorname{grd}^{\mathrm{e}}$ valim $^{\text {to }}$, e veio $\mathrm{p}^{\mathrm{a}}$ Tibãens, e logo o mandaraõ em companhia dos mais $\mathrm{p}^{\mathrm{a}}$. o Brazil, e chegando a este Mostro ${ }^{\mathrm{o}}$, nelle ficou $\mathrm{p}^{\mathrm{r}}$ conventual alguns $\mathrm{a}^{\mathrm{s}}$ athe q' saio $\mathrm{p}^{\mathrm{r}}$ Provincial o N.Rm ${ }^{\mathrm{o}} \mathrm{P}^{\mathrm{e}}$. $\mathrm{M}^{\mathrm{e}}$ Fr Alexandre da Porificaçaõ Vieira, oq ${ }^{\mathrm{l}}$ olevôu em sua comp $p^{\mathrm{a}} ; \mathrm{q}^{\mathrm{do}}$ foi vizitar toda a Provincia, dep $^{\mathrm{s}}$ ficou $\mathrm{p}^{\mathrm{r}}$ conventual deste Mostr ; o attendendo o Prelado q' a Botica estava distruida, e quaze aca= bada de todo $\mathrm{p}^{\mathrm{r}}$ ser governada $\mathrm{p}^{\mathrm{r}}$ Buticarios de fora, q' cuidavaõ som ${ }^{\text {te }}$ nasua conveniência, determinou q' od..$^{o}$ Irmaõ Boticario tornasse p. ${ }^{a}$ aBotica com o cargo de dar os Remedios necessarios p. ${ }^{a}$ as infermid ${ }^{\text {es }}$ do Religiozos, e $\mathrm{Es}=$

/cravos/, alem de pagar os Selarios dos Medicos, e surigiões [个cirurgaẽs] ${ }^{187}$, etaõ bem com $=$

prar a sua custa oprovim ${ }^{\text {to }}$ necessario, e q' $\mathrm{de}^{\mathrm{s}}$ resto do seu rendim ${ }^{\text {to }}$ se poderia utilizar ao q' tudo se obrigou $\mathrm{p}^{\mathrm{r}}$ hum termo, q' fez nos livros dos concelhos, sendo D.Abbd deste Mostr $^{\mathrm{o}}$ o M.R.P. ${ }^{\mathrm{e}}$. Fr. Pascual da da Ressurreiçaõ, e tomando logo posse da Botica, achou-a $\mathrm{m}^{\text {to }}$ dete $=$ riorada $\mathrm{p}^{\mathrm{r}}$ falta de remedios, e de $\mathrm{m}^{\text {tos }}$ vazos, $\mathrm{q}^{\prime}$ se lhe tinhaõ vendido, logo comecou a reforma la de necessario, como lhe foi possivel, e des $=$ ta sorte esteve n'ella, $<$ athé $>$ athe ofim da vida; mas como ja n'aq ${ }^{\text {le }}$ tem= po a Botica estava $\mathrm{m}^{\text {to }}$ detiriorada no seu Rendim ${ }^{\text {to }} \mathrm{p}^{\mathrm{r}}$ lhe terem faltado os milhores partidos, e od ${ }^{\circ}$, Irmaõ Buticario fazer $\mathrm{m}^{\text {tas }}$ dispezas, e algumas crecidas, e (...) $[\uparrow \mathrm{d}]$ esnesseçarias; $\mathrm{p}^{\mathrm{r}}$ isso $\mathrm{q}^{\mathrm{do}}$ morrêo deixou aBotica inpenhada $-248-$ 
$\left[\mathrm{f}^{\mathrm{0}} 126 \mathrm{r}^{\mathrm{0}}\right]$

/em 7 mil e/ tantos cruzados, q' sepagaraõ dep ${ }^{\mathrm{s}}$ da sua morte. Finalm ${ }^{\mathrm{e}} \mathrm{p}^{\mathrm{a}} \mathrm{o}$ fim da vida foi-se enchendo de varis molestias, athé q' $p^{r}$ fim lhederaõ humas sezoẽs malignas, e naõ obstante varios remedios, q.' tomou p. ${ }^{a}$ as curar, senpre the cortaraõ o fio da vida, de q' veio a falecer a 18 de $\mathrm{Ma}(\mathrm{r}=)$ ço de 1791, sendo D.Ab..$^{\mathrm{e}}$ deste Mostr. ${ }^{\circ}$ o M $^{\text {to }}$ R.P. ${ }^{\text {e }}$ Pregador Fr. Antonio da Encarnaçaõ Pina.

255 - Segue-se a vida, e morte do $\mathrm{M}^{\text {to }}$ R.P.Pregador Exprovincial Fr. Luis da Conceiçaõ Souza, natural da V.a de Taipú, Capitania do Rio de Janr ${ }^{\circ}$, filho de pais honrados, que o crearaõ no temor de Deos, $<$ eo= mandaraõ $>$ e o mandaraõ instruir nas Escollas, e lingua Latina, q' sôbe sufficientem ${ }^{\mathrm{e}}$, e alcando-lhe huma Patente $\mathrm{p}^{\mathrm{a}}$ ser Religiozo nosso, veio tomar ohabito a este Mostro; en'elle profeçou, e dep. ${ }^{\mathrm{s}}$ foi $\mathrm{p}^{\mathrm{a}}{ }^{\mathrm{a}}$ o Mostr. $^{\circ}$ do Rio de Janr $^{\circ}$, onde teve o seu Coll. ${ }^{\circ}$ da Filozofia, e The $<1>$ /o $\backslash$ logia. De $\mathrm{p}^{\mathrm{s}}$ de feito pregador, $\mathrm{p}^{\mathrm{a}}$ o Mostr ${ }^{\mathrm{o}}$ de S.Paulo, se passou, onde teve $\mathrm{m}^{\text {tos }}$ annos en varias occupações, satisfazendo a todos com $\mathrm{m}^{\text {ta }}$ diligencia, e porificaçaõ, e tornando-se a mudar p. $^{\text {a o }}$ Mostr. ${ }^{\circ}$ do Rio de Janr ${ }^{\circ}$; nel, le foi Prior, e de p..$^{\mathrm{s}}$ o ellegeraõ em D.Abd. ${ }^{\mathrm{e}}$ das Brottas, /cujo/ cargo exercêo com $\mathrm{m}^{\text {ta }}$ occupaçaõ, digo, ${ }^{\text {com }} \mathrm{m}^{\text {ta }}$ perfeicaõ, e prudencia, e como no trienio seg ${ }^{\mathrm{e}}$ ficou sem cargo algum, foi p. ${ }^{\mathrm{a}}$ o Mostr. ${ }^{\circ}$ de Per= nanbuco, onde esteve hum trienio, de $\mathrm{p}^{\mathrm{s}}$ tornaraõ a ellege $(-10) \mathrm{p}^{\mathrm{r}}$ defe $=$ nidor tercr ${ }^{\mathrm{o}}$, e tornou-se a mudar $\mathrm{p}^{\mathrm{a}}$ este Mostr $^{\mathrm{o}}$; onde esteve alguns tempos, exercendo o seu cargo, mas como o Prelado naõ tinha rele $=$ gioso algum, que podesse p. ${ }^{\mathrm{r}}$ no Eng. ${ }^{\circ}$ de $\mathrm{S}$ Bento, pedio=lhe q' fosse p. ${ }^{\mathrm{a}}$ lá alguns tempos admemistra-lo, en q..$^{\text {to }}$ aparecia algum Religi= ozo, que o fosse render. Depois vendo que ja naõ podia com aquella vida de lidar com os trabalhos do Eng ${ }^{\circ}$; mandou dizer ao Prelado, q' o mandasse render. e com effeito veio p. $^{\text {a }}$ este Mostro; on= de ainda vivêo alguns annos, e como lhe foraõ falecendo as forças 
preparou-se com todos os Sacram. ${ }^{\text {tos }}$ da S.M. ${ }^{\mathrm{e}}$ Igreja, e falecêo em 20

de Agosto de 1791 sendo D.Ababe o $\mathrm{m}^{\text {to }} \mathrm{R}^{\mathrm{o}}$.P.Pregador Fr. Antonio da Encarnaçaõ Pina.

256 - Segue-se a vida, e morte do M.R.P.Preg ${ }^{\text {or }}$ F.Joaõ de S. Joze Fraga. Este Monge era natural da Villa Rial, filho de Pais honrados, q' o cre= araõ no temor de Deos, e o mandaraõ instruir nas Escollas, e lingua latina, e como sentiaõ n'elle grande Vocaçaõ $\mathrm{p}^{\mathrm{a}}$ ser Religiozo nosso pediraõ huma patente ao nosso $\operatorname{Rev}^{\mathrm{mo}} \mathrm{P}^{\mathrm{e}}$ Geral, e veio com ella to= mar o habito no Mostr. ${ }^{\circ}$ do Rio de Janr ${ }^{\circ}$; e nelle foi noviço, professou, e teve o seus collegios da filozofia, e Theologia; e depois do feito Preg ${ }^{\text {or }}$ veio mudado $\mathrm{p}^{\mathrm{a}}$ este Mostro ${ }^{\mathrm{o}}$ e equi foi conventual, e na graça, onde esteve alguns $\mathrm{a}^{\mathrm{s}}$, e lá foi Prior, e depois D. $\mathrm{Ab}^{\mathrm{e}}$; e acabada a sua $\mathrm{Aba}=$ dia, ,veio $\mathrm{p}^{\mathrm{r}}$ procurador geral deste Mostr ${ }^{\mathrm{O}}$; digo da provincia,como lhe foi percizo tornar $\mathrm{p}^{\mathrm{a}}$ este Mostr ${ }^{\mathrm{o}} \mathrm{p}^{\mathrm{a}}{ }^{\mathrm{a}}$ comprir com as obrigações do seu cargo, nelle se fez conventual, e foi vivendo alguns $\mathrm{a}^{\mathrm{s}}$, sem= pre quexando-se de varias molestias, procedida de huma $\mathrm{du}=$ reza grande, que tinha, procedidas de $\mathrm{m}^{\text {tas }}$ sezões, que teve na Graça, e em outra partes, de q' se lhe veio a seguir a morte, e pre= parado com todos os Sacram ${ }^{\text {tos }}$ da Igreja, faleceo em 13 de Maio /de 179/2, sendo D.Abade deste Mostr. ${ }^{\circ}$ o M.R.P.Pregador Fr. An= tonio da Encarnaçaõ Pina.

257 - Segue-se a vida, e morte do M.R.P.Pregador, e ex $\mathrm{Abd}^{\mathrm{e}} \mathrm{Fr}$. Fr ${ }^{\mathrm{co}}$ da Conceiçaõ, natural desta Cid ${ }^{\mathrm{e}}$, filho de Pais honrados, q' o crea= raõ no temor de Deos, e omandaraõ instruir na gramatica, eco= mo viraõ inclinado a ser Religiozo, alcançaraõ-lhe huma $\mathrm{Pa}=$ tente, e com ella veio tomar o habito neste Mostro; e nelle profe= çou, e teve o seu curistado, e taõ bem principiou a ter o curço da Filozofia, mas como o Mestre delle arribou, tendo já 7 mezes foi precizo ir com todos os mais collegiais p. ${ }^{\mathrm{a}}$ o Mostro de Pernanbuco, onde acabou o dito seu Coll. ${ }^{\circ}$, e teve o de Theologia, e no fim d'elle 
/feitos os actos de*/ Pregador, tornou $\mathrm{p}^{\mathrm{a}}$ este Mostr ${ }^{\mathrm{o}}$, e nelle sempre vivêo com edificaçaõ, e bom exemplo da sua vida Religioza. Foi taõ bem $\mathrm{m}^{\text {tos }} \mathrm{a}^{\mathrm{s}}$ Prior deste Mostr. ${ }^{\circ}$ em cujo cargo bem mostrou, q' era amigo da observancia Religioza, chamando sempre $\mathrm{p}^{\mathrm{a}}$ o côro os Religio= zos, q' lhe faltavaõ, e castigando sempre aos Coristas com repetidas penitencias, $\mathrm{p}^{\mathrm{r}}$ quais quer faltas, que comettiaõ; dep ${ }^{\mathrm{s}}$ veio elleito em D. $\mathrm{Ab}^{\mathrm{e}}$ do Mostr ${ }^{\mathrm{o}}$ das Brottas, cujo cargo executou côm ${ }^{\text {tas }}$ satisfaçaõ. Por fim veio-lhe huma molestia grave, de q' veio curar-se nesta Cidad. ${ }^{\mathrm{e}}$ da B. ${ }^{\mathrm{a}}$, mas como naõ pode vence-la; $\mathrm{p}^{\mathrm{r}}$ meio de varios reme $=$ dios, conheceu, que era chegado ofim da sua vida, $\mathrm{p}^{\mathrm{r}}$ cuja cauza $\mathrm{se}=$ /recolhêo*/ a este Mostr ${ }^{\circ}$, afim de sepreparar com os Sacram ${ }^{\text {tos }}$ da Santa Madre Igreja, os quais recebidos, e preparando-se com os mais actos de verdadr ${ }^{\circ}$ Religiozo, falecêo neste Mostro ${ }^{\mathrm{o}}$ sendo ja Prezid ${ }^{\text {te }}$ das Brotas a 2 de Novembro 1792 sendo D.Ab ${ }^{\mathrm{e}}$ deste Mostr $^{\mathrm{o}}$ o $\mathrm{M}^{\text {to }}$ R.P.Pre= gador Fr. Antonio da Conceiçaõ Pina.

258 - Segue-se a vida, e morte do Irmaõ Donado Fr. Silvestre de Jezus Maria. Este Irmaõ Leigo era natural das Ilhas, e tinha /a prenda/ de ser bom ferreiro, e serralheiro, e $\mathrm{p}^{\mathrm{r}}$ ella entrou na Religiaõ. Depois de professo, mandou o o Prelado ser Mestre da Ferraria, e nella este= ve $\mathrm{m}^{\text {tos }}$ annos, ensignando aos Escravos do Mostr. ${ }^{\circ}$, a ferreiros, e serralhei $=$ ros, e butou $\mathrm{m}^{\text {tos }}$ discipulos grandes offiiciaes do seu officio. Taõ bem esteve no Mostro de Olinda de Pernanbuco, e o puzeraõ na $\mathrm{m}^{\mathrm{ma}}$ offecina da ferraria, e no $\mathrm{m}^{\mathrm{mo}}$ emprego; mas aturou pouco tempo n'elle, $\mathrm{p}^{\mathrm{r}}$ ser $\mathrm{m}^{\text {to }}$ aspero $\mathrm{p}^{\mathrm{a}}$ os escravos, que os castigava com excesso. Parece q' neste tempo tinha estado no Mostr. ${ }^{\circ}$ do Rio de Janr. ${ }^{\circ}$ e taõ bem no da Graça, onde foi procurador mordomo. Por ultimo veio $\mathrm{p}^{\mathrm{a}}$ este Mostr. ${ }^{\mathrm{o}}$ 
$\left[\mathrm{f}^{\mathrm{0}} 127 \mathrm{v}^{\mathrm{o}}\right]$

onde servio varios cargos, em q'; os prelados o punhaõ, $\mathrm{p}^{\mathrm{r}}$ conhecerem a sua capacid $^{\mathrm{e}}$, principalm ${ }^{\mathrm{e}}$ exercêo o de Procurador, e mordomo $\mathrm{m}^{\text {tos }}$ annos, e $\mathrm{p}^{\mathrm{r}}$ fim dando-lhe huma febre com grande excesso, conhecêo q' era chegado o fim da sua vida, e preparando-se com os Sacram ${ }^{\text {tos }}$ da Santa Madre Igreja, faleceo em 9 de Novembro de 1792, sendo D.Ab ${ }^{\mathrm{e}}$ deste Mostr. ${ }^{\circ}$ o M.R.P.Pregador Fr. Antonio da Encarnaçaõ Pina.

259 - Segue-se a vida, e morte do M.R.P.M ${ }^{\mathrm{e}}$ Jubilado, e ex $\mathrm{Ab}^{\mathrm{e}}$ o $\mathrm{D}^{\text {or }} \mathrm{Fr}$. Pas coal da Ressurreiçaõ. Este Monge era filho de Pais honrados, $\mathrm{p}^{\mathrm{r}} \mathrm{q}$ ' o crearaõ no temor de Deos, mandando o instruir nas escollas, na solfa, e na gramatica, era natural desta Cid ; como seus Pais viraõ q' elle dezeja= va ser Religiozo nosso, tal vez $\mathrm{p}^{\mathrm{r}}$ ter ja cá dous Irmaõs Religiozos nossos chamados F Fran ${ }^{\mathrm{co}}$ e Fr Salvador, alcançaraõ-lhe huma Patente $\mathrm{p}^{\mathrm{a}}$ elle taõ bem o ser, e com effeito veio com ella tomar ohabito neste Mostr ${ }^{\mathrm{o}}$; e nelle professou, e teve o seu curistado, athe q' foi tempo de hir $\mathrm{p}^{\mathrm{a}}$ o seu Coll. ${ }^{\mathrm{o}}$ da Filozia, e Theologia, donde sahio passante, e de pois foi nomiado $\mathrm{p}^{\mathrm{r}}$ lente de Filozofia do Coll. ${ }^{\mathrm{o}}$ deste Mostr. ${ }^{\mathrm{o}} \mathrm{p}^{\mathrm{r}}$ mor= te do $\mathrm{P}^{\mathrm{e}} \mathrm{M}^{\mathrm{e}}$ Coimbra, $\mathrm{q}^{\prime}$ era a lente della, e proseguio com a sua diligencia de leitura da Filozofia, e Theologia athe o fim, athe q' se jubilou, e se doutorou n'ella. Depois foi $\mathrm{p}^{\mathrm{a}}$ o Certan /pregar de/ missaõ, e $\mathrm{p}^{\mathrm{r}}$ la andou $\mathrm{m}^{\text {to }} \mathrm{s}$ annos, fazendo suas Missões, conficões, e ga nhando almas $\mathrm{p}^{\mathrm{a}}$ Deos, e tornando $\mathrm{p}^{\mathrm{a}}$ este Mostr. $^{\mathrm{o}} ;$ n'elle foi D.A ${ }^{\mathrm{e}}$, e se occupou no $\mathrm{m}^{\mathrm{s}}$ restante de sua vida no exercicio do Pulp ${ }^{\text {to }}$ sempre com $\mathrm{m}^{\text {to }}$ credito da sua pessoa, e de Religiaõ, e cheio ja de $\mathrm{a}^{\mathrm{s}}$ lhe foraõ faltando as forças, athé q' conheceo-se lhe avizinhava a morte, e preparado com todos os Sacram $^{\text {tos }}$ da $\mathrm{S}^{\text {ta }} \mathrm{M}^{\mathrm{e}}$ Igreja dêo a alma a $\mathrm{D}^{\mathrm{s}}$ aos 24 de Dezembro 1792, sendo D. $\mathrm{Ab}^{\mathrm{e}}{ }^{\mathrm{e}}$ deste Mostr. ${ }^{\circ}$ o M. ${ }^{\text {to }}$ R.P.Pregador Fr. An ${ }^{\text {to }}$ da Conceiçaõ Pina. 
$\left[\mathrm{f}^{\mathrm{p}} 128 \mathrm{r}^{\mathrm{0}}\right]$

260 - Segue-se a vida, e morte do M.R.P.M ${ }^{\mathrm{e}}$.Fr. $\mathrm{An}^{\text {to }}$ Bernardo da Expectaçaõ. Este Monge era natural desta Cid. ${ }^{\mathrm{e}} \mathrm{da} \mathrm{B}^{\mathrm{a}}$, filho e Pais honrados, q' o crearaõ no temor de $\mathrm{D}^{\mathrm{s}}$, e o mandaraõ instruir, nas escollas, Gramatica, e Filozofia, e como viraõ q' elle dezejava ser Religiozo, alcançaraõ-lhe huma Patente, e veio com ella tomar o habito neste Mostro ${ }^{\circ}$, e estando quaze no fim do seu Noviciado, houve huma duvida sobre as suas inquiricões, de genere, de q' se tinha avizado ao Nosso $\mathrm{R}^{\mathrm{mo}} \mathrm{P}$. Geral, o qual o mandou que alcançassem fora da Religiaõ, juntam ${ }^{\mathrm{e}}$ com trez sem compa $=$ nheiros, assim se executou, mas elles pozeraõ logo hum agravo na coroa, e /obtiveraõ/ sentença o seu favor, e com ella embacaraõ $\mathrm{p}^{\mathrm{a}} \mathrm{Lx}^{\mathrm{a}}$, e lá a foraõ aprezentar ao Secretario, ultramarino, q' entaõ era $\mathrm{Se}=$ bastiaõ Jozé de Carvalho, o qual mandou $\mathrm{p}^{\mathrm{r}}$ decreto real ao D.Ab ${ }^{\mathrm{e}}$ de $\mathrm{S}$. Bento da Saude, q' os Professasse, e com efeito professou entaõ o Sobredito Fr. An ${ }^{\text {to }} /$ Bernardo*/, e Fr Joaõ da Macena seu companheiro, e de $\mathrm{p}^{\mathrm{s}}$ de Professos vieraõ $\mathrm{p}^{\mathrm{r}}$ conventuaes deste Mostro ${ }^{\mathrm{o}}$. Dep ${ }^{\mathrm{s}}$ foi $\mathrm{p}^{\mathrm{a}}$ o Mostr ${ }^{\circ}<$ do Rio $>$ do Rio de Janr ${ }^{\circ}$, onde teve os seus Collegios, e no fim d'elles sahio passan te, e feito todos os mais actos custumados foi $\mathrm{p}^{\mathrm{a}} \mathrm{o} \operatorname{Mostr}^{\mathrm{o}}$ de Peranbuco ler Theologia. Depois tornou $\mathrm{p}^{\mathrm{a}}$ este Mostro ${ }^{\mathrm{o}}$; aonde lêo mais athé q' se jubi= lou; e logo começou decostrar nos cargos da Religiaõ; $\mathrm{p}^{\mathrm{r}}$ que foi D.Ab ${ }^{\mathrm{e}}$ do Mostr $^{\circ}$ da Graça, e dep $p^{\mathrm{s}}$ difinidor segundo, e outra vez lhe tornaraõ a el= leger em D.Ab ${ }^{\mathrm{e}}$ do $\mathrm{d}^{\mathrm{o}} \mathrm{Mostr}^{\mathrm{o}}$, em cuja Abadia $<$ padeceo $>$ /padecêo/ algumas afrontas dos Seculares, $\mathrm{p}^{\mathrm{r}}$ defender os bens dos Mostr ${ }^{\mathrm{o}}$; $/$ principalm $^{\mathrm{e}} / \mathrm{de}$ hum q'o acometeo /atrividam / mas elle naõ obstante ter consigo os escravos do Mostr ${ }^{\circ}$ naõ quiz tomar vingança d'elle, antes $\mathrm{p}^{\text {lo }} /$ contrario soffrêo a sua/ injuria com $/ \mathrm{m}^{\text {ta }}$ humild ${ }^{\mathrm{e}} *$ / e de boa vont ${ }^{\mathrm{e}}$, lhe perduôu. Foi este Mon= ge $\mathrm{m}^{\text {to }}$ bom[ $†$ orador em toda sua vida], e adquerio avultadas esmollas de va= rios Sermões, q' pre(gou, com que favo)recia $m^{\text {to }}$ a sua Irmam Religz ${ }^{\mathrm{a}}$. Final= mente sendo prezidente do Mostr ${ }^{\circ}$ da Graça, lhe deraõ humas Sezões 
$\left[\mathrm{f}^{\mathrm{o}} 128 \mathrm{v}^{\mathrm{o}}\right]$

taõ malignas, as $\mathrm{q}^{\mathrm{s}}$ naõ pode vencer $\mathrm{p}^{\mathrm{r}}$ meio de $\mathrm{m}^{\text {tos }}$ remedios, $\mathrm{q}^{\mathrm{T}}$ tomou em ca= za de seus Parentes; e $\mathrm{p}^{\mathrm{r}}$ isso conhecêo-se lhe avizinhava a morte, recolhêo-se a este Mostr. ${ }^{\circ}$ com brevid ${ }^{\mathrm{e}}$ afim de se preparar $\mathrm{p}^{\mathrm{a}}$ ella, e recebidos todos os Sacram $^{\text {tos }}$ da $\mathrm{S}^{\text {ta }} \mathrm{M}^{\mathrm{e}}$ Igreja faleceu em 25 de Maio 1793, sendo D.Ab ${ }^{\mathrm{e}}$ deste Mostro $^{\circ}$ o ${ }^{\text {to }}$ R.P.Pr ${ }^{\text {or }} \mathrm{Fr} \mathrm{An}^{\text {to }}$ da Encarnaçaõ Pina. Segue-se a vida, [个-261-] [个-261-]e morte do R.P.Pregador Fr. Bernardo $\mathrm{An}^{\text {to }}$ de $\mathrm{S}^{\text {ta }}$ Maria dos Anjos Del=

gado. Este Monge era natural do pé de Almeida, donde veio com Patente do N.Rm ${ }^{\circ} \mathrm{P}^{\mathrm{e}}$.Geral, tomar habito neste Mostro ; e nelle foi $\mathrm{No}=$ viço, e corista, etaõ bem teve os seus Coligiaes de Filozofia, e Theologia, efei= to Pregador, foi admenistrar o nosso $\mathrm{Eng}^{\mathrm{o}}$ das Tapaçarócas, onde esteve alguns $\mathrm{a}^{\mathrm{s}}$; $\mathrm{ep}^{\text {los }} \mathrm{m}^{\text {tos }}$ sóes, q' apanhou nas viagens, q' fazia da administraçaõ do Eng ${ }^{0}$ foi-se lhe destemperando o sangue, e disparou em calor de figado, e $\mathrm{p}^{\mathrm{r}}$ fim na molestia chamada morféa, de q' se curou do $\mathrm{m}^{\text {to }}$ passivel, e dep ${ }^{\mathrm{s}}$ de ter algumas milhoras, foi admenistrar a nos $=$ sa fazenda da Ilha $\mathrm{gr}^{\mathrm{de}}$ de Rio de S.Fran ${ }^{\mathrm{co}}$, onde esteve alguns annos, $\mathrm{li}=$ /dando semp*/re com a sua molestia, athé q' $\mathrm{p}^{\mathrm{r}}$ fim; conhecendo-lhe que se lhe avizinhava a morte, recolhêo-se ao Conv ${ }^{\text {to }}$ da Villla de $\mathrm{S} . / \mathrm{Fran}^{\mathrm{co}} \mathrm{do}^{*} /$ Penedo, onde se preparou com todos os Sacram ${ }^{\text {tos }}$ da $\mathrm{S}^{\text {ta }} \mathrm{M}^{\mathrm{e}}$ Igreja, e falecêo em 4 de Abril de 1794, sendo D.Ab ${ }^{\mathrm{e}}$ deste Mostr ${ }^{\mathrm{o}}$ o M.R.P.Pr ${ }^{\text {or }} \mathrm{Fr} . \mathrm{An}^{\text {to }}$ da Encarnaçaõ Pina.-261- (262) Segue-se a vida, e morte do $\mathrm{m}^{\text {to }}$ R.P. $\mathrm{P}^{\mathrm{e}} \cdot \mathrm{Pr}^{\text {or }}$ Urbico Fr.Jozé de S.Bernardo Ro= cha. Este Monge era natural da $\mathrm{Cid}^{\mathrm{e}}$ de Penna fiel, filho de Pais honestos, os (...quais o man)daraõ instruir nas escollas, e na Gramatica, e dep ${ }^{\mathrm{s}}$ lhe alcan= çaraõ huma Patente $\mathrm{p}^{\mathrm{a}}$ ser Religiozo nosso, e com ella veio tomar ohabito a este Mostr ${ }^{\circ}$, e n'elle professou, e teve o seu Coristado, donde foi $\mathrm{p}^{\mathrm{a}} \mathrm{o}$ de Per= /nambuco ter os seus/ Colegios; e no fim d'elles foi feito Pregador Urbico, cujo $\mathrm{im}=$ prego exercitou no $\mathrm{m}^{\mathrm{mo}}$ Mostr. $^{\circ}$ donde o mandraõ p. ${ }^{\mathrm{a}}$ o Rio de Janr ${ }^{\mathrm{o}}$, e passado pouco tempo o mandaraõ $\mathrm{p}^{\mathrm{a}}$ este Mostr. ${ }^{\circ}$ da Bahia, e nelle exercitou a sua 
$\left[\mathrm{f}^{\mathrm{o}} 129 \mathrm{r}^{\mathrm{0}}\right]$

occupaçaõ athé jubilar, de $\mathrm{p}^{\mathrm{s}}$ foi $\mathrm{p}^{\mathrm{a}}{ }^{\mathrm{o}}$ Mostr. ${ }^{\mathrm{o}}$ das Brotas, onde esteve alguns annos $\mathrm{p}^{\mathrm{r}}$ conventual, athé q' foi elleito em D.Ab. ${ }^{\mathrm{e}}$ do Mostr. ${ }^{\circ}$ de N.Senr ${ }^{\mathrm{a}}$ da Graça, e vindo tomar posse do dito Mostro ${ }^{\circ}$ logo lhe deraõ as Sezões, e sem= pre o foraõ perseguindo de $\mathrm{q}^{\mathrm{do}}$, athé $\mathrm{q}^{\text {' }} \mathrm{p}^{\mathrm{r}}$ ultimo o amiaçou hum ramo de Estupor, e logo se recolhêo a este Mostr. ${ }^{o} \mathrm{p}^{\mathrm{a}}$ se preparar $\mathrm{p}^{\mathrm{a}}$ amorte, e tor= nando-lhe a repitir a molestia chamada apoplezia, mal se lhe pô= de admenistrar os Sacram ${ }^{\text {tos }}$ da Extrema Unçaõ, e com elle falecêo, sen= do D.Ab actual a 7 de $\operatorname{Janr}^{\mathrm{o}} 1794$, sendo D.Ab ${ }^{\mathrm{e}}$ deste Mostr $^{\mathrm{o}}$ o M.R. $\mathrm{P}^{\mathrm{e}}$.M ${ }^{\mathrm{e}}$.Fr. Jozé de Jezus Maria Campos.-262- (263) Segue-se a vida, e morte do $m^{\text {to }}$ R.P.Pr ${ }^{\text {or }}$. Fr. Antonio de S.Catharina Neves. Este Monge era natural da $\mathrm{V}^{\mathrm{a}}$ de Paõ do Arcebisado de Bra= ga, filho de Pais honestos, os quais o crearaõ no temor de $\mathrm{D}^{\mathrm{s}}$; e omandaraõ instruir nas escollas, e na lingua latina, e depois lhe al= cançaraõ huma patente $<\mathrm{p}>/$ d $\backslash$ o Nosso $\mathrm{R}^{\mathrm{mo}}$ Geral $\mathrm{p}^{\mathrm{a}}$ ser Religiozo nos= so, e com ella veio tomar ohabito neste Mostro ; e n'elle mesmo teve o seu Coristado, e passados quatro annos entrou no Collegio da $\mathrm{Fi}=$ lozofia, mas como o mestre d'ella arribou, ja dep' de passados oito mezes foi precizo ir com os mais Collegiados p. ${ }^{\mathrm{a}}$ Pernanbuco, onde acabou de ter odito curço, e o de Theologia, e feito Pregador, passados poucos annos, tornou p. ${ }^{a}$ este Mostr $^{\circ}$ da Bahia, onde foi conventual toda sua vida. N'elle foi Mestre de seremonias $\mathrm{m}^{\text {tos }}$ annos, taõ bem foi enhum trienio Prior deste Mostr. ${ }^{\circ}$, e de $\mathrm{p}^{\mathrm{s}}$ entrou logo a servir al= guns cargos da Religiaõ. Foi Procurador geral muitos annos, em resistidos trienios, taõ bem esteve $\mathrm{m}^{\text {tos }}$ annos $\mathrm{p}^{\mathrm{r}}$ admenistrador da Capella, ou hospicio de N. Senhora do Monserrate, onde $\mathrm{p}^{\mathrm{r}}$ fim lhe dêo huma molestia chamada Carnozid ${ }^{\mathrm{e}}$, da $\mathrm{q}^{1}$ seveio curar $-255-$ 
$\left[\mathrm{f}^{\mathrm{0}} 129 \mathrm{v}^{\mathrm{o}}\right]$

em caza de S. Prima D. Catharina, na rua do passo; mas como a mo= lestia foi crescendo, pertendeo vir p..$^{a}$ este Mostr. ${ }^{\circ}$, p. $^{a}$ se aparelhar com os $\mathrm{Sa}=$ $\operatorname{cram}^{\text {tos }}$ p. ${ }^{\mathrm{a}}$ morrer; mas como ja fosse tarde esta rezuluçaõ naõ o concenti= raõ os Professores da Medicina; e $\mathrm{p}^{\mathrm{r}}$ isso foraõ lá trez Monges sacramen= ta-lo no Oratori $<\mathrm{a}>/ \mathrm{o} \backslash$ das mesmas cazas, com licença do Paroco da Matriz, e lhe assistiraõ a sua morte, q' foi em 30 de Julho de 1794 , sendo D. $\mathrm{Ab}^{\mathrm{e}}$ deste Mostro o M.R.P. ${ }^{\mathrm{e}}$. M . Fr.Jozé de Jezus Maria Campos.-26<2>/3〉- $(264)^{188}$ Segue-se a vida e Morte do $\mathrm{M}^{\text {to }}$ R.P.M. $\mathrm{M}^{\mathrm{e}}$. $\mathrm{D}^{\mathrm{or}}$ Fr. Jozé de Santa An= na Coimbra. Este Monge era natural da $\mathrm{Cid}^{\mathrm{e}}$ de Coimbra, filho de Pais honrados, que o crearaõ no temor de Deos, eo mandaraõ enci= gnar nas Escollas costumadas, e o instruir na Gramatica, q' sobe m. ${ }^{\text {to }}$ bem, e tendo ja vercado a universid. ${ }^{\mathrm{e}}$ alguns annos em direito Civil, rezolvêo-se a ser Religiozo nosso, $\mathrm{p}^{\mathrm{a}}$ q' pedio Patente ao nosso $\mathrm{Rm}^{\circ}$ Padre Geral, e com ella veio tomar ohabito aeste Mostro; e n'elle professou, e teve o seu Coristado, e sempre procedêo n'elle com grande exemplo dos seus condiscipulos, exicutado com $\mathrm{m}^{\text {ta }}$ pontualid ${ }^{\mathrm{e}}$; e diligencia, todas as suas obrigaçoẽs. Depois foi p. ${ }^{\mathrm{a}}$ o collegio da Filozofia, e Theologia, os quais teve neste Mostro ${ }^{\mathrm{o}}$, sendo o seu $\mathrm{M}^{\mathrm{e}}$ o M.R.P. $\mathrm{P}^{\mathrm{e}}$. ${ }^{\mathrm{e}}$.o D $\mathrm{D}^{\mathrm{or}}$ Fr. Pasco= al da Resurreiçaõ, q' the lêo já depois de Jubilado, e as revultou tanto, que no fim sahio passante. Depois foi p. $^{\mathrm{a}}$ o Mostr. ${ }^{\circ}$ de Pernanbuco ler Theologia $<\tilde{\mathrm{o}}>$, e taõ bem ta se doutorou, e acabou de jubilar. Tornou $\mathrm{p}^{\mathrm{r}}$ fim p. ${ }^{\mathrm{a}}$ este Mostro ; onde taõ bem lêo moral, e foi Mestre de Cazos. Por ultimo foi ser administrador da nossa fazenda, e olaria de $\mathrm{S}^{\text {to }}$ Antonio das Barreiras, a $\mathrm{q}^{1}$ tornou a reedificar de novo fazendo ca= zas da Vivenda, e levantando a Olaria, e comprando a fabrica ne $=$ cessaria $\mathrm{p}^{\mathrm{a}}$ ella poder ter exercicio no seu ministerio. Finalm ${ }^{\mathrm{e}}$ 
deo-lhe huma febre maligna, com excesso, q'elle no principio dispre $=$

$\left[\mathrm{f}^{\mathrm{p}} 130 \mathrm{r}^{\mathrm{0}}\right]$ zou, e $\mathrm{p}^{\mathrm{r}}$ isso se foi augmentando, de sorte q' quando lhe quiz acudir, já foi tarde; $p^{\text {lo }}$ que conhecendo que lhe era chegada amorte, embarcou= se $\mathrm{p}^{\mathrm{a}}$ a Villa de Nazareh, $\mathrm{p}^{\mathrm{a}}$ ir morrer a caza de hum seu amigo, ja que naõ podia vir p. $^{\mathrm{a}} \mathrm{o}$ Mostro ; e chegando lá, logo lhe adminis= traraõ todos os Sacram ${ }^{\text {tos}}$; e passados alguns dias, faleceu em 31 de Agos= to de 1794 , sendo D.Abbade deste Mostro o M.R.P. . M $^{\mathrm{e}}$. Fr, Joze de Jezus Maria Campos. $-26<3>/ 4 \backslash(265)^{189}$ Segue-se a vida, e morte do $\mathrm{R}^{\mathrm{do}} \mathrm{P}^{\mathrm{e}}$ Pregador Fr. Filipe de Jezus Meirel= les. Este Religiozo era natural do Rio de Janeiro filho de Pais honra= dos, que tinhaõ vindo das Minas assistir na Cidade do Rio de $\mathrm{Ja}=$ neiro, e como tinhaõ muito dezejo, de que este seu filho fosse Reli= giozo nosso solicitaraõ huma patente, e com effeito a admittiraõ, no Noviciado do Rio de Janr ${ }^{\circ}$ sem que elle tivesse $\mathrm{m}^{\text {ta }}$ vocaçaõ de ser Religiozo; mas com tudo sempre professou, e nelle foi corista, e $\mathrm{Co}=$ ligial Filozofo, e Theologo, e tendo feito os actos de Pregador, foi $\mathrm{mu}=$ dado $\mathrm{p}^{\mathrm{a}}$ o Mosteiro de Pernanbuco, digo da Parahiba, onde o man= dou o Prelado assistir na Cap. ${ }^{\text {a }}$ de Santa Anna, e juntam ${ }^{\text {te }}$ administrar a fazenda de Jurema; mas como elle queria dispen= der todo o Rendimento da dita fazenda no seu gasto sem dar na= da ao Mostr. ${ }^{\circ}$ teve sua disavença com o Prelado; $\mathrm{e}^{\mathrm{r}}$ isso fugio $\mathrm{p}^{\mathrm{a}}$ $\mathrm{S} . \mathrm{Fran}^{\mathrm{co}}$; onde esteve alguns tempos, e $\mathrm{p}^{\mathrm{r}}$ mais vezes q' o foraõ rogar, o Prelado, e alguns Monges, pedindo-lhe q' tornasse p. ${ }^{a}$ o Mostr. ${ }^{\circ}$, naõ quiz, e $\mathrm{p}^{\mathrm{r}}$ fim, determinou embarcar-se em huma jangada, e veio ter as Alagôas, onde esteve, quazi hum anno, e de lá veio p. ${ }^{a}$ este Mostro onde foi castigado p. ${ }^{\text {la }}$ fuga, q' fez da Parahiba, e perdoado, vivêo 
alguns annos, quaze sempre molesto da grande Erizipella, q' pa

$\left[\mathrm{f}^{\mathrm{0}} 130 \mathrm{v}^{\mathrm{o}}\right]$ decia, e como para alivio das suas molestias, determinou ir com o D. $\mathrm{Ab} .^{\mathrm{e}}$ do Mostr. ${ }^{\circ}$ da Graça ter huns dias de recreaçaõ na fazenda de Jereguiçá do dito Mostr. ${ }^{\circ}$. La lhe repetio a Erisipella com tal força que lhe cortou aos dias da vida, e conhecendo que lhe era che $=$ gada a sua morte, tractou de se dispor p. $^{\mathrm{a}}$ ella, assistindo=lhe o D.Ab ${ }^{\mathrm{e}}$ seu Companheiro com os Sacram ${ }^{\text {tos }}$, que lhe eraõ pos $=$ siveis naquelle lugar, com os quais falecêo a 17 de Novembro de 1796 seu Corpo foi sepultado na Matriz de Nossa Senr ${ }^{\mathrm{a}}$ da Lapa de Jereguiça, sendo D.Ab. ${ }^{\text {e }}$ deste Mostr. ${ }^{\circ}$ o M.R.P. ${ }^{\mathrm{e}}$. Pregador Fr. Joaõ da Trindade Suares; acabou a sua vida, sendo $\mathrm{Re}=$ ligiozo; $p^{r}$ que supposto tinha alcancado hum Breve do Pontifi= ce $<\mathrm{s}>\mathrm{P} .^{\circ} 6^{190} \mathrm{p}^{\mathrm{a}}$ se disfradar, com tudo naõ chegou a dar-lhe execuçaõ, $\mathrm{p}^{\mathrm{r}}$ naõ ter $\mathrm{q}^{\mathrm{m}}$ lhe fizesse o Patrimonio, a lem de attender q' esta $=$ va impossibilitado $p^{\text {a }}$ poder viver no Seculo $p^{r}$ cauza das suas grandes molestias, que o privaraõ de poder adquerir couza alguma $\mathrm{p}^{\text {las }}$ suas ordens, com que se podesse sustentar inde $=$ pendente da sua Religiaõ. $-26<4>/ 5 \backslash(266)$ Segue-se a vida, e morte do Reverendo $\mathrm{P}^{\mathrm{e}}$ Pregador Fr. Constantino de S.Jozé. Este Religiozo era natural desta Cid. ${ }^{\mathrm{e}}$ da B. ${ }^{\mathrm{a}}$ filho de Pais honrados, que o criaraõ no temor de Deos, e dezejando mette $=$ lo na nossa Religiaõ, solicitaraõ Patente do nosso $\mathrm{Rm}^{\mathrm{mo}}$; e o meteraõ no Noviciado deste Mostro ; onde vivêo com admiraçaõ dos seus Com= panheiros $\mathrm{p}^{\mathrm{r}}$ ser $\mathrm{m}^{\text {to }}$ diligente no Comprimento das suas obrigações, e depois de professo vivêo com $\mathrm{m}^{\text {to }}$ gosto na Religiaõ, $\mathrm{p}^{\mathrm{r}}$ ter taõ bem n'ella o seu Irmaõ Fr. Francisco de S.Antonio,, com quem /fazia*/ 
$\left[\mathrm{f}^{\mathrm{o}} 131 \mathrm{r}^{\mathrm{0}}\right]$

grande armonia. Foi Collegial de Filozofia, e Theologia neste

Mostro ; e feito Pregador viveo Alguns annos n'elle, athé que o mudaraõ

p. $^{\text {a }}$ o Mostr ${ }^{\circ} ;<$ efeito $>$ das Brottas, onde vivêo $\mathrm{m}^{\text {tos }}$ annos juntam ${ }^{\mathrm{e}}$ com o seu Irmaõ. Depois tornou $\mathrm{p}^{\mathrm{a}}$ este Mostr. $^{\mathrm{o}}$, onde estava $\mathrm{q}^{\mathrm{do}}$ impediraõ a posse de certo Abbade, em que elle taõ bem ficou culpado, e $\mathrm{p}^{\mathrm{r}}$ isso foi prezo $\mathrm{p}^{\mathrm{a}}{ }^{\mathrm{a}}$ Portugal $\mathrm{p}^{\mathrm{r}}$ ordem de Elrei juntam ${ }^{\mathrm{e}}$ com os mais, q' todos foraõ remeti= dos a Tibães, onde foraõ castigados $\mathrm{p}^{\text {lo }}$ nosso $\mathrm{Rm}^{\mathrm{o}}$ Padre Geral, o $\mathrm{q}^{1}$ os tor $=$ nou a mandar $\mathrm{p}^{\mathrm{a}}$ este Mostr ${ }^{\mathrm{o}}$; e nelle elle vivêo alguns annos athe q' foi mudado $\mathrm{p}^{\mathrm{a}} \mathrm{o}$ da Parahiba, onde esteve alguns Trienios. Depois tornou $\mathrm{p}^{\mathrm{a}}$ esse Mostr ${ }^{\circ}$; vivendo n'elle alguns annos, ja avançado em idade nat ${ }^{\text {al }}$ perseguiraõ-no humas Çarnas, juntam ${ }^{\mathrm{e}}$ com hum $\mathrm{Ca}=$ tarraõ, que lhe foraõ cortando os dias da vida, e conhecendo q' lhe avizinhava a morte dispôsse com os Sacram. ${ }^{\text {tos }}$ da Igreja, efalecêo em 8 de $7 b^{\circ}{ }^{\circ}$ de 1797 , sendo D.Ab. ${ }^{\text {e deste Mostr. }}{ }^{\circ}$ o M.R.P.Pr ${ }^{\text {or }}$ Fr. Joaõ da Trindade Suares. Foi sepul ${ }^{\text {do }}$ no Claustro, entre seus Irmaõs. $<$ Esta $>$ $-259-$ 
$\left[\mathrm{f}^{\mathrm{o}} 131 \mathrm{v}^{\mathrm{o}}\right]^{191}$

$-260-$

${ }^{191}$ Este fólio não apresenta mancha escrita. 


$$
-26<5>/ 6 \backslash-(267)
$$

$\left[\mathrm{f}^{\mathrm{o}} 132 \mathrm{r}^{\mathrm{o}}\right]$

/Segue-se a vida/ e morte do M.R.P.P. ${ }^{\mathrm{e}}$.Preg ${ }^{\text {or }}$ Fr. /Antonio*/ da Encarnaçaõ Penna; Ex Abb ${ }^{\mathrm{e}}$. Este Religioso era natu ral do Reino da Ribr ${ }^{a}$ de Penna, do Arcebisp ${ }^{\circ}$ de Braga; ve io a este Mostr ${ }^{\mathrm{o}}$ com patente do Nosso $\mathrm{R}^{\mathrm{mo}} \mathrm{P}^{\mathrm{e}} /$ Geral o $\mathrm{D}^{\mathrm{r}} * /$ Fr Sebastiaõ de S.Placido tomar o nosso $\mathrm{S}^{\text {to }}$ habito, e com effeito o tomou e passou o seo noviciado com admiraçaõ dos seos Companheiros, $\mathrm{p}^{\mathrm{r}}$ ser $\mathrm{m}^{\text {to }}$ delig. ${ }^{\mathrm{e}}$ em cumprir com $\mathrm{su}=$ as obrigaçoẽs. Professou, e depois viveo $\langle\dagger\rangle$ neste Mostr. ${ }^{\circ}$ alguns an $=$ nos sendo Corista onde se ordenou de Sacerdote. Depois foi mudado $\mathrm{p}^{\mathrm{a}}$ o Mostr. ${ }^{\mathrm{o}}$ de Pern. ${ }^{\mathrm{co}} \mathrm{p}^{\mathrm{a}}$ o Coll. ${ }^{\circ}$ de Philosophia e The $=$ ologia onde comprio sempre com as obrigações dos estudos defendendo conclusões com explendor. Feito Preg ${ }^{\text {or }}$ foi manda= do administrar algumas fasendas do Mostr. ${ }^{\circ}$ do Rio de $\mathrm{Ja}=$ $\mathrm{nr}^{\mathrm{o}}$ (digo do Mostr ${ }^{\mathrm{O}}$ de Pern. ${ }^{\mathrm{co}}$ )onde esteve alguns annos. Depois tornou a vir $\mathrm{p}^{\mathrm{a}}$ este Mostr $^{\mathrm{o}}$ onde esteve tambem alguns annos. Foi tambem man ${ }^{\text {do }}$ ser Prezid ${ }^{\mathrm{e}}$ do Mostr ${ }^{\mathrm{o}}$ das Brotas onde esteve oito meses e nesse tempo fes bast ${ }^{\mathrm{e}}$ beneficio ao do $\mathrm{d}^{\mathrm{o}} \mathrm{Mostr}^{\mathrm{o}}$. Depois tornou $\mathrm{p}^{\mathrm{a}} \mathrm{o} \mathrm{Mostr}^{\mathrm{o}}$ de Per= $/$ nanbuco*/ onde foi Prior e Procurador e no seg ${ }^{\mathrm{e}}$ trienio foi mandado administrar o Engenho de $\mathrm{Ma} / \mathrm{nsu}<\mathrm{p}>/ \mathrm{r} \mid$ pe $^{*} /$ onde es= /teve alguns trienios. De*/pois foi $\mathrm{p}^{\mathrm{a}}$ o Mostr ${ }^{\mathrm{o}}$ do Rio de Janr ${ }^{\mathrm{o}}$ /onde esteve alguns $\mathrm{an}^{\mathrm{s} *} /$ feito fazendeiro em cujo tempo o $\mathrm{Ca}=$ pitulo Geral o elegeo em Procurador Geral da Prov ${ }^{\mathrm{a}}$ deste Mos= $-261-$ 
teiro $\mathrm{p}^{\mathrm{a}}$ onde veio exercer o seo cargo, e no fim delle veio $\mathrm{p}^{\mathrm{r}} \mathrm{D}$.

$\left[\mathrm{f}^{\mathrm{o}} 132 \mathrm{v}^{\mathrm{0}}\right]$ $\mathrm{Abb}^{\mathrm{e}} \mathrm{d}^{\mathrm{e}}$ 'este Mosteiro ao qual administrou com grande cuid ${ }^{\mathrm{O}}$ e aumento delle; $\mathrm{p}^{\mathrm{r}} \mathrm{q}$ ' feitas as contas das despesas do seo tri= enio e Pre $<\mathrm{z}>/ \mathrm{s} \backslash$ idencia, inda lhe sobejaraõ trinta mil crusados com que pagou a grande devida q' o Mostr ${ }^{\circ}$ devia à Capella mór, e em outras partes; alem dos escravos q' comprou e dos $\mathrm{m}^{\text {tos }}$ mil cruzados q' entregou ao seo successor. Depois veio eleito em Difinidor primeiro, e descançando hum trienio, nesse tempo principiou huma molestia interna de ourinas, de o perseguir com excesso de sorte q' estando molesto della lhe sobreveio hum accidente apopletico q' o privou da falla; /mas sacramentou-se*/ do modo possivel, e faleceo aos 5 de Agosto de 1798. Sendo D.Abb ${ }^{\mathrm{e}}$ deste Mostro o M.R.P. Preg $^{\text {or }}$ Fr. Joaõ da Trin ${ }^{\text {de }}$ Soares. Depois de ter falecido, veio outra ves eleito em D.Abb ${ }^{\mathrm{e}}$ deste Mostro na elleiçaõ futura foi sepultado no Claustro. $-26<6>/ 7 \backslash$ - (268)

Segue-se a vida e morte do Irmaõ Corista Fr. Antonio da Victoria. Este irmaõ era natural do Reino da $V^{\mathrm{a}}(\ldots)$ saõ-frio f. ${ }^{\circ}$ de uma Viuva honrada, q' o criou no /temor*/ de Deos, e mais a outros f. ${ }^{\text {os }}$ q' tinha e dezejando q' este seo f. ${ }^{\circ}$ fosse Religioso nosso pedio huma patente do nosso $\mathrm{Rm}^{\mathrm{o}}$ $\mathrm{P}^{\mathrm{e}}$ Geral e mandou-o com ella tomar o nosso $\mathrm{S}^{\text {to }}$ habito neste Mostro ${ }^{\circ}$, e com effeito tomou com algum receio 
$p^{r} q^{\prime}$ naõ se agradou da terra quando se embarcou, $m^{s}$ proseguio o seo noviciado com muito gosto e vocaçaõ athe q' lhe chegou a profissaõ, e depois veveo no Coristado $\mathrm{m}^{\text {to }} \mathrm{sa}=$ tisfeito de ser Religioso, applicando-se ao cantoxaõ com $\mathrm{m}^{\text {to }}$ gosto $\mathrm{p}^{\mathrm{r}}$ ter vós cheia, e estudando $\mathrm{m}^{\text {to }}$ de noite $\mathrm{p}^{\mathrm{r}}$ cuja cau $=$ sa veio a lançar sangue pela boca p. $^{\mathrm{r}}$ varias veses, de que se curou com alguns remedios q' lhe applicaraõ os Pro fessores de Medicina, e vevia com resguardo de tudo q' lhe pudesse provocar a tal molestia. Mas querendo ordem= nar-se de Sacerdote foi-lhe preciso ir ao Rio de Janr. ${ }^{\circ}$ receber as ordens $\mathrm{p}^{\mathrm{r}}$ impedim ${ }^{\text {to }}$ de certas molestias q' padeci= a o Nosso Arcebispo, e chegando lá com bom succeso principiou a ordemnar-se, e tendo tomado ordens de $\mathrm{Di}=$ ácono, repetio-lhe o $\mathrm{d}^{\mathrm{a}}$ molestia com tal excesso q' conhe= ceo-se lhe avesinhava a morte, e logo tratou em se despor $\mathrm{p}^{\mathrm{a}}$ morrer, e recebendo os Sacram ${ }^{\text {tos }}$ da Igreja com muita contriçaõ, faleceo no d ${ }^{\circ} \operatorname{Mostr}^{\circ}$ do Rio de Janr. ${ }^{\circ}$ a 9 de Outubro de 1798. Sendo D. $\mathrm{Abb}^{\mathrm{e}}$ deste Mostr ${ }^{\mathrm{o}}$ o M.R.P. $\mathrm{P}^{\mathrm{e}}$.Preg ${ }^{\text {or }}$ Fr. Joaõ da Trindade Soares. Foi excessiva a caride ${ }^{\text {' }}$ ' ex= /perimentou naõ só*/ do Prelado, mas tambem de todos

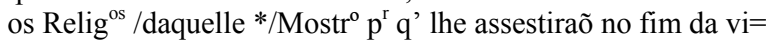
da com tudo o q' /hera necessa/rio, e nas suas exequias 
lhe feseraõ muitas honras; $\mathrm{p}^{\mathrm{r}} \mathrm{q}$ ' o sepultaraõ com hum officio, e Missas solemnes do Corpo presente, Celebrando todos Missa ${ }^{r}$ sua alma, e p. ${ }^{r}$ fim mandou o Prelado fazer-lhe o Trintario das missas de S.Gregorio q' se costu= ma na ordem: tudo de graça. $-26<7>/ 8 \backslash$ - (269) Segue-se a vida e morte do M.R.P. Preg $^{\text {or }} \mathrm{Ex} \mathrm{Abb}^{\mathrm{e}}$ Fr. Salvador de $\mathrm{S}^{\text {ta }}$ Ignes. Este Religioso era natural desta Cedade da B. ${ }^{\text {a }}$ f. ${ }^{o}$ de Paes honrados q' o crearam no temor de Deos, e como desejavaõ q' este seo f. ${ }^{\circ}$ fosse Religi= so lhe alcançaraõ huma patente e $\mathrm{p}^{\mathrm{r}}$ vertude della o me= teraõ no noviciado deste Mostr. ${ }^{\circ}$, no qual deo $\mathrm{m}^{\text {tas }}$ provas de sua grande vocaçaõ $\mathrm{p}^{\mathrm{r}}$ ser $\mathrm{m}^{\text {to }}$ deligente em todas as suas obrigaçoẽs; athe q' chegou a professar com $\mathrm{m}^{\text {to }}$ gosto de ser Religioso com o mesmo conti= nuou todo o tempo do seo Coristado; applicando-se ao cantoxaõ e ao estudo de Moral com m. $^{\text {to }}$ cuidado, e deligen= cia, e tendo os annos de id ${ }^{\mathrm{e}}$ natural, e de Religiaõ ordemnou= -se de Sacerdote. Depois de ter bat. ${ }^{\text {es }}$ annos de habito entrou no Coll $^{\circ}$ de Philosophia, e Theologia neste Mostr. ${ }^{\circ}$ onde cum= pria bem com a sua obrigaçaõ dos estudos; e feito Preg ${ }^{\text {or }}$ veveo $\mathrm{m}^{\text {tos }}$ an $^{\mathrm{s}}$ neste Mostr. ${ }^{\circ}$ Depois mandou-o o Prela $=$ do governar a fasenda da Itapoán; mas como o $\mathrm{P}^{\mathrm{e}}$ fa= 
fasendeiro q' estava nella se levantou com elle, naõ querendo entregar-/lha*/, tornou $\mathrm{p}^{\mathrm{a}}$ o Mostr ${ }^{0}$ até se compor a tal desor= $\mathrm{dem}$; e depois de composto tornou a ir governar o $\mathrm{d}^{\mathrm{a}}$ fazenda; mas como apanhou sesões tornou a vir $\mathrm{p}^{\mathrm{a}}$ o Mostr ${ }^{\circ}$ curar-se dellas. Depois ${ }^{192}$ foi governar as fazendas do Rio de S.Francisco onde es teve bat. ${ }^{\mathrm{es}}$ annos, e sahindo de lá tornou $\mathrm{p}^{\mathrm{a}}$ este Mostro e da= qui foi mudado $\mathrm{p}^{\mathrm{a}} \mathrm{o}$ da Graça, $<$ osde $>\left[\downarrow_{\text {onde }}\right]$ esteve bast. ${ }^{\mathrm{es}}$ annos athe q' veio eleito em D.Abb. ${ }^{\mathrm{e}}$ do $\mathrm{d}^{\mathrm{o}}$ Mostr. $^{\mathrm{o}}$ Acabado o seo trienio foi $\mathrm{p}^{\mathrm{a}}$ a fazenda de Jicrijjá onde esteve $\mathrm{m}^{\text {tos }}$ annos. Depois tor= nou a vir eleito em D.Abb ${ }^{\mathrm{e}}$ do $\mathrm{d}^{\mathrm{o}} \mathrm{Mostr}^{\mathrm{o}}$ e acabado o seu tri enio, veio eleito em Procurador Geral da Congreg. ${ }^{\mathrm{m}}$ nesta Prov. ${ }^{\mathrm{a}}$ Cujo cargo veio exercer neste Mostr. ${ }^{\circ}$, mas como padecia huma molestia enterna de Hedropesia, foi-se esta au= mentando até que em huma tarde sem ser esperada ca= hio de repente morto. Faleceo a 6 de Março de 1799. Sen=

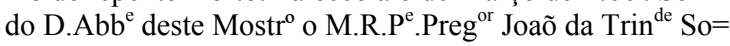
ares. Foi sepultado no claustro entre seos irmaõs.- $26<8>/ 9 \backslash-(270)$ Segue-se a vida e morte do M.R.P. Preg $^{\text {or }}$ e Ex $\mathrm{Abb}^{\mathrm{e}} \mathrm{Fr}$. Vecente da Trin ${ }^{\text {de }}$ Ferreira. Era Religioso natural desta $\mathrm{Cid}^{\mathrm{e}}$ da B. ${ }^{\mathrm{a}}{ }^{\mathrm{o}}{ }^{\mathrm{o}}$ de Pais honrados q' o crearaõ no temor de D. ${ }^{\mathrm{s}}$ /e the mandaraõ ensinar as $\operatorname{Prim}^{\text {as }} *$ Letras e tambem a Gram= /matica */Latina, /q' soube sufficientem ${ }^{\mathrm{e}} *$ /, /e como viaõ */q'elle ti= $-265-$

192 "foi governar as fasendas do Rio S. Francisco". Esta frase encontra-se escrita com grafia diferente, porém, não identificada. 
tinha vocaçaõ $\mathrm{p}^{\mathrm{a}}<\mathrm{t}>/$ sler Religioso nosso, /alcançaraõ $* /$-lhe $\mathrm{pa}=$

$\left[\mathrm{f}^{\mathrm{0}} 134 \mathrm{v}^{\mathrm{o}}\right]$ tente do $\mathrm{R}^{\mathrm{mo}}$ e com ella veio tomar o $\mathrm{S}^{\text {to }} /$ habito ne*/ste Mos= $\mathrm{tr}^{\mathrm{o}}$ e nelle teve o seo noviciado com $\mathrm{m}^{\text {ta }}$ edificaçaõ de todos no cumprim $^{\text {to }}$ de todas as suas obrigaçoẽs pela $\mathrm{g}^{\text {de }}$ agelidade de que era doutado. Chegado o fim fez profíssaõ $\mathrm{m}^{\text {to }}$ contente de seo estado, e com $\mathrm{m}^{\text {to }}$ gosto de seos Pais; ermaõ Relig ${ }^{\mathrm{e}} \mathrm{e}$ Parentes q' lhe assistiraõ. Depois viveo $\mathrm{m}^{\text {to }}$ tempo no $\mathrm{Co}=$ ristado deste Mostr. ${ }^{\circ}$ athé q.' foi mudado $\mathrm{p}^{\mathrm{a}} \mathrm{Pern}^{\mathrm{co}}$ onde te $=$ ve o seo Coll ${ }^{\circ}$ de Felosophia e Theologia e tendo feito os a= ctos de Preg $^{\text {or }}$, tornou p. ${ }^{\text {a }}$ este Mostr. ${ }^{\circ}$ onde o mandaraõ $p .^{r}$ fasendr ${ }^{\circ}$ da Itapoán onde esteve alguns annos. Depois o feseraõ Subprior deste Mostr ${ }^{\circ}$ e no fim do trienio foi $m u=$ dado $\mathrm{p}^{\mathrm{a}} \mathrm{o}$ das Brotas onde o fizeraõ Prior; no fim do trienio foi mudado $\mathrm{p}^{\mathrm{a}} \mathrm{Pern}^{\mathrm{co}}$ onde tambem o fiseraõ Prior e de lá veio eleito em D. $\mathrm{Abb}^{\mathrm{e}}$ das Brottas, cujo cargo exerceo com muita satisfaçaõ. No fim do trienio veio eleito $\mathrm{p}^{\mathrm{r}} \mathrm{Comp}^{\text {ro }}$ e Secretario do N.R ${ }^{\mathrm{mo}} \mathrm{P}^{\mathrm{e}}$ Provincial, q' tambem exerceo. Ul= timamente veio eleito em D.Abb ${ }^{\mathrm{e}}$ do Most. ${ }^{\text {ro }}$ da Parahiba, $\mathrm{cu}=$ jo cargo recusou, e foi logo administrar o Engenho de S.Ben= to da Lage; onde padeceo a molestia de ourinas doces de que se curou $\mathrm{p}^{\mathrm{r}}$ varias veses, sem nunca puder extinguir, eassim foi vivendo alguns annos, até que foi accome $=$ 
accometido de huma etiricia, e vendo q' se lhe appro/xim/a va a morte recolheo-se ao Mostr ${ }^{\circ}$ onde desenganado dos $\mathrm{Me}=$ dicos tratou de se Sacramentar, despondo-se $\mathrm{p}^{\mathrm{a}}$ morrer, e fale= ceo a 9 de Fevr ${ }^{\circ}$ de 1800 . Sendo Prezi ${ }^{\text {de }}$ deste Mostr. ${ }^{\circ}$ o M.R. $P^{\mathrm{e}}$. Preg ${ }^{\text {or }}$ Fr Joaõ da Trin ${ }^{\text {de }}$ Soares. $-2<6>/ 7 \backslash<9>/ 0 \backslash-(\underline{271})$

Segue-se a vida e morte do M.R.P. Preg $^{\mathrm{or}}$ Geral Jub ${ }^{\mathrm{o}}$ Fr. Felip= pe da Natividade, natural da $\mathrm{Cid}^{\mathrm{e}}$ do Porto, onde estudou a Grammatica Latina, e depois q' a soube pedio huma pa= tente do $\mathrm{R}^{\mathrm{mo}} \mathrm{P}^{\mathrm{e}}$ Geral $\mathrm{p}^{\mathrm{a}}$ vir ser Religioso nesta Prov ${ }^{\mathrm{a}}$ do Brasil, e neste Mosteiro vindo com ella nelle entrou no= seo noviciado, o qual proseguio com $\mathrm{m}^{\text {ta }}$ edificaçaõ dos seos comdiscipulos; e no fim delle fez a sua profissaõ, e /depois*/ viveo alguns annos no Coristado deste Mostr. ${ }^{\circ}$ até q' o mudaraõ $\mathrm{p}^{\mathrm{a}}$ o Mostr. ${ }^{\circ}$ do Rio de Janr. ${ }^{\circ}$ onde teve o seo Coll ${ }^{\circ}$ de Philosophia e Theologia, e feitos os actos de Preg ${ }^{\text {or }}$ tornou $\mathrm{p}^{\mathrm{a}}$ este Mostr. onde alcançou a patente de Preg ${ }^{\text {or }}$ Urbico, cujo exercicio teve neste Mostr $^{\mathrm{o}}$ juntam $^{\mathrm{e}}$ com o cargo de Subprior e $\mathrm{M}^{\mathrm{e}}$ de Irmaõs, em alguns trienios. Depois foi mudado $\mathrm{p}^{\mathrm{a}} \mathrm{o}$ Mos= $\operatorname{tr}^{\mathrm{o}}$ de Pern ${ }^{\mathrm{co}}$ onde foi Prior e Procurador do Mostro ; e de lá tor $=$ nou $\mathrm{p}^{\mathrm{a}}$ este $\mathrm{Mostr}^{\mathrm{o}}$ feito Definidor, e no fim do trienio ve $=$ io eleito $/ \mathrm{em}^{*} / \mathrm{D} \cdot \mathrm{Abb}^{\mathrm{e}}$ deste Mostro ${ }^{\mathrm{o}}$, cuja posse repudearaõ al= guns Monges deste Mostr $^{\circ}$, logo elle tomou posse delle e go= -267 - 
governou ate o fim do trienio, tanto que os Monges /foraõ meti*/=

$\left[\mathrm{f}^{\mathrm{0}} 135 \mathrm{v}^{\mathrm{o}}\right]$ dos no cárcere deste Mostro ${ }^{\mathrm{o}}$, foraõ prezos $\mathrm{p}^{\mathrm{a}}$ Lis/boa $\mathrm{p}^{\mathrm{r}}$ Decreto*/ de ElRei, e de lá foraõ $\mathrm{p}^{\mathrm{a}}$ Tibães onde foraõ castigados. Ultima= $\mathrm{m}^{\text {te }}$ foi eleito em Defenidor $1^{\circ}$ cujo cargo exerceo neste Mostr. ${ }^{\circ}$ Depois foi ser fasendeiro da nossa fasenda da Ilha grande / $\underline{\text { da }}$ $\mathrm{V}^{\mathrm{a}}$ de S.Fran ${ }^{\mathrm{co}}$ (digo) do Rio de S.Fran ${ }^{\mathrm{co}}$ onde esteve alguns annos. Depois tornou pa este Most $^{\text {ro }}$ e ultemam o man= daraõ administrar o engenho de S.Bento da Lage, onde tambem esteve bast ${ }^{\mathrm{es}}$ annos: e representando aos Prelados q' ja naõ podia com aquella vida $\mathrm{p}^{\mathrm{r}}$ estar adiantado em id $^{\mathrm{e}}$; consederaõ-lhe q' viesse $\mathrm{p}^{\mathrm{a}} \mathrm{o}$ Mostro ${ }^{\mathrm{o}}$ onde viveo algũs annos; ate que já falto de forças $\mathrm{p}^{\mathrm{r}}$ ja ter oitenta e tres $a^{\mathrm{s}}$ de id $\mathrm{i}^{\mathrm{e}}$ tratou em se preparar cõ os Sacram ${ }^{\text {tos }}$ da $\mathrm{S}^{\text {ta }} \mathrm{Ma}$ dre Igreja, e faleceo em o $1^{\circ}$ de Outubro de 1800 . Sendo D. Abb. ${ }^{\mathrm{e}}$ deste Most ${ }^{\mathrm{ro}}$ o M.R.P. ${ }^{\mathrm{e}}$ Ex Prov ${ }^{\mathrm{al}}$ Fr. Antonio de S. José Valença. $-27<0>/ 1 \backslash$ - (272)

Segue-se a vida e morte do $\mathrm{R}^{\text {do }} \mathrm{P}^{\mathrm{e}}$ Fr. Bento de $\mathrm{S}^{\text {ta }}$ Bárba= ra. Este Religioso era do Reino, natural da $\mathrm{V}^{\mathrm{a}}$ de Munçaõ, f. ${ }^{\circ}$ de Pais honrados, q' o crearaõ no temor de Deos, e depois de oporem na escolla, onde apprehendeo Prim ${ }^{\text {as }}$ letras, o manda $=$ raõ ensinar tambem a lingua Latina; e vendo q' elle ti= nha vocaçaõ $\mathrm{p}^{\mathrm{a}}$ ser Religioso, alcançaraõ huma patente 
do $/ \mathrm{R}^{\mathrm{mo}} \mathrm{P}^{\mathrm{e}} \mathrm{Geral} /$, e com ella o mandaraõ ser religioso nesta Pro

$\left[\mathrm{f}^{\mathrm{0}} 136 \mathrm{r}^{\circ}\right]$ $v^{\mathrm{a}}$ do Brasil; e chegando a este Mostr ${ }^{\mathrm{o}}$ juntam $^{\mathrm{e}}$ com Fr $\mathrm{Ant}^{\mathrm{o}}$ da Victoria entraraõ ambos no noviciado, onde bem deo provas da sua vocaçaõ; cumprindo promptam ${ }^{\mathrm{e}}$ com suas obrigações, pois era $\mathrm{m}^{\text {to }}$ agil no comprim ${ }^{\text {to }}$ dellas todas. Chegando ao fim do noviciado fês a profissaõ solemne com $\mathrm{m}^{\text {to }}$ gosto seu e conten= tam $^{\text {to }}$ dos Religosos todos. Depois foi $\mathrm{p}^{\mathrm{a}}$ o Coristado onde viveo com $\mathrm{m}^{\text {ta }}$ edificaçaõ dos seos condiscipulos, $\mathrm{p}^{\mathrm{r}} \mathrm{q}$ ' se applicava ao estudo das Cerimonias da ordem, e sempre estava lendo va= rios livros de humanid ${ }^{\mathrm{es}}$ e historias. Foi $\mathrm{p}^{\mathrm{r}}$ varias veses dis= penceiro, e Mestre de obras, assistindo aos officiaes, q' concerta= vaõ as casas da Relegiaõ com $\mathrm{m}^{\text {to }}$ zelo ecuidado, obrigando aos $\mathrm{d}^{\text {os }}, \mathrm{o}^{\text {to }}$ mais aos escravos q' andassem ligeiros no cumprim ${ }^{\text {to }}$ de suas obrigações, ao q' nenhum faltava, sabendo q' elle era $\mathrm{m}^{\text {to }}$ rigoroso nos seos castigos, e $\mathrm{p}^{\mathrm{r}}$ isso todos o temiaõ $\mathrm{m}^{\text {to }}$. Tam= bem foi algum tempo administrador da fazenda da Itapoan, onde concertou as casas de vivenda $\mathrm{m}^{\text {to }}$ bem. Vindo ao Mostr começou a adoecer de humas dores de cabeça motivadas de hu= mas dores de estomago excessivas, as $\mathrm{q}^{\mathrm{s}}$ foraõ crescendo cada ves mais, de sorte que em sete dias lhe tiraraõ a vida /dentro*/ em sete dias; tendo recebido os Sacram ${ }^{\text {tos }}$ da Igreja, menos da Eucaristia $p^{r}$ causa dos $m^{\text {tos }}$ vômitos q' tinha 
e com $\mathrm{m}^{\text {tos }}$ signaes de contriçaõ faleceo a 23 de Novem= bro de 1800 Sendo D.Abb..$^{\mathrm{e}}$ deste Mostr. ${ }^{\circ}$ o M.R.P. ${ }^{\mathrm{e}}$. Ex Prov ${ }^{\mathrm{al}}$ Fr. An ${ }^{\text {to }}$ de S. José Valença.-27<1>/2〉- $\left(\underline{273)^{193}}\right.$

Segue-se a vida e morte do M.R.P $P^{\mathrm{e}}$.Preg ${ }^{\text {or }}$ e Ex $\mathrm{Abb}^{\mathrm{e}} \mathrm{Fr}$. Ben= to da Con. ${ }^{\text {cam }}$ Araujo. Este Religoso era do Reino natural da freguesia de Campanha, visinha da $\mathrm{Cid}^{\mathrm{e}}$ do Porto; era f. ${ }^{\circ}$ de Paes honrados, q' o crearaõ no temor de Deos, e o puseraõ no es tudo com tençaõ q'elle se ordemnasse de Clerigo, mas como morreraõ no tempo em q' elle era estudante; acabando de ap= prender os estudos determinou ser Religioso; pelo q' pedio huma patente ao $\mathrm{R}^{\mathrm{mo}}{ }^{\mathrm{P}}{ }^{\mathrm{e}}$.Geral $\mathrm{p}^{\mathrm{a}}$ vir ser Religioso nesta Prov. ${ }^{a}$ do Brasil, o q $\mathrm{q}^{1}$ logo lhe concedeo, e com ella ve= io ter o sio noviciado neste Mostr. ${ }^{\circ}$, no qual entrou com $\mathrm{m}^{\text {to }}$ gosto, e no decurso delle bem mostrou, q' a sua voça $=$ çaõ era verdadr. ${ }^{a} p^{r} q^{\prime}$ cuidava $m^{\text {to }}$ em cumprir com as obri $=$ gações de Verdadr ${ }^{\circ}$ Religioso. Acabado o noviciado fez profis $=$ saõ solemne, depois foi $\mathrm{p}^{\mathrm{a}}$ o coristado, onde viveo bast ${ }^{\mathrm{es}}$ an $=$ nos com edificaçaõ dos seos Condiscipolos. Logo cuidou em se ordemnar de Sacerdote, e depois foi mandado $\mathrm{p}^{\mathrm{a}}$ a fazen= da da Itapoan onde viveo algus̃ an ${ }^{\text {s; }}$ mas como lhe deraõ cesões veio $\mathrm{p}^{\mathrm{a}} \mathrm{o} \operatorname{Mostr}^{\mathrm{o}}$ curar-se dellas, ainda q' sempre lhe ficou obstruçaõ de q' foi acabar de curar-se em Pern ${ }^{\text {co }}$. Depois $-270-$

${ }^{193}$ APFL 
foi $\mathrm{p}^{\mathrm{a}}$ o Mostro de Olinda $\mathrm{p}^{\mathrm{a}}$ lá entrar no Collo de Filosophi

$\left[\mathrm{f}^{\mathrm{o}} 137 \mathrm{r}^{\mathrm{0}}\right]$ a e Theologia, e feitos os actos de Preg ${ }^{\text {or }}$ o elegeraõ Subprior do mesmo Mostr. ${ }^{\circ}$ Depois foi $\operatorname{mud}^{\mathrm{o}} \mathrm{p}^{\mathrm{a}}$ o Mostro da Parahiba, donde o mandaraõ governar o engenho de Marahú, esa $=$ hindo delle ofiseraõ Prior de $\mathrm{m}^{\mathrm{mo}} \mathrm{Mostr}^{\mathrm{o}}$, Depois veio elei= to em $\operatorname{Proc}^{\text {or }}$ geral da Prov ${ }^{\mathrm{a}}$ neste Mostro ${ }^{\circ}$, e no fim do trie $=$ nio o elegeraõ em D.Abb ${ }^{\mathrm{e}}$ do $\mathrm{Mostr}^{\mathrm{o}}$ da Parahiba. Depois veio eleito em $\mathrm{M}^{\mathrm{e}}$ de Novissos neste $\mathrm{Mostr}^{\mathrm{o}}$ e no fim do trienio veio eleito em Secretario e $\operatorname{Comp}^{o}$ do N.R.P.Prov ${ }^{\mathrm{al}}$ Depois o elegeraõ em D.Abb ${ }^{\mathrm{e}}$ do Mostro de N.Snr ${ }^{\mathrm{a}}$ das Bro= tas, cujo cargo $<$ ri $>$ renunciou. Logo começou a o per= seguir hum gde defluxo q' desparou-lhe em Reumatis mo, de $\mathrm{q}^{1}$ nunca sepoude curar, e assim foi vivendo athé cahir em huma tisica; e conhecendo q' se lhe abre= viaraõ os dias de vida, tratou em se dispor com os Sacra $\mathrm{m}^{\text {tos }}$ da Igreja, confesando-se depois sempre o miudo com $\mathrm{m}^{\text {ta }}$ contriçaõ, faleceo a 31 de Março de $180<0>1$. Sendo D. $\mathrm{Abb}^{\mathrm{e}}$ deste Mostr ${ }^{\mathrm{o}}$ o M.R. ${ }^{\mathrm{mo}}{ }^{\mathrm{P}}{ }^{\mathrm{e}}{ }^{\mathrm{E}}$ Ex Provincial Fr.An ${ }^{\text {to }}$ de S. José Valença. $-27<2>/ 3 \backslash(\underline{274)}$ Segue-se a vida e morte do M.R.P ${ }^{\mathrm{e}}$ Preg $^{\text {or }}$ e Ex Prov $^{\text {al }}$ Fr. Marcelenio de $\mathrm{S}^{\text {ta }}$ Anna. Este Religioso era natural desta $\mathrm{Cid}^{\mathrm{e}}$ da $\mathrm{B}^{\mathrm{a}}$, f. ${ }^{\mathrm{o}}$ de Pais honrados, q' o crearaõ no te= $-271-$ 
temor de Deos, e metendo logo nas escollas; depois lhe man

$\left[\mathrm{f}^{\mathrm{0}} 137 \mathrm{v}^{\mathrm{o}}\right]$ daraõ ensinar a Lingua Latina, e vendo q' elle tinha voca çaõ $\mathrm{p}^{\mathrm{a}}$ ser Religioso; lhe alcançaraõ huma patente do Re verendissimo, e com ella veio tomar o habito de Novisso neste Mostr. ${ }^{\circ}$, em cujo Noviciado bem deu mostras da sua $\operatorname{grd}^{\mathrm{e}}$ vocaçaõ pela $\operatorname{grd}^{\mathrm{e}}<$ vocação $>$ promptidaõ e deligencia, com $\mathrm{q}^{1}$ cumpria todas as suas obrigações. $\mathrm{No}$ fim do $\mathrm{No}=$ viciado professou com grd $^{\text {e }}$ contentam ${ }^{\text {to }}$ de todos; e da m. ${ }^{\text {ma }}$ sorte viveu alguns annos no Coristado deste Mostr. ${ }^{\circ}$ depois foi mudado p. ${ }^{\mathrm{a}}$ o Mosteiro do Rio de Janr ${ }^{\mathrm{o}}$; onde teve e seu Collegio de Philosofia, e Theologia, e depois de fazer os seos actos de Preg ${ }^{\text {or }}$ tornou $\mathrm{p}^{\mathrm{a}}$ este Mostro onde viveo alguns annos em comp ${ }^{a}$ dos Religiosos, q' todos o veneravaõ $m^{\text {to }}$ $\mathrm{p}^{\mathrm{r}}$ ser de bons costumes, e amavel, q' naõ murmurava[ $\uparrow$ murmurava] de ninguem, e sempre estava prompto $\mathrm{p}^{\mathrm{a}}$ confessar a to $=$ dos q' lhe pediaõ. Depois de passados alguns annos foi mand $^{\mathrm{e}}$ pelo $\mathrm{P} / \mathrm{r} / \mathrm{el}^{\mathrm{o}}$ administrar a fasenda do Rio de S.

Francisco, mas como logo lhe deraõ cesões lá esteve pouco tem= po, e tornou logo $\mathrm{p}^{\mathrm{a}}$ este Mostr ${ }^{\mathrm{o}}$ curar-se dellas, e aqui ficou em Cõpanhia dos mais Religosos. Este Religioso foi tambem dos q' recusaraõ a posse de D.Abb a Fr. Felipe da Nativid $^{e}$ e $p^{r}$ esse crime foi preso com os mais $p^{r}$ decreto 
de El Rei, e foi com os mais p $\mathrm{p}^{\mathrm{a}}$ Lisboa, e de lá $\mathrm{p}^{\mathrm{a}}$ o Mostro de

Tibães, onde foraõ todos castigados ao arbit $<$ rario $>[\uparrow$ rio $]$ de N.R ${ }^{\mathrm{mo}}$ $\mathrm{P}^{\mathrm{e}}$.Geral, e depois tornaraõ $\mathrm{p}^{\mathrm{a}}$ esta Prov ${ }^{\mathrm{a}}$; mas este Religioso foi mais favorecido $\mathrm{p}^{\mathrm{r}}$ ter lá huma Tia q' (digo huma Prima Religiosa) q' pedio $\mathrm{p}^{\mathrm{r}}$ elle ao N.R ${ }^{\text {mo }} \mathrm{P}^{\mathrm{e}}$. Geral, e $\mathrm{p}^{\mathrm{r}}$ isso no Cap ${ }^{\circ}$ futuro do Brasil o fes D.Abb ${ }^{\mathrm{e}}$ do Mostro de N.S das Brottas, e no fim veio ser conventual deste deste Mostr ${ }^{\circ}$ onde viveo alguns annos, i contando já $83 \mathrm{de} \mathrm{id}^{\mathrm{e}}$ natural, foraõ-lhe crescendo de tal sorte as molestias q' conheceo se lhe avisinhar a morte, e cuidou em se dispor com os Sacra= $\mathrm{m}^{\text {tos }}$ da $\mathrm{S}^{\text {ta }}$ Madre Igreja, q' recebeo com $\mathrm{m}^{\text {ta }}$ Contriçaõ, $\mathrm{pe}=$ dio sempre a $\mathrm{D}^{\mathrm{s}} \mathrm{q}$ ' the perdoasse os seos pecados e q' levasse a sua alma $\mathrm{p}^{\mathrm{a}}$ a sua eterna Bemaventurança $\mathrm{p}^{\mathrm{a}}$ cujo fim atinha criado, i faleceo a 14 de Julho de 1802. Sendo D.Abb ${ }^{\mathrm{e}}$ deste Mostro o N.M.R ${ }^{\mathrm{mo}} \mathrm{P}^{\mathrm{e}}$. Ex Prov ${ }^{\mathrm{al}}$ Fr.Antonio de S.José Valença.-27<3>/4 $\mid(\underline{275})^{19}$ Segue-se a vida e morte do M.R.P. ${ }^{\mathrm{e}}$.Preg ${ }^{\text {or }}$ Fr. José de S.Bento Leal. Este Religioso foi nat ${ }^{\text {al }}$ da Freguesia de S.Miguel do Souto Bispo ${ }^{\circ}$ do Porto. Se ordinariam a boa educaçaõ se manifesta nas acç̧o $=$ ẽs de nossa vida, devemos crer q' seos virtuosos Paes se dis= vellaraõ na cultura della desde seos premeiros annos: po= is vindo este Monge tomar o $\mathrm{S}^{\text {to }}$ habito nesta casa $-273-$

${ }^{194} \mathrm{APFL}$ 
professando nella, deo logo a conhecer q' se elle possuia as

$\left[\mathrm{f}^{\mathrm{o}} 138 \mathrm{v}^{\mathrm{o}}\right]$ virtudes da vocaçaõ sua, naõ possuia menos aquellas q' se de= vem ao genio, e a indole, e aos progenitores enchendo com humas os deveres doseo estado e com outras as da Socied ${ }^{\mathrm{e}}$ em que se achava. O seo merecim ${ }^{\text {to }}$ pois o fes digno da profissaõ, e os seos talentos de q' o mandassem entrar no Collegio de Filosophia em Pern ${ }^{\mathrm{co}}$ onde depois de feitos os actos de Preg ${ }^{\text {or }}$ ser= vio nos empregos de Subprior e Sacristaõ mór desempenhan= do $q^{1} q^{r}$ destes empregos com zelo e satisfaçaõ dos Religiosos. Naõ tardou, q' onaõ mandassem administrar a Capella de N.S . dos Prazeres, onde demorou-se $\mathrm{m}^{\text {tos }}$ annos edeficando o Publico com suas virtudes, e trabalhando eficazm ${ }^{\text {te }}$ no aumento da $\mathrm{m}^{\text {ma }}$ capella, q' lhe deve os mais avultados serviços: os quaes pesados na balança da Justiça $\mathrm{p}^{\mathrm{a}}$ os apprecearem o elegeraõ em D.Abb ${ }^{\mathrm{e}}$ das Brottas e ahi se demorou alem dos 3 an= nos do seo governo q' foi louvavel $\mathrm{m}^{\mathrm{s}} 3$ annos em qualid ${ }^{\mathrm{e}} \mathrm{de}$ Subdito. Ja os annos o chamavaõ a huma vida mais descan çada, e com efeito elle a poderia gozar neste Mostr ${ }^{\mathrm{o}} \mathrm{p}^{\mathrm{a}}$ onde se retirou se quisesse aproveitar das esenções q' a Religiaõ lhe permetia pelos seos annos: mas conhecido q' a vida do homem he huma continuada malicia sobre a terra, /e q' o*/ Religioso tanto mais se aproxima a seo fim, quan= $-274-$ 
quanto mais deve trabalhar $\mathrm{p}^{\mathrm{r}}$ prevenir os ataques daquella

$\left[\mathrm{f}^{\mathrm{o}} 139 \mathrm{r}^{\mathrm{0}}\right]$ ultima hora; ja mais passou hum instante q' naõ fosse em= pregado, ja dirigindo os Monges novos na qualid ${ }^{\mathrm{e}} \mathrm{de}^{\mathrm{e}}$ Coris= tas, ja cumprindos com os deveres dos cargos de $1^{\circ}$ e $3^{\circ}$ Defini $<\mathrm{t}>/$ d $\backslash$ or de q' foi condecorado, ja utilizando ao publico na continua assis $=$ tência do conficionario sem exepçaõ de pessoa nem de tem= po, ja finalm ${ }^{\text {te }}$ seguindo todos os actos de communid princi $^{\mathrm{e}}$ palm ${ }^{\text {te }}$ choro ao $\mathrm{q}^{1}$ nunca faltou nem de dia nem denoi= te com edificaçaõ da qulles q' o frequentaõ, e confusaõ de $\mathrm{m}^{\text {tos }}$ q' nunca lá vaõ, e o julgaõ só $\mathrm{p}^{\mathrm{r}}$ hum exercicio dos $\mathrm{pr}^{\mathrm{os}}$ annos. Era este Monge apaixonadam ${ }^{\text {te }}$ applicado ao es tudo das Rubrícas, Decretos e Estatutos Eclesiasticos relati= vos ao culto Divino, de q' tinha huma gr ${ }^{\text {de }}$ noticia procu= rando com isto q' todas as cousas se fisessem conforme a mente da Igreja, e deveres do nosso estado. He digno de se notar o desapego do Seculo com q' sempre vi= veo este Religioso; pois passando a maior parte de sua vi= da nesta casa, só huma ou duas veses, como elle mesmo confessava foi estar fora conventualm ${ }^{\text {te }}$ conservando-se o mais resto do tempo no claustro nos exercicios de sua profissaõ. Assim foi passando a sua virtuosa vida, athe q' a morte lhe bateo a porta prevando-o da Existencia, com huma furio 
furiosa herisipela molestia de q' era ccometido muitas ve= ses, achando-o disposto com os ultimos Sacram ${ }^{\text {tos }}$ tendo de id ${ }^{\mathrm{e}}$ $80 \mathrm{an}^{\mathrm{s}}$ e 9 meses; foi o dia do seo falecim ${ }^{\text {to }}$ a 4 de Maio de 1806 sendo D.Abb ${ }^{\text {e }}$ o M.R.P. ${ }^{\mathrm{e}}$. $\mathrm{M}^{\mathrm{e}}$ Fr. Manoel do Sacram ${ }^{\text {to }}$. $-27<4>/ 5 \backslash-(\underline{276})$

Entre os Monges falecidos nesta Casa, e q' se acriditaraõ $\mathrm{m}^{\mathrm{s}}$ pelos votos da sua profíssaõ foi o M.R.P $P^{\mathrm{e}}$. $\mathrm{M}^{\mathrm{e}} \mathrm{D} \cdot \mathrm{Abb}^{\mathrm{e}} \mathrm{actu}=$ al Fr.Manoel do Sacram ${ }^{\text {to }}$ nascido de Paes honestos na Fregue= sia de S.Andre de Bostr ${ }^{\circ}$ Bisp $^{\circ}$ do Porto, depois de passar os pr $^{\text {os }}$ annos de sua id ${ }^{\mathrm{e}}$ no Seminario dos Meninos Orfaõs da $\mathrm{m}^{\text {ma }}$ $\mathrm{Cid}^{\mathrm{e}}$, foi mandado noviciar neste Mostr ${ }^{\circ}$ com Patente do N. $\mathrm{R}^{\mathrm{mo}}$ vestindo nelle a Cogulla Benedictina. Experimentado em todos os rigores do ano de aprovaçaõ; sua constancia ao tra= balho, sua applicaçaõ aos livros, seo amor a virtude, e todos os exercicios peniveis da Religiaõ fes com q' esta o contasse no numero de seos $\mathrm{f}^{\text {os }}$ admetindo-o a profissaõ. Aqui pois passo/* $\mathrm{u} /$ o seo Coristado e $3 \mathrm{an}^{\mathrm{s}}$ de Filosophia appresentando a todos sem= pre huma conducta sem taxa q' conservou athe morrer.

Mudado Para Pern ${ }^{\mathrm{co}}$ juntam ${ }^{\mathrm{e}}$ com seo $\mathrm{M}^{\mathrm{e}}$ ahi concluio o seo curso Teologico. Os actos de Passante q' fes no fim delle de= raõ a conhecer q' naõ perdeo o seo tempo inutilm ${ }^{\mathrm{e}} \mathrm{e}$ talves da sua $\mathrm{m}^{\text {ta }}$ applicaçaõ lhe sobreveio a molestia de sangue pela boca, q' deixando-o sempre atenuado de forças veio $\mathrm{p}^{\mathrm{r}}$ $-276-$ 
$\mathrm{p}^{\mathrm{r}}$ fim de alguns annos a ser o verdugo de sua vida. Neste

$\left[\mathrm{f}^{\mathrm{o}} 140 \mathrm{r}^{\mathrm{0}}\right]$ estado de Passante e doente foi $\mathrm{p}^{\mathrm{a}}$ Pernc $^{\mathrm{o}}$ digo $\mathrm{p}^{\mathrm{a}}$ o Rio de Jan ${ }^{\text {ro }}$ onde teve muito q' sofrer da parte do Prelado, q' entaõ era $p^{r}$ oca siaõ da $\mathrm{m}^{\text {ma }}$ molestia, $\mathrm{q}^{\prime}$ sendo verdadr ${ }^{\mathrm{a}} \mathrm{p}^{\mathrm{a}}$ elle foi reputada $\mathrm{p}^{\mathrm{r}} \mathrm{a}$ quelle e $\mathrm{p}^{\mathrm{r}}$ outros $\mathrm{m}^{\text {tos }}$ monges $\mathrm{p}^{\mathrm{r}}$ fengem. ${ }^{\text {to }}$, e prevençaõ, donde lhe resultaraõ $\mathrm{m}^{\text {tos }}$ desgostos, q' o obrigaraõ sungo [ $\uparrow$ segundo] o Conselho de [个pedir] Ha pedir muda daquella Caza p. ${ }^{a}$ esta, onde tinha professado. Fugindo ao Perturbador do seu Espirito, naõ pode nunca fugir a molestia, que o acompanhava p. $^{\mathrm{a}}$ toda parte, mas assim nun= ca esteve ossiozo; servindo ao mostr ${ }^{\mathrm{o}}$ no imprego de mestre das hobras, e Procurador das Demandas; e aplicando-se sempre aos livros, mais $p^{r}$ paixaõ, do $q^{\prime} p^{r}$ possibilid ${ }^{e}, p^{s}$ tinha a respiraçaõ preza, que o privava de longas leituras; naõ foi isto $\mathrm{p}^{\mathrm{m}}$ bastante p. ${ }^{a}$ o deixarem de prover em huma Cadr. ${ }^{a}$ de Theologia, cujos encargos dezempenhôu mais $\mathrm{p}^{\mathrm{r}}$ superiorid $^{\mathrm{e}}$ dos seus conhecim ${ }^{\text {tos }}$, do q' com a possibilid das suas forças, estando ainda neste exer= cicio, $/ \mathrm{e}^{* /} /$ ao $\mathrm{m}^{\mathrm{mo}}$ tempo no d'Procurador Geral da Provincia, $\mathrm{p}^{\text {la }}$ renun= cia do $\mathrm{Ab}^{\mathrm{e}}$; elleito p. $^{\mathrm{a}}$ esta caza, foi elle promovido neste lugar, naõ concordando $\mathrm{p}^{\mathrm{r}}$ si $\mathrm{p}^{\mathrm{a}} \mathrm{o}$ alcançar, nem directam ${ }^{\mathrm{e}}$ nem indi= rectam $^{\mathrm{e}}$, antes lhe cauzou huma grande mortificaçaõ o aceita-lo, de $\mathrm{p}^{\mathrm{s}}$ de consultar os $\mathrm{m}^{\mathrm{es}}$ da Moral, naõ achou meios de subtra= hir-se a hum preceito expresso da S.obediencia, q' o obrigava a isso, constrangido p. ${ }^{\mathrm{s}}$ a submeter-se ao pezo, elle fez tudo da $\mathrm{su}=$ a parte p. ${ }^{a}$ manter aobservancia regular, e concervar o $\mathrm{Pa} /$ trimonio*/ 
da Religiaõ, aprezentando-se a todos como o premr $^{\circ}$ nos exemplos, $\mathrm{p}^{\mathrm{a}}$

$\left[\mathrm{f}^{\mathrm{o}} 140 \mathrm{v}^{\mathrm{0}}\right]$ o que naõ foi precizo pedir hum carater emprestado, $\mathrm{p}^{\mathrm{s}}$ elle mesmo desde o seu noviciado foi observante. Os trabalhos da Prelazia junto a hum gênio nimiam ${ }^{\mathrm{e}}$ escrupulozo, accenderaõ novam ${ }^{\mathrm{e}}$ esta faisca da antiga Molestia; que se achava com suffoca= da $\mathrm{p}^{\mathrm{r}}$ mais de 14 annos, brotando com tanta força, q' o fez lan= çar $p^{r}$ varias vezes quantid ${ }^{e}$ de sangue $p^{\text {la }}{ }^{\text {b }}$ boca, $q^{\prime}$ conduzindo-o len= $\operatorname{tam}^{\mathrm{e}}$ a huma tizica, reduzio a hum dolorozo suffrim ${ }^{\text {to }} \mathrm{em}$ huma cama $p^{r}, m^{\text {tos }}$ mezes, q' elle converteo em bem $p .{ }^{a}$ sua alma $p .{ }^{\text {la }}$ paci $=$ encia Christam, com q' o supportou, $\mathrm{p}^{\mathrm{r}}$ fim succumbindo a vio= lencia do seu mal, entregou seu espirito ao $<\mathrm{c}>$ /C $\backslash$ riador, tendo-se dis= posto p. $^{\mathrm{a}}$ isso com repetidas confições, e com os ultimos Sacramen= tos, q' o recebêo com $\mathrm{m}^{\text {ta }}$ devoçaõ aos 12 de Junho de 1707, na idade de 46 an ${ }^{\mathrm{s}}$, faltando-lhe ainda $\mathrm{p}^{\mathrm{a}}$ completar o seu trienio 5 mezes. Foi interrado na Capella mor com grande pompa, e honras devi $<$ di $>$ das ao seu lugar.

Este Monge foi sumam ${ }^{\mathrm{e}}$ observante dos seus votos, sua castidade foi sem Lezaõ, sua pobreza resplandeceo nos seus moveis, no seu vestido, e no seu sustento; nada /recebia*/ de ninguem, a penas, alguás [baga $]^{195}$ telas $\mathrm{m}^{\text {to }}$ insignifcantes $\mathrm{am}^{\text {tas }}$ instancias dos seus amigos. Depois da sua morte, nada de $\mathrm{su}=$ perfuo se lhe achou, antês se conhecêo q' athé o nescessario lhe faltava. Em obsequio de verd 'deve-se dizer, q' as suas intenço= ẽs eraõ boas, no q' obrava, e naõ contentou a todos nos governos ( o que hé moralm ${ }^{\mathrm{e}}$ impossível,) foi mais erro do seu intendim ${ }^{\text {to }}$ que da vontade, hum escrupulo demaziado o fazia embara= çado, q' de generou algumas vezes emtenacid ${ }^{\mathrm{e}}$ defeito ordenario $-278-$

\footnotetext{
${ }^{195}$ APFT. Foram acrescidas as duas primeiras silábas da palavra $<$ bagatela $>$ por Silva Nigra em virtude de o suporte do documento original ora transcrito não permitir a leitura dessa parte.
} 
dos escrupulozos; mas disculpemos ao homem, em attençaõ ao Relig. ${ }^{\text {zo }}$

$\left[\mathrm{f}^{\mathrm{o}} 141 \mathrm{r}^{\mathrm{o}}\right]$

$$
-27<5>/ 6 \backslash \text { - }(\underline{277})
$$

A vida do monge, q' se segue hé um ticido de vertudes, e deboas qualidades do coraçaõ, e do Espirito, q' se uniraõ ao $\mathrm{m}^{\mathrm{mo}}$ tempo $\mathrm{p}^{\mathrm{a}} \mathrm{o}$ fazerem digno dos maiores elogios, e dos lugares auctorizados, q' na ordem occupou. Este Religiozo, q' hé o M.R.P ${ }^{\mathrm{e}}$.Ex Abb ${ }^{\mathrm{e}}$ F.Jozé da Trindade Roxa nascêo nesta Cid $^{\mathrm{e}}$ de Pais honrados, e veio esta Caza tomar o S.Habito na $i^{\mathrm{e}}$ de $20 \mathrm{a}^{\mathrm{s}}$. O seu noviciado apenas foi hum prelodio da sua futura Religiozidade; mas n'elle logo bem reconhecêo $p .^{\text {lo }}$ fervor dos seus exercicios, $p .^{\text {la }}$ obediencia ao seu $\mathrm{M}^{\mathrm{e}} ;$ p. $^{\text {la }}$ paciencia, mortificaçaõ, e observancia de concelho, oq ${ }^{\text {to }}$ nestas virtudes devia ser exacto logo q' ellas fossem de preceito. Depois de professo foi ter o seu Colegio em Pernanbuco; e posto q' naõ lhe faltassem os talentos $\mathrm{p}^{\mathrm{a}}$ as letras, nem a vontad ${ }^{\mathrm{e}} \mathrm{de}$ fazer actos de passante, com tudo elle vio frustradas as suas perten= çoes $\mathrm{p}^{\mathrm{r}}$ motivos de preferenças graciozas, sobrevindo-lhe ao mesmo tempo huma molestia de peito, que o obrigou a abandonar inteiram ${ }^{\text {e }}$ estes intentos. Rezolvido a procurar ares mais benignos a sua quexa pedio mudar p. ${ }^{a}$ este Mosteiro, que principiou o logo a servir com zelo, e fidelidade no imprego de Superior. Aqui mesmo começou no exercicio da urbica, q' deixou taõ bem incompleto $\mathrm{p}^{\mathrm{r}}$ molestia. /Muda*/do p. ${ }^{\mathrm{a}}$ o Mostr. ${ }^{\circ}$ de Nossa Senhôra da Graça, e conhecendo o Prelado d'aquella caza, que(...) era regular, a sua capacid ${ }^{\text {e }}$; e intereza, o elegêo seu Prior, o efeito mostrou o acerto da eleiçaõ, $p .{ }^{s}$ desde logo começou a trabalhar com grande actividade na cons $=$ trucaõ da Igreja de Senra de q' era $\mathrm{m}^{\text {to }}$ devoto, levando as suas obras a hum augmento consideravel; o mesmo fez quando se vio $\mathrm{Ab}^{\mathrm{e}}$ da mesma caza, cujo lugar dezimpenhôu um credito da Reli= giaõ sedeficaraõ dos Siculares; sem sessar a observ/a/ncia $\mathrm{Re}=$ gular a todos, fazia hum favoravel $/ \mathrm{a} * / \mathrm{ccolhim}^{\text {to }}$, procurando agradalhes sem baixeza, e prestando-lhes os caritativos officios do minis= 
terio sacerdotal, conduta esta necessaria a todos os Prelados dos pe quenos Mosteiros. Concluido o seu trienio, voltou outra vez $\mathrm{p}^{\mathrm{a}}$ esta caza, onde, $\mathrm{p}^{\mathrm{r}}$ ser notorio a todos o seu prestimo $\mathrm{p}^{\mathrm{a}}$ tudo, servio successi vam $^{\text {te }}$ com zelo, e feliscid ; merecedora de todos os ellugios, nos impregos de Sacristaõ mor, ropeiro, e contador. Ja a este tempo, sendo assaz co= nhecidas suas virtudes na Provincia, e congregaçaõ, o elegeo a junta geral $\mathrm{M}^{\mathrm{e}}$ de Noviços, empregado empenhozo e dilicado . $^{\text {la }}$ pruden= cia, $q$ ' se requer $\mathrm{p}^{\text {a }}$ conduzir a mocidade a huma vida regular $p .^{\text {la }}$ perspicacia em discubrir aq ${ }^{\text {le }}$; q' naõ tem espirito de Religiaõ, e q' serviria mais $\mathrm{p}^{\text {la }}$ sua profissaõ de a perturbar, do q' de a idificar, $p^{\text {lo }}$ dizinterece em naõ querer dos seus noviços mais q' as suas almas p. ${ }^{\text {a }} \mathrm{D}^{\mathrm{s}}$; e principalm ${ }^{\mathrm{e}}$ p. ${ }^{\text {lo }}$ bom exemplo, q' lhes deve dar, praticando aq ${ }^{\text {lo }}$ mesmo, q' encigna, e encignando aq ${ }^{\text {lo }}$ mesmo, q' pratica; mas q' elle dizimpenho $\mathrm{p}^{\mathrm{r}} \mathrm{m}^{\text {tos }}$ annos com $\mathrm{m}^{\text {to }}$ credito da sua pessoa, e pro $=$ veitamento dos seu discipulos, e utilidade da Religiaõ, naõ ha= vendo huma só falta em tudo isto, q' se lhe notasse, p. ${ }^{\text {s }}$ alem de en= cinar, edificar, e nada receber nem d'elles, nem de seus Pais, foi morar com elles no mesmo noviciado $\mathrm{p}^{\mathrm{a}}$ notar mais de perto as $\mathrm{su}=$ as condutas, e vigiar sobre as suas nescessidades, sendo elle $\mathrm{m}^{\mathrm{mo}} \mathrm{o} \mathrm{pr}^{\mathrm{O}}$ nas mortificações, e em todos os exercicios proprios da $q^{\text {le }}$ ano, a pezar das suas infermid ${ }^{\text {es }}$; e de outras occupações. As suas forças pareciaõ estancadas com a laborioza tarefa $\mathrm{d} / \mathrm{a} * /$ educaçaõ $/ \mathrm{m} * / \mathrm{as}$ ainda assim naõ esteve, dep $/ \mathrm{q}$ '/ /o/ deixou $\mathrm{p}^{\mathrm{r}} \mathrm{m}^{\text {to }}$ tempo descancado, p. $^{\mathrm{s}}$ sendo eleito em $\mathrm{Ab}^{\mathrm{e}}$ das Brotas, ahi se demorou sempre, a tra $=$ balhar $\mathrm{p}^{\mathrm{r}}$ dois trienios, hum como $\mathrm{Ab}^{\mathrm{e}}$; e outro como Prezid ${ }^{\mathrm{e}}$; e difican= do ao publico com sua boa vida, servindo-o no Conficionario, no $\mathrm{q}^{1}$ consumia a maior parte do dia, principalm ${ }^{\mathrm{e}}$ na Quaresma, e con= solando aos escravos com a sua caridade. Afinal retirôu-se p. ${ }^{\mathrm{a}}$ esta caza, que a servio athé morrer, servio em diversos tempos os lugares de Procurador Geral, e Definidor, e se naõ occupou o lugar supremo da Prov $^{\mathrm{a}}$; foi p ${ }^{\mathrm{r}} \mathrm{q}$ ' a sua ambiçaõ mais procurava abater-se, do q' levantar-se. 
$\mathrm{Naõ} / \mathrm{se}^{*} /$ pode assas louvar a dilicadeza de conciencia deste Monge, naõ recebendo senaõ aq ${ }^{\text {lo }}$, q' podia consumir, e entregando tudo $\mathrm{q}^{\mathrm{to}}{ }^{\mathrm{O}}$ lhe restava: v.g. s/e*/ huma galinha lhe bastava p. 2 dias, naõ recebia outra antes daq ${ }^{\text {la }}$ consumida, naõ obstante assignar a Religiaõ ao Monge infermo huma $\mathrm{p}^{\mathrm{a}}$ cada dia, o mesmo praticava, $\mathrm{q} .{ }^{\mathrm{do}}$ vinha de Moncerrate passar alguns dias no Mostro; entregando do $\mathrm{dr}^{\mathrm{o}}$; q' The estava distinado $a q^{\text {la }} \mathrm{p}^{\text {te }}{ }^{\mathrm{q}}$ ' via ter poupado nesta estada, e cada q. $p^{r}$ esta fidelid. ${ }^{\mathrm{e}}$ nas couzas pequenas, pode julgar $\mathrm{q}^{\text {to }}$ mas $\operatorname{grd}^{\mathrm{es}}$ seria exacto. Sua fidelid. ${ }^{\mathrm{e}}$ nas couzas da renda da Religiaõ naõ merece menos louvor, como seu zelo em procurar seus intereces, e em discobrir com incancavel tabalho os titulos das suas posiçoẽs, e dos seus incargos $\mathrm{p}^{\mathrm{r}}$ isso ja $\mathrm{m}^{\mathrm{s}}{ }^{\mathrm{s}}$ esteve oci= oza a sua pena, tudo examinava, tudo escrevia p. ${ }^{\text {a }}$ dexar $L^{\text {cas }}$ aos vindouros; naõ ha livro nas diversas administraçoes do Mostr. ${ }^{\circ}$ onde se naõ ache a sua letra; e isto naõ só neste, mas em todos, onde esteve, ou governou. Alem disto teve hum grd. ${ }^{\mathrm{e}}$ conhecim ${ }^{\text {to }}$ de contas, e com esta prenda servio $\mathrm{m}^{\text {to }}$ a Religiaõ, prin= cipalm. ${ }^{\text {te }}$ a esta caza, trabalhando $\mathrm{m}^{\text {tas }}$ vezes athé alta note, apezar de seus acha $=$ ques em ajustar os recibos com as datas dos officiaes; q. ${ }^{\text {do }}$ estas estavaõ dessonan= tes, attribuindo estas faltas a discuido, e advertindo-se particularm ${ }^{\text {e }}$ q. ${ }^{\text {do }}$ naõ as podia conciliar; $\mathrm{p}^{\mathrm{a}}$ q.' elles corregissem seus assentos, só afim de evitar o seu discredito, e de praticar acarid. ${ }^{\mathrm{e}}$ de q'era taõ $\mathrm{am}^{\mathrm{e}} ; \mathrm{p}^{\mathrm{r}}$ estas, e outras $\mathrm{m}^{\text {tas }}$ qualid. ${ }^{\mathrm{es}}$ foi sempre atend. ${ }^{\circ}$ dos Prelados. Sua conduta era irreprehendivel, naõ adula $=$ va a ninguem, e dizia as verd. ${ }^{\text {es }}$ ainda as $\mathrm{m}^{\mathrm{s}}$ duras (mas so $\mathrm{q}^{\mathrm{do}}$ era perguntado) aq. ${ }^{\text {les }}$ q.' pediaõ o seu parecer. Foi bom amigo, seu carater era afavel, mas sezudo; sua linguagem era franca, mas (se...ra), seu genio era dilicado mas suffredor;

25 tinha intereza, verd ${ }^{\mathrm{e}}$; probid $^{\mathrm{e}}$; enfim era hum perfeito Religiozo. Alguns a. ${ }^{\mathrm{s}}$ antes da sua morte foi administrar a capella do Montecerrate, onde vinha varias vezes, principalm ${ }^{\mathrm{e}}$ no tempo da Quaresma a praticar na comp $p^{\mathrm{a}}$ dos seus Irmaõs os deveres da sua profiçaõ. Hum difluxo q' o perseguia desde Colegial, e q' augmentado com a id. ${ }^{\mathrm{e}} \mathrm{o}$ digenerou $\mathrm{p}^{\mathrm{r}}$ fim, conhecêo ser chegada /a sua*/ hora, pedio os Sacram. ${ }^{\text {tos }}$ da Igreja, q' os recebêo com ${ }^{\text {ta }}$ devoçaõ, e estando assim disposto, sahio deste mundo p. ${ }^{\mathrm{a}}$ a eternid. ${ }^{\mathrm{e}}$ aos 18 de Abril $1806 \mathrm{com} 79 \mathrm{a}^{\mathrm{s}}{ }^{\mathrm{a}}$ de id $\mathrm{d}^{\mathrm{e}}$; sendo D.Ab ${ }^{\mathrm{e}}$ deste Mostr $^{\mathrm{o}}$ o M.R.P. ${ }^{\mathrm{e}}$.Pregador Fr. Jozé da Cruz. 


$$
27<6>/ 7 \backslash(278)
$$

$\left[\mathrm{f}^{\mathrm{0}} 142 \mathrm{v}^{\mathrm{0}}\right]$

Segue-se a vida e morte do M.R.P ${ }^{\mathrm{e}}$.D.Abb ${ }^{\mathrm{e}}$ actual Fr. José da Cruz nascido em Portugal de Pais honrados na Fregue sia de S.Joaõ de Ayo. Naõ foi logo o seu destino o ser Religi= oso antes o de seguir a vida mercantil na Comp. ${ }^{a}$ de hum Tio q' tinha no Rio de Janr ${ }^{\mathrm{O}}$; mas mostrando-lhe $\mathrm{D}^{\mathrm{s}}$ bens mais solidos na Religiaõ, procurou este $\operatorname{Mostr}^{\circ} \mathrm{p}^{\mathrm{a}}$ n'elle tomar o $\mathrm{S}^{\text {to }}$ habito, preferindo huma honesta pobresa no Claus tro, a huma fortuna brilhante no seculo. Desde o seu No viciado deo logo a conhecer o desembaraço do seu espirito, e activid $^{\mathrm{e}}$ do seu genio de sorte q' ao depois de Professo a Religiaõ o incumbio de commisoens, q' só confia dos Monges esperimen tados, como foraõ do recadar as rendas do seo patrimonio tanto na Cid. ${ }^{\mathrm{e}}$ como nas terras de Inhatá em cujas laboriosas occupaçoens trabalhou $\mathrm{m}^{\text {to }} \mathrm{p}^{\mathrm{r}} \mathrm{m}^{\text {tos }}$ annos com credito de sua pessoa, e utilid d' esta casa; compondo com summa pruden cia as desordens dos rendeiros, e augmentando com seus modos polidos, e civis os re/cib*/os das $\mathrm{m}^{\text {mas }}$ Rendas, de sor te, q' todos o amavaõ, e lhi ficavaõ obrigados ainda $\mathrm{q}^{\text {do }}$ se op punha as suas pertenções. Administrou tambem o $\mathrm{Eng}^{\mathrm{O}}$ da cima com ${ }^{\text {to }}$ zêlo, (fidelid. ${ }^{\mathrm{e}}$ e augmento, digo) e conhe $\mathrm{cim}^{\text {to }} \mathrm{d}$ 'aquelle genero de agricultura. Foi mordomo nes ta casa, sendo farto $\mathrm{p}^{\mathrm{a}}$ os Monges, sem desperdiço, e ecconomico sem vileza. Trabalhou tambem $\mathrm{m}^{\text {to }}$ 
na arrumaçaõ das contas, $\mathrm{p}^{\mathrm{a}}<\mathrm{q}>/ \mathrm{a} \backslash \mathrm{s}$ quaes tinha grd $^{\mathrm{e}}$ intelli gencia, e paciencia. Naõ tinha nem amigos, nem in terisses proprios $\mathrm{q}^{\mathrm{do}}$ se tractava da Religiaõ, e o seu ze lo $\mathrm{p}^{\text {lo }}$ augmento de seu patrimonio, esteve a par de sua fidelid. ${ }^{\mathrm{e}}$ em arrecadar, e despender as suas rendas nas quaes já mais teve nota alguma. Depois de $\mathrm{m}^{\text {tos }}$ annos teve neste Mostr. ${ }^{\circ}$ o seu Collegio no fim de q pas sou à Portugal a visitar os seus parentes, e com elles se de morou perto de 5 , merecendo em todo este tempo $\mathrm{p}^{\text {lo }}$ seu bom comportam. ${ }^{\text {to }} \mathrm{m}^{\text {tas }}$ estimações dos Monges daCongregaçaõ, e particulares attençoens dos Nossos $\mathrm{R}^{\mathrm{mos}} \mathrm{P}^{\mathrm{es}}$ Geraes. Avoltar $\mathrm{p}^{\mathrm{a}}$ esta casa na Comp. ${ }^{\mathrm{a}}$ de Ex. ${ }^{\mathrm{mo}} \mathrm{Snr}$. Arcepisbo D.Fr.José de S. ${ }^{\text {ta }}$ Escholastica, veio condecorado com o emprego de Procu rador Geral. Foi $\mathrm{m}^{\text {to }}$ estimado deste Prelado honrando-o com huma amizade $\mathrm{p}^{\mathrm{ar}} \mathrm{q}$ ' athé lhe chegou adar hum quar to no seu Palácio $\mathrm{p}^{\mathrm{a}}$ assistir $\mathrm{q}^{\text {do }}$ la fosse. Como tinha $\mathrm{m}^{\text {to }}$ conhecim $^{\text {to }}$ do Patrimonio /deste*/ Mostr ${ }^{\circ}$ e o unico talvez, q' lhe podesse dar algum remedio no estado deploravel em q' se achava $\mathrm{p}^{\text {las }}$ desgraças do tempo, o elegeraõ em D.Abb ${ }^{\mathrm{e}}$ desta Casa; com effeito tomou posse do seu lugar e o primr $^{\circ}$ cuidado foi hir vêr com os seus proprios olho os diver sos ramos da administraçaõ patrimonial, $\mathrm{p}^{\mathrm{a}}$ acertar o remedio q' lhe havia dar estendendo-se as suas vistas 
$\mathrm{N}^{\circ}$ a: as paginas 281-284 estão depois da $260 .{ }^{196}$

$\left[\mathrm{f}^{\mathrm{o}} 143 \mathrm{v}^{\mathrm{0}}\right]$ naõ só a conservaçaõ do presente, como a melhora do futuro. com este designio sahio a visitar as faz. ${ }^{\text {das }}$ principalm ${ }^{\text {te }}$ de Rio de S.Fran ${ }^{\text {co }}$, q' mais q' todas necessitavaõ $\mathrm{p}^{\text {la }}$ distançia em q' estaõ e $\mathrm{p}^{\text {lo }}$ longo intervalo de tempo q' havia passado depois da ul tima visitaçaõ; mas chegando a Ilha grd infelizm $^{\text {te }}$ encon trou a sepultura nas cesoens epidemicas de q' abunda $a q^{\text {le }}$ Paiz. Seos planos abortaraõ com sua morte naõ ficando depois d'ella senaõ o sentim ${ }^{\text {to }}$ da perda de hum Prelado, q' sem perder nada dos direitos Abaciaes, tratava aos seus sub ditos ainda aq $q^{\text {les }} \mathrm{m}^{\text {mos }} \mathrm{q}^{\prime}$ lhe eraõ pouco afeiçoados com a maior urbanid. ${ }^{\mathrm{e}}$, naõ fazendo ja mais estas distinçoens odiosas, q' se paraõ os filhos dos Pais; os $\mathrm{m}^{\text {mos }}$ seculares o choraraõ, pois $\mathrm{sa}=$ bia unir a civilid. ${ }^{\text {e }}$ com a observancia, o affavel como gra ve, e $p^{\text {lo }} q$ ' respeita o seu caracter ja mais deixou de dizer a ver= dade $\mathrm{q}^{\text {do }}$ se tratava dos interesses do Mostr. ${ }^{\circ} \mathrm{p}^{\text {lo }}$ temor dos ho mens; seus sentim ${ }^{\text {tos }}$ eraõ francos, e a constancia de os sustentar a prova de todas as contrariedades. Faleceo como disse na dita $\left\langle\uparrow>\right.$ fazenda no $1^{\circ}$ de Dezembro de 1808, digo em 14 de Novembro de 1808 tendo de id $^{\mathrm{e}} 38$ annos e de governo 2 incompletos. O P ${ }^{\mathrm{e}}$ Fr. Luiz de N.Snr ${ }^{\mathrm{a}}$ da Penna, q' ti nha hido $\mathrm{p}^{\mathrm{r}}$ seu Comp. ${ }^{\mathrm{o}}$ e confessou, e depois de morto foi condusido ao Conv ${ }^{\text {to }}$ dos Franciscanos da $\mathrm{V}^{\mathrm{a}}$ do Penedo onde lhe deraõ a honrosa sepultura $\mathrm{p}^{\text {lo }} \mathrm{P}^{\mathrm{e}}$. Fr. $\mathrm{M}^{\mathrm{el}}$ de Jesus Ma 
ria entaõ Administrador daq ${ }^{\text {las }}$ fazendas. $-27<7>/ 8 \backslash-(279)$

$\left[\mathrm{f}^{\mathrm{0}} 144 \mathrm{r}^{\circ}\right]$

279 - Segue-se a vida e morte do $\mathrm{R}^{\mathrm{mo}}$ Ex Prov $^{\text {al }}$ Fr. Antonio de S.

José Valença. Era natural este Monge da V. a da Va

lença. Na idade de 18 annos buscou a Religiaõ, e n'este Mos

tr. ${ }^{\circ}$ teve o seu noviciado, e $\mathrm{p}^{\text {te }}$ do seu Collegio, e aoutra em

Pernambuco. Passou quase toda sua vida ou em ad-

ministrar as granjas da Religiaõ, ou em Prelasias, sen

do a primr ${ }^{\mathrm{a}}$ q' administrou a de Ignassú no Rio de Ja $n r^{0}$ da $q^{1}$ sahio $\mathrm{p}^{\mathrm{a}}$ Presidente de $\mathrm{S}^{\mathrm{tos}} \mathrm{D}^{\text {'este }}$ primr ${ }^{\mathrm{o}}$ lugar foi se sempre elevando gradualm ${ }^{\text {te }}$ aos de maior authorid. ${ }^{\mathrm{e}}$, e privilegios: veio logo eleito Abb. ${ }^{\mathrm{e}}$ de $\mathrm{Pern}^{\mathrm{co}}$; governou aq ${ }^{\text {la }}$ casa $\mathrm{p}^{\mathrm{r}}$ espaço de 5 annos. No trienio seg. ${ }^{\text {te }}$ o elegeraõ Secre tario da Provincia, e neste tempo visitou as fazendas do Ri o de S.Fran. ${ }^{\text {co }}$. Passou ao depois a ser Abb. ${ }^{\mathrm{e}}$ deste Mostr. ${ }^{\circ}$ q' gemendo de $\mathrm{m}^{\text {to }}$ tempo com huma grande divida [个de] $60 \mathrm{mil}$ crusados a juros, elle p. ${ }^{\text {la }}$ felicid. ${ }^{\mathrm{e}}$ dos tempos o aliviou de $\mathrm{m}^{\text {ta }} \mathrm{p}^{\text {te }}$ d'este encargo, e no discurso dos mais governos de todo; sendo este talvez o motivo, ou outros q' par/eciaõ*/ justos aos Padres da Congregaçaõ de o reelegerem recc/essiv/am ${ }^{\text {te }}$ mais 2 trienios, q' foraõ destincto $\mathrm{p}^{\mathrm{r}}$ esta soluçaõ, e $\mathrm{p}^{\text {la }}$ pedra q' mandou vir $\mathrm{p}^{\mathrm{a}}$ a conclusaõ da Capella mor. Conclu idos os 3 trienios lhe concederaõ os privilegios de Ex Proval; mas ao depois lhe conferiraõ realm ${ }^{\text {te }}$ o titulo, privilegios, 
e poderes, elegendo-o a Junta Geral Provincial, q' p ${ }^{\text {a }}$

$\left[\mathrm{f}^{\mathrm{o}} 144 \mathrm{v}^{\mathrm{o}}\right]$ cumprir com os deveres do seu cargo correo $<\mathrm{P}>/$ thoda Provincia, deixando em cada Mostr ${ }^{\circ}$ as providencias q' lhe parece raõ necessarias. Foi tambem Definidor. Descançou algum tempo na Capella do Monserrate $\mathrm{p}^{\mathrm{a}}$ onde se retirou e dahi sahio à administrar o Eng $^{\circ}$ de S.Caetano. A

Morte do Ex Abb ${ }^{\mathrm{e}}$ Fr. Ant ${ }^{\mathrm{o}}$ de N.Snr ${ }^{\mathrm{a}}$ da Penna, e /a/ renuncia, q' fez Fr. $\mathrm{M}^{\text {el }}$ de $\mathrm{S}^{\text {ta }}$ Anna Araujo do $\mathrm{m}^{\mathrm{mo}}$ lugar, o as sentou de novo na cadeira Abacial deste Mostr. ${ }^{\circ}$; e p $^{r} q^{\prime}$ nestes intermedios da morte morte, e renuncias se tinha passa do quase 2 annos foi recondusido no $\mathrm{m}^{\mathrm{mo}}$ emprego no trienio seg. ${ }^{\text {te }}$, q' concluio com 4 annos, 4 meses e 14 dias de governo. Entregou a casa ao seu Successor tendo ja seg ${ }^{\text {da }}$ vez apa tente de Prov. ${ }^{\text {al }}$ desta ultima $<$ vez $>$ só foi a Pern. ${ }^{\text {co }} \mathrm{p}^{\mathrm{r}}$ estar já $\mathrm{m}^{\text {to }}$ adiantado na idade. Por ultimo retirou-se $\mathrm{p}^{\mathrm{a}} \mathrm{o}$ Monser rate, e la esteve athe q' sentindo faltarem-se as forças pou co a pouco veio ao Mostr. ${ }^{\circ}$ reparallas com alguns remedios; mas a morte aqui o esperava, e huma soltura de ventre q' parecia ao principio naõ ser nada foi levando len tam $^{\text {te }}$ as bordas da sepultura, athé q' em fim e precicpitou n'ella. Faleceo aos 11 deJunho de 1810 de id. ${ }^{\mathrm{e}}$ perto de 80 an nos. Sendo D.Abb. ${ }^{e}$ deste Mostr. ${ }^{\circ}$ O.M.R.P.Pr.Fr.Manoel a Conc ${ }^{\text {am }}$ Rexa. Naõ lhe faltaraõ os Sacram ${ }^{\text {tos }}$ q' todos pe dio 
dio, e recebeo com $\mathrm{m}^{\text {ta }}$ devoçaõ, pedindo a Maria San tissima q' o ajudasse naq ${ }^{\text {la }}$ tremenda hora, e a $\mathrm{D}^{\mathrm{s}}$ lhe per doasse os seos peccados de q' reconhecia $\mathrm{m}^{\text {to }}$ devedor. Foi sepul tado na Capella mor com as honras devidas ao seu lugar.

Tem sido $\mathrm{m}^{\text {tos }}$ Monges falecidos n'esta casa, $\mathrm{q}$ ' foraõ sempre com sua huma escolla de virtudes Re ligosas; q' deixaraõ $\mathrm{p}^{\mathrm{r}}$ sua morte as mais bem fun dadas <almas> esperanças da sua salvaçaõ eterna, e q' serviaõ com suas prendas em $\mathrm{q}^{\text {to }}$ poderaõ a Mai de $\mathrm{q}^{\mathrm{m}}$ eraõ filhos: Hum delles foi o M.R.P.Fr. José de Je sus Maria S.Paio. Educado desde os seus primr ${ }^{\circ \mathrm{s}}$ annos no Collegio dos Orfaõs na Cid. ${ }^{\mathrm{e}}$ do Porto (sendo elle natural da Freguesia de S.Lourenço de Asures Bis pado da ${ }^{\text {ma }} \mathrm{Cid}^{\mathrm{e}}$ ) e applicando se ahi com todas as forças do seu espirito ao estudo de Grammatica, musica, orgaõ, e cantochaõ, foi a sua primr $r^{\mathrm{a}}$ vocaçaõ o prefessar na Religi aõ dos Crusios onde entrou, e onde tambem se acabou de aper feiçoar n'estas, com as $q^{\mathrm{s}}$ servio depois de $\mathrm{m}^{\text {to }}$ a nossa, em toda a sua vida, mas $\mathrm{D}^{\mathrm{s}}$, q' o destinava $\mathrm{p}^{\mathrm{a}}$ a nossa edificaçaõ per mittio, q' nesse $\mathrm{m}^{\text {mo }}$ tempo houvesse a reforma da $\mathrm{d}^{\text {ta }}$ Ordem; q' ou $\mathrm{p}^{\mathrm{r}}$ lhe parecer ardua, ou $\mathrm{p}^{\mathrm{r}}$ outro $\mathrm{q}^{1} \mathrm{q}^{\mathrm{r}}$ motivo lhe /deo*/ occa siaõ de sahir, e de buscar este Most..$^{\circ}$ com Patente de N.R ${ }^{\mathrm{mo}} P^{\mathrm{e}}$. Geral q' entaõ era, $\mathrm{p}^{\mathrm{a}}$ nelle tomar o $\mathrm{S}^{\text {to }}$ habito. Com effeito ves $-288-$ 
tio a Cogulla Benedictina e desde entaõ se dedicou todo aos ex

$\left[\mathrm{f}^{\mathrm{0}} 145 \mathrm{v}^{\mathrm{0}}\right]$ ercicios de pied. ${ }^{\mathrm{e}}<$ desde $>$ e a satisfazer as obrigaçoens do seu es tado, de sorte, q' mereceo $\mathrm{p}^{\mathrm{r}}$ sua boa conducta a ser admi ttido a profissaõ. Esta estreitando lhe as obrigaçoẽs o fez mais observante e sabendo q' $\mathrm{aq}^{\mathrm{le}} \mathrm{aq}^{\mathrm{m}}$ mais se dá se lhe pede, cuidou $\mathrm{m}^{\text {to }}$ em lucrar com os talentos q' havia re cebido $\mathrm{p}^{\mathrm{a}}$ os tornar com usura $\mathrm{q}^{\mathrm{do}} \mathrm{oS}^{\mathrm{r}}$ lhos pedisse. Para isto começou logo depois de professo a trabalhar no edi ficio di virtudes $\mathrm{p}^{\text {la }}$ observancia de seos votos, e das suas regras, vivendo como Religioso, e empregando o seu tẽ po em servir a Religiaõ com as prendas de q' era do tado consumindo mais de 40 annos no continuo ex ercicios do orgaõ compondo varias Missas $\mathrm{p}^{\mathrm{a}} \mathrm{o}$ uso do choro, e instruindo os Monges moços no Canto xaõ. Para melhor comprir com estas obrigações a q' voluntariam ${ }^{\text {te }}$ se tinha sujeitado na sua entrada, renunciou o Collegio; $\mathrm{p}^{\mathrm{r}}$ lhe ser quase incompativel cumprir exatamte com as de Collegial, e com as de hum Choro diario, e nocturno q' is tava entaõ na sua maior observancia. Applicado já á só coisa, e conhecendo, q' o homem Religioso naõ está separado do homem util, e social <utilis $>$ determi nou utilizar ao publico tambem com a sua arte abrin do . $^{\text {a }}$ isso huma escola publica de musica, e orgaõ d'on $-289$ 
de sahiraõ $\mathrm{mt}^{\mathrm{os}}$ discipulos perfeitos em huma e outra coisa vindo $\mathrm{p}^{\mathrm{a}}$ seu conehcim ${ }^{\text {to }}$ a ser oraculo dos musi $\cos$ da B. ${ }^{\mathrm{a}} \mathrm{q}$ ' sendo entaõ pouco peritos n'esta arte e vi nhaõ consultar como a $\mathrm{M}^{\mathrm{e}}$ pagando-lhe este ensino em virem gratuitam ${ }^{\text {te }}$ cantar, e tocar nas festivid ${ }^{\text {es }}$ do Mostr. ${ }^{\circ} q^{\text {do }}$ elle convidava: mas se elle os instruia com suas liçoens, naõ os edificava com suas virtudes, sendo este o motivo p ${ }^{r}$ q' os Prelados de quasi todos os Conventos de Frei ras o rogaraõ $\mathrm{p}^{\mathrm{a}}$ hir dar liçoens de musica e orgaõ as su as Religiosas e q' elle fez com ${ }^{\text {to }}$ credito da Religiaõ, abono de sua pessoa, e aproveitam ${ }^{\text {to }}$ de suas discipulas consentindo is so o $\mathrm{S}^{\mathrm{r}}$ Arce $<\mathrm{p}>/ \mathrm{b} \backslash$ ispo $\mathrm{p}^{\text {lo }}$ tem conceito lhes merecia. Do meio des tas occupaçoens foi tirado $\mathrm{p}^{\mathrm{a}}$ ser Prior, depois $\mathrm{p}^{\mathrm{a}}$ dirigir a mocid ${ }^{\mathrm{e}}$ no emprego de $\mathrm{M}^{\mathrm{e}}$ de Noviços conferido $\mathrm{p}^{\text {la }}$ Jun ta Geral da Provincia. Bom era q' todos tivessem o seu espirito; mas querendo medir os seu Noviços $\mathrm{p}^{\text {las }}$ suas forças trabalhou $\mathrm{m}^{\text {to }}$ sem approveitar quase nada, o q' prova q'o talento de governar e dirigir he hum dom do Ceo, $\mathrm{q}^{\prime} \mathrm{D}^{\mathrm{s}}$ dá $<\mathrm{q}>/ \mathrm{a} \backslash \mathrm{q}^{\mathrm{m}}$ lhe parece disgastado pois $\mathrm{p}^{\mathrm{r}}$ algumas opposicoens, q' encontrou, abdicou esti emprego, e nada mais servio na ordem a excepçaõ de Sacristaõ mor ficando $\mathrm{p}^{\mathrm{r}}$ este modo desembaraçado $\mathrm{p}^{\mathrm{a}}$ se empregar livre $\mathrm{m}^{\text {te }}$ aos seus exercicios de pied $^{\mathrm{e}}$. No taremos aqui, q' sen 
do Monge de $\mathrm{m}^{\text {tos }}$ respeitos na sua meia id. ${ }^{\mathrm{e}} \mathrm{p}^{\mathrm{a}}$ os secula

$\left[\mathrm{f}^{\mathrm{o}} 146 \mathrm{v}^{\mathrm{o}}\right]$ res ja mais os importunou com solicitaçoens imper tinentes, nem tirou lucro das suas amisad. ${ }^{\text {es }}$, tendo $\mathrm{m}^{\text {tas }}$ occasioens de o fazer; pois andando $\mathrm{p}^{\text {los }}$ certoens perto de hum anno na Comp ${ }^{\text {a }}$ de hum Corregedor seu $\mathrm{Am}^{\circ}$ naõ consta q' lhe pedisse hum só favor e beneficio de nin guem, respondendo aos q' o procuravaõ, q' o seo estado nao the permittia o entremetter se nas causas judiciaes. Ja adi antado em annos veio the ao pensam ${ }^{\text {to }} \mathrm{o}$ hir correr a Pro $v^{\mathrm{a}}$, e alcancando licença $\mathrm{p}^{\mathrm{a}}$ isto foi $\mathrm{p}^{\mathrm{r}}$ terra a Pern ${ }^{\mathrm{co}}$ em cuja viagem se portou em ordem ao regulam ${ }^{\text {to }}$ da sua vida, co mo se estivera no Claustro. Recolhido q' fosse no Mostr ${ }^{\circ}$ naõ se importou mais de si $\mathrm{m}^{\mathrm{mo}}$. A sua occupaçaõ mais amada era o choro, o $\mathrm{q}^{1}$ frequentou toda a sua vida de dia, e de noite sem attençaõ aos seus $\mathrm{m}^{\text {tos }}$ annos, e achaques. Quando ja naõ podia ler a estante nas Matinas das duas, horas, elle as resava $\left\langle\dagger>{ }\right.$ no $m^{\text {mo }}$ tempo de joelhos na sua cella era impreterivel $\mathrm{p}^{\mathrm{a}}$ elle a satisfaçaõ de todos os Officios nas suas horas determinadas. $\mathrm{O}$ restante da noite até amanhecer o gasta $\mathrm{va}<\mathrm{va}>$. em oraçaõ nas tribunas, e a visitar o SS.Sacram ${ }^{\text {to }}$, e todos os Altares da Igreja, repetindo $\mathrm{m}^{\text {tas }}$ vezes este exercicio no decurso do dia. Dizia missa logo cedo com $\mathrm{m}^{\text {ta }}$ devoçaõ, e de $\mathrm{p}^{\mathrm{s}}$ se recolhia na sua cella, onde naõ estava hum estante ocioso, 
pois eu estava resando os Psalmos do Psalterio, lendo, escrevendo, ou occupado em serviços manuaes; assim dizia elle, de com ter o pensam ${ }^{\text {to }}$, q' voa na ociosid ${ }^{\mathrm{e}} \mathrm{p}^{\mathrm{a}}$ as coisas inuteis; Foi ${ }^{\text {to }}$ austero consigo, comia pouco, e sem escolha de guisados passava as noites quasi com vigilias, eos poucos instantes q' dava de descanço ao corpo era hum leito nú, e so bre hum traviceiro de pao, enfim mortificava se em tu do. Era $\mathrm{m}^{\text {to }}$ am $^{\text {te }}$ da castid. ${ }^{\text {e }}$ naõ se ouvindo ja mais hu ma palavra, (naõ digo) obscena; mas nem ainda mal so an te. Observava com exactidaõ o seu voto de pobresa, desapro piando-se de tudo $\mathrm{m}^{\text {tos }}$ annos antes de morrer. Na sua cel la nada havia nem curioso, [nem] superfluo, só constava de poucos trastes, e estes $\mathrm{m}^{\text {tos }}$ velhos, e carimxozos, e incapazes de passarem seg ${ }^{\text {do }}$ uso; $\mathrm{O}$ amor dos pobres estava gravado no seu coraçaõ; despendia com elles tudo $\mathrm{q}^{\text {to }}$ tinha, e ainda $\mathrm{m}^{\mathrm{mo}}$ se dispensava $\mathrm{p}^{\mathrm{r}}$ os soccorrer do seu necessario. Vivia no Mostro $^{\circ}$ como se nelle naõ existisse, pois apenas ap parecia a visitar algum enfermo, e a ent/re/ter meia hora de honesta conversaçaõ na Botica, e logo se recolhia. Para elle era indeferente q' viesse este, ou $<\mathrm{q}>/ \mathrm{a} \backslash \mathrm{q}^{\text {le }}$ Prelado; pois como nada pertendia senaõ a viver bem, tambem naõ temia q' algum lhe fizesse mal. Sobre tudo he dig no de admirar-se o summo recato q' tinha em occul $-292-$ 
tar as faltas dos seus Irmaõs calando as certas, e descul

$\left[\mathrm{f}^{\mathrm{0}} 147 \mathrm{v}^{\mathrm{o}}\right]$ pando as publicas com a fraquesa humana.

Naõ escandilisava a ninguem, de nada se queixa va, e sempre lançava a boa $\mathrm{p}^{\mathrm{te}}$ as intençoens equi vocas dos Prelados, e dos Subditos; qualid ${ }^{\text {es }}$ estas q' procedi a da moralid ${ }^{\mathrm{e}}$ de seus costumes; pois logo naõ ha esta desapare o homem de bem, e desaparece o Chris taõ, desaparece o Religioso; e q q q $\mathrm{q}^{\mathrm{r}}$, q' a naõ possue se torna hum tigre, hum assacino de credito alheio hum fardo pesado, hum verdugo, hum monstro de $q^{1} q^{r}$ socied. ${ }^{e}$ onde se acha. Em fim naõ tinha deffeito q' lhe notasse-se, a exceptuar hum genio, hum tanto forte, e austero, acompanhado de huma tenacid ${ }^{\mathrm{e}}$; mas devemos lembrar nos, q' a virtude naõ consiste em naõ ter paixoens, mas em sabe-las mortificar, e q' $\mathrm{m}^{\text {tas }}$ acções dos $S^{\text {tos }}$ nem todos foraõ, e ninguem duvida q' elle mor tificou $\mathrm{m}^{\text {to }}$ este defeito do seu proprio natural, /dei*/ xando-o em $\mathrm{m}^{\text {ta }}$ distancia de sua sepultura. Alguns annos antes de falecer, deixou de dizer missa impe dido $\mathrm{p}^{\mathrm{r}}$ huma trabalhosa quebradura, q' de repen te lhe sahia, e o mortificava em extremo; mas naõ deixou de ouvir 2 ou 3 todos os dias, e de continuar nos seus exercicios diarios, e nocturnos nos quais ad qui 
rio tal habito, q' ficando alienado dos sentidos em hum ataque de cerebro, q' teve hum anno antes de mor rer, era a sua especie de loucura e praticalos. Assim vivendo como verdadeiro Religioso caminhava com tranquillid $\mathrm{p}^{\mathrm{a}}$ a morte; elle a esperava com resigna çaõ, e com aq ${ }^{\text {la }}$ segurança q' anima o vir tuoso: esta finalm ${ }^{\text {te }}$ chegou com a velhice, $q$ ' foi a sua principal molestia, a sua aproxima çaõ naõ o alterrou, taõ convencido estava elle de sua certesa, e taõ penetrado das misericordias do Snr q' dizendo lhe hum Religioso 3 dias antes da sua morte q' chamasse o Medico, e elle lhe repondeo; saõ estas as suas formaes palavras - Naõ ha mais nada senaõ eu e D. ${ }^{\mathrm{s}}$ e como eu estou conforme a sua vontad. ${ }^{\mathrm{e}}$ tudo o mais he peta $=$ Em hum dia achando-se mais ata cado de hum sufocaçaõ de peito deitou se na cama andando até ahi de pé, e advertido o Prelado q' estava mal, lhe mandou administrar o Sacram. ${ }^{\text {to }}$ da extre ma Unçaõ, tendo recebido ja antes e da Eucaristia $\mathrm{p}^{\mathrm{r}}$ Viatico, e confessando se repetidas vez es como era o seu costume. Hum quarto depois de ungido espi rou tranquilam ${ }^{\text {te }}$ no amplexo do Snr. deixando atodos os Monges $\mathrm{m}^{\text {to }}$ cancados; pois todos creraõ piam ${ }^{\text {te }}$ a julgar $-294-$ 
da sua vida Christam e Religiosa, q' elle era do numero dos Predestinados. Foi o dia do seu falecim ${ }^{\text {to }}$ aos 23 de Agosto de 1810 tendo de id 89 e 6 meses. Era Abb. ${ }^{\text {e }}$ d este Mos tr $^{\mathrm{o}}$ o M.R.P.P ${ }^{\mathrm{r}}$ Fr. $\mathrm{M}^{\mathrm{el}}$ da Conc ${ }^{\mathrm{am}}$ Rocha.

$$
-2<7>/ 8 \mid<9>/ 0 \backslash-(\underline{280})^{197}
$$

Segue-se a vida e morte de M.R.P.Pr.Jubilado Fr Tho maz de Aquino Gama. Este Religioso nascido na

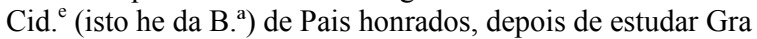
matica nos Pateos da Companhia foi admittido ao nosso $\mathrm{S}^{\text {to }}$ Habito. Teve o seu Noviciado /no Rio*/ de Janr ${ }^{\circ}$. A profissaõ Religiosa, q' lhe foi dada, prova q' elle tinha vocaçaõ pa o Estado q' a naõ desmereceo com os seus costumes, e q' comprio exactam ${ }^{\text {te }}$ com todos os encargos da $\mathrm{q}^{\text {le }}$ anno da approvaçaõ. Depois de chorista foi manda[do] $\mathrm{p}^{\mathrm{a}}$ o Collegio de Perm ${ }^{\mathrm{co}}$; o q aca bado veio $\mathrm{p}^{\mathrm{a}}$ esta casa, e como era pouco soffrido se vio $\mathrm{m}^{\text {tas }}$ vezes a variar de Mostr $^{\circ}$ ja mandando se $\mathrm{p}^{\mathrm{a}}$ os das Brotas, e ja seg ${ }^{\mathrm{da}}$ vez $\mathrm{p}^{\mathrm{a}}$ o de Perm. ${ }^{\mathrm{co}}$ onde deo prin cipio a Urbica, q' concluio neste Mostro ${ }^{\mathrm{o}}$, ja $\mathrm{p}^{\mathrm{a}}$ o da Graça, ja pa este Mostr. ${ }^{\circ}$ donde sempre sahia $p^{a}$ os m. $^{\mathrm{s}}$ e onde afinal acabou. Este Religioso nada apre senta de singular na sua vida senaõ hum genio forte, q' elle chamara zello; mas q' naõ era senaõ -295 -

${ }^{197}$ APFL 
efeito de hum humor cholerico, melancolico q' o

$\left[\mathrm{f}^{\mathrm{0}} 149 \mathrm{r}^{\circ}\right]$

fazia obrar, $\mathrm{p}^{\mathrm{r}}$ este motivo era pouco ama/do dos*/ Re

ligiosos os q' detestavaõ naõ a sua pessoa, mas os seus

transportes violentos, e talve $<\mathrm{s}>|\mathrm{z}|^{198} \mathrm{p}^{\mathrm{r}}$ esta causa foi pouco

empregado nos cargos da Religiaõ; som $^{\text {te }}$ occupou

o Cargo, de Mordomo, de Prior nas Brotas, e de Proc. ${ }^{\text {or }}$ Geral

e renunciou a Abbadia da Graça, q' lhe veio nos seus

ultimos annos, contudo fora deste seu genio, era Reli

gioso observante, devoto veio lhe; e mettido con

10

sigo $\mathrm{m}^{\text {mo }}$ Estava ja jub ${ }^{\mathrm{o}}$, e gozando em boa saude

das $<$ ceso $>$ isençoẽs, e commodos, q' a Religiaõ lhe permit

tia $\mathrm{p}^{\text {los }}$ os seus annos, jubilado do Pulpito, $q^{\text {do }}$ quasi

de repente lhe sobreveio huma hidropesia q' se adi

antou a longos passos $\mathrm{p}^{\mathrm{a}}$ as suas ruinas estas depois

de lhe dar $\mathrm{m}^{\text {to }} \mathrm{q}$ ' sofrer no espaço de 5 mezes (nos q

com effeito naõ se lhe notou alguma impaciencia q' desacreditasse a sua Religiaõ nem fosse filha do seu genio insofrido) the mostrou de perto a sepultura. Conheceo elle o perigo, e desenganado do melhoram $^{\text {to }}$ do corpo cuidou som ${ }^{\text {te }}$ em purificar sua alma $\mathrm{p}^{\mathrm{a}}$ a conta final com repetidas confissoẽs; e receben do $\mathrm{m}^{\text {ta }}$ pied. ${ }^{\mathrm{e}}$ os Sacram. ${ }^{\text {tos }}$ da Igreja pedindo per daõ a todos, e fazendo todos os actos Catholicos e Religiozos $-296-$

${ }^{198}$ A letra $<$ S $>$ foi alterada pelo scriptor que a transforma em $<\mathrm{Z}>$ ao prolongar a sua parte inferior. 
entregou o seu espirito nas maõs do Creador aos 29

de Março de 1811 tendo de id. ${ }^{\mathrm{e}} 70$ annos pouco mais ou menos, e sendo D.Abb ${ }^{\mathrm{e}}$ o M.R.P.Pr.Fr.M ${ }^{\mathrm{el}}$. da Conc ${ }^{\text {an }}$ Rocha.

282 - Segue-se a vida e morte de R.P ${ }^{\mathrm{e}}$.Pr.Urbico Fr. Jose de $\mathrm{S}^{\text {ta }}$ Josepha, e Alm ${ }^{\text {da }}$. Este Religioso natural da $\mathrm{Pa}$ rochia de S.Pedro do Sul, e nascido de Pais honra dos, veio a este Mostr $^{\mathrm{o}}$ na id ${ }^{\mathrm{e}}$ de 25 annos a tomar o nosso $\mathrm{S}^{\text {to }}$ habito < trazendo $>$ trazendo $\mathrm{p}^{\mathrm{r}}$ isso patente de N.R ${ }^{\mathrm{mo}} \mathrm{P}^{\mathrm{e}}$. Geral. Aqui pois noviciou, professou teve o seu Collegio, donde sahio $\mathrm{p}^{\mathrm{a}} \mathrm{o}$ emprego de Pregador Urbico, e foi eleito Prór, e $\mathrm{M}^{\mathrm{e}}$ de obras ao $\mathrm{m}^{\mathrm{mo}}$ tempo: no exercicios d'estes empregos acometteo-o a morte $\mathrm{p}^{\mathrm{a}}$ a q' naõ estava de sorte alguma preparado pri vando-o da vida $\mathrm{p}^{\mathrm{r}}$ meio de huma erisipela, q' the costumava a dar desde o Noviciado. Foi o deste tris te acontecim ${ }^{\text {to }}$ aos 4 de Janr $^{\circ}$ de 1812 , e sendo D. $\mathrm{Abb}^{\mathrm{e}}$ deste Mostr $^{\circ}$ o M.R.P.Pr.Fr.M ${ }^{\mathrm{el}}$ da Conc ${ }^{\mathrm{am}}$ Rocha, tendo de id ${ }^{\mathrm{e}}$ natural 39 annos, e 14 de Religiaõ.(283) Naõ tendo nada q' dizer da vida de R.P.Pr.Fr.M ${ }^{\text {el }}$ de S.Ca etano nos passos $[\dagger]$ particularm $^{\text {te }}$ da sua morte, q' nos pode fazer acautelados. Este Reli gioso nasceo na $\mathrm{V}^{\mathrm{a}}$ da Caxoeira, e foi educado na 
Jacobina debaixo das vistas de seu Pai, q' era Cap ${ }^{\text {am }}$ mor dam ${ }^{\text {ma }}$ villa d'onde veio atomar o habito Mo nastico neste Mostr. ${ }^{\circ}$ Depois de professo, e concluido o seu Collegio teve Patente de Urbico de NR. ${ }^{\text {mo }}$ q' foi obri gado a largar de pois de trez annos de exercicio. Achando se pois desembaraçado, e vendo q' sua Mai viuva vivia pro brem $^{\text {te }}$ em Jacobina, solicitou o seu Nuncio hum Breve de Habito Retento $\mathrm{p}^{\mathrm{a}}$ viver em sua comp. ${ }^{\mathrm{a}}$ e socorrela, mas naõ alcançando senaõ huma liç trienal d'ella se approveitou $\mathrm{p}^{\mathrm{a}}$ seguir o seu intento. Tudo estava prom pto, e feitas as suas despedidas do Mostr ${ }^{\circ}$ acompanha do de huma excessiva alegria q' lhe saltava ao rosto e athé doprojecto de voltar mais, se foi embarcar no caiz de $\mathrm{S}^{\text {ta }}$ Barbara. Mas a morte q' hia escondida no seu seio segurou a sua presa poucos minu tos de pois de se ter elle metido no barco, e no mo $\mathrm{m}^{\text {to }} \mathrm{em} \mathrm{q}^{\text {' jogava as cartas com outros comp }} \mathrm{ros}^{\text {ro }}$ de via gem. Hum agudo grito foi signal do ataque, e a perda da vida se seguio imediatam ${ }^{\text {te }}$. Debalde se ap plicaraõ na $\mathrm{m}^{\mathrm{ma}}$ occasiaõ alguns espiritos, $\mathrm{e}$ depois de todos os soccorros, d'arte $\mathrm{p}^{\mathrm{a}}$ fazer tornar a si, q' ja estava na eternid ${ }^{\mathrm{e}} \mathrm{aq}^{\text {le }}$ q' a pouco antes gozava da perfeita saude, e q' nutria o seu espirito mais das 
risonhas esperanças de ver a patria, q' das funebres imagens de sepulchro. Assim voltou em poucas ho ra $^{\mathrm{a}}$ o Mostr ${ }^{\mathrm{o}}$ ja defunto o $\mathrm{m}^{\mathrm{mo}} \mathrm{q}$ ' projectava naõ voltar mais aelle, deixando a todos os Monges consterna dos, e espavoridos, e ao $\mathrm{m}^{\text {mo }}$ tempo instruidos com seu triste exempl ${ }^{199}$ o da necessid ${ }^{\mathrm{e}}$ de andarmos sempre a parelhados; pois anaõ estarem vigilantes seraõ infa livelm ${ }^{\text {te }}$ desagraçados. Succedeo este lamentavel catastofre em 21 de Junho de 1812 tendo o d ${ }^{\text {to }} \mathrm{P}$. de id $^{\text {e }}$ natural 34 an nos, e de Religoso 13 sendo D.Abb ${ }^{\mathrm{e}}$ d'este Mostr ${ }^{\circ}$ o M.R.P. Pr.Fr. M ${ }^{\text {el }}$ da Conc ${ }^{\text {am }}$ Rocha- $28<1>/ 2 \backslash-(284)$.

Segue-se a vida e morte de M.R.O.D.Abb ${ }^{\mathrm{e}}$ de $\mathrm{S}^{\text {to }}$ Adal berto Fr.Joaõ de $\mathrm{S}^{\text {ta }}$ Anna Nobre. Este Religioso nascido em Pern ${ }^{\mathrm{co}}$ de Pais honrados, e virtuosos, q' o educaraõ no temor de D. ${ }^{\mathrm{s}}$ veio ter o Noviciado a este Mostr ${ }^{0}$ no $\mathrm{q}^{\mathrm{l}}$ feita a sua Profissaõ, depois de alguns annos de chorista passou se a sua patria onde teve o seu collegio, concluidos pois os estudos foi mudado $\mathrm{p}^{\mathrm{a}} \mathrm{o}$ da Paraíba on de foi bastantes annos conventual, servindo-o no Coro Altar Confissionario, e Pulpito; conhecendo o $\mathrm{Abb}^{\mathrm{e}} \mathrm{daq}^{\text {le }}$ Mostr $^{\circ}$ a sua natural activid ${ }^{\mathrm{e}}$ o mandou administrar a fazenda de Maraú /daq ${ }^{\text {le }}$ Mostro*/ onde exerceo $\mathrm{m}^{\text {to }}$ bem as suas obrigaçoens, mas $\mathrm{p}^{\mathrm{r}}$ algumas des $-299-$

${ }^{199}$ A letra $<\mathrm{l}>$ foi escrita com um traço horizontal acima. 
desavenças q' teve com o ${ }^{\text {mo }}$ Prelado, recolheo ao Mostr $^{\circ}$

$\left[\mathrm{f}^{\mathrm{0}} 151 \mathrm{r}^{\mathrm{0}}\right]$ sem ter $\mathrm{p}^{\mathrm{a}}$ isto ordem expressa. $\mathrm{O}$ seo genio forte, in sofrivel, e tena $<\mathrm{s}>/ \mathrm{z}^{200}$ encontrando no $\mathrm{Abb}^{\mathrm{e}} \mathrm{daq}^{\mathrm{le}}$ Mostr. ${ }^{\circ}$ naõ menos aspero, lhe deo q' sofrer dissabores, athé q' ${ }^{r}$ huã obediencia foi removido $\mathrm{p}^{\mathrm{a}}$ o do Rio de $\operatorname{Janr}^{\mathrm{o}}$ alli $<\mathrm{p}^{\mathrm{a}}>$ pou co se demorou, $p^{r} q^{\prime}$ passou se novam ${ }^{\text {te }} p^{a}$ esta casa a $q^{\prime}$ servio nos empregos e Contador, e de Depositario, Proc $^{\text {or }}$ das demandas, no q' tudo mostrou o seu prestimo, e sagacid. ${ }^{\mathrm{e}}$. Aqui entrou a carreira dos seus trabalhos, e encomo dos, q' se pode dizer, o acompanharaõ até a sepultura; $\mathrm{p}^{\mathrm{s}}$ vindo $\mathrm{p}^{\mathrm{r}}$ Proval $\mathrm{aq}{ }^{\mathrm{le}}, \mathrm{q}^{\text {' havia tido }} \mathrm{p}^{\mathrm{r}}$ Prelado na Paraiba, atiou se o antigo odio de $\mathrm{p}^{\text {te }}$ ap $^{\text {te }}$ sem se perdoarem $<\mathrm{d}>/$ m $_{\text {lutuam }}{ }^{\text {te }}$ toda occasiaõ de vingança, $\mathrm{p}^{\mathrm{r}}$ elle com huma constancia, e pertinacia inabalavel triumphou de tudo até q' alcnaçou o previlégio de Missionario, na< $\tilde{o}^{>}$occasiaõ em q' o $\mathrm{S}^{\mathrm{r}}$. Arce Bispo da va principio a visita da sua Diocese. Por toda $\mathrm{p}^{\text {te }} \mathrm{q}^{\text {' }}$ andou foi hum fiel dispenseiro da palavra Divi na, com $\mathrm{m}^{\text {ta }}$ diligencia, e naõ menos proveito recolhen do $\mathrm{m}^{\text {tos }}$ fructos de seu trabalho. Desejoso porem (como elle disia) de ver hum Irmaõ na Corte de Lisboa, $\mathrm{p}^{\mathrm{a}}$ ella se diri(...gio com bene)placito de S.Magestad e depois de pas sados alguns tempos, $\mathrm{q}^{\mathrm{do}}$ se deliberava acompanhar ao

${ }^{200}$ A letra $<\mathrm{S}>$ foi alterada pelo scriptor que a transforma $\mathrm{em}<\mathrm{Z}>$ ao prolongar a sua parte inferior. 
Maranhaõ o Snr'. Bispo de Vizéo po de Jacobina

$\left[\mathrm{f}^{\mathrm{o}} 151 \mathrm{v}^{\mathrm{0}}\right]$ mudou de projecto, e de repente passou-se a Corte de Roma provalvelm ${ }^{\text {te }}$ sem liç̧ do N.R. ${ }^{\mathrm{mo}} \mathrm{P}^{\mathrm{e}}$. Geral Naquella corte, e obteve do $S^{\text {mo }}$ P.Pio VI huma Abbadia in partibus, tendo (como elle contava) a distincta honra de ser Bento pelo Nosso S. ${ }^{\text {mo }}$ P. ${ }^{e}$ Pio VII era Rei nante, q' era entaõ Bispo de Tripole. Depois dever $\mathrm{m}^{\text {tas }}$ rarid. ${ }^{\text {es }}$ e correr algumas Cid. ${ }^{\text {es }}$ da Italia passou -se a Lx. ${ }^{\text {a }}$ onde a nossa Congregação qui $<\mathrm{s}>/\left.\mathrm{z}\right|^{201}$ recolher a Secretaria dos Estados os seus papeis; mas com a pro cteçaõ do Sobredito Bispo de vizêo, conseguio, < conseguio > de sua Magestad ${ }^{\mathrm{e}}<$ deusar $>$ de usar do prevelegio comce dido $\mathrm{p}^{\mathrm{r}}<\mathrm{p}>/$ S.. .Santid. ${ }^{\mathrm{e}}$ e concluidos os seus negocios, partio $\mathrm{p}^{\mathrm{a}}$ a Prov. ${ }^{\mathrm{a}}$ chegou finalm ${ }^{\text {te }}$ a este Mostr. ${ }^{\circ}$ no ano 1783 e poucos dias dep ${ }^{\mathrm{s}}$ foi prestar obediencia ao $\mathrm{Ex}^{\mathrm{mo}} \mathrm{Snr}$ ' ArceBispo D.Fr. An ${ }^{\text {to }}$ Corrêa. Passados aluns annos chegaraõ algumas Actas da Congregaçaõ, onde se ordenava, q' o expulsassem do Mostr ${ }^{\mathrm{o}}, \mathrm{p}^{\mathrm{r}}$ isso q' não convinha residirem na Clausura $\mathrm{Abb}^{\mathrm{es}}$ titulares, q' sem conhecer superiores, nem sugeitar as pensõens, querem perce ber as regulias, mas allegando elle a simples razaõ de q' S.Santid. ${ }^{\mathrm{e}}$ o naõ despensara dos votos Religosos (m. ${ }^{\text {mo }}$ e da obediencia q' naõ queria prestar) $\mathrm{v}(. .$.$) / fei-/$

$$
\text { po } \begin{array}{r}
\text { tas } \\
-301-
\end{array}
$$

${ }^{201}$ A letra $<$ S $>$ foi alterada pelo scriptor que a transforma $\mathrm{em}<\mathrm{z}>$ ao inserindo uma haste inferior na letra. 
poseraõ lhe uma demanda $\mathrm{p}^{\mathrm{a}}$ a lançar fora. Resol veo Bullas, invictou privelegios, não poupou artificios delig. ${ }^{\text {cia }}$ e dinr. ${ }^{\circ} \mathrm{p}^{\mathrm{a}} \mathrm{o}$ bom exito de sua causa, mas vendo frustados os seus intentos passando mil encomodos, miserias, e (em abono da verd ${ }^{\mathrm{e}}$ ) varias desfeitas de alguns Religiosos, lá foi a seg. ${ }^{\text {da }} \mathrm{ve}<\mathrm{s}>|\mathrm{z}|{ }^{202} \mathrm{a} \mathrm{Lx}$ e nada conseguindo do q' intentava, passou-se a Pernam. ${ }^{\mathrm{co}}$, onde pouco se demorou, e d'alli $\mathrm{p}^{\mathrm{a}}$ este Mos teiro. Continuou a demanda, e em virtude d'ella con tinuaraõ os seus trabalhos, e necessid. ${ }^{\text {es }}$ Em huma vi da errante, e atropellada foi passando ora no Mos tr. $^{\circ}$ ora na $<$ Graça $>$ Barra da Caxr. ${ }^{a}$ negociando $\mathrm{p}^{\mathrm{r}}$ todos os modos $\mathrm{p}^{\mathrm{a}}$ assim se mãter insuficientem ${ }^{\text {te }}$ no q' foi $\mathrm{m}^{\text {to }}$ infeli $<\mathrm{s}>/ \mathrm{z} \backslash$, e ainda mais costante. Finalm ${ }^{\text {te }}$ huma viagem q' fez a Inhmabube, alem de huma id. $.^{\mathrm{e}}<\mathrm{a}>$ avançada veio $\mathrm{p}^{\mathrm{r}}$ termo a Sua laboriosa vida; $\mathrm{p}^{\mathrm{r}} \mathrm{q}$ ' na volta embarcando apesar do furor do vento Sul nau fragou perdendo tudo q' trasia, e ainda $\mathrm{p}^{\mathrm{r}}$ felicid ${ }^{\mathrm{e}}$ foi aportar a humas praias rigorosas, e desabridas d'on $\mathrm{de}<\mathrm{a}>/ \mathrm{o} \backslash$ troxeraõ $\mathrm{p}^{\mathrm{a}}$ este Mostr. ${ }^{\circ}$, e em poucos dias com cluio-se. He cousa dificultosa clacificar o carater d'es te Religioso, $\mathrm{p}^{\mathrm{s}}$ (com elle dizia, e praticava) sempre es/tudou q'/ ninguem soubesse q o tinha $\mathrm{p}^{\text {los }}$ pez nem $\mathrm{p}^{\mathrm{la}}$ $-302-$

${ }^{202}$ A letra $<$ S $>$ foi alterada pelo scriptor que a transforma $\mathrm{em}<\mathrm{Z}>$ ao inserir, apenas, uma haste inferior na letra. 
cabeça, e q' se verificou até arespeito da sua morte

$\left[\mathrm{f}^{\mathrm{0}} 152 \mathrm{v}^{\mathrm{o}}\right]$ com tudo era estado de juiso our e de bastante perspi cacia, e artificios, era as ve $<\mathrm{s}>/$ zles jovial; porem sempre teimoso, e malfazejo: porem deve se confessar q' naõ faltava oChoro de cujo Snr' era mũi devoto inculcando $\mathrm{p}^{\mathrm{r}}$ toda $\mathrm{p}^{\text {rte }}$ a sua devoçaõ, $\mathrm{q}^{\prime}$ conservou até a morte. Foi o dia do seu fallecim ${ }^{\text {to }}$ aos 29 de Fever. $^{\circ}$ de 1813 com de id. $^{\text {e }}$ sendo D.Abb. ${ }^{\mathrm{e}}$ e M.R.P.Pr.Fr.M ${ }^{\mathrm{e}}$ de Conc ${ }^{\text {am }}$ Rocha. $-28<2>/ 3 \backslash-(285)^{203}$ Segue se a vida e a morte do M.R.P ${ }^{\mathrm{e}}$.Fr.Joaõ de $\mathrm{S}^{\text {ta }}$ Gertrudes Carnoto, este Religioso nascido nesta $\mathrm{Ci}$

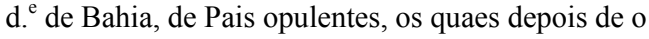
instruirem no Santo timor de Deos o mandaraõ frequentar as escollas, e vendo q' elle tinha inclina çaõ $\mathrm{p}^{\mathrm{a}}$ vida Religiosa, lhe alcançaraõ Patente do $\mathrm{R}^{\mathrm{mo}} \mathrm{P}^{\mathrm{e}}$.Geral. Neste Mostr. ${ }^{\circ}$ tomou o $\mathrm{S}^{\text {to }}$ habito; Com pletos os annos do Chorista, ordenado de Sacerdote foi ouvir Filosofia, e Theologia no Mostr. ${ }^{\circ}$ de Per nanbuco Donde voltou $\mathrm{p}^{\mathrm{a}}$ este, onde foi Contador toda a sua vida. Procurador Geral 18 annos, D Abb do Mostr. ${ }^{\circ}$ das Brotas. $\mathrm{Abb}^{\mathrm{e}}$ eleito do Mostr ${ }^{\mathrm{o}}$ do Rio de Janr. ${ }^{\circ}$, da Graça, da Paraíba e finalm ${ }^{\text {te }}$. Definidor N. ${ }^{\circ}$ Foi Religioso honesto; amigo de prestar sem de $-303-$

${ }^{203} \mathrm{APFL}$ 
defferença de pessoas, recolhido, e taõ amante do silencio, q' pou< $<$ ç>/clas vezes apparecia nos Salões e $\mathrm{p}^{\mathrm{r}}$ este motivo nenhum Religioso se queixava d'elle. Este $\mathrm{P}^{\mathrm{e}}$. cuja vida devia ser immortal $\mathrm{p}^{\mathrm{a}}$ reforma de alguns, q' vivem descuidados pagou o tributo de nascido na id. ${ }^{\mathrm{e}} 85$ annos incompletos no seu ju iso perfeito tendo recebido os Sacram ${ }^{\text {tos }}$ da Igreja com toda a disposiçaõ, q' deve ter hum Chris taõ, hum Sacerdote, hum Religioso. Foi o dia de sua morte no dia [个de] Reis no anno de 1814 Sendo Presid $^{\text {te }}$ deste Mostr. ${ }^{\circ}$ o M.R.P. ${ }^{\mathrm{e}}$.M.DrJub ${ }^{\mathrm{o}}$ Fr. Jose de $\mathrm{S}^{\text {ta }}$ Escolastica e Olivr. ${ }^{\text {a }}-28<3>/ 4 \backslash-(286)^{204}$ Segue se a vida, e morte do P. Pregador Fr.An ${ }^{\text {to }}$ Joaq $^{\mathrm{m}}$ de N.S. das Dores Rocha. Este religioso nascido em Portugal de Pais honestos, tomou o habito no nosso Mostr ${ }^{\circ}$ do Porto, e neste Mostro teve o seu Noviciado fei ta a profissaõ como ja tinha id. ${ }^{\mathrm{e}}$ foi logo orde nado. Neste Mostr. ${ }^{\circ}$ foi Collegial, feito o Sermaõ de prova, e os mais actos recebeo Patente de Pre gador. Administrou o Eng. ${ }^{\circ}$ de S.Bento, foi Prior, Procurador do Mostr. ${ }^{\circ}$ da Graça d'onde 
foi removido para este Mosteiro, por ordem do N.R. ${ }^{\mathrm{mo}}$ Geral P.M.Fr.Francisco d/os/

Prazeres. Foi Porteiro mor, administra/dor/ da capella de Monteserrate, e por fim [hor- $]^{205}$ telaõ. Vendo, que, alguns visinhos the qu/e*/ riaõ mal, porque nimiamente zeloso, $\mathrm{n}[\mathrm{aõ}]^{206}$ consentia que se fizessem furtos na dita ho[r- $]^{207}$ ta, e continuadamente contra elle faziaõ queixas, e representações ao Prelado, que po/r/ esse motivo lhe tirou a administraçaõ, recolh/e/ o-se a sua cella dizendo que estava doente, /e/ o que naõ foi acreditado, inda mesmo pelos medicos: passado pouco mais de um anno foi accommettido de uma apoplexia, que lhe tirou a vida aos 62 annos incompletos de sua idade: dizem que se tinha con fessado dias antes. Foi o dia de seo falleci mento em $1^{\circ}$ de Abril de 1815 - sendo D.Abb. ${ }^{\text {e }}$ ' este Mosteiro - O.N.M.R.P.M. $\mathrm{Jub}^{\circ}$ e $\mathrm{D}^{\mathrm{or}}$ Fr. Jose de Santa Escol ${ }^{208}$ astica e Oliveira.- - . - . $-305-$

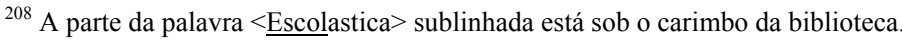





\section{CONSIDERAÇÕES FINAIS}

Claire Blanche-Benveniste (1998) chama atenção para o fato de que nos textos manuscritos medievais é usual que o editor não corrija as grafias do texto, pois estas são características de um estado antigo da língua, o que significa que toda modernização seria uma espécie de traição. No entanto, para textos mais recentes o problema se apresenta de formas diversas. Quanto mais antiga é a época do texto, mais normal parece ser o fato de respeitar a grafia.

Edições modernizadoras têm sua função específica e são de grande utilidade quando o objetivo do trabalho é prioritariamente dar acesso, a um público mais amplo, ao conteúdo em si do texto em questão. No entanto, claro está que esse tipo de edição torna-se absolutamente sem valor para os estudos linguísticos, posto que subtraem dos que a consultam a possibilidade de perceber no texto características de um estado de língua nos mais variados aspectos: sejam eles sintáticos, semânticos, morfológicos ou fonológicos.

Como os dados linguísticos de séculos passados têm praticamente como única possibilidade de estudo os textos preservados através do tempo, a edição conservadora é uma das ferramentas mais importantes e indispensável para o trabalhos linguísticos nesta linha. Portanto, a edição deste material, ora apresentada, é apenas o primeiro passo para muitas possibilidade de leitura e análise da história deste que é o primeiro Mosteiro de todas as Américas, de uma das congregações religiosas mais antigas e mais importantes do mundo.

A intenção desta edição, cujo trabalho está apenas no início, visto que, em tempo oportuno, se pretende editar todos os demais volumes existentes deste documento, é a de preservar o material e seu conteúdo, com valor histórico para a Ordem Religiosa em questão e para a Bahia, e, principalmente, trazer à tona uma "realidade" e um texto representativo em termos de vocabulário, sintaxe, grafia e abreviaturas, dos primeiros séculos de fundação do Brasil. A proposta do trabalho partiu dos próprios monges do Mosteiro de São Bento da Bahia, que querem dar a conhecer ao público em geral, um pouco da sua história cotidiana, que aqui está. 


\section{REFERÊNCIAS}

ACCIOLI, Vera Lúcia Costa. A escrita no Brasil colonial: um guia para leitura de documentos manuscritos. Recife: EDUFPE; Fund. Joaquim Nabuco; Massangana, 1994.

AUDISIO, Gabriel; BONNOT-RAMBAUD, Isabelle. Lire le français d'hier: manuel de paléographie moderne (XVème-XVIIIème siécles). Paris: Armand Colin, 1991.

AZZI, Riolando. A Sé Primacial de Salvador: a igreja católica na Bahia. 1551-2001. v. 1. Petropólis: Vozes, 2001.

BERWANGER, Ana Regina; LEAL, João Eurípedes Franklin. Noções de Paleografia e de Diplomática. 2. ed. Santa Maria: Editora da UFSM, 1995.

BLANCHE-BENVENISTE, Claire. Estudios linguisticos sobre la relación entre oralidad y escritura. Barcelona: Gedisa, 1998.

BLEUCA, José Manuel; GUTIÉRREZ, Juan; SALA, Lídia (Ed.). Estúdios de grafemática em el domínio hispânico. Colômbia: Imprenta Patriótica del Instituto Caro y Cuervo, 1998.

BLOOMFIELD, Leonard. Lenguaje. Lima: USMSM, 1964.

CAMBRAIA, César Nardelli. Introdução à crítica textual. São Paulo: Martins Fontes, 2005.

CANO AGUILAR, Rafael. Introducción al análisis filológico. Madrid: Editorial Castalia, 2000.

CASTRO, Ivo. Curso de História da Língua Portuguesa. Lisboa: Universidade Aberta, 1991.

CHASSANT, L. A. Dictionnaire des abéviations latines et françaises: usités dans les inscriptions lapidaires et métalliques, les manuscrits et les chartes du Moyen-âge. Hildensheim: Georg Olms, 1965.

CINTRA, Lindley; CUNHA, Celso. Nova Gramática do Português Contemporâneo. 3. ed. Rio de Janeiro: Nova Fronteira, 2001.

CONDÉ, Gérard D'Arundel de. Apprendre a lire les archives: 100 exercices pratiques (XVème-XIXème siécles). Paris: Christian, 1996.

CONTRERAS, Lídia. Ortografia y grafémica. Madrid: Visor, 1994.

CONTRERAS, Luis Núñez. Manual de paleografia: fundamentos e historia de la escritura latina hasta el siglo VIII. Madrid: Catedra, 1994. 
CUNHA, Antônio Geraldo da. Dicionário etimológico Nova Fronteira da língua portuguesa. 2. ed. Rio Janeiro: Nova Fronteira, 2000.

FIORIN, José Luiz. Elementos da análise do discurso. 6. ed. São Paulo: Contexto, 1997.

FLEXOR, Maria Helena Ochi. Abreviaturas: manuscritos dos séculos XVI ao XIX. 2. ed. São Paulo: UNESP, 1990.

FOUCAULT, Michel. Arqueologia do saber. 7. ed. Rio de Janeiro: Forense Universitária, 2004.

GAMA, Albertina Ribeiro da. Glossário de abreviatura. In: GAMA, Nilton Vasco da. Album de paleografia. v. 3 Salvador: UFBA; IL; DLR, 1982.

HIGOUNET, Charles. História concisa da escrita. 10. ed. São Paulo: Parábola Editorial, 2003.

LEÃO, Duarte Nunes do. Ortografia da língua portuguesa: reduzida a arte e preceitos. In: LEÃO, Duarte Nunes do. Ortografia e origem da língua portuuguesa. Lisboa: Imprensa Nacional; Casa da Moeda, 1983. Introd.,notas e leitura de Maria Leonor Carvalhão Buescu. p. 43-186.

LOSE, Alícia Duhá. Critérios para edição conservadora do Dietário (1582-1815) do Mosteiro de São Bento da Bahia. São Paulo: ABRALIC, 2007 (comunicação oral não publicada).

MAINGUENAU, Dominique. Discurso literário. Tradução Adil Sobral. São Paulo: Contexto, 2006. p. 13-45

MARQUILHAS, Rita. A Faculdade das letras: leitura e escrita em Portugal no séc. XVII. Lisboa: Imprensa Nacional Casa da Moeda, 2000.

MARQUILHAS, Rita. Norma gráfica setecentista: do autógrafo ao impresso. Lisboa, Instituto Nacional de Investigação Científica; Centro de linguística da Universidade de Lisboa, 1991.

MARTINEZ ORTEGA, Maria de Los Angeles Martínez. La lengua de los síglos XVI y $X V I I$ : a través de los textos jurídicos los pleitos cíviles de la escribaria de Alonso Rodrigues. Valladolid: Secretariado de Publicações, 1999.

MARTINS, Wilson. A palavra escrita: história do livro, da imprensa e da biblioteca. 3 . ed. São Paulo: Ática, 2002.

MICHON, Louis-Marie; CALOT, Frantz; ANGOULVENT, Paul. L'art du livre en France. Des origines à nos jours. Paris: Delagrave, 1931.

MOISÉS, Massaud. Dicionário de termos literários. São Paulo: Cultrix, 1974.

MONTEIRO, José Lemos. A estilística. São Paulo: Ática, 1991.

NOGUEIRA, Carlos Roberto F. O Diabo no imaginário cristão. Bauru: EDUSC, 2000. 
NÚÑEZ CONTRERAS, Luis. Manual de paleografia: fundamentos e história de la escritura latina hasta el siglo VIII. Madrid: Catedra, 1994.

ORTEGA, Maria de los Ángeles Martínez. La lengua de los síglos XVI y XVII através de los textos jurídicos, los pleitos cíviles de la escribaria de Alonso Rodriguez.

Valladolid: Universidad de Valladolid, 1999.

PAIXÃO, OSB., Dom Gregório. São Bento: um mestre para o nosso tempo. 2. ed. Salvador: Edições São Bento, 1996.

PEREIRA, Teresa Leal Gonçalves; TELLES, Célia Marques. A problemática concernente ao desenvolivimento de abreviaturas. In: SEMINÁRIO DE

ARQUIVOLOGIA. Salvador: EBD, 1982. 12 f. Comunicação não publicada.

PICCHIO, Luciana Stegagno. A Lição do texto: filologia e literatura (Idade Média).

Lisboa: Edições 70, 1979. (Colecção Signos, 20)

POTTIER, Bernard. Linguística General: teoria y descripción. Madrid: Gredos, 1976.

PROU, Maurice. Manuel de paléogrphie latine et française. Paris: Alphonse Picard, 1910 .

ROCHA, Mateus Ramalho. Igreja do Mosteiro de São Bento da Bahia: história de sua construção. Separata da Revista do Instituto Histórico Geográfico da Bahia, 1997.

ROMAN BLANCO, Ricardo. Estudos paleográficos. São Paulo: Laserprint, 1987.

SANTOS, Arlete Silva. Revelações de um documento do séc XVIII. Disponível em: $<$ www.filologia.org.br/vcnlf/anais>. Acesso em: 14 set. 2007.

SÃO BENTO. A Regra de São Bento. Tradução dos monges beneditinos, OSB. Salvador: Edições São Bento, 2004.

SILVA, Tais Cristófaro. Fonética e Fonologia do Português. São Paulo: Contexto, 2000 .

SPINA, Segismundo. Introdução à edótica: crítica textual. 2. ed. São Paulo: Ars Poetica; EDUSP, 1994.

TELLES, Célia Marques; RIBEIRO, Ilza. A Crônica geral de Espanha: aspectos discursivos e a ordenação dos constituintes. Estudos Linguísticos e Literários, Salvador, n. 33-34, p. 127-155, jan.-dez. 2006.

WEENRICH, Harold. Estructura y función de los tiempos em el lenguage. Trad. De Federico Latorre. Madrid: Gredos, 1968. 


\section{DIETÁRIO \\ ÍNDICE \\ DE \\ NOMES}

\section{A}

\begin{tabular}{|c|c|}
\hline Adriano de S. Escolastica & {$\left[\mathrm{f}^{\mathrm{o}} 109 \mathrm{v}^{\mathrm{o}}\right]$} \\
\hline Agostinho da Encarnação & {$\left[\mathrm{f}^{\mathrm{o}} 89 \mathrm{r}^{\mathrm{o}}\right]$} \\
\hline Agostinho do Nascimento & {$\left[\mathrm{f}^{\circ} 84 \mathrm{r}^{\circ}\right]$} \\
\hline da Piedade & {$\left[\mathrm{f}^{\mathrm{o}} 15 \mathrm{r}^{\circ}\right]$} \\
\hline Ribeiro & {$\left[\mathrm{f}^{\mathrm{o}} 64 \mathrm{r}^{\circ}\right]$} \\
\hline de $\mathrm{St}^{\mathrm{a}}$ Monica & {$\left[\mathrm{f}^{\mathrm{0}} 54 \mathrm{r}^{\circ}\right]$} \\
\hline Alberto da Purificação & {$\left[\mathrm{f}^{0} 52 \mathrm{r}^{\mathrm{o}}\right]$} \\
\hline Alcuino de Jesus & {$\left[\mathrm{f}^{\mathrm{o}} 41 \mathrm{v}^{\mathrm{o}}\right]$} \\
\hline Alexandre de S. Bento & {$\left[\mathrm{f}^{\mathrm{o}} 52 \mathrm{r}^{\mathrm{o}}\right]$} \\
\hline da Encarnação & {$\left[\mathrm{f}^{\circ} 10 \mathrm{r}^{\circ}\right]$} \\
\hline da Purificação & {$\left[\mathrm{f}^{\mathrm{o}} 122 \mathrm{r}^{\mathrm{o}}\right],\left[\mathrm{f}^{\mathrm{o}} 125 \mathrm{r}^{\mathrm{o}}\right]$} \\
\hline Vieira & {$\left[\mathrm{f}^{\circ} 76 \mathrm{v}^{\mathrm{o}}\right]$} \\
\hline Alvaro da Madre de Deus & {$\left[\mathrm{f}^{\mathrm{o}} 66 \mathrm{v}^{\mathrm{o}}\right]$} \\
\hline Amaro de S. Domingos & {$\left[\mathrm{f}^{\mathrm{o}} 22 \mathrm{r}^{\mathrm{o}}\right]$} \\
\hline Ambrosio da Assumpção & {$\left[\mathrm{f}^{\mathrm{o}} 81 \mathrm{v}^{\mathrm{o}}\right]$} \\
\hline Anastacio da S. Quiteria & {$\left[\mathrm{f}^{\mathrm{o}} 61 \mathrm{r}^{\mathrm{o}}\right]$} \\
\hline André, da Cruz & (Diet. Rio: 82$)\left[\mathrm{f}^{\mathrm{o}} 31 \mathrm{r}^{\mathrm{o}}\right],\left[\mathrm{f}^{\mathrm{o}} 31 \mathrm{v}^{\mathrm{o}}\right],\left[\mathrm{f}^{\mathrm{o}} 32 \mathrm{v}^{\mathrm{o}}\right]$ \\
\hline André do Espirito Santo & {$\left[\mathrm{f}^{\mathrm{o}} 116 \mathrm{r}^{\mathrm{o}}\right]$} \\
\hline Angelo da Assumpção & {$\left[\mathrm{f}^{\mathrm{0}} 71 \mathrm{v}^{\mathrm{o}}\right]$} \\
\hline Anselmo da Annunciação & {$\left[\mathrm{f}^{\mathrm{o}} 46 \mathrm{r}^{\mathrm{o}}\right]$} \\
\hline do paraizo & {$\left[\mathrm{f}^{\circ} 90 \mathrm{v}^{\circ}\right]$} \\
\hline da Trindade & {$\left[\mathrm{f}^{\circ} 42 \mathrm{r}^{\circ}\right]$} \\
\hline Antonio de Santana Buticario & {$\left[\mathrm{f}^{\mathrm{o}} 125 \mathrm{r}^{\circ}\right]$} \\
\hline Barreiros (Bispo) & {$\left[\mathrm{f}^{0} 2 \mathrm{v}^{\mathrm{o}}\right]$} \\
\hline de S. Bento (1) & {$\left[\mathrm{f}^{\circ} 34 \mathrm{r}^{\circ}\right]$} \\
\hline " " " " (2) & {$\left[\mathrm{f}^{\mathrm{o}} 60 \mathrm{v}^{\mathrm{o}}\right]$} \\
\hline " " " $"$ (3) & {$\left[\mathrm{f}^{\mathrm{o}} 91 \mathrm{v}^{\mathrm{o}}\right]$} \\
\hline " " " (4) & {$\left[\mathrm{f}^{\mathrm{o}} 106 \mathrm{v}^{\circ}\right]$} \\
\hline Bernardo da Expectação & {$\left[\mathrm{f}^{\mathrm{o}} 128 \mathrm{r}^{\mathrm{o}}\right]$} \\
\hline Antonio Catelam & {$\left[\mathrm{f}^{\mathrm{o}} 25 \mathrm{v}^{\mathrm{o}}\right]$} \\
\hline 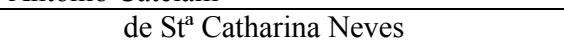 & {$\left[\mathrm{f}^{\mathrm{o}} 129 \mathrm{r}^{\circ}\right]$} \\
\hline da Conceição & {$\left[\mathrm{f}^{0} 81 \mathrm{v}^{\mathrm{o}}\right]$} \\
\hline Antonio Corrêa, Dom. Fr: Arcebispo & {$\left[\mathrm{f}^{\mathrm{o}} 151 \mathrm{v}^{\mathrm{o}}\right]$} \\
\hline da Costa (Camarista) & {$\left[\mathrm{f}^{\mathrm{o}} 2 \mathrm{v}^{\circ}\right]$} \\
\hline da Encarnação Pinna & {$\left[\mathrm{f}^{\mathrm{o}} 11 \mathrm{r}^{\mathrm{o}}\right]$} \\
\hline " " " " & {$\left[\mathrm{f}^{\mathrm{o}} 128 \mathrm{v}^{0}\right],\left[\mathrm{f}^{\mathrm{o}} 132 \mathrm{r}^{\mathrm{o}}\right]$} \\
\hline " Esperança & {$\left[\mathrm{f}^{\mathrm{o}} 22 \mathrm{r}^{\circ}\right]$} \\
\hline "Fernandez Pantoja (Camarista) & {$\left[\mathrm{f}^{0} 2 \mathrm{v}^{\mathrm{o}}\right]$} \\
\hline da Graça & {$\left[\mathrm{f}^{\mathrm{o}} 63 \mathrm{v}^{\circ}\right]$} \\
\hline de Jesus & {$\left[\mathrm{f}^{\mathrm{o}} 65 \mathrm{r}^{\mathrm{o}}\right]$} \\
\hline Joaquim de N.S. das Dôres Rocha & {$\left[\mathrm{f}^{\mathrm{o}} 153 \mathrm{r}^{\circ}\right]$} \\
\hline de S.José Valença & {$\left[\mathrm{f}^{\mathrm{o}} 144 \mathrm{r}^{\mathrm{o}}\right]$} \\
\hline Antonio Lessa & {$\left[\mathrm{f}^{\mathrm{0}} 73 \mathrm{r}^{\mathrm{o}}\right]$} \\
\hline Luiz de Camará Coitinho (governador) & {$\left[\mathrm{f}^{\mathrm{0}} 57 \mathrm{v}^{\mathrm{o}}\right]$} \\
\hline
\end{tabular}




\begin{tabular}{|c|c|}
\hline da Luz & {$\left[\mathrm{f}^{\mathrm{p}} 111 \mathrm{v}^{0}\right]$} \\
\hline Manoel & {$\left[\mathrm{f}^{\mathrm{o}} 102 \mathrm{v}^{\circ}\right]$} \\
\hline dos Martires & {$\left[\mathrm{f}^{0} 33 \mathrm{r}^{\circ}\right]$} \\
\hline de Santa Margarida & {$\left[\mathrm{f}^{\mathrm{o}} 121 \mathrm{r}^{\mathrm{o}}\right]$} \\
\hline da Natividade & {$\left[\mathrm{f}^{\circ} 27 \mathrm{v}^{\circ}\right]$} \\
\hline de S.Paulo & {$\left[\mathrm{f}^{0} 14 \mathrm{r}^{\circ}\right]$} \\
\hline Pereira & {$\left[\mathrm{f}^{0} 36 \mathrm{r}^{\circ}\right]$} \\
\hline do Rosario & {$\left[\mathrm{f}^{\circ} 120 \mathrm{r}^{\circ}\right]$} \\
\hline Luiz de N.S.da Penna & {$\left[\mathrm{f}^{\mathrm{0}} 143 \mathrm{v}^{\circ}\right]$} \\
\hline Antonio dos Serafins & {$\left[\mathrm{f}^{\mathrm{0}} 92 \mathrm{v}^{\circ}\right]$} \\
\hline da Silva & {$\left[\mathrm{f}^{0} 47 \mathrm{r}^{\circ}\right]$} \\
\hline Antonio da Santa Cardêra (governador) & {$\left[\mathrm{f}^{4} 46 \mathrm{v}^{0}\right]$} \\
\hline da Trindade (1) & {$\left[\mathrm{f}^{0} 28 \mathrm{r}^{\circ}\right]$} \\
\hline$" \prime \prime \quad(2)$ & {$\left[\mathrm{f}^{0} 79 \mathrm{v}^{\circ}\right]$} \\
\hline " "Ramos & {$\left[\mathrm{f}^{0} 55 \mathrm{r}^{\circ}\right]$} \\
\hline Ventura (fundador) & {$\left[\mathrm{f}^{\mathrm{o}} 4 \mathrm{v}^{\circ}\right]$} \\
\hline da Victoria (1) & {$\left[\mathrm{f}^{\circ} 95 \mathrm{r}^{\circ}\right]$} \\
\hline$" \quad " \quad(2)$ & {$\left[\mathrm{f}^{\mathrm{0}} 132 \mathrm{v}^{\circ}\right]$} \\
\hline Augusto da Apresentação & {$\left[\mathrm{f}^{\mathrm{o}} 62 \mathrm{v}^{\circ}\right]$} \\
\hline da Encarnação & {$\left[\mathrm{f}^{\mathrm{o}} 89 \mathrm{r}^{\circ}\right]$} \\
\hline
\end{tabular}

B

\begin{tabular}{|c|c|}
\hline Balthazar de S. Bento & {$\left[\mathrm{f}^{\mathrm{0}} 116 \mathrm{v}^{\circ}\right]$} \\
\hline " de S. Catharina & {$\left[\mathrm{f}^{0} 34 \mathrm{v}^{\circ}\right]$} \\
\hline de S. Gertrudes & {$\left[\mathrm{f}^{0} 57 \mathrm{r}^{\circ}\right]$} \\
\hline Bartolomeu de Jesus & {$\left[\mathrm{f}^{\mathrm{o}} 116 \mathrm{r}^{\circ}\right]$} \\
\hline dos Martires & {$\left[\mathrm{f}^{\mathrm{o}} 117 \mathrm{r}^{\circ}\right]$} \\
\hline Basilio das Neves & {$\left[\mathrm{f}^{\mathrm{o}} 103 \mathrm{r}^{\circ}\right]$} \\
\hline Bazilio da Ascenção & {$\left[\mathrm{f}^{\mathrm{o}} 26 \mathrm{r}^{\circ}\right]$} \\
\hline Belchior da Encarnação & {$\left[\mathrm{f}^{\mathrm{o}} 100 \mathrm{r}^{\circ}\right]$} \\
\hline "da Trindade & {$\left[\mathrm{f}^{\mathrm{0}} 58 \mathrm{v}^{\circ}\right]$} \\
\hline Benedicto de $\mathrm{St}^{\circ}$ Antonio & {$\left[\mathrm{f}^{\mathrm{o}} 107 \mathrm{r}^{\circ}\right]$} \\
\hline " S. Bernardo & {$\left[\mathrm{f}^{0} 44 \mathrm{r}^{0}\right]$} \\
\hline Bento & {$\left[\mathrm{f}^{\mathrm{o}} 3 \mathrm{r}^{\mathrm{o}}\right]$} \\
\hline " & {$\left[\mathrm{f}^{\mathrm{0}} 123 \mathrm{r}^{\circ}\right]$} \\
\hline da Conceição Araujo & {$\left[\mathrm{f}^{\mathrm{o}} 136 \mathrm{v}^{\circ}\right]$} \\
\hline da Cruz & {$\left[\mathrm{f}^{0} 21 \mathrm{r}^{\mathrm{o}}\right]$} \\
\hline da Graca & {$\left[\mathrm{f}^{\circ} 105 \mathrm{r}^{\circ}\right]$} \\
\hline da Piedade & {$\left[\mathrm{f}^{\mathrm{p}} 33 \mathrm{v}^{\circ}\right]$} \\
\hline Rangel & {$\left[\mathrm{f}^{\mathrm{o}} 19 \mathrm{v}^{\circ}\right]$} \\
\hline do Rosario & {$\left[\mathrm{f}^{\mathrm{0}} 34 \mathrm{v}^{\circ}\right]$} \\
\hline da Santa Barbara & {$\left[\mathrm{f}^{\mathrm{o}} 135 \mathrm{v}^{\circ}\right]$} \\
\hline da Victoria & {$\left[\mathrm{f}^{\mathrm{P}} 31 \mathrm{r}^{\mathrm{o}}\right]$} \\
\hline da Victoria & {$\left[\mathrm{f}^{\circ} 45 \mathrm{v}^{\circ}\right]$} \\
\hline Viegas & {$\left[\mathrm{f}^{\mathrm{p}} 9 \mathrm{r}^{\mathrm{o}}\right]$} \\
\hline Bernardinho de S. Miguel & {$\left[\mathrm{f}^{\mathrm{o}} 106 \mathrm{r}^{\circ}\right]$} \\
\hline
\end{tabular}




\begin{tabular}{|c|c|}
\hline dos Reis & {$\left[\mathrm{f}^{\mathrm{o}} 25 \mathrm{r}^{\mathrm{o}}\right]$} \\
\hline $\begin{array}{l}\text { Bernardo Antonio de St }{ }^{\mathrm{a}} \text { Maria dos Anjos } \\
\text { Delgado }\end{array}$ & {$\left[\mathrm{f}^{\mathrm{0}} 128 \mathrm{v}^{\circ}\right]$} \\
\hline " de Braga & $\begin{array}{l}\text { Olinda: Ver. Inst. Arq Vol. XXXVII; } \\
\text { pg. } 33\end{array}$ \\
\hline da Cruz & {$\left[\mathrm{f}^{\mathrm{o}} 121 \mathrm{r}^{\circ}\right]$} \\
\hline Bernardo da Encarnação & {$\left[\mathrm{f}^{\mathrm{o}} 4 \mathrm{v}^{\mathrm{o}}\right],\left[\mathrm{f}^{\mathrm{o}} 110 \mathrm{r}^{\mathrm{o}}\right]$} \\
\hline de Santa Maria & {$\left[\mathrm{f}^{\mathrm{P}} 29 \mathrm{v}^{\circ}\right]$} \\
\hline Boaventura de Santa Quiteria & {$\left[\mathrm{f}^{\mathrm{p}} 63 \mathrm{r}^{\mathrm{o}}\right]$} \\
\hline Bonifacio da Conceição & {$\left[\mathrm{f}^{\mathrm{0}} 91 \mathrm{r}^{\circ}\right]$} \\
\hline
\end{tabular}

\begin{tabular}{|c|c|}
\hline Caetano de S. Domingos & {$\left[\mathrm{f}^{0} 68 \mathrm{v}^{0}\right]$} \\
\hline de S. Gertrudes & {$\left[\mathrm{f}^{0} 90 \mathrm{r}^{\circ}\right]$} \\
\hline de S. José & {$\left[\mathrm{f}^{0} 84 \mathrm{r}^{\circ}\right]$} \\
\hline da Purificação & {$\left[\mathrm{f}^{0} 46 \mathrm{v}^{\circ}\right]$} \\
\hline Calisto de S. Caetano & {$\left[\mathrm{f}^{\mathrm{0}} 121 \mathrm{v}^{\circ}\right]$} \\
\hline " de Faria & {$\left[\mathrm{f}^{\mathrm{o}} 11 \mathrm{r}^{\mathrm{o}}\right],\left[\mathrm{f}^{\mathrm{o}} 11 \mathrm{v}^{\mathrm{o}}\right]$} \\
\hline Camara do Senado & {$\left[\mathrm{f}^{\mathrm{0}} 2 \mathrm{r}^{\mathrm{o}}\right]$} \\
\hline Christovão da Luz & {$\left[\mathrm{f}^{0} 42 \mathrm{v}^{\circ}\right]$} \\
\hline Cipriano da Conceição & {$\left[\mathrm{f}^{0} 80 \mathrm{v}^{0}\right]$} \\
\hline Clemente das Chagas & {$\left[\mathrm{f}^{\mathrm{p}} 7 \mathrm{v}^{\circ}\right]$} \\
\hline Coimbra & {$\left[\mathrm{f}^{\mathrm{0}} 127 \mathrm{v}^{\circ}\right]$} \\
\hline Columbano de S. Bernardo & {$\left[\mathrm{f}^{0} 81 \mathrm{r}^{0}\right]$} \\
\hline Constantino & {$\left[\mathrm{f}^{\mathrm{o}} 104 \mathrm{r}^{\circ}\right]$} \\
\hline da Apresentação & {$\left[\mathrm{f}^{0} 26 \mathrm{r}^{\circ}\right]$} \\
\hline de S. José & {$\left[\mathrm{f}^{\mathrm{0}} 130 \mathrm{v}^{\circ}\right]$} \\
\hline Cosme de S. Damião & {$\left[\mathrm{f}^{0} 64 \mathrm{r}^{\circ}\right]$} \\
\hline 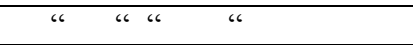 & {$\left[\mathrm{f}^{\circ} 120 \mathrm{r}^{\circ}\right]$} \\
\hline De S. Tiago & {$\left[\mathrm{f}^{\mathrm{0}} 8 \mathrm{v}^{\circ}\right]$} \\
\hline
\end{tabular}

\begin{tabular}{|c|c|}
\hline Diogo Lourenço da Veiga (governador) & {$\left[\mathrm{f}^{\mathrm{0}} 2 \mathrm{v}^{\mathrm{o}}\right]$} \\
\hline Diogo Rangel (M. da Paixão) & (Diet. do Rio, 37) $\left[\mathrm{f}^{\circ} 22 \mathrm{r}^{\circ}\right]$ \\
\hline Diogo da Silva & Diet. do Rio, $6\left[\mathrm{f}^{\circ} 8 \mathrm{r}^{\circ}\right]$ \\
\hline Dionisio & {$\left[\mathrm{f}^{0} 68 \mathrm{r}^{\circ}\right]$} \\
\hline Dionisio de S. Bento & {$\left[\mathrm{f}^{\mathrm{O}} 34 \mathrm{r}^{\circ}\right]$} \\
\hline Dionisio de S. José & {$\left[\mathrm{f}^{0} 74 \mathrm{v}^{\circ}\right]$} \\
\hline Domingos de S. Amaro & {$\left[\mathrm{f}^{0} 35 \mathrm{r}^{\circ}\right]$} \\
\hline da Conceição & {$\left[\mathrm{f}^{\circ} 119 \mathrm{r}^{\circ}\right]$} \\
\hline do Rosario & {$\left[\mathrm{f}^{\mathrm{o}} 13 \mathrm{v}^{\circ}\right]$} \\
\hline
\end{tabular}




\begin{tabular}{|c|c|}
\hline & $F$ \\
\hline Felippe de Jesus Meirelles & {$\left[\mathrm{f}^{\mathrm{o}} 130 \mathrm{r}^{\mathrm{o}}\right]$} \\
\hline da Natividade & {$\left[\mathrm{f}^{\mathrm{o}} 135 \mathrm{r}^{\circ}\right]$} \\
\hline dos Santos & {$\left[\mathrm{f}^{0} 27 \mathrm{r}^{\circ}\right]$} \\
\hline Feliciano de S. Miguel & {$\left[\mathrm{f}^{\mathrm{p}} 60 \mathrm{v}^{\mathrm{o}}\right]$} \\
\hline Felis & {$\left[\mathrm{f}^{\mathrm{0}} 122 \mathrm{v}^{0}\right]$} \\
\hline da Cruz & {$\left[\mathrm{f}^{0} 12 \mathrm{r}^{0}\right]$} \\
\hline da Piedade & {$\left[\mathrm{f}^{\mathrm{o}} 103 \mathrm{r}^{\circ}\right]$} \\
\hline Fernando Felis & {$\left[\mathrm{f}^{0} 40 \mathrm{r}^{\circ}\right]$} \\
\hline da Trindade & {$\left[\mathrm{f}^{0} 77 \mathrm{r}^{\circ}\right]$} \\
\hline Vaz & {$\left[\mathrm{f}^{\mathrm{0}} 3 \mathrm{r}^{\mathrm{o}}\right]$} \\
\hline Francisco & {$\left[\mathrm{f}^{\mathrm{0}} 3 \mathrm{r}^{\mathrm{o}}\right]$} \\
\hline Francisco & {$\left[\mathrm{f}^{\mathrm{0}} 127 \mathrm{v}^{\circ}\right]$} \\
\hline Francisco dos Anjos & {$\left[\mathrm{f}^{\mathrm{o}} 13 \mathrm{v}^{\mathrm{o}}\right]$} \\
\hline Francisco de $\mathrm{St}^{\circ}$ Antonio & {$\left[\mathrm{f}^{\mathrm{0}} 130 \mathrm{v}^{0}\right]$} \\
\hline Francisco da Apresentação & {$\left[\mathrm{f}^{\mathrm{p}} 12 \mathrm{v}^{\mathrm{o}}\right]$} \\
\hline Barcellon (bemfeitor) & {$\left[\mathrm{f}^{\mathrm{p}} 113 \mathrm{v}^{0}\right]$} \\
\hline Francisco das Chagas & {$\left[\mathrm{f}^{\mathrm{o}} 12 \mathrm{v}^{\mathrm{o}}\right]$} \\
\hline Francisco " & {$\left[\mathrm{f}^{0} 76 \mathrm{r}^{\mathrm{0}}\right]$} \\
\hline Francisco da Conceição & {$\left[\mathrm{f}^{0} 56 \mathrm{r}^{\circ}\right]$} \\
\hline “ $" “$ & {$\left[\mathrm{f}^{\mathrm{0}} 126 \mathrm{v}^{\circ}\right]$} \\
\hline Gama & {$\left[\mathrm{f}^{\mathrm{o}} 123 \mathrm{r}^{\circ}\right]$} \\
\hline Francisco de S. Gertrudes & {$\left[\mathrm{f}^{\mathrm{p}} 69 \mathrm{v}^{\mathrm{o}}\right]$} \\
\hline de Jesus Maria & {$\left[\mathrm{f}^{0} 88 \mathrm{r}^{\circ}\right]$} \\
\hline Lamberto (proc. da Coroa) & {$\left[\mathrm{f}^{0} 50 \mathrm{r}^{\circ}\right]$} \\
\hline Francisco da Natividade & {$\left[\mathrm{f}^{\mathrm{o}} 108 \mathrm{r}^{\mathrm{o}}\right]$} \\
\hline da Piedade $\mathrm{Pt}^{\circ}$ & {$\left[\mathrm{f}^{\mathrm{o}} 120 \mathrm{r}^{\circ}\right]$} \\
\hline dos Prazeres & {$\left[\mathrm{f}^{\mathrm{o}} 153 \mathrm{v}^{\circ}\right]$} \\
\hline do Rosario & {$\left[\mathrm{f}^{\mathrm{p}} 84 \mathrm{v}^{\mathrm{o}}\right]$} \\
\hline de S. Elena & {$\left[\mathrm{f}^{\circ} 99 \mathrm{r}^{\circ}\right]$} \\
\hline Francisco de S. Luzia & {$\left[\mathrm{f}^{\mathrm{o}} 102 \mathrm{r}^{\mathrm{o}}\right]$} \\
\hline de S. Rita & {$\left[\mathrm{f}^{\mathrm{o}} 109 \mathrm{r}^{\circ}\right]$} \\
\hline de Souza (Marques de Minas) & {$\left[\mathrm{f}^{\mathrm{0}} 36 \mathrm{v}^{\mathrm{o}}\right]$} \\
\hline de S. Thomé & {$\left[\mathrm{f}^{\mathrm{p}} 90 \mathrm{v}^{\mathrm{o}}\right]$} \\
\hline da Trindade & {$\left[\mathrm{f}^{\mathrm{p}} 33 \mathrm{v}^{\circ}\right]$} \\
\hline da Visitação & {$\left[\mathrm{f}^{\mathrm{p}} 23 \mathrm{v}^{\circ}\right]$} \\
\hline " & {$\left[\mathrm{f}^{\mathrm{0}} 41 \mathrm{v}^{\circ}\right]$} \\
\hline Francisco Xavier de Santa Maria & {$\left[\mathrm{f}^{\mathrm{o}} 107 \mathrm{v}^{\circ}\right]$} \\
\hline
\end{tabular}

G

\begin{tabular}{|l|l|}
\hline Gabriel Soares de Souza & {$\left[\mathrm{f}^{0} 2 \mathrm{v}^{0}\right]$} \\
\hline \multicolumn{1}{|c|}{ S. Souza (Camarista) } & {$\left[\mathrm{f}^{0} 2 \mathrm{v}^{0}\right]$} \\
\hline Gaspar da Assumpção & {$\left[\mathrm{f}^{0} 20 \mathrm{v}^{0}\right]$} \\
\hline \multicolumn{1}{|c|}{ das Neves } & {$\left[\mathrm{f}^{0} 48 \mathrm{r}^{\circ}\right]$} \\
\hline Gonçalo & {$\left[\mathrm{f}^{0} 10 \mathrm{v}^{0}\right]$} \\
\hline Gonçalo Annes (Elmes) & {$\left[\mathrm{f}^{0} 24 \mathrm{r}^{\circ}\right]$} \\
\hline
\end{tabular}




\begin{tabular}{|c|l|}
\hline da Conceição & {$\left[\mathrm{f}^{0} 61 \mathrm{v}^{0}\right]$} \\
\hline Gregorio Machado & {$\left[\mathrm{f}^{0} 32 \mathrm{v}^{0}\right]$} \\
\hline da Madre de Deus & {$\left[\mathrm{f}^{0} 83 \mathrm{v}^{0}\right]$} \\
\hline Pereira & {$\left[\mathrm{f}^{0} 25 \mathrm{v}^{0}\right]$} \\
\hline do Paraizo & {$\left[\mathrm{f}^{0} 70 \mathrm{v}^{0}\right]$} \\
\hline
\end{tabular}

$\mathrm{H}$

I

\begin{tabular}{|c|c|}
\hline Ignacio da Assumpção & {$\left[\mathrm{f}^{\mathrm{0}} 95 \mathrm{r}^{\circ}\right]$} \\
\hline de $\mathrm{St}^{\mathrm{a}}$ Anna & {$\left[\mathrm{f}^{\mathrm{o}} 108 \mathrm{v}^{\mathrm{o}}\right]$} \\
\hline de S. Bento & {$\left[\mathrm{f}^{\mathrm{o}} 13 \mathrm{v}^{\mathrm{o}}\right]$} \\
\hline da Conceição & {$\left[\mathrm{f}^{\circ} 98 \mathrm{v}^{\circ}\right]$} \\
\hline da Encarnação & {$\left[\mathrm{f}^{0} 104 \mathrm{r}^{\circ}\right]$} \\
\hline de $\mathrm{St}^{\mathrm{a}}$ Izabel & {$\left[\mathrm{f}^{\mathrm{o}} 99 \mathrm{r}^{\circ}\right]$} \\
\hline da Purificação & {$\left[\mathrm{f}^{\mathrm{o}} 49 \mathrm{v}^{\circ}\right]$} \\
\hline Innocencio de $\mathrm{St}^{\mathrm{a}}$ Joanna & {$\left[\mathrm{f}^{\mathrm{0}} 57 \mathrm{v}^{\mathrm{o}}\right]$} \\
\hline Isidoro da Visitação & {$\left[\mathrm{f}^{0} 9 \mathrm{v}^{0}\right]$} \\
\hline Izidoro da Trindade & {$\left[\mathrm{f}^{\mathrm{o}} 24 \mathrm{v}^{\circ}\right]$} \\
\hline Irmão de nome desconhecido & {$\left[\mathrm{f}^{\mathrm{o}} 123 \mathrm{v}^{\circ}\right]$} \\
\hline
\end{tabular}

J

\begin{tabular}{|c|c|}
\hline Jacinto do Desterro & {$\left[\mathrm{f}^{\mathrm{0}} 35 \mathrm{v}^{\mathrm{o}}\right]$} \\
\hline Jeronimo da Ascenção & {$\left[\mathrm{f}^{\mathrm{o}} 119 \mathrm{r}^{\circ}\right]$} \\
\hline Jeronimo de S. Bento & {$\left[\mathrm{f}^{0} 37 \mathrm{v}^{0}\right]$} \\
\hline de Ivo & {$\left[\mathrm{f}^{\mathrm{0}} 45 \mathrm{r}^{\mathrm{o}}\right]$} \\
\hline João & {$\left[\mathrm{f}^{\mathrm{o}} 2 \mathrm{v}^{\mathrm{o}}\right]$} \\
\hline D. João IV & {$\left[\mathrm{f}^{\mathrm{o}} 64 \mathrm{v}^{\mathrm{o}}\right]$} \\
\hline João dos Anjos & {$\left[\mathrm{f}^{\mathrm{0}} 51 \mathrm{v}^{\mathrm{o}}\right]$} \\
\hline João d' Assumpção & {$\left[\mathrm{f}^{0} 75 \mathrm{v}^{0}\right]$} \\
\hline João Baptista & {$\left[\mathrm{f}^{\mathrm{0}} 28 \mathrm{v}^{\circ}\right]$} \\
\hline João Baptista da Cruz & {$\left[\mathrm{f}^{0} 75 \mathrm{v}^{\circ}\right]$} \\
\hline João de S. Bento & {$\left[\mathrm{f}^{0} 86 \mathrm{r}^{\mathrm{o}}\right]$} \\
\hline João de S. Bento Camargo & {$\left[\mathrm{f}^{\mathrm{o}} 52 \mathrm{r}^{\mathrm{o}}\right]\left[\mathrm{f}^{\mathrm{o}} 56 \mathrm{r}^{\mathrm{o}}\right]$} \\
\hline João de S. Boaventura & {$\left[\mathrm{f}^{\mathrm{o}} 87 \mathrm{v}^{\circ}\right]$} \\
\hline João de Christo & {$\left[\mathrm{f}^{\mathrm{0}} 32 \mathrm{r}^{\mathrm{o}}\right]$} \\
\hline João Damasceno de S. José & {$\left[\mathrm{f}^{\mathrm{o}} 116 \mathrm{r}^{\mathrm{o}}\right]$} \\
\hline João do Deserto & {$\left[\mathrm{f}^{\circ} 8 \mathrm{r}^{\circ}\right]$} \\
\hline João da Encarnação & {$\left[\mathrm{f}^{\mathrm{o}} 69 \mathrm{r}^{0}\right]$} \\
\hline João do Espirito Santo & {$\left[\mathrm{f}^{0} 46 \mathrm{v}^{\circ}\right]$} \\
\hline D. João Frnaco de Oliveira, Arceb. & {$\left[\mathrm{f}^{\mathrm{o}} 153 \mathrm{v}^{\circ}\right]$} \\
\hline João Gondim & {$\left[\mathrm{f}^{\mathrm{o}} 29 \mathrm{v}^{\circ}\right]$} \\
\hline José de Jesus & {$\left[\mathrm{f}^{0} 33 \mathrm{r}^{\mathrm{o}}\right]$} \\
\hline D. João de Lancastro & {$\left[\mathrm{f}^{0} 51 \mathrm{r}^{0}\right]$} \\
\hline João Lopez & {$\left[\mathrm{f}^{\mathrm{0}} 25 \mathrm{v}^{0}\right]$} \\
\hline João da Macena & {$\left[\mathrm{f}^{\mathrm{o}} 128 \mathrm{r}^{0}\right]$} \\
\hline
\end{tabular}




\begin{tabular}{|c|c|}
\hline João da Madre de Deus & {$\left[\mathrm{f}^{\mathrm{o}} 96 \mathrm{r}^{\circ}\right]$} \\
\hline D. João Mascarenhas & {$\left[\mathrm{f}^{0} 65 \mathrm{v}^{\circ}\right]$} \\
\hline D. João Mascarenhas, fidalgo & {$\left[\mathrm{f}^{\mathrm{o}} 123 \mathrm{v}^{\circ}\right]$} \\
\hline D. João do Nascimento & {$\left[\mathrm{f}^{\mathrm{o}} 83 \mathrm{r}^{\circ}\right]$} \\
\hline João Neves, Pe. (Vigario) & {$\left[\mathrm{f}^{\mathrm{0}} 68 \mathrm{v}^{\circ}\right]$} \\
\hline João Porcalho & {$\left[\mathrm{f}^{\mathrm{0}} 3 \mathrm{r}^{\mathrm{o}}\right]$} \\
\hline João do Sacramento & {$\left[\mathrm{f}^{0} 60 \mathrm{r}^{\circ}\right]$} \\
\hline João de S. Agostinho & {$\left[\mathrm{f}^{\circ} 41 \mathrm{r}^{\circ}\right]$} \\
\hline João de S. Anna & {$\left[\mathrm{f}^{0} 79 \mathrm{r}^{\circ}\right]$} \\
\hline João de $\mathrm{St}^{\mathrm{a}}$ Anna Nobre & {$\left[\mathrm{f}^{\mathrm{0}} 150 \mathrm{v}^{0}\right]$} \\
\hline João de Santo Antonio & {$\left[\mathrm{f}^{\mathrm{o}} 114 \mathrm{v}^{0}\right]$} \\
\hline João de St ${ }^{\mathrm{a}}$ Gertrudes Cardoso & {$\left[\mathrm{f}^{\mathrm{p}} 152 \mathrm{v}^{\circ}\right]$} \\
\hline João de S. José Fraga & {$\left[\mathrm{f}^{\mathrm{p}} 126 \mathrm{v}^{\circ}\right]$} \\
\hline João de $\mathrm{St}^{\mathrm{a}}$ Maria & {$\left[\mathrm{f}^{\mathrm{p}} 40 \mathrm{v}^{\mathrm{o}}\right]$} \\
\hline João de S. Maria & {$\left[\mathrm{f}^{0} 117 \mathrm{v}^{\circ}\right]$} \\
\hline João de Souza & {$\left[\mathrm{f}^{\mathrm{0}} 27 \mathrm{v}^{\circ}\right]$} \\
\hline João da Trindidade & {$\left[\mathrm{f}^{\mathrm{p}} 120 \mathrm{v}^{\circ}\right]$} \\
\hline João da Trindade Suares & {$\left[\mathrm{f}^{\mathrm{p}} 130 \mathrm{v}^{\circ}\right]$} \\
\hline João Velho Galvão (Camarista) & {$\left[\mathrm{f}^{0} 2 \mathrm{v}^{0}\right]$} \\
\hline João Vieira & {$\left[\mathrm{f}^{0} 27 \mathrm{r}^{\circ}\right]$} \\
\hline João da Virgem Maria & {$\left[\mathrm{f}^{\mathrm{p}} 100 \mathrm{r}^{\circ}\right]$} \\
\hline Joaquim da Natividade & {$\left[\mathrm{f}^{\circ} 122 \mathrm{r}^{\circ}\right]$} \\
\hline José & {$\left[\mathrm{f}^{\mathrm{p}} 3 \mathrm{r}^{\mathrm{o}}\right]$} \\
\hline José d'Assumpção & {$\left[\mathrm{f}^{0} 74 \mathrm{r}^{\circ}\right]$} \\
\hline José da Conceição & {$\left[\mathrm{f}^{\mathrm{0}} 118 \mathrm{v}^{\circ}\right]$} \\
\hline José da Cruz & {$\left[\mathrm{f}^{\circ} 141 \mathrm{r}^{\circ}\right]$} \\
\hline José da Esperança & {$\left[\mathrm{f}^{\mathrm{o}} 13 \mathrm{v}^{\mathrm{o}}\right]$} \\
\hline D. José Fialho Bispo de Perú & {$\left[\mathrm{f}^{0} 70 \mathrm{v}^{\circ}\right]$} \\
\hline José de Jesus & {$\left[\mathrm{f}^{0} 33 \mathrm{r}^{\circ}\right]$} \\
\hline José de Jesus Buticario & {$\left[\mathrm{f}^{\mathrm{0}} 125 \mathrm{r}^{\mathrm{o}}\right]$} \\
\hline José de Jesus Maria & {$\left[\mathrm{f}^{\mathrm{o}} 4 \mathrm{v}^{\circ}\right]$} \\
\hline José de Jesus Maria & {$\left[\mathrm{f}^{\mathrm{0}} 70 \mathrm{v}^{0}\right],\left[\mathrm{f}^{\mathrm{o}} 111 \mathrm{r}^{\circ}\right]$} \\
\hline José de Jesus Maria Campos & {$\left[\mathrm{f}^{\mathrm{0}} 129 \mathrm{v}^{0}\right]$} \\
\hline José de Jesus Maria S. Paio & {$\left[\mathrm{f}^{\circ} 145 \mathrm{r}^{\circ}\right]$} \\
\hline José de Madre de Deus & {$\left[\mathrm{f}^{\mathrm{p}} 122 \mathrm{r}^{\mathrm{o}}\right]$} \\
\hline José da Natividade & {$\left[\mathrm{f}^{0} 53 \mathrm{r}^{\circ}\right]$} \\
\hline José de Nazareth & {$\left[\mathrm{f}^{0} 78 \mathrm{r}^{\circ}\right]$} \\
\hline José de Santa Anna Coimbra & {$\left[\mathrm{f}^{\mathrm{p}} 129 \mathrm{v}^{0}\right]$} \\
\hline José de Santo Antonio & {$\left[\mathrm{f}^{\mathrm{p}} 66 \mathrm{v}^{\circ}\right]$} \\
\hline José de S. Bento & {$\left[\mathrm{f}^{0} 113 \mathrm{v}^{\circ}\right]$} \\
\hline José de S. Bento Leal & {$\left[\mathrm{f}^{\circ} 138 \mathrm{r}^{\circ}\right]$} \\
\hline José de S. Bernardo Rocha & {$\left[\mathrm{f}^{\mathrm{0}} 128 \mathrm{v}^{\circ}\right]$} \\
\hline José de S. Boaventura & {$\left[\mathrm{f}^{\mathrm{p}} 75 \mathrm{v}^{\mathrm{o}}\right]$} \\
\hline José de Santa Catharina & {$\left[\mathrm{f}^{0} 71 \mathrm{v}^{0}\right]$} \\
\hline D. Fr. José de Santa Escolastica & {$\left[\mathrm{f}^{\mathrm{p}} 142 \mathrm{v}^{\circ}\right]$} \\
\hline José de Santa Escolastica e Oliveira & {$\left[\mathrm{f}^{\mathrm{o}} 153 \mathrm{r}^{\mathrm{o}}\right.$} \\
\hline José de S. Jeronimo & {$\left[\mathrm{f}^{\mathrm{p}} 94 \mathrm{r}^{\mathrm{O}}\right]$} \\
\hline José de Santa Josepha e Almeida & {$\left[\mathrm{f}^{\mathrm{o}} 149 \mathrm{v}^{0}\right]$} \\
\hline
\end{tabular}




\begin{tabular}{|c|c|}
\hline José de Santa Rosa & {$\left[\mathrm{f}^{\mathrm{o}} 104 \mathrm{v}^{\circ}\right]$} \\
\hline José de Santa Thereza & {$\left[\mathrm{f}^{\mathrm{o}} 114 \mathrm{r}^{\mathrm{o}}\right]$} \\
\hline José da Trindade Rocha & {$\left[\mathrm{f}^{\mathrm{0}} 141 \mathrm{r}^{\mathrm{o}}\right]$} \\
\hline \multicolumn{2}{|c|}{$\mathrm{K}$} \\
\hline \multicolumn{2}{|c|}{$\mathrm{M}$} \\
\hline Leandro & {$\left[\mathrm{f}^{\mathrm{0}} 58 \mathrm{v}^{\circ}\right]$} \\
\hline Leandro do Desterro & {$\left[\mathrm{f}^{\circ} 96 \mathrm{r}^{\circ}\right]$} \\
\hline Leão de S. Bento & {$\left[\mathrm{f}^{\mathrm{o}} 30 \mathrm{r}^{\circ}\right],\left[\mathrm{f}^{0} 47 \mathrm{r}^{\circ}\right]$} \\
\hline Leão da Piedade & {$\left[\mathrm{f}^{\mathrm{0}} 79 \mathrm{r}^{\circ}\right]$} \\
\hline Leonardo de S. José & {$\left[\mathrm{f}^{\mathrm{0}} 89 \mathrm{r}^{\circ}\right]$} \\
\hline Lourenço da Conceição & {$\left[\mathrm{f}^{\circ} 92 \mathrm{v}^{\circ}\right]$} \\
\hline da Purificação & {$\left[\mathrm{f}^{\mathrm{o}} 13 \mathrm{r}^{\mathrm{o}}\right]$} \\
\hline de São José & {$\left[\mathrm{f}^{\mathrm{e}} 86 \mathrm{r}^{\circ}\right]$} \\
\hline Lucas da Assumpção & {$\left[\mathrm{f}^{0} 36 \mathrm{v}^{0}\right]$} \\
\hline Luiz da Conceição Souza & {$\left[\mathrm{f}^{\mathrm{o}} 126 \mathrm{r}^{\circ}\right]$} \\
\hline do Espirito Santo & {$\left[\mathrm{f}^{0} 7 \mathrm{r}^{\mathrm{o}}\right]$} \\
\hline Luiz de N. Senhora da Penna & {$\left[\mathrm{f}^{\mathrm{o}} 143 \mathrm{v}^{\circ}\right]$} \\
\hline Pereira Torres de S. $\mathrm{P}^{\circ}$ Novo & {$\left[\mathrm{f}^{\mathrm{0}} 68 \mathrm{v}^{\circ}\right]$} \\
\hline de Souza & {$\left[\mathrm{f}^{\mathrm{0}} 30 \mathrm{r}^{\mathrm{r}}\right]$} \\
\hline
\end{tabular}

\begin{tabular}{|c|c|}
\hline Macario de S. João & {$\left[\mathrm{f}^{\mathrm{o}} 26 \mathrm{r}^{\mathrm{o}}\right]$} \\
\hline Mancio das Martires & {$\left[\mathrm{f}^{0} 14 \mathrm{v}^{\circ}\right],\left[\mathrm{f}^{\mathrm{o}} 15 \mathrm{r}^{0}\right]$} \\
\hline Manoel & {$\left[\mathrm{f}^{\mathrm{p}} 11 \mathrm{v}^{\mathrm{o}}\right]$} \\
\hline Manoel dos Anjos & {$\left[\mathrm{f}^{0} 65 \mathrm{v}^{\circ}\right]$} \\
\hline da Conceição & {$\left[\mathrm{f}^{0} 91 \mathrm{r}^{\circ}\right]$} \\
\hline Manoel da Conceição & {$\left[\mathrm{f}^{9} 95 \mathrm{v}^{\circ}\right]$} \\
\hline " " " " & {$\left[\mathrm{f}^{\mathrm{0}} 99 \mathrm{r}^{\circ}\right]$} \\
\hline “ & {$\left[\mathrm{f}^{\mathrm{o}} 148 \mathrm{v}^{0}\right]$ a $\left[\mathrm{f}^{\mathrm{o}} 152 \mathrm{v}^{\circ}\right]$} \\
\hline Manoel do Desterro & {$\left[\mathrm{f}^{0} 24 \mathrm{v}^{\circ}\right]$} \\
\hline do Desterro & {$\left[\mathrm{f}^{0} 43 \mathrm{v}^{\circ}\right]$} \\
\hline da Encarnação & {$\left[\mathrm{f}^{0} 98 \mathrm{r}^{\circ}\right]$} \\
\hline da Encarnação & {$\left[\mathrm{f}^{\mathrm{p}} 120 \mathrm{v}^{\circ}\right]$} \\
\hline do Espirito Santo & {$\left[\mathrm{f}^{\circ} 82 \mathrm{r}^{\circ}\right]$} \\
\hline da Gloria & {$\left[\mathrm{f}^{\mathrm{o}} 85 \mathrm{v}^{\circ}\right]$} \\
\hline de Jesus Maria & {$\left[\mathrm{f}^{0} 60 \mathrm{v}^{0}\right]$} \\
\hline de Jesus Maria & {$\left[\mathrm{f}^{\circ} 143 \mathrm{v}^{\circ}\right]$} \\
\hline de Mesquita & {$\left[\mathrm{f}^{\mathrm{p}} 3 \mathrm{r}^{\mathrm{o}}\right],\left[\mathrm{f}^{\mathrm{o}} 12 \mathrm{r}^{\mathrm{o}}\right]$} \\
\hline do Nascimento & {$\left[\mathrm{f}^{0} 67 \mathrm{r}^{\circ}\right]$} \\
\hline “ & {$\left[\mathrm{f}^{\mathrm{p}} 99 \mathrm{v}^{\circ}\right]$} \\
\hline da Natividade Passos & {$\left[\mathrm{f}^{0} 96 \mathrm{v}^{\circ}\right]$} \\
\hline do Sacramento & {$\left[\mathrm{f}^{\mathrm{0}} 139 \mathrm{v}^{\circ}\right]$} \\
\hline de Sant Anna Araujo & {$\left[\mathrm{f}^{\mathrm{o}} 144 \mathrm{v}^{\circ}\right]$} \\
\hline de Santo Antonio & {$\left[\mathrm{f}^{0} 73 \mathrm{r}^{\mathrm{0}}\right]$} \\
\hline
\end{tabular}




\begin{tabular}{|c|c|}
\hline de S. Bernardo & {$\left[\mathrm{f}^{\mathrm{o}} 109 \mathrm{v}^{\mathrm{o}}\right]$} \\
\hline de S. Bento & {$\left[\mathrm{f}^{\circ} 93 \mathrm{r}^{\mathrm{o}}\right]$} \\
\hline de S. Caetano & {$\left[\mathrm{f}^{\mathrm{o}} 149 \mathrm{v}^{\mathrm{o}}\right]$} \\
\hline de S. Lourenço & {$\left[\mathrm{f}^{\mathrm{o}} 51 \mathrm{v}^{\mathrm{o}}\right]$} \\
\hline de Santa Rosa & {$\left[\mathrm{f}^{\mathrm{o}} 62 \mathrm{r}^{\mathrm{o}}\right]$} \\
\hline de " Thereza & {$\left[\mathrm{f}^{\mathrm{o}} 121 \mathrm{r}^{\mathrm{o}}\right]$} \\
\hline da Trindade & {$\left[\mathrm{f}^{\mathrm{o}} 121 \mathrm{v}^{\mathrm{o}}\right]$} \\
\hline Marcelino de Sant Anna & {$\left[\mathrm{f}^{\mathrm{o}} 137 \mathrm{r}^{\mathrm{o}}\right]$} \\
\hline Marcelino de Madre de Deus & {$\left[\mathrm{f}^{\mathrm{o}} 98 \mathrm{r}^{\mathrm{o}}\right]$} \\
\hline Marcos do Desterro & {$\left[\mathrm{f}^{\mathrm{o}} 28 \mathrm{r}^{\mathrm{o}}\right]$ a $\left[\mathrm{f}^{\mathrm{o}} 28 \mathrm{v}^{\mathrm{o}}\right]$} \\
\hline " de Jesus & {$\left[\mathrm{f}^{\circ} 90 \mathrm{v}^{\mathrm{o}}\right]$} \\
\hline Marques de Minas D. $\operatorname{Frc}^{\circ}$ de Souza & {$\left[\mathrm{f}^{\mathrm{0}} 36 \mathrm{v}^{\circ}\right]$} \\
\hline Martinho de Jesus & {$\left[\mathrm{f}^{0} 29 \mathrm{v}^{\mathrm{o}}\right]$} \\
\hline “ da Assumpção & {$\left[\mathrm{f}^{\mathrm{o}} 73 \mathrm{v}^{\mathrm{o}}\right]$} \\
\hline Matheus de S. Anna & {$\left[\mathrm{f}^{\mathrm{o}} 124 \mathrm{r}^{\circ}\right]$} \\
\hline Matheus da Encarnação Pinna & {$\left[\mathrm{f}^{\circ} 90 \mathrm{r}^{\circ}\right],\left[\mathrm{f}^{\mathrm{o}} 93 \mathrm{r}^{\circ}\right]$} \\
\hline Matias de S. Bento & {$\left[\mathrm{f}^{0} 38 \mathrm{v}^{\circ}\right]$ Diet. do Rio 180} \\
\hline Mauro das Chapas & {$\left[\mathrm{f}^{\mathrm{0}} 56 \mathrm{v}^{\mathrm{o}}\right]$} \\
\hline Mauro da Assumpção & {$\left[\mathrm{f}^{0} 9 \mathrm{v}^{0}\right]$} \\
\hline Mauro da Incarnação & {$\left[\mathrm{f}^{\mathrm{o}} 27 \mathrm{v}^{\mathrm{o}}\right]$} \\
\hline Mauro da Trindade & {$\left[\mathrm{f}^{0} 59 \mathrm{r}^{\circ}\right]$} \\
\hline Miguel do Paraizo & {$\left[\mathrm{f}^{0} 14 \mathrm{r}^{0}\right]$} \\
\hline da S. Escolastica & {$\left[\mathrm{f}^{0} 56 \mathrm{v}^{\circ}\right]$} \\
\hline Conceição & {$\left[\mathrm{f}^{\mathrm{o}} 114 \mathrm{v}^{0}\right]$} \\
\hline de Jesus Maria & {$\left[\mathrm{f}^{0} 119 \mathrm{v}^{\circ}\right]$} \\
\hline \multicolumn{2}{|c|}{$\mathrm{N}$} \\
\hline Nicolau dos Martires & $81\left[\mathrm{f}^{\mathrm{o}} 43 \mathrm{r}^{\circ}\right]$ \\
\hline \multicolumn{2}{|c|}{$\mathrm{O}$} \\
\hline \multicolumn{2}{|c|}{$P$} \\
\hline Pantaleão de S. Bento & {$\left[\mathrm{f}^{\mathrm{0}} 58 \mathrm{r}^{\mathrm{o}}\right]$} \\
\hline Pascoal da Resurreição & {$\left[\mathrm{f}^{\mathrm{o}} 119 \mathrm{v}^{\mathrm{o}}\right]$ a $\left[\mathrm{f}^{\mathrm{o}} 120 \mathrm{v}^{\mathrm{o}}\right],\left[\mathrm{f}^{\mathrm{o}} 125 \mathrm{v}^{\mathrm{o}}\right],\left[\mathrm{f}^{\mathrm{o}} 127 \mathrm{v}^{\mathrm{o}}\right]$} \\
\hline Pascual do Espirito Santo & {$\left[\mathrm{f}^{0} 34 \mathrm{r}^{\circ}\right]$ a $\left[\mathrm{f}^{\mathrm{o}} 34 \mathrm{v}^{\mathrm{o}}\right]$} \\
\hline Paulo da Conceição & {$\left[\mathrm{f}^{\mathrm{o}} 58 \mathrm{v}^{\mathrm{o}}\right]$} \\
\hline Paulo do Espirito Santo & {$\left[\mathrm{f}^{0} 8 \mathrm{v}^{0}\right],\left[\mathrm{f}^{0} 14 \mathrm{v}^{0}\right]$} \\
\hline 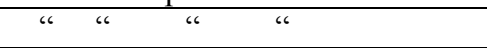 & {$\left[\mathrm{f}^{0} 28 \mathrm{r}^{\circ}\right],\left[\mathrm{f}^{0} 111 \mathrm{r}^{\circ}\right]$} \\
\hline de Jesus & {$\left[\mathrm{f}^{0} 23 \mathrm{v}^{0}\right],\left[\mathrm{f}^{0} 25 \mathrm{v}^{\mathrm{o}}\right]$} \\
\hline Peixoto & {$\left[\mathrm{f}^{\mathrm{o}} 7 \mathrm{v}^{\mathrm{o}}\right]$} \\
\hline Pedro & {$\left[\mathrm{f}^{\mathrm{o}} 12 \mathrm{v}^{\mathrm{o}}\right]$} \\
\hline D. Pedro II & {$\left[\mathrm{f}^{\mathrm{o}} 50 \mathrm{r}^{\mathrm{o}}\right]$} \\
\hline Pedro da Conceição & {$\left[\mathrm{f}^{\circ} 81 \mathrm{r}^{\circ}\right]$} \\
\hline do Espirito Santo & {$\left[\mathrm{f}^{0} 25 \mathrm{r}^{\circ}\right]$ a $\left[\mathrm{f}^{\mathrm{o}} 26 \mathrm{r}^{\circ}\right]$} \\
\hline Ferraz & {$\left[\mathrm{f}^{\mathrm{o}} 3 \mathrm{r}^{\mathrm{o}}\right],\left[\mathrm{f}^{\mathrm{o}} 6 \mathrm{r}^{\mathrm{o}}\right]$} \\
\hline Pedro de Jesus & {$\left[\mathrm{f}^{\mathrm{o}} 17 \mathrm{r}^{\circ}\right]\left[\mathrm{f}^{\mathrm{o}} 27 \mathrm{r}^{\circ}\right]$} \\
\hline
\end{tabular}




\begin{tabular}{|c|c|}
\hline Pedro dos Martires & {$\left[\mathrm{f}^{\mathrm{o}} 24 \mathrm{v}^{\mathrm{o}}\right]$} \\
\hline da Natividade & {$\left[\mathrm{f}^{0} 53 \mathrm{r}^{\circ}\right]$} \\
\hline de S. Bento & {$\left[\mathrm{f}^{0} 2 \mathrm{r}^{\mathrm{o}}\right]$} \\
\hline S. Caetano Pontes & {$\left[\mathrm{f}^{9} 96 \mathrm{r}^{\circ}\right]$} \\
\hline de S. Francisco & {$\left[\mathrm{f}^{3} 37 \mathrm{r}^{\circ}\right]$} \\
\hline de Vasconcellos Governador & {$\left[\mathrm{f}^{5} 54 \mathrm{r}^{0}\right]$} \\
\hline Phelipe dos Santos & {$\left[\mathrm{f}^{0} 27 \mathrm{r}^{\circ}\right]$} \\
\hline Pio VI Papa, Breve de & {$\left[\mathrm{f}^{\mathrm{0}} 151 \mathrm{v}^{\circ}\right]$} \\
\hline “ VII “ & {$\left[\mathrm{f}^{\mathrm{0}} 151 \mathrm{v}^{\circ}\right]$} \\
\hline Placido das Chagas & {$\left[\mathrm{f}^{\mathrm{o}} 10 \mathrm{r}^{\mathrm{o}}\right],\left[\mathrm{f}^{\mathrm{o}} 10 \mathrm{v}^{\mathrm{o}}\right]$} \\
\hline da Cruz & {$\left[\mathrm{f}^{\mathrm{o}} 13 \mathrm{r}^{\mathrm{o}}\right]$} \\
\hline da Esperança & {$\left[\mathrm{f}^{0} 6 \mathrm{v}^{\circ}\right]$} \\
\hline de Sant'Anna & {$\left[\mathrm{f}^{0} 98 \mathrm{r}^{\circ}\right]$} \\
\hline de Villalobos & {$\left[\mathrm{f}^{\mathrm{p}} 2 \mathrm{r}^{\mathrm{o}}\right]$} \\
\hline Prudencio da Assumpção & {$\left[\mathrm{f}^{0} 54 \mathrm{v}^{0}\right]$} \\
\hline
\end{tabular}

\begin{tabular}{|c|c|}
\hline Rafael do Espirito Santo & {$\left[\mathrm{f}^{\circ} 90 \mathrm{r}^{\circ}\right]$} \\
\hline da Trindade & {$\left[\mathrm{f}^{\circ} 40 \mathrm{v}^{\circ}\right]$} \\
\hline Raimundo de S. Miguel & {$\left[\mathrm{f}^{\mathrm{0}} 86 \mathrm{v}^{\circ}\right]$} \\
\hline Rodrigo do Espirito Santo & {$\left[\mathrm{f}^{\circ} 39 \mathrm{v}^{\circ}\right]$} \\
\hline Romualdo de $\mathrm{St}^{\mathrm{a}}$ Catharina & {$\left[\mathrm{f}^{\mathrm{0}} 37 \mathrm{r}^{\circ}\right]$} \\
\hline Roque da Assumpção & {$\left[\mathrm{f}^{\mathrm{e}} 84 \mathrm{v}^{\circ}\right]$} \\
\hline " " & {$\left[\mathrm{f}^{\mathrm{o}} 123 \mathrm{v}^{\circ}\right]$} \\
\hline Rozendo de Souza & {$\left[\mathrm{f}^{\circ} 57 \mathrm{r}^{\circ}\right]$} \\
\hline Ruberto de Jesus & {$\left[\mathrm{f}^{\mathrm{0}} 33 \mathrm{r}^{\circ}\right]\left[\mathrm{f}^{\mathrm{0}} 33 \mathrm{v}^{0}\right]\left[\mathrm{f}^{0} 48 \mathrm{v}^{0}\right]$} \\
\hline “" “ & {$\left[\mathrm{f}^{\mathrm{o}} 88 \mathrm{r}^{\mathrm{o}}\right]$} \\
\hline
\end{tabular}

\section{S}

\begin{tabular}{|c|c|}
\hline Salvador & {$\left[\mathrm{f}^{\mathrm{0}} 127 \mathrm{v}^{0}\right]$} \\
\hline de Santa Ignez & {$\left[\mathrm{f}^{\mathrm{o}} 133 \mathrm{v}^{\circ}\right]$} \\
\hline dos Santos & {$\left[\mathrm{f}^{\circ} 97 \mathrm{r}^{\circ}\right]$} \\
\hline da Trindade & {$\left[\mathrm{f}^{\mathrm{e}} 89 \mathrm{v}^{\circ}\right]$} \\
\hline Sebastião das Chagas & {$\left[\mathrm{f}^{\mathrm{0}} 44 \mathrm{r}^{\mathrm{o}}\right]$} \\
\hline "José de Carvalho (Secret. da Corôa) & {$\left[\mathrm{f}^{\mathrm{o}} 128 \mathrm{r}^{\circ}\right]$} \\
\hline Dom Sebastião Monteiro Arceb. da Bahia & {$\left[\mathrm{f}^{\mathrm{0}} 54 \mathrm{r}^{\mathrm{0}}\right]$} \\
\hline $\begin{array}{l}\text { "Sebastião Monteiro da "Vide Arceb. } \\
\text { da Bahia }\end{array}$ & {$\left[\mathrm{f}^{0} 68 \mathrm{r}^{\circ}\right]$} \\
\hline Sebastião de S. Placido & {$\left[\mathrm{f}^{\mathrm{0}} 132 \mathrm{r}^{\mathrm{o}}\right]$} \\
\hline Silvestre de Jesus Maria & {$\left[\mathrm{f}^{\mathrm{o}} 127 \mathrm{r}^{\mathrm{o}}\right]$} \\
\hline \multicolumn{2}{|c|}{$\mathrm{T}$} \\
\hline $\begin{array}{l}\text { Theodoro da Purificação (grande musico } \\
\text { Olinda) }\end{array}$ & {$\left[\mathrm{f}^{\mathrm{0}} 40 \mathrm{r}^{\circ}\right]$ a $\left[\mathrm{f}^{\mathrm{0}} 41 \mathrm{v}^{\circ}\right]$} \\
\hline Thomaz de Aquino Gama & {$\left[\mathrm{f}^{\mathrm{o}} 148 \mathrm{v}^{\circ}\right]$} \\
\hline
\end{tabular}




\begin{tabular}{|c|c|}
\hline da Conceição & {$\left[\mathrm{f}^{0} 70 \mathrm{r}^{\mathrm{0}}\right]$} \\
\hline \multicolumn{2}{|c|}{$\mathrm{U}$} \\
\hline Urbano, Frei & {$\left[\mathrm{f}^{\mathrm{o}} 7 \mathrm{r}^{\mathrm{o}}\right]$} \\
\hline \multicolumn{2}{|c|}{$\mathrm{V}$} \\
\hline Valentim de S. Bernardo & {$\left[\mathrm{f}^{\mathrm{0}} 63 \mathrm{r}^{\mathrm{0}}\right]$} \\
\hline Vicente da Trindade Ferreira & {$\left[\mathrm{f}^{\mathrm{o}} 134 \mathrm{r}^{\mathrm{o}}\right]$} \\
\hline Virissimo do Espirito Santo & {$\left[\mathrm{f}^{\mathrm{o}} 101 \mathrm{r}^{\mathrm{o}}\right]$} \\
\hline Vivaldo da Cruz & {$\left[\mathrm{f}^{0} 45 \mathrm{r}^{0}\right]$} \\
\hline
\end{tabular}


Este livro foi publicado no formato $17 \times 24 \mathrm{~cm}$

Com a fontes Times New Roman no corpo do texto e títulos

Miolo em papel $75 \mathrm{~g} / \mathrm{m}^{2}$

Tiragem 400 exemplares

Impresso no setor de reprografia da EDUFBA

Impressão de capa e acabamento: Bigraf 


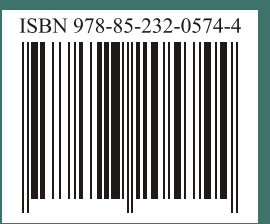

